\title{
Przywództwo nauczycieli
}


Przywództwo nauczycieli 



\section{Przywództwo nauczycieli}

Obszary:

Przywództwo edukacyjne i zmiana,

Przywództwo nauczycieli - perspektywy i inspiracje,

Przywództwo nauczycieli - perspektywa międzynarodowa

redakcja naukowa

Joanna Madalińska-Michalak

\begin{tabular}{l|l} 
fen & Wydawnictwo \\
Se) & FRSE
\end{tabular}

Warszawa 2018 
SERIA NAUKOWA, TOM 2

Przywództwo nauczycieli

Obszary:

Przywództwo edukacyjne i zmiana,

Przywództwo nauczycieli - perspektywy i inspiracje

Przywództwo nauczycieli - perspektywa międzynarodowa

Redaktor naukowy: $\quad$ prof. dr hab. Joanna Madalińska-Michalak

Recenzent: $\quad$ prof. dr hab. Wanda Dróżka

Redaktor prowadzący: Tadeusz Wojciechowski

Tłumaczenie: Poliglota

Redakcja i korekta językowa: Beata Wawrzyńczak-Jędryka

Projekt graficzny i skład: Diana Makulska/Podpunkt

Druk: $\quad$ Pracownia Poligraficzno-Introligatorska INTRO-DRUK Anna Dębińska

Wydawca: $\quad$ Fundacja Rozwoju Systemu Edukacji Narodowa Agencja Programu Erasmus+ Al. Jerozolimskie 142a, 02-305 Warszawa www.frse.org.pl | kontakt@frse.org.pl

(C) Fundacja Rozwoju Systemu Edukacji, Warszawa 2018

ISBN: 978-83-65591-43-2

Publikacja została wydana przy wsparciu finansowym Komisji Europejskiej w ramach programu Erasmus+. Publikacja odzwierciedla jedynie stanowisko jej autorów i Komisja Europejska nie ponosi odpowiedzialności za zamieszczoną w niej zawartość merytoryczną.

Publikacja bezpłatna

\section{firse}

Cytowanie:

Przywództwo nauczycieli, red. nauk. J. Madalińska-Michalak, Fundacja Rozwoju Systemu Edukacji, Seria Naukowa, t. 2, Warszawa 2018

Dotychczas w ramach Serii Naukowej ukazało się:

Tom 1: Teacher Education Policy and Practice - International Perspectives and Inspiration Publikacja dostępna jest na stronie czytelnia.frse.org.pl 


\section{Spis treści}

9

Wstęp

13

Wykaz skrótów

Przywództwo edukacyjne i zmiana

16

Przywództwo edukacyjne - wyzwania teorii i praktyki

Joanna Madalińska-Michalak

42

Znaczenie przywództwa nauczycieli

w przywództwie edukacyjnym

Roman Dorczak

56

Przywództwo edukacyjne w kontekście więzi społecznych specyficznych dla grup (podgrup) wewnątrzszkolnych

Stefan M. Kwiatkowski

74

Zmiana jako podstawowa kategoria rozwoju szkoły Inetta Nowosad

102

Przyszłość przywództwa edukacyjnego.

Tylko martwe ryby płyną z prądem

Grzegorz Mazurkiewicz 


\section{Przywództwo nauczycieli - perspektywy i inspiracje}

136

Przywództwo nauczycieli - przesłanki prawne

Antoni J. Jeżowski

164

Nauczyciele jako nieformalni przywódcy

Malwina Magdalena Kałużyńska

190

Przywództwo dyrektorów szkół i klimat szkoły jako podłoże dla rozwoju przywództwa nauczycieli

Jakub Kołodziejczyk

206

Klimat szkoły i jego znaczenie dla podejmowania przez nauczycieli ról oraz zadań liderskich

Karolina Malinowska

220

Rozwijanie kompetencji przywódczych nauczycieli w trakcie ponadnarodowej mobilności w projektach edukacyjnych programu Erasmus+

Liliana Budkowska

236

Znaczenie postaw liderskich dla rozwoju polskich szkól.

Doświadczenia zagranicznych mobilności szkolnej kadry edukacyjnej

Michat Pachocki

256

Nauczyciel akademicki - przywódca, ekspert, mistrz czy przewodnik?

Mirosław J. Szymański 
274

Przywództwo edukacyjne nauczycieli

Maria Assunção Flores

298

Przywództwo na rzecz uczenia się.

Nauczyciele-liderzy mediatorami innowacji i zmian w szkole

Livia Rößler, Michael Schratz

322

Argumenty za upodmiotowieniem: brakujący element kluczowy Christopher Bezzina

352

Przywództwo zorientowane na nauczanie.

Dylematy wspierające badania nad praktyką zawodową nauczycieli w warunkach wysokiej rozliczalności za wyniki

Pete Boyd, Lesley Curtis

380

Przywództwo nauczycieli na Ukrainie.

Rola nauczycieli w zarządzaniu szkołą i rozwoju zawodowym

Oksana Zabolotna, Svitlana Shchudlo, Olena Kovalchuk

416

Przywództwo nauczycieli w szkolnictwie wyższym w Laosie.

Wyzwania i szanse

Bouakhong Keo Asa, Joanna Madalińska-Michalak

448

Autorzy 



\section{Wstęp}

Niniejsza książka jest zbiorem prac polskich i zagranicznych autorów na temat przywództwa nauczycieli i jego roli w rozwoju szkoły. Zasadniczym kryterium doboru tekstów była ich reprezentatywność wobec najważniejszych problemów dotyczących przywództwa nauczycieli oraz ich jakość merytoryczna. Książka składa się z trzech ściśle ze sobą powiązanych następujących części: „Przywództwo edukacyjne i zmiana”, „Przywództwo nauczycieli - perspektywy i inspiracje” oraz „Przywództwo nauczycieli - perspektywa międzynarodowa".

Autorzy książki podzielają przekonanie, że przywództwo nauczycieli istnieje - jest rzeczywistością, która ma swoje przesłanki w prawie oświatowym, a jego obraz jest wielowymiarowy, zaś jego rozwój powinien być wspierany mądrymi działaniami dyrektorów szkół i ich postawami oraz odpowiednią polityką oświatową w danym kraju.

Przedstawione przez Autorów wyniki rozważań teoretycznych i badań empirycznych dotyczących zjawisk oraz procesów składających się na przywództwo edukacyjne nauczycieli oraz jego uwarunkowania odsłaniają złożoność podejmowanej problematyki. Autorzy odczytują możliwości i wymagania, jakie stoją przed tą grupą zawodową. Dzielą się swoimi refleksjami nad istotą działań przywódczych nauczyciela i wymagań, jakie powinno się stawiać jego edukacji w stale rozwijającym się świecie.

Przywództwo nauczycieli związane jest z ich sprawczością i odpowiedzialnością za kształt edukacji. Mówi ono o świadomym i zorganizowanym uczestnictwie nauczycieli w procesie rozwoju szkoły oraz o przenoszeniu do członków środowiska zawodowego i pozazawodowego, $w$ tym do społeczeństwa (a zwłaszcza do najmłodszego pokolenia), podstawowych wartości, zasad i sposobów działania na rzecz podnoszenia jakości edukacji w warunkach współpracy, zaangażowania, 
zrozumienia, w oderwaniu od wszelkich alienacji, anomii i deprywacji. Nauczyciele jako formalni i nieformalni przywódcy w edukacji to osoby mające swoje idee, marzenia i projekty dotyczące edukacji, osoby twórcze, wewnątrzsterowne, proaktywne, prospołeczne, nastawione prospektywnie, kładące nacisk na uczestnictwo w przemianach edukacyjnych i społecznych.

Złożoność problemów w obszarze edukacji sprawia, że poszukujemy nauczycieli-liderów, poszukujemy nauczycieli, dla których motorem działania stają się odpowiedzialność, odwaga, integralność, wiarygodność, sprawczość i kreatywność. Bez nauczycieli potrafiących podejmować wyzwania i ryzyko oraz rozpoznawać i przekraczać bariery rozwojowe uczestników dziejącego się w szkole i poza szkołą procesu edukacyjnego trudno o jakąkolwiek rzeczywistą, dobrą zmianę w szkole.

Wiedza merytoryczna, umiejętności oraz odpowiednio rozwinięte i ukształtowane postawy z zakresu przywództwa edukacyjnego, składające się na kompetencje przywódcze nauczycieli, są niezbędne w podejmowaniu wyzwań edukacyjnych, wprowadzaniu innowacji i zmian w życie szkoły. Stawanie się liderem, osiąganie swego rodzaju wirtuozerii zawodowej wymaga zatem nie tylko ich oddania się wykonywanej pracy, angażowania swej osoby w realizowane zadania, ale także tworzenia odpowiednich warunków nauczycielom, by ci mogli się rozwijać. Stąd też wszelkie przemyślane działania na rzecz tworzenia warunków, zarówno na poziomie kraju, jak i lokalnym, czy poszczególnych szkół, sprzyjających rozwijaniu kompetencji przywódczych nauczycieli należy współcześnie postrzegać jako niezmiernie pożądane.

Z prezentowanych w publikacji rozważań z pewnością wyłania się zasadniczy wniosek mówiący o tym, iż optymistyczną przesłanką prognozowania rozwoju przywództwa nauczycieli jest coraz bardziej powszechna świadomość nieodwracalności przemian demokratycznych w szkołach. Dziejące się przemiany wymagają szkoły zwróconej ku przyszłości vs. ku przeszłości. Niemniej jednak ta dość obiecująca perspektywa skłania do postawienia szeregu pytań. Oto część z nich:

$\rightarrow$ Jaka jest zdolność środowisk nauczycielskich do wprowadzania innowacji i zmian w szkole?

$\rightarrow$ Jak różnego rodzaju uwarunkowania rzutują na pracę nauczycieli, na ich potrzebę i możliwości przewodzenia innym?

$\rightarrow$ Jakie są rzeczywiste granice autonomii nauczycieli w oświacie i szkolnictwie wyższym? 
$\rightarrow$ Jak w oświacie odejść od rozliczalności, od skupienia uwagi wyłącznie na efektach edukacyjnych, a skupić się na odpowiedzialności nauczycieli zarówno za wynik, jak i za proces ich działania oraz za tworzenie warunków na rzecz wprowadzania innowacji i zmian w szkole?

$\rightarrow$ Jak wzmagać w szkole potrzebę budowania jej kultury opartej na etosie szkoły?

$\rightarrow$ Jak nauczyciele - ludzie niejednokroć sami będący rezultatem systemu, który kładł nacisk na hierarchię, na przywództwo formalne, nie pozwalał na urzeczywistnianie przywództwa opartego na wartościach współpracy i wzajemnego uczenia się - mogą kształtować ludzi zaangażowanych, otwartych, zdolnych do realizowania alternatywnych wizji?

$\rightarrow$ Jak przejść z pozycji władzy w szkole do roli służby wobec innych i społeczeństwa?

$\rightarrow$ Jak pogodzić odgórne przekształcanie i reformowanie oświaty z oddolnym ruchem jej uspołecznienia i różnicowania oświaty?

$\rightarrow$ Jak wyzwalać wśród nauczycieli zainteresowania, motywacje i działania prospołeczne i proedukacyjne w sytuacji zmniejszającego się uznania społecznego dla zawodu nauczyciela?

$\rightarrow$ Jak tworzyć nowe rozwiązania w szkole bez starych, uznanych fundamentów, by odbijając się od jednych dogmatów, nie ugrzęznąć w innych?

Przedstawione pytania wypływają ze świadomości nadziei, jaką niesie ze sobą przywództwo nauczycieli, ale także ograniczeń, które niejako z założenia są w nie wpisane. Pytania te pokazują ogrom problemów i dylematów, jakie stawia perspektywa demokratyzacji i uspołecznienia edukacji. Skłaniają one do rozróżnienia tego, co jest konieczne i możliwe tu i teraz, od tego, na co należy położyć nacisk w przyszłości. Bez świadomości tego, do jakiego celu się zmierza - bez wizji edukacji i szkoły trudno jest myśleć o koncepcjach rozwoju szkoły. Wszakże to, co dzieje się tu i teraz, co jest doraźne, a często i konieczne, choć cząstkowe, nie może i nie powinno w żaden sposób przeszkadzać przyszłości, która określa nową jakość rzeczywistości, nową jakość - powiedzmy nieco patetycznie - świata, w którym przyjdzie żyć kolejnym pokoleniom.

Z pewnością prezentowane w książce dociekania nad przywództwem edukacyjnym i zmianą, a zwłaszcza nad istotą przywództwa 
nauczycieli, nad jego miejscem w szkole i rolą w jej rozwoju czy też relacją między przywództwem dyrektorów szkół a klimatem szkoły i przywództwem nauczycieli oraz rozwijaniem kompetencji przywódczych nauczycieli, stanowią ważne źródło inspiracji poznawczych i praktycznych w poszukiwaniu skutecznych rozwiązań pedagogicznych na rzecz rozwoju szkoły. Rozważania te mogą stać się punktem wyjścia do analiz i dyskusji nad pożądanym wzorem przywództwa w szkołach w rzeczywistości edukacyjnej w Polsce i innych krajach.

Jestem przekonana, że teksty składające się na niniejszą publikację dostarczą cennego materiału badaczom, pracownikom naukowym, studentom pedagogiki i studentom nauk o zarządzaniu, a dyrektorom szkół i nauczycielom pomogą w trudnym zadaniu wdrażania innowacji i zmian w szkole. Wszystkim Autorom, którzy przyjęli moje zaproszenie do współpracy nad książką, których entuzjazm, zaangażowanie i samodyscyplina przyczyniły się do jej powstania i wydania, pragnę z całego serca gorąco podziękować.

Joanna Madalińska-Michalak

Warszawa, 2018 


\section{Wykaz skrótów}

\begin{tabular}{|c|c|}
\hline $\mathrm{cz}$. & część \\
\hline Dz. U. & Dziennik Ustaw \\
\hline Dz. Urz. UE & Dziennik Urzędowy Unii Europejskiej \\
\hline Karta & ustawa z 26 stycznia 1982 r. - Karta Nauczyciela \\
\hline Nauczyciela & (tekst jednolity: Dz. U. z 2018 r. poz. 967) \\
\hline $\mathrm{nr}$ & numer \\
\hline pkt & punkt \\
\hline poz. & pozycja \\
\hline Prawo & ustawa z 14 grudnia 2016 r. - Prawo oświatowe \\
\hline oświatowe & (tekst jednolity: Dz. U. z 2018 r. poz. 996) \\
\hline red. & redakcja \\
\hline s. & strona \\
\hline $\mathrm{t}$. & tom \\
\hline tłum. & tłumaczenie \\
\hline ust. & ustęp \\
\hline
\end{tabular}




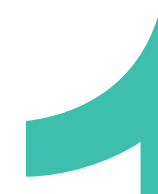


Przywództwo edukacyjne i zmiana 


\section{Przywództwo edukacyjne \\ - wyzwania teorii i praktyki}

Joanna Madalińska-Michalak

Artykuł podejmuje problematykę przywództwa edukacyjnego. Koncentruje się na wyzwaniach, jakie stoją przed teorią i praktyką przywództwa edukacyjnego. W pierwszej części artykułu wśród wyzwań zwrócono uwagę na kwestię nowych kierunków w badaniach nad przywództwem, na systematyzację wiedzy z zastosowaniem analizy porównawczej badanych teorii, określenie pojęcia przywództwa jako pojęcia naturalnego (probabilistycznego), stawianie nowych pytań w odniesieniu do tzw. wielkich teorii przywództwa. W drugiej części ukazano złożoność i problematyczność sytuacji dotyczącej rozwoju teorii i praktyki przywództwa edukacyjnego. Jednocześnie zaproponowano szereg rozwiązań mogących sprzyjać rozwojowi teorii i praktyki przywództwa edukacyjnego.

\section{Słowa kluczowe:}

teorie przywództwa

przywództwo edukacyjne

przywództwo partycypacyjne

analiza krytyczna 


\section{Educational leadership \\ - challenges of theory and practice}

Joanna Madalińska-Michalak

The paper addresses key issues of educational leadership. There is a particular focus on the challenges of relating theory and practice in educational leadership. The first part of the paper discusses new approaches in the research on educational leadership, analyses and classifies the theories in question, identifies the concept of leadership as a natural concept and asks new questions in relation to core leadership theories. The second part shows the complexity and problematic nature of the development of theory and practice in educational leadership. At the same time, a number of solutions that may foster the development of educational leadership theory and practice are proposed.

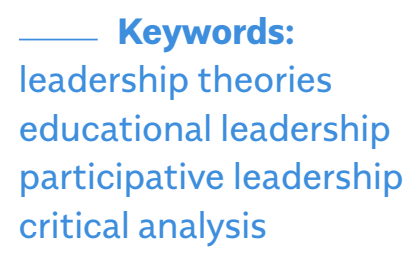




\section{Wstęp}

Problematyka przywództwa coraz silniej przyciąga uwagę tych teoretyków, którzy zajmują się badaniami nad sprawnym kierowaniem zespołami, relacjami międzyludzkimi (zwłaszcza w środowisku pracy), zależnościami między cechami działania i zachowaniami ludzi, osiąganiem celów czy też harmonizowaniem działań zapewniających skuteczne wprowadzanie zmian oraz tworzenie korzystnych warunków ku uzyskiwaniu osiągnięć. Rozwój badań nad przywództwem na gruncie nauk humanistycznych, nauk społecznych czy nauk ekonomicznych jest imponujący. Podejmowane problemy badawcze coraz bardziej się różnicują i dotyczą szerokiego spektrum zjawisk.

Analiza literatury przedmiotu odsłania wielorakość podejść związanych z definiowaniem i opisywaniem przywództwa, w tym interesującego nas przywództwa edukacyjnego. Istniejąca wiedza teoretyczna pozwala dokonać wglądu w naturę przywództwa i wskazać czynniki decydujące o jego skuteczności oraz stanowi podstawę do badania i przewidywania złożonego charakteru zachowań przywódczych. Bogactwo piśmiennictwa poświęconego problematyce przywództwa jest nie tylko jednym z widocznych znaków popularności tego pojęcia wśród teoretyków, ale także jest ono odbiciem funkcjonującego przekonania o wadze procesów przywództwa w rozwoju społeczeństw, organizacji i jednostek (zob. Madalińska-Michalak, 2012, s. 31).

W niniejszym rozdziale podejmuję kwestię wyzwań, jakie stoją wobec teorii i praktyki przywództwa edukacyjnego. Nakreślając perspektywy badawcze w zakresie poszukiwań naukowych dotyczących przywództwa, w tym zwłaszcza przywództwa edukacyjnego, pokazuję problematyczność sytuacji dotyczącej chociażby poszukiwania istoty przywództwa i wraz z tym podejmowanie prób jego definiowania. Po drugie, odnosząc się do niektórych stanowisk teoretycznych, staram się ukazać silne i słabe strony istniejących rozwiązań teoretycznych oraz zastosowanie tych rozwiązań nie tylko we współczesnych rozważaniach naukowych, ale także w praktyce. Uwzględniam przy tym potrzeby współczesnej pedagogiki i badań nad szkołą, w szczególności badań dotyczących przywództwa edukacyjnego. W końcowej części artykułu pokazuję, jak można myśleć o przywództwie edukacyjnym i jakie pytania warto stawiać w tym zakresie, by przyczyniać się do rozwoju teorii i praktyki edukacyjnej. 


\section{Przywództwo}

Studia literatury przedmiotu dowodzą, że trudno jest wskazać choćby jedną teorię "dobrego" przywództwa, z którą by się wszyscy zgadzali. Obecnie - z coraz większą siłą - widać, że żadna pojedyncza teoria czy koncepcja nie są najlepsze. Istniejące teorie i koncepcje przywództwa sugerują możliwe sposoby podejścia do przewodzenia innym. Poszczególne podejścia teoretyków do przywództwa mówią jedynie o pewnej ścieżce zachowań dla przywódców, dlatego też każda z nich może być uznana za nieco zawężoną. Liczne teorie i koncepcje można potraktować jako elementy złożonej układanki zwanej przywództwem.

Analiza literatury przedmiotu poświęconej przywództwu, w tym przywództwu edukacyjnemu, pokazuje, jak wiele wyzwań stoi zarówno przed teorią, jak i praktyką przywództwa. Poniżej zwrócę uwagę tylko na niektóre z nich, odwołując się przy tym do uzyskanych przeze mnie wyników badań w tym zakresie (zob. Madalińska-Michalak, 2012, 2015).

\section{Teorie i koncepcje przywództwa - systematyka}

Istniejące bogactwo teorii, koncepcji i modeli przywództwa, które wpisują się w rozwój myśli naukowej nad tym zjawiskiem, odsłania odmienne punkty widzenia dotyczące istoty tego zjawiska. Rozumienie przywództwa i roli przywódcy ewoluowało wraz z rozwojem różnych nauk, a zwłaszcza wraz rozwojem socjologii, politologii, psychologii społecznej czy też nauk o zarządzaniu. Pojawiające się zmiany następowały wskutek przeobrażeń rzeczywistości oraz pojawiających się wyzwań, jakie stawały przed organizacjami i ich przywódcami.

Niezmiernie ważną kwestią pozostaje wciąż uporządkowanie prezentacji istniejących oraz wyłaniających się teorii i koncepcji przywództwa. Sposobów na prezentację ewolucji poglądów na przywództwo może być wiele, w zależności od tego, jakie kryteria przyjmują autorzy w doborze podejść teoretycznych. Jeśli chcielibyśmy zastanowić się nad tym, jak należałoby wszystkie te elementy nawzajem do siebie dopasować, zapewne okazałoby się, że można znaleźć szereg rozwiązań w tym zakresie.

Jednym z pomocnych działań mogłoby być zastosowanie analizy porównawczej badanych teorii, co pewnie pozwoliłoby nam na jeszcze głębsze rozumienie spraw z zakresu przywództwa i metod jego badania. 


\section{Pojęcie przywództwa - w stronę pojęć naturalnych}

Przegląd literatury przedmiotu pokazuje, że kategorii przywództwa przypisywane jest olbrzymie znaczenie i że literatura naukowa obfituje w różne propozycje definicji pojęcia przywództwo. Definicje te wyrastają na gruncie odmiennych koncepcji teoretycznych, które często posługują się różnymi językami i jako istotne podkreślają różne aspekty przywództwa. W efekcie nadają one różnoraki sens rozumieniu tego fenomenu. Wśród badaczy wciąż nie ma zgodności co do tego, czym jest w istocie przywództwo i jak należy je definiować. Pojawia się wiele odmiennych punktów widzenia dotyczących istoty przywództwa i tym samym mamy do czynienia z niejednorodnością stanowisk w zakresie sposobów rozumienia pojęcia "przywództwo" (zob. Madalińska-Michalak, 2015). Wielość koncepcji teoretycznych przywództwa prowadzi do sytuacji, w której niejeden Czytelnik może poczuć się przytłoczony ogromem informacji, przeciwstawnych poglądów, rozbieżnych teorii i ogólnego braku spójności w zakresie definiowania pojęcia "przywództwo".

Zmiany, które można odnotować w zakresie definiowania przywództwa, wynikają z jednej strony z dążenia do coraz lepszego opisu zjawiska, jakie się za nim kryje, z drugiej zaś są wywoływane przez przekształcające się otoczenie i zmieniające się wyzwania, jakie stają przed organizacjami i ich liderami. Postępujący rozwój wiedzy naukowej na temat przywództwa przynosi ze sobą coraz lepsze odzwierciedlenie istotnych cech tego zjawiska, co oznacza większą precyzację interesującego nas pojęcia. Nie oznacza to jednak, że mamy do czynienia z jego ostro zakreślonymi granicami.

Wspomniana wielość sposobów rozumienia interesującego nas tu pojęcia bezsprzecznie pokazuje, że jest to pojęcie niejednoznaczne, które może być ujmowane z różnych punktów widzenia w zależności od przyjętej perspektywy (zob. Madalińska-Michalak, 2015). Pojęcie tojak trafnie zauważa Gayle C. Avery $(2009$, s. 21) - „pozostaje nieuchwytne i enigmatyczne, mimo lat wysiłków zmierzających do wypracowania intelektualnie emocjonalnie zadowalającej interpretacji przywództwa".

Istniejąca w tym zakresie sytuacja skłania do dalszych poszukiwań badawczych prowadzących do odpowiedzi na pytanie o to, co kryje się za pojęciem przywództwo i dlaczego tak trudno jest je zdefiniować. Jest to o tyle istotne zadanie, że istniejące rozbieżności w sposobie pojmowania przywództwa nie pozostają bez wpływu na rozwój nauk, dla 
których przywództwo jest ważnym pojęciem. Trudno jest mówić o konstruktywnym budowaniu wiedzy naukowej, w tym wiedzy pedagogicznej na temat przywództwa edukacyjnego, gdy aparatura pojęciowa jest daleka od niezbędnej jednoznaczności. Możliwe sposoby definiowania przywództwa pokazują jednocześnie skalę trudności stojących przed naukowcami, którzy chcieliby stworzyć definicję analityczną biorącą pod uwagę przyjęty już sposób rozumienia tego terminu.

Biorąc pod uwagę specyfikę życia społecznego i toczących się w nim procesów, a wraz z tym specyfikę poznania na gruncie nauk humanistycznych i społecznych, raczej nie tyle powinniśmy oczekiwać, że pojęcie przywództwa będzie pojęciem o ostrych granicach, w którym zawierałaby się reprezentacja zbioru obiektów obejmująca wszystkie istotne właściwości tego zbioru, ile raczej skierować naszą uwagę w stronę pojęć naturalnych (probabilistycznych), odzwierciedlających zespół wspólnych cech, które w różnym stopniu przysługują desygnatom danej kategorii. Pojęcie, jakim jest "przywództwo", jest zatem w literaturze przedmiotu charakteryzowane za pomocą zbioru cech jakościowych, które występują z różnym prawdopodobieństwem.

\section{Definicja przywództwa - pytanie o jej uniwersalność}

Sytuacja, z którą mamy do czynienia, kieruje naszą uwagę także w stronę problemu dotyczącego uniwersalności definicji przywództwa. Należy się zastanowić, czy poszczególne nauki zajmujące się przywództwem mają posługiwać się odrębnymi, własnymi definicjami, czy też nie jest to konieczne. Czy definicje te miałby różnić się językiem opisu, ale jednak byłyby równoznaczne, czy też miałyby nadawać pojęciu przywództwa różne znaczenia?

Niewątpliwie, przegląd literatury przedmiotu dowodzi, że należy dokonać pogłębionej analizy pojęcia "przywództwo" i postarać się określić punkty graniczne, kiedy zjawisko przywództwa jeszcze jest nim, a kiedy przestaje już nim być. Taka sytuacja być może mogłaby okazać się pomocna przy definiowaniu odmian przywództwa, na przykład przywództwa edukacyjnego.

\section{Poszukiwanie istoty przywództwa \\ - przezwyciężanie wieloznaczności}

Niewątpliwie, trzeba podkreślić, że różne tendencje, założenia i orientacje poznawcze odsłaniające swoiste dla nich rozumienie 
fenomenu przywództwa, powodują, iż poszukiwanie jego istoty, $w$ tym istoty przywództwa edukacyjnego, może być utrudnione $z$ kilku zasadniczych powodów.

Po pierwsze, wyobrażenia leżące u postaw koncepcji przywództwa i praktyki przywódcze ulegały wraz z upływem czasu zmianom. Po drugie, ludzie, używając określenia "przywództwo”, „mogą mówić o zupełnie innych rzeczach. Tradycyjne modele przywództwa zawierają najczęściej błędne założenie, że wszyscy członkowie danej organizacji lub społeczeństwa mają to samo doświadczenie przywództwa i w ten sam sposób je rozumieją. Tymczasem, nawet pracownicy tej samej uczelni mają zróżnicowane wyobrażenie o tym, co oznacza bycie przywódcą" (Avery, 2009, s. 22-23). Po trzecie, nie istnieje jedna powszechnie uznana definicja przywództwa, a istniejące definicje są raczej niespójne. Nie ma wśród badaczy zgody odnośnie do tego, co powinno zawierać się w pojęciu "przywództwo". I po czwarte, "duża część badań nad przywództwem jest obecnie zbyt uproszczona i nie odzwierciedla w pełni bogactwa ani złożoności, z którymi mają do czynienia praktycy w swojej codziennej działalności" (tamże, s. 23).

Dociekania nad istotą przywództwa wymagają wobec tego przezwyciężenia wieloznaczności utrwalonej zarówno w przyzwyczajeniach językowych, jak i w terminologii niektórych stanowisk teoretycznych, uznawanych za uprawnione i sprzyjające wyjaśnianiu tego pojęcia. Istniejący stan rzeczy związany z odpowiedzią na pytanie o to, czym jest przywództwo, powoduje, że wszelkie próby definiowania interesującego nas pojęcia stają się swoistym wyzwaniem badawczym. Niemniej jednak, pomimo niejednorodności stanowisk, należy podjąć wysiłek w celu doprecyzowania tego pojęcia. Zadanie to jest szczególnie ważne w obszarze pedagogiki, gdzie wciąż widać niedostatek prac badawczych podejmujących problematykę przywództwa, a zwłaszcza ważnego dla pedagogów przywództwa edukacyjnego.

\section{Wielkie teorie - stawianie nowych pytań}

W badaniach nad przywództwem zawsze będą ważne tzw. wielkie teorie, $w$ tym teorie osobowościowe, teorie zachowań, teorie sytuacyjne czy teorie relacyjne. Tym, co łączy większość współczesnych podejść teoretycznych podejmujących problematykę przywództwa, jest jednak koncentracja na sprawczych cechach przywódcy. Pomimo wielu słabości, jakimi odznacza się podejście skupiające się na cechach 
skutecznego przywódcy, w ostatnich latach wróciło ono ponownie do łask.

Nawet jeśli przywódca wyzwala tylko pewien rodzaj energii wśród członków zespołu, z którym pracuje, to jego udział okazuje się niezbędny dla osiągnięcia sukcesu przez zespół - bez przywódcy zespół ten nie mógłby osiągnąć tak dużo, jak przy jego udziale. Stąd pojawia się w pierwszej kolejności pytanie o to, czy jest możliwe stworzenie listy idealnych cech przywódcy. Jeśli tak, to jakie cechy byłyby obecnie najbardziej pożądane oraz jakie ważne wnioski dla myślenia o przywództwie, w tym przywództwie dyrektora szkoły, płyną z teorii cech. Przy wyprowadzaniu wniosków warto pomyśleć o tym, czy obecnie należy poszukiwać "urodzonego przywódcy" o stałych cechach, czy też raczej badać możliwości osoby, mającej potencjalnie być przywódcą.

Tak postawionym pytaniom towarzyszyć powinno także pytanie o rolę charyzmy w procesie oddziaływań przywódczych oraz o specyficzne warunki wywołujące potrzebę lidera charyzmatycznego. Warto przy tym wziąć pod uwagę fakt, że koncepcja przywództwa charyzmatycznego, jakkolwiek użyteczna $w$ wielu sytuacjach, spotyka się z krytyką w literaturze przedmiotu ze względu na potencjalne zagrożenia, jakie ze sobą niesie. Czesław Sikorski w książce Organizacje bez wodzów. Od przywództwa emocjonalnego do koordynacji demokratycznej - podobnie jak inni autorzy podchodzący sceptycznie do przywództwa charyzmatycznego - dowodzi, że lider charyzmatyczny uwodzi swoich podwładnych, a przez to ich ogranicza i hamuje rozwój. Osoby, na które oddziałuje lider charyzmatyczny, stają się mniej zdolne do myślenia za siebie i podejmowania rozsądnych decyzji. Autor wręcz pisze: „Im bardziej dominujący, silny i kreatywny przywódca, tym słabsi i mniej samodzielni stają się jego podwładni" (Sikorski, 2006, s. 35). Przywództwo charyzmatyczne niesie ze sobą wiele potencjalnych zagrożeń. W skrajnych przypadkach, jak pokazuje Czesław Sikorski, może w praktyce zniszczyć organizację lub społeczeństwo.

W kontekście postawionych wyżej pytań o naturę przywództwa i charakterystykę skutecznego przywódcy trzeba podkreślić, że osobowościowym teoriom przywództwa zarzuca się, iż rozpatrywanie istoty przywództwa w organizacjach przez pryzmat cech, które mają charakteryzować przywódców, jest obecnie niewystarczające, gdyż współczesność wymaga definiowania organizacji co najmniej jako "organizacji profesjonalnej”, nie zaś jako „organizacji hierarchicznej". Badanie przy- 
wództwa wyłącznie z perspektywy cech wyróżniających "wielkich liderów” i z punktu widzenia koncepcji „organizacji profesjonalnej” nie sprawdziło się. Najpoważniejszym ograniczeniem myślenia o przywództwie z punktu widzenia cech lidera, zwłaszcza wówczas, gdy chcielibyśmy tego rodzaju badania prowadzić w organizacjach, jest brak uwzględnienia szerszego kontekstu funkcjonowania kierownika, co prowadzi do analizowania przywództwa bez odniesień kulturowych. Poza tym podejście to opiera się na mylnym założeniu, że głównym wyznacznikiem funkcjonowania lidera są stabilne i izolowane cechy osobowościowe lidera. Podejście to nie daje wskazówek co do tego, jak cechy te są ułożone (jak wiążą się ze sobą) oraz jakie powinno być ich natężenie.

Obecnie w badaniach nad przywództwem pojawia się zatem tendencja, by nie wyjaśniać skutecznych zachowań przywódcy za pomocą wyłącznie analizy określonych cech. Wyniki badań na temat korelacji pomiędzy analizowanymi cechami przywódcy a efektywnością przywództwa, pokazały, że korelacje te są zwykle słabe bądź co najwyżej umiarkowane, a więc cechy nie są w stanie samodzielnie wyjaśnić zbyt wiele, jeżeli idzie o sprawność przewodzenia. Pod uwagę bierze się zatem bardziej rozbudowane modele badawcze. Odchodzi się od podejścia statycznego, które zakładało, że ktoś jest taki, jaki się urodził. Kładzie się nacisk na dynamikę przywództwa i na możliwości modyfikowania zachowań lidera wraz z upływem czasu (Sternberg, 2005). Badacze starają się poszukiwać predykatorów (Zaccaro, 2007) funkcjonowania przywódców. Badania dowodzą, że warunkiem koniecznym efektywnego przywództwa są chociażby takie atrybuty, jak: osobowość, zdolności poznawcze, motywy i wartości czy też zdolności społeczne, sprawność w zakresie rozwiązywania problemów i wiedza ukryta/ ekspercka. Atrybuty te wzajemnie oddziałują na siebie i razem wzięte zapewniają skuteczność działania w większości sytuacji - niezależnie od dziedziny, w jakiej funkcjonuje przywódca.

Tak jak teorie cech znajdują obecnie coraz większe zainteresowanie, to teorie zachowań raczej nie cieszą się popularnością. W teoriach zachowań zakłada się, że zdolności przywódcze tkwią głównie w predyspozycjach do zachowania i w dużej mierze w samym zachowaniu. Jednak jedną z zasadniczych słabości behawioralnych koncepcji przywództwa jest, jak dowiódł Sternberg (2005), uproszczone rozumienie zachowania przejawiającego się przede wszystkim w nieuwzględnieniu kontekstu, w jakim zachowanie się odbywa. 
Pytając o działania i zachowania przywódców, warto przemyśleć, czy jest możliwe przedstawienie uniwersalnych zachowań skutecznych przywódców. Badania pokazały, że w analizie przywództwa autorzy skupiają się raczej na poszukiwaniu indywidualnych stylów przewodzenia oraz oceny ich sprawności i efektywności, niż na zachowaniach przywódców. Szukanie odpowiedzi na pytanie, jaki styl jest najskuteczniejszy, pozwoliły - jak to zostało pokazane - na sformułowanie dwóch kryteriów podziału, a mianowicie: orientację na zadania, pracę lub wyniki oraz orientację na ludzi i relacje. Na pytanie o to, dlaczego kierownik podejmuje decyzje bardziej nakierowane na ludzi lub na zadania, próbowano odpowiedzieć na gruncie tzw. sytuacyjnych koncepcji przywództwa, wśród których do najistotniejszych zaliczyć można takie propozycje, jak teoria dopasowanego przywódcy Freda Fiedlera, teoria sytuacyjnego kierowania Tannenbauma i Schmidta czy koncepcja Roberta Blake a i Jean Mouton. Wyniki badań dowodzą, że trudno jest wyodrębnić jeden, uniwersalny i skuteczny styl zachowania przywódcy, styl, który można byłoby wykorzystać niezależnie od wymagań zespołu oraz realizowanych zadań. Tego rodzaju sytuacja może utrudniać pracę kierownikom różnego szczebla i wszystkim aspirującym do pełnienia roli przywódczej. Muszą oni sami na własną odpowiedzialność zdecydować się na wybór właściwego stylu kierowania, w tym przewodzenia.

Odpowiedzi na pytania: „Co lepsze - więcej demokracji czy autokracji, a być może coś pomiędzy?", "Jaki styl przewodzenia wybrać i czy go zmieniać", zazwyczaj nastręczają, zwłaszcza osobom o małym doświadczeniu kierowniczym, wiele trudności. Wybór odpowiedniego stylu przewodzenia zależy nie tylko od właściwości sytuacji, ale w dużej mierze od cech osobowości przywódcy, cech i oczekiwań podwładnych, przyjętych w organizacji zasad postępowania, a także od oczekiwań i zachowań bezpośrednich przełożonych danego kierownika oraz jego kolegów.

Przegląd różnych poglądów na efektywność działań przywódczych pokazuje, że nie można wskazać idealnego stylu przewodzenia, który sprawdziłby się w każdym zespole. Dla przywódcy najistotniejsze jest uświadomienie sobie, jaki jest jego naturalny styl oraz jakie inne style mogą w danym zespole sprawdzać się lepiej. Przywódca, który ma świadomość swoich mocnych i słabych stron, może modyfikować swoje zachowanie i działania. Najłatwiejszą sytuację w tym przypadku mają przywódcy, o których współcześnie mówi się „przywódcy transforma- 
cyjni" - potrafią oni dostosować swój styl do istniejących warunków i nie zasklepiają się w jednym sposobie działania.

Teorie przywództwa, które koncentrują się na osobie przywódcy czy na jego zachowaniach, najczęściej łączą przywództwo z formalną władzą w organizacji. Tymczasem w wielu sytuacjach osoby z formalną władzą nie są prawdziwymi liderami w swoich organizacjach. Zdarza się, że trudno jest mówić o jednym „prawdziwym” liderze w organizacji, często można ich wyróżnić wielu.

W literaturze przedmiotu można spotkać wiele nowych koncepcji i modeli przywództwa oferujących praktyczne wskazówki dla osób, które podejmują się kierowania innymi. Jednak ukształtowany przez Johna Adaira już we wczesnych latach sześćdziesiątych ubiegłego wieku model przywództwa jest jednym z nielicznych modeli, który wytrzymuje próbę czasu i należy dziś do klasyki w teorii zarządzania. Model funkcji przywódczych Johna Adaira pokazuje, co przywódcy powinni robić, aby skutecznie wypełniać swoje role. Zgodnie z tym modelem przywódca powinien jednocześnie skupić się na trzech następujących zadaniach:

$\rightarrow$ wykonywanie zadań,

$\rightarrow$ budowanie i podtrzymywanie zespołu,

$\rightarrow$ pomoc w rozwoju członków zespołu.

Model ten pokazuje, że zbytnie skupienie się na zadaniu poprzez dążenie do uzyskania coraz lepszych wyników może oznaczać, że jednostki i/lub zespoły postrzegają swoje potrzeby jako niewiele znaczące dla przywódcy. I odwrotnie, zbytnia koncentracja na potrzebach osób, próby stałego zadowalania współpracowników i unikanie trudnych decyzji w sytuacjach tego wymagających mogą szybko doprowadzić do niskich osiągnięć.

Funkcjonalne teorie przywództwa powiązane są z „teorią potrzeb grupy" (Adair, 2007, s. 23). Ich uwaga bardziej jest skupiona na tym, jak przywództwo przejawia się w organizacji, jak realizowana jest funkcja przywódcza, niż kto przewodzi organizacjom. W obrębie tych teorii definiowane są i opisywane typy zachowań, które są ważne w przewodzeniu organizacji. W ramach teorii funkcjonalnych ważna jest dystrybucja przywództwa. Zakłada się tutaj, że każdy może brać udział w zarządzaniu organizacją.

Konkludując, warto podkreślić, że zdarza się, iż tzw. wielkie teorie są traktowane często a priori jako przebrzmiałe. Niemniej jednak, mogą 
one, dzięki nowym badaniom empirycznym, nabierać znowu blasku - ważne jest to, jakie stawiamy pytania badawcze. $Z$ drugiej strony należy uwzględnić fakt, że wszelkie dociekania naukowe nad przywództwem stale rozwijają się i pojawiają się coraz to nowe formy interpretacji zjawiska przywództwa, które powoli przekształcają się w koncepcje, a czasami i w teorie przywództwa. Świadczą o tym chociażby teorie przywództwa transformacyjnego, przywództwa partycypacyjnego, przywództwa służebnego i przywództwa opartego na kompetencjach (zob. Madalińska-Michalak, 2015).

\section{Przywództwo w organizacjach - ku partycypacji}

Namysł nad perspektywami badawczymi nad przywództwem kieruje naszą uwagę nie tylko w stronę poszukiwania definicji, istoty przywództwa, ale pokazuje, że w badaniach nad przywództwem niezmierne istotne jest pogłębienie odpowiedzi na pytanie o potrzebę czy wręcz zasadność przywództwa w organizacjach, w tym w szkołach.

Analizy w tym obszarze kierują naszą uwagę w stronę ewentualnych niebezpieczeństw, które mogą towarzyszyć przywództwu. Prace kwestionujące przywództwo czynią wyraźniejszymi pewne słabości przywództwa pojmowanego i praktykowanego w tradycyjny sposób (przywództwo przynależy się jedynie kierownikom najwyższego szczebla i wynika z racji pełnionej roli). Prace te przyniosły też ze sobą nowe spojrzenie na przywództwo. Współcześnie w ramach różnych nauk zajmujących się przywództwem podejmowane są rozważania na temat tego, jak przywództwo uwolnić od ewentualnych negatywnych właściwości, stąd pojawia się nowe spojrzenie na sprawy odpowiedzialności za przywództwo, o czym świadczą chociażby takie koncepcje, jak koncepcja przywództwa służebnego i przywództwa partycypacyjnego (zob. Madalińska-Michalak, 2015).

Najnowsze doniesienia badawcze pokazują, że jeśli odniesiemy przywództwo do formalnych organizacji, to przywództwo należy ściśle wiązać z zarządzaniem (Jeżowski, Madalińska-Michalak, 2015), zaś nowoczesny przywódca działa przede wszystkim dla dobra innych, wspiera rozwój innych i dba o ich dobrostan, stara się budować relacje oparte na zaufaniu, zrozumieniu, współpracy i odpowiedzialności za proces przywódczy i jego efekty. Jest on nie tylko projektantem przyszłości, ale w dużej mierze "nauczycielem" wspomagającym rozwój organizacji i jej pracowników, co szczególnie uwidacznia się w takich koncepcjach, 
jak przywództwo partycypacyjne, przywództwo służebne, przywództwo integralne czy też przywództwo racjonalne.

Obecnie sukcesy przywódców zależą o wiele bardziej od oryginalności rozwiązań problemów w danych sytuacjach niż od przestrzegania ściśle ustalonych recept dla rozwiązania tego czy innego problemu. Punktem wyjścia do ustanowienia najbardziej odpowiedniego stylu przywództwa, który może doprowadzić do sukcesu, jest przede wszystkim świadomość warunków, w jakich się działa, i dążenie do zrozumienia sytuacji, którym należy stawić czoła. W zależności od szeregu zmiennych w grę wchodzić mogą różne działania przywódcze. Jednak nie oznacza to, że nie istnieją naczelne zasady, które można byłoby zastosować do procesu przywódczego dziejącego się na przykład w organizacjach $\mathrm{i}$ ich otoczeniu.

Współcześnie autorzy są raczej zgodni co do tego, że przywództwo powiązane jest nie tyle $z$ działaniem osamotnionego przywódcy na szczycie organizacji, ile mówi o pracy kompetentnego kierownika, jednoczącego wysiłki wielu osób, ukierunkowanych zarówno na osiąganie pożądanych rezultatów przez organizację, jak i na kreowanie warunków sprzyjających atrakcyjności organizacji i jej jedności (Madalińska-Michalak, 2015). Tego rodzaju podejście ma ogromne znaczenie dla rozwoju myślenia i praktyk w zakresie przywództwa nieformalnego, a zwłaszcza interesującego nas przywództwa nauczycieli.

U podstaw przywództwa partycypacyjnego leżą dwa fundamentalne założenia. Pierwsze związane jest z uznaniem wolności i sprawczości każdej osoby, która pracuje w danej organizacji. Uznanie wolności pracownika mówi o tym, że nie można nikomu nic nakazać zrobić ani nikogo do niczego przymusić. Sprawczość to potencjalna możliwość wpływania pracownika na rzeczywistość. Sprawczość jest warunkiem zaangażowania i odpowiedzialności. Najlepszym sposobem motywowania jest ten, który wynika z rozumienia sensu własnej pracy, odpowiedzialności, sprawczości i decyzyjności w firmie oraz dostrzegania rezultatów własnej pracy. Tak określony system motywacyjny mówi o traktowaniu drugiego człowieka, bez względu na jego pozycję w organizacji, jako partnera.

Drugie z zasadniczych założeń mówi o konieczności skupiania się nie na tym, kim człowiek jest $w$ danej chwili, ale na tym, kim może się stać. W przywództwie partycypacyjnym podkreśla się wagę edukacji i rozwoju pracownika oraz dąży do tego, by rozwój indywidualny był 
zrównoważony z interesami firmy. W organizacjach, które są prowadzone przy pełnej partycypacji, każdy pracownik ma poczucie ogromnych możliwości wzrostu i rozwoju.

Te podstawowe założenia pokazują, jak duży kładzie się w nich nacisk na umiejętność wykorzystania potencjału podwładnych przez przywódcę. Umiejętność ta była często pomijana w różnych teoriach dotyczących przywództwa. Przywództwo partycypacyjne - jak słusznie pisze Czesław Sikorski (2006a) - mówi o przejściu „od przedmiotowego do podmiotowego traktowania podwładnych" (tamże, s. 37), co w praktyce przekłada się na wzmacnianie poczucia odpowiedzialności zarówno przywódcy, jak i jego zwolenników/podwładnych za odkrycie wartości współpracy wpisującej się w proces uczenia się przywódcy i jego zwolenników. Organizacje, w których dąży się do pełnej partycypacji, z reguły czynią swoich pracowników bardziej odpowiedzialnymi za znacznie więcej zadań niż tradycyjne. Idealni pracownicy to tacy, którzy dbają o wysoką jakość pracy i chcą nieustannie podnosić swoje kompetencje. Potrafią spojrzeć na organizację jako całość i dostrzec jej złożoność oraz wpływ własnej pracy na innych. Potrafią myśleć strategicznie i rozwiązywać problemy. Pełna partycypacja pozwala na zerwanie z czymś, co możemy określić mianem - jak zauważają Ryszard Stocki, Piotr Prokopowicz i Grzegorz Żmuda (2012) - „mentalności pracowniczej, która w najmniej drastycznej formie przejawia się jako skupianie się wyłącznie na niewielkim wycinku własnej pracy, a nie na myśleniu o organizacji jako całości, w najbardziej drastycznej zaś polega na całkowitym ignorowaniu interesu firmy lub nawet działaniu na jej niekorzyść" (tamże, s. 37).

Dla urzeczywistnienia pełnej partycypacji ważne są zaufanie, duma i zadowolenie z własnej pracy. Organizacja może osiągać sukcesy jedynie wówczas, gdy jej pracownicy są pełni pasji i zapału. Chcą osiągać sukcesy i są dumni z tego, co robią. "Chcąc walczyć i wygrywać, ludzie muszą także pragnąć tego, żeby ktoś inny dostrzegał to, co robią - muszą być dumni ze swojej pracy" (tamże, s. 42). Muszą chcieć pokazywać, gdzie pracują, jak pracują oraz jakie są efekty ich pracy.

\section{Przywództwo edukacyjne}

Silny wzrost zainteresowań naukowców problematyką przywództwa, z widocznymi oznakami wzrastającej popularności tej problematyki wśród praktyków edukacji w zderzeniu z sytuacją, w której wciąż ob- 
serwujemy pewien niedostatek opracowań wystarczająco wnikliwie podejmujących próbę naukowej interpretacji pojęcia, jakim jest przywództwo edukacyjne, stawia przed badaczami tej problematyki nie lada wyzwanie.

Pisząc o przywództwie edukacyjnym, warto raz jeszcze silnie podkreślić, że w ostatnich latach obraz przywództwa uległ diametralnej zmianie. Przywództwo przywykło się kojarzyć z biografiami wielkich ludzi, którzy mieli wpływ na losy świata, religię czy kierunek zmian politycznych i przemysłowych. Niemniej jednak najnowsze wyniki badań, uzyskane zwłaszcza na gruncie nauk o zarządzaniu i psychologii, pokazują rzeczywistą zmianę kierunku zainteresowań naukowych i poszukiwanie nowych narzędzi w rozwiązywaniu realnych problemów w organizacjach różnego typu. Podobna sytuacja ma miejsce na gruncie pedagogiki, na co wskazują chociażby w niniejszej książce autorzy jej poszczególnych tekstów, a zwłaszcza Julia Rößler i Michael Schratz w tekście „Przywództwo dla uczenia się. Nauczyciele-liderzy mediatorami innowacji i zmiany w szkole" czy Maria Assunção Flores w tekście "Przywództwo nauczycieli - perspektywy".

Biorąc pod uwagę różne teorie i koncepcje przywództwa oraz ich możliwe zastosowanie w praktyce edukacyjnej w szkole, należy podkreślić, że istniejące stanowiska teoretyczne odsłaniają niektóre sposoby opisywania kategorii „przywództwo”. Mogą one być w wysokim stopniu pomocne w myśleniu o przywództwie w szkole, co przejawia się chociażby w poszukiwaniu odpowiedzi na pytanie o skuteczne style przewodzenia w szkole czy o możliwość wykorzystania przywództwa służebnego, przywództwa partycypacyjnego i przywództwa opartego na kompetencjach. Jednak nie stanowią one gotowych do realizacji wzorców.

Istniejące, zarówno klasyczne, jak i współczesne modele przywództwa wymagają przemyślenia możliwości ich recepcji w obszarze pedagogiki. Złożoność i dynamika kontekstu, w którym funkcjonuje szkoła, oraz wielość teorii na temat przywództwa powodują, że trudno jest wskazać choćby jedną teorię "dobrego" przywództwa i jednocześnie pokazać, jak można ją wdrożyć do codziennego życia szkoły.

Nauczyciele i dyrektorzy, tworząc wspólnie społeczność szkoły, sami muszą odnaleźć swoją własną, najlepszą drogę do przywództwa. Uwzględnienie w obrazie przywództwa koncepcji lokowanych w obrębie teorii może ułatwić pracownikom oświaty konstruowanie 
wizji przywództwa w ich własnej szkole. Analiza sposobów podejścia do przywództwa we współczesnej szkole jest istotna, gdyż może stać się podstawą diagnozy dominujących ścieżek zachowań przywódców szkolnych oraz kierunków, w jakich zmierza przywództwo w polskich szkołach. Jednocześnie może pozwolić na określanie pożądanych kierunków przemian w zakresie przywództwa.

Ze względu na złożoność treści kryjących się za terminem „przywództwo", trudno jest stworzyć jednolitą definicję interesującego nas tutaj pojęcia, jakim jest "przywództwo edukacyjne". Przegląd rodzimej literatury przedmiotu z zakresu nauk o wychowaniu ewidentnie dowodzi, że jeszcze do niedawna w Polsce brakowało opracowań teoretycznych i badań empirycznych podejmujących problematykę przywództwa edukacyjnego, w tym przywództwa edukacyjnego dyrektora szkoły. Potrzeba dogłębnego spojrzenia na przywództwo edukacyjne i podjęcie próby zdefiniowania tego pojęcia oraz poszukiwania jego istoty jawi się obecnie jako niezmiernie istotna kwestia.

Atrakcyjność problematyki przywództwa edukacyjnego w kontekście poszukiwania jego istoty, znaczeń, dylematów, skuteczności i efektywności w odniesieniu do miejsca i czasu, w którym się ono wydarza lub ma wydarzyć, stwarza szansę na otwarcie się pedagogiki na współpracę z takimi dyscyplinami, jak: socjologia, filozofia, psychologia, historia, nauki o zarządzaniu, ekonomia czy prawo. Skupienie uwagi przez pedagogów na kategorii przywództwa edukacyjnego zwiększa możliwość przekraczania granic między dziedzinami nauki, minimalizacji różnic wytyczonych między dyscyplinami naukowymi czy obszarami badawczymi.

Prace naukowe z wykorzystaniem kategorii przywództwa edukacyjnego, które dotyczą szkoły, otwierają nowe i wartościowe poznawczo pola analiz teoretycznych oraz ukazują rozległy obszar badań empirycznych. Przywództwo edukacyjne prowokuje do stawiania pytań, podejmowania refleksji naukowych i badań, staje się źródłem inspiracji dla myślenia o pracy osób, które przewodzą innym: w naszym przypadku o pracy dyrektora szkoły i wyzwań, z jakimi mierzy się w szkolnej codzienności.

Zainteresowanie problematyką przywództwa edukacyjnego wynika ze znaczenia, jakie jest przypisywane temu zjawisku. Niezaprzeczalna wartość przywództwa edukacyjnego przejawia się w tym, że uwidacznia się ono w wartości życia szkolnego i działania na rzecz tej wartości, 
z nastawieniem na przyszłość przez wiązanie bieżących, dzisiejszych zadań z zadaniami, które będą realizowane w przyszłości ze względu na cele, do których się zmierza.

Przywództwo edukacyjne z pewnością ma to do siebie, że jego głównym polem działania jest sfera edukacji i z założenia ma ono służyć rozwojowi jednostek, instytucji (niekoniecznie muszą to być instytucje edukacyjne), organizacji czy społeczności poprzez osiąganie celów ustalonych przez przywódcę edukacyjnego i jego zwolenników.

Wieloznaczność pojęcia „przywództwo" uniemożliwia definitywne powiązanie tego pojęcia wyłącznie z rodzajem cech, przymiotów charakteryzujących przywódców, z rodzajem umiejętności, uzdolnień, zachowań przywódców czy też z relacjami społecznymi lub procesem społecznym. Podobnie ma się rzecz w odniesieniu do przywództwa edukacyjnego. Występujące $w$ literaturze przedmiotu różnice w zakresie definiowania pojęcia „przywództwo" biorą się z odmiennych punktów wyjścia w myśleniu o istocie przywództwa.

W ramach prac nad uściśleniem i pogłębieniem rozumienia przywództwa edukacyjnego proponuję odejść od postrzegania przywództwa edukacyjnego wyłącznie z określnej perspektywy myślenia o nim jako o zjawisku społecznym, które ma miejsce jedynie dzięki:

$\rightarrow$ przymiotom, cechom przywódcy uznawanym przez jego zwolenników w danym miejscu i czasie (przywództwo jako cecha),

$\rightarrow$ wrodzonym predyspozycjom $w$ dziedzinie przywództwa edukacyjnego i umiejętności ich wykorzystania w sprzyjających warunkach, aby być liderem (przywództwo jako uzdolnienie),

$\rightarrow$ doświadczeniu przywódczemu lidera edukacyjnego i jego kompetencjom (przywództwo jako umiejętność),

$\rightarrow$ zachowaniom przywódczym, oddziaływaniom na innych w różnych sytuacjach (przywództwo jako zachowanie),

$\rightarrow$ relacji wzajemnego oddziaływania na siebie przywódców i ich zwolenników (przywództwo jako relacja społeczna),

$\rightarrow$ ciągowi zmian, następujących po sobie w określonym czasie, mającym miejsce dzięki wpływowi przywódców na ich zwolenników w celu osiągania celów (przywództwo jako proces społeczny).

Każdy z tych punktów widzenia jest istotny w pracach nad pogłębieniem znaczenia przywództwa edukacyjnego i w próbach jego definiowania. Niemniej jednak proponuję w pierwszej kolejności wyjść 
od tego, co stanowi fundamentalny element konstruujący procesy edukacyjne już od ich zarania. Proponuję skoncentrować się na zagadnieniu relacji interpersonalnych i nieodłącznie wiążącej się z nim problematyki wpływu społecznego. Relacje interpersonalne rozważane w kontekście problemowym przywództwa dyrektora szkoły stanowią niezwykle interesujące zagadnienie, pozostawiające nadal wiele kwestii ad deliberandum. Spośród różnych rodzajów relacji interpersonalnych w szkole, w której dzieją się procesy edukacyjne, warto skupić się na relacjach między dyrektorem szkoły a jego podwładnymi lub na relacjach między dyrektorem szkoły a rodzicami uczniów. Jednocześnie uważam, że należy skupić się na procesualnym charakterze przywództwa i na rozumieniu przywództwa jako skomplikowanego procesu społecznego, który sprzyja osiąganiu przez jednostki lub grupy określonego celu.

Niewątpliwie jakość związków i więzi oraz zależności zachodzących pomiędzy dyrektorem szkoły a nauczycielami, członkami relacji interpersonalnych warunkuje przede wszystkim odpowiedzialność wobec siebie i odpowiedzialność wobec innych za budowanie tych relacji. $\mathrm{Na}$ jakość tych relacji rzutuje osobowość ich uczestników, a zwłaszcza ich predyspozycje, postawy i wzajemne aspiracje, wyznawane i ucieleśniane wartości, wymagania zadań, jakie stają do realizacji, a także sposoby realizacji obieranych celów. Wyrazem tego mogą być takie zjawiska sytuujące się w przestrzeni relacyjnej między dyrektorem szkoły a nauczycielami, jak na przykład: zaufanie, współpraca, życzliwość, kompromisowość, przychylność czy, niestety, irytacja, rygoryzm, podporządkowanie, agresja, wrogość, obojętność, konflikt, zerwany kontakt, manipulowanie, kontrolowanie, dystansowanie się i wiele, wiele innych. Wszędzie, gdzie ma miejsce relacja, którą - za filozofami dialogu - określić można jako relacja JA - TY, tam zakorzeniona jest etyka. W myśleniu o przywództwie edukacyjnym warto położyć nacisk nie tyle na stawiane od pewnego czasu w centrum zainteresowań zjawisko uczenia się, które cieszy się popularnością wraz z rozpowszechnianiem się idei społecznego konstruktywizmu w edukacji oraz dominującego w wymogach polityki oświatowej nastawienia na ocenę jakości szkoły poprzez ocenę uczenia się, ile na wartości, które stanowią o jakości relacji między ludźmi wchodzącymi ze sobą we wzajemne interakcje (zob. Biesta, 2014).

Przywództwo edukacyjne to zjawisko społeczne, intersubiektywne (międzypodmiotowe), którego podstawą są relacje pomiędzy przy- 
wódcą a jego zwolennikami oraz współdziałanie na rzecz osiągania uzgodnionych wspólnie celów, zamierzeń. W rozwijających się relacjach pomiędzy przywódcą a osobami, którym przewodzi, pojawiają się, rozciągnięte w czasie, określone odpowiedzi zwolenników przywódcy i osób, które niekoniecznie go popierają, na jego działania przywódcze oraz na jego cechy, przymioty czy umiejętności przywódcze.

Tak rozumiane przywództwo edukacyjne pokazuje, że powinniśmy je raczej kojarzyć z odpowiedzialnością za tworzenie warunków na rzecz zaangażowania innych w proces przywódczy oraz ze zdolnością pozyskiwania zwolenników, niż z funkcją i pozycją społeczną. Ponadto nie musi koniecznie - przynajmniej w teorii - obejmować ono autorytetu formalnego (autorytetu związanego ze stanowiskiem).

W pracach nad systematyzacją wiedzy na temat przywództwa edukacyjnego należy dążyć - poprzez wypracowanie określonych narzędzi analizy - do rozpoznawania złożoności tego pojęcia. Szczególna uwaga powinna być skierowana na poszukiwanie istoty przywództwa edukacyjnego, rozpoznanie jego wymiarów, atrybutów, funkcji i dysfunkcji, ukazanie jego odmian, określenie jego związków z innymi rodzajami przywództwa (np. przywództwo polityczne, przywództwo biznesowe, przywództwo religijne) czy też na określenie jego uwarunkowań, zwłaszcza wówczas, gdy mówimy o efektywnym lub skutecznym przywództwie edukacyjnym.

Konceptualizacja tego pojęcia w odniesieniu do szkoły, wymaga identyfikacji „podstawowych wymiarów, uwzględnienia specyfiki kierowania szkołą polegającej na współpracy nie tylko z jej pracownikami, ale też rodzicami, władzami samorządowymi i oświatowymi oraz szeroko rozumianym środowiskiem lokalnym - przy zachowaniu podmiotowej roli uczniów. Chodzi więc o przywództwo na wielu poziomach - wewnętrzne (w obrębie grup formalnych i nieformalnych funkcjonujących w szkole) i zewnętrzne (między dyrektorem i jego przedstawicielami - liderami grup, zespołów - a przedstawicielami instytucji zewnętrznych wobec szkoły)" (Kwiatkowski, Madalińska-Michalak, 2014, s. 5).

Zasadnicze dla teorii i praktyki pytania, wokół których warto koncentrować uwagę badawczą, biorąc pod uwagę przywództwo edukacyjne, można sformułować następująco:

$\rightarrow$ Co kryje się za tym pojęciem?

$\rightarrow$ Jaki zespół cech współoznacza to pojęcie?

$\rightarrow$ Czym jest przywództwo edukacyjne w jego ontycznym sensie? 
$\rightarrow$ Jakie są jego desygnaty, odpowiedniki jednostkowe w rzeczywistości?

$\rightarrow$ Kim są przywódcy edukacyjni, jakimi charakteryzują się cechami wyróżniającymi ich spośród innych osób?

$\rightarrow$ W jakich postaciach występuje przywództwo edukacyjne?

$\rightarrow$ W jakich sytuacjach przejawia się fenomen przywództwa edukacyjnego?

$\rightarrow$ Jakie wartości leżą u podstaw przywództwa edukacyjnego?

$\rightarrow$ Jakie są warunki przywództwa edukacyjnego?

Odpowiedzi na tak postawione pytania z pewnością przybliżą nas do zgłębienia istoty przywództwa edukacyjnego.

Prowadząc dociekania nad istotą przywództwa edukacyjnego, powinniśmy mieć na uwadze nie tylko wiedzę teoretyczną o tym fenomenie, zawierającą jego uzasadnienie tkwiące w określonych poglądach, podejściach teoretycznych czy stanowiskach, ale także sferę praktyki i wymiar przywództwa edukacyjnego, wpisujący się w życie codzienne organizacji, instytucji, różnych grup, środowisk i społeczności-miejsc, w których mamy do czynienia z tym przywództwem, i ludzi, którzy go doświadczają.

Badania nad istotą przywództwa edukacyjnego powinny skupiać się na udzieleniu odpowiedzi na pytanie: Czym w ogóle jest przywództwo edukacyjne, a czym przywództwo edukacyjne nie jest? Chcąc pojąć przywództwo edukacyjne w jego ogólności, należy wyeliminować wszelką jego jednostronną interpretację.

W badaniach nad przywództwem edukacyjnym ewidentnie wyłania się potrzeba holistycznego podejścia do tego fenomenu. Wszelkie próby zrozumienia przywództwa edukacyjnego poprzez rozłożenie go wyłącznie na elementy składowe nie oddają istoty sprawy, gdyż skupiając się na wybranych przez badaczy aspektach, postrzegają przywództwo edukacyjne jedynie przez pryzmat tychże aspektów.

Szczególna uwaga mogłaby być skierowana na relacyjny i procesualny aspekt tego fenomenu, a wraz z tym na:

$\rightarrow$ osoby zaangażowane $w$ proces przywództwa edukacyjnego i relacje wpływu pomiędzy nimi,

$\rightarrow$ więzi i sposoby ich budowania,

$\rightarrow$ cele i zadania przywództwa edukacyjnego,

$\rightarrow$ przedmiot przywództwa edukacyjnego, 
$\rightarrow$ sposoby osiągania celów, a zwłaszcza, biorąc pod uwagę dłuższą perspektywę czasu, strategie działań przywódczych,

$\rightarrow$ kontekst przywództwa edukacyjnego oraz

$\rightarrow$ wsparcie, jakie uzyskują przywódcy.

Niezmiernie inspirujące są pytania o wartości i warunki przywództwa edukacyjnego. To one otwierają nowe i szerokie możliwości dochodzenia do istotowości tego pojęcia i do ustalania jego konsekwencji praktycznych.

Myślę, że dobrze byłoby skupić uwagę na takich warunkach ontycznych, jak: miejsce, czas, wolność, władza, istnienie świadomego podmiotu, zdolnego do postrzegania wartości przywództwa edukacyjnego i płynących z nich powinności. Należałoby także zastanowić się równocześnie nad tym, co stanowi antytezę przywództwa edukacyjnego. Jak przejawia się ona w społecznej makro- i mikroskali, a jak w wymiarze psychologicznym? Jakie wynikają stąd wnioski dla teorii edukacji i praktyki pedagogicznej, zwłaszcza w kontekście przywództwa edukacyjnego dyrektora szkoły i przywództwa edukacyjnego nauczycieli?

\section{Podsumowanie}

Przywództwo staje się we współczesnej nauce kategorią interdyscyplinarną, w której tkwi olbrzymi ładunek poznawczy. Przegląd badań nad przywództwem odsłania bogate zaplecze teoretyczne tej kategorii i jednocześnie kłopoty z jej precyzyjnym określeniem.

Problematyka przywództwa coraz silniej przyciąga uwagę tych teoretyków, którzy zajmują się poznawaniem i wyjaśnianiem relacji międzyludzkich, zależności między cechami działania i zachowania ludzi, sposobów osiągania celów, zwłaszcza w formalnych organizacjach, czy też sposobów i zakresu harmonizowania działań zapewniających skuteczne wprowadzanie zmian i prawidłowe funkcjonowanie instytucji. Różne perspektywy oglądu przywództwa pokazują, że współcześnie trudno jest wyznaczyć choćby jedną, "dobrą" teorię przywództwa, z którą wszyscy by się zgadzali i wyprowadzić jedną, obowiązującą definicję tego pojęcia.

Chociaż nie ma dzisiaj wątpliwości co do roli, jaką mają odgrywać przywódcy na przykład $w$ formalnych organizacjach, i wręcz podkreśla się, że brak odpowiedniego przywództwa "może nawet w krótkim czasie doprowadzić dobrze funkcjonujące organizacje do kryzysu, którego 
skutki niezwykle trudno jest przezwyciężyć" (Mrówka, 2010, s. 11), to brakuje wśród teoretyków zgody co do tego, jakiego potrzebujemy przywództwa, jak powinni działać przywódcy czy też jakie funkcje powinni oni spełniać. Kwestie te stają się szczególnie istotne wówczas, gdy pod uwagę weźmiemy otoczenie, w jakim przyszło działać przywódcom i na rzecz, którego mają oni działać. Otoczenie różnego rodzaju organizacji, grup formalnych i nieformalnych, zarówno to bliższe (społeczeństwo lokalne), jak i dalsze (społeczeństwo globalne) staje się coraz bardziej "burzliwe" i zmienne, a wobec tego i nieprzewidywalne. Zmieniające się otoczenie wymusza na teoretykach problematyki przywództwa potrzebę ciągłego rewidowania założeń odnoszących się do tego fenomenu, zaś od praktyków wymaga umiejętności elastycznego odpowiadania na pojawiające się wyzwania.

Współcześnie potrzebujemy w organizacjach, w tym w organizacjach edukacyjnych, przywództwa, które będzie odpowiadało na wyzwania, z jakimi mierzy się organizacja $i$ jej otoczenie. Wyjście naprzeciw temu wyzwaniu jest możliwe jedynie wówczas, gdy w pełni będziemy rozumieć, na czym polega przywództwo i „po co być liderem”. Zrozumienie zjawiska przywództwa może pomóc w rozwijaniu organizacji oraz w określaniu kierunków działań zwiększających prawdopodobieństwo sukcesu organizacji.

Reasumując prowadzone tutaj rozważania, trzeba podkreślić, że pojęcie przywództwa edukacyjnego oraz fenomen tego zjawiska wciąż wydają się niewystarczająco opisane na gruncie nauk o wychowaniu. Jednocześnie przywództwo edukacyjne jest obecnie postrzegane jako niezmiernie pożądane w szkołach. Przypisuje się mu niezwykłą wartość, jaką jest bycie tą siłą napędową, która może poprowadzić szkołę do sukcesu. Dyrektorzy szkół, jako skuteczni przywódcy, często potrafią przygotować szkołę na zmierzanie się z sytuacjami trudnymi, na podejmowanie aktualnych i przyszłych wyzwań.

Pojawiają się zatem pytania: Jak przenieść znaczenie przywództwa edukacyjnego dyrektora szkoły na konkretne sytuacje w szkole jako miejscu pracy? Jak niekonfliktowo zestawić ze sobą przywództwo nauczycieli z przywództwem dyrektora szkoły? Czy osoba kierująca organizacją publiczną świadczącą jedną z usług publicznych może być postrzegana przez rodziców uczniów w roli przywódcy w sytuacji, gdy dla części z nich ich stosunek do szkoły jest zdystansowany lub wręcz wrogi? Na ile pożądane cechy przywódcy dopełniają walory oczekiwane 
od dyrektora zarządzającego, a w jakim stopniu wiedza z zakresu zarządzania wspomaga przywódcę w jego społecznej samorealizacji?

Badania nad przywództwem edukacyjnym odsłaniają nie tylko stan rozwoju teorii nad tym zjawiskiem, ale także potrzeby praktyki edukacyjnej w tym zakresie. Wyniki badań ewidentnie pokazują, że obecnie jednym z tematów, który wymaga szczególnej uwagi badawczej, jest przywództwo nauczycieli. 


\section{Bibliografia}

$\rightarrow$ Adair, J. (2007), Rozwijanie kompetencji przywódczych, tłum. M. Lany, Kraków: Wolters Kluwer business.

$\rightarrow$ Adair, J. (2001), Anatomia biznesu. Budowanie zespołu. Jak stworzyć dynamiczny zwycięski zespół, tłum. E. Czerwińska. Warszawa: Studio Emka.

$\rightarrow$ Avery, G.C. (2009), Przywództwo w organizacji: paradygmaty i studia przypadków, tłum. G. Dąbkowski, Warszawa: Polskie Wydawnictwo Ekonomiczne.

$\rightarrow$ Biesta, G.J.J. (2014), The Beautiful Risk of Education, Boulder: Paradigm Publishers.

$\rightarrow$ Jeżowski, A., Madalińska-Michalak, J. (2015), Dyrektor szkoły-koncepcje i wyzwania. Między teoriq i praktykq, Warszawa: ORE.

$\rightarrow$ Kwiatkowski, S.M., Madalińska-Michalak, J. (2014), Wstęp [w:] S.M. Kwiatkowski, J. Madalińska-Michalak (red.), Przywództwo edukacyjne - współczesne wyzwania, s. 5-6, Warszawa: Wolters Kluwer.

$\rightarrow$ Madalińska-Michalak, J. (2015), Dyrektor szkoły liderem - inspiracje i perspektywy, Warszawa: Wolters Kluwer.

$\rightarrow$ Madalińska-Michalak, J. (2013), Przywództwo edukacyjne: rola dyrektora w kreowaniu kultury organizacyjnej szkoły [w:] G. Mazurkiewicz (red.), Przywództwo i zmiana w edukacji, s. 23-45, Kraków: Wydawnictwo Uniwersytetu Jagiellońskiego.

$\rightarrow$ Madalińska-Michalak, J. (2012), Skuteczne przywództwo w szkołach na obszarach zaniedbanych społecznie. Studium porównawcze, Łódź: Wydawnictwo Uniwersytetu Łódzkiego.

$\rightarrow$ Mrówka, R. (2010), Przywództwo w organizacjach. Analiza najlepszych praktyk, Warszawa: Wolters Kluwer.

$\rightarrow$ Sikorski, C. (2006), Organizacje bez wodzów. Od przywództwo emocjonalnego do koordynacji demokratycznej, Warszawa: C.H. Beck. 
$\rightarrow$ Sternberg, R.J. (2005), WICS: A Model of Positive Educational Leadership Comprising Wisdom, Intelligence, and Creativity Synthesized, Educational Psychology Review, 17, 191-262.

$\rightarrow$ Stocki, R., Prokopowicz, P., Żmuda, G. (2012), Pełna partycypacja w zarzqdzaniu. Tajemnica sukcesu największych eksperymentów menedżerskich świata, Warszawa: Wolters Kluwer.

$\rightarrow$ Zaccaro, S.J. (2007), Trait-based perspectives of leadership, American Psychologist, 62, 6-12. 



\title{
Znaczenie przywództwa nauczycieli w przywództwie edukacyjnym
}

\author{
Roman Dorczak
}

Rozwój teorii i praktyki przywództwa w edukacji zmierza w kierunku zastąpienia podejść polegających na prostym transferze ogólnych teorii przywództwa, przez podejścia budujące specyficznie edukacyjne teorie przywództwa w oparciu o wartości kluczowe w edukacji. Potrzeba przywództwa nauczycieli wydaje się być kluczowym elementem określającym specyfikę przywództwa edukacyjnego z powodu uznania, że prymarnymi celami szkół jako organizacji są rozwój indywidualny i uczenie się uczniów. Warunkiem pozwalającym osiągać tak widziane cele jest aktywność przywódcza nauczycieli, którzy muszą umieć wywierać wpływ na innych członków zespołu, ale przede wszystkim na uczniów, by możliwy był rozwój zaangażowanych w procesy edukacyjne osób i służące mu uczenie się. Kompetencje przywódcze muszą więc stać się ważnym elementem tożsamości profesjonalnej nauczycieli budowanej od momentu przygotowania do zawodu.

\section{Słowa kluczowe:}

przywództwo edukacyjne

przywództwo nauczycieli

cele szkoły

wartości edukacyjne 


\section{The importance of teacher leadership in educational leadership}

Roman Dorczak

Development of theory and practice of leadership in education aims at replacement of simple attempts of transferring general leadership theories to education by attempts of building educationally specific theories based on key educational values. Teacher leadership seems to be a key element of such specific understanding of educational leadership because of the fact that central aims of schools as organizations are individual human development and learning. Teacher leadership activity is no doubt the main condition that allows to reach such goals. Teacher leaders have to influence their colleagues and students in such a way as to support development and learning. Leadership competencies have to become an important element of professional identity of teachers that develops starting from initial teacher training phase.

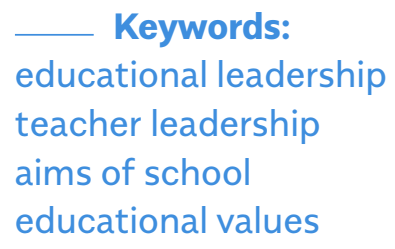




\section{Wprowadzenie}

W ostatnim czasie coraz wyraźniej w teorii i praktyce przywództwa w edukacji zaznacza się wątek przywództwa nauczycieli. Z jednej strony, zainteresowanie jest to wynik rozwoju teorii i praktyki zarządzania i przywództwa w edukacji i ciągłych poszukiwań czynników wpływających na jakość i efektywność pracy szkoły, który to rozwój, podobnie zresztą jak w ogólnej teorii zarządzania i przywództwa, zmierza w kierunku coraz wyraźniej akcentowanej potrzeby angażowania członków organizacji w procesy kierowania, jako koniecznego warunku dobrego funkcjonowania współczesnych złożonych organizacji. Z drugiej zaś strony, zainteresowanie to wydaje się być wynikiem rosnącej świadomości specyfiki procesów edukacyjnych i leżących u ich podstaw edukacyjnych wartości, które wymagają specyficznie edukacyjnych rozwiązań w obszarze teorii i praktyki zarządzania i przywództwa w edukacji.

Uznanie, że uczenie się i rozwój indywidualny to zasadnicze cele szkół jako organizacji oraz zrozumienie ich społecznej natury, w naturalny sposób doprowadziło do uznania przywództwa nauczycieli za kluczowy element składowy przywództwa edukacyjnego.

\section{Źródła i rozwój teorii przywództwa w edukacji}

Jak już wspomniano, można postawić tezę, że pojawienie się zainteresowania przywództwem nauczycieli jest wynikiem naturalnego rozwoju teorii i praktyki przywództwa w edukacji. Wzrastające zainteresowanie przywództwem zaobserwować można w edukacji i zarządzaniu edukacyjnym od kilku już dekad. Przywództwo staje się dla wielu odwołujących się do niego $w$ teorii i praktyce autorów, swego rodzaju odpowiedzią na problemy związane z kryzysem tradycyjnych menedżerskich podejść dominujących w myśleniu o kierowaniu w sferze edukacji od przełomu lat osiemdziesiątych i dziewięćdziesiątych XX wieku. Przywództwo wydało się być dla wielu z nich kluczem do poprawy funkcjonowania systemów edukacyjnych stawiających na wzrost jakości pracy szkół nastawionych na nauczanie i uczenie się uczniów (Pont, Nusche, Moorman, 2008; DuFour, Marzano, 2011).

Nadzieje pokładane w teorii i praktyce przywództwa okazały się w dużym stopniu słuszne, jak pokazały to liczne badania nad efektywnością systemów edukacji, prowadzone głównie w kręgu anglosaskim (Hellinger, Heck 1996; Leithwood i in., 2004). Należy jednocześnie za- 
uważyć, że samo odwołanie się do teorii przywództwa, podobnie zresztą jak wcześniejsze odwołanie się do teorii zarządzania, zakładające ich proste zastosowanie w budowaniu teorii i praktyki zarządzania w edukacji, wydaje się niewystarczające lub wręcz błędne i prowadzące do wypaczenia edukacyjnego sensu funkcjonowania szkół jako organizacji (Łuczyński, 2011). Podejścia takie, choć często wynikające z ważnych potrzeb szkół i całych systemów edukacyjnych, nie mogą w pełni właściwie odpowiadać na ich potrzeby jako szczególnych, z powodu swych prymarnych celów, organizacji (Jurkowski, 2000). Wymagają one bowiem specyficznego, adekwatnego do ich edukacyjnej natury, sposobu rozumienia przywództwa, które zbudowane być musi od podstaw z uwzględnieniem specyfiki szkół jako organizacji nastawionych na rozwój indywidualny i uczenie się uczniów.

Poszukiwanie takiego specyficznie edukacyjnego rozumienia przywództwa podejmowane było od dawna. Próby te dokonywały się na dwa różne sposoby, które określić można jako: transfer wybiórczy - polegający na przenoszeniu do sfery edukacji wybranych, „pasujących” do specyfiki sfery edukacji teorii przywództwa lub próby tworzenia nowych, specyficznie edukacyjnych teorii przywództwa (Dorczak, 2012b).

Pierwszy ze sposobów zakłada potrzebę (i zarazem możliwość) dopasowywania do potrzeb edukacji niektórych - odpowiednich i „pasujących" do edukacyjnego kontekstu teorii przywództwa. Podejście takie reprezentują choćby zwolennicy zastosowania w sferze edukacji koncepcji przywództwa transformacyjnego czy transformatywnego, kluczowych ich zdaniem z punktu widzenia potrzeb szkoły jako organizacji, która ciągle musi się zmieniać by odpowiadać na potrzeby współczesności (Precey, 2008) i wpływać na zmiany społeczne zapewniające osiąganie szerszych społecznych celów, w tym zapewnianie sprawiedliwości społecznej (Shields, 2009). Do tej grupy zaliczyć też można, szczególnie istotne $w$ edukacyjnym kontekście, próby zastosowania teorii przywództwa dystrybuowanego, partycypacyjnego, kolegialnego i innych podobnych, zwracających uwagę na potrzebę włączenia w procesy przywódcze szerszej grupy członków organizacji niż tylko formalni przywódcy (np. Gronn, 2002; Pearce, Conger, 2003; Bennett, Wise, Woods, Harvey, 2003). Należy zwrócić uwagę, że wprowadzenie tych ostatnich koncepcji do rozważań w obszarze przywództwa w edukacji stało się istotnym czynnikiem powodującym pojawienie się w nim kwestii przywództwa nauczycieli. 
Drugi z tych sposobów, polegający na budowaniu specyficznie edukacyjnej teorii przywództwa w oparciu o ważne edukacyjnie wartości, widać w takich choćby dawniej pojawiających się koncepcjach, jak przywództwo instrukcyjne (Hallinger, Murphy, 1985), koncentrujące się na procesach nauczania i czynnikach na nie wpływających, czy też przywództwo pedagogiczne (Evans, 1999), dla którego obok nastawienia na procesy uczenia się, ważne są też takie wartości, jak ogólnie rozumiany dobrostan ucznia i jego szeroko rozumiane bezpieczeństwo indywidualne.

W ostatnich latach pojawiły się dwa inne jeszcze rodzaje koncepcji, które odwołują się do centralnych w edukacji wartości, jakimi są uczenie się i rozwój indywidualny człowieka. Pierwszą z nich, jak się zdaje, dominującą w większości systemów edukacyjnych, jest teoria przywództwa dla uczenia się stawiająca tezę, że jest ono centralną i najważniejszą wartością w edukacji, na którą przywództwo edukacyjne musi się nastawiać (MacBeath, Dempster, 2009). Mniej popularne, choć zdaniem autora bardziej edukacyjnie adekwatne, są koncepcje postrzegające rozwój indywidualny człowieka (a nie uczenie się, które jest dla rozwoju tylko jednym z ważnych jego warunków) jako wartość centralną przywództwa edukacyjnego. Tak na przykład widzi przywództwo edukacyjne Michael Fielding (2006), nazywając je przywództwem skoncentrowanym na osobie, które tworzy w szkole czy też szerzej - w systemie edukacji, warunki rozwoju indywidualnego jednostki. Takie najbardziej adekwatne edukacyjnie widzenie przywództwa nazwać można najtrafniej przywództwem skoncentrowanym na rozwoju (Dorczak, 2012b). Postawienie w centrum zainteresowania teorii przywództwa edukacyjnego procesów uczenia się i rozwoju indywidualnego, które ze swej natury mają społeczny charakter i najlepiej przebiegać mogą w społecznej interakcji, stało się kolejnym powodem zainteresowania przywództwem nauczycieli, gdyż to nauczyciele właśnie są dla uczniów źródłem niezwykle istotnych z punktu widzenia rozwoju i uczenia się interakcji i doświadczeń.

\section{Kluczowe elementy przywództwa w edukacji}

Jak widać, w dyskusji o przywództwie w edukacji obecne są różne teorie i podejścia. Każde z nich bez wątpienia zwraca uwagę na istotny aspekt przywództwa, a jednocześnie każde jest jego niepełnym uchwyceniem. Z punktu widzenia przywództwa w edukacji można jednak wskazać 
elementy, które w związku ze specyfiką organizacji edukacyjnych i procesów w nich zachodzących, wydają się kluczowe i dla tego przywództwa niezbędne.

Po pierwsze, jak się zdaje, w kontekście edukacyjnym istnieje potrzeba rozumienia przywództwa raczej jako relacji i procesu społecznego niż jako umiejętności czy też cechy. Potrzebę takiego sposobu rozumienia postuluje wielu autorów zajmujących się przywództwem edukacyjnym, zwracając uwagę na okoliczność, że przywództwo w praktyce wyłania się $w$ relacji pomiędzy ludźmi i w toku rozwoju tej relacji kształtuje się jako społeczny w swej naturze i interaktywny proces (Mazurkiewicz, 2011; Madalińska-Michalak, 2013, 2015).

Podkreślić należy to, że istotą procesu przywództwa jest powodowanie tego, by poprzez wywieranie wpływu przez jednych ludzi na innych ludzi, który możliwy jest dzięki wchodzeniu w relacje, możliwe było dokonujące się $w$ toku tego procesu osiąganie celów organizacji (Northouse, 2007). Wpływ ten powinien dokonywać się w kontekście wartości uznanych za centralne i w ramach pewnej, spójnej z tymi wartościami wizji rzeczywistości (Bush, Bell, Middlewood, 2010). Jeśli zgodzimy się, że wartościami centralnymi i celami prymarnymi szkoły jest uczenie się i rozwój indywidualny uczniów, a następnie uznamy społeczną naturę tych procesów oznaczającą, że zachodzić mogą dobrze tylko $w$ relacji z innymi ludźmi, oczywisty staje się postulat widzenia przywództwa edukacyjnego jako procesu dokonującego się z udziałem wielu różnych podmiotów, w tym przywództwa wszystkich nauczycieli, a nie tylko jednoosobowo rozumianego i formalnie wyznaczonego przywódcy.

Takie spojrzenie stanowi drugą ważną cechę przywództwa w edukacji. Musi ono być przywództwem dzielonym wśród wielu członków organizacji, jaką jest szkoła. Jak wspomniano już wcześniej, koncepcje zwracające uwagę na ten wątek stały się bardzo popularne wśród zajmujących się przywództwem edukacyjnym, którzy odwoływali się do takich, powstałych w ogólnej teorii przywództwa koncepcji, jak na przykład przywództwo dystrybuowane, podzielane, partycypacyjne, kolegialne itp. Potrzeba takiego zespołowego w swej naturze przywództwa, angażującego możliwie wielu członków zespołu szkolnego, jest szczególnie widoczna z perspektywy praktyki przywództwa edukacyjnego w szkołach, gdzie na co dzień trzeba realizować skomplikowane zadania niemożliwe do wykonania bez aktywnego angażowania 
wielu różnych podmiotów w szkole i poza nią (Dorczak, 2012a). Nie jest to możliwe w warunkach jednoosobowego przywództwa związanego z formalnymi pozycjami kierowniczymi w szkole, stąd potrzeba takiego typu, jak opisywany w wymienionych wyżej koncepcjach, oraz przywództwa nauczycieli.

Trzecim wreszcie, niezbędnym dla przywództwa edukacyjnego elementem, który już wielokrotnie był przywoływany, jest kwestia centralnych wartości przywództwa edukacyjnego. Bez wątpienia są nimi (lub być powinny) uczenie się i rozwój indywidualny człowieka. I znów, należy podkreślić, że samo wskazanie tych wartości jako centralnych nie jest wystarczające, by właściwie skonstruować oparte na nich przywództwo. Problem polega na wieloznaczności tych pojęć wynikającej z istnienia różnych teorii uczenia się i rozwoju, obecnych zarówno w teoriach psychologicznych, jak i w umysłach ludzi edukacji.

Uczenie się jako proces można widzieć na co najmniej trzy różne sposoby. Po pierwsze, jako proces polegający na warunkowaniu, jak chcą to widzieć behawioryści; po drugie, jako proces stopniowego dojrzewania i kształtowania się struktur umysłowych, jak opisują go konstruktywiści; po trzecie wreszcie, jako interaktywny proces społecznej konstrukcji (i rekonstrukcji) wiedzy, jak widzą go społeczni konstruktywiści (por. Dumont, Istance, Benavides, 2013).

Podobnie rzecz ma się z teoriami rozwoju indywidualnego człowieka, które akcentują znaczenia czynników zewnętrznych warunkujących rozwój, jak teorie mechaniczne; wskazują na znaczenie procesów stopniowego ujawniania się określonej przez predyspozycje psychiki, jak widzą to teorie zwane teoriami dojrzewania; czy też wskazują, że rozwój to wynik twórczego procesu dialogu różnych czynników, określany głównie przez aktywność własną jednostki, jak widzą to teorie rozwoju autonomicznego (Dorczak, 2014).

Przyjęcie ostatniego z trzech wymienionych sposobów rozumienia uczenia się i rozwoju indywidualnego, jak się zdaje w świetle współczesnych teorii i badań psychologicznych - najtrafniejsze, oznacza jednocześnie konieczność przyjęcia, że warunkiem niezbędnym do zaistnienia tych procesów jest wejście $w$ interakcje $z$ innymi ludźmi, w tym szczególnie w interakcje z nauczycielami, których zadaniem w szkole jest wpływać na rozwój i uczenie się uczniów. Przyjmując, że przywództwo to wywieranie wpływu zmierzające do osiągania celów organizacji, znów niezbędne staje się tu przywództwo nauczycieli. 


\section{Przywództwo nauczycieli}

\section{jako istota przywództwa edukacyjnego}

Jak pokazano to wyżej, przywództwo nauczycieli jest kluczowym elementem adekwatnie do specyfiki sfery rozumianego przywództwa w edukacji, elementem, bez którego nie da się dobrze zrealizować zadań i osiągnąć celów szkoły jako organizacji.

$\mathrm{Na} z$ naczenie aktywnej, przywódczej roli nauczycieli dla rozwoju szkoły, pozwalającego osiągać stawiane jej jako organizacji cele, zwracają uwagę liczni autorzy, określając nauczycieli jako ciągle niewykorzystany, "uśpiony" kapitał organizacyjny, który musi być uruchomiony, jeśli chcemy stawiać czoła wyzwaniom współczesnej, niezwykle dynamicznej i jednocześnie złożonej rzeczywistości społecznej (Hargreaves, Fullan, 2012; Katzenmeyer, Moller, 2001).

Dla większości spośród postulujących przywództwo nauczycieli oznacza ono jednak tylko potrzebę formalnego wyznaczania szczegółowych ról i obowiązków określanych jako przywódcze (Lieberman, Friedrich, 2008), które muszą być delegowane lub zlecane niektórym nauczycielom zajmującym określone pozycje kierownicze, by poprawiać efektywność szkół w różnych sferach ich funkcjonowania. Często używa się tu określenia "nieformalne przywództwo nauczycieli", który to termin z jednej strony pozwala na mnożenie różnych zadań stawianych nauczycielom (York-Barr, Duke, 2004), z drugiej zaś obniża rangę przywództwa nauczycielskiego, jako czegoś gorszego od formalnego przywództwa pełniących funkcje kierownicze dyrektorów i innych członków formalnie powoływanych zespołów kierowniczych (Frost, 2014a).

Takie rozumienie przywództwa nauczycieli nie wydaje się edukacyjnie właściwe, jest raczej wyrazem prostego transferu sposobu rozumienia przywództwa dystrybuowanego z ogólnej teorii przywództwa, która rozwinęła się w kontekście organizacji gospodarczych. Ograniczanie rozumienia przywództwa nauczycieli do związanego z rolami kierowniczymi osób pełniących funkcję dyrektora i wybranych innych nauczycieli nie jest właściwe w kontekście szkoły jako organizacji (Hargraves, Fink, 2006; Madalińska-Michalak, 2012).

Właściwie rozumiane przywództwo nauczycieli, jeśli ma dobrze służyć prymarnemu celowi szkoły, jakim jest uczenie się i rozwój indywidualny wszystkich bez wyjątku uczniów, musi być przywództwem wszystkich bez wyjątku (traktując tę zasadę jako ideał) nauczycieli. Tylko wtedy może być przywództwem autentycznie edukacyjnym w swo- 
im profesjonalnym sensie (Frost, 2014b). Tylko wtedy też może w najlepszym możliwym stopniu przyczyniać się do osiągania przez uczniów sukcesów edukacyjnych, będąc - jak wiadomo - istotniejszym nawet czynnikiem tych osiągnięć niż społeczno-kulturowy status uczniów (Goddard, Hoy, Hoy, 2004). Taką potrzebę koncentracji nauczyciela przywódcy na rozwoju indywidualnym ucznia i wartościach, które mu służą, należy uznać za najważniejszy z aspektów określających cechy przywódcy nauczyciela, stojący ponad innymi istotnymi w jego działaniach aspektami, takimi jak na przykład dobre relacje i współpraca w zespole nauczycielskim, co dla wielu teoretyków przywództwa nauczycieli zdaje się być najważniejsze (Covey, 1989).

Swego rodzaju paradoksem jest fakt, że myśl o przywództwie każdego z nauczycieli, do tego takim przywództwie, które jest skoncentrowane na uczniu, jest właściwie obecna w edukacji od jej greckich (przynajmniej w naszym kręgu kulturowym) początków, gdzie nauczyciela określano mianem paidagogos, czyli "prowadzący dziecko" albo inaczej „przywódca” właśnie. Na taką rolę czy też funkcję nauczyciela zwracają współcześnie uwagę nieliczni autorzy zajmujący się kształceniem i rozwojem nauczycieli (Pielachowski, 2007), choć wydaje się to być kluczowym elementem profesjonalnej tożsamości nauczyciela.

Kompetencje przywódcze nauczycieli to zatem przede wszystkim kompetencje związane $z$ wywieraniem wpływu i kształtowaniem relacji z uczniem, jego uczeniem się i rozwojem indywidualnym. By dobrze kształtować te relacje, musi nauczyciel przywódca dobrze rozumieć podstawowe wartości edukacyjne, jakimi są rozwój indywidualny i uczenie się uczniów, by móc adekwatnie kształtować kulturę organizacyjną szkoły nastawionej na te wartości (Muhammad, Hollie, 2012).

Realizacja zadań przywódcy nauczyciela służących rozwojowi ucznia nie byłaby jednakże możliwa bez różnych innych kompetencji przywódczych składających się na pełną przywódczą tożsamość profesjonalną nauczyciela, które nie sposób tu wszystkie opisać. Wydaje się jednak, że należy podkreślić znaczenie co najmniej dwóch kluczowych zespołów kompetencji przywódczych ważnych dla skutecznego przywództwa nauczycieli w praktyce.

Pierwsze z nich związane są z relacjami w zespole nauczycielskim i takimi aspektami procesu przywódczego, które ujawniają się w pracy zespołowej i wspólnym uczeniu się profesjonalnym (Hunzicker, 2012). Przywódca nauczyciel jest nim (powinien być) zarówno w relacjach 
z uczniami, jak też kolegami z zespołu pedagogicznego, którzy wywierając wpływ nawzajem na siebie, tworzą warunki pozwalające budować profesjonalną kulturę organizacyjną nastawioną na rozwój indywidualny i uczenie się uczniów (Muhammad, 2009).

Drugi zespół kompetencji związany jest z koniecznością wchodzenia w relacje z innymi podmiotami poza szkołą i takiego kształtowania tych relacji, które służyć będzie realizacji celu, jakim jest rozwój indywidualny i uczenie się uczniów w szkole. Nauczyciel przywódca, musi stawać się przywódcą w społeczności lokalnej i w różnych sytuacjach społecznych ważnych dla funkcjonowania szkoły, bo tylko wtedy będzie tworzył dobre warunki dla rozwoju szeroko rozumianego potencjału i kompetencji uczniów jako aktywnych członków tejże społeczności (Mazurkiewicz, 2011; Kaczmarek-Śliwińska, Szczudlińska-Kanoś, 2015).

Przywództwo nauczycieli zbudowane na fundamencie z tych trzech rodzajów kompetencji uznać należy za kluczowy element przywództwa w edukacji w ogóle. Takie przywództwo może pozwolić na najlepszą realizację celów szkół jako organizacji mających służyć przede wszystkim rozwojowi indywidualnemu i uczeniu się uczniów.

\section{Zakończenie}

Należy zdecydowanie stwierdzić, że rozwój szkół i podnoszenie poziomu jakości ich pracy zależy wręcz od wzrostu poziomu profesjonalizmu nauczycieli, którego kluczowym elementem składowym jest rozwój ich potencjału przywódczego (Fullan, 1993). A to w istniejącym kontekście społeczno-politycznym forsującym wąsko rozumiane cele szkoły nie jest zadaniem prostym, ale niezbędnym, jeśli szkoła ma być źródłem czy wręcz motorem społecznej zmiany (Fullan, 1994).

Wymaga to uznania wagi kompetencji przywódczych nauczycieli i zbudowania systemu wsparcia rozwoju tych kompetencji zarówno na etapie przygotowania do zawodu nauczycielskiego, jak też w toku pracy zawodowej w ramach rozwoju i doskonalenia zawodowego nauczycieli. Niestety, istniejące sposoby przygotowania i rozwoju zawodowego nauczycieli ignorują kwestię przywództwa, koncentrując się mocno na kompetencjach przedmiotowych oraz dydaktycznych, stawiając sobie za cel przygotowanie nauczyciela przedmiotu, a nie nauczyciela uczącego i wspomagającego wszechstronny rozwój ucznia. Zadanie rozwoju kompetencji przywódczych nauczycieli ciągle jest zadaniem, które stoi przed przyszłymi reformatorami edukacji. 


\section{Bibliografia}

$\rightarrow$ Bennett, N., Wise, Ch., Woods, P., Harvey, J.A. (2003), Distributed Leadership, Nottingham: National College for School Leadership.

$\rightarrow$ Bush, T., Bell, L., Middlewood, D. (2010), The Principles of Educational Leadership and Management, 4th Edition, Los Angeles: Sage.

$\rightarrow$ Covey, S.R. (1989), The Seven Habits of Highly Effective People. Restoring the Character Ethic, New York: Simon \& Schuster.

$\rightarrow$ Dorczak, R. (2014), Rozwój jako wartość centralna w profesjonalnym systemie normatywnym nauczyciela - sposoby rozumienia i ich praktyczne konsekwencje [w:] G. Mazurkiewicz (red.), Edukacja jako odpowiedź. Odpowiedzialni nauczyciele w zmieniającym się świecie, s. 133-147, Kraków: Wydawnictwo Uniwersytetu Jagiellońskiego.

$\rightarrow$ Dorczak, R. (2013), Modele współpracy szkoły z organizacjami w środowisku lokalnym [w:] G. Mazurkiewicz (red.), Jakość edukacji. Różnorodne perspektywy, s. 311-331, Kraków: Wydawnictwo Uniwersytetu Jagiellońskiego.

$\rightarrow$ Dorczak, R. (2012a), Developmental leadership - an attempt to define specificity of educational leadership, Zarządzanie Publiczne. Zeszyty Naukowe Instytutu Spraw Publicznych UJ, 4, 19-26.

$\rightarrow$ Dorczak, R. (2012b), Specyfika zarzq̨dzania w edukacji-rozwój indywidualny człowieka jako wartość centralna, Zarządzanie Publiczne. Zeszyty Naukowe Instytutu Spraw Publicznych UJ, 3(19), 39-47.

$\rightarrow$ DuFour, R., Marzano, R.J. (2011), Leaders of Learning: How District, School, and Classroom Leaders Improve Student Achievement, Bloomington: Solution Tree Press.

$\rightarrow$ Dumont, H., Istance, D., Benavides, F. (2013), Istota uczenia się. Wykorzystanie wyników badań w praktyce, Warszawa: Wolters Kluwer.

$\rightarrow$ Evans, R. (1999), The Pedagogic Principal, Edmonton: Qual. Institute Press. 
$\rightarrow$ Fielding, M. (2006), Leadership, radical students engagement and the necessity of person-centred education, International Journal of Leadership in Education, 9, 299-313.

$\rightarrow$ Frost, D. (2014a), Changing teacher professionality through support for teacher leadership in Europe and beyond, ECER 2014, Conference paper.

$\rightarrow$ Frost, D. (red.) (2014b), Transforming Education through Teacher Leadership. Leadership for Learning, Cambridge: Cambridge University.

$\rightarrow$ Goddard, R.D., Hoy, W.K., Hoy, A.W. (2004), Collective efficacy belief. Theoretical developments, empirical evidence and future directions, Educational Researcher, 33(3), 3-13.

$\rightarrow$ Gronn, P. (2002), Distributed leadership as a unit of analysis, Leadership Quarterly, 13 (4), 423-451.

$\rightarrow$ Hallinger P., Heck, R. (1996), Reassessing the principal's role in school effectiveness: A review of empirical research, 1980-1995, Educational Administration Quarterly, 32 (15), 5-44.

$\rightarrow$ Hallinger, P., Murphy, J. (1985), Assessing the instructional management behaviour of principals, The Elementary School Journal, 86(2), 217-248.

$\rightarrow$ Hargreaves, A., Fink, D. (2006), Sustainable leadership. San Francisco: Jossey-Bass.

$\rightarrow$ Hargreaves, A., Fullan, M. (2012), Professional capital. Transforming teaching in every school, New York: Teachers College Press.

$\rightarrow$ Hunzicker, J. (2012), Professional development and job-embedded collaboration: how teachers learn to exercise leadership, Professional Development in Education, 38(2), 267-289.

$\rightarrow$ Jurkowski, A. (2000), Ewaluacja psychologiczna oświaty w dobie przemian - postulaty i sugestie, Psychologia Rozwojowa, 5(1-2), 37-48.

$\rightarrow$ Kaczmarek-Śliwińska, M., Szczudlińska-Kanoś, A. (2015), Dyrektor szkoły jako lider w środowisku lokalnym [w:] G. Mazurkiewicz (red.), Przywództwo edukacyjne. Zaproszenie do dialogu, s. 107-119, Kraków: Wydawnictwo Uniwersytetu Jagiellońskiego.

$\rightarrow$ Katzenmeyer, M., Moller, G. (2001), Awakening the Sleeping Giant. Helping Teachers Develop as Leaders, Thousand Oaks, CA: Corwin Press.

$\rightarrow$ Lieberman, A., Friedrich, L. (2008), Changing teaching from within: Teachers as leaders [w:] J. MacBeath, Y.C. Cheng (red.), Leadership for Learning. International Perspectives, s. 41-64, Rotterdam: and Taipei Sense Publishers.

$\rightarrow$ Łuczyński. J. (2011), Zarządzanie edukacyjne a wychowanie uczniów w szkole, Kraków: Wydawnictwo Uniwersytetu Jagiellońskiego. 
$\rightarrow$ MacBeath, J., Dempster, N. (red.) (2009), Connecting Leadership and Learning: Principles for Practice, London, New York: Routledge.

$\rightarrow$ Madalińska-Michalak, J. (2015), Dyrektor szkoły liderem - inspiracje i perspektywy, Warszawa: Wolters Kluwer.

$\rightarrow$ Madalińska-Michalak, J. (2013), Przywództwo edukacyjne: rola dyrektora w kreowaniu kultury organizacyjnej szkoły [w:] G. Mazurkiewicz (red.), Przywództwo i zmiana w edukacji, s. 23-45, Kraków: Wydawnictwo Uniwersytetu Jagiellońskiego.

$\rightarrow$ Madalińska-Michalak, J. (2012), Skuteczne przywództwo w szkołach na obszarach zaniedbanych społecznie. Studium porównawcze, Łódź: Wydawnictwo Uniwersytetu Łódzkiego.

$\rightarrow$ Mazurkiewicz, G. (2011), Przywództwo edukacyjne. Odpowiedzialne zarządzanie edukacjq wobec wyzwań współczesności, Kraków: Wydawnictwo Uniwersytetu Jagiellońskiego.

$\rightarrow$ Muhammad, A. (2009), Transforming School Culture: How to Overcome Staff Division (Leadership strategies to build a professional learning culture), Bloomington: Solution Tree Press.

$\rightarrow$ Muhammad, A., Hollie, S. (2012), The Will to Lead, the Skill to Teach. Transforming Schools at Every Level, Bloomington: Solution Tree Press.

$\rightarrow$ Northouse, P.G. (2007), Leadership: Theory and Practice, Thousand Oaks, London, New Delhi: Sage Publications.

$\rightarrow$ Pearce, C.L., Conger, J.A. (red.) (2003), Shared leadership, Thousand Oaks, CA: Sage.

$\rightarrow$ Pielachowski, J. (2007), Organizacja, kierowanie i nadzór pedagogiczny w szkole, Poznań: Wydawnictwo eMPi².

$\rightarrow$ Pont, B., Nusche, D., Moorman, H. (2008), Improving Shool Leadership, vol. 1: Policy and practice, Paris: OECD Publishing.

$\rightarrow$ Precey, R. (2008), Transformational school leadership development: What works?, Journal of Research in Professional Development, 1, 4-20. 



\section{Przywództwo edukacyjne w kontekście więzi społecznych \\ specyficznych dla grup (podgrup) \\ wewnątrzszkolnych}

Stefan M. Kwiatkowski

Tekst dotyczy problematyki więzi społecznych występujących w społeczności szkolnej. Wyróżniono specyficzne dla szkoły podgrupy nauczycieli, uczniów, pracowników administracji i rodziców. Na tak zarysowanym tle wskazano możliwości i warunki skutecznego przywództwa w szkole i w funkcjonujących w niej podgrupach.

__ Słowa kluczowe:

przywództwo edukacyjne

więzi społeczne

więzi obiektywne

więzi subiektywne i behawioralne 


\section{Educational leadership in the context \\ of social ties specific \\ to in-school groups (subgroups)}

Stefan M. Kwiatkowski

The text concerns the issues of social ties in the school community. A school-specific subgroups of teachers, students, administrators, and parents were distinguished. On that background the opportunities and conditions for effective leadership in the school and its subgroups were illustrated.

\section{Keywords:}

educational leadership

social ties

objective ties

subjective and behavioral ties 


\section{Wprowadzenie}

Fenomen przywództwa jest znakiem współczesności - z jej całą złożonością i nieprzewidywalnością. Trudności obiektywne, ale też subiektywne, wynikające ze skomplikowanej materii funkcjonowania w zmieniającej się niezwykle dynamicznie rzeczywistości społecznej oraz gospodarczej sprawiają, iż poszukujemy osób, które potrafią uporządkować i nadać odpowiednią strukturę naszej wiedzy o bliższym i dalszym otoczeniu, a także wskazać drogi rozwiązywania pojawiających się problemów. Innymi słowy, poszukujemy przywódców, którym można zaufać i pod ich kierownictwem osiągać cele indywidualne i grupowe. Chcielibyśmy, by mieli oni szczególne cechy, które wyróżniają ich spośród danej zbiorowości, by byli osobami wybitnymi, godnymi szacunku, o dużym prestiżu wynikającym z dotychczasowych sukcesów zawodowych (Wren, 2005, s. 98-100).

Niezbędność przywódców odczuwamy we wszystkich obszarach życia. Jeszcze do niedawna dominowały $w$ tym względzie sfery gospodarcze, w których właściwie rozumiane przywództwo jest warunkiem odniesienia sukcesu w procesie produkcji i świadczenia usług na konkurencyjnym rynku. Obecnie coraz częściej zauważana i artykułowana jest potrzeba efektywnego przywództwa również poza szeroko pojętą gospodarką, w tym w edukacji - na wszystkich jej poziomach (Madalińska-Michalak, 2012, 2015).

W takim ujęciu przywództwo edukacyjne jest jednym z wielu dających się wyróżnić podzbiorów przywództwa, w tym przypadku ograniczonego do oddziaływań występujących w placówkach edukacyjnych. Jest to zatem rodzaj przywództwa definiowanego przez teren działań grup (podgrup) funkcjonujących w tych placówkach.

Rozpatrywanie przywództwa edukacyjnego w kategorii podzbioru przywództwa pozwala z jednej strony na odwoływanie się do ogólnych prawidłowości związanych z wywieraniem wpływu przez przywódców na osoby będące w ich otoczeniu, z drugiej zaś na akcentowanie znaczenia oddziaływań specyficznych dla obszaru edukacji (Michalak, 2006, s. 64-66).

Jeżeli przywództwo edukacyjne analizujemy z poziomu szkoły, to należy zastanowić się, jakie grupy (podgrupy) można w niej zidentyfikować i jaki jest dominujący typ więzi społecznych między ich członkami. Od nich zależy bowiem efektywność przywództwa w każdej z grup (podgrup), a także przywództwa, które przekracza ich ramy. 


\section{Grupy wewnątrzszkolne}

Z socjologicznego punktu widzenia szkołę zaliczamy do organizacji społecznych mających cechy grupy zorganizowanej, w której interakcje między poszczególnymi podgrupami i wewnątrz podgrup mają charakter normatywny. Wynika to ze specyfiki funkcjonowania szkoły, szczególnie z precyzyjnego rozróżnienia pozycji podgrup, ich ról i sposobów kontroli realizacji zadań (Sztompka, 2004, s. 191).

Społeczność szkolna, czyli najogólniej rzecz ujmując, nauczyciele, uczniowie i pracownicy administracyjni, ale także rodzice, może tworzyć dwa rodzaje grup - wielkie i małe. $W$ grupach wielkich ich członkowie na ogół słabo się znają, są w dużej mierze anonimowi. Interakcje między nimi w praktyce nie występują lub zamykają się w podgrupach. $Z$ taką sytuacją mamy do czynienia w przypadku dużych szkół, a także zespołów szkół. Na drugim biegunie sytuują się grupy małe - niezbyt liczne, które sprzyjają bliższym kontaktom i wynikającym z nich interakcjom.

Jest rzeczą oczywistą, że interesujące nas przywództwo edukacyjne ma inne cechy w grupie wielkiej i w grupie małej. Przywództwo w dużej zbiorowości jest z reguły częściowo delegowane na innych członków grupy. W takiej sytuacji nie ma możliwości i okazji do bezpośredniego poznania przywódcy, nawet jeśli brało się udział w jego wyborze. Inaczej jest w małej zbiorowości, w której wszyscy dobrze się znają i mają codzienny, bezpośredni kontakt z przywódcą. Mogą wówczas dyskutować z nim i wpływać na kształt podejmowanych decyzji, co w przypadku dużej zbiorowości jest mało realne.

Niezależnie od tego, czy społeczność szkolna tworzy grupę wielką, czy małą, są to przeważnie grupy trwałe, zachowujące - mimo zmian składu (przede wszystkim w podgrupach uczniów i rodziców) - ciągłość i tożsamość. Jest to możliwe dzięki swoistej tradycji szkoły wyrażanej przez jej organizację i kulturę pracy. W szkole, jak w każdej grupie społecznej, mogą występować również podgrupy, w których dominują sporadyczne kontakty - związane np. z udziałem w wycieczce szkolnej czy też incydentalnymi działaniami na rzecz szkoły (przygotowywanie uroczystości szkolnych i imprez sportowych). W każdym z tych przypadków mamy do czynienia $z$ innym typem przywództwa: długookresowym lub krótkookresowym, a także generacyjnym lub transgeneracyjnym (Kwiatkowski, 2011, s. 17-18).

Szkoła rozpatrywana jako grupa społeczna jest coraz częściej postrzegana jako elitarna lub egalitarna. Elitarność lub egalitarność odnosi 
się w pierwszej kolejności do podgrup nauczycieli i uczniów. Szkoła elitarna stawia przed kandydatami na nauczycieli, a następnie przed nauczycielami określone, często wysokie i trudne do spełnienia wymagania. Wybór najlepszych, według przyjętego w takiej szkole kryterium, nauczycieli, a także uczniów jest rodzajem bariery, wysoko zawieszonej poprzeczki. W szkole o charakterze egalitarnym takie ograniczenia nie występują - nie ma w niej żadnych standardów związanych z wiedzą, umiejętnościami i kompetencjami społecznymi uczniów - kandydatów do nauki w tego typu placówce. Nie występują także specjalne oczekiwania formułowane w stosunku do nauczycieli. Inaczej mówiąc, łatwo w takiej szkole podjąć pracę i rozpocząć naukę. Pochodną wyróżnionych typów szkół jest rodzaj przywództwa - inny w szkole elitarnej i inny w szkole egalitarnej. Różne są także mechanizmy wyłaniania przywódców, szczególnie wśród nauczycieli.

Analizując szkołę z perspektywy grupy społecznej, warto zauważyć, że wyróżnione wyżej podgrupy nauczycieli i uczniów, a także pracowników administracji szkolnej i rodziców mają swoją wewnętrzną strukturę. Tworzą ją:

$\rightarrow$ w podgrupie nauczycieli:

- dyrektor (dyrektorzy),

- nauczyciele zróżnicowani według stopnia awansu zawodowego (stażyści, kontraktowi, mianowani i dyplomowani),

- członkowie zespołów przedmiotowych,

- nauczyciele teoretycznych i praktycznych przedmiotów zawodowych (w szkołach zawodowych),

- wychowawcy,

- członkowie rady szkoły;

$\rightarrow$ w podgrupie uczniów:

- uczniowie poszczególnych klas i roczników,

- członkowie samorządu uczniowskiego,

- członkowie zespołów artystycznych i sportowych,

- członkowie rady szkoły;

$\rightarrow$ w podgrupie pracowników administracyjnych:

- pracownicy sekretariatów,

- pracownicy techniczni;

$\rightarrow$ w podgrupie rodziców:

- członkowie rady szkoły,

- członkowie rady rodziców. 
Przywództwo w szkole, rozumiane jako umiejętność łączenia często sprzecznych interesów wyróżnionych przez nas podgrup, wymaga właściwych relacji między przywódcami (formalnymi i nieformalnymi) a członkami ich podgrup oraz między samymi przywódcami. Różne rodzaje relacji natury psychologicznej, charakterystyczne dla analizowanego kontekstu ujmuje te oria in terakcyjna wyjaśniająca mechanizmy zależności i identyfikacji podwładnych z przywódcą (Jakubowska, 2002, s. 100-105).

Każdą z tych wyróżnionych wyżej podgrup, po niezbędnych modyfikacjach i uzupełnieniach (związanych np. z uwzględnieniem relacji towarzyskich), można rozpatrywać pod kątem różnych kryteriów. Z perspektywy przywództwa edukacyjnego podstawowe znaczenie ma podział na podgrupy jednorodne i niejednorodne.

Nauczyciele z reguły są podgrupą niejednorodną. Łączy ich poziom wykształcenia, ale różni kierunek ukończonych studiów, staż pracy, miejsce w hierarchii zawodowej (stopień awansu zawodowego), a także status społeczny rodziny - uzależniony w dużej mierze od pozycji zawodowej współmałżonka.

Najbardziej jednorodną podgrupę tworzą uczniowie, ale również wśród nich mogą znajdować się tacy, którzy mają różnego rodzaju dysfunkcje (znajdujące swój wyraz w specjalnych potrzebach edukacyjnych). Mogą się także różnić podejściem do samodzielnego uczenia się oraz zainteresowaniami i zdolnościami.

Stosunkowo mniejszą wagę przypisujemy na ogół jednorodności lub jej brakowi w podgrupie pracowników administracyjnych szkoły. Jest to być może uzasadnione w małych szkołach - w małych grupach społecznych. Jednakże w dużych szkołach (w wielkich grupach) społeczność tworząca administrację szkolną jest stosunkowo liczna i silnie zróżnicowana pod względem wykształcenia i stopnia identyfikacji ze szkołą. Poza tym pracownicy, którzy nie są nauczycielami, zatrudnieni w szkołach prowadzonych przez jednostki samorządu terytorialnego są pracownikami samorządowymi.

Bardzo zróżnicowaną podgrupę stanowią także rodzice. Chodzi przy tym nie tylko o ich wykształcenie i status społeczny, ale też o wyobrażenie o predyspozycjach własnych dzieci oraz stosunek do szkoły jako instytucji. Istotnym problemem jest wzbudzenie zainteresowania rodziców codziennym funkcjonowaniem szkoły, włączanie ich do współdziałania z dyrekcją i nauczycielami. Również interakcje między 
rodzicami są bardzo ograniczone, mimo że sprzyjają temu, przynajmniej teoretycznie, odpowiednie rozwiązania formalno-prawne.

Efektywność przywództwa edukacyjnego jest niewątpliwie pochodną:

$\rightarrow$ wieku (nauczycieli i uczniów),

$\rightarrow$ doświadczenia zawodowego (nauczycieli i rodziców),

$\rightarrow$ statusu zawodowego (nauczycieli i rodziców),

$\rightarrow$ zaangażowania i motywacji (nauczycieli, uczniów, pracowników administracji szkolnej i rodziców).

Wartości wyróżnionych zmiennych, traktowanych jako zmienne niezależne, wpływają w pierwszej kolejności na jednorodność (lub jej brak) rozpatrywanej podgrupy, a następnie na możliwy do zastosowania styl przywództwa - autokratyczny, demokratyczny lub permisywny (Schultz, Schultz, 2002, s. 251).

\section{Więzi społeczne w grupie i podgrupach}

\section{wewnątrzszkolnych - uwagi ogólne}

W szkole, jako w grupie zorganizowanej, można wyróżnić więzi występujące między wszystkimi uczestnikami życia społecznego, więzi między członkami podstawowych podgrup oraz więzi wewnątrz poszczególnych podgrup. W każdym z tych przypadków więź jest rodzajem interakcji specyficznej dla relacji między pracownikami szkoły, uczniami i ich rodzicami.

Budowanie więzi społecznych w szkole jest procesem, którego efekty zależą od wielu wzajemnie ze sobą powiązanych czynników. Do najbardziej znaczących można zaliczyć:

$\rightarrow$ ogólną akceptację grupy (szkoły i jej klimatu) przez wszystkich jej członków,

$\rightarrow$ pierwsze wrażenie wynikające ze wstępnych kontaktów z członkami grupy, a szczególnie własnej podgrupy,

$\rightarrow$ nastawienie prospołeczne członków grupy (chęć wspólnego działania, świadomość własnej roli, otwartość na innych, akceptacja ich zachowań, zgoda na błędy połączona z kredytem zaufania),

$\rightarrow$ znajomość hierarchii wartości członków własnej podgrupy i innych podgrup, 
$\rightarrow$ wspólne rozwiązywanie problemów (w całej grupie lub w podgrupach) istotnych dla szkoły,

$\rightarrow$ gotowość do częściowej rezygnacji z celów indywidualnych na rzecz celów wspólnych,

$\rightarrow$ rodzaj kontaktów (bezpośredni - pośredni, werbalny - niewerbalny).

W procesie, o którym mowa, można wyróżnić kilka podstawowych etapów wynikających z chronologii zdarzeń:

$\rightarrow$ wzajemne poznanie się w grupie i w podgrupach (wymiana informacji o sobie, o przebytej drodze edukacyjnej lub zawodowej, o osiągnięciach i porażkach),

$\rightarrow$ nawiązywanie współpracy (najpierw we własnej podgrupie, a następnie między członkami innych podgrup),

$\rightarrow$ ustalanie wspólnych celów działań (dydaktycznych, opiekuńczo-wychowawczych, infrastrukturalnych i organizacyjnych),

$\rightarrow$ działanie wewnątrz podgrup i na forum całej szkoły (identyfikacja postaw, zdolności i wytrwałości oraz kompetencji społecznych poszczególnych członków własnej podgrupy, a także innych podgrup,

$\rightarrow$ rozszerzanie kontaktów na sytuacje i zadania występujące poza szkołą (organizacje społeczne, kluby sportowe, wspólne spędzanie wolnego czasu),

$\rightarrow$ krytyczna analiza siły, trwałości i zwrotności tworzonych więzi,

$\rightarrow$ eliminowanie bądź ograniczanie więzi utrudniających właściwy rozwój poszczególnych członków podgrup i realizacje wspólnych przedsięwzięć.

Więzi w każdej z podgrup, a także więzi między podgrupami możemy rozpatrywać z perspektywy siły i częstotliwości tworzących je relacji.

Siła interakcji, w skrajnych przypadkach, może być oceniana jako bardzo duża (silna) lub bardzo mała (słaba). Między tymi skrajnymi stanami mieści się cała gama oddziaływań specyficznych dla społeczności szkolnej. Silne interakcje są na ogół zabarwione emocjonalnie - w praktyce są dzięki temu znacznie trwalsze od tych, które oparte są wyłącznie na wspólnocie celów. Osiągnięcie celu lub zaniechanie działań prowadzących do niego osłabia bowiem interakcje wśród członków podgrup pozbawionych więzi emocjonalnych. Słabe interakcje, 
a także oczywiście brak interakcji wewnątrz podgrup prowadzi z kolei do marginalizacji niektórych jej członków, a w jej następstwie do ich wykluczenia. W przypadku podgrup o słabych interakcjach mamy do czynienia z izolacją i autonomizacją ich działań, a w efekcie z zanikiem wspólnoty szkolnej.

Częstotliwość interakcji można mierzyć liczbą oddziaływań określonego rodzaju (rozmowa bezpośrednia, rozmowa telefoniczna, wymiana sms-ów, wymiana informacji za pomocą różnorodnych aplikacji internetowych) w jednostce czasu, np. w ciągu tygodnia. Co istotne - częstotliwość nie ma bezpośredniego wpływu na poziom siły interakcji w przypadku istnienia więzi emocjonalnych. Jest jednak niezwykle ważna dla podtrzymywania więzi w podgrupach i między nimi w sytuacji braku lub niedostatku więzi tego rodzaju. Trzeba też podkreślić, że częstotliwość interakcji ma istotny wpływ na trwałość więzi społecznych (nawet przy ich słabej sile), przede wszystkim wewnątrz podgrup funkcjonujących w szkole. Dotyczy to najsilniej podgrup uczniów, którzy po ukończeniu szkoły danego poziomu przechodzą do różnych typów szkół, ale nadal kontaktują się ze sobą i wspólnie spędzają czas. Brak takiego kontaktu powoduje zerwanie więzi - ze szkodą indywidualną i społeczną.

\section{Przywództwo edukacyjne w kontekście problematyki więzi}

Specyfika przywództwa w edukacji polega na rozszerzeniu typowego układu: przywódca, podwładny, sytuacja (Schultz, Schultz, 2002, s. 245) o podgrupy uczniów i rodziców, których nie można zaliczyć do kategorii podwładni w stosunku do dyrektora szkoły. Są to podgrupy, które w sposób nieformalny decydują o charakterze szkoły, o jej opinii w środowisku lokalnym. Uczniowie i rodzice, łącznie z dyrektorem i nauczycielami oraz pracownikami administracji szkolnej, z jednej strony tworzą wspólnotę szkolną, z drugiej zaś stanowią różniące się między sobą podgrupy wewnątrzszkolne. Więzi między nimi decydują o jakości procesu kształcenia i wychowania, podobnie jak więzi między członkami poszczególnych podgrup (Kwiatkowski, 2010, s. 15-19).

Nauczyciele, uczniowie i pracownicy administracji szkolnej oraz rodzice tworzą podgrupy, między którymi występuje więź obiektywna, subiektywna i behawioralna. Obiektywność więzi wynika z obywatelstwa, terenu zamieszkania i rodzaju pracy. Subiektywność dotyczy i odzwierciedla warunki obiektywne danej podgrupy - np. sytuację ekonomiczną, ale jest też wynikiem wspólnego systemu wartości i wspólnoty przeko- 
nań. Behawioralność więzi w zbiorowości jest zaś uzewnętrznieniem postaw w zachowaniach (Sztompka, 2004, s. 184-185, 190).

Szkoła jest organizacją, w której między członkami poszczególnych podgrup występują zdefiniowane (normatywne) zależności, a przez to określone zostają pozycje społeczne i wynikające z nich role. Jeżeli całą społeczność szkoły potraktujemy jako grupę, to można jej przypisać, jak już wspomniano, cechy grupy zorganizowanej. Grupa taka przejawia zdolności kooperacyjne, jest w stanie, dzięki podziałowi funkcji, zapewnić ciągłość działania organizacji - w przypadku naszych rozważań jest to realizacja funkcji szkoły (Gęsicki, 2008, s. 10-17). Każde zakłócenie więzi obiektywnych, subiektywnych lub behawioralnych powoduje trudności, bądź wręcz uniemożliwia płynne dochodzenie do celu. W praktyce zmiana miejsca zamieszkania kilku uczniów z danej klasy dezorganizuje więzi obiektywne, a dołączenie do podgrupy nauczycieli z długoletnim stażem młodych absolwentów wyższych uczelni o innej wrażliwości społecznej może być przyczyną rozerwania dotychczasowych więzi subiektywnych. Trwałości tych więzi nie sprzyjają też różnice w możliwościach zarobkowych nauczycieli różnych specjalności. Osłabienie więzi behawioralnych wynika ze zmiany zachowań w obrębie podgrup lub między nimi - dotyczy to przede wszystkim uczniów. Każdy z tych przypadków przyczynia się do podważenia statusu interesujących nas podgrup jako wspólnej dużej grupy społecznej. Sprzeczne interesy nauczycieli (w tym dyrektora), uczniów i rodziców prowadzą do rozbicia grupy i uniemożliwiają realizację celów, które przestały być wspólne.

Na więzi obiektywne, subiektywne i behawioralne nakłada się więź moralna, która najsilniej koreluje z więzią typu subiektywnego, jest wręcz jej odmianą.

Przywództwo w edukacji wpisuje się idealnie w trzy podstawowe komponenty więzi moralnej:

$\rightarrow$ zaufanie,

$\rightarrow$ lojalność,

$\rightarrow$ solidarność (Sztompka, 2004, s. 187).

Zaufanie w procesach nauczania - uczenia się i wychowania ma szczególną wartość. Ryzyko i niepewność towarzyszące wszelkim wyborom i działaniom edukacyjnym powodują, iż zaczynamy tęsknić za ludźmi i instytucjami, do których można mieć zaufanie. Wybór szkoły, 
jako decyzja rodzinna, zależy od wielu czynników, ale jednym z głównych jest zaufanie budowane dzięki opinii społecznej, w tym opinii osób, którym wierzymy (osoby te bywają często określane jako liderzy opinii). Po wyborze szkoły wybieramy klasy i nauczycieli. Jest to już wybór ograniczony pragmatyką edukacyjną, ale przynajmniej w teorii możliwy. Istotne znaczenie na poziomie szkoły podstawowej ma zaufanie, jakim darzymy konkretne szkoły ponadpodstawowe, a na poziomie maturalnym - uczelnie wyższe. Ten rodzaj zaufania nazywamy instytucjonalnym, dotyczy bowiem szkoły (jej typów) traktowanej jako organizacja.

Zaufanie instytucjonalne ma swe źródła w zaufaniu osobistym i w autorytecie szkoły jako instytucji. Ten ostatni jest pochodną efektów i stylu pracy dyrektora oraz grona nauczycielskiego. Integralnie traktowane zaufanie instytucjonalne i osobiste prowadzi do zaufania komercyjnego. W rozpatrywanym przez nas kontekście przejawia się ono w decyzjach edukacyjnych uwarunkowanych jakością pracy i rzetelnością nauczycieli, ich kompetencjami merytorycznymi, metodycznymi i wychowawczymi.

Efektywne przywództwo w sytuacji zróżnicowanych podgrup wewnątrzszkolnych wymaga zaufania między poszczególnymi podgrupami. Chodzi więc o zaufanie między dyrektorem a nauczycielami i pracownikami administracji szkolnej, o zaufanie między nauczycielami a uczniami i rodzicami. Zaufanie jest warunkiem współpracy. Przerwanie więzi tego rodzaju w którymkolwiek miejscu łańcucha relacji (szczególnie na styku podgrup) powoduje wzrost niepewności i ryzyka. Utrata zaufania przez znaczącą liczbę członków jednej z wyróżnionych podgrup wewnątrzszkolnych zmienia postrzeganie szkoły przez grupy będące na zewnątrz szkoły - w jej bliższym i dalszym otoczeniu.

Specyficzny charakter ma zaufanie rodziców do szkoły. Wynika on z faktu, iż nie mają oni możliwości obserwowania i kontrolowania codziennej pracy dyrektora i nauczycieli. Polegają na opinii dzieci i odczuciach innych rodziców. Muszą ufać, że efekt działań szkoły będzie odpowiedni - umożliwi ich dzieciom promocję do następnej klasy, przejście do kolejnego etapu edukacyjnego. Warto w tym miejscu zauważyć, że czym innym jest zaufanie do poziomu dydaktycznego szkoły, a czym innym zaufanie do kształtowanego w szkole systemu wartości (Szymański, 1998, s. 9-21). W ostatnich latach, wraz z nasilaniem się fali przemocy, która nie omija szkoły (por. Komendant-Brodowska, 2014), 
istotne staje się też zaufanie w dziedzinie bezpieczeństwa - przeświadczenie, że szkoła jest bezpieczna.

Przeciwieństwem zaufania jest nieufność. Jeżeli dyrektor nie ufa nauczycielom, to wprowadza system kontroli formalnej, mnoży zarządzenia wewnętrzne - w efekcie ogranicza autonomię nauczycieli i skłania ich do rezygnacji z wprowadzania w życie jakichkolwiek innowacji. Nieufność nauczycieli wobec uczniów skutkuje wzrostem liczby sprawdzianów (nieufność dydaktyczna) i wzmożoną obserwacją zachowań, a nawet ingerencją w relacje między uczniami (nieufność wychowawcza). Nieufność rodziców w stosunku do dzieci (uczniów) - do ich możliwości intelektualnych i postaw - wyraża się skłonnością do korzystania z korepetycji i drobiazgowego "monitoringu" zachowań domowych, szkolnych, towarzyskich. I wreszcie nieufność rodziców skierowana do dyrektora i nauczycieli (nawet tylko niektórych) prowadzi do poszukiwań nowej szkoły, nowego (lepszego) otoczenia edukacyjnego dla własnego dziecka.

Drugi z wyróżnionych komponentów więzi moralnej - lojaln ość łączy się w pewien sposób z zaufaniem. Jeżeli bowiem ktoś obdarza nas zaufaniem, to lojalność możemy rozumieć jako dążenie do spełnienia pokładanych w nas oczekiwań.

W przypadku lojalności rozszerzamy pole dotychczasowych rozważań o relacje: dyrektor szkoły - jednostka samorządu terytorialnego, kuratorium oświaty. Mamy więc kolejny poziom relacji, tym razem niezauważalny lub trudno poddający się obserwacji przez przedstawicieli podgrup wewnątrzszkolnych. Dyrektor w dążeniu do lojalności wobec nadrzędnych instytucji powinien w pierwszej kolejności zidentyfikować oczekiwania i nadzieje, jakie z nim samym i kierowaną przez niego placówką wiążą "zwierzchnicy". Problem polega na tym, że lojalność dyrektora oparta jest często na jego wyobrażeniach dotyczących życzeń innych osób. Jeżeli te życzenia nie są jasno (formalnie) wyartykułowane, to pozostaje intuicja, która może być zawodna. Inny charakter ma lojalność nauczycieli wobec dyrektora. Z reguły dyrektor jest jednym z nauczycieli, kolegą (koleżanką) - jeszcze do niedawna członkiem podgrupy, którą teraz (po przystąpieniu do konkursu i pozytywnym zakończeniu procedury konkursowej) kieruje. Pojawia się więc lojalność wobec niedawnych kolegów, a nawet przyjaciół, wobec wspólnych ideałów, projektów. Jak być lojalnym wobec wszystkich nauczycieli, z którymi się wcześniej współpracowało, współtworzyło 
klimat zaufania do szkoły? Czy nowy, „zewnętrzny" rodzaj lojalności związany z otoczeniem szkoły - nie wpływa destrukcyjnie na lojalność "wewnętrzną"? Czy okresowość przywództwa dyrektora ma wpływ na jego relacje wewnątrzszkolne? Czy ci, którzy zawierzyli dyrektorowi, a więc też rodzice, nie odbierają jego działań jako nielojalnych? Trzeba pamiętać, że zawierzyli mu w konkretnej sytuacji, która mogła ulec zmianie (Kwiatkowski, 2006, s. 37-46).

Zasygnalizowane tylko pytania dotyczące lojalności prowadzą nas do pojęcia konfliktu lojalności, który zwykle poprzedzony jest dylematem lojalności, czyli sytuacją, w której jednostka (ewentualnie podgrupa) staje przed koniecznością dokonania następującego wyboru: po czyjej stanąć stronie, jeżeli nie można być jednocześnie lojalnym wobec wszystkich zaangażowanych w sprawę podgrup. W sytuacji "0-1" (klasycznej dla teorii gier) opowiedzenie się po którejkolwiek stronie oznacza nie tylko poparcie jednego ze stanowisk, ale oczywiście wiąże się jednocześnie z odrzuceniem drugiego (lub kolejnych). Prowadzi to nieuchronnie do wejścia w konflikt lojalności ze zwolennikami zignorowanych rozwiązań. Aby uniknąć konfliktu lojalności, przywódcy różnych podgrup wewnątrzszkolnych uciekają się do pozorów lojalności, okazywanych przede wszystkim najsilniejszym, tym, z którymi za wszelką cenę w danym momencie chcą uniknąć konfrontacji. Pozorna lojalność może występować w relacjach: uczniowie - rodzice (gdy lojalność wobec grupy rówieśniczej bierze górę nad lojalnością rodzinną; rzadziej mamy do czynienia z sytuacja odwrotną), nauczyciele - rodzice (w szkołach, w których rodzice mają duży wpływ na ich działalność), a także: dyrektor - nauczyciele (konformizm z obu stron). Pozorna lojalność może przeradzać się w przeciwieństwo lojalności i prowadzi, prędzej czy później, do manipulacji, żywi się półprawdami, odwołuje się do naiwności i dobroci tych, którzy nam zaufali. W dalszej perspektywie jest wyniszczająca psychicznie dla każdego przywódcy.

Trzecim, a zarazem ostatnim, komponentem więzi moralnej jest bliska nam wszystkim solidarność rozumiana jako otwartość i dbałość o innych - zarówno członków swojej podgrupy wewnątrzszkolnej, jak i szerzej ujmowanej społeczności szkolnej. Istotą solidarności, także tej edukacyjnej, jest wzniesienie się ponad interesy indywidualne i własnej podgrupy - w imię dobra wspólnego. W skrajnych przypadkach troska o dobro wspólne (wspólnotowość) może kolidować z celami wyznaczanymi przez poszczególnych uczestników życia szkolnego 
lub przez podgrupy funkcjonujące w szkole. Solidarność jest rodzajem zjednoczenia w słusznej sprawie i w praktyce edukacyjnej ma głównie wymiar wychowawczo-organizacyjny.

Typowym przejawem solidarności natury wychowawczej jest zjednoczenie się wobec przemocy kierowanej ku uczniom z jakichś powodów nieakceptowanych przez część grupy lub też wobec przemocy, jakiej podlegają nauczyciele ze strony uczniów. Solidarność w tych sprawach ma często charakter przekraczający mury szkoły, staje się powszechnym ruchem społecznym.

Z solidarnością organizacyjną mamy najczęściej do czynienia w przypadku zamiaru likwidowania placówki edukacyjnej przez grupy zewnętrzne w stosunku do społeczności szkolnej. Wówczas jednoczą się nauczyciele (przy aktywnym wsparciu dyrektora), pracownicy administracyjni szkoły, uczniowie i rodzice. Poszukują sojuszników wśród innych grup zewnętrznych - doceniających dotychczasowe osiągnięcia szkoły i dostrzegających perspektywy jej rozwoju. W szerszym kontekście przejawem solidarności jest uznanie „innego" za osobę, a cel działań solidarnościowych można sprowadzić do budzenia świadomości dobra wspólnego, ukazywania współzależności moralnej i ekonomicznej między grupami społecznymi.

Brak solidarności w szkole, podobnie jak brak zaufania czy lojalności, może grozić zanikiem więzi moralnej. Podgrupy wewnątrzszkolne atomizują się wówczas i skupiają na realizacji własnych interesów, wzmagają się postawy egoistyczne, rośnie poziom obojętności wobec problemów członków własnej podgrupy, a tym bardziej innych podgrup.

Do omawianej triady: zaufanie, lojalność i solidarność, tworzącej więzi natury moralnej, można jeszcze dodać autonomię rozumianą jako atrybut instytucjonalny $i$ indywidualny.

W wymiarze instytucji - szkoły, autonomia przejawia się w wolnym od zewnętrznych nacisków kształtowaniu polityki kadrowej (dyrektor, nauczyciele) i rekrutacyjnej (uczniowie), nieskrępowanej możliwości przygotowywania i wdrażania autorskich programów nauczania, doboru metod pracy z uczniami oraz systemów ich oceniania.

W parze z tak pojętą autonomią instytucjonalną idzie odpowiedzialność za realizację obowiązujących podstaw programowych i przestrzeganie odpowiednich przepisów (ustawa o systemie oświaty, kodeks pracy).

Autonomia indywidualna, jako wyraz samostanowienia, dotyczy członków wszystkich wyróżnionych podgrup społeczności szkol- 
nej. Również w tym przypadku autonomię należy postrzegać łącznie z odpowiedzialnością.

Brak lub niedostatek odpowiedzialności zarówno instytucjonalnej, jak i indywidualnej prowadzi, prędzej czy później, do ograniczenia lub nawet zawieszenia wcześniej przyznanej autonomii. Dzieje się to ze szkodą dla siły i trwałości więzi występujących wśród społeczności szkolnej.

\section{Zakończenie}

Na tle tak zarysowanych charakterystyk podgrup wewnątrzszkolnych i podgrupy z pogranicza - rodziców, można zastanowić się nad budowaniem więzi moralnej w szkole. Innymi słowy, można pokusić się o analizę relacji: styl przywództwa - zaufanie, styl przywództwa - lojalność i styl przywództwa - solidarność (wspólnotowość) oraz styl przywództwa - autonomia. Analiza tego rodzaju, obok ujęcia teoretycznego, wymaga jednak badań, i to interdyscyplinarnych - z pogranicza psychologii, socjologii, filozofii, pedagogiki i zarządzania. Ich wyniki pozwoliłyby na wybór przywódców sprzyjających więziom moralnym, na przygotowywanie uczniów do ról przywódczych w szkole i po jej ukończeniu - w myśl zasady "człowiek to styl" (przywództwa), a styl to efekt w postaci poziomu więzi moralnych w szkole.

Rozważania na temat miejsca i roli przywództwa w edukacji nie powinny ograniczać się do szkoły jako instytucji i grup społecznych w niej funkcjonujących. Budowanie więzi moralnych w szkole jest bowiem elementem tworzenia kapitału społecznego, który na owych więziach jest oparty. W najprostszym ujęciu kapitał społeczny tworzą ludzie i sieć powiązań między nimi. Zręby tak rozumianego kapitału pojawiają się $w$ instytucjach edukacyjnych, a następnie są umacniane w pracy zawodowej i działalności społecznej. Szkolny kapitał społeczny jest rodzajem kapitału początkowego, który jest pomnażany przez całe życie. Ważne jest więc stworzenie warunków wstępnych do inicjowania sieci powiązań między uczniami danej szkoły, a następnie (chociaż równolegle) między uczniami a pozostałymi grupami wewnątrzszkolnymi. Jest to zadanie stojące przede wszystkim przed dyrektorem szkoły i nauczycielami (Kwiatkowski, 2008, s. 18-21). Polega ono na motywowaniu uczniów do realizacji projektów o charakterze ogólnoszkolnym i pozaszkolnym, do wspólnego myślenia i działania na rzecz społeczności lokalnej. Tego typu projekty sprzyjają nawiązywaniu więzi 
kooperacyjnych integrujących wszystkie podgrupy wewnątrzszkolne (Michalak, red., 2009).

Erozja więzi, o których była mowa, w podgrupach charakterystycznych dla placówek edukacyjnych jest krokiem w kierunku dezintegracji całej grupy. To z kolei utrudnia członkom podgrup wyłanianie przywódców, a tym ostatnim, jeżeli podejmą się tej roli, skuteczne przewodzenie. 


\section{Bibliografia}

$\rightarrow$ Gęsicki, J. (2008), Kształtowanie kultury organizacyjnej szkoły [w:] E. Adamczyk, E. Matczak (red.), Dyrektor szkoły a wyzwania XXI wieku, s. 10-17, Warszawa: Wydawnictwo Instytutu Badań Edukacyjnych.

$\rightarrow$ Jakubowska, U. (2002), Przywództwo polityczne [w:] K. Skarżyńska (red.), Podstawy psychologii politycznej, s. 82-107, Poznań: Zysk i S-ka Wydawnictwo.

$\rightarrow$ Komendant-Brodowska, A. (2014), Agresja i przemoc szkolna. Raport o stanie badań, Warszawa: Instytut Badań Edukacyjnych.

$\rightarrow$ Kwiatkowski, S.M. (2006), Dyrektor placówki oświatowej jako przywódca [w:] J.M. Michalak (red.), Przywództwo w szkole, s. 37-46, Kraków: Oficyna Wydawnicza "Impuls".

$\rightarrow$ Kwiatkowski, S.M. (2008), Standard kwalifikacji zawodowych dyrektora szkoły [w:] E. Adamczyk, E. Matczak (red.), Dyrektor szkoły a wyzwania XXI wieku, s. 18-21, Warszawa: Wydawnictwo Instytutu Badań Edukacyjnych.

$\rightarrow$ Kwiatkowski, S.M. (2010), Miejsce i rola przywództwa w edukacji [w:] S.M. Kwiatkowski, J.M. Michalak (red.), Przywództwo edukacyjne w teorii i praktyce, s. 13-23, Warszawa: Fundacja Rozwoju Systemu Edukacji.

$\rightarrow$ Kwiatkowski, S.M. (2011), Typologie przywództwa [w:] S.M. Kwiatkowski, J.M. Michalak, I. Nowosad (red.), Przywództwo edukacyjne w szkole i jej otoczeniu, s. 13-22), Warszawa: Difin.

$\rightarrow$ Madalińska-Michalak, J. (2015), Dyrektor szkoły liderem - inspiracje i perspektywy, Warszawa: Wolters Kluwer.

$\rightarrow$ Madalińska-Michalak, J. (2012), Skuteczne przywództwo w szkołach na obszarach zaniedbanych społecznie. Studium porównawcze, Łódź: Wydawnictwo Uniwersytetu Łódzkiego.

$\rightarrow$ Michalak, J.M. (2006), Istota i modele przywództwa szkolnego [w:] J.M. Michalak (red.), Przywództwo w szkole, s. 63-80, Kraków: Oficyna Wydawnicza "Impuls".

$\rightarrow$ Michalak, J. M. (red.) (2009), Przywództwo w kształtowaniu warunków edukacji, Łódź: Wydawnictwo Uniwersytetu Łódzkiego. 
$\rightarrow$ Schultz, D.P., Schultz, S.E. (2002), Psychologia a wyzwania dzisiejszej pracy, Warszawa: Wydawnictwo Naukowe PWN.

$\rightarrow$ Sztompka, P. (2004), Socjologia, Kraków: Wydawnictwo "Znak".

$\rightarrow$ Szymański, M.J. (1998), Młodzież wobec wartości, Warszawa: Wydawnictwo Instytutu Badań Edukacyjnych.

$\rightarrow$ Wren, K. (2005), Wpływ społeczny, Sopot: Gdańskie Wydawnictwo Psychologiczne. 


\section{Zmiana jako podstawowa kategoria rozwoju szkoły}

Inetta Nowosad

W artykule analizie poddano kategorię zmiany, która służyć ma zrozumieniu możliwości i ograniczeń rozwoju szkoły. W tym celu zwrócono uwagę na istotę zmiany, jej źródła i rodzaje, które mogą inicjować i konsolidować proces rozwoju szkoły. W przyjętym podejściu systemowym wyeksponowano grupę zawodową nauczycieli jako odpowiedzialną za rodzaj i treść wdrażanych zmian mogących prowadzić do jakościowej odnowy szkoły.

\section{Słowa kluczowe:}

rozwój szkoły

zmiana edukacyjna

kultura szkoły

jakość i efektywność szkoły

nauczyciel 


\section{Change as a main category of school development}

Inetta Nowosad

The article analyses the category of change, which is meant to facilitate the understanding of the possibilities and limits of school development. To this end, a great deal of attention has been paid to the nature of change, its origins and types, all of which may initiate and consolidate the process of school development. In the adopted approach, teachers have been identified as those directly responsible for the type and content of changes that may be conducive to a qualitative restoration of schools.

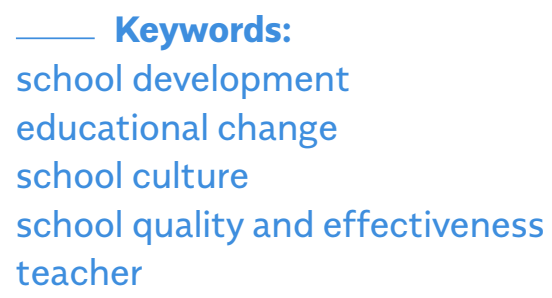




\section{Wstęp}

W większości państw wysoko rozwiniętych dyskurs oświatowy skupia się na procesach jakości i efektywności szkolnictwa, zwracając coraz większą uwagę na procesy wewnątrzszkolne interpretowane przez wielu badaczy jako reforma wewnętrzna lub rozwój szkoły. Istotną rolę w osiągnięciu lepszych wyników i warunków do nauki odgrywają zmiany, jakie zachodzą wewnątrz placówki, a nie te zaordynowane z zewnątrz. Fakt ten stanowił podstawę do "odkrycia" lub odkrywania na nowo znaczenia i potencjału szkoły; wszystkiego, co stanowi o jakości jej pracy. Według Marii Dudzikowej szkoła, która jest świadoma swojego potencjału, staje się samoczynnie "bąblem zmiany" (2001, s. 137-138).

Przyjęcie takiego założenia eksponuje szkołę jako miejsce tworzenia i zapewnienia jakości i pozwala lepiej zrozumieć rangę procesów wewnątrzszkolnych, tym samym fakt, że to, co się dzieje w szkole, może być barierą lub warunkiem jakości edukacji, zaporą lub wsparciem rozwoju dzieci i młodzieży. W tak przyjętej optyce procesy zmian prowadzące do wzrostu jakości i efektywności procesów edukacyjnych uwzględniające potrzeby uczniów (jakość ich życia) można określić jako rozwój szkoły.

Można przyjąć, że w rozwoju szkoły, na plan pierwszy wysuwa się opanowanie przez społeczność szkolną nowych zadań, które oznaczają postęp w znaczeniu osiągania nowego etapu i nowej formy adaptacji. Jest to zarazem osiąganie właściwego na danym poziomie przystosowania społecznego i psychicznego członków danej społeczności. Z tych względów na znaczeniu zyskują procesy wewnętrzne pozwalające na tworzenie warunków do wypełniania owych zadań, a nie tylko stanowiące presję czynników społeczno-kulturowych. Mamy wówczas do czynienia nie tylko z presją warunków zewnętrznych; procesów kulturowych, lecz także z możliwością realizacji w ich ramach nowych pragnień, dążeń, aspiracji i wartości poszczególnych jednostek - w większości przypadków - kombinacji tych czynników działających łącznie (Michalak, 2006, 2010; Madalińska-Michalak, 2012).

Wszelkie zmiany rozwojowe wyjaśniane są zwykle za pośrednictwem określonych czynników pojmowanych jako zewnętrzne i wewnętrzne mechanizmy. Jednak należy podkreślić, że wpływy te są różnorodne i uzależnione od momentu, w którym zachodzą, oraz od poziomu, na jakim znajduje się obiekt. W efekcie, czynniki te uruchamiają tak ilo- 
ściowy, jak i jakościowy proces rozwoju, a także mają wpływ na jego ukierunkowanie (Havighurst, 1981).

Na tej płaszczyźnie dyferencjacja przeplata się z dojrzewaniem, specjalizacja z integracją, rozwój ilościowy z jakościowym (Kunowski, 1993, s. 181). Jednak kierunek zmian w szkole uwarunkowany jest panującymi w danym kraju stosunkami społeczno-ekonomicznymi i politycznymi. Jest też uzależniony od sytuacji międzynarodowej. Można uznać, że "szkoła stanowi pole napięć interakcji mnogości rozmaitych sił, (...) jej kształt i sposób funkcjonowania nie jest ich prostą wypadkową. Nie wyłania się ona z różnorodnych praktyk pedagogicznych, nie jest ich pluralistyczną syntezą, (...) w dużym stopniu uzależniona od czynników pozapedagogicznych, jest niedefiniowalna" (Głażewski, 1996, s. 41). W literaturze pedagogicznej rozwój szkoły postrzegany jest jako proces uczenia się ludzi i organizacji. Uzasadnia to potrzebę ciągłego tworzenia szkoły od nowa i eksponuje kategorię zmiany. Jednak i tu pojawia się pewien problem, który wynika z niemożności określenia jasnych proporcji zachodzących między tym, co w szkole stałe (decydujące o ciągłości i stabilności), oraz tym, co podlega zmianie, rzutuje na jej dynamikę jako instytucji, a zarazem mikrosystemu wychowawczego.

\section{Zmiana jako podstawowa kategoria w rozumieniu świata}

Kategoria zmiany fascynowała badaczy od zarania ludzkich dziejów. W obserwacji nawet najbliższego otoczenia wyłaniała się ogromna różnorodność występujących w nim rzeczy, zjawisk i procesów. W podejmowanej refleksji, zauważano istniejące różnice: wyglądu, właściwości, przemian w nich zachodzących, czasokresu trwania czy swoistego oddziaływania wywieranego na otoczenie. Znamienne były tu poglądy Heraklita, który uważał, że najbardziej charakterystyczną cechą otaczającej rzeczywistości jest jej ciągła zmienność. „Wszystko płynie”, jest w ciągłym ruchu, nic nie trwa wiecznie. Dlatego nie możemy "dwa razy wejść do tej samej rzeki" (Leśniak, 1972, s. 171), bowiem wchodząc po raz drugi, jest się już innym i rzeka jest inna.

Dążąc do uogólnienia dorobku filozofii klasycznej w zakresie ujętym w pytaniu Sokratesa: „Dlaczego powstaje każda rzecz i czemu istnieć przestaje i przez co istnieje?" (Krońska, 1983, s. 131), wyodrębnić można trzy główne koncepcje zmiany (Hempoliński, 1989, s. 234).

$\rightarrow$ Koncepcja heraklitejska, w której źródłem zmiany są istniejące w świecie przeciwieństwa ścierające się ze sobą (sprzeczność), 
co prowadzi do zmiany, czyli przechodzenia zdarzenia lub układu zdarzeń w ich przeciwieństwo. Przeciwieństwa są skutkiem i zarazem przyczyną różnorodności, która stanowi źródło zmian i jest ich nieuchronną konsekwencją.

$\rightarrow$ Koncepcja mechanistyczna, w której ruch (zmienność) obiektu materialnego ma zawsze swe przyczyny zewnętrzne i spowodowany jest przez takie zetknięcie się z drugim obiektem, które prowadzi do przemieszczenia się obiektu w przestrzeni, a tym samym do zmiany jego położenia wobec innych obiektów.

$\rightarrow$ Koncepcja arystotelesowska, zgodnie z którą wszelka zmiana polega na urzeczywistnieniu się możliwości, czyli na akcie przejścia czegoś z możności w rzeczywistość.

Mimo pojawiających się nowych poglądów na bieg wydarzeń dokonujący się w świecie, cechą wspólną jest eksponowana przez badaczy kategoria zmiany, czyli przejście określonego obiektu od jednego stanu do drugiego. Przez tysiąclecia ludzkość zadziwiała wszechogarniająca zmienność. A współcześnie? Choć nasza wiedza różni się zdecydowanie od tej sprzed lat, to $w$ dalszym ciągu kategoria zmiany nacechowana jest wieloma pytaniami bez odpowiedzi. Efekt "płynnej nowoczesności” zauważony przez Zygmunta Baumana, stanowiący opis współczesności nacechowanej nieznanym dotąd tempem doświadczanych zmian, potęguje tylko pragnienie poznania, dotarcia do źródeł - przyczyny rzeczy. „Naukowa rewolucja naszych czasów przeniosła nas z epoki pewności i dogmatyzmu w rzeczywistość niepewności i wątpliwości" (Szempruch, 2012, s. 16). W tej sytuacji, fascynacja tempem i zakresem dokonujących się zmian, można by rzec, przybiera tylko na sile.

Zmiana jest pojęciem o szerokim znaczeniu semantycznym, wykorzystywanym do opisu pewnej dynamiki. Zmianę określa się często jako: postęp, rozwój, przekształcenie, restrukturyzację, transformację, innowację czy też usprawnienie. Problematyka zmian, ich charakter, źródła oraz skutki wydają się mieć fundamentalne znaczenie w każdej dziedzinie nauki (np. zmiany technologiczne, strukturalne, kulturowe) i dla każdego badacza, bez względu na czasy, w których żyje. Bowiem, jak to ujął I. Kant, rzeczą ludzką jest pragnienie dotarcia do przyczyny każdego zdarzenia. Człowiek w swojej historii zawsze stawał przed wyzwaniem zrozumienia świata i z całą mocą pragnął oswoić go sobie. Zawsze stawał przed koniecznością zrozumienia istoty zmiany - odkry- 
cia jej sensu. „Jeśli się rozumie pojęcie zmiany i jej rodzaje, łatwiej jest określić źródło oraz łatwiej i pewniej zgadywać jej skutki, bo przewidzieć ich dokładnie nie da się nigdy" (Ornstein, Hunkins, 1998, s. 292).

\section{Typologia zmian}

W najprostszym ujęciu procesy zmian mogą realizować się na dwóch poziomach, pomiędzy którymi przejście jest płynne i często dla badacza niedostrzegalne. „Są to poziomy - jednostek i małych grup społecznych (mikrostruktur), takich jak rodzina, grupa sąsiedzka czy rówieśnicza; oraz wielkich grup społecznych (makrostruktur), takich jak klasa społeczna, społeczeństwo globalne, naród" (Chłopecki, 1993, s. 30).

Najbardziej widoczne dla jednostki są zmiany obecne na najniższych poziomach, w które człowiek osobiście uwikłany jest w codziennym życiu. Aby zauważyć zmiany o charakterze makrostrukturalnym, należy „spojrzeć na nie z dalszej perspektywy czasowej (...) w perspektywie długiego trwania" (tamże). Występująca w tych procesach zmiana niesie ze sobą bardziej lub mniej gwałtowne przekształcenie istniejącej struktury społecznej, określa również kierunek i trend przemian. Można wówczas mówić o zmianach przebiegających "w ramach systemu" (change within the system) oraz zmianach "systemu jako całości" (change of the system) (tamże). Procesy zmian mają także istotne konsekwencje dla jednostki, która może być zarazem ich podmiotem, jak i przedmiotem "tworzy ją wedle własnej miary, kształtuje ją z siebie, przez siebie i dla siebie" (Legowicz, 1981, s. 71), stając się zarazem źródłem, sprawcą oraz celem zmiany.

Wnikając w możliwe do zaistnienia rodzaje zmian, dostrzec można ich bogactwo, które nie od razu jest zauważalne ze względu na mniej lub bardziej widoczne ich skutki wyznaczane ich dynamiką (Szymański, 2013, s. 55-61). Rzadko kiedy mamy też do czynienia z prostym, wyizolowanym typem zmiany. Najczęściej dochodzi do nakładania się na siebie różnych procesów powodowanych często odmiennymi interesami. Ich uporządkowanie ma zatem charakter umowny.

W rozwoju szkoły na znaczeniu zyskują zmiany celowe, mające przez społeczność szkolną świadomie inicjować proces odnowy i doskonalenia. Paleta zmian zwraca uwagę na kryteria eksponujące istotę zmiany:

$\rightarrow$ Ze względu na źródła zmian: pochodzące „z zewnątrz" systemu (np. z zewnątrz społeczności danej szkoły - egzogenne) oraz opracowane „w ramach systemu” (przez społeczność szkolną - endogenne). 
$\rightarrow$ Ze względu na strategię wprowadzania zmian: zmiany odgórne i oddolne.

$\rightarrow$ Ze względu na przebieg zmian: ewolucyjne i radykalne - rewolucyjne.

$\rightarrow$ Ze względu na wolę przyjęcia zmiany: akceptowane (pożądane) i nieakceptowane (niechciane, często są to np. zmiany zaordynowane, zadane - najczęściej w formie wytycznych formalno-prawnych lub zaleceń przełożonych).

$\rightarrow$ Ze względu na wdrożenie danej zmiany: zmiany rzeczywiste oraz pozorne (fikcyjne).

$\rightarrow$ Ze względu na siłę oddziaływania: zmiany powierzchowne i dogłębne.

$\rightarrow$ Ze względu na zakres oddziaływania: zmiany przebiegające "W ramach systemu" oraz zmiany "systemu jako całości".

$\rightarrow$ Ze względu na kryterium poznawcze: zmiany racjonalne i irracjonalne.

$\rightarrow$ Ze względu na kryterium identyfikacji systemu: zmiany funkcjonalne dotyczące procesu oraz zmiany strukturalne dotyczące modelu.

$\rightarrow$ Ze względu na doświadczany postęp: zmiany regresywne i progresywne.

$\rightarrow$ Ze względu na kontynuowanie zmiany: incydentalne, skokowe, ciągłe.

$\rightarrow$ Ze względu na udział jednostkowy: zmiany jednostek; małych grup społecznych (mikrostruktur), wielkich grup społecznych (makrostruktur).

$\rightarrow$ Ze względu na stosunek społeczeństwa do zmiany: zwalczane, kontestowane, ignorowane, akceptowane, popierane.

$\rightarrow$ Ze względu na zasięg terytorialny: zmiany lokalne, ogólnokrajowe, regionalne, globalne.

$\rightarrow$ Ze względu na zasięg przedmiotowy: zmiany fragmentaryczne, dziedzinowe, kompleksowe, totalne.

Zmiany współwystępują i współtworzą dzieje oświaty. Trudno je wyselekcjonować, a ich podział ma raczej charakter umowny. W wielostronnych i wieloaspektowych przeobrażeniach, jakie dokonują się na tej płaszczyźnie działalności ludzkiej, możliwe jest odszukanie wszystkich wspomnianych wyżej typów zmian, które nieustannie nakładają 
się na siebie nawzajem. Pozwala to ujmować rzeczywistość oświatową jako proces o charakterze raczej ewolucyjnym, w którym dokonuje się konfrontacja świata teorii i zasad normatywnych z jednej strony, a z drugiej - świata realnych zachowań ludzi biorących w niej udział.

\section{Źródła zmiany edukacyjnej}

W praktyce zakres i dynamika zmian edukacyjnych (w szkolnictwie) podyktowana jest głównie panującymi w danym kraju stosunkami społeczno-ekonomicznymi i politycznymi, jednakże we współczesnym świecie zachodzą również inne zjawiska, procesy, wydarzenia, które mają niebagatelny wpływ na rodzaj, zakres i jakość przyjmowanych zmian. Wśród najważniejszych wymienić należy lawinowo narastający chaos informacyjny wymagający racjonalnej selekcji, przetworzenia i przechowania, ale również coraz silniejszą presję powodującą napięcia i potrzebę ich przezwyciężenia. Ponadto zmiana nie jest prostą wypadkową owych źródeł, ale zależy od całego kontekstualnego splotu wyznaczonego przez historię, tradycję i kulturę danego kraju.

Podejmując się analizy źródeł zmian edukacyjnych, można wskazać na trzy ich rodzaje (Nowosad, 2011):

$\rightarrow$ Zmiana jako pochodna uwarunkowań społeczno-ekonomicznych i politycznych. Wynika z dokonujących się przemian społecznych, z nowych potrzeb indywidualnych i wartości określających priorytety edukacji oraz zadania i funkcje szkolnictwa (Bogaj, Kwiatkowski, Szymański, 1997, s. 118). Transformacja systemu społeczno-politycznego postawiła przed polską oświatą pytania o zmianę instytucji edukacyjnych, które powinny przekształcić się z instrumentów uzależnienia i uprzedmiotowienia jednostek i grup społecznych w środki otwierania i wspomagania rozwoju jak największej liczby ludzi. Ważny przy tym wydaje się sposób, w jaki edukacja i uczestniczące w niej podmioty mogą się stać uczestnikami wielkiej transformacji społecznej, spełniającej oczekiwania, nadzieje i możliwości (Kwieciński, 2000, s. 7).

$\rightarrow$ Zmiana jako konsekwencja naturalnego przyrostu wiedzy. W jej następstwie, jak pisze C. Kupisiewicz, „człowiek znalazł się pod presją lawinowo wzrastającej liczby wiadomości" (1995, s. 12). W następstwie narastania wiedzy o świecie jej zakres podwaja się obecnie co sześć, siedem lat. Pomimo tworzącego się natłoku, wiedza utrzymuje swoją silną pozycję. Zdaniem A. Tofflera zwy- 
cięży ten, kto będzie miał dostęp do informacji i umiejętność jej przetwarzania i stosowania. Wiedza stanie się najważniejszą wartością współczesnej cywilizacji (cyt. za: Pachociński, 1999, s. 7). Zatem, jeśli szkoła chce uczestniczyć w przetwarzaniu i tworzeniu własnej wiedzy, musi uczyć, jak się uczyć, czyli poruszać się w tym bogactwie i z niego korzystać, dokonując właściwych wyborów. Dokonując zaś wyborów, rozpoczyna proces zmiany.

$\rightarrow$ Zmiana jako wynik istnienia napierających na siebie przeciwieństw, kontrastów, różnic. Rozumienie to odnosi się do postrzegania współczesnej rzeczywistości, w tym również edukacyjnej, jako ambiwalentnej, w której jedności przeciwstawia się wielość linearności, zwielokrotnienie różnic i upowszechnienie marginesów, a równowadze nierównowagę. "Tysiące sprzecznych prawd rywalizuje ze sobą o status „jedynej prawdy", relatywizując siebie nieustannie. (...) Kanon i różnica, lokalne i globalne, intelektualne i afektywne, popularne i elitarne (...) wszystko jest już "na raz" (Melosik, 2000, s. 175). Istnienie różnic stanowi tu jednak walor. W wyniku ich pokonywania możliwe jest uruchomienie machiny rozwoju, postępu w świecie, w którym kontrasty wplotły się $w$ jego opis. Postrzeganie $w$ istnieniu napięć potencjału do zaistnienia zmiany można odnaleźć w opracowaniu Komisji ds. Edukacji Dwudziestego Pierwszego Wieku pod przewodnictwem J. Delorsa (1998, s. 12-15). Wyróżniono sześć ich typów: napięcie między tym, co globalne, a tym, co lokalne; napięcie między tym, co uniwersalne, a tym, co jednostkowe; napięcie między tradycją a nowoczesnością; napięcie między działaniem perspektywicznym a działaniem doraźnym; napięcie między niezwykłym rozwojem wiedzy a zdolnością przyswojenia jej przez człowieka; napięcie między duchowością i materialnością. Inaczej mówiąc, między "być" a "mieć".

Sprawę jednak dodatkowo komplikują wpływy zewnętrzne. Środowisko dostarczać może dodatkowych informacji, przekazywać nowe oczekiwania, nagradzać albo przysparzać trudności. Może być dodatkowym źródłem napięć i wywołać stan braku równowagi między składnikami systemu, a tym samym wprawiać system w ruch ukierunkowany na osiągnięcie równowagi w nowych warunkach. Zmiana jest procesem dynamicznym i zachodzi poprzez ciągły proces tracenia i odzyskiwania 
równowagi oparty na rozwiązywaniu problemów. Ważne wydają się tu reakcje zarówno na wpływy czynników wewnętrznych, jak i zewnętrznych. Od tego, jak inicjatorzy zmian sobie z tym poradzą, zależy, czy zmiana okaże się konstruktywna, czy niepotrzebna.

W okresach szybkich zmian społecznych oraz szybkiego rozwoju cywilizacji technicznej, oświata i wychowanie stają się jednym z zasadniczych warunków postępu. Zdaniem Baumana cechami współczesnego oblicza postępu jest deregulacja i prywatyzacja (2006, s. 209-210). Deregulacja wiąże się z ogromną liczbą i różnorodnością ofert wprowadzania zmian, które nie podlegają jednoznacznej ocenie, oraz z koniecznością stałego dokonywania wyborów, które nie wiążą się z pewnością co do ich prawdziwości czy słuszności. Prywatyzacja natomiast oznacza konieczność całkowicie samodzielnego dokonywania tych wyborów czy wprowadzania zmian i podejmowania ryzyka popełniania błędów. Jednostka musi też samodzielnie planować, realizować i oceniać życiowe przedsięwzięcia, a także podejmować decyzje o ich ewentualnym zaniechaniu" (Szempruch, 2012, s. 13-14).

\section{Specyfika zmiany szkoły - rozwoju szkoły}

Zainteresowanie badaniem funkcjonowaniem szkoły jako organizacji społecznej podejmowane w latach siedemdziesiątych w krajach anglosaskich i niemieckojęzycznych umocniły pogląd, że takie organizacje, jak szkoła nie są monolitycznymi blokami i należy je postrzegać jako układy "żyjące". „Przełom" nastąpił jednakże dopiero z początkiem lat dziewięćdziesiątych, kiedy polityka oświatowa prawie wszystkich państw Unii Europejskiej wspierała rozwój pojedynczych szkół jako jednostek prowadzących samodzielnie działalność dydaktyczno-wychowawczą w wyniku przyznanej szkołom autonomii. Rozpoczęte zostały poszukiwania koncepcji angażującej szkoły w działania rozwojowe, promując koncepcję rozwoju organizacyjnego, która z czasem uległa ogromnemu zróżnicowaniu. Skutkiem tego były wielokrotnie wypróbowywane nowe pomysły (Türk, 1989). Jak zaznacza H.-G. Rolff, analiza instytucji szkoły nie jest możliwa za pomocą jednej teorii organizacji: „Jeśli szkoły chce się nie tylko analizować, ale i tworzyć, trzeba zrozumieć ich całą złożoność. To wymaga szerokiego, wielostronnego spojrzenia na szkołę, 
co z kolei wymaga - w języku nowego rozumienia organizacji - spojrzenia nie obiektywnego, lecz perspektywicznego. Szkoła jako całość nie poddaje się obiektywnej ocenie części, jest czymś więcej. W szkole przeplatają się techniczne, polityczne i kulturalne sprawy, a mimo to nie jest ona wyłącznie ich prostą sumą" (1997, s. 45).

Spojrzenie na szkołę jako plastyczny układ istniejących w niej powiązań dynamicznie reagujący na zmieniające się warunki zewnętrzne wzbudził poszukiwania nowej interpretacji rozwoju szkoły jako organizacji. Eksponuje ona rozwój szkół „od środka”, od jej wnętrza, rozwój inicjowany głównie przez jej członków. Kluczową rolę odgrywa zawsze kierownictwo, a nierzadko i „doradcy procesowi” z zewnątrz (French, Bell, 1990).

Rysunek 1. Zmiana jako przemienny stosunek między twórczym rozwojem a adaptacją

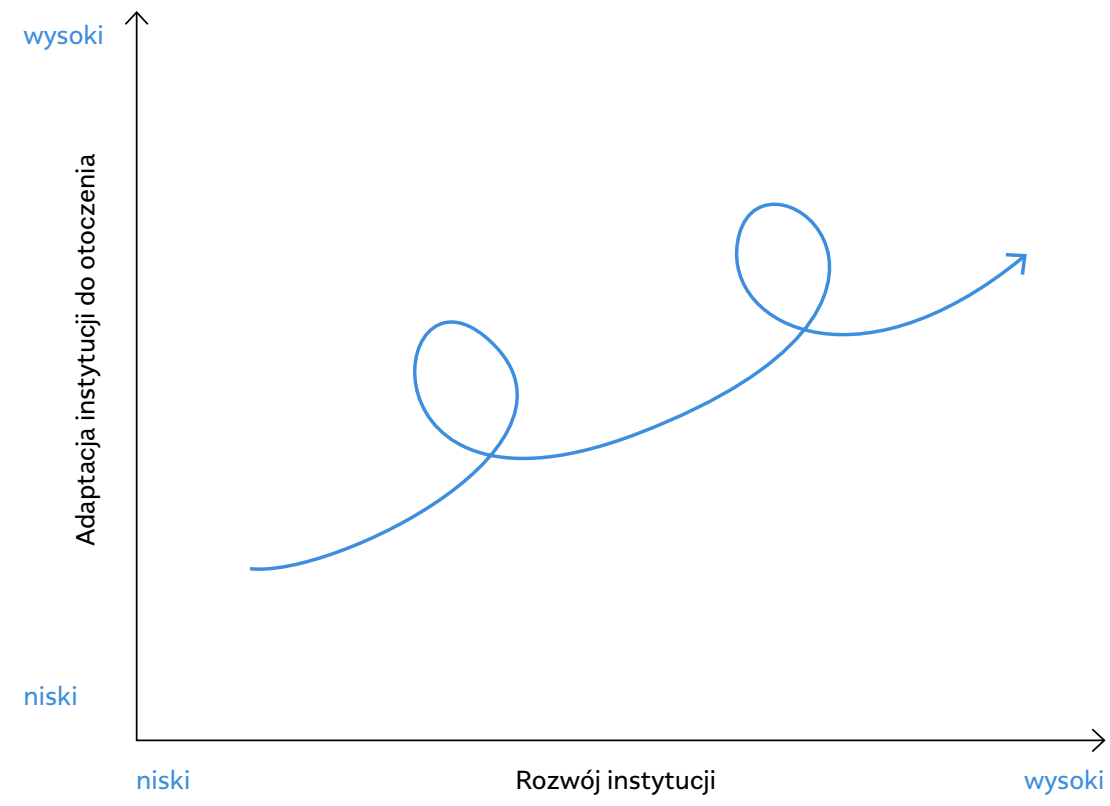

Źródło: opracowano na podstawie Dalin, 1997, s. 52. 
Warto dodać, że przyjmowane do teorii szkoły teorie zależności w rozwoju organizacyjnym miały początkowo rys psychologii społecznej K. Lewina oraz psychologii humanistycznej. Obecnie dominuje ewolucyjna teoria systemowa, opierająca się zarówno na systemowej terapii rodzinnej, jak i na socjologicznej teorii systemowej (Baumgartner, 1988). Już na początku lat osiemdziesiątych H.-G. Rolff oraz K.J. Tillmann pisali: "owego postępu nie można redukować wyłącznie do zwykłej analizy organizacji szkoły, jak to zwykle bywa. Z pewnością szkoła jest organizacją społeczną, lecz ma ona bardzo nietypowe, pedagogiczne cele. Z jednej strony podlega ona ustawom dotyczącym produkcji »towarów «, nawet jeśli koszty kształcenia ograniczane są przez dominujące interesy finansowe. Z drugiej strony cele instytucji szkolnej są specyficzne, odróżniają ją od wszystkich innych instytucji społecznych" (1980, s. 249-250).

Rozwój organizacyjny jest przedstawiany jako "rama koncepcyjna oraz strategia dla wspierania szkół w spełnianiu wymagań stawianych im przez podlegające szybkim zmianom pluralistyczne społeczeństwo. Obejmuje to teorię oraz narzędzia ( $w$ formie metod), które mają pomóc szkołom jako systemom w samoodnowie i samokierowaniu. Rozwój organizacyjny pomaga szkołom wich próbach zwiększenia wzajemnego zrozumienia, zaangażowania i współpracy pomiędzy nauczycielami, rodzicami, uczniami i obywatelami" (R. Schmuck, za: Warnken, 1997, s. 78).

H.-G. Rolff, C.G. Buhren, D. Lindau-Bank i S. Müller (1999, s. 15-18) interpretują rozwój szkoły jako angażowanie jej sił oddolnych. Sprowadzają je do trzech istotnych komponentów: rozwoju osobowego (zamiennie określane w innych publikacjach jako mistrzostwo osobiste), rozwoju procesów nauczania - uczenia się oraz rozwoju organizacyjnego. W kategoriach zależności związków systemowych rozwój poszczególnych obszarów placówki przenika do pozostałych, inicjując w nich dalsze zmiany. Przedstawiony związek systemowy ujmowany jest przez Rolffa w słowach: „nie ma poprawy jakości procesu nauczania - uczenia się bez rozwoju osobowego nauczyciela i rozwoju organizacyjnego; nie ma rozwoju organizacyjnego bez rozwoju osobowego i rozwoju uczenia się i nauczania; nie ma mowy o rozwoju osobowym nauczycieli bez rozwoju organizacyjnego i doskonalenia procesów nauczania - uczenia się" (Rolff, 1998, s. 306). W szkole niemożliwe są zmiany w jednej dziedzinie, które nie miałyby jednocześnie wpływu na pozostałe obszary. Jednakże wszelkie działania pociągają za sobą, poza zamierzonymi efektami, również mniej lub bardziej nieprzewidywalne skutki uboczne. Wówczas 
rozwiązanie jednego problemu oznacza potrzebę pokonania następnej trudności. Funkcjonowanie szkoły ukazuje się tym samym jako zjawisko złożone, którego nie można opisać mechanicznie lub linearnie w prostej zależności typu „akcja - reakcja”.

Zależności pomiędzy rozwojem organizacyjnym, rozwojem procesów nauczania - uczenia się i rozwojem osobowym wynikają z założenia, że system pojedynczej placówki ulega przeobrażeniom, jeśli następują zmiany w podsystemach: „organizacja”, „nauczanie - uczenie się”, „nauczyciele" i "uczniowie". Systemy składają się z elementów oraz wzajemnych relacji, jakie między nimi zachodzą. Wynika stąd, że złożonych zadań, jakie ma do zrealizowania szkoła, nie sposób osiągnąć, jedynie opierając się na zmianach samych elementów, ale przede wszystkim w wyniku zachodzących związków pomiędzy tymi elementami. Jeden element wpływa na drugi i odwrotnie, na zasadzie zachodzącego pomiędzy nimi sprzężenia zwrotnego. Tym samym zjawisko to może mieć zarówno charakter hamujący, jak i budujący. Pojawienie się efektu synergicznego może nastąpić wówczas, gdy dwa podsystemy w sposób pozytywny się uzupełniają i wzajemnie wspierają (Rolff, Buhren, Landu-Bank, Müller, 1999, s. 15). Z tego założenia wynika, że podejmowane działania, by miały charakter rozwojowy, muszą przebiegać w jednym kierunku. Jednakże mówiąc o szkole jako systemie, nie sposób zapomnieć, że tworzą go aktywni ludzie, którzy nie tylko reagują na zastane sytuacje, ale również, stawiając sobie cele, mogą sami pewne sytuacje tworzyć lub zmieniać. Czynnik ludzki ma w szkole priorytetowe znaczenie; tworzące ją osoby nie są zwykłymi elementami systemu, lecz jego członkami, którzy rozmaicie odbierają otaczającą rzeczywistość. Fakt ten wiernie oddają słowa Goethego: „nie oko patrzy, jeno człowiek".

W rozwoju szkoły, jak uważa H.-G. Rolff, istnieją trzy płaszczyzny, w ramach których procesy te powinny zachodzić: indywidualna, na której można kształtować wartości, normy, wiedzę osób tworzących społeczność; nauczania, gdzie owe normy i wiedza przełożone zostają na czyny i ostatnia płaszczyzna organizacji, na której stwarza się struktury umożliwiające ograniczenie lub rozwój działania. Warto podkreślić, że prezentowany związek systemowy jest natury wewnątrzszkolnej i wymaga pewnego uzupełnienia wpływami zewnętrznymi. Do otoczenia szkoły należą bowiem rodzice, ale również "odbiorcy" absolwentów: zakłady pracy, uniwersytety. Swój wpływ wywiera prasa, dzielnica miasta i oczywiście organ nadzorujący. Bowiem, szkoła jako system może 
być ujmowana $z$ jednej strony jako system zamknięty (w operacyjnym obszarze nauczania i wychowania), z drugiej zaś jako system otwarty, który nie może pozostać obojętny na to, co się dzieje w otoczeniu. W tym rozumieniu szkoła pozostaje dynamiczna. Ulegając zewnętrznym wpływom, aktywnie na nie odpowiada, modyfikując tym samym otaczające ją środowisko. Z takiego ujęcia wynika wniosek dla rozwoju szkoły. Dopasowywanie się szkoły do stale zmieniających się warunków otoczenia sprawia, że proces rozwojowy nie kończy się w jakiejś określonej chwili, lecz trwa tak długo, jak sama szkoła.

Rozwój szkoły może być zainicjowany od wewnątrz, przez członków organizacji, lub z zewnątrz; czyli szkoły mogą się rozwijać zarówno o własnych siłach lub sięgać po pomoc zewnętrznych doradców (Dalin, 1997, s. 53). W obu przypadkach można wyróżnić pewne zadania oraz kompleksy problemowe występujące $w$ formie modeli fazowych przedstawiających procesy rozwoju organizacyjnego.

Wszystkie modele fazowe opierają się na trójfazowym modelu opracowanym wstępnie przez K. Lewina, który odnosi się przede wszystkim do procesów wewnątrz organizacji oraz podejmowanych działań jej członków. W pierwszej fazie, rozpoczynającej proces, istniejące wzory zachowań zostają podane w wątpliwość. Niezadowolenie z istniejących nastawień służy poszukiwaniu nowych rozwiązań, zawsze biorąc pod uwagę aktualnie istniejące nastawienia, wartości lub struktury działań. W kolejnej fazie pojawiają się już planowe działania służące rozwojowi nowych postaw twórczych, ewentualnie interwencje wspierające identyfikację z nimi. W trzeciej fazie dominuje stabilizacja nowego stanu i powstałej struktury. Następuje utrwalenie nowych zachowań i postaw w codziennej praktyce szkolnej. Model K. Lewina, uznany za podstawowy, uległ w ostatnich dziesięcioleciach dalszemu rozszerzeniu i zróżnicowaniu.

Przeciwnicy podejścia "fazowego" podkreślają, że rozwój organizacyjny sprowadzony jest tu do mechanicznego działania następującego po sobie automatycznie. Wyodrębnienie jednak pewnych etapów ma swoje uzasadnienie praktyczne, gdyż różne są w nich punkty wyjścia, potrzeby, treści i występujące konflikty. Fazy rozwoju organizacyjnego tworzą pewne struktury, systematycznie ukazują nowe wymagania i potrzeby stosowania określonych metod lub instrumentów.

Przeniesienia fazowego modelu rozwoju organizacyjnego na obszar szkolny dokonali w latach osiemdziesiątych P. Dalin i H.-G. Rolff. 
Podobnie jak inni badacze, przyjęli założenie, iż procesy rozwojowe przebiegają cyklicznie (1996, s. 52-53). W zaprezentowanym programie instytucjonalnego rozwoju szkoły wyodrębniono pięć podstawowych etapów. Pierwszy: opisuje postępowanie doradcze od momentu zainicjowania kontaktu do podjęcia działań roboczych. Istotne jest powołanie grupy kierowniczej, która powinna reprezentować różne interesy szkoły i przedstawić swoje oczekiwania. W dalszej kolejności, na etapie drugim, dochodzi do wspólnego postawienia diagnozy, na przykład dzięki danym zebranym $w$ ankietach. W sposób naturalny prowadzi to do następnego etapu określającego perspektywy rozwojowe szkoły. $\mathrm{Na}$ etapie czwartym planowane są projekty ukierunkowane na osiągnięcie zamierzonych celów. Członkowie grupy kierowniczej przekazują wypracowaną wiedzę podzespołom koordynującym cały proces zmian. Wiedza i kwalifikacje doradców oraz osób prowadzących powinny bowiem mieć swoje odzwierciedlenie w szkole. Etap ostatni, piąty, odnosi się do ewaluacji, czyli pełnej oceny wyników projektu.

Zaproponowany przez P. Dalina i H.-G. Rolffa fazowy model rozwoju organizacyjnego wysuwa na pierwszy plan systematyczne "towarzyszenie" procesom zmian. Autorzy nie proponują gotowej koncepcji, lecz zmierzają do stworzenia nowej, ulepszonej struktury komunikacji wewnątrz organizacji. Jednakże, podobnie jak w wypadku wielu koncepcji, tak i tu nie brakuje osób nieszczędzących słów krytycznych. Można spotkać się z poglądem, że popularne metody i projekty rozwoju szkoły w niewystarczającym stopniu zajmują się podmiotem działającym człowiekiem, i ten aspekt należy uzupełnić. Jak można przeczytać: "Koncentracja na jednostce wydaje się (...) w najlepszym przypadku jedynie przybliżeniem do człowieka, ale nie uznaniem go za siłę sprawczą wszelkich procesów rozwojowych" (Mietz, 1994, s. 56). Niewłaściwe rozumienie rozwoju organizacyjnego pojawia się wówczas, gdy jest on utożsamiany wyłącznie z metodami i projektami, czyli z techniczną stroną swojego obrazu. Jest ona istotna, ale nie przeważa w wyraźnej orientacji na człowieka, któremu powinna służyć.

W podejmowanych rozważaniach dotyczących rozwoju szkoły pojawiły się również inne problemy, które zwróciły uwagę badaczy i pojawiały się w refleksji dotyczącej wyznaczenia kierunku tegoż rozwoju. Jakie interesy uznać za najistotniejsze? Jakie ostatecznie wytyczyć cele? Inne nieporozumienia wynikają z pytania o to, kto jest właściwym "motorem" rozwoju - siłą prowokującą aktywność? Nietypowe 
w rozwoju szkoły jest bowiem to, że jako czynnik sprawczy rozwoju należy postrzegać współpracujące i wewnętrznie powiązane ze sobą zespoły, a nie "pojedynczego" nauczyciela. Tworzenie, umacnianie i usamodzielnianie tychże zespołów nazywane jest przez niektórych królewską drogą (French, Bell, 1990).

Rozwój szkoły można zatem rozumieć jako doradztwo dotyczące rozwoju systemu, co często bywa określane jako doradztwo systemowe. Zawiera się w nim doradztwo w zakresie kierowania szkołą oraz praca z wewnątrzszkolnymi grupami kierującymi, wspólne diagnozowanie, planowanie oraz autoewaluacja szkół. Wszystko to nie może jednak zostać sprowadzone do zabiegu technicznego. Ważne wydaje się, by nauczyciele w każdym z wymienionych zabiegów w sposób profesjonalny tworzyli swoją własną szkołę, wykorzystując ku temu własną autonomię i autonomię placówki. Z tej perspektywy rozwój organizacyjny jawi się jako idea profesjonalizacji pracy pedagogicznej.

W Polsce pod koniec lat dziewięćdziesiątych za sprawą P. Dalina i H.-G. Rolffa upowszechniono koncepcję szkoły jako organizacji uczącej się (lernende Organisation), w której podstawę stanowi kwestia zmiany i radzenia sobie z nią przez społeczność szkolną. Założenia uczącej się szkoły włączone zostały w projekt reformy systemu edukacji wprowadzonej w 1999 roku. Upowszechniano wybrane prace P. Dalina i H.-G. Rolffa oraz innych naukowców, które przetłumaczono na język polski. Na szkoleniach nauczycieli zachęcano do podejmowania prób adaptacji „uczącej się organizacji” do warunków szkolnych typowych dla Polski. „Uczące się szkoły” są zdolne do zmiany, do nieustającego rozwoju, po to, by sprostać nowym wymaganiom sytuacyjnym zachodzącym w szybko zmieniającym się społeczeństwie, zatem nie uczą się w nich tylko uczniowie, lecz cała społeczność szkolna (Hildebrandt, 2001, s. 62). W przyjętym rozumieniu, szkoła ma do spełnienia niepowtarzalną rolę $w$ definiowaniu jakości uczenia się, co sprawia, że powinna zawsze rozpatrywać stawiane przed nią wymagania w świetle własnej wizji i misji, kreując $w$ ten sposób swoją przyszłość. Samoistna i autentyczna odnowa szkoły jest efektem bezpośredniego zaangażowania wszystkich jej pracowników i uczniów w określanie potrzeb, ustanawianie celów programu rozwoju. Jednakże, co wyraźnie podkreśla Dalin, przyjęcie takiego punktu widzenia jest możliwe jedynie przy formalnie ugruntowanej autonomii. Poziom autonomii szkoły wobec państwa jest dla niego istotnym 
czynnikiem wykorzystującym strategię rozwoju organizacyjnego dla odnowy szkoły (tamże, s. 64).

Wybitni badacze rozwoju organizacyjnego szkoły P. Dalin i H.-G. Rolff (1990) uważają, że najpóźniej od roku 1990 jednostkę szkolną, czyli pojedynczą placówkę przyjmuje się za "siłę napędową rozwoju szkolnictwa", za którego skuteczność odpowiedzialni są w pierwszej linii nauczyciele i dyrektorzy szkół, a pozostałe instytucje pełnią raczej funkcję wspierającą i zabezpieczającą. Istotne znaczenie w kształtowaniu się nowego podejścia do szkoły miały coraz intensywniej podejmowane badania, a także polityczna wola. Nie bez znaczenia okazały się też procesy koniunkturalne w rozwoju szkoły, wiedza dotycząca skuteczności procesów reformowania szkół i teorii kształcenia, jak również zmiany społeczne ostatnich lat. Wszystkie one razem stworzyły dogodny klimat dla nowego spojrzenia na instytucję szkoły. Ponadto silnie oddziałujące zróżnicowanie wszystkich sfer życia, polaryzacja stosunków społecznych oraz położenie nacisku na rozwój indywidualny - razem zjawiska te spowodowały, że centralne procesy sterowania nie były już możliwe. To, co rozgrywa się w klasie i co rzeczywiście ma w niej miejsce, nie może zostać "uskutecznione" z zewnątrz. "Szkoła nie poddaje się planistom bezwarunkowo" (Warnken, 1997, s. 75). Tym samym kadra kierownicza w szkolnictwie nie może zarządzić, a co jest ważne - może jedynie umożliwić osiąganie wyników i wspierać procesy lub w najlepszym razie je inicjować (Dalin, 1997, s. 55). Nie dyskredytuje to szczebla centralnego, wręcz przeciwnie, w dalszym ciągu przypisuje się mu ważną rolę w procesie zmian, bowiem ważna jest kombinacja nacisku i wspomagania (Rolff, 1998, s. 314-315). Ważniejsze jednak jest zrozumienie, że procesy zmian rozpowszechniają się przez dialog i rzeczywiste wywieranie wpływu (Hubermann, Milles, 1984, cyt. za: Dalin, 1997, s. 55).

\section{Nauczyciele wobec zmiany}

Sedno zmian oświatowych tkwi w tym, jak ludzie poradzą sobie z nowymi realiami, wymaganiami i obowiązkami (Fullan, 1982, s. 82). Ta refleksja składa w ręce nauczycieli istotę przemian, wraz z odpowiedzialnością za nie, "każąc" im w ten sposób udźwignąć cały ciężar. Reforma w tym przypadku nie decyduje o rzeczywistej zmianie - jest zapisem wytycznych na papierze, a nie realnym ich odbiciem. 
Dlatego już dziś można powiedzieć z przekonaniem, że procesy zmian oświatowych 2 będą przebiegały bardzo wolno, gdyż będą zależały od postrzegania nowych doświadczeń przez pojedynczych ludzi i od zmiany ich stosunku do samych siebie (Arends, 1995, s. 320). Zmiana, aby mogła zaistnieć, musi objąć swym zasięgiem nauczyciela i jego życie wewnętrzne. Dopiero po pewnym czasie wychowankowie to zauważą i przystosują się do nowej rzeczywistości, odnajdując w nowej pedagogicznej sytuacji oferowanej przez nauczyciela swój osobisty sens.

Wydaje się, że ważną prawidłowością przy uwzględnianiu procesu zmiany jest właśnie zauważenie jej sensu - zrozumienie istoty, ale też oswojenie się z czymś, co wcześniej było obce. Takie podejście wymaga ciągłego doświadczania siebie po nowemu, patrzenia na rzeczywistość oświatową z nowej perspektywy, przez pryzmat zmiany w sobie. Oznacza to, że zmiany w sobie następują później niż zmiany w postrzeganiu innych. Wynika z tego, że w większości ludzie nie mogą zmienić się tylko w wyniku otrzymania nowych wiadomości lub instrukcji pokazujących kierunek nowego działania, czy też po przedstawieniu im zalet tego, co nowe. Jedynie dzięki własnym przeżyciom zdołają "stare" zastąpić "nowym".

W takim ujęciu priorytetowego znaczenia w postrzeganiu zmiany, a właściwie szansy jej zaistnienia w szkole, nabiera stan świadomości nauczyciela. Ważne wówczas wydaje się zwrócenie większej uwagi na myśli, sądy, refleksje nauczycielskie dotyczące współczesnego świata i jego rozwoju, własnego w nim miejsca i miejsca w nim szkoły. H. Kwiatkowska przyjmuje założenie, „że działanie nauczyciela na rzecz zmiany ( $w$ tym również zmiany rozwojowej ucznia) jest tym skuteczniejsze, im bardziej nauczyciel sam podlega procesom rozwojowym, im bardziej jest świadomy siebie, a także świadomy realizacji przez szkołę jego własnych potrzeb zawodowych (poznawczych, sprawnościowych), a także egzystencjalnych (np. potrzeby uznania, autonomii)" (1997, s. 52).

Badacze zmiany wskazują na to, że nauczyciele nie od razu wykorzystują " "nowe" w całości. Ludzie, którzy zaczynają robić coś innego niż zwykle, robią to stopniowo "kawałek po kawałku". Nie prędzej zdecydują się na pełne wykorzystanie innowacji, aż zrozumieją ją i zyskają zaufanie do własnych możliwości postępowania zgodnie z nowymi zasadami. G.E. Hall wylicza następujące stopnie wykorzystywania innowacji: bez- 
czynność, orientacja, przygotowanie, stosowanie mechaniczne; następnie: rutyna lub dalsze doskonalenie, przejście do integracji jako działanie wspólnotowe "z" i „na” rzecz innych i znów doskonalenie w kierunku poszukiwania dalszych modyfikacji (Hall, Loucks, 1977, s. 266-267).

Nastawienie nauczyciela do zmiany eksponuje jego oczekiwania. Przytaczane jest wówczas sześć faz w jego ustosunkowaniu się do innowacji, które odpowiadają staraniom o nadanie zmianie osobistego sensu. Są to fazy: uświadomienia, poinformowania, zindywidualizowania, wykonania, zaistnienia następstw, ale też faza współdziałania w celu skoordynowania działań i racjonalizacji jako wyrobiona refleksja o ewentualnych dalszych doskonalszych zmianach (Arends, 1995, s. 421-422). W doświadczanej przez nauczycieli współczesności ścierają się siły regresywne z progresywnymi. Na tle tych różnych, nie zawsze pozytywnych odczuć, dochodzi do kształtowania się stanowiska nauczycieli wobec zmiany, które przejawia się w całokształcie relacji między przeświadczeniem a działaniem, między tym, jak wykorzystują to, co wiedzą, a tym, w co wierzą, do podejmowania decyzji na temat tego, co robić (szerzej: Pearson, 1994) (rysunek 2.).

Rysunek 2. Model działania sił

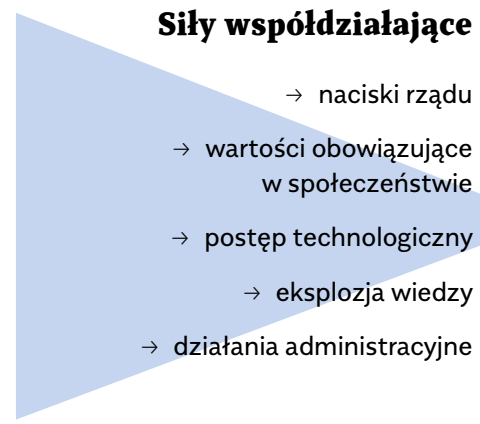

\section{Sily konfliktowe}

$\rightarrow$ lęk przed nieznanym

$\rightarrow$ zagrożenia dla posiadanej władzy i kompetencji

$\rightarrow$ przestarzała wiedza i kwalifikacje

$\rightarrow$ tradycyjne wartości

$\rightarrow$ ograniczone zasoby

Źródło: Ornstein, Hunkins, 1998, s. 293.

Przyjęcie przez nauczyciela nowego, zmodyfikowanego kierunku pracy powinno być poparte fachową wiedzą, która ma odgrywać rolę stymulatora inwencji pedagogicznej, będąc równocześnie czynnikiem racjonalizującym marzenia i aspiracje. Nakłada to pewne ograniczenia 
na różnorodne, ale jednocześnie potrzebne emocje, wizje i pragnienia. "Nie może jednak nad misją zawodową nauczyciela dominować fetysz metodyczny i prakseologiczny. Wszak mechanizm budowania przyszłości polega nie na doskonaleniu instytucji, lecz na wypełnianiu treścią życia i celów jednostki" (Pilch, 1999, s. 163).

Ze strony nauczyciela proces innowacyjny wymaga związania się ze zmianą mającą dla niego osobisty sens, wyrobienia poglądu na istotę zmiany, odczucia i wypróbowania innowacji. Dodatkowo godny podkreślenia wydaje się towarzyszący temu klimat szkolny, wyzwalający i wspierający oddolne inicjatywy - sprzyjający urzeczywistnianiu się i rozwojowi pojawiających się nowych symptomów ogarniających być może z czasem całą społeczność szkoły. Bez warunków umożliwiających nauczycielowi pracę "po nowemu" wpływ innowacji nie może trwać długo. Bowiem każda ze szkół, jako system społeczny, reaguje na zmianę w sieci skomplikowanych powiązań, w których każdy element jest $z$ innym ściśle powiązany $i$ żaden nie działa w izolacji. Kiedy zmieni się jeden odcinek tych powiązań lub kiedy zmieni się choćby jeden nauczyciel, muszą zmienić się wszyscy pozostali. Badania tej orientacji teoretycznej zostały przeprowadzone już w latach sześćdziesiątych w Stanach Zjednoczonych przez zespół S. Sarasona (1971) i rozwijane były przez kolejnych badaczy. Jednak ich aktualność jesteśmy w stanie doświadczać współcześnie, bowiem zmiana, czy tego chcemy, czy nie, przenika powoli, właśnie poprzez te nieliczne osoby, które mają ją w sobie wcześniej niż pozostali.

Refleksje na temat możliwości wprowadzenia zmian uświadamiają, jak wielka siła tkwi w nauczycielach jako ich kreatorach. $\mathrm{H}$. Giroux i P. Freire (1993) uważają, że nauczyciela nie wolno wykluczać z prac koncepcyjnych przy tworzeniu i wdrażaniu zmian. Nauczyciele, myśląc refleksyjnie, są świadomi założeń, na których opierają swoje działanie i dzięki nim kreowanie zmiany może nabrać realnego sensu. Nie wymaga też specjalnego potwierdzenia, że spośród osób pracujących w oświacie właśnie nauczyciele mogą wiedzieć najwięcej o praktycznej stronie pedagogicznego działania, mogąc służyć najlepszym doświadczeniem klinicznym. Należąc do rzeczywistości oświatowej, są jedynym jej ogniwem przygotowanym pedagogicznie, posiadającym predyspozycje i powołanie do wdrażania pożądanych modyfikacji. W miarę postępującego zaangażowania nauczyciela rośnie też jego przeświadczenie, że uczestnictwo w zmianie nie kończy się wraz z wprowadzeniem „nowe- 
go", bowiem instytucje wypełniające przestrzeń edukacyjną zmieniają się i rozwijają nieustannie (Ornstein, Hunkins, 1998, s. 308).

Założenie, że stawanie się nauczyciela podmiotem własnej praktyki zawodowej związane jest $z$ uczestnictwem w poznawaniu i wiążącym się z nim krytycznym osądzie, a następnie z odpowiedzialnym i odważnym zmienianiu elementów w przestrzeni edukacyjnej, wskazuje, że pierwszym etapem wynikającym z powyższego rozumowania i jednocześnie warunkiem dalszych następstw jest poznanie, a dokładniej - rozpoznanie potrzeby zmiany. Zmiana nierozerwalnie wiąże się z jej poznaniem, czyli ze szczególną okazją do uchwycenia własnej sytuacji i roli w niej osobistego sprawstwa, odkrycia, co i jak można zrobić. Takie rozpoznanie może stanowić - jak podaje M. Czerepaniak-Walczak (1998, s. 293) - "o jakości nauczycielskiego badania w działaniu jako swoiście zintegrowanego myślenia i działania, poznania i zmiany". Autorka wymienia tu trzy etapy postępowania: decyzja (zmiany), dyskusja (z innymi, dostrzegającymi podobne zjawiska) oraz informowanie (o wynikach własnych odkryć i projektach dalszych zmian). Istotą tak widzianego procesu przekształcania rzeczywistości szkolnej jest osobiste zaangażowanie w planowanie i wprowadzanie przekształceń w obszarze objętym własną praktyką badacza, będące podstawą studiowania rzeczywistości oświatowej. Przyjęty przez autorkę proces stanowi, jak sama mówi, „trójfazowy schemat rozwoju nauki” (tamże) wyrażający się w cyklicznej sekwencji następujących po sobie działań nakierowanych na poznanie i zmianę. Ciekawość poznawcza i pragnienie zmiany mogą się wówczas stać wystarczającym powodem do podjęcia dalszego wysiłku i odnawiania się procedury.

Inicjując proces zintegrowanego poznania i zmiany, nauczyciel ma szansę rzeczywistego i świadomego przekształcania własnej działalności, pomimo wszechobecnej złożoności i dynamiki procesów towarzyszących lub tylko współwystępujących. Ważny wydaje się już sam projekt zmiany, będący wyrazem krytycznego osądu dotychczasowego stanu i odzwierciedlający własną opcję praktycznego działania,czy też propozycję zmiany własnej praktyki zawodowej. Biorąc udział w tworzeniu rzeczywistości edukacyjnej lub, inaczej, nadając pewnym ideom sens ich istnienia, nauczyciel jako jedyny ma szansę poznawania, odkrywania tego, co można i należy robić, by robić to lepiej. Warto dodać, że w procesie realizacji zmiany jednostka może jej podlegać przez naśladownictwo bądź uczestniczenie w doświadczeniach in- 
nych; w tym przypadku zarówno świadomie, jak i nieświadomie. Proces adaptacyjno-identyfikacyjny wobec zaistniałej zmiany przebiega w trzech płaszczyznach:

$\rightarrow$ normatywnej, gdy dotyczy dostosowania się do nowych norm i wzorów,

$\rightarrow$ komunikatywnej, gdy dotyczy wymiany informacji,

$\rightarrow$ funkcjonalnej, związanej z wykonywaniem zadań (Radziewicz-Winnicki, 1995, s. 38).

Nauczyciel widzący możliwości poprawy, a więc pewnej zmiany na lepsze, staje przed szansą widzenia swojej pracy w szerszym kontekście. Nie tylko w perspektywie swojej szkoły, ale również bliskiego i dalszego środowiska. Osoby odpowiedzialne za wdrożenie zmiany muszą także dobrze znać jej właściwości i liczyć się z oporem wynikającym z niezrozumienia lub braku potrzeby zmiany. „To, co uznajemy za potrzebne odzwierciedla nasz system wartości. Jeżeli zmiana wydaje się z nim zgodna, łatwiej uznamy potrzebę jej wprowadzenia" (Ornstein, Hunkins, 1998, s. 304). Przezwyciężanie oporu i pozyskiwanie zwolenników dla nowych rozwiązań wiąże się z pozyskaniem na szeroką skalę osób, które zechcą się zaangażować w coś nowego, poszerzyć horyzonty, zbadać nowe tereny, zachęcić swoich współpracowników do tworzenia w szkole społeczności zwolenników innowacji programowej.

W procesie wprowadzania zmian na znaczeniu zyskuje przezwyciężenie wielu obaw i pokonanie wielu zagrożeń. Niezbędne jest również wyrobienie przekonania, że zmiana uwzględnia wszystko to, co nauczyciele cenią, w co wierzą i czego by chcieli dla szkoły, uczniów, ale również dla siebie. Jednak nauczyciel został nauczony wysłuchiwania sloganów, za którymi nic się nie kryło, nauczono go również niedotrzymywania danego słowa. Jak zatem dziś ma uwierzyć i komu? Są to trudne do przezwyciężenia wątpliwości, bo kryją się za nimi doświadczenia zdobyte w całym życiu zawodowym nauczyciela. Nie wystarczą tu same słowa. Potrzebne są namacalne dowody i rzeczywista pomoc. Zwiększając obciążenia nauczycieli, stawiając dodatkowe wymagania i nie oferując nic w zamian, można jedynie obniżyć i tak już zachwiany stan równowagi, narażając się na spotęgowanie zjawiska dysfunkcjonalności szkoły, która zgubi wizję pełnego integralnego człowieka i tworzącą ją humanistyczną „tkankę ludzką". „Dążenie do zmiany realności edukacji musi uwzględniać zmianę świadomości jej podmiotów dokonującą się 
na skutek i w trakcie aktywnego działania na rzecz zmiany" (Szkudlarek, 2000, s. 288). Zmiana nie może być „zadawana" przez teorię i dekretowana przez jakkolwiek pomyślaną ideologię. Radykalizm myślenia edukacyjnego $w$ tym przypadku sprowadza się do uznania rangi oddolnych inicjatyw jako podstawy demokratycznej samoorganizacji społeczeństwa, nieustającej interpretacji zastanego, dziejącego się świata.

W coraz większej złożoności strukturalnej i funkcjonalnej nowoczesnych społeczeństw wzrasta potrzeba wzbogacania zdolności człowieka do reagowania na różnorodność wpływów otoczenia. Jeśli zatem przyszłość oferuje człowiekowi konieczność podporządkowania się zmianom - podporządkowanie to nie może być ślepe, musi być świadomym kompromisem pomiędzy tym, co człowiek może, czego chce i powinien (Radziewicz-Winnicki, 1995, s. 35 i 191). Tak ilustrowane przykłady ludzkiej aktywności, odczytywane są w filozofii personalistycznej jako potężny imperatyw i powinność moralna oraz subiektywne dobro każdej osoby podejmującej się takiego działania. Można przyjąć, że uczestniczenie nauczyciela w zmianie oświatowej, jej koncypowaniu i realizacji staje się takim samym jego obowiązkiem, jak choćby planowanie procesu dydaktycznego. 


\section{Bibliografia}

$\rightarrow$ Arends, R.I. (1995), Uczymy się nauczać, tłum. K. Kruszewski, Warszawa: Wydawnictwa Szkolne i Pedagogiczne.

$\rightarrow$ Bauman, Z. (2006), Płynna nowoczesność, tłum. T. Kunz, Kraków: Wydawnictwo Literackie.

$\rightarrow$ Baumgartner, I. (1988), OE-Prozesse - Die Prinzipien systemischer Organisationsenticklung, Bern-Stuttgart-Wien: Paul Haupt.

$\rightarrow$ Bogaj, A., Kwiatkowski, S.M., Szymański, M.J. (1997), System edukacji w Polsce. Osiągnięcia - Przemiany-Dylematy, Warszawa: Instytut Badań Edukacyjnych.

$\rightarrow$ Chłopecki, J. (1993), Ciągłość, zmiana i powrót. Szkice z socjologii wychowania, Rzeszów: Wydawnictwo WSP w Rzeszowie.

$\rightarrow$ Czerepaniak-Walczak, M. (1998), Badanie w działaniu-fanaberia czy konieczność? (Integrowanie poznania i zmiany jako wyróżnik profesjonalizmu nauczycielskiego) [w:] A. Siemak-Tylikowska, H. Kwiatkowska, S.M. Kwiatkowski (red.), Edukacja nauczycielska w perspektywie wymagań zmieniającego się świata, s. 287-303, Warszawa: Wydawnictwo Akademickie „Żak".

$\rightarrow$ Dalin, P. (1997), Program instytucjonalnego rozwoju szkoły (ISP), tłum. B. Przybytniak [w:] Z. Radwan (red.), Rozwój organizacyjny szkoły, s. 49-67, Radom: Wydawnictwo ITE.

$\rightarrow$ Dalin, P., Rolff, H.- G., Buchen, H. (1996), Institutioneller Schulentwicklung-Prozeß, Bönen/Westf: Verlag für Schule und Weiterbildun.

$\rightarrow$ Dalin P., Rolff H.-G. (1990), Institutionelles Schulentwicklungs-Programm, Soest: Soester Verlagskontor.

$\rightarrow$ Dudzikowa, M. (2001), Mit o szkole jako miejscu wszechstronnego rozwoju ucznia, Kraków: Oficyna Wydawnicza „Impuls".

$\rightarrow$ Delors, J. (red.) (1998), Edukacja: jest w niej ukryty skarb. Raport dla UNESCO Międzynarodowej Komisji do spraw Edukacji dla XXI wieku pod przewodnictwem J. Delorsa, tłum. W. Rabczuk, Warszawa: Stowarzyszenie Oświatowców Polskich - Wydawnictwa UNESCO. 
$\rightarrow$ French, W.L., Bell, C.H. (1990), Organisationsentwicklung, Bern-Stuttgart: Paul Haupt.

$\rightarrow$ Fullan, M. (1982), The meaning of Educational Change, New York: Teachers College Press.

$\rightarrow$ Giroux, H.A., Freire, P. (1993), Edukacja, polityka i ideologia, tłum. L. Witkowski [w:] Z. Kwieciński (red.), Nieobecne dyskursy, s. 412-432, cz. III: Studia kulturowe i edukacyjne. Toruń: Wydawnictwo Naukowe Uniwersytetu Mikołaja Kopernika.

$\rightarrow$ Głażewski, M. (1996), O witalności szkoły, Zielona Góra: Wydawnictwo WSP w Zielonej Górze.

$\rightarrow$ Hall, G.E., Loucks, S.F. (1977), A Developmental Model for Determining whether the Treatment is Actually Implemented, American Educational Research Journal, 14, 263-276.

$\rightarrow$ Havighurst, R.J. (1981), Developmental Tasks and Education, New York, London: McKay.

$\rightarrow$ Hempoliński, M. (1989), Filozofia współczesna. Wprowadzenie do zagadnień i kierunków, Warszawa: PWN.

$\rightarrow$ Hildebrandt, A. (2001), Koncepcja rozwoju organizacyjnego szkoły Pera Dalina [w:] E. Potulicka (red.), Szkice z teorii i praktyki zmiany oświatowej, s. 61-139, Poznań: ERUDITUS.

$\rightarrow$ Hubermann, U.A., Miles, M.B. (1984), Innovation Up Close, New York-London: Plenum Press.

$\rightarrow$ Krońska, I. (1983), Sokrates, tłum. W. Witwicki, Warszawa: Wiedza Powszechna.

$\rightarrow$ Kunowski. S. (1993), Podstawy współczesnej pedagogiki, Warszawa: Wydawnictwo Salezjańskie.

$\rightarrow$ Kupisiewicz, C. (1995), Szkolnictwo w procesie przebudowy, Warszawa: Wydawnictwo Akademickie "Żak".

$\rightarrow$ Kwiatkowska, H. (1997), Edukacja nauczycieli. Konteksty, kategorie, praktyki, Warszawa: Instytut Badań Edukacyjnych.

$\rightarrow$ Kwieciński, Z. (2000), Pedagogika i edukacja wobec wyzwania kryzysu i gwałtownej zmiany społecznej, Warszawa: Instytut Badań Edukacyjnych.

$\rightarrow$ Legowicz, J. (1981), Tradycja, dziedzictwo i spadek $w$ historii pokoleń, Studia Filozoficzne, 7-8, 97-100.

$\rightarrow$ Leśniak, K. (1972), Materialiści greccy w epoce przedsokratejskiej, Warszawa: Wiedza Powszechna.

$\rightarrow$ Melosik, Z. (2000), Edukacja i przemiany kultury współczesnej (czyli czy teoria ponowoczesna jest pedagogice potrzebna) [w:] Z. Kwieciński (red.), Alternatywy myślenia o/dla edukacji. Wybór tekstów, s. 171-186, Warszawa: Instytut Badań Edukacyjnych. 
$\rightarrow$ Mietz, J. (1994), Das vernachlässigte Subjekt, Pädagogische Führung, 5(2), 56-59.

$\rightarrow$ Madalińska-Michalak, J. (2012), Przywództwo w szkołach na obszarach zaniedbanych społecznie. Studium porównawcze, Łódź: Wydawnictwo Uniwersytetu Łódzkiego.

$\rightarrow$ Michalak, J.M. (2006), Doskonalenie pracy szkół funkcjonujq̨cych na obszarach zaniedbanych. Rola przywództwa [w:] J.M. Michalak (red.), Przywództwo w szkole, s. 127-144, Kraków: Oficyna Wydawnicza "Impuls".

$\rightarrow$ Michalak, J.M. (2010), Przywództwo edukacyjne w budowaniu potencjału szkoły [w:] S.M. Kwiatkowski, J.M. Michalak (red.), Przywództwo edukacyjne w teorii i praktyce, s. 63-83, Fundacja Rozwoju Systemu Edukacji: Warszawa.

$\rightarrow$ Nowosad, I. (2011), O potrzebie integralnego podejścia do zmian w edukacji szkolnej. Od zmian w szkole do zmiany szkoły, Studia Pedagogiczne, LXIV: M. Dudzikowa, S. Jaskulska (red.), Edukacja szkolna w zmianach? Zmiany w edukacji szkolnej? Problematyzowanie problemów.

$\rightarrow$ Nowosad, I. (2003), Perspektywy rozwoju szkoły. Szkice z teorii szkoły, Warszawa: Instytut Badań Edukacyjnych.

$\rightarrow$ Nowosad, I. (2008), Autonomia szkoły publicznej w Niemczech. Poszukiwania - konteksty - uwarunkowania, Zielona Góra: Wydawnictwo Uniwersytetu Zielonogórskiego.

$\rightarrow$ Ornstein, A.C., Hunkins, F.P. (1998), Program szkolny. Założenia, zasady, problematyka, Warszawa: WSiP.

$\rightarrow$ Pachociński, R. (1999), Oświata XXI wieku. Kierunki przeobrażeń, Warszawa: Instytut Badań Edukacyjnych.

$\rightarrow$ Pearson, A.T. (1994), Nauczyciel. Teoria i praktyka w kształceniu nauczycieli, tłum. A. Janowski, M. Janowski, Warszawa: WSiP.

$\rightarrow$ Pilch, T. (1999), Spory o szkołę. Pomiędzy tradycją a wymaganiami współczesności, Warszawa: Wydawnictwo Akademickie "Żak".

$\rightarrow$ Radziewicz-Winnicki, A. (1995), Modernizacja niedostrzegalnych obszarów rodzimej edukacji, Katowice: Wydawnictwo Uniwersytetu Śląskiego.

$\rightarrow$ Rolff, H.-G., Buhren, C.G., Lindau-Bank, D., Müller, S. (1999), Manual Schulentwicklung, Weinheim-Basel: Beltz.

$\rightarrow$ Rolff, H.-G. (1998), Schulentwicklung im Systemzusammenhang [w:] H.-G. Rolff, K.O. Bauer, K. Klemm, H. Pfeiffer (red.), Jahrbuch der Schulentwicklung: Daten, Beispiele und Perspektiven, s. 295-326, Weinheim-München: Juventa.

$\rightarrow$ Rolff, H.-G. (1997), Szkoła jak organizacja społeczna, tłum. B. Przybytniak [w:] Z. Radwan, Rozwój organizacyjny szkoły, s. 35-48, Radom: Wydawnictwo ITE. 
$\rightarrow$ Rolff, H.-G., Tillmann K.J. (1980), Schulentwicklungsforschung: Theoretischer Rahmen und Forschungsperspektive [w:] H.-G. Rolff, K. Hansen, K. Klemm, K.J. Tillmann (red.), Jahrbuch der Schulentwicklung. Daten, Beispiele und Perspektiven, s. 237-264, Weinheim-München: Juventa.

$\rightarrow$ Sarason, S. (1971), The Culture of School and the Problem of Change, Boston: Allyn and Bacon.

$\rightarrow$ Szempruch, J. (2012), Nauczyciele w warunkach zmiany społecznej i edukacyjnej, Kraków: Oficyna Wydawnicza "Impuls".

$\rightarrow$ Szkudlarek, T. (2000), Radykalna krytyka, pragmatyczna zmiana [w:] Z. Kwieciński (red.), Alternatywy myślenia o/dla edukacji. Wybór tekstów, s. 277-288, Warszawa: Instytut Badań Edukacyjnych.

$\rightarrow$ Szymański, M.J. (2013), Socjologia edukacji. Zarys problematyki, Kraków: Oficyna Wydawnicza "Impuls".

$\rightarrow$ Śliwerski, B. (1998), Jak zmienić szkołę. Studia z zakresu polityki oświatowej i pedagogiki porównawczej, Kraków: Oficyna Wydawnicza „Impuls".

$\rightarrow$ Śliwerski, B. (2008), Oświatowy remanent, czyli o ideologicznym majsterkowaniu polityków oświatowych w latach 1989-2006 [w:] M. Dudzikowa, M. Czerepaniak-Walczak (red.), Wychowanie. Pojęcia-Procesy-Konteksty, t. 4, s. 95-140, Gdańsk: GWP.

$\rightarrow$ Śliwerski, B. (red.) (2006), Pedagogika, t. 2: Pedagogika wobec edukacji, polityki oświatowej i badań naukowych, Gdańsk: GWP.

$\rightarrow$ Türk, K. (1989), Neuere Entwicklungen der Organisationsforschung, Stuttgart: Verlag.

$\rightarrow$ Warnken, G. (1997), Kultura szkoły, rozwój organizacyjny, doskonalenie - rozważania na temat reformy szkolnej, tłum. B. Przybytniak [w:] Z. Radwan (red.), Rozwój organizacyjny szkoły, s. 69-95, Radom: Wydawnictwo ITE. 



\title{
Przyszłość przywództwa edukacyjnego. Tylko martwe ryby płyną z prądem
}

Grzegorz Mazurkiewicz

\begin{abstract}
Aby spełniać swoje zadania polegające na przygotowaniu młodych ludzi do radzenia sobie z przyszłością, szkoła musi się zmienić i stać adekwatna do potrzeb. W tym celu należy też zmienić przywództwo edukacyjne. Niestety, wszelkie zmiany są utrudnione przez modele mentalne ukształtowane w czasach rewolucji przemysłowej oraz jednoklasowych szkół, wsparte przez, tak powszechny dziś, neoliberalizm i przekonanie, że to rywalizacja jest podstawową formą relacji międzyludzkich w zglobalizowanym świecie. Aby zmienić szkoły, niezbędny jest dialog i odpowiedź na pytanie: dlaczego i jakich szkół potrzebujemy?
\end{abstract}

\section{Słowa kluczowe:}

przywództwo edukacyjne

kontekst edukacji

determinizm historyczny

zmiana

dialog 


\section{Future of educational leadership. Only dead fish follow the current}

Grzegorz Mazurkiewicz

To fulfill its tasks of preparing young people to deal with future, school has to change and become adequate to needs. To do this the change of the leadership is also needed. Unfortunately, all changes are difficult because of the mental models shaped during industrial revolution and one class school buildings supported by neoliberalism, so common today, and premise that competition is the base for human interaction in the globalized world. In order to change school we need dialogue and answer to the question: what and what kind of schools do we need?

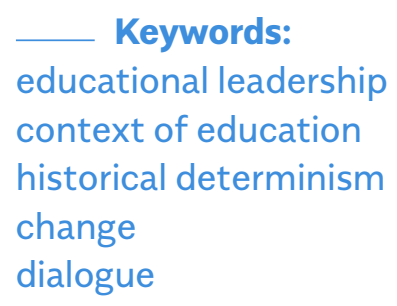




\section{Wprowadzenie}

Mimo różnych katastrof, których doświadczyła ludzkość, wciąż chcemy wierzyć w możliwość nieograniczonego wzrostu i ciągłego poprawiania naszych dotychczasowych osiągnąć. Może przez to pragnienie przemawia naiwność, może ambicja, może doświadczenie.

Trudno ocenia się świat, w którym żyjemy. Dochodzą do nas różne, sprzeczne ze sobą informacje. Tradycyjne źródła wiedzy o świecie, takie jak media, różnego rodzaju publikacje, autorytety i liderzy opinii publicznej, instytucje zaufania publicznego, bliskie nam osoby, zdają się być zagubione w olbrzymiej ilości danych. Reprodukują lub tworzą treści, co do których nie ma pewności, czy są prawdziwe, a często brak narzędzi, aby te treści zweryfikować. Czasami manipulują danymi dla osiągnięcia konkretnych korzyści politycznych czy ekonomicznych, często wygłaszają całkowicie sprzeczne opinie na jakiś temat, pozostawiając nas w niepewności, a i w pewnym sensie udowadniają $w$ ten sposób, że "wszystko" jest kwestią interpretacji.

Można dziś próbować udowodnić tezę, że „wszystko idzie ku lepszemu" albo że "jeszcze nigdy nie było tak źle". Przeważa pesymizm w ocenie naszej sytuacji, chociaż zarówno globalnie, jak i lokalnie, gdy porównujemy historyczne statystyki z tymi dzisiejszymi, widać postęp. To zresztą dziwne, że w czasach postępu technicznego, rozwoju medycyny, zmniejszającego się ubóstwa, długoletniego wzrostu gospodarczego, upowszechnienia edukacji, poprawiającego się zdrowia i wydłużającej średniej długości życia tak trudno o optymizm. Przeważa krytyka tego, co dzieje się wokół nas, a coraz trudniejsze wyzwania i niepokojące sygnały na temat fatalnego stanu naszej planety, naszych społeczeństw, biedy, gospodarki i prognoz na przyszłość rodzaju ludzkiego tylko potęgują niepokój (Bregman, 2017). Wiąże się to $z$ dostępem do wiedzy na temat tego, jak żyją inni, a także z coraz większymi oczekiwaniami wynikającymi zarówno ze zwiększającej się świadomości, jak i popularyzacji idei praw człowieka, nie tylko jako istniejącego dokumentu prawnego, ale również sytuacji konkretnych osób w realnej rzeczywistości.

Niezależnie od tego, jak oceniamy dzisiejszy stan rzeczy, gdy mierzymy się z sytuacją, w której sprawdzone sposoby radzenia sobie z rzeczywistością zawodzą, zaburza to naszą wiarę w człowieka, w rozum i w możliwość nieustannego rozwoju cywilizacyjnego. Wtedy najczęściej zwracamy się do tradycyjnych rozwiązań i staramy się robić to, co właśnie robimy i co prawdopodobnie doprowadziło nas do punktu, w którym się 
znajdujemy, ,jeszcze lepiej", to znaczy zamiast szukać zupełnie nowych, innych, rozwiązań danego problemu, nawołujemy do poprawy jakości tego, co robiliśmy do tej pory, chociaż ta metoda już nie jest skuteczna.

Wśród takich sprawdzonych rozwiązań, które można tu wymienić, są z pewnością sformalizowane systemy edukacyjne, które zostały ukształtowane w okresie ostatnich dwustu lat i całkowicie zdominowały organizację procesu uczenia się i nauczania. W sytuacjach kryzysowych to właśnie na szkoły patrzymy z nadzieją, wierząc, że znajdziemy w nich sposób na teraźniejszość i przyszłość. Doświadczenia pierwszych kilkunastu lat XXI wieku, chociaż nie potwierdzają tej nadziei, to jednak całkowicie jej nie przekreślają. Nie proponuje się więc zorganizowania szkoły inaczej, ale liczy na to, że formuła, według której działa ona dzisiaj, zacznie w końcu przynosić efekty. Wciąż to szkoła jest instytucją, do której zwracamy się po rozwiązania. To pierwsze założenie, na którym mam zamiar oprzeć logikę opracowania: szkoły są ważne dla społeczeństw, ponieważ społeczeństwa wierzą, że szkoły pomagają im radzić sobie $z$ wyzwaniami (choć nie jest to takie pewne).

A szkoły, aby móc z sukcesem spełniać oczekiwanie, że staną się ważnym elementem procesu rozwiązywania problemów współczesnego świata, muszą się zmienić. Postulaty zmiany edukacyjnych systemów, szkół i procesów w niej zachodzących są znane i akceptowane, pozostaje odpowiedzieć na pytanie, jak mają się zmienić. Za jeden z mechanizmów usprawniania edukacji według sprawdzonych algorytmów, ale też za jedno ze źródeł innowacyjnych pomysłów na radzenie sobie z rzeczywistością edukacyjną, uznaje się jej wewnętrzny system, tradycyjnie zwany administracją i zarządzaniem, umożliwiający sterowanie tą skomplikowaną strukturą. Ilekroć więc jest mowa o reformach edukacyjnych, myśli się równocześnie o roli administracji w tych reformach oraz o zmianach w administrowaniu i zarządzaniu jako takim. Niestety, większość reform nie przynosi oczekiwanych efektów z różnych powodów. Moim drugim założeniem, pomocnym w konstruowaniu niniejszej pracy, było stwierdzenie, że aby szkoły mogły pomagać społeczeństwom w radzeniu sobie z wyzwaniami, same muszą się zmieniać, a z tego wynika, że muszą się również zmieniać ich wewnętrzne mechanizmy, na przykład takie, jak modele administrowania i zarządzania.

W tym tekście, wychodząc z zasygnalizowanego powyżej założenia dotyczącego wpływu edukacji na losy społeczeństw oraz panującego przekonania o potencjale naprawczym, jaki tkwi w strukturach admi- 
nistracyjnych, chcę wspomnieć o dwóch przyczynach niepowodzeń: zbyt konserwatywnym podejściu do problemu, zakładającym wspomniane już robienie tego samego, tyle że lepiej, szybciej i taniej, oraz zbyt dużej rozbieżności między akceptowanymi sposobami radzenia sobie $z$ danym problemem a proponowanymi zmianami niezbędnymi do osiągnięcia pożądanych rezultatów. Jednocześnie postaram się pokazać źródła tej sytuacji.

Podsumowując moje intencje związane z niniejszym opracowaniem, wskażę kontekst, w którym funkcjonują współczesne społeczeństwa i ich szkoły, domagając się szkół, które będą pomagać uczyć się adekwatnie do potrzeb, opiszę przydatne, w mojej opinii, transformacje związane z zarządzaniem szkołami i przesuwaniem środka ciężkości w stronę przywództwa edukacyjnego, które będzie w stanie zmienić szkoły, przedstawię historyczne źródła mentalnych modeli stanowiących zasadnicze przeszkody we wprowadzaniu proponowanych transformacji, i wreszcie zaproponuję, nie nowe, ale wciąż nierealizowane działania mające na celu zmianę dzisiejszej sytuacji.

\section{Edukacja mechanizmem rozwoju w czasach chaosu?}

Edukacja jest ważnym elementem życia społecznego, politycznego i gospodarczego. Widać to również wtedy, gdy patrzy się na nią, jak na odrębną kategorię gospodarczą, obszar generujący zyski, podobnie jak na przykład przemysł rozrywkowy, który stał się w niektórych miejscach bardziej dochodowy niż przemysł ciężki. Miasta, które w niedalekiej przeszłości zainwestowały w rozwój uniwersytetów, kwitną w porównaniu z tymi, które stawiały na przykład na przemysł samochodowy. Zjawisko to obserwować można między innymi na Środkowym Zachodzie Stanów Zjednoczonych w tak zwanym pasie rdzy (rust belt), gdzie Uniwersytet Stanowy w Columbus generuje efekt ekonomiczny (economic impact) w wysokości 2,4 miliarda dolarów rocznie (High Points, 2015).

Tradycyjnie za najważniejszą funkcję edukacji uznawano wkład w budowanie kapitału ludzkiego. Wraz z popularyzacją neoliberalnej perspektywy w interpretowaniu zjawisk społecznych i w procesie podejmowania decyzji politycznych i gospodarczych, funkcja ta stawała się coraz ważniejsza dla gospodarki. Rozwój przemysłowy i rozwój powszechnego szkolnictwa były ze sobą nierozerwalnie związane. Wprawdzie nie ma jednoznacznych dowodów na to, że wzrost gospodarczy wynika z tego, czego ludzie uczą się w szkołach i nigdy też nie udo- 
wodniono, że zwiększająca się produktywność ekonomiczna uruchamiała jakościowe zmiany w edukacji, to związek gospodarki ze szkołą jest zauważalny. Przez cały XIX wiek i na początku wieku XX część potężnych zysków ekonomicznych generowanych przez industrializację inwestowano w edukację, która to, jak wierzono, stawała się coraz istotniejsza dla społeczno-ekonomicznych sukcesów jednostek oraz dla rozwoju przemysłu na poziomie regionalnym i narodowym (Carl, 2009). To przekonanie widoczne jest zresztą do dzisiaj, gdyż rządy na całym świecie inwestują w edukację olbrzymie środki, chcąc stymulować wzrost gospodarczy. Wybrane dane statystyczne potwierdzają, że im wyższe wykształcenie, tym łatwiej o pracę (OECD, 2017, s. 100101), że społeczeństwa o wyższym poziomie wykształcenia są bogatsze, zdrowsze, szczęśliwsze (OECD, 2012), ale nie do końca wiadomo, co jest skutkiem, a co przyczyną.

Istotność edukacji wiąże się również z tym, że uznano ją za dobro publiczne, co powoduje zaangażowanie rządów w kontrolowanie obowiązku szkolnego, czy dopływu nauczycieli do zawodu. Zgoda obywateli na finansowanie edukacji wynika z przekonania, które raczej nie ma odzwierciedlenia w rzeczywistości, że system edukacyjny wyposaży młodych ludzi w umiejętności, które zapewnią wzrost produktywności, a w konsekwencji - zyski, które będzie można wykorzystać, wynagradzając tych, którzy finansowali edukację na początku cyklu (Glavan, Anghel, Avrigeanu, 2010).

Przed współczesnymi społeczeństwami, a zwłaszcza przed edukacją, gdy przyjmiemy założenie o jej wiodącej roli w radzeniu sobie z rzeczywistością, nie tylko tą gospodarczą, stoją dziś olbrzymie i często nieuświadamiane wyzwania. Szkoła będzie mieć sens tylko wtedy, gdy będzie zaprojektowana tak, aby działać adekwatnie do potrzeb wynikających z tych wyzwań. Dlatego pierwszym krokiem dla poprawy szkoły jest zwiększenie świadomości tychże wyzwań dla osadzenia jej w kontekście społeczno-gospodarczym.

Przedstawię tu, bardzo krótko, subiektywny wybór największych wyzwań, czyli problemów do rozwiązania, oraz pytań, na które należy znaleźć odpowiedzi, aby móc wciąż wierzyć, że ludzie mogą dalej, dostatnio i szczęśliwie, zamieszkiwać Ziemię. Te problemy są ze sobą powiązane w bardzo skomplikowany sposób, wpływając na siebie nawzajem i dotyczą (w różnym natężeniu) wszystkich krajów, czyli wszystkich ludzi. To globalne wyzwania, które rozwiązywać należy: w tym samym czasie, 
globalnie i lokalnie. W żadnym wypadku nie zamierzam twierdzić, że szkoła może sobie poradzić $z$ tymi problemami w osamotnieniu, bez poważnych zmian społecznych, politycznych i gospodarczych, ale może zainicjować te procesy.

Do najważniejszych problemów, podnoszonych przez społeczeństwa, ekspertów, polityków, nauczycieli, aktywistów, „zwykłych ludzi” oraz omówionych już dokładnie w setkach publikacji czy pokazanych w filmach dokumentalnych, w programach publicystycznych czy w różnych projektach, zaliczyłbym: zdegradowane środowisko naturalne, nierówności społeczne, budzącą obawy różnorodność, schyłek gospodarki opartej na kopalinach i rywalizacji, oraz rosnące rozczarowanie, jakie wyczuć można wobec demokracji.

Jesteśmy świadkami katastrofy ekologicznej, która wyraża się poprzez ekstremalne zjawiska pogodowe wywołane globalnym ociepleniem, poprzez wymieranie gatunków i zmniejszanie różnorodności biologicznej oraz poprzez coraz większą obecność azotu w naturze spowodowaną przemysłowym rolnictwem i masowym korzystaniem z nawozów sztucznych. Wielkie migracje, konflikty wywołane walką o dostęp do czystej wody i powietrza, podwyższający się poziom oceanów, głód i wiele innych konsekwencji tej katastrofy uczynią Ziemię miejscem trudnym lub nawet niemożliwym do zamieszkania (Klein, 2016), ale nasze szkoły nie przygotowują uczniów do odpowiedzialnego korzystania z zasobów, które nam pozostały.

Problemem jest kryzys społeczny wywołany wzrastającymi nierównościami społecznymi. Przepaść między bogatymi a biednymi pogłębia się drastycznie z roku na rok, a niesprawiedliwe mechanizmy akumulacji bogactwa i skostniałe struktury społeczne uniemożliwiają zmianę aktualnej sytuacji (Piketty, 2015), chociaż badania dowodzą, że nierówności szkodzą całym społeczeństwom, a nie tylko jej biednym warstwom. Koszty edukacji i opieki zdrowotnej, poziom przestępczości, koszty usług publicznych, poziom społecznej solidarności i wiele innych aspektów decydujących o jakości życia zależą od stopnia, w jakim społeczeństwa dbają o równość i sprawiedliwość (Wilkinson, Pickett, 2011; Patel, 2010). Szkoły, niestety, zamiast wspierać awans społeczny i wyrównywanie poziomu życia członków społeczeństw, reprodukują niesprawiedliwą rzeczywistość społeczną i system klasowy poprzez własną strukturę, relacje międzyludzkie, dzielenie uczniów i uczennice na kategorie, wzmacniając zwyczaj rywalizacji, oferując odmienne 
usługi uczniom pochodzącym z różnych klas społecznych (Apple, 2013; McLaren, 2015).

Innym problemem, o którym nie wolno zapominać, jest brak umiejętności radzenia sobie z różnorodnością, ze wznoszącą się falą nacjonalizmów i werbalizowaną potrzebą funkcjonowania w homogenicznych społeczeństwach napędzaną przez lęk przed spotkaniem z Innym, ale i przez zagrożenie terrorystyczne. Olbrzymie grupy ludzi wykluczane są z udziału w zyskach ze wspólnej pracy tylko dlatego, że różnią się kolorem skóry, religią, płcią, orientacją seksualną, wiekiem i innymi cechami. Warto pamiętać, że w pewnym stopniu jesteśmy zależni od tego, czy uda nam się pokonać te ograniczenia, ponieważ tylko trudna współpraca w poprzek granic i kultur, a nie jak ją nazywa Richard Sennett (2013), współpraca plemienna, polegająca na działaniu wspólnym z podobnymi do nas przeciw odmiennym od nas, da nam szansę na poradzenie sobie z powiązanymi ze sobą problemami współczesności. Bez porozumień ponad podziałami i interdyscyplinarnego podejścia do problemów, na przykład do stosowania paliw kopalnych czy przemysłowej hodowli bydła, nie poradzimy sobie z globalnym ociepleniem. Bez rozwiązań na skalę globalnych problemów, takich jak: bieda, nierówności społeczne, dostęp do edukacji, produkcja i handel bronią, nie da się rozwiązać problemu terroryzmu czy eksploatowania różnych grup.

Seria ekonomicznych trzęsień ziemi, od Azji, przez obie Ameryki, po Europę i nieustająca walka Afryki, aby zbudować stabilną gospodarkę, unaoczniają kłopoty, z jakimi borykamy się w obszarze ekonomii. Niektórzy badacze, jak na przykład Jeremy Rifkin (2016), twierdzą, iż w wyniku rozwoju technologii, logistyki i sposobów pozyskiwania energii kończy się dominująca rola kapitalizmu. Wprawdzie jego umieranie może potrwać jeszcze lata, ale jego czas nieuchronnie się kończy. Pozostanie nam poradzić sobie z problemem produkcji, zastąpienia rywalizacji współpracą, generowania i podziału zysków oraz wszystkimi innymi aspektami decydującymi o zdrowej gospodarce. Rifkin pisze o wspólnocie współpracy i Internecie przedmiotów, jak o zjawiskach decydujących o naszej przyszłości. To na razie ekstrapolacje poczynione na podstawie obserwacji widocznych trendów albo nawet tylko luźne spekulacje o przyszłości gospodarczej i społecznej, ale nie da się ukryć, że musimy na nowo wymyślić sposób na relacje gospodarcze, finansowe oraz sektory energetyczny i produkcji. 
W pewnym stopniu kryzys gospodarczy, a właściwie kryzys paradygmatu, według którego organizowaliśmy życie gospodarcze przez ostatnie 250 lat, wiąże się z ostatnim wymienionym przeze mnie problemem czekającym dziś na rozwiązanie - kryzysem demokracji. Jednym z jego wskaźników jest niski poziom zaufania do polityków i do siebie nawzajem, niski poziom partycypacji w życiu społecznym i politycznym, ogólna niechęć do angażowania się, ale być może, tak jak w przypadku gospodarki, chodzi tu o radykalną zmianę modelu działania systemu demokratycznego. Niestety, zmiany zachodzą w coraz szybszym tempie, a my nie mamy pomysłu na to, jak sobie z nimi poradzić, jak reagować, co zmienić w tym, co robimy. Zygmunt Bauman (2017) mówi o niebezpiecznym okresie interregnum, w którym stare modele mentalne i sposoby rozwiązania problemów już nie działają, ale nowych jeszcze nie wygenerowaliśmy. Często nawet nie jesteśmy świadomi, jak bardzo potrzebujemy fundamentalnej zmiany społecznej i nowej organizacji społeczeństwa bez dominującej „elity” (Judt, 2010). Kto może w tym pomóc?

Nie udało się nam, jak dotąd, znaleźć lepszego sposobu na podniesienie poziomu świadomości i jednocześnie zdolności do rozwiązywania problemów niż edukacja. Choć niekoniecznie musi nią być edukacja szkolna, to jednak ona, jako najbardziej powszechna forma zorganizowanej edukacji staje się adresatką postulatów, pytań i rekomendacji. Można odnieść wrażenie, że wśród wielu instytucji społecznych, które zmieniają się, ulegają destrukcji czy też tracą zaufanie, między innymi takich, jak: państwo, policja, służba zdrowia, kościół, rodzina, to szkoła - pomimo ciągłej krytyki - jest wciąż uważana za najlepsze antidotum, a nawet wręcz magiczny środek w rodzaju złotej rybki spełniającej wszystkie życzenia, na zauważane bolączki.

Od szkoły, a więc skomplikowanego organizmu, o którym w jakimś stopniu decydują różnorodne grupy, w skład których wchodzą politycy, przywódcy edukacyjni i menedżerowie, nauczyciele, eksperci, twórcy podręczników i materiałów dydaktycznych, projektanci i producenci nowych mediów, architekci, a także w pośredni sposób uczniowie i rodzice, media tradycyjne i społecznościowe, liderzy religijni i liderzy opinii, oczekuje się, że zrealizuje wiele zadań (wymieniam bez wskazywania, co uznawane jest za najważniejsze). Szkoła ma przygotować młodych ludzi do pracy, chociaż nie wiadomo, jaki będzie rynek pracy, jakie będą potrzebne zawody, do rozwiązywania problemów i krytycznego my- 
ślenia. Oczekuje się, że nauczy stosowania algorytmów, czytania ze zrozumieniem, posługiwania się myśleniem matematycznym, wyrówna szanse, przygotuje do ciągłej zmiany i niepewności, da podstawy do funkcjonowania w społeczeństwie, umożliwiając poznanie języka, filozofii i historii, wesprze w rozwoju ludzi głęboko moralnych, którzy poradzą sobie w złożonej sytuacji i będą zdolni do współpracy, przygotuje do sensownego wykorzystania sztucznej inteligencji. Wreszcie, że wyrobi umiejętność krytycznego myślenia i pomoże w zrozumieniu, że dzisiaj żaden poziom edukacji nie daje gwarancji bezpieczeństwa socjalnego i sukcesu (Herold, 2017). Czy to możliwe?

Czy edukacja jest w stanie zaproponować jakieś rozwiązania? Dotychczasowe propozycje reform skupiały się na skuteczności rozwiązań organizacyjnych, albo na zwiększaniu rozliczalności szkół, a w ostatecznym rozrachunku na efektywności finansowej. Potrzebna nam dzisiaj krytyczna refleksja i niekonwencjonalne rozwiązania proponujące podejścia sprzeczne z dotychczasową zdroworozsądkową wiedzą. Czy przywództwo edukacyjne może być tym czynnikiem, który da szansę na zmiany w edukacji prowadzące w konsekwencji do niezbędnych zmian społecznych, które pozwolą na bardziej skuteczne radzenie sobie z zagrożeniami współczesności? Czy w ogóle takie funkcjonalne myślenie ma jeszcze dzisiaj rację bytu?

Zakładam, że edukacja to ten obszar ludzkiej działalności, który ma odpowiedni potencjał i znaczenie dla budowania naszej zdolności do radzenia sobie z problemami, także na nowy, niespotykany dotąd sposób. Dlatego szkołę czeka zmiana. Paradygmat, w którym funkcjonuje, już się wyczerpał. Szkole brakuje inspirujących celów. Zorganizowana na wzór fabryki, zasklepia się w sobie, zamiast otwierać na świat i poszukiwać nowych rozwiązań. Zakładam też, że to przywództwo edukacyjne może stać się mechanizmem, który wesprze rozwój edukacji wyobraźnią, kreatywnością, w sposób innowacyjny, aczkolwiek odpowiedzialny. Aby jednak móc sprawnie wywiązywać się ze swojej funkcji, konieczne jest zrozumienie rzeczywistości, w której się operuje, a także poznanie opinii, stanowisk oraz ludzkich teorii i założeń na temat tejże rzeczywistości (to ważne, zwłaszcza w przypadku grup decydujących o edukacji). Bez tego kroku nawet najlepsze pomysły będą zawodzić, ponieważ nie można wprowadzać zmian wbrew dominującym ideologiom i ludzkim przekonaniom, które powodują, że wolimy znane i wielokrotnie testowane sposoby działania. 
W dalszej części niniejszego opracowania postaram się pokazać rekomendowane kierunki dla rozwoju przywództwa edukacyjnego, ale też przede wszystkim bariery, które uniemożliwiają wprowadzanie autentycznej zmiany w szkołach.

\section{Przywództwo edukacyjne: proponowane kierunki rozwoju}

Naprawianie edukacji od lat uważane było za domenę administracji. W XX wieku mogliśmy obserwować niezwykle dynamiczny rozwój, a wręcz dominację edukacyjnej biurokracji. Biurokracja szkolna polegała na stosowaniu technik menedżerskich, czyli instrumentów zarządzania wykorzystywanych w firmach biznesowych1, w celu kreowania procesu nauczania i uczenia się wzorowanego na procesach produkcji przemysłowej. W podobny sposób jak firmy, prywatne szkoły stawały się coraz bardziej skomplikowanymi organizmami, robiły się większe, scentralizowane i biurokratycznie zarządzane. Jakość edukacji, jak wierzono, wiązała się ze standaryzacją, procedurami i niskimi kosztami działania. Warto pamiętać, że w dużym stopniu to właśnie dzięki wprowadzaniu biurokratycznych i naukowych metod, także zewnętrznych testów, udało się pozytywnie wpłynąć na sposób nauczania, między innymi dzięki wprowadzeniu mierzalnych wskaźników uczenia się ${ }^{2}$.

Ostatnie dekady przyniosły sporą popularność terminowi „przywództwo edukacyjne", co jest widoczne w olbrzymiej liczbie publikacji, badań naukowych i programach nauczania na uniwersytetach ${ }^{3}$. Administracja, rozumiana jako organizowanie pracy (nie jako zbiór powiązanych instytucji), znaczeniowo bardzo blisko zarządzania, oraz biurokracja, czyli

1. Z różnym skutkiem próbowano zarządzania przez cele, delegowania uprawnień, zarządzania strategicznego, zarządzania zmianą, zarządzania czasem i innych.

2. Jednym z najlepszych przykładów jest rozpoczęty w latach dziewięćdziesiątych XX wieku program PISA (Programme for International Student Assessment), koordynowany przez OECD (Organizację ds. Współpracy Gospodarczej i Rozwoju), czyli międzynarodowe badanie, którego celem jest uzyskanie porównywalnych danych o umiejętnościach uczniów, którzy ukończyli 15. rok życia, w celu poprawy jakości nauczania i organizacji systemów edukacyjnych. Pomimo realizacji (przynajmniej częściowo) tego celu i dostarczania wiarygodnych danych, program jest krytykowany zarówno ze względu na metodologię, jak i efekty-zamiast koncentracji na poprawie jakości rządy i społeczeństwa koncentrują się na tworzeniu rankingów i porównywaniu z innymi. Podobnie jest z problemem standaryzowanych testów w wielu państwach, które zdecydowały się na ich wprowadzenie.

3. Autorzy i badacze, tacy jak (wymieniam tylko kilka nazwisk): Thomas Sergiovanni, Carl D. Glickman, Arthur Costa, John I. Goodlad, Linda Lambert, Rodney Ogawa, Kenneth Leithwood, Andy Hargreaves, John MacBeath, Mike Bottery i wielu innych. 
system organizacyjny, stanęły wobec nieprzekraczalnych ograniczeń, które mogły zostać przezwyciężone przez podejście przywódcze dające szansę na rozwiązanie w sposób innowacyjny "nierozwiązywalnych" problemów. Zarządzanie, odpowiadając na pytanie "jak?", a przywództwo, odpowiadając na pytania "co?" oraz "dlaczego?", wspólnie dawały większą szansę na zrównoważony rozwój organizacji edukacyjnych.

Przywództwo edukacyjne to specyficzna forma przywództwa, charakterystyczna dla edukacji. To złożony i długotrwały proces zachodzący w grupach ludzi, związany z nauczaniem i uczeniem się. Dzięki przywództwu edukacyjnemu uzewnętrznia się potencjał osób zaangażowanych w konkretne działanie. Powinno ono służyć, wspólnemu z grupą, projektowaniu i tworzeniu sytuacji umożliwiających uczenie się i rozwiązywanie problemów, a cele i sposób realizacji zadań edukacyjnych powinny zależeć od przyjętego $w$ danej społeczności systemu wartości. Ponieważ jest to proces grupowy, który wymaga czasu i przebiega zgodnie z przyjętymi wartościami, mniejsze znaczenie mają wizje kreowane przez heroicznych przywódców, a liczą się bardziej te negocjowane i uzgadniane w grupie. Potencjał przywództwa edukacyjnego wiąże się więc nie z charyzmą jednostek czy z ich autorytetem, lecz ze zdolnością organizacji (często zaprojektowaną przez mniejsze zespoły) do zwiększania partycypacji jej członków w procesie decyzyjnym i w uczeniu się. W ten sposób dzięki przywództwu formuje się wspólnota uczących się (Mazurkiewicz, 2015).

W Polsce, pod koniec XX wieku, po transformacji ustrojowej w 1989 roku, toczyła się dyskusja dotycząca koncepcji roli dyrektora: czy ma być bardziej nauczycielem, czy menedżerem, częściowo zakończona kompromisem - dyrektor miał nie tylko "pierwszym nauczycielem w szkole", ale pełnić także funkcję menedżera (Więsław, 2011). Niestety, koncepcja przywództwa edukacyjnego nie przebiła się do głównego nurtu myślenia o roli dyrektorów szkół i innych liderów funkcjonujących w systemie oświatowym. Nie było (i nie ma) w Polsce spójnej polityki w zakresie przywództwa edukacyjnego, brak powszechnego i profesjonalnego dyskursu, co najwyżej pojawiają się indywidualne próby czy pojedyncze, czyli niesystemowe, inicjatywy skupiające 
się głównie na badaniu, rzadziej na projektowaniu (mało widocznego) przywództwa edukacyjnego ${ }^{4}$.

Trwa jednak spór o to, co jest najlepsze dla uczniów i uczennic, o to, co działa w szkołach. Pomimo wielokrotnych prób reformowania szkolnictwa, a także bogatej literatury powstającej na podstawie prowadzonych badań naukowych, nie udało się stworzyć trwałego i spójnego modelu uzgodnionych i powszechnie stosowanych praktyk edukacyjnych. Z problemem fluktuacji pomysłów na edukację borykają się społeczeństwa na całym świecie. Nieodmiennie, na świecie, a niekoniecznie w Polsce, jednym z głównych postulatów zgłaszanych w celu zmiany edukacji, tak aby stawała się adekwatna i odpowiadająca na potrzeby ludzkości, jest postawienie przywództwa edukacyjnego w centrum wszelkich reform. W tych głosach widać przekonanie, powszechnie podzielane, choć często odmiennie rozumiane, że to przywództwo edukacyjne ma największy potencjał w projektowaniu i wprowadzaniu oczekiwanych zmian. Bez niego nie da się niczego zmienić (English, Papa, Mullen, Creighton, 2012).

Podkreśla się zwłaszcza, że przywództwo edukacyjne powinno skupiać się na tworzeniu różnego rodzaju warunków dla uczenia się. Jest to zdecydowanie ważniejsze niż jakiekolwiek inne funkcje menedżerskie, biurokratyczne cele czy rozliczalność nauczycieli i uczniów. Trudność tkwi w tym, aby nie powtarzać sprawdzonych modeli, lecz tworzyć je, przewidując przyszłe potrzeby. Nie uda się zaprojektować procesu nauczania i uczenia się ani zaproponować modelu przywództwa edukacyjnego, bez wzięcia pod uwagę na przykład rozwoju nowych technologii i wpływu, jaki mają one na społeczeństwa. Nie wystarczy "posiadać" czy "mieć dostęp", konieczne jest też, aby wprowadzać nowe technologie w procesy myślowe, uczenia się i zarządzania.

4. Wymienić należy badaczy, takich jak Antoni Jeżowski, Jarosław Kordziński, Stefan M. Kwiatkowski, Joanna Madalińska-Michalak, których wysiłek twórczy i badawczy wiąże się z przywództwem edukacyjnym, ale, niestety, ich prace nie tworzą jeszcze dojrzałej kultury, dyskursu czy choćby spójnego głosu naukowców wywierającego mocny wpływ na praktykę edukacyjną. Warto też wspomnieć projekt "Przywództwo i zarządzanie w oświacie - opracowanie i wdrożenie systemu kształcenia i doskonalenia dyrektorów szkół/placówek" realizowany przez Uniwersytet Jagielloński (Zakład Zarządzania w Edukacji, Instytut Spraw Publicznych, Wydział Zarządzania i Komunikacji Społecznej) w partnerstwie z ORE w latach 2013-2015, którego celem było zaproponowanie nowego modelu przywództwa, a także kształcenia i doskonalenia przywódców (niestety, po zrealizowaniu celów projektu i pilotażu nie prowadzono działań służących wprowadzaniu tych modeli w życie). 
Z jednej strony przywództwo edukacyjne wykorzystuje wiedzę, aby próbować zrozumieć rzeczywistość, dokonać krytycznej analizy i podjąć adekwatne działanie, z drugiej strony akceptuje dwuznaczność i złożoność środowiska szkolnego. Nie próbuje oceniać ani ferować wyroków, nie popełnia błędu mikrozarządzania, wprowadzania gotowych rozwiązań tam, gdzie potrzeba namysłu. Każda zmiana dodatkowo powiększa dwuznaczność i niepewność jednostek co do znaczenia tego doświadczenia. Jednym ze sposobów na zmiejszenie niepokoju jest angażowanie nauczycieli w proces projektowania zmian. Nauczyciele wiedzą najlepiej czego potrzebują, aby pomóc uczniom się uczyć, dlatego koniecznie jest, aby zaangażowali się oni w proces przywództwa. Szkoła może się stać organizacją samo-zarządzającą się, jeśli tylko uda się menedżerom uniknąć pokusy kierowania tym procesem (Hoyle, Wallace, 2005).

Przywództwo edukacyjne, skoncentrowane na uczeniu się, wymaga rozumienia procesu nauczania i uczenia się5. Konieczne jest budowanie kultury organizacyjnej szkół skoncentrowanej na procesach uczenia się, nauczania i rozwoju. Społeczność czy też ucząca się wspólnota rozwijająca wiedzę o tym, jak się uczymy i rozwijamy, to najważniejszy cel przy projektowaniu zadań i procesów przywództwa. W takiej wspólnocie rozumie się też powiązania między stosowaną konkretną praktyką pedagogiczną a teoretycznymi perspektywami oraz wykorzystuje ewaluację dla oceny efektów tych praktyk.

Miarą profesjonalizmu przywódców edukacyjnych jest ciągłe uczenie się, inwestycje w rozwój i ciężka praca, a nie talent otrzymany w wyniku genetycznej loterii. Zwłaszcza gdy chodzi o potencjał przywódczy tkwiący w grupach ludzi, a nie o zdolności czy charyzmę pojedynczych osób. W tradycji myślenia o przywództwie jest ono zwykle zarezerwowane dla wybitnych z jakiegoś powodu jednostek (najczęściej mężczyzn), które, niestety, w przeszłości raczej zawodziły albo prowadziły w ostateczności do porażek czy nawet katastrof humanitarnych. Przywództwo edukacyjne XXI wieku powinno wyłaniać się ze współpracy, solidarności i szacunku dla innych i angażować jak najwięcej sprzymierzeńców. Przywództwa należy się uczyć. Potencjał przywódczy

5. Nie jest moim celem prezentowanie najnowszych osiągnięć z tego zakresu, ale trudno sobie wyobrazić sukces w tym obszarze bez zinternalizowanej wiedzy, informacji i wskazówek chociażby z takich źródeł, jak wyniki badań Johna Hattiego czy publikacji OECD „Istota uczenia się". 
jest nieustannie wypracowywany i zdobywany, a jego specyfika wynika z kontekstu i odpowiedzialnego reagowania na ten kontekst. Dlatego tak trudno ustalić jeden wzorzec przywództwa. Nie ma też jednego scenariusza dla przywództwa edukacyjnego, choć są elementy, z których przywództwo można budować. Eric Hoyle i Mike Wallace (2005, s. 23) uczulają, że należy zaakceptować myśl o dwuznaczności i niepewności, jakie ogarniają wszystkich schodzących z ubitej ścieżki. Trudno w pełni zrozumieć nowy sposób działania zanim się go nie wypróbuje. Nikt nie wie, jak pracować inaczej zanim zacznie się tak pracować. Żadne przygotowania nie pomogą, ponieważ wiedza o tym, jak robić coś inaczej, wyłania się z nowego sposobu działania.

Krytyczne myślenie i refleksja nad stanem świata to punkt wyjścia. Przywództwo edukacyjne powinno prowadzić do nieustającej refleksji nad warunkami funkcjonowania szkoły, akceptowanymi wartościami i potrzebami społeczności, której szkoła służy, tendencjami społecznymi, filozofią i podejściem do procesu uczenia. Refleksja ta owocuje działaniami adekwatnymi do kontekstu. W organizacji o wysokim potencjale przywódczym panują więc przekonania o sensowności działań prowadzonych w szkole, chęć poszukiwania nowych rozwiązań i zgoda na ewentualne błędy wynikające z aktywności, a nie lekceważenia.

Przywództwo edukacyjne nieustannie domaga się i wspiera się na partycypacji wszystkich pracowników, a także uczniów i rodziców w procesie decyzyjnym i w dialogu, dzięki któremu definiuje się kierunki działania szkoły. Nie można zmienić szkolnej rzeczywistości przez nakazy, ale przez wspólną pracę i budowanie kultury organizacyjnej w codziennym zmaganiu się z rzeczywistością. Przywódcy potrafią zrozumieć potrzeby i emocje innych, ale są też świadomi siebie, co pozwala im na służenie ludziom bez obawy o utratę prestiżu, a z przekonaniem, że nie osiągnie się sukcesu bez pełnego zaangażowania. Tacy przywódcy działają przede wszystkim dla dobra innych, wspierają ich w rozwoju i dbają o ich dobrostan. Bycie w służbie wymaga ukierunkowania ludzi i organizacji na realizację wizji i długofalowy sukces oraz dostrzeganie celów związanych ze społecznością i środowiskiem (Bezzina, Madalińska-Michalak, 2014). Nie pracują w osamotnieniu, ale w grupie, która jest w stanie przejąć obowiązki przywódcze w zależności od sytuacji i potrzeb. Przywództwo edukacyjne powinno być doświadczeniem grupowym i demokratycznym. 
Przywództwo edukacyjne wiąże się również z uszanowaniem autonomii i różnorodności, nawet tej trudnej, odmiennej od głównego nurtu. Przywódcy starają się więc wykorzystać potencjał wszystkich, zwłaszcza tych, których odmienność wydaje się utrudnieniem w pracy organizacji. Różnorodne perspektywy, zwyczaje, a przede wszystkim wartości mogą przy umiejętnym podejściu do sytuacji zróżnicowania wesprzeć organizację w rozwoju (Mazurkiewicz, 2015).

Nie skupiajmy się na reorganizacji hierarchicznych struktur, lecz na zachęcaniu nauczycieli i uczniów do wspólnej pracy z dzisiejszymi przywódcami i menedżerami nad uadekwatnianiem procesu uczenia się do jego kontekstu. To postulat zajmujących się kształceniem przywódców edukacyjnych, myślących o tym, jak dodać energii debatom nad pedagogiką, a nie prawem czy finansami. Oddajmy przywództwo nauczycielom (to znaczy dyrektorom również), dając im też wolność, apelując, przypominając, że to nauczyciele mają unikalną wiedzę na temat procesu nauczania i samej szkoły jako organizacji. Zwiększy to prawdopodobnie także ich zaangażowanie w procesy wprowadzania zmian oraz da szansę na zróżnicowanie ścieżek nauczycielskich karier (English, Papa, Mullen, Creighton, 2012, s. 101-107).

Nie uda się, niestety, wprowadzić powyższych postulatów w życie bez zaufania w społeczeństwie i w jego instytucjach. Zaufanie to istotny warunek pojawienia się zarządzania i przywództwa przynoszącego korzyści organizacjom, ludziom w nich pracującym i całemu społeczeństwu. Zaufanie umożliwia i wzmacnia wiarygodność oraz przewidywalność w relacjach między ludźmi i organizacjami. W zasadzie ufamy, że inni zrobią to, czego się od nich oczekuje, i że zrobią to w sposób uczciwy, sprawiedliwy i przejrzysty. Gdy ufamy sobie nawzajem, jesteśmy również skłonni zaufać drugiej osobie, nawet wtedy, gdy pojawia się jakieś nieporozumienie, gdy ufamy innym, wierzymy, że będziemy chcieli i umieli je rozwiązać. Z perspektywy wymiany ekonomicznej "coś za coś" zaufanie zmniejsza ryzyko, zwiększa innowacyjność, jest niezbędne w trakcie wszelkich negocjacji (Cerna, 2015).

Zaufanie pojawia się, gdy widoczne są kompetencje osób zaangażowanych oraz wartości wpływające na zachowania ludzi. Można wtedy zachęcać do wspierania przywództwa edukacyjnego dla budowania w szkołach wspólnej wizji skoncentrowanej na uczeniu się wszystkich uczniów i pracowników, dla domagania się współpracy i uczenia się zespołowego, budowania kultury refleksji dzięki prowa- 
dzeniu badań, ewaluacji, zbieraniu danych i poszukiwań wewnątrz szkoły i w jej otoczeniu.

\section{Spójrzmy prawdzie w oczy, czyli co nam przeszkadza}

Trudno zrozumieć zależność między szkołą a społeczeństwem, jeśli nie rozumie się tego, jak zbudowane jest i zgodnie z jakimi mechanizmami funkcjonuje społeczeństwo. Wręcz niemożliwe jest zrozumienie tego, w jaki sposób ewoluowała szkoła i zawód nauczyciela, ani tego, jak zachowują się uczniowie, czy też w jaki sposób kształtował się model szkolnej administracji i przywództwa, jeśli nie rozumie się społeczeństwa. Tylko podejmowanie ciągłych prób zrozumienia świata daje szansę wszystkim pracującym w obszarze edukacji na to, aby stali się refleksyjnymi praktykami, by byli w stanie spojrzeć krytycznie na to, w co się angażują. Nasz świat jest tak różnorodny, że bez społecznej, a właściwie socjologicznej perspektywy nauczycielom i przywódcom edukacyjnym trudno wywiązywać się ze swoich zadań. Pierwszy etap refleksji nad relacją między szkołą a społeczeństwem może polegać tylko na uświadomieniu sobie współzależnych od siebie poziomów analizy tejże relacji. Jest to niezbędny krok do zrozumienia tego, w jak dużym stopniu wszelkie działania, a więc również reformy szkolnictwa albo dziedzin, takich jak przywództwo edukacyjne, zależą od szerszego kontekstu społecznego.

Poziom pierwszy to ogólne struktury społeczne, w tym systemy polityczne i ekonomiczne, poziom rozwoju społecznego, system stratyfikacji i zinstytucjonalizowanych nierówności. To na tym poziomie kształtują się struktury dominacji i ideologie społeczne, według których budowane są systemy edukacyjne, a później wykluwają się decyzje dotyczące organizacji pracy szkoły czy programów nauczania. Poziom drugi to poziom instytucjonalny, w skład którego wchodzą instytucje, takie jak: rodzina, kościoły, polityka, rząd, firmy, wszelkie podmioty gospodarcze, media i oczywiście szkoły. Na tym poziomie rozstrzygane są konkretne dylematy i odpowiada się na pytania o struktury oświatowe, koncepcje teoretyczne i ideologie edukacyjne. Trzeci poziom to poziom interpersonalny, zawierający procesy, symbole, interakcje, gesty, rytuały, zwyczaje, od których zależy codzienne życie. Tu kształtowane są oczekiwania nauczycieli wobec uczniów, wobec siebie nawzajem, wobec mężczyzn, kobiet, dzieci, wobec różnych zawodów czy ról społecznych, wobec miejsca pracy, jakim jest szkoła. Tysiące interakcji kształtują 
szkolną rzeczywistość. Czwarty poziom to poziom wewnętrzny, psychiczny, obejmujący, kształtowane przez społeczne instytucje i interakcje, przekonania, wierzenia, myśli, wartości, uczucia, które w dużym stopniu bywają uwspólniane w grupach (przynamniej te dominujące). Także wyobrażenia na własny temat. To wszystko wpływa na procesy poznawcze i rozumienie tego, czym są procesy oraz efekty uczenia się (zob. Sadovnik, Cookson, Semel, 2006).

Jednym z najważniejszych procesów kształtujących istniejące do dzisiaj struktury i ideologie społeczne, czyli pierwszy poziom analizy relacji szkoła - społeczeństwo, była industrializacja, od samych jej początków w drugiej połowie XVIII wieku. Ekspansja publicznej edukacji ściśle się z nią wiąże. Znaczenie edukacji było oczywiste - więcej „instrukcji" dawało pewność, że ludzie będą mniej podatni na zabobony, ale za to bardziej uporządkowani. Wraz z rozwojem przemysłu zwiększało się wsparcie publicznej edukacji, zamieniając coś, co było bardzo elitarne w coś szeroko dostępne. To industrializacja wprowadziła do szkół podstawy nauk ścisłych i przyrodniczych. Tuż przed industrializacją głównymi zadaniami szkoły było wzmacnianie ducha obywatelskiego i kontrola społeczna. Zresztą szkolnictwo w ogóle nie było przedmiotem zainteresowania przedsiębiorców, kapitalistów czy menedżerów wczesnej ery przemysłowej. Umiejętności zdobywano raczej poprzez czeladnikowanie i dzięki kapitałowi społecznemu, czyli dzięki ludziom, z którymi się pracowało lub mieszkało. W Wielkiej Brytanii na przykład, większe znaczenie dla rozprzestrzeniania się myśli naukowej miało członkostwo w towarzystwach naukowych i publiczne wykłady (Carl, 2009).

Jednak postulaty uczynienia edukacji masową stawały się coraz popularniejsze ze względu na rosnący popyt na pracę dzieci oraz fakt, iż większość populacji pracującej w raczkującym przemyśle nie miała żadnego wykształcenia. Zmiany technologiczne pierwszej rewolucji przemysłowej przyczyniły się do olbrzymich zmian społecznych, zwłaszcza wśród pracującej biedoty. Poprzez zmianę miejsca zamieszkania, przydzielenie do innych zadań w fabrykach, niż te, które były im znane na roli, zabrano im ich pre-industrialne doświadczenia, tradycję, mądrość i moralność, więc trzeba było dać coś w zamian. Reformatorzy skupili się na budowaniu sieci edukacyjnej dla wszystkich, jednak szybko, zarówno industrializacja, jak i masowa edukacja przyczyniły się do pogłębienia różnic klasowych. Robotnicy postulowali wzmocnienie szkół podstawowych, klasa średnia koncentrowała uwagę na szkołach 
średnich i uniwersytetach dla swoich dzieci, wspierając jednocześnie opinię, że szkoły podstawowe są właściwsze dla mas. Admiracja szkół masowych wiązała szkolnictwo z fabryką. W XIX wieku poszukiwano sposobów jak najtańszej edukacji dla jak największej liczby dzieci i przekonywano, że setki dzieci w różnym wieku i różnej gotowości mogą być uczone w jednym pomieszczeniu dzięki podziałowi pracy zastosowanemu w procesie intelektualnym (Carl, 2009). To przekonanie na lata zaważyło na organizacji systemów edukacyjnych i procesu kształcenia. Dzisiaj utrudnia wprowadzanie zmian również w obszarze przywództwa edukacyjnego. Głęboko zakorzenione zwyczaje, wsparte silnymi, aczkolwiek często nieuświadomionymi przekonaniami, czynią reformatorskie zabiegi trudnymi do zrealizowania.

Przyglądając się poziomowi pierwszemu, owemu oprogramowaniu społecznemu i kulturowemu, jak nazywał je Geert Hoefstede (2000), nie sposób nie zauważyć, że od końca XX wieku dominuje neoliberalna wizja świata, systemów społecznych, a więc i oświaty, według której to wizji wszystkie elementy struktury społecznej są uzależnione od decyzji ekonomicznych, regulowanych przez wolny rynek. Dodatkowo, prawie w niewidoczny sposób, przyjęto założenie, że rywalizacja jest jedyną prawowitą zasadą organizującą życie społeczne. Większość polityk i praktyk pozostaje pod przemożnym wpływem globalnej gospodarki, co powoduje, że widzimy trendy społeczne i ekonomiczne jako nieuniknione, wynikające z procesu niesterowalnej ewolucji i wpływu niewidzialnej ręki rynku. I chociaż neoliberalizm, podobnie jak wiele innych koncepcji, to twórczość człowieka, zapomnieliśmy o tym i zaczęliśmy jego prawa traktować jak prawa obiektywne. To powoduje, że społeczna niesprawiedliwość jest traktowana jako efekt również obiektywnych procesów i wiąże się z potencjałem jednostek, a nie systemowymi rozwiązaniami. Wierzy się więc, w edukacji, w wolny wybór i promuje autonomię szkół. Niestety, wspomniana autonomia dotyczy nie tyle myślenia o edukacji, ile walki o "klienta", z głębokim przekonaniem głosząc, że zdrowa konkurencja ma wyłącznie pozytywny wpływ na edukację (Fielding, Moss, 2011). W tej sytuacji główne trendy reformatorskie odwołują się do modeli rynkowych, opierając się na deregulacji i prywatyzacji (Ball, 2007) albo, jak ostatnio w Polsce, koncentrują się na, nieistotnych z perspektywy rozwoju społecznego, aspektach strukturalnych systemu oświatowego. To czyni postulowany powyżej kierunek rozwoju przywództwa edukacyjnego prawie niemożliwym do 
zrealizowania, ale z drugiej strony jeszcze mocniej uzasadnia oczekiwania wobec przywódców, iż zaangażują się w odbudowę społecznej solidarności i wykorzystają edukację jako narzędzie społecznej zmiany.

Poziom drugi, instytucjonalny, oraz poziom trzeci, interpersonalny, w dużym stopniu łączą się, ponieważ instytucje tworzone są przez ludzi, a ludzie uczą się i kształtują nawyki, działając w instytucjach. To, co dzieje się w instytucjach i między ludźmi, poza kontekstem edukacyjnym, wpływa na rozwiązania organizacyjne i charakter relacji w edukacji. Niezależnie od tego, czy wierzymy, że działania jednostek są determinowane przez zewnętrzne uwarunkowania, czy też, że jednostki mają możliwość w miarę dowolnego kształtowania rzeczywistości, w której funkcjonują, to działając $w$ obszarze edukacji, należy zdawać sobie sprawę ze społecznych okoliczności. Skłaniając się ku stanowisku, że ludzie mają wolną wolę oraz możliwość kształtowania rzeczywistości zgodnie z własnymi założeniami (uświadomionymi bądź nie), przyjmuję jednak, że dzieje się to w specyficznych dla danego miejsca i momentu w historii uwarunkowaniach. Mimo podejmowania autonomicznych wyborów, ludzie pozostają pod określonym wpływem zewnętrznych wobec nich sił.

Te różne konteksty, różni ludzie z odmiennymi doświadczeniami i wizjami oraz różne efekty ludzkich interakcji powodują, że szkoły są bardzo różne, nawet wtedy, gdy funkcjonują w podobnych krajach, kulturach, miejscach. Myślę tu o czynnikach wpływających na kulturę organizacyjną, takich jak profesjonalizm nauczycieli czy styl zarządzania, które decydują o tym, jak w szkole reaguje się na sukcesy i porażki, na propozycje zmian, o tym, jak widzi się role uczniów i nauczycieli, o tym, jaki sposób uczenia się i nauczania dominuje, o tym, jak podejmuje się decyzje. Ta różnorodność powoduje konkretne konsekwencje, z jednej strony daje szansę na wypróbowywanie różnorodnych rozwiązań oraz na uczenie się od siebie nawzajem, z drugiej strony przyczynia się do braku spójności w systemie oświatowym. Jeśli ta różnorodność nie znajdzie platformy, na której można by się porozumieć, to nigdy nie zostanie wykorzystana dla uczenia się, lecz będzie przyczyną fragmentaryzacji. Pojawiają się wtedy odmienne podejścia do proponowanych reform i całkowicie odmienne sposoby ich implementacji, wreszcie pojawia się coś, co jest przedmiotem dyskusji w tym tekście: niemożność wprowadzenia i swego rodzaju "zadomowienia" się opisanego wcześniej przywództwa edukacyjnego. 
Przyczyny tego „rozproszenia” są znane. Po pierwsze, większość społecznych i politycznych założeń dotyczących szkolnictwa bierze się z przeszłości, z czasów naiwno-idyllicznych oraz z czasów, wspomnianej już, przemysłowej rewolucji. W obu, chociaż bardzo odmiennych, obrazach dominują poważne uproszczenia co do roli szkoły i tego, jak może lub powinna funkcjonować. Wersja naiwna nawiązuje do małych, często wiejskich szkół, w których to niepodzielnie rządzili samodzielnie nauczyciele i nauczycielki, otaczający matczyną lub ojcowską opieką zgromadzone dzieci, w różnym wieku, raczej bez ambicji studiów za granicą, doktoratu lub dobrze płatnej pracy profesjonalisty. Nauczyciele w tych szkołach byli odpowiedzialni nie tylko za nauczanie, ale również za ich utrzymanie (sprzątanie, drobne naprawy). Była to praca „służebna", nisko płatna, ale otoczona szacunkiem (Lortie, 1975). Wszystko, co działo się w szkole, zależało od nauczyciela, jeśli chciał czegoś uczyć, to tego uczył, a jeśli uczył w swojej klasie, to jednocześnie działo się to w całej szkole, gdyż owa klasa to była cała szkoła.

To dziedzictwo niezależności, izolacji i prywatyzacji pedagogicznej praktyki pozostaje widoczne w większości szkół do dzisiaj. Zamiast jednej klasy w szkole znajduje się dziś wprawdzie szereg klas, ale równie izolowanych jak kiedyś owe małe szkoły. Nauczyciele przez większą część dnia widzą tylko swoich uczniów w swojej klasie. Chociaż nie dzielą ich już kilometry, to ten dystans wciąż wywiera wpływ na sposób myślenia i działania nauczycieli. Niestety, praktyka prywatności w wielu klasach ma się nijak do wyników badań, które wskazują, że uczniowie częściej odnoszą sukcesy w tych szkołach, w których nauczycieli zachęca się do współpracy i profesjonalnego dialogu, zmniejszając tym samym ich izolację (Glickman, Gordon, Ross-Gordon, 2013, s. 17). Skuteczne szkoły to szkoły, w których nauczanie jest działaniem kolektywnym, czyli takim, do jakiego nawołuje się dzisiaj przywódców edukacyjnych. Niestety, próby wprowadzania współpracy, uczenia się dzięki krytycznej refleksji, wymianie doświadczeń i obserwacji innych, w szkołach kultywujących tradycje, które pojawiły się lata temu, będą skazane na porażkę. Dziać się tak będzie, tym bardziej że tradycje szkolne wzmacniane są przez przekonania ukształtowane w społeczeństwie, a uznające rywalizację, współzawodnictwo, rankingi, prywatyzowanie doświadczeń za coś przydatnego i służącego rozwojowi.

Dla zbudowania uczącej się społeczności, wspólnie poddającej krytycznej refleksji swoje działania, konieczne jest zminimalizowanie 
wspomnianej już izolacji i indywidualizmu. Robert Dreeben (1973) już prawie pół wieku temu wskazywał, jak bardzo szkolna architektura, izolowane klasy czy organizacja dnia utrudniają nauczycielom wzajemną obserwację. Kilkanaście minut kontaktu z innymi dorosłymi w ciągu dnia nie pozwala nauczycielom na budowanie wiedzy o tym, jak nauczają inni, jak pracuje się z uczniami w szkole. Zarówno rozwiązania architektoniczne, jak i organizacyjne to spuścizna po czasach, gdy nauczyciele samotnie pracowali w odosobnionych budynkach małych szkół lub nauczali w dużych szkołach według schematów wzorowanych na tym, co działo się w przemyśle. W wyniku takiej izolacji pojawiają się też konsekwencje psychologiczne. Wśród nauczycieli, którzy przecież nie wybierali świadomie takiej formy pracy na początku swej kariery, można zauważyć tendencję do ograniczania swojej odpowiedzialności wyłącznie do "własnej" klasy, uczniów, własnego działania, a w konsekwencji także do oporu przed współpracą i dialogiem z innymi nauczycielami (Glickman, Gordon, Ross-Gordon, 2013, s. 18).

Te mocno osadzone w naszej kulturze (myślę tu o kontekście europejskim i amerykańskim) początki masowej szkoły przyczyniły się do zbudowania i wzmocnienia kluczowych dla edukacji przekonań wyrażających się w izolacji, rutynowych działaniach, nieodpowiednim wprowadzaniu do zawodu, nierówności, braku odpowiednich etapów rozwoju zawodowego, braku profesjonalnego dialogu, braku zaangażowania w proces podejmowania decyzji, braku współposiadanej kultury zawodowej i w konserwatyzmie kadry pedagogicznej. Wiele osób pracujących w oświacie jest przekonanych, że to nieodłączne cechy szkoły i, nawet gdy im to nie odpowiada, nie protestują, nie próbują zmieniać rzeczywistości, która je rozczarowuje (Glickman, Gordon, Ross-Gordon, 2013).

Jeszcze jednym efektem specyfiki pracy nauczycieli jest upraszczanie rzeczywistości i własnej aktywności, sprowadzanie jej do procedur, dobrze znanych metod czy prostych technik. Każdy nauczyciel spotyka w ciągu dnia od kilkudziesięciu do kilkuset uczniów i angażuje się w niezliczone interakcje o różnym charakterze: zadaje pytania, odpowiada na pytania, podaje instrukcje, sprawdza i kontroluje, dyscyplinuje, a jednocześnie pracuje ze świadomością, że wszystkie te działania mają prowadzić do uczenia się uczniów, który to proces będzie poddany zewnętrznym procesom ewaluacyjnym. Świadomi trudności własnego zadania i kompleksowości procesu nauczania i uczenia się nauczyciele 
zwykle postulują danie im więcej czasu na konkretne zadania, zmniejszenie liczebności klas, ale też, często dla dbałości o własne zdrowie psychiczne, sprowadzają te zadania do działań rutynowych, w których nie ma miejsca na krytyczną refleksję, dialog z innymi czy współpracę. Przyzwyczajeni do procedur, trochę znudzeni, ale pewnie czujący się w wypracowanym przez lata stylu, nauczyciele niechętnie odpowiadają na nawoływania o krytyczną refleksję nad kontekstem edukacji, kondycją świata i szkoły, uznając, zresztą słusznie, branie odpowiedzialności za to, co dzieje się w szkole, za wysoce niebezpieczne. Przywódcy edukacyjni powinni uświadomić sobie uwarunkowania i odziedziczone modele mentalne nauczycieli na temat tego, jak wygląda ich praca, a następnie zadać sobie pytanie, na ile to, co było akceptowane w przeszłości, jest adekwatne w dzisiejszej sytuacji, ale też na ile to, co wydaje się przydatne dzisiaj, jest możliwe do przyjęcia w szkołach.

Carl Glickman i jego współpracownicy (2013) jako jedną z przyczyn sytuacji, w której konserwuje się tradycyjne, aczkolwiek nieprzydatne dzisiaj, rozumienie szkoły i edukacji, wskazują nieadekwatne wprowadzanie nauczycieli do zawodu. To też wiąże się z rozwiązaniami instytucjonalnymi. W tej jakże trudnej profesji to początkujący pracują zwykle w najgorszych warunkach. Ponieważ często nie potrafią się jeszcze poruszać w szkolnej sieci społecznych powiązań, nie mają dostępu do zasobów, do których mają doświadczeni nauczyciele, kończą w najmniej popularnych salach i ze sprzętem, którego inni nie chcieli. Zdarza się, że przypisuje się im najtrudniejsze zadania, wychowawstwo czy uczenie dużych klas lub uczniów postrzeganych jako sprawiających trudności, często obarczani są obowiązkami biurokratycznymi, co tłumaczone może być jako swego rodzaju "chrzest" czy rytuał przejścia w nowej pracy. Można się spotkać z przekonaniem, że to niezbędny element socjalizacji do zawodu, który jest swoistym mechanizmem selekcji pozwalającym wyłonić najsilniejszych i wyrobić odpowiednie nawyki. Bez wsparcia dyrekcji i doświadczonej kadry początkujący nauczyciele skarżą się na nieznane im oczekiwania, brak jasnych dyspozycji i instrukcji, i pozostawienie samym sobie w zmaganiu się z postulatami różnych grup (dyrekcja, uczniowie, nauczyciele, rodzice). Szok związany ze zderzeniem z rzeczywistością przyczynia się do zgorzknienia i porzucenia ideałów czy wizji edukacji, z jaką przyszli do szkoły. Obawa, że są zupełnie nieprzygotowani do niespodziewanych obowiązków, paraliżuje wielu początkujących nauczycieli, co w efekcie prowadzi do bierności, 
gorszej opinii o uczniach i samym sobie, wypalenia zawodowego, a często opuszczenia zawodu.

Z podobnymi problemami zmagamy się w obszarze przywództwa edukacyjnego. Dyrektorzy szkół $i$ inne osoby pełniące funkcje przywódcze w Polsce tworzą środowisko edukacyjne w sposób intuicyjny, bez odpowiedniego przygotowania i osadzenia własnej praktyki w badaniach naukowych. W obawie przed porównywaniem i krytyką przywódcy stwarzają pozory działania dla realizacji wartościowych celów i w sposób przydatny dla ich uczniów i uczennic. Są przy tym poważnie obciążeni pracą, ponieważ, używając słowa "pozory", nie mam na myśli sytuacji, w której osoby te nie pracują, ale raczej twierdzę, że pracują ciężko, aczkolwiek nieracjonalnie (Mazurkiewicz, 2012).

Przywódca edukacyjny dbający o profesjonalny rozwój nauczycieli zajmuje się rozwojem nauczycieli i zapewnianiem ku temu odpowiednich warunków. Odwiedza systematycznie wszystkich nauczycieli, obserwuje, dyskutuje, organizuje i prowadzi spotkania, udziela informacji zwrotnej, monitoruje, wspiera nauczycieli i współpracę między nimi, organizuje proces szkoleniowy, dba o sensowną ewaluację i refleksję, odpowiednio projektuje i zarządza procesem decyzyjnym angażującym nauczycieli, a dotyczącym uczenia się i nauczania, pomaga tworzyć programy nauczania i je koordynować, współtworzy szkolną atmosferę i motywuje, pomaga ludziom ustalać wizję edukacji i zajmuje się jeszcze wieloma innymi zadaniami skoncentrowanymi na procesie nauczania i uczenia się. Niestety, w dzisiejszych realiach, zwykle nie ma na to czasu z przyczyn, których nie będę tu omawiał, choć część z nich już zasygnalizowałem wcześniej. Jeśli dyrektor zajmuje się czymś, co uważa za ważne w szkole, to rzadko jest to proces uczenia się i nauczania.

Większość dyrektorów szkół, którzy brali udział w prowadzonych przeze mnie badaniach "Przywództwo edukacyjne - modele mentalne” z 2012 roku, wśród najczęstszych zadań własnych wymieniali kontrolę nauczycieli (!) (jakby sami nauczyciele nie byli odpowiedzialnymi profesjonalistami), dbałość o finanse oraz organizowanie pracy szkoły, co w praktyce jednak głównie oznaczało dbanie o warunki pracy, remonty, rozbudowy, wyposażenie, czyli o szkolną infrastrukturę i jeszcze o zapewnienie istnienia odpowiednich dokumentów. Tego rodzaju działania mają na celu raczej zapewnienie bezpieczeństwa sobie i nauczycielom aniżeli intelektualny rozwój uczniów i uczennic (Mazurkiewicz, 2012). 
Dzisiaj, gdy wzrasta rozczarowanie związane z systemami oświatowymi, szkolna administracja również poddawana jest krytyce, ale wciąż poszukiwane są alternatywne sposoby działania administracji. Przecież chcemy wierzyć, że kierujący szkołami są nie tylko elementem struktury systemu oświatowego, ale i narzędziem zmiany, instrumentem wszelkich reform (English, Papa, Mullen, Creighton, 2012). Z tego, co próbuję tu z niemałym trudem pokazać, wynika jednak, że modele mentalne, służące jako struktury myślowe pomagające zrozumieć rzeczywistość i profesjonalne obowiązki raczej utrudniają aniżeli pomagają urealnić przekonanie o potencjale leżącym w "nowym" przywództwie edukacyjnym.

Warto wspomnieć o jeszcze jednym elemencie ukształtowanym w historycznym procesie rozwoju systemów edukacyjnych wpływającym na szkoły i decydującym o skuteczności wprowadzanych zmian. To dyscyplina i posłuszeństwo, których oczekujemy od obywateli, pracowników, uczniów. Nasze społeczeństwa domagają się dyscypliny. Instytucją będącą modelowym przykładem wykorzystania dyscypliny dla sprawnego jej funkcjonowania była i jest armia. Szkoła zaakceptowała różne procedury podporządkowywania ludzi wypracowane w wojsku. Michel Foucault (2009, s. 131-157) podkreślał polityczną użyteczność różnych technik kontrolowania i manipulowania społeczeństwem. Szkoły były ogniwem w łańcuchu procedur skoncentrowanych na izolacji, segregacji i porządku, zaprojektowanych dla wojska, z jego hierarchią, planami, gospodarowaniem czasem, budynkami i wyposażeniem. Projektowano je jak wysoce wyspecjalizowane mechanizmy, a nawet fabryki nauczania i szkolenia. Nadzór stał się ważnym czynnikiem ekonomicznym, integralnym elementem procesu produkcji, połączonym z władzą polityczną. Wprowadzono egzaminy dla kategoryzowania uczniów według ich zdolności i zachowań, która to kategoryzacja decydowała o ich miejscu w społecznej stratyfikacji. Obsesja kontrolowania czasu wpłynęła na praktykę pedagogiczną, i na wizję życia, w której uczenie się oddzielono od dorosłego życia i pracy.

Nowoczesne, przemysłowe społeczeństwa ujęto, dzięki tak zorganizowanej edukacji, w ramy procedur służących akumulacji kapitału oraz procedur zarządczych, co pozwoliło na oderwanie kosztownych i brutalnych procedur wywodzących się z tradycji wojskowych od dnia codziennego oraz ich transformacji w bardziej subtelne technologie podporządkowywania (Foucault, 2009, s. 178-187). W szkołach po- 
kazujących posłuszeństwo jako pożądaną wartość oraz cechę osobowości umacniano hegemonię dominującej ideologii i klasy posiadaczy. Podświadomie więc bardziej dzisiaj cenimy dyscyplinę i podporządkowanie narzuconemu porządkowi niż śmiałe reformatorskie idee, innowacyjność czy kreatywność, których tak bardzo się domagamy i których oczekujemy w szkołach. Dominacja wolnego rynku, metody organizacji pracy wzięte z przemysłu, izolacja, brak kontaktu z innymi profesjonalistami, rywalizacja, kontrola, podział, manipulacja - efekty tych zjawisk odczuwamy do dzisiaj.

\section{Pod prąd}

Żadna reforma nie będzie prosta. Jest jednak niezbędna. Nie zaproponuję niczego nowego, ale nie jest to łatwe. Myślę, że szkoła, tak jak i społeczeństwo, potrzebują dzisiaj zmiany paradygmatu, wedle którego działają. Nie zrobią tego pojedyncze osoby, politycy czy eksperci. Nawet gdyby mieli najlepsze pomysły, które wprowadzone przyniosłyby oczekiwane rezultaty, to się nie uda. Głęboka zmiana wymaga legitymizacji w procesie deliberacji i współdecydowania. Nie w referendum, ale bolesnych, choć demokratycznych, negocjacjach. Nie mamy pewności, jakich szkół potrzebujemy, ale to nie jest problem. Istnieje sporo różnych propozycji, które można i należy rozważyć. Nie róbmy tego za zamkniętymi drzwiami gabinetów polityków i ekspertów. Potrzebna jest nam powszechna i poważna rozmowa na temat wartości demokracji, solidarności i sprawiedliwości. Konieczna jest rozmowa o tym, dlaczego potrzebujemy szkoły, jakie cele ma realizować, w jaki sposób ma to robić. Przywództwo edukacyjne może pomóc w znalezieniu odpowiedzi na te pytania, ale też na postawione na początku problemy związane ze środowiskiem naturalnym, nierównościami, różnorodnością, gospodarką i demokracją.

Zacznijmy rozmowy i prace nad rekonstrukcją dominującej metafory edukacji. Metafora opisująca edukację jako proces produkcji nie powinna dalej dominować dyskursu dotyczącego projektowania i praktyki edukacji. To trudne do osiągnięcia w świecie, który nieustannie reprodukuje wizje industrialnego społeczeństwa. Jednak nieustanny wzrost gospodarczy, budowany na wyzysku, nie musi być naszym celem, dyscyplina i posłuszeństwo nie muszą być naszym losem, pozory demokracji - naszym przeznaczeniem, obcy niekoniecznie jest zagrożeniem, środowisko naturalne nie jest niewyczerpywalnym zasobem. 
Systemy edukacyjne i szkoły mogą stać się miejscami otwartymi na demokratyczne praktyki, w których ludzie chcą i potrafią wziąć odpowiedzialność za siebie i innych.

Wiemy, że potrzebne nam demokratyczne społeczeństwa, w których zaangażowani obywatele współpracują dla realizacji zadań służących zrównoważonemu rozwojowi i spójności społecznej. Ludzie chcą robić rzeczy dla własnego rozwoju i dla dobra innych, a nie tylko po to, aby utrzymać posadę, nie chcą już dłużej pracować w organizacjach budowanych na wzór fabryki i taśmy produkcyjnej (Godin, 2008). Tkwimy jednak gdzieś między lękiem przed nieznanym i popełnieniem błędu a tradycyjnymi modelami mentalnymi, rozwiązaniami, które być może były przydatne w przeszłości, ale przestały. Powinniśmy zachęcać siebie i innych do herezji, do kontestowania przekonania o tym, że jest, jak "być powinno". Stawiajmy na tych, którzy ośmielają się kwestionować status quo. Każdy może przewodzić, a przywództwo nie jest trudne, ale przekonano nas, aby go unikać (Mazurkiewicz, 2015). Nawoływanie do rozmów, zachęcanie do kontestowania istniejącego porządku i zaangażowania się w budowanie nowego jest dzisiaj działaniem ryzykownym, a z pewnością mało skutecznym. Nie tylko Polska podzielona jest przez silne wewnętrzne konflikty, nie tylko Polska boryka się z ułożeniem poprawnych stosunków z zagranicznymi partnerami, to problem globalny. Nie mamy jednak innego wyjścia.

Nie ma już miejsca na szybkie rozwiązania. Musimy się przeorganizować, tak abyśmy sami mogli decydować o tym, co się dzieje wokół nas. Samoorganizacja wymaga wysiłku, czasu i ustalenia, co jest najważniejsze. Do prawdy dochodzi się wspólnie, w dialogu (Tischner, 2009). Społeczeństwo demokratyczne to społeczeństwo, w którym cel edukacji nie jest narzucony z zewnętrz, ale jest przedmiotem ciągłych dyskusji i deliberacji (Biesta, 2007). Prowadzenie tej dyskusji nie może być wyłącznie zadaniem sektora edukacyjnego, zaangażować trzeba większe grupy społeczne i ich liderów, obywateli, organizacje, stowarzyszenia, polityków, wreszcie globalne społeczeństwo, które może w końcu pokaże polityczną wolę włączenia edukacji w główny nurt rozważań dotyczących przyszłości ludzkości. Ta rozmowa powinna być prowadzona przez przywódców edukacyjnych, czyli nauczycieli, którzy rozumieją potrzeby współczesnych społeczeństw, widzą konieczność transformacji szkół i nie boją się odpowiedzialności wiążącej się z przywództwem. W ten sposób uda się zrealizować postulaty Paolo Freire 
(1993) dotyczące dialogu, który twierdził, że dialog nie jest sposobem wymiany informacji, ale egzystencjalną koniecznością, gdyż to przez dialog tworzymy rzeczywistość.

Dialog jest w dzisiejszym świecie rzadkim dobrem, społeczeństwa polaryzują się, a język publicznej debaty zaostrza się, ograniczając wy-

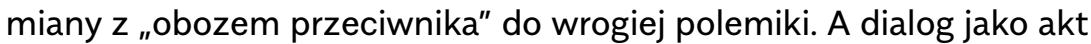
kreacji nie może służyć dominacji jednych nad drugimi. Dialog nie może istnieć bez miłości do świata i do ludzi. Jako akt odwagi miłość nie może być sentymentalna, jako akt wolności nie może służyć manipulacji. Dialog nie może istnieć bez pokory. Dialog załamuje się, jeśli stronom brak pokory. Dialog wymaga wiary w ludzkość, wiary w możliwość budowania i przebudowywania świata (Freire, 1993, s. 69-73). Potrzebny nam jest dialog. Gdzie rozpocząć dialog, jeśli nie w szkołach i wokół nich?

Młodzi ludzie muszą mieć szansę na odnoszenie sukcesów w życiu osobistym i w pracy, ale też muszą mieć ideały. Uczenie dla wolności i demokracji to uczenie szacunku dla siebie i innych, wyrażające się w zdolności do prowadzenia działań adekwatnych do kontekstu, zgodnie z przyjętymi zasadami. Dlatego najpilniejsze zadanie przywództwa w edukacji to kreowanie przestrzeni autentycznego dialogu umożliwiającego powstawanie wspólnot krytycznych obywateli świadomych znaczenia swoich interakcji w procesie transformacji rzeczywistości. Szkoła już nigdy nie będzie miejscem oderwanym od rzeczywistości, trochę śmiesznym w swym trwaniu w przeszłości, nudnym ze swoją biurokracją i miałkimi konfliktami o podstawę programową, trochę strasznym z powodu marnowania czasu i energii ludzi, którzy zamiast siedzieć w ławkach mogliby w świecie rzeczywistym zmieniać nasz los. Przywództwo edukacyjne przyszłości to przywództwo 3D - dzielące się władzą, realizowane $\mathrm{w}$ dialogu, służące demokratyzacji - pod prąd, ale $z$ sensem. 


\section{Bibliografia}

$\rightarrow$ Apple, M. (2013), Can Education Change Society?, New York: Routledge.

$\rightarrow$ Bauman, Z., Bauman, I., Kociatkiewicz, J., Kostera, M. (2017), Zarządzanie w płynnej rzeczywistości, Warszawa: Fundacja Bęc Zmiana.

$\rightarrow$ Bezzina, Ch., Madalińska-Michalak, J. (2014), Przywództwo służebne: spojrzenie w przyszłość [w:] S.M. Kwiatkowski, J. Madalińska-Michalak (red.), Przywództwo edukacyjne. Współczesne wyzwania, s. 81-93, Warszawa: ABC a Wolters Kluwer business.

$\rightarrow$ Biesta G. (2007), Why "what works" won't work: Evidence-based practice and the democratic deficit in educational research, Educational Theory, 57(1), 1-22.

$\rightarrow$ Bregman, R. (2017), Utopia for Realists. And How We Can Get There, London, New York: Bloomsbury Publishing.

$\rightarrow$ Carl, J. (2009), Industrialization and Public Education: Social Cohesion and Social Stratification [w:] R. Cowen, A.M. Kazamias (red.), International Handbook of Comparative Education, s. 503-518, London-New York: Springer Science \& Business Media B.V.

$\rightarrow$ Cerna, L. (2015), Trust and Education, Background paper for OECD/CERI Conference. Hague: OECD.

$\rightarrow$ English, F.W., Papa, R., Mullen, C.A., Creighton, T. (2012), Educational Leadership at 2050. Conjectures, Challenges, and Promises, Lanham, New York, Toronto, Plymouth: Rowman \& Littlefield Education.

$\rightarrow$ Fielding, M., Moss, P. (2011), Radical Education and the Common School. A Democratic Alternative, London, New York: Routledge.

$\rightarrow$ Foucault, M. (2009), Nadzorować i karać. Narodziny więzienia, Warszawa: Wydawnictwo Aletheia.

$\rightarrow$ Freire P. (1993), The Pedagogy of The Oppressed, London: Penguin Books.

$\rightarrow$ Glavan, B., Anghel, F., Avrigeanu, A.F (2010), Public Education, Market and Human Capital Formation, Romanian Economic and Business Review, 5, 17-22. 
$\rightarrow$ Glickman, C.D., Gordon, S.P., Ross-Gordon, J.M. (2013), The Basic Guide to SuperVision and Instructional Leadership, Boston: PEARSON.

$\rightarrow$ Godin, S. (2008), Tribes: We need you to lead us, London: Piatkus.

$\rightarrow$ Herold, B. (2017), Preparing Students for Tomorrow's Jobs: 10 Experts Offer Advice to Educators. Education Week, September 26, pozyskano: http://www. edweek.org/ew/articles/2017/09/27/preparing-students-for-tomorrows-jobs10-experts.html?cmp=eml-enl-eu-news2\&M=58214979\&U=1459776

$\rightarrow$ Hoefstede, G. (2000), Kultury i organizacje, Warszawa: Polskie Wydawnictwo Ekonomiczne.

$\rightarrow$ Hoyle, E., Wallace, M. (2005), Educational Leadership: Ambiguity, Professionals and Managerialism, London, Thousand Oaks, New Delhi: Sage Publications.

$\rightarrow$ Klein, N. (2016), To zmienia wszystko. Kapitalizm kontra klimat, Warszawa: Wydawnictwo Muza.

$\rightarrow$ Kools, M., Stoll L. (2016), What Makes a School a Learning Organisation?, OECD Education Working Papers, No. 137, Paris: OECD Publishing.

$\rightarrow$ Lortie, D.C. (1975), Schoolteacher: A Sociological Study, Chicago: University of Chicago Press.

$\rightarrow$ McLaren, P. (2015), Życie w szkołach. Wprowadzenie do pedagogiki krytycznej, Wrocław: Wydawnictwo Naukowe Dolnośląskiej Szkoły Wyższej.

$\rightarrow$ Mazurkiewicz, G. (2015), Przywództwo edukacyjne. Zmiana paradygmatu [w:] G. Mazurkiewicz (red.), Przywództwo edukacyjne. Zaproszenie do dialogu, s. 9-36, Kraków: Wydawnictwo Uniwersytetu Jagiellońskiego.

$\rightarrow$ Mazurkiewicz, G. (2012), Edukacja i przywództwo. Modele mentalne jako bariery rozwoju, Kraków: Wydawnictwo Uniwersytetu Jagiellońskiego.

$\rightarrow$ OECD (2012), What are the return on higher education for individuals and countries, OECD: Education Indicators in Focus, June.

$\rightarrow$ OECD (2013), What Are the Social Benefits of Education, OECD: Education Indicators in Focus, January.

$\rightarrow$ OECD (2017), Education at a Glance 2017: OECD Indicators, Paris: OECD Publishing.

$\rightarrow$ Ohio State University (2015), High Points. Economic Impact, Columbus: Ohio State University.

$\rightarrow$ Patel, R. (2010), Wartość niczego. Jak przekształcić społeczeństwo rynkowe i na nowo zdefiniować demokrację, Warszawa: Warszawskie Wydawnictwo Literackie Muza SA.

$\rightarrow$ Piketty, T. (2015), Kapitał w XXI wieku, Warszawa: Wydawnictwo Krytyki Politycznej. 
$\rightarrow$ Rifkin, J. (2016), Społeczeństwo zerowych kosztów krańcowych. Ekonomia współdzielenia. Zmierzch kapitalizmu, Warszawa: Wydawnictwo Studio EMKA.

$\rightarrow$ Sadovnik, A.R., Cookson, P.W., Semel, S.F. (2006), Exploring Education. An Introduction to the Foundation of Education, New York, London: Routledge Taylor \& Francis Group.

$\rightarrow$ Sennett, R. (2013), Razem. Rytuały, zalety i zasady współpracy, Warszawa: Wydawnictwo Literackie Muza.

$\rightarrow$ Tischer, J., Żakowski, J. (2009), Tischner czyta katechizm, Kraków: Znak.

$\rightarrow$ Więsław, Sz. (2011), Sytuacja i status zawodowy dyrektorów szkół i placówek oświatowych (Badanie zrealizowane w ramach projektu "Doskonalenie strategii zarządzania oświatą na poziomie regionalnym i lokalnym”), Warszawa: Ośrodek Rozwoju Edukacji.

$\rightarrow$ Wilkinson, R., Pickett, K. (2011), Duch równości. Tam gdzie panuje równość, wszystkim żyje się lepiej, Warszawa: Czarna Owca. 



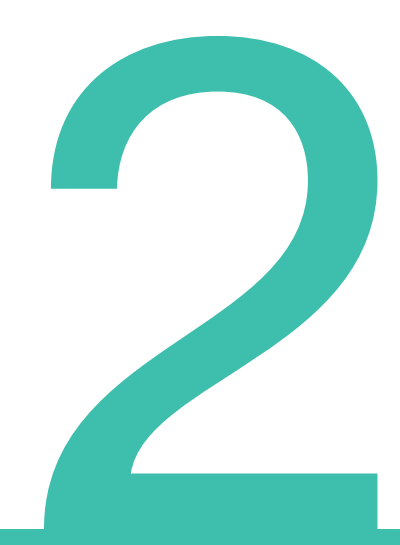


Przywództwo nauczycieli

- perspektywy i inspiracje 


\section{Przywództwo nauczycieli \\ - przesłanki prawne}

Antoni J. Jeżowski

Badania naukowe oraz projekty realizowane na styku nauki i praktyki oświatowej pokazują, że od jakiegoś czasu zarysowała się antynomia: zarządzanie szkołą a przywództwo edukacyjne. Z jednej strony kwestię tę determinują rozstrzygnięcia prawne obowiązujące w polskiej edukacji, a z drugiej - duże zainteresowanie odformalizowaniem zarządzania polską szkołą na rzecz bardziej humanistycznego przywództwa edukacyjnego. Pojawiają się jednak pytania: czy oba te ujęcia wykluczają się wzajemnie? Czy zarządzanie wyklucza stosowanie technik i stylów właściwych przywódcom i - odwrotnie - czy przywódca nigdy, w żadnej sytuacji nie może (nie powinien) podejmować działań właściwych przywódcom? Analiza wybranych fragmentów rozwiązań prawnych w tych obszarach prowadzi do ciekawych konkluzji.

\section{Słowa kluczowe:}

dyrektor szkoły

nauczyciel

przywódca

wymagania

zadania

zarządzanie 


\section{Teacher leadership - legal premises}

Antoni J. Jeżowski

Research and projects conducted at the interface of science and educational practice show that an antinomy has emerged: school management and educational leadership. On the one hand, this issue determines the legal solutions in force in Polish education, and on the other, the great interest in the deformation of the management of the Polish school for more humanistic educational leadership. But the questions arise: are both of these shots mutually exclusive? Does management exclude the use of techniques and styles appropriate to the leaders and, conversely, does the leader never, in any situation, be able to (do not) take the right action for the leaders? Analysis of the selected fragments of legal solutions in these areas leads to the interesting conclusions.

\section{Keywords: \\ school principal \\ teacher \\ leadership \\ requirements \\ tasks \\ management}




\section{Wprowadzenie}

W życiu szkoły istotne jest przywództwo formalne, wynikające z przepisów prawa, ale nie mniej ważne jest także przywództwo nieformalne - to, jak nauczyciele układają sobie relacje z innymi nauczycielami, z uczniami i jakie pełnią role w szkole i poza nią. Różnorodność ról sprawia, że nauczyciele mogą znaleźć sposoby, które odpowiadają ich kompetencjom, talentom i zainteresowaniom, potrzebom własnym i potrzebom szkoły. Niezależnie od ich ról, nauczyciele-liderzy kształtują kulturę swoich szkół, poprawiają uczenie się uczniów i wpływają na pracę innych nauczycieli (Madalińska-Michalak, 2012; Madalińska-Michalak, 2015).

W polskiej szkole przywódcy i niesione przez nich przywództwo przebija się z niejakim trudem - w szczególności polskie rozwiązania prawne bardziej wyznaczają zadania dla nauczycieli, niż stawiają ich w konkretnych sytuacjach i podpowiadają, że należy podjąć działanie. Oczywiście jest to zapewne pokłosie systemu nakazowo-rozdzielczego, który swoimi korzeniami sięga lat czterdziestych ubiegłego wieku. W wykreowanych wówczas warunkach łatwiej było na przykład realizować scentralizowany system nadzoru pedagogicznego, bo działania i nadzorowanych, i nadzorujących sprowadzały się do kontrolowania systemu zero-jedynkowego - zbędne były interpretacje, wyjaśnienia, tłumaczenia i obrony swojego stanowiska. Bez wątpienia to pewne uproszczenie, ale moje osobiste doświadczenia - i te pod tablicą (jako nauczyciela) i w instytucji nadzorującej (jako wizytatora) taką przywołują refleksję.

Zmiana systemu politycznego wiązała się z silnymi postulatami autonomizacji organizacji i funkcjonowania szkoły, a zatem jej nauczycieli i dyrektorów. Nauczyciele zyskali samodzielność, ale nie wyposażono ich ani uprzednio, ani w wyniku zmian w stosowne kompetencje. Co więcej, nawet tam, gdzie iskierka samodzielności budziła w niektórych takie czy inne działania, zrazu była modyfikowana przez oczekiwania środowiska, a w szczególności przez upodmiotowionych wreszcie rodziców, którzy w sprawie warsztatu pracy nauczycieli zawsze chcieli coś powiedzieć i wreszcie mogli to czynić swobodnie, a czasem bezpardonowo. $Z$ kolei dyrektorzy zyskali ogromne uprawnienia - obok kierowania szkołą mogli wreszcie (uprzednio robił to wydział oświaty) samodzielnie zatrudniać (bo już zwalniać nie bardzo) nauczycieli, dysponować "własnymi” środkami finansowymi, gospodarować mieniem itp. I gdy już poprzez kursy i szkolenia z zakresu zarządzania oświatą i stosowne studia po- 
dyplomowe wniknęli w ową materię, gdy zrozumieli, ile energii, pracy i odpowiedzialności ten obszar ich działania i powiązanej z nim wolności pochłania, to poczęły do nich docierać zrazu tylko sygnały, później wyraźne postulaty, by zajęli się przywództwem, gdyż leadership to jest to, a nauka, Europa i świat tego właśnie od nich oczekuje.

W niniejszym artykule spróbuję podjąć się analizy tej dość złożonej i oczekiwanej z dystansem, a nawet obawami przez nauczycieli i ich dyrektorów nowej roli, jaka została im póki co wskazana. Oczywiście przyjmuję, że nauczyciel w polskiej szkole, a już dyrektor w szczególności, winien być jej liderem. Wnioski co do tego, jakie to niesie wyzwania, ale i konsekwencje, pozostawię pedagogom, socjologom, psychologom, a nawet specjalistom od zarządzania czy marketingu. Moim wyzwaniem jest spojrzenie na obecną sytuację w polskiej szkole i zastanowienie się, czy są dziś ku takim działaniom przesłanki, przede wszystkim przesłanki prawne.

\section{Rzut oka na zarys badań porównawczych}

Przykładem zaprezentowania owych badań porównawczych będzie krótka i dość wybiórcza analiza najnowszej publikacji OECD pt. Education at a Glance 2016. OECD Indicators (OECD, 2017), która została opublikowana w ostatnich tygodniach. Autorzy opracowania, posiłkując się wynikami badań zrealizowanych w ramach TALIS i PISA, próbują ująć kwestię przywództwa edukacyjnego w systemowy opis, a nawet przypisać realizowanym już działaniom standardy, w tym także liczbowe. W roku 2001 kwestionariusz szkolny PISA zawierał 21 pytań dotyczących przywództwa w szkole, z czego 13 stanowiło dane dla 4-krotnych wskaźników. W ostatnim roku szkolnym poproszono dyrektorów, aby wskazywali częstotliwość wymienionych działań i zachowań w swojej szkole. Sześć kategorii odpowiedzi to: "nie wystąpiły”, "1-2 razy w ciągu roku", „3-4 razy w ciągu roku", „raz w miesiącu", „raz w tygodniu", "częściej niż raz w tygodniu". PISA 2012 zwróciło się do dyrektorów szkół, aby odpowiedzieli, jak często różne działania i zachowania związane z zarządzaniem szkołą ( $w$ tym udział nauczycieli w zarządzaniu szkołami) miały miejsce w poprzednim roku szkolnym (tamże, s. 458).

Dyrektorzy odpowiedzieli na trzy pytania dotyczące zaangażowania nauczycieli w zarządzanie szkołami: zapewnienie pracownikom możliwości podejmowania decyzji dotyczących szkoły, angażowanie nauczycieli w budowanie kultury ciągłego doskonalenia w szkole, a także 
zachęcanie nauczycieli do udziału w analizie praktyk w zakresie zarządzania szkołą. Odpowiedzi na te trzy pytania zostały połączone w celu opracowania wskaźnika złożonego udziału nauczycieli w zarządzaniu szkołami. Wskaźnik ten ma średnią wartość zero i odchylenie standardowe jeden dla krajów OECD. Dla przykładu w Turcji i Brazylii dyrektorzy poinformowali, że nauczyciele angażują się w zarządzanie szkołą w większym stopniu, podczas gdy dyrektorzy w Szwajcarii i Francji, ale i w Polsce poinformowali, że nauczyciele są zaangażowani w tę działalność w stopniu mniejszym. Poniższe zestawienie pokazuje też rozpiętość między najwyższymi i najniższymi wartościami tego wskaźnika.

Wykres 1. Wskaźnik uczestnictwa nauczycieli w zarządzaniu szkołami (PISA 2012)

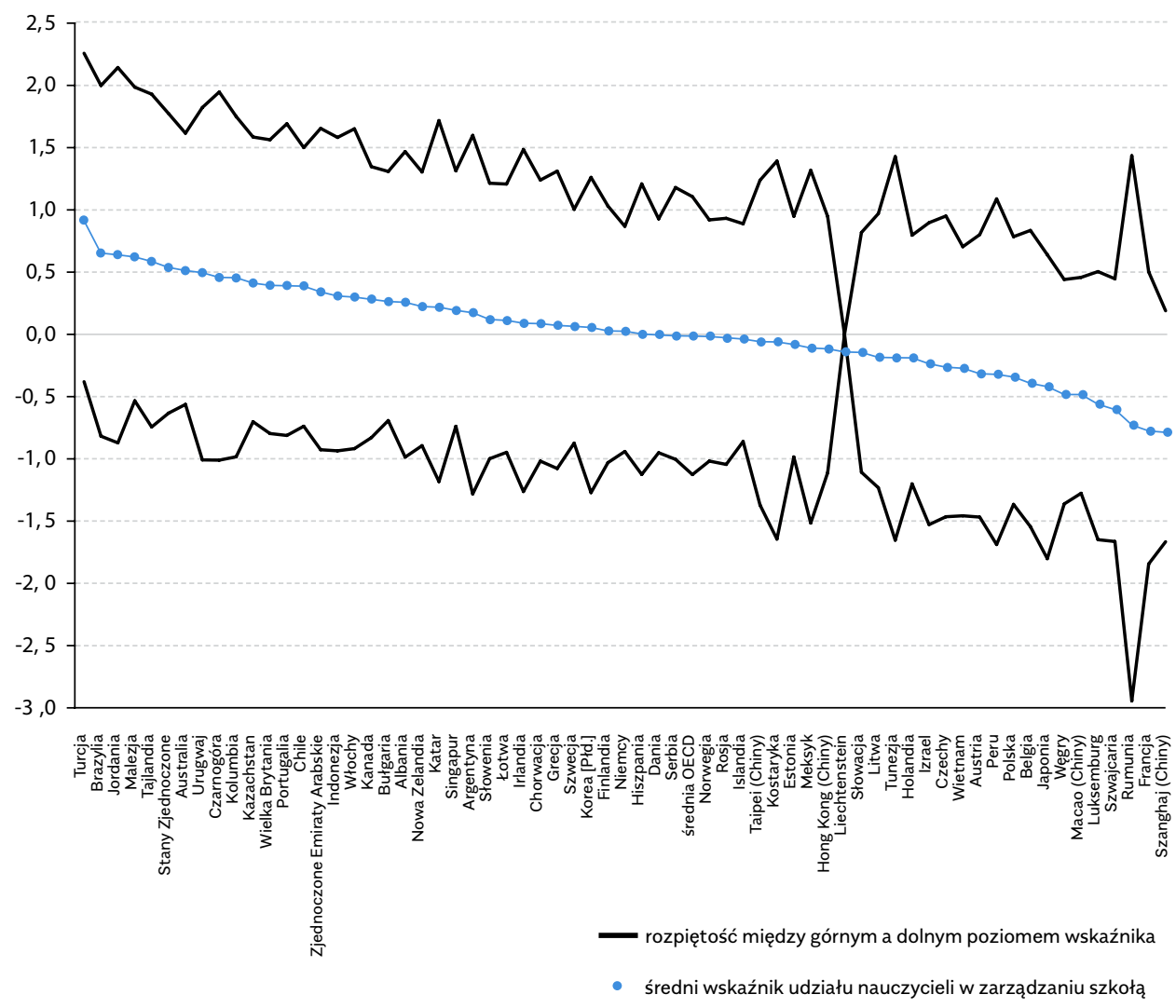

Źródło: opracowanie własne na podstawie Education at a Glance 2016. OECD Indicators (OECD, 2017). 
Jednocześnie dane TALIS wskazują, że dyrektorzy, którzy biorą udział w rozwoju zawodowym, częściej angażują się w kierowanie rozproszone, chociaż rodzaj działalności w zakresie rozwoju zawodowego związany z kierowaniem rozproszonym różni się w poszczególnych krajach. Te same dane wskazują, że kiedy dyrektorzy wykazują większe zaangażowanie w przywództwo instruktażowe w szkołach, wówczas ich nauczyciele są bardziej zaangażowani we współpracę. To sugeruje, że jeśli dyrektorzy podejmują działania na rzecz wspierania współpracy nauczycieli w celu opracowania nowych praktyk nauczycielskich, nauczyciele są bardziej skłonni do tej współpracy.

Autorzy zauważają też, że ze względu na złożoność organizacji pracy szkoły, praca dyrektora jest coraz częściej związana z odpowiedzialnością, która jest lub powinna być szerzej podzielona. Rozproszone przywództwo odzwierciedla fakt, że kierownictwo w szkołach nie jest wynikiem pracy tylko dyrektorów, ale że inne osoby w organizacji działają również jako liderzy (tamże, s. 456). Zwróćmy też uwagę, że nauczanie i rozproszone przywództwo są uważane za istotne dla tworzenia i wspierania profesjonalnych społeczności edukacyjnych oraz tworzenia klimatu sprzyjającego uczeniu się uczniów. I tak, przywództwo instruktażowe obejmuje praktyki przywódcze, które zajmują się planowaniem, oceną, koordynacją i poprawą nauczania i uczenia się, zaś rozproszone przywództwo odzwierciedla sytuację, gdy przywództwo w szkołach jest nie tylko wynikiem pracy dyrektorów, ale że inni członkowie organizacji działają tu również jako liderzy (tamże, s. 458).

Warto może jeszcze zacytować z tegoż opracowania fragment dotyczący współdziałania dyrektorów szkół z nauczycielami w zakresie sprawowania przez nich nadzoru pedagogicznego.

Dla bardziej wyrazistego ukazania danych z polskiej szkoły na tle krajów OECD w zakresie współpracy nauczycieli i dyrektorów szkół średnich II stopnia (TALIS, 2013, s. 453) materiał z opracowania przedstawię na trzech oddzielnych wykresach. 
Wykres 2. Odsetek dyrektorów deklarujących, że w ciągu 12 miesięcy poprzedzających badanie „często" lub „bardzo często" obserwowali pracę nauczyciela w klasie

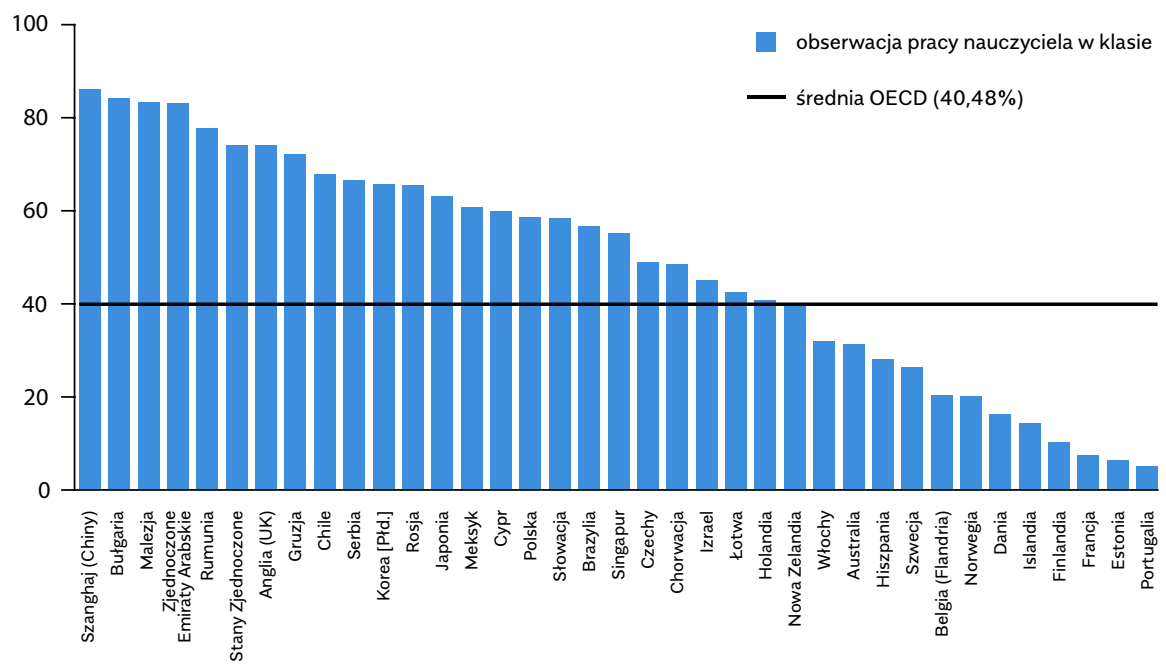

Źródło: opracowanie własne na podstawie Education at a Glance 2016. OECD Indicators (OECD, 2017).

Wykres 3. Odsetek dyrektorów, którzy deklarują, że w okresie 12 miesięcy poprzedzających badanie "często" lub "bardzo często" angażowali się we wspieranie współpracy pomiędzy nauczycielami w celu wypracowania nowych technik nauczania

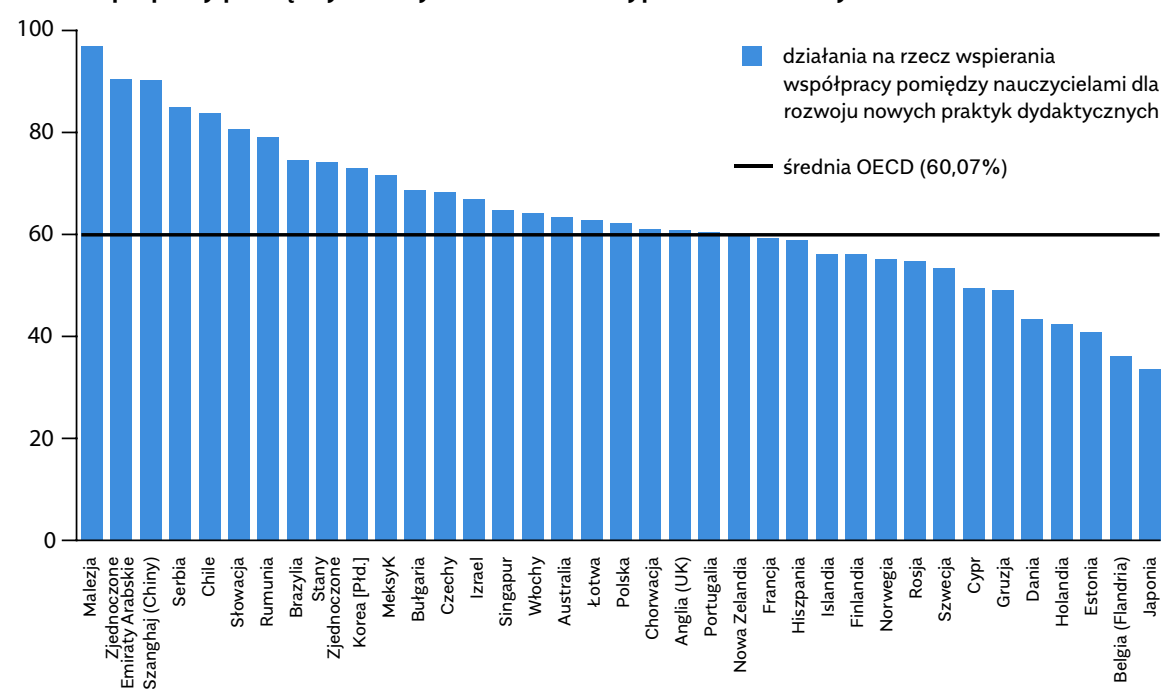

Źródło: opracowanie własne na podstawie Education at a Glance 2016. OECD Indicators (OECD, 2017). 
Wykres 4. Odsetek dyrektorów deklarujących, że w okresie 12 miesięcy poprzedzających badanie "często" lub „bardzo często" angażowali się w działania zapewniające, że nauczyciele wezmą odpowiedzialność za doskonalenie swoich umiejętności pedagogicznych

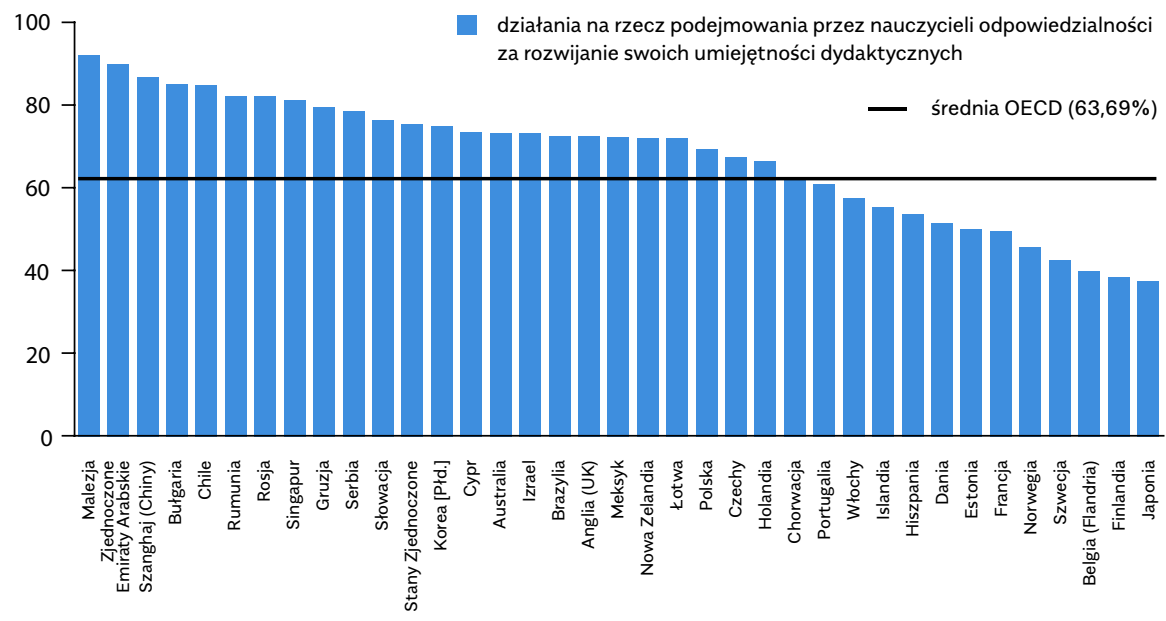

Źródło: opracowanie własne na podstawie Education at a Glance 2016. OECD Indicators (OECD, 2017).

Prezentowane wykresy dostarczają informacji, że polscy nauczyciele w tym typie szkół (ponadgimnazjalne) w każdej z trzech deklarowanych wypowiedzi sytuowali się z wynikami w grupie państw powyżej średniej dla krajów wysoko rozwiniętych. To, oczywiście, powód do pewnej satysfakcji, w sytuacji gdy - jak wspomniałem - przywództwo ani nie leżało, ani nie leży wśród priorytetowych rozwiązań prawnych w Polsce, ani choćby w orbicie zainteresowań polityków.

Jednocześnie sami dyrektorzy polskich szkół bardzo wysoko ocenili swój udział w wykorzystaniu wyników uczniów i ich ocenę (w tym ocen krajowych i międzynarodowych) dla opracowania celów i programów edukacyjnych. Polscy dyrektorzy zadeklarowali, że aż w 94,8\% (średnia OECD - 89,3\%) owe działania realizowało w oparciu o przywołane przesłanki, a jednocześnie w 94,7\% (średnia OECD - 77,4\%) zadeklarowało swój udział w budowaniu planów rozwoju szkoły. Tym samym (patrz wykres 5.) polscy dyrektorzy zaistnieli w grupie dziesięciu najbardziej zaangażowanych dyrektorów z krajów OECD. 
Jeśli więc materiał Organizacji ocenia nasze działania przywódcze w szkołach tak wysoko, to dlaczego tu i ówdzie, także na kartach tej książki, wyrażamy swoje niezadowolenie? Czy rzeczywiście jest tak dobrze, że tylko sami nie umiemy dostrzec tego, co jest mocną stroną organizacji polskich szkół? Czy może teoria mija się praktyką? Czy piszący o przywództwie w polskiej szkole znają jej realia, a zwłaszcza uwarunkowania prawne, i owo przywództwo - mimo malkontenctwa i powierzchownych ocen serwowanych od czasu do czasu - niejako na przekór im dzieje się i to na poziomie dość satysfakcjonującym? A może jednak nieco inaczej rzecz się ma w grupie nauczycieli, a inaczej w grupie dyrektorów, co sugerowałyby przywołane dane?

Wykres 5. Uczestnictwo dyrektorów szkół w planowaniu rozwoju szkół średnich ponadgimnazjalnych

- praca nad planem rozwoju szkoły

- wykorzystanie wyników pracy ucznia i osiągnięć edukacyjnych ucznia ( $w$ tym osiągnięć w programach krajowych i międzynarodowych) w określaniu celów i programów edukacyjnych szkoły

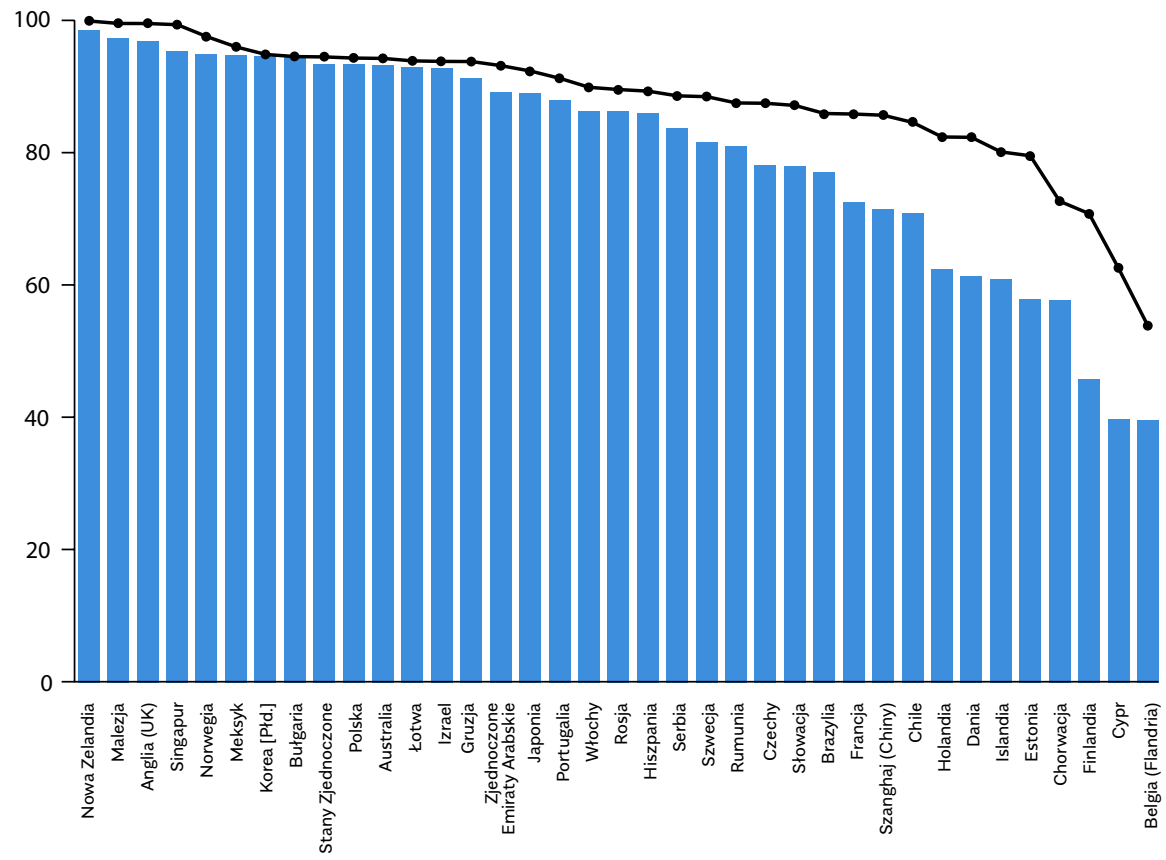

Źródło: opracowanie własne na podstawie TALIS 2013 Results: An International Perspective on Teaching and Learning (OECD, 2014, s. 454). 


\section{Kilka refleksji ogólnych, mimo wszystko}

Pochylając się nad kwestią przywództwa, szczególnie edukacyjnego, gdzie mamy do czynienia w zasadzie tylko z ludźmi, a inne czynniki, takie jak baza, dostępne środki itp. mają raczej drugoplanowe znaczenie, warto zadać sobie kilka pytań, aby mniej było niedopowiedzeń i rozczarowań. Tak więc, kto to jest przywódca, w szczególności edukacyjny? A rodzice? Jakie jest ich usytuowanie w szkole z przywódcą? Rodzic-przywódca wspiera szkołę, czy może jej przeszkadza?

Inną kwestią jest odpowiedzialność prawna dyrektora a odpowiedzialność społeczna (publiczna) tego samego człowieka w roli przywódcy - przed kim, w jakim zakresie, z jakimi konsekwencjami, jakie są (będą) standardy (benchmarki) doskonałego, wzorowego, poprawnego, a jakie beznadziejnego przywódcy? Konstruując prawo, antycypujemy przyszłość - przewidujemy więc sytuacje, które prawo wyznacza, które wspiera, ale i którym ma zapobiec. Ma więc wyznaczyć standardy na przykład zachowań i ewentualnie wskazać sankcje za ich naruszenie. A co z przywódcą? Czy przywódca może podlegać odpowiedzialności karnej (cywilnej, sądowej)? Wszak bywa, że sytuuje się poza systemem, nie uczestniczy w strukturach, gra rolę trybuna, jak choćby wspomniany już rodzic czy inny lokalny działacz, który coś narzuca, wymusza, ale w zasadzie "bywa nikim i znikąd".

Dyrektor ma w aktach prawa zaordynowanych grubo ponad tysiąc zadań, które w codziennej pracy musi realizować, aby byś dobrym, skutecznym i efektywnym dyrektorem (Jeżowski, 2009). Jakie są więc relacje między przewodzeniem a realizowaniem zadań poprzez administrowanie, kierowanie i zarządzanie? (Jeżowski, Madalińska-Michalak, 2015) Czy przywódca to taki realizator zadań, ale z charyzmą? Jeśli tak, to po co to tak komplikować, udziwniać? A jeśli jednak nie, to gdzie jest ten "haczyk"?

Henryk Mizerek pisze: „Dyskurs rynkowy stworzył okazję do agresywnego wkraczania języka ekonomii na teren edukacji. W praktyce zastąpił on język współczesnej humanistyki (w tym pedagogiki) jako narzędzie opisu i interpretacji tego, co się w szkole dzieje. Dyskurs edukacji w czasach współczesnych staje się coraz bardziej dyskursem rynku. Prawdę, Dobro, Piękno - triadę wartości, na której straży ma stać szkoła, wypiera nowa trójca - Klient, Rynek, Usługa. Kluczowe kategorie pedagogiki zostały, wyparte przez pojęcia czysto ekonomiczne. Procesy kształcenia, nauczania i wychowania zredukowano do procesów 
produkcji usług. Szkoły jako dostawcy usług edukacyjnych konkurują na wolnym rynku. Uczniów i rodziców zastąpili konsumenci (jeszcze do niedawna nazywani »klientami ). Metaforę szkoły jako »świątyni wiedzy « czy "kliniki kształcenia « miałaby zastąpić metafora »edumarketu«" (Mizerek, 2012, s. 17). Z tak postawionymi problemami trudno podejmować jakiś sensowny dyskurs. Czy dyrektor polskiej szkoły ma zarzucić wymagania stawiane mu przez prawo i własnym postanowieniem skupić się jedynie na ideach? Pewnie ważnych i podstawowych, ale pamiętać czasem trzeba, że nie wszyscy uczniowie podzielają z nim pogląd, że do szkoły idą po Prawdę, Dobro i Piękno. Może i tak było, gdy szkoła była wyborem, ale dziś jest obowiązkiem...

Czasem można odnieść wrażenie, że przywódca edukacyjny to postać ideowa, intelektualna, wykoncypowana w umysłach nieco oderwanych od twardej rzeczywistości teoretyków, choć przecież trudno tu o wzorce i przykłady; jego obecność w postulatywnych opisach polskiej oświaty wynika chyba tylko z imperatywu przeniesienia do polskiej rzeczywistości angielskiego leadership... Będziemy przez to bardziej europejscy, światowi? A Brytyjczycy uciekają nam z Europy, więc może to chybiony wzorzec?

Pojawia się też inne pytanie: czy polski nauczyciel może być przywódcą? Czy może on tylko kieruje procesami edukacyjnymi, wychowawczymi czy opiekuńczymi, bo chyba przestał już być jedynie pasem transmisyjnym encyklopedycznej wiedzy, ale żeby zaraz pomawiać go o przywództwo... I dalej: czy polscy dyrektorzy są przywódcami, czy są do tego predysponowani i przygotowani choćby teoretycznie lub mentalnie? Czy dobór osób na to stanowisko uwzględnia przyszłe potencjalne przywództwo? Czy może dziś urzędującym dyrektorom chce się wcisnąć jeszcze jedną nową dla nich rolę? Poniekąd chcieliśmy pogodzić te z pozoru sprzeczne stanowiska w naszym niezbyt obszernym, ale ważnym opracowaniu przygotowanym kilka lat temu z prof. Madalińską-Michalak: Dyrektor szkoły - koncepcje i wyzwania. Między teoriq̨ a praktyką (Jeżowski, Madalińska-Michalak, 2015). Była to próba synkretycznego połączenia obu tych podejść, pokazująca, że nie muszą być ze sobą sprzeczne, ba, w warunkach polskiej szkoły mogą się pięknie uzupełniać.

Pewnie nierozstrzygniętym pozostaje dylemat, czy przywódca winien być "na etacie" i angażować się w działania typu przywódczego non stop, w pełnym wymiarze, czy może aktywność przywódcza to jedna 
z form jego aktywności zawodowej, występująca niejako obok realizowania precyzyjnie wyznaczonych prawem zadań? A może odwrotnie - przywódca, aby być wiarygodnym, musi żmudną pracą w obszarze zarządzania udowadniać, że jest skuteczny, że nie ma sprzeczności w tym, iż przywódca nie tylko wskazuje drogę, ale także podąża nią, gdyż świetnie zna wszystkie niespodzianki, jakie mogło mu zgotować choćby prawo.

Stąd też dylemat: czy dyrektorzy szkół są od zarządzania (Griffin, 2004) i/lub kierowania (Stoner, Wankel, 1994) oraz administrowania (np. danymi osobowymi), czy od przywództwa? Czy management w polskim znaczeniu nie jest (zbyt?) nacechowany produkcją (przemysłową, usług) i jest nakierowany na zysk, co w przypadku szkoły może być chybione? Jak się to ma do polskich rozwiązań prawnych i do rzeczywistości polskiego dyrektora (szkoły)?

Wszak zarządzanie to zestaw działań (obejmujący planowanie i podejmowanie decyzji, organizowanie, przewodzenie, tj. kierowanie ludźmi, i kontrolowanie), skierowanych na zasoby organizacji (ludzkie, finansowe, rzeczowe i informacyjne) i wykonywanych z zamiarem osiągnięcia celów organizacji w sposób sprawny i skuteczny (Griffin, 2004 , s. 6). A przywództwo (kierownicze) to proces kierowania i wpływania na związaną z zadaniami działalność członków grupy. Pojawiają się trzy ważne wnioski: 1) przywództwo musi wiązać się z innymi ludźmi - podwładnymi lub stronnikami. Przez skłonność do podporządkowania się wskazaniom przywódcy członkowie grupy przyczyniają się do określenia pozycji przywódcy i umożliwiają proces przewodzenia. Bez podwładnych wszystkie przywódcze cechy kierownika byłyby bez znaczenia; 2) przywództwo wiąże się z nierównym podziałem władzy między przywódcami i członkami grup. Przywódcy mają władzę kierowania niektórymi działaniami członków grup, ci ostatni zaś nie mogą kierować działaniami przywódcy. Niemniej członkowie grup na różne sposoby wpływają na te działania; 3) oprócz uprawnień do wydawania podwładnym czy zwolennikom rozkazów lub poleceń, przywódcy mogą także wpływać na podwładnych (Stoner, Wanker, 1994, s. 382-383).

Rozbudzeni kontrowersyjnymi wypowiedziami i pytaniami, poniekąd uzbrojeni w śladowe informacje o wynikach badań, ale też w zasygnalizowane jedynie spojrzenia speców od zarządzania na wierzchołek góry, która nas pociąga, spróbujemy dokonać analizy tego, co znaleźć można w subiektywnie wybranych aktach polskiego prawa powszech- 
nie obowiązującego, zwanych często w sposób nieuprawniony i dość niefrasobliwie prawem oświatowym¹.

\section{Nauczyciel w szkolnej społeczności}

Obecna w polskim systemie prawnym od roku 1982 ustawa z 26 stycznia 1982 r. - Karta Nauczyciela² zawiera w swej treści przede wszystkim prawa i obowiązki nauczycieli, ale wśród 102 jej artykułów można znaleźć kilka takich, których normatywny charakter jest nieco spolaryzowany. Oto czytamy, że „nauczyciel obowiązany jest rzetelnie realizować zadania związane z powierzonym mu stanowiskiem oraz podstawowymi funkcjami szkoły: dydaktyczną, wychowawczą i opiekuńczą, w tym zadania związane z zapewnieniem bezpieczeństwa uczniom w czasie

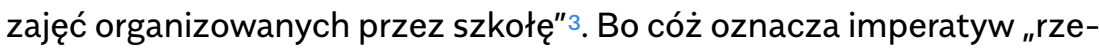
telnie" i czym są owe zadania związane? Zapewne ustawodawca zdaje się tu na pewną samodzielność nauczyciela, który w każdej sytuacji potrafi ocenić, co jest realizacją rzetelną, a co nierzetelną. Czy ta rzetelność oddziaływuje na innych nauczycieli, czy ma wpływ na uczniów i innych członków szkolnej społeczności? Wszak porywać można nie tylko słowem, ale też działaniem, postawą, przykładem.

Dalej czytamy, że nauczyciel ma „wspierać każdego ucznia w jego rozwoju" 4. Ustalenie znaczenia terminu "wspierać" pozostawiono adresatowi tego postulatu. Wszak wspierać można także słowem, działaniem, przykładem. Czy nauczyciel może jawić się w konkretnej sytuacji jako porywający innych uczniów lub nauczycieli do owego wspierania ucznia ze specjalnymi potrzebami edukacyjnymi, albo może w specyficznej sytuacji na drodze jego młodego życia. Czy będą to jedynie działania wynikające z wykonywania konkretnego zawodu, czy stworzona szkolna grupa wolontariuszy wspierająca słabszych kolegów posłucha nauczyciela tylko dlatego, że ich porwał?

Dwa kolejne, dość ogólnie, ale i dobrze brzmiące w każdym momencie historycznym zapisy, powiadają, iż nauczyciel powinien „kształcić i wychowywać młodzież w umiłowaniu Ojczyzny, w poszanowaniu

1. W odróżnieniu od obowiązującej od 1 września 2017 r. ustawy z 14 grudnia 2016 r. - Prawo oświatowe (Dz. U. z 2017 r. poz. 59 ze zm.); dalej: Prawo oświatowe

2. Tekst jednolity: Dz. U. z 2017 r. poz. 1189 ze zm.; dalej: Karta Nauczyciela.

3. Art. 6 pkt 1 Karty Nauczyciela.

4. $\quad$ Art. 6 pkt 2 Karty Nauczyciela. 
Konstytucji Rzeczypospolitej Polskiej, w atmosferze wolności sumienia i szacunku dla każdego człowieka" 5 , a także "dbać o kształtowanie u uczniów postaw moralnych i obywatelskich zgodnie z ideą demokracji, pokoju i przyjaźni między ludźmi różnych narodów, ras i światopoglądów" ${ }^{6}$. Nie dyskutując ze słusznością cytowanych unormowań, trudno odmówić nauczycielowi prawa do dość swobodnej ich interpretacji, a co za tym idzie, dość autonomicznego stosowania ich w praktyce nauczycielskiej. Od jego mądrości, przekonań, postaw etycznych i predyspozycji osobistych zależy, czy nauczyciel w tych działaniach będzie wiarygodny i czy osiągnie sukces, czy będzie zaledwie pasem transmisyjnym między podstawami programowymi a sceptycznie nastawionym młodym człowiekiem.

Ustawa systemowa uzupełnia ten katalog zapisem, że: „Nauczyciel w swoich działaniach dydaktycznych, wychowawczych i opiekuńczych ma obowiązek kierowania się dobrem uczniów, troską o ich zdrowie, postawę moralną i obywatelską, z poszanowaniem godności osobistej ucznia"7. Niektóre z tych podpowiedzi są dość jednoznaczne, inne bez wątpienia wymagają redefiniowania, bo czymże jest dobro ucznia lub jego godność osobista? Ponownie więc doświadczeniu, wyczuciu pedagogicznemu, ale i jego cechom osobistym (przywódczym?) postawiono przed nauczycielem ogromny obszar działań wobec uczniów, którym - bez odpowiednich predyspozycji - trudno będzie podołać w postulowanym wymiarze.

W ustawie został nakreślony zakres zadań nauczycieli, którzy obowiązani są realizować zajęcia dydaktyczne, wychowawcze i opiekuńcze, prowadzone bezpośrednio z uczniami lub wychowankami albo na ich rzecz, oraz inne zajęcia i czynności wynikające z zadań statutowych szkoły, w tym zajęcia opiekuńcze i wychowawcze uwzględniające potrzeby i zainteresowania uczniów ${ }^{8}$, choć nie ulega wątpliwości, że w takich działaniach część nauczycieli wykorzysta nie tylko wiedzę merytoryczną i metodyczną. Dla nich ważne będą takie atrybuty dobrego nauczyciela z naszych osobistych wspomnień, jak dobry przykład,

\footnotetext{
5. Art. 6 pkt 4 Karty Nauczyciela.

6. Art. 6 pkt 5 Karty Nauczyciela.

7. Art. 5 Prawa oświatowego.

8. Art. 42 ust. 2 pkt 1 i 2 Karty Nauczyciela.
} 
wzorcowa postawa, zaangażowanie, szanowanie uczniów itp. Rodzi się zatem pytanie, czy to nie są przypadkiem cechy także dobrego przywódcy? Czy nauczyciel, który nie ma cech przywódczych, potrafi porwać uczniów, tak by polubili „jego" przedmiot? Czy pozostanie tylko rzemieślnikiem, który wykonuje sumiennie swoją pracę?

Ustawa zagwarantowała nauczycielom spory obszar autonomii. Jeśli więc postanawia, że nauczyciele zatrudnieni na podstawie mianowania, a takich nauczycieli było w minionym. roku szkolnym $77 \%$ ogółu zatrudnionych, nie podlegają podporządkowaniu służbowemu określonemu w innych przepisach prawnych dla mianowanych funkcjonariuszy państwowych ${ }^{9}$, to jest to mocne postawienie na ich samodzielność i autonomię. Dalej ustawa doprecyzowuje, że nauczyciel w realizacji programu nauczania ma prawo do swobody stosowania takich metod nauczania i wychowania, jakie uważa za najwłaściwsze spośród uznanych przez współczesne nauki pedagogiczne, oraz do wyboru spośród zatwierdzonych do użytku szkolnego podręczników i innych pomocy naukowych ${ }^{10}$. Oczywiście, można orzec, iż normy te dotyczą wszystkich nauczycieli, ale warto dostrzec, że nie zabraniają jednocześnie tym z charyzmą przywódcy wykorzystywać owe atuty dla eleganckiego i bezstresowego przeprowadzenia uczniów przez niełatwe obszary wiedzy dziś dostępnej, jak i przygotować na spotkanie tej, którą napotkają w przyszłości.

Pod koniec ubiegłego wieku dodano dostępną dla niektórych nauczycieli nową rolę - rolę opiekuna stażu. Tym razem działania nauczycieli nie są nakierowane na ich tradycyjne podmioty (uczniów), ale na młodszych kolegów. Zadaniem opiekuna stażu jest udzielanie nauczycielowi pomocy, w szczególności w przygotowaniu i realizacji w okresie stażu planu rozwoju zawodowego nauczyciela oraz opracowanie projektu oceny dorobku zawodowego nauczyciela za okres stażu11. Z tej roli zapewne nie można się dobrze wywiązać, jeśli opiekun stażu nie jest mentorem, nie jest tutorem lub nie ma cech przywódczych. Bo w takim wypadku nie tylko nie przygotuje młodego kolegi do ról, jakie są przed nim w jego życiu zawodowym, ale może mu (i szkole) wyrządzić

\footnotetext{
9. $\quad$ Art. 12 ust. 1 Karty Nauczyciela.

10. Art. 12 ust. 2 Karty Nauczyciela.

11. Art. 9c ust. 4, 5 i 6 pkt 1 Karty Nauczyciela.
} 
krzywdę, którą trudno będzie w przyszłości skorygować. Uwieńczeniem pracy nauczyciela w roli opiekuna stażu jest jego udział w pracach komisji kwalifikacyjnej dla nauczycieli ubiegających się o awans na stopień nauczyciela kontraktowego ${ }^{12}$.

Zmodyfikowane nieco podejście do roli nauczyciela w szkole prezentuje ustawodawca we wspomnianej już ustawie ustrojowej. Otóż stanowi tam, że szkoły i placówki podejmują niezbędne działania w celu tworzenia optymalnych warunków realizacji działalności dydaktycznej, wychowawczej i opiekuńczej oraz innej działalności statutowej, zapewnienia każdemu uczniowi warunków niezbędnych do jego rozwoju, podnoszenia jakości pracy szkoły lub placówki i jej rozwoju organizacyjnego, natomiast minister winien określić, jakie będzie pożądane zaangażowanie nauczycieli w działania szkoły lub placówki13.

Rozporządzenie wykonawcze ukazało się w sierpniu 2017 roku ${ }^{14}$ i warto je w tym miejscu pokrótce omówić, jako że bez wątpienia każdy nauczyciel-przywódca znajdzie w jego treściach dla siebie inspiracje do działania. Zwraca też uwagę terminologia - wobec nauczycieli postawiono wymagania, a nie zadania. To nieco inaczej sytuuje te osoby wobec treści rozporządzenia. Bez wątpienia dyrektywnie nakazane zadania podlegają bezwzględnemu wykonaniu - bardziej miękko określone "wymagania" dopuszczają (być może) sytuacje, gdy ktoś tym wymaganiom nie podoła, choć pewnie powinien. Jest jeszcze dość istotny szczegół różnicujący: wymagania postawione są nauczycielom jako zespołom, a nie indywidualnym osobom. To stwarza kolejną sytuację: w zespole albo powołuje się przewodniczącego dla sprawnego sprostania wyzwaniu, albo w samym działaniu ujawnia się samoistny lider. Być może właśnie tak skonstruowane wymogi rozporządzenia sprzyjają wspomnianym sytuacjom.

12. Art. $9 \mathrm{~g}$ ust. 1 pkt 3 Karty Nauczyciela

13. Art. 44 ust. 1 i 3 pkt 4 Prawa oświatowego.

14. Rozporządzenie Ministra Edukacji Narodowej z 11 sierpnia 2017 r. w sprawie wymagań wobec szkół i placówek (Dz. U. z 2017 r. poz. 1611). 
Tabela 1. Wymagania wobec nauczycieli w wybranych

szkołach i placówkach oraz ich charakterystyki

WYMAGANIE

CHARAKTERYSTYKA WYMAGANIA

I. Wymagania wobec przedszkoli

\begin{tabular}{l|l}
\hline $\begin{array}{l}\text { Procesy wspomagania rozwoju } \\
\text { i edukacji dzieci są zorganizowane } \\
\text { w sposób sprzyjający uczeniu się }\end{array}$ & $\begin{array}{l}\rightarrow \text { Nauczyciele pracują zespołowo. Wspólnie planują } \\
\text { przebieg procesów edukacyjnych, współpracują przy ich } \\
\text { realizacji i analizują efekty swojej pracy. } \\
\rightarrow \text { Nauczyciele pomagają sobie nawzajem i wspólnie } \\
\text { rozwiązują problemy. }\end{array}$ \\
\hline $\begin{array}{l}\text { Dzieci są aktywne } \\
\begin{array}{l}\text { Przedszkole w planowaniu } \\
\text { pracy uwzględnia wnioski } \\
\text { z analizy badań zewnętrznych } \\
\text { i wewnętrznych }\end{array}\end{array}$ & $\begin{array}{l}\rightarrow \text { Nauczyciele planują i podejmują sytuacje, które zachęcają dzieciania edukacyjne } \\
\text { i wychowawcze z uwzględnieniem wyników badań } \\
\text { zewnętrznych i wewnętrznych oraz wniosków z tych badań, } \\
\text { w tym ewaluacji zewnętrznej i wewnętrznej. }\end{array}$ \\
\hline
\end{tabular}

II. Wymagania wobec szkół podstawowych, szkół ponadpodstawowych, szkół artystycznych, placówek kształcenia ustawicznego, placówek kształcenia praktycznego oraz ośrodków dokształcania i doskonalenia zawodowego

\begin{tabular}{l|l}
\hline $\begin{array}{l}\text { Procesy edukacyjne są } \\
\text { zorganizowane w sposób } \\
\text { sprzyjający uczeniu się }\end{array}$ & $\begin{array}{l}\rightarrow \text { Nauczyciele, w tym nauczyciele pracujący } \\
\text { w jednym oddziale, współpracują ze sobą w planowaniu, } \\
\text { organizowaniu, realizowaniu i modyfikowaniu } \\
\text { procesów edukacyjnych. } \\
\rightarrow \text { Nauczyciele pomagają sobie nawzajem i wspólnie } \\
\text { rozwiązują problemy. } \\
\rightarrow \text { Nauczyciele motywują uczniów do aktywnego uczenia się } \\
\text { i wspierają ich w trudnych sytuacjach, tworząc atmosferę } \\
\text { sprzyjającą uczeniu się. } \\
\rightarrow \text { Nauczyciele kształtują u uczniów umiejętność uczenia się. }\end{array}$ \\
\hline Uczniowie są aktywni & $\begin{array}{l}\rightarrow \text { Nauczyciele stwarzają sytuacje, które zachęcają uczniów } \\
\text { do podejmowania różnorodnych aktywności. }\end{array}$ \\
\hline
\end{tabular}

III. Wymagania wobec placówek oświatowo-wychowawczych i placówek artystycznych

Planuje się i organizuje pracę w sposób sprzyjający osiąganiu celów placówki $\rightarrow$ Nauczyciele i inne osoby realizujące zadania placówki współpracują ze sobą w planowaniu, organizowaniu, realizowaniu i modyfikowaniu podejmowanych działań.

$\rightarrow$ Nauczyciele i inne osoby realizujące zadania placówki uwzględniają opinie wychowanków w celu doskonalenia podejmowanych działań.

Źródło: opracowanie własne na podstawie załącznika do rozporządzenia Ministra Edukacji

Narodowej z 11 sierpnia 2017 r. w sprawie wymagań wobec szkół i placówek. 
Zmieniła się też formuła pracy w zespołach grona pedagogicznego ${ }^{15}$. Wstępnie zapowiedziała te nowe rozwiązania ustawa, sygnalizując, iż minister właściwy do spraw oświaty i wychowania określi szczegółową organizację publicznych szkółi publicznych przedszkoli, uwzględniając prawidłową realizację celów i zadań szkół i przedszkoli, w tym warunki i tryb tworzenia zespołów nauczycieli do realizacji zadań szkoły określonych w statucie ${ }^{16}$. Przyszłość pokazuje, że dyrektor szkoły może powołać zespół nauczycieli na czas określony lub nieokreślony. Jednocześnie pracą zespołu kieruje przewodniczący powoływany przez dyrektora szkoły lub przedszkola na wniosek tego zespołu. Dyrektor szkoły, na wniosek przewodniczącego zespołu, może wyznaczyć do realizacji określonego zadania lub zadań zespołu także innych nauczycieli, specjalistów i pracowników odpowiednio szkoły lub przedszkola. W pracach zespołu mogą brać udział również osoby niebędące pracownikami tej szkoły lub przedszkola ${ }^{17}$. Zastosowano tu klasyczne rozwiązanie z wyłanianiem liderów, gdyż to zespół nauczycieli oddolnie go wskazuje, a dyrektor mocą władczą akceptuje. Uprawnienia przywódcy zespołu są spore, jeśli chodzi o poszerzenie jego składu, ale też wyboru metod pracy i ostatecznie wypracowania produktu końcowego. Wszak to zespół określa plan pracy i zadania do realizacji w danym roku szkolnym. Podsumowanie pracy zespołu odbywa się podczas ostatniego w danym roku szkolnym zebrania rady pedagogicznej.

Problem z taką organizacją zespołów będzie w małych szkołach, z nielicznym zespołem nauczycieli, często dojeżdżających na kilka godzin w tygodniu i przy słabych więziach ze szkołą. Możliwość poszerzania zespołów przez osoby spoza szkoły znakomicie rozszerza ten postulat i umożliwia włączanie w jej życie przedstawicieli szeroko rozumianego środowiska.

Zespoły zadaniowe w nowym wydaniu to istotny krok w kierunku formalnego, gdyż nieformalne działania zawsze były możliwe, ukonstytuowania w szkole szkolnych liderów, póki co od zadań na okres

15. Bo nie rady pedagogicznej, gdyż to organ wewnętrzny szkoły, który winien pracować in gremio, chyba że jej regulamin przewiduje odstępstwa od tej zasady.

16. Art. 111 pkt 5 Prawa oświatowego.

17. Rozporządzenie Ministra Edukacji Narodowej z 17 marca 2017 r. w sprawie szczegółowej organizacji publicznych szkół i publicznych przedszkoli (Dz. U. z 2017 r. poz. 649), § 4 ust. 1-3; dalej: rozporządzenie ws. organizacji szkół. 
maksimum roku. Ale też nie jest wzbronione ich wznawianie w kolejnych latach.

Prawo przewiduje także, w różnych konfiguracjach, przypisanie nauczycielom licznych ról opiekunów. Jedna z nich wyłaniana jest w działaniu oddolnym, bo to uczniowie sami wybierają sobie opiekuna samorządu uczniowskiego. Ustawa stanowi, że samorząd ma prawo wyboru nauczyciela pełniącego rolę opiekuna samorządu ${ }^{18}$. I w zależności od osobistych cech danego nauczyciela, rola ta może być spełniana bardzo formalistycznie, ale też może, a może powinna, przybierać walory przewodnika, nieformalnego przywódcy, który przeprowadzi uczniów przez zakamarki szkolnej demokracji. Nie można też przecenić tej roli w budowaniu relacji między organem reprezentującym interesy uczniów a pozostałymi organami szkoły.

Inną rolą nauczyciela może być wychowawstwo oddziału szkolnego. Ustawa stanowi, że podstawową jednostką organizacyjną szkoły, z wyjątkiem szkoły artystycznej realizującej wyłącznie kształcenie artystyczne, jest oddział, a oddziałem opiekuje się nauczyciel-wychowawca. Zaleca też, by w celu zapewnienia ciągłości i skuteczności pracy wychowawczej nauczyciel-wychowawca opiekował się danym oddziałem w ciągu całego etapu edukacyjnego ${ }^{19}$. Podobne rozwiązania przewiduje w przedszkolu rozporządzenie, gdy stanowi że dyrektor przedszkola powierza poszczególne oddziały opiece jednego lub dwu nauczycieli zależnie od czasu pracy oddziału i realizowanych w nim zadań oraz z uwzględnieniem propozycji rodziców dzieci z tego oddziału. Jednocześnie zapewnienia ciągłości i skuteczności pracy dydaktycznej, wychowawczej i opiekuńczej jest wskazane, aby ten sam nauczyciel opiekował się danym oddziałem do czasu zakończenia korzystania z wychowania przedszkolnego przez dzieci tego oddziału20. Przywództwo wychowawcy, czy to w przedszkolu, czy to w szkole, jest raczej niekwestionowane. Oczywiście można tę rolę sprowadzić do spraw formalnych (dziennik zajęć, obecność, usprawiedliwienia, składki, wywiadówki itp.), ale można też sobie znanymi sposobami porwać dzieciaki do działań, które pozostaną z nimi często na całe życie.

18. Art. 85 ust. 5 pkt 6 Prawa oświatowego.

19. Art. 96 ust. 1-3 Prawa oświatowego.

20. § $§ 12$ ust. 2-3 rozporządzenia ws. organizacji szkół. 
Szczególną sytuacją w szkole jest praca z uczniami ze specjalnymi potrzebami edukacyjnymi, często tymi ponadstandardowymi, związanymi z rozwijaniem poza szkołą swoich pasji czy talentów. Dlatego na wniosek lub za zgodą rodziców albo pełnoletniego ucznia dyrektor szkoły może zezwolić uczniowi na indywidualny program lub tok nauki oraz wyznaczyć nauczyciela-opiekuna. W podobnych sytuacjach dyrektor szkoły realizującej wyłącznie kształcenie artystyczne może zezwolić uczniowi na indywidualny program lub tok nauki realizowany pod opieką nauczyciela przedmiotu głównego tego ucznia21. I znów opiekun ucznia realizującego indywidualny program lub tok nauki może stać na uboczu i ingerować w sytuacjach, gdy coś zgrzyta na linii uczeń-szkoła, ale może też, jak anioł stróż, stymulować te relacje, animować działania, kierować rozwojem podopiecznego. A to oznacza wyjście z roli opiekuna i przejście do roli kreatywnego przywódcy.

Ten pobieżny przegląd ról nauczycielskich, w których wykorzystując stosowne przesłanki prawne, mogą oni sytuować się gdzieś między profesjonalnym nauczycielem a perfekcyjnym przywódcą, dowodzi, że przywództwo nauczycieli w polskiej szkole nie jest zabronione. Co więcej-prawodawca często świadomie stwarza sytuacje, w których chętny, przygotowany i świadomy swej roli nauczyciel może wychylić się poza mundurek funkcjonariusza publicznego 22 i wcielić $w$ rolę dyskretnego lidera. Pewnie za każdym razem będzie to z korzyścią dla polskiej szkoły i jej uczniów. Choć zapewne nie wszyscy to docenią...

\section{Dyrektor - nauczyciel w szczególnej roli}

Tak, dyrektor szkoły to na ogół nauczyciel. Na bez mała 27 tys. dyrektorów szkół i placówek oświatowych zaledwie stu to menedżerowie, tak przynajmniej wynika z danych statystycznych (Jeżowski, Madalińska-Michalak, 2015, s. 13-14). Mówiąc więc w Polsce o dyrektorze szkoły, mamy na myśli właśnie nauczyciela w tej szczególnej roli. Wszak prawo stanowi, że szkołą lub placówką kieruje nauczyciel mianowany lub dyplomowany, któremu powierzono stanowisko dyrektora ${ }^{23}$. Założenie takie poczyniono zapewne też dlatego, że dyrektor szkoły lub

21. Art. 115 ust. 1 i 2 Prawa oświatowego.

22. Art. 63 ust. 1 Karty Nauczyciela.

23. Art. 62 ust. 1 Prawa oświatowego. 
placówki oraz inni nauczyciele zajmujący stanowiska kierownicze sprawują nadzór pedagogiczny w stosunku do nauczycieli zatrudnionych w tych szkołach i placówkach, a w szkołach i placówkach prowadzących kształcenie zawodowe oraz u pracodawców, u których jest organizowana praktyczna nauka zawodu, także w stosunku do instruktorów praktycznej nauki zawodu24. Problem jest ze wszech miar poważny, gdyż kwestia nadzoru pedagogicznego 25 to rzecz urzędowa i brzmi bardzo groźnie. Doświadczenie jednak uczy, że właśnie dyrektor, jako ten najniższy szczebel nadzoru, może czasem wychodzić z uniformu nadzorcy i nadzorować w sposób bardziej przyjazny, oczywiście nie spoufalając się. Zapewne sztuka ta jest nieobca części kadry dyrektorskiej i w żadnym miejscu ustawy nie ma nakazu traktowania tej kompetencji w sposób sformalizowany czy biurokratyczny. Z drugiej strony zbyt permisywne traktowanie uprawnień może wypaczać całą ideę, funkcje i role nadzoru pedagogicznego. Potrzebna jest więc mądrość, wyczucie i pewnie spore doświadczenie... Najlepiej zapewne zrozumie to dyrektor-przywódca.

Prawo wyznacza dyrektorowi ogromnie dużo zadań, a niektóre z nich bez wątpienia "ocierają się" o przywództwo. Jeśli czytamy, że dyrektor szkoły lub placówki26 W szczególności kieruje działalnością szkoły lub placówki oraz reprezentuje ją na zewnątrz, sprawuje opiekę nad uczniami oraz stwarza warunki harmonijnego rozwoju psychofizycznego po-

24. Art. 60 ust. 7 Prawa oświatowego; także art. 62 ust. 3.

25. Art. 55 ust. 1 Prawa oświatowego. Nadzór pedagogiczny polega na: 1) obserwowaniu, analizowaniu i ocenianiu przebiegu procesów kształcenia i wychowania oraz efektów działalności dydaktycznej, wychowawczej i opiekuńczej oraz innej działalności statutowej szkół i placówek; 2) ocenianiu stanu i warunków działalności dydaktycznej, wychowawczej i opiekuńczej oraz innej działalności statutowej szkół i placówek; 3) udzielaniu pomocy szkołom i placówkom, a także nauczycielom w wykonywaniu ich zadań dydaktycznych, wychowawczych i opiekuńczych; 4) inspirowaniu nauczycieli do poprawy istniejących lub wdrożenia nowych rozwiązań w procesie kształcenia, przy zastosowaniu innowacyjnych działań programowych, organizacyjnych lub metodycznych, których celem jest rozwijanie kompetencji uczniów. Tamże, art. 55, ust. 2. W zakresie wymienionym w ust. 1 pkt 1 i 2 nadzorowi podlega w szczególności: 1) posiadanie przez nauczycieli wymaganych kwalifikacji do prowadzenia przydzielonych im zajęć; 2) realizacja podstaw programowych i ramowych planów nauczania; 3) przestrzeganie zasad oceniania, klasyfikowania i promowania uczniów oraz przeprowadzania egzaminów, a także przestrzeganie przepisów dotyczących obowiązku szkolnego oraz obowiązku nauki; 4) przestrzeganie statutu szkoły lub placówki; 5) przestrzeganie praw dziecka i praw ucznia oraz upowszechnianie wiedzy o tych prawach; 6) zapewnienie uczniom bezpiecznych i higienicznych warunków nauki, wychowania i opieki.

26. Art. 68 ust. 1 Prawa oświatowego; także: art. 7 ust. 1 Karty Nauczyciela. 
przez aktywne działania prozdrowotne, realizuje uchwały rady szkoły lub placówki oraz rady pedagogicznej, dysponuje środkami określonymi w planie finansowym szkoły lub placówki, wykonuje zadania związane z zapewnieniem bezpieczeństwa uczniom i nauczycielom w czasie zajęć organizowanych przez szkołę lub placówkę, stwarza warunki do działania w szkole lub placówce wolontariuszy, stowarzyszeń i innych organizacji, odpowiada za realizację zaleceń wynikających z orzeczenia o potrzebie kształcenia specjalnego ucznia, współpracuje z pielęgniarką albo higienistką szkolną, lekarzem i lekarzem dentystą, sprawującymi profilaktyczną opiekę zdrowotną nad dziećmi i młodzieżą, to skłania to do określonych refleksji.

Oczywiste jest, że realizując choćby przywołane to zadania, dyrektor może być niedostępnym, formalistycznie nastawionym, chłodnym w obejściu czy nawet mało życzliwym „funkcjonariuszem", ale może też postawić na zupełnie inne, mniej formalne relacje, prosząc choćby część nauczycieli, by niektóre z tych obowiązków wzięli na siebie, bo mają doświadczenie, wiedzę, autorytet, znają metody czy posiadają kompetencje. Oczywiście nikt nie zwolni dyrektora z odpowiedzialności za właściwą realizację zadań, ale model wspólnej pracy może scalić zespół i sprawić, że wszyscy poczują się odpowiedzialni za „ich" szkołę.

Podobne dylematy, a może i szanse powstają, gdy przyjrzymy się typowo polskim zadaniom stojącym przed dyrektorem szkoły. Dyrektor jest kierownikiem zakładu pracy dla zatrudnionych w szkole lub placówce nauczycieli i pracowników niebędących nauczycielami. Dyrektor w szczególności decyduje więc w sprawach ${ }^{27}$ zatrudniania i zwalniania nauczycieli oraz innych pracowników szkoły lub placówki, przyznawania im nagród, wymierzania kar porządkowych oraz występowania z wnioskami w sprawach odznaczeń, nagród i innych wyróżnień dla nauczycieli oraz pozostałych pracowników szkoły lub placówki. Doświadczenia większości zagranicznych dyrektorów są w tym obszarze znikome (no, może poza Szkotami), ale to nie oznacza, że nie można sobie wyobrazić, iż polski dyrektor w tych sprawach musi być bezwzględnym szefem, jeśli do wyboru ma też opcję przywódcy. Nie jest to traktat o przywództwie, a moją rolą jest jedynie dowieść, że mnogość zadań i zobowiązań dyrektorskich może być spokojnie realizowana w stylu przywódcy. Być 
może "styl" jest tym słowem-kluczem, które właściwie definiuje postawę dyrektora w tych i innych sprawach, nie umniejszając innych jego ról.

Kolejne dwa przykłady dowodzą, iż polskie prawo nie tylko wskazuje konkretne zadania do wykonania, ale sugeruje też określone style działania. Bo jak inaczej odczytać dyspozycję, zgodnie z którą dyrektor szkoły lub placówki w wykonywaniu swoich zadań współpracuje $z$ radą szkoły lub placówki, radą pedagogiczną, rodzicami i samorządem uczniowskim ${ }^{28}$. Wydaje się, że trudno $w$ akcie prawnym zadekretować współpracę, bo jak - idąc tropem standaryzacji - ostatecznie orzec: współpracuje, czy nie? lle razy? Co jest poziomem pożądanym, a co ponadstandardowym? Myślę, że nie takie były intencje ustawodawcy. $Z$ każdym z wymienionych podmiotów szkoły dyrektor ma relacje często władcze, aż tu ustawodawca mówi mu, że powinien współpracować. Może więc ustawodawca już ćwierć wieku temu sygnalizował bardziej spolegliwą, empatyczną rolę dyrektora szkoły. Czyż nie był to krok w kierunku przywództwa w szkole?

Był to zatem przykład współpracy w samej szkole, w jej wnętrzu. Kolejny - to wyjście poza szkołę, choć bardziej już sformalizowane. Dyrektor szkoły prowadzącej kształcenie zawodowe w porozumieniu z organem prowadzącym szkołę ustala zawody, w których kształci szkoła, ale po zasięgnięciu opinii powiatowej i wojewódzkiej rady rynku pracy co do zgodności z potrzebami rynku pracy29. Taki wymóg wydaje się logiczny, jednak warto nań spojrzeć także od strony relacji zewnętrznych - dyrektor szkoły zawodowej (zresztą nie tylko tej) nie może zamknąć się w murach szkoły i zabiegać o to, by nauczyciele mieli pracę, ale powinien rozumieć uwarunkowania lokalnego rynku pracy i z całą instytucją szkolną działać na jego rzecz. Nie trzeba sięgać do pokładów dobrej woli, by dostrzec, że łatwiej będzie to osiągnąć komunikatywnemu przywódcy, niż występującemu z formalnymi pismami dyrektorowi zza biurka.

Zbliżone zakresem działania oczekiwane są też od dyrektora przedszkola. To on wnioskuje wspólnie z radą przedszkola lub radą rodziców do organu prowadzącego o ustalenie czasu pracy przedszkola, ale i ter- 
minów przerw w tej pracy ${ }^{30}$. Uwagi podnoszone w sprawie dyrektora szkoły zawodowej i tu są jak najbardziej zasadne.

Pragmatyka zawodu nauczyciela traktuje wyzwania stojące przez dyrektorem w kategoriach odpowiedzialności, co nawet jest zrozumiałe, gdyż dla związków zawodowych dyrektor reprezentuje pracodawcę. Stąd jej zapisy brzmią w tym miejscu mniej przyjaźnie. W jej ujęciu dyrektor szkoły odpowiedzialny ${ }^{31}$ jest między innymi za dydaktyczny i wychowawczy poziom szkoły, tworzenie warunków do rozwijania samorządnej i samodzielnej pracy uczniów i wychowanków, zapewnienie pomocy nauczycielom w realizacji ich zadań i ich doskonaleniu zawodowym, zapewnienie w miarę możliwości odpowiednich warunków organizacyjnych do realizacji zadań dydaktycznych i opiekuńczo-wychowawczych oraz zapewnienie bezpieczeństwa uczniom i nauczycielom w czasie zajęć organizowanych przez szkołę. Trudno oprzeć się wrażeniu, że tej ustawy nie pisali politycy i prawnicy, ale raczej działacze związków zawodowych, choć zapewne tak nie było. Jestem jednak przekonany o tym, że charyzmatyczny przywódca pedagogiczny i tutaj znajdzie dla siebie ogromny obszar niesformalizowanej aktywności.

Na potrzeby tej analizy zwróćmy jeszcze uwagę, że dyrektor szkoły (i nie tylko) jest przewodniczącym rady pedagogicznej ${ }^{32}$. W tej roli przygotowuje i prowadzi zebrania rady pedagogicznej oraz jest odpowiedzialny za zawiadomienie wszystkich jej członków o terminie i porządku zebrania zgodnie $z$ regulaminem pracy rady ${ }^{33}$, a także przedstawia radzie pedagogicznej, nie rzadziej niż dwa razy w roku szkolnym, ogólne wnioski wynikające ze sprawowanego nadzoru pedagogicznego oraz informacje o działalności szkoły ${ }^{34}$. Na ten obszar relacji dyrektora z radą pedagogiczną zwracam szczególną uwagę.

Nie miejsce tu na wymienianie wszystkich ról i relacji, jakie występują w omawianych przepisach, a rzecz jest nad wyraz delikatna. Wiele zależy nie tylko od wiedzy dyrektora, od jego kultury osobistej i taktu, ale także od postawy, jaką przyjął w szkole w ogóle, a w relacjach z na-

30. Art. 102 ust. 1 pkt 10 Prawa oświatowego; także: $\S 12$ ust. 1 rozporządzenia ws. organizacji szkół.

31. Art. 7 ust. 2 Karty Nauczyciela.

32. Art. 69 ust. 4 Prawa oświatoweg

33. Art. 69 ust. 6 Prawa oświatowego.

34. Art. 69 ust. 7 Prawa oświatowego. 
uczycielami w szczególności. Z pewnością przywódcy będzie tu łatwiej... Tym bardziej że w sytuacjach krytycznych, na przykład konfliktu z radą pedagogiczną, dyrektor wstrzymuje wykonanie uchwał rady, w jego ocenie, niezgodnych z przepisami prawa ${ }^{35}$, a dalej postępuje przecież bardzo formalnie, czyli zgodnie z procedurami.

\section{Podsumowanie}

Z zaprezentowanej analizy wyłaniają się, moim zdaniem, następujące konkluzje:

$\rightarrow$ w polskim prawie znajdujemy kilkadziesiąt przykładów, gdy od nauczyciela, w tym także od dyrektora, może nie z mocy prawa, ale z mocy tradycji pedagogicznej, oczekuje się, by ujawniał on w swojej pracy kompetencje przywódcze, skutecznie je wykorzystywał z pożytkiem dla ucznia i szkoły, ale też dla niego samego;

$\rightarrow$ polskie prawo okołooświatowe nie reguluje pracy przywódcy edukacyjnego, nie stosuje terminologii związanej z jego potencjalnym funkcjonowaniem w szkole; cały swój impet normatywny, w szczególności w zakresie prawa ustrojowego, materialnego, jak i procesowego koncentruje na nauczycielu lub dyrektorze szkoły, wyposażając ich przede wszystkim w zadania, ale i nierzadko we władcze uprawnienia;

$\rightarrow$ szerszy, w odniesieniu do dyrektorów szkół w innych państwach, zakres kompetencji wymaganych od polskiego dyrektora, szczególnie w zakresie znajomości prawa, w tym prawa administracyjnego (zarządzenia, uchwały, decyzje administracyjne, protokoły...), prawa finansów publicznych (pominiętego w tej analizie, gdyż margines swobody jest w nim dość zawężony), czy prawa pracy powoduje, że role, jakie spełnia, nie zawsze sprzyjają porównaniom, w szczególności międzynarodowym;

$\rightarrow$ prawo nie zabrania dyrektorowi, by obok administrowania, kierowania czy zarządzania także przewodził - w szkole czy środowisku, choć trzeba mieć świadomość, że ani system przygotowania formalnego do objęcia stanowiska (studia), ani postępowanie konkursowe o stanowisko zupełnie nie podnoszą kwestii przywództwa; 
$\rightarrow$ najnowsze akty prawne, obok zadań, stawiają na wymagania, podnosząc często potrzebę pracy w zespołach (nauczycielskich), co pozwala dostrzec pewną polaryzację stanowisk organów decyzyjnych, ułatwiającą podejmowanie owych działań przywódczych.

Podejmowane dziś próby działania w szkole przywódców edukacyjnych nie są wywiązywaniem się z przypisanych do tych stanowisk ról czy nałożonych prawem obowiązków, a raczej wynikającym z potrzeby tych osób, ich wiedzy, doświadczenia, kultury osobistej czy kontekstu społecznego STYLEM PRACY wybranych jednostek, wzbogacających tym samym obraz polskiej szkoły $i$ - być może bez wiedzy i świadomości celu - kierującym tę szkołę na nowe zupełnie tereny. Choć, przy obojętności systemu edukacji nauczycieli i braku zainteresowania ze strony decydentów i polityków, działania te przed długie jeszcze lata mogą pozostać tylko przyczynkarskimi ciekawostkami i stanowić kolejne studia przypadków w dysertacjach naukowców. 


\section{Bibliografia}

$\rightarrow$ Griffin, R.W. (2004), Podstawy zarzq̨dzania organizacjami, tłum. M. Rusiński, Warszawa: Wydawnictwo Naukowe PWN.

$\rightarrow$ Jeżowski, A. (2009), Zadania dyrektora szkoły i placówki oświatowej, Wrocław: IBO.

$\rightarrow$ Jeżowski, A., Madalińska-Michalak, J. (2015), Dyrektor szkoły-koncepcje i wyzwania. Między teoriq a praktykq, Warszawa: ORE.

$\rightarrow$ Madalińska-Michalak, J. (2015), Dyrektor szkoły liderem - inspiracje i perspektywy, Warszawa: Wolters Kluwer.

$\rightarrow$ Madalińska-Michalak, J. (2012), Skuteczne przywództwo w szkołach na obszarach zaniedbanych społecznie. Studium porównawcze, Łódź: Wydawnictwo Uniwersytetu Łódzkiego.

$\rightarrow$ Mizerek, H. (2012), Jakość edukacji: społeczne oczekiwania, polityczne decyzje i praktyczne implementacje [w:] G. Mazurkiewicz (red.), Jakość Edukacji. Różnorodne perspektywy, s. 13-28, Kraków: Wydawnictwo Uniwersytetu Jagiellońskiego.

$\rightarrow$ OECD (2017), Education at a Glance, 2016. OECD Indicators, Paris: OECD Publishing.

$\rightarrow$ OECD (2014), TALIS 2013 Results: An International Perspective on Teaching and Learning, Paris: OECD Publishing.

$\rightarrow$ Stoner, J.A.F., Wankel, Ch. (1994), Kierowanie, tłum. A. Ehrlich, Warszawa: Polskie Wydawnictwo Ekonomiczne.

Wykorzystane akty prawne

$\rightarrow$ Ustawa z 26 stycznia 1982 r. - Karta Nauczyciela (tekst jednolity: 2018 r. poz. 967).

$\rightarrow$ Ustawa z 14 grudnia 2016 r. - Prawo oświatowe (tekst jednolity: Dz. U. z 2018 r. poz. 996). 
$\rightarrow$ Rozporządzenie Ministra Edukacji Narodowej z 17 marca 2017 r. w sprawie szczegółowej organizacji publicznych szkół i publicznych przedszkoli (Dz. U. z 2017 r. poz. 649).

$\rightarrow$ Rozporządzenie Ministra Edukacji Narodowej z 11 sierpnia 2017 r. w sprawie wymagań wobec szkół i placówek (Dz. U. z 2017 r. poz. 1611). 


\title{
Nauczyciele jako \\ nieformalni przywódcy
}

\author{
Malwina Magdalena Kałużyńska
}

Współczesne szkoły często nie przystają do współczesnych czasów. Potrzebują zatem skutecznych przywódców (nie tylko menedżerów), którzy staną się inspiracją oraz bodźcem do zmian dydaktycznych, społecznych i mentalnych. Refleksyjni, autonomiczni i odpowiedzialni nauczyciele mogą sprostać temu wyzwaniu poprzez proponowanie i wdrażanie oddolnych inicjatyw w społecznościach szkolnych. Dzięki swojemu profesjonalizmowi i poprzez dzielenie się swoją wizją z innymi mogą stanąć na "mostku kapitańskim", nawet jeśli nie posiadają formalnej władzy. Celem tego tekstu jest zaprezentowanie wyników własnych badań nad nieformalnym przywództwem nauczycieli, które pokazały szansę, jaką daje m.in. ich upoważnianie w szkołach. Innym omówionym tutaj aspektem będzie przedstawienie autorskiej typologii różnych podejść do zmiany edukacyjnej (nazwanych: „Dekoratorami”, "Rekonstruktorami" i „Restauratorami”), które dają wyobrażenie tego, jak można identyfikować pojęcie dobrej szkoły.

\section{_ Słowa kluczowe \\ autonomia i odpowiedzialność nauczycieli \\ nieformalne przywództwo edukacyjne \\ wizje dobrej szkoły \\ zmiana edukacyjna}




\section{Teachers as \\ informal leaders}

Malwina Magdalena Kałużyńska

Contemporary schools often do not fit contemporary times. They need effective leaders (not only managers) who will be an inspiration and a driving force to didactic, social and mental changes. Reflective, autonomous and responsible teachers can meet the challenge by proposing and implementing bottom-up initiatives in school's environment. By being an example of professionalism and by sharing their vision with others they can stand on the "captain's bridge" even though they do not have a formal power. The purpose of this paper is to present the results of the author's research on informal teachers' leadership that show the opportunities of, among other things, empowerment of them in schools. Another raised issue is an author's typology of different approaches towards educational change (named: "Scene designers", "Rebuiders/ Reconstructionists" and "Restorers") that can give us a sense of how do we identify a good education.

\section{Key words}

teachers' autonomy and responsibility

informal educational leadership

visions of good school

educational change 


\section{Wprowadzenie}

Wielu nauczycieli, rodziców, dzieci, wykładowców akademickich, edukatorów, polityków i publicystów łączy wspólne przekonanie, że polska szkoła w obecnym kształcie nie odpowiada na aktualne potrzeby (tak społeczeństwa, jak i poszczególnych osób) i nie spełnia stawianych przed nią oczekiwań. Trudno usłyszeć głosy, które jednoznacznie pozytywnie oceniałyby obowiązujący w naszym kraju system kształcenia. Powstają kolejne książki, raporty, artykuły i przemówienia traktujące między innymi o tym, że szkoła jako instytucja nie podąża za zmianami cywilizacyjnymi i współczesną wiedzą na temat procesów uczenia się (Żylińska, 2013), „zabija kreatywność" ${ }_{1}$ „niszczy integralność tak wielu osób" (Juul, 2013, s. 35), czy też jest miejscem przemocy symbolicznej (Kopciewicz, 2011). Powszechnej krytyce szkoły towarzyszą jednak różne wizje zmian i wiele propozycji rozwiązań, u podłoża których stoją zasadnicze pytania: Co możemy zrobić, żeby było lepiej? Jak wspólnie przekuć szanse i możliwości (na przykład potencjał ludzki czy organizacyjny) w edukacyjny sukces i szczęście dzieci? Innymi słowy, jak zbudować dobrą szkołę (oczywiście, o ile w ogóle nie negujemy jej istnienia)?

Postulat dobrej szkoły zawiera w sobie wiele różnych, nieredukowalnych wymiarów, z których każdy ma duże znaczenie. Mamy zatem kwestie związane między innymi z wizją kształcenia i wartościami wychowawczymi, rozwijaniem poszczególnych sfer rozwoju (poznawczego, społeczno-emocjonalnego i fizycznego), wyrównywaniem szans edukacyjnych i niwelowaniem deficytów, wspieraniem uzdolnień i rozwijaniem zainteresowań ucznia, programem nauczania, metodyką pracy, sposobami wykorzystania przestrzeni i pomocy dydaktycznych, przygotowaniem nauczycieli czy relacjami międzyludzkimi i "klimatem" szkoły. Nie jest łatwym zadaniem uwzględnienie wszystkich tych aspektów jednocześnie. Nie stanie się to za sprawą decyzji jednej osoby. Zmiana edukacyjna to długotrwały proces wymagający współpracy wielu odpowiedzialnych ludzi, refleksyjności i ciągłego, wzajemnego uczeTEDTalks.

2. Tytuł przewodni konferencji NPSEO „Jakość edukacji, czy/i jakość ewaluacji” zorganizowanej przez Ośrodek Rozwoju Edukacji, Uniwersytet Jagielloński i Erę Ewaluacji, która odbyła się w Krakowie, w dniach 28-31.03.2015 r. 
nia się. Nie wszyscy postulatorzy zmian zgadzają się jednak ze sobą co do ich kierunku i samej ich istoty. Niektórzy mówią o "jakości" edukacji - określaniu standardów i procedur realizacji, które mają pomóc uzyskać wymierne efekty (przykładem może być centralnie sterowany system ewaluacji szkół). Inni odcinają się od uniwersalnych norm i odgórnych rozporządzeń (będących dla nich przejawami dominacji i uprzedmiotowienia), wskazując na lokalne i kontekstowe wymiary oceny pracy szkoły oparte na nadanym przez siebie "znaczeniu” (Dahlberg, Moss, Pence, 2013).

Niezależnie od dominującego dyskursu, oddani pracy (utożsamianej nieraz z "powołaniem") nauczyciele wkładają codziennie wiele wysiłku, by ich uczniowie mogli rozwijać się na miarę swoich możliwości, zdobywać wiedzę i stawać się lepszymi ludźmi. Będąc w samym centrum edukacyjnych przeobrażeń, nauczyciele nie zawsze mogą lub chcą angażować się w ich przebieg. Tymczasem to od ich nastawienia i konkretnych działań zależy, czy wspomniane już oczekiwania spotkają się z realizacją, czy ich praca zyska nowe znaczenie - innymi słowy, czy rzeczywiście cokolwiek zmieni się w praktyce szkolnej (a nie tylko na papierze). Dlatego warto pytać nauczycieli, przyglądać się ich pracy nie tylko po to, by poddawać ją ocenie, ale także po to, by szukać w niej inspiracji, uczyć się z dobrych praktyk, poszerzać perspektywę patrzenia na edukację, która dzieje się za zamkniętymi drzwiami klas, ale również w przestrzeni pozaszkolnej.

Opracowanie to można traktować jako zaproszenie do spojrzenia na nauczycieli nie tylko jak na realizatorów zmian („zewnętrznych procedur, które zajmują się polityką szkoły, strukturami lub praktykami": Zellermayer, Margolin, 2005, s. 1302, cyt. za: Day, 2014, s. 143), ale również jak na potencjalnych inicjatorów przemian przyjętych przez ludzi nowych sposobów postrzegania zjawisk, "wewnętrznego procesu reorientacji i transformacji" (tamże). Ich głos: Nihil de nobis sine nobis! powinien być słyszalny, ponieważ często poza zwykłym sprzeciwem niesie ze sobą określoną wartość płynącą z wiedzy, doświadczenia, pasji nauczania oraz umiejętności zjednywania ludzi w imię wspólnego celu, czyli przywództwa.

W rozdziale tym przedstawię szereg własnych przemyśleń na temat roli nauczycieli w edukacyjnych przeobrażeniach i postrzegania owych przeobrażeń. Nawiążę także do wyników przeprowadzonych przeze 
mnie badań jakościowych nad przejawami i obszarami nieformalnego przywództwa nauczycieli (Kaczyńska, 2015).

\section{Wizje szkoły w obliczu zmian}

Zmiany edukacyjne zachodzące w szkołach mogą mieć zarówno dydaktyczny, jak i społeczny charakter. O ile te pierwsze dotyczą procesów nauczania i uczenia się (mogą na przykład opierać się na wprowadzeniu innowacji pedagogicznych), drugie odnoszą się do budowania sieci relacji międzyludzkich, które poza nimi samymi mogą przeistaczać także całe środowisko, jego kulturę. Sama zmiana sposobu pracy z uczniami (jego zewnętrzna forma) może nie wystarczyć do zmiany nastawienia nauczycieli, do nadania sensu własnej aktywności. Potrzebne jest głębsze poznanie i rozumienie nie tylko potocznej pedagogii, czyli osobistych przekonań na temat "natury umysłu uczniów" oraz samych zjawisk zachodzących w szkole, ale również fundamentów, na jakich ta jest zbudowana, kultury, w jakiej funkcjonuje (Bruner, 2006).

Moje badania i wyprowadzone z nich wnioski pokazują, że wśród osób poddających krytyce obecny system kształcenia i wychowania możemy wyszczególnić trzy znaczące grupy ludzi: Dekoratorów, Rekonstruktorów i Restauratorów ${ }^{3}$. Każda z tych grup dostrzega inny charakter wypaczeń, w czym innym upatruje źródła problemów i porusza się na innych poziomach rozumienia sensu edukacyjnych oddziaływań. Choć wszystkim postulatorom zmian zazwyczaj przyświeca szczytny cel, zgoła odmienne wystawiają oni diagnozy, jak i w konsekwencji - recepty.

Pierwsza grupa zauważa przede wszystkim braki w "zaopatrzeniu” i sposobach pracy. Nie neguje idei szkoły jako takiej, ale stwierdza, że w swojej obecnej formie nie wpisuje się ona w odpowiadający wymogom współczesności ideał. „Dekoratorzy” bardziej niż na burzeniu fundamentów szkoły, skupiają się na jej renowacji, swoistym „przemeblowaniu". Koncentrują się na tym, co najłatwiej zmienić i czego efekty można szybko dostrzec, a więc przede wszystkim na zasobach (narzędziach) i ich metodycznym wykorzystaniu. Chcą przeorganizować przestrzeń do swojej wizji nowoczesnego kształcenia, prezentując programy i pa-

3. Inspiracją do tego rozróżnienia były wybrane podejścia do zmian edukacyjnych opisane przez Theodore'a Bramelda (zob. Gutek, 2003, s. 281-295, 311-325) - Restauratorów można powiązać z perenializmem, a Rekonstruktorów z rekonstrukcjonizmem. 
kiety oparte na atrakcyjnych "innowacjach" (bywają one jednak wtórne i nie zawsze są wyrazem rzeczywistej potrzeby). Niektórzy ograniczają pomoce dydaktyczne do niezbędnego minimum, stawiając na powrót do naturalnych i ekologicznych źródeł, inni stawiają na interaktywne tablice i „tabletyzację". Proponowane przez nich zmiany stanowią próbę nadążenia za tempem dość chaotycznych społeczno-ekonomicznych przemian, mogą być przez to pobieżne, często niemal kosmetyczne, ale też i przełomowe. „Dobra szkoła” nie jest w tym kontekście tworem stałym i niezmiennym, lecz bardzo elastycznym, podatnym na edukacyjne trendy i dominujące $w$ danym nurcie (czy dyskursie) zapotrzebowania. "Dekoratorzy" są najczęściej słyszani w przestrzeni publicznej, gdyż pokazują dość wygodną " drogę na skróty" - oferują gotowe rozwiązania mówiące: „jak" i pomijają debatę o tym: „po co", która wymaga głębszego namysłu. Mogą być jednak prądem napędowym zmian.

Druga grupa, w przeciwieństwie do poprzedniej, wyraźnie dostrzega błędy konstrukcyjne w idei szkoły jako takiej, dlatego postuluje totalny remont fundamentów, na których ta została niegdyś zbudowana (najczęściej odcięcie się od pruskiego modelu edukacji). „Rekonstruktorzy" nie utożsamiają się z instytucją szkoły w obecnej formie, dlatego chcą ją zburzyć i zbudować od nowa w oparciu o własną wizję, którą propagują najczęściej jako społecznie sprawiedliwą i wolnościową. Ich wizja wyrasta z teorii krytycznej i postawy buntu wobec wszelkich form rzeczywistego i wyobrażonego ucisku, także w postaci zewnętrznych form zwierzchności i kontroli. „Dobra szkoła” jest po prostu ich szkołą - szkołą, w której każdy ma takie samo (równe i niepodważalne) prawo decydowania o jej losach, demokratyczną u swych podstaw, ale niedopuszczającą możliwości ograniczenia zakresu jej autonomii. Przejawem takiego "rekonstrukcjonizmu" mogą być szkoły alternatywne lub różne formy deschoolingu.

Trzecia grupa nie zajmuje się budową nowej szkoły ani odświeżaniem obecnej. „Restauratorzy" nad wyraz uważnie studiują plany konstrukcji szkoły, a więc przede wszystkim koncentrują się na filozoficzno-ideologicznych podstawach edukacji. Nie zamierzają burzyć zastanego ładu, który ich zdaniem opiera się na trwałych fundamentach w postaci nadrzędnych idei. Doceniają oni wartość dorobku poprzednich pokoleń (najczęściej odwołując się do tradycji filozofii klasycznej i scholastyki) - stanowi on dla nich wyznacznik tego, czym w swej naturze powinna być "dobra szkoła". Dlatego w nakreślonych przez siebie wizjach 
przyszłości powielają (konserwują) wzorce z przeszłości (ich zdaniem jedyne słuszne), martwiąc się jednocześnie, że współczesny świat w coraz większym stopniu odcina się od swoich źródeł. Ich zdaniem szkoła sama w sobie nie jest zła, ale powinna stawać się coraz lepsza i powinna służyć wzrostowi (zwłaszcza duchowemu) człowieka, niemającego już oparcia w ponowoczesnym, pełnym kontrowersji świecie.

Nakreślone wizje zmiany szkoły każdej z wyszczególnionych grup mają zarówno zalety, jak i wady. Ich zestawienie przedstawiam w poniższej tabeli (tabela 1).

Tabela 1. Mocne i słabe strony różnych wizji zmian edukacji

\begin{tabular}{|c|c|c|c|}
\hline & DEKORATORZY & REKONSTRUKTORZY & RESTAURATORZY \\
\hline 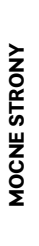 & $\begin{array}{l}\rightarrow \text { podążając za potrzebami } \\
\text { zmieniającego się świata, } \\
\text { kładą duży nacisk na orga- } \\
\text { nizację i praktyczne aspekty } \\
\text { kształcenia (techne) }\end{array}$ & $\begin{array}{l}\rightarrow \text { dostrzegają niepokojące } \\
\text { zjawiska (społeczne) i me- } \\
\text { chanizmy rządzące społe- } \\
\text { czeństwem oraz uwikłanie } \\
\text { w nie szkoły }\end{array}$ & $\begin{array}{l}\rightarrow \text { oparcie na funda- } \\
\text { mentach (społ.-kult. } \\
\text { dorobku) daje im trwały } \\
\text { punkt odniesienia } \\
\text { w procesie ciągłego } \\
\text { poszukiwania } \\
\text { "udoskonaleń" }\end{array}$ \\
\hline 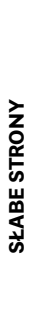 & $\begin{array}{l}\rightarrow \text { oferują niekonsekwentne } \\
\text { i pobieżne działania, często } \\
\text { "na pokaz" (zgodne z opinią } \\
\text { publiczną i zmienną modą) } \\
\rightarrow \text { brakuje im głębszego } \\
\text { namysłu nad istotą edukacji, } \\
\text { jej sensem }\end{array}$ & $\begin{array}{l}\rightarrow \text { mogą burzyć zastane fun- } \\
\text { damenty i odrzucać tradycję } \\
\text { nie oferując w zamian nic } \\
\text { poza wolnością negatywną } \\
\rightarrow \text { chcą narzucać swoją } \\
\text { własną, nieraz utajoną wizję } \\
\text { "lepszego świata" }\end{array}$ & $\begin{array}{l}\rightarrow \text { przywiązanie } \\
\text { do określonych idei może } \\
\text { zawężać ich spojrzenie } \\
\text { na edukację } \\
\rightarrow \text { za namysłem filo- } \\
\text { zoficznym nie musi } \\
\text { podążać realna zmiana } \\
\text { praktyki edukacyjnej }\end{array}$ \\
\hline
\end{tabular}

Źródło: opracowanie własne.

Wizje wspomnianych grup wydaje się więcej dzielić niż łączyć - każda opiera się na innych wartościach i skupia na innych aspektach pracy szkoły. Jednakże nie sposób nie docenić faktu, że każda wnosi nowe spojrzenie na edukację, wskazuje na brak zaspokojenia pewnych fundamentalnych potrzeb. „Restauratorzy" pragną odnaleźć (odzyskać) prawdę o człowieku, trwały punkt oparcia, który pomoże mu utrzymać 
równowagę w pełnym nieokreśloności i niepewności świecie. „Rekonstruktorzy" walczą o prawo człowieka do godności i samostanowienia. "Dekoratorzy" zwracają uwagę na zewnętrzny (ekspresyjny) wymiar funkcjonowania człowieka i osadzanie go we współczesnych realiach.

Każda z wizji może znaleźć odzwierciedlenie w sposobach funkcjonowania szkół i samych nauczycieli. Wizja "Dekoratorów" wyrazi się między innymi w nacisku na: zmianę sposobów prowadzenia lekcji, ustawienia ławek czy opracowanie nowych metod pracy i pomocy dydaktycznych. Manifest "Rekonstruktorów” będzie mocno podkreślał znaczenie zmian społecznych, upodmiotowienia wszystkich osób i włączenia ich w procesy decyzyjne. Z kolei „Restauratorzy” zorganizują szereg spotkań i debat podejmujących najważniejsze zagadnienia związane z rolą szkoły w jej tradycyjnym rozumieniu, pokazując zachodzące w niej przemiany $\mathrm{i}$ ich konsekwencje.

\section{Kierunki zmian a autonomia i odpowiedzialność nauczycieli}

Na styku różnych dyskursów edukacyjnych i wizji edukacji pojawiają się gotowe do wprowadzenia propozycje zmian. Mogą być one albo "odgórne" (ang. top-down changes), albo "oddolne" (ang. bottom-up changes) (Steffy, 1993). Pierwszy typ zmian wynika z formalnego zwierzchnictwa i opiera się na narzuconych wymaganiach, na przykład w postaci rozporządzeń czy poleceń służbowych. Ich realizacja podlega kontroli i nie podlega dyskusji. Nie muszą one wiązać się z krytyczną postawą realizatorów oraz z przejęciem przez nich odpowiedzialności za efekty własnych działań. Jako przykład może posłużyć stwierdzenie jednego z nauczycieli: „Jesteśmy zespołem, niekoniecznie pracujemy zespołowo" (Kaczyńska, 2015, s. 28; Dorczak i in., s. 58). Słowa te mogą świadczyć o tym, że samo powołanie w placówce zespołów zadaniowych nie sprawi, że praca w ich ramach będzie miała znamiona prawdziwej współpracy i przyniesie oczekiwane rezultaty. Drugi typ zmian jest z kolei nieodłącznie związany z poczuciem odpowiedzialności i wewnętrzną motywacją, czyli z osobistym uzasadnieniem dla podejmowanych działań, z dostrzeżeniem sensu własnej pracy. 
Jak pośrednio pokazało badanie dzienników doświadczeń zawodowych ${ }^{4}$, nauczyciele podlegający zewnętrznym "naciskom" (jakiekolwiek by one nie były) mogą przyjąć w swej pracy postawę "namiestnika" (lub jak określiłby to Legowicz, „wyrobnika", zob. Legowicz, 1993, s. 19), który może, ale nie musi utożsamiać się z ustalonymi poza nim wartościami i celami. Posługując się metaforą, nauczyciele mogą wybrać rolę, jak pokazałam w swoich badaniach (Kaczyńska, 2016a, s. 241-247), skupionego na realizacji programu "Statku rejsowego", bezrefleksyjnego "Dryfującego statku" lub "metodycznie uwiedzionego" "Nowoczesnego jachtu"). "Statek rejsowy", odpowiadający "byciu w roli" lub "tożsamości roli" nauczyciela (Kwiatkowska, 1997, s. 74-75; Kwiatkowska, 2005, s. 85), skrupulatnie wypełniając powierzone mu zadania wykazuje się co prawda dużą obowiązkowością i skutecznością, ale brakuje mu własnej inicjatywy i często popada w rutynę. „Dryfujący statek", przypominający "bycie bezrefleksyjne" tudzież "tożsamość anomijną" (tamże), cechuje się inercją i brakiem pełnej świadomości własnych dążeń (można powiedzieć, że "płynie z prądem"). Z kolei „Nowoczesny jacht" tak mocno koncentruje się na narzędziach pracy (metodach, formach i środkach), że stają się one dla niego nie środkiem do celu, ale samym celem. Trasa każdej jednostki wygląda inaczej: albo poddając się temu, co przyniesie harmonogram, pływa tam i z powrotem, albo płynie bezwiednie, poddając się fali, albo goniąc za zmieniającym się wiatrem (trendami) - pływa w kółko. Wspomniane nastawienia nauczycieli utrudniają wprowadzanie zmian (i przemian) zarówno w nich samych, jak i w szkole.

Szansą na "oddolny" rozwój oświaty może być nauczyciel, którego metaforycznie możemy umiejscowić na "mostku kapitańskim" 6 (Kaczyńska, tamże, s. 242-243). Nauczyciel tymczasowo pełniący rolę kapitana (co nie znaczy będący kapitanem) jako "refleksyjny praktyk" czy też "autonomiczny podmiot" (zob. Kwiatkowska, 1997, s. 75), sam

4. Badanie zostało przeprowadzone na próbie 18 dzienników nauczycielek wczesnej edukacji, napisanych bez ingerencji badacza, zanalizowanych w warstwie prezentowanej narracji i skategoryzowanych przy pomocy metody fenomenograficznej.

5. Określenie to przyjęłam za Małgorzatą Lewartowską-Zychowicz (2009, s. 178).

6. Różne obrazy nauczycieli wyłaniające się z Dzienników doświadczeń zawodowych były przedmiotem analizy także w innym artykule autorki: M. Kaczyńska (2016b), Nauczyciele wczesnej edukacji - między pasjq̨ a cierpiętnictwem [w:] M. Żytko (red.), Skq̨d przyszliśmy - dokąd idziemy? Pedagogika wobec wyzwań współczesności (s. 125-142), Warszawa: Wydawnictwo Naukowe Katedra. 
wyznacza cele, za których osiągnięcie odpowiada. Opierając się na wiedzy i doświadczeniu (swoim, ale także innych osób) oraz stale badając różne czynniki oddziaływań, prowadzi "załogę" w obranym kierunku. Cieszy się autorytetem osobistym, który nie wynika tylko z racji pełnionej funkcji, ale także (a właściwie przede wszystkim) z racji swojej wzbudzającej zaufanie wiedzy eksperckiej (ang. expert power) oraz ze wzbudzających szacunek i stanowiących wzór do naśladowania cech osobowych (ang. referent power) ${ }^{7}$. Obraz nauczyciela stojącego na "mostku kapitańskim" może kojarzyć się z uprawomocnioną i stwarzającą pewien dystans władzą formalną (ang. legitimate power), lecz nią nie jest - jest natomiast jej uzupełnieniem. Zamiast próbować dewaluować przełożonego, stara się go aktywnie wspierać, czym różni się od obrazu nauczyciela-kapitana, uobecnionego $w$ kinematografii w postaci Johna Keatinga w "Stowarzyszeniu umarłych poetów". Ten drugi, pomimo iż kierował się jak najlepszymi intencjami (chciał rozbudzić w uczniach prawdziwą pasję życia i nauczyć ich samodzielnego myślenia), koncentrował swoje siły na działaniach o charakterze dywersji - na podważaniu autorytetu przełożonych, przełamywaniu utartych schematów oraz burzeniu zastanego ładu i porządku (a więc na swoistym buncie). Celem nauczyciela na "mostku kapitańskim" nie jest stanięcie w opozycji do swojego zwierzchnika, ale to, by razem z nim "przejąć stery" - zostaje poniekąd włączony do "kierowania statkiem" i „przewodzenia jego załogą" na zasadzie przywództwa rozproszonego (ang. distributive leadership) i partycypacyjnego (ang. participative leadership). To bardziej "drugi kapitan", osoba ciesząca się zaufaniem i autonomią działań oraz dużym zakresem odpowiedzialności. Takiego nauczyciela możemy nazwać nieformalnym przywódcą edukacyjnym.

\section{Nieformalne przywództwo nauczycieli w teorii i badaniach}

Nieformalny przywódca to osoba, która posiadając wpływ w grupie nieformalnej (Sikorski, 2006, s. 33), podejmuje działania przywódcze (zarówno skoncentrowane na zadaniach, jak też na relacjach międzyludzkich) stanowiące uzupełnienie dla formalnej władzy, ale niebędące 
jednocześnie „formalnie uznane przez organizację lub grupę"8 (Griffin, 2004, s. 283). Jako "naturalny" przywódca "czerpie siłę wpływu z osobistej przewagi nad pozostałymi członkami grupy w zakresie cech istotnych dla realizacji wartości uznanych w tej grupie za ważne", przy czym przewagę tę wyznacza "subiektywne przekonanie" owej grupy (Holly, 2000, s. 250). Tym, co wyróżnia przywództwo nauczycieli (ang. teacher leadership, $T L$ ), jest jego edukacyjny charakter i nastawienie na zmianę.

Edukacyjny charakter przywództwa zakłada "umożliwienie pracownikom szkoły poszukiwanie sensu tego, co wymaga przeobrażeń i co można zmienić" (Smyth, 1986 cyt. za: Schratz, 2014, s. 22). Przywództwo edukacyjne jako proces umożliwia odkrywanie i uzewnętrznianie potencjału ludzi oraz rozwiązywanie problemów zgodnie z przyjętymi wspólnie wartościami i z szacunkiem wobec innych (Mazurkiewicz, 2015, s. 28). Wenner i Campbell za innymi badaczami (Curtis, 2013; Leithwood i in., 2004; Muijs, Harris, 2003, 2006) wyrażają przekonanie, że to właśnie nauczyciele są najbardziej wpływowymi przywódcami edukacyjnymi. O wartości przywództwa nauczycieli i jego przełożeniu na praktykę w różnych krajach pisali także między innymi Frost (2011) oraz Flores (2014), pokazuje ją także dokument Teacher Leader Model Standards (Teacher Leadership Exploratory Consortium, 2010). Jak z kolei referuje Leithwood (2005, s. 104-105), nauczyciele mogą z powodzeniem pełnić nieformalne funkcje przywódcze poprzez realizacje takich zadań, jak: dzielenie się wiedzą, pomaganie współpracownikom w pełnieniu ich obowiązków w klasie, wspieranie rozwoju praktyki edukacyjnej poprzez zachęcanie innych do eksperymentowania i poszukiwania bardziej efektywnych rozwiązań czy przypisywanie cech przywódczych osobom biorącym odpowiedzialność za swój rozwój zawodowy, promującym misję szkoły i działanie na rzecz jej rozwoju, tak jak i całego systemu szkolnego. Ponadto wskazuje on, że przywództwa nauczycieli nie określają tylko cechy osoby (traits), ale też: zdolności (capacities), uzdolnienia (abilities) i efekty pracy (outcomes) (tamże, s. 105-107). Te ostatnie dotyczą przede wszystkim wkładu w rozwój (ciągłego) uczenia się szkolnej społeczności i budowania wspólnoty. Podobnie badaczki Wenner i Campbell (tamże) zaznaczają, że nauczyciele-przywódcy oprócz przejmowania odpowiedzialności

8. W literaturze można także spotkać określenie "niewidzialne przywództwo” (ang. invisible leadership, zob. Donaldson, 2007, s. 26). 
za nauczanie w swojej klasie (na wszystkich etapach powszechnego kształcenia), przejmują jednocześnie odpowiedzialność za przewodzenie poza nią, choć wciąż w obrębie szkoły (tamże, s. 7). Zwracają także uwagę na znaczenie efektu współpracownika (peer) oraz afordancji dla rozumienia specyfiki danego środowiska i znajomości jego ograniczeń (tamże, s. 8). Hattie (2015) pisze natomiast o „szkolnych liderach", którzy wykorzystując "siłę oddziaływania" w swoim środowisku, między innymi: inicjują wspólne planowanie lekcji, monitorują i dyskutują na temat osiągnięć, zabiegają o ciągłe doskonalenie (się), a nade wszystko kształtują "ramy myślenia". To właśnie oddziaływanie na innych (współpracowników, dyrektora szkoły i innych członków szkolnej społeczności) w celu udoskonalania praktyki nauczania i uczenia w szkole jest tym, co definiuje przywództwo nauczycieli (York-Barr, Duke, 2008). Bez promowania przywództwa w nauczaniu przez nauczycieli trudno mówić o poprawie szkolnych osiągnięć (Little, 1988, s. 78).

W literaturze wyodrębnia się wiele różnych sposobów definiowania przywództwa. Jednym z nich, na które warto w tym miejscu zwrócić uwagę, jest przywództwo rozumiane jako relacja społeczna. Podkreśla się w nim między innymi znaczenie komunikacji między osobami oraz współpracy w zakresie realizacji wspólnych dla nich celów (Madalińska-Michalak, 2015, s. 36 oraz 40-41). Anderson (2004, s. 100), opisując przywództwo o charakterze relacyjnym, definiuje je jako: „płynny, interaktywny proces wzajemnego wpływu pomiędzy liderem i jego naśladowcami". Takie rozumienie zakłada, że przywództwo nie jest zarezerwowane jedynie dla formalnie desygnowanych osób, ale jest dostępne praktycznie dla wszystkich ludzi, w zależności od kontekstu i pojawiającego się zapotrzebowania. To „atrybut, po który sięgają nie tylko liderzy, ale także ich zwolennicy" (Madalińska-Michalak, 2015, s. 36). $Z$ tej perspektywy każdy nauczyciel wchodzący $z$ innymi $w$ interakcje służące zmianie może stać się potencjalnym liderem w swojej szkole i poza nią. Jego przywództwo będzie polegało na "ustalaniu kierunków i sprawianiu, że inni je obierają" (Anderson, 2004, s. 100). Należy tu wspomnieć, że same relacje między nauczycielami-liderami a ich zwolennikami w założeniu powinny raczej polegać na inspirowaniu i odwoływać się do potrzeb "wyższego rzędu", a więc bazować na motywacji wewnętrznej obydwu stron. Taki styl przywództwa nazywamy transformacyjnym (Burns, 1978 za: Madalińska-Michalak, 2015, 
s. 87-89)9 ${ }^{9}$ Jego wartość zawiera się między innymi w tym, że może prowadzić do zmiany całej kultury organizacji, a więc na zmianie kierunku, w jakim rozwija się szkoła. Samo przywództwo nauczycieli może być zatem utożsamiane ze „sprawczością zbiorową i wspólnymi, profesjonalnymi działaniami nakierowanymi na pedagogiczny cel" (Muijis, Harris, 2003, s. 3). Polskie badania pokazują, że "nauczyciele chcieliby uczestniczyć w kierowaniu szkołą w większym stopniu, niż obecnie" (Tołwińska, 2011, s. 109). Mogą oni jednak pełnić istotną rolę w budowaniu kultury organizacyjnej szkoły i partycypować we władzy pod warunkiem przyjęcia przez dyrektora perspektywy "szkoła to my"10 i uwzględnienia „łańcucha przywództwa" obejmującego całą szkołę (Fullan, 2006 za: Michalak, 2010, s. 19).

Przeprowadzone przeze mnie badanie eksploracyjne nad przejawami i obszarami nieformalnego przywództwa w szkołach i przedszkolach (Kaczyńska, 2015; Dorczak i in., 2016) ukazało niejednoznaczność sposobów definiowania nauczyciela - lidera edukacyjnego. Badanie to obejmowało jakościową analizę ankiet audytoryjnych pod kątem postawionych wcześniej otwartych pytań badawczych, odnoszących się do następującej problematyki: postrzeganie siebie/uznanie kogoś za lidera, przejawy przywództwa nauczycieli, proponowanie i wdrażanie zmian w szkole czy stosunek dyrektora do owych zmian. Grupa badawcza była wyselekcjonowana spośród nauczycieli wykazujących wyższy niż przeciętnie poziom zaangażowania i potrzebę rozwoju osobistego (byli to uczestnicy kursu pilotażowego "Przywództwa Edukacyjnego" dla przyszłych dyrektorów szkół/placówek edukacyjnych oraz konferencji dotyczącej jakości edukacji i ewaluacji). Na podstawie 75 anonimowo wypełnionych kwestionariuszy dokonano porównania i kategoryzacji udzielonych odpowiedzi.

W opinii respondentów pojęcie lidera edukacyjnego kryje w sobie zarówno nieformalnych przywódców, czyli osoby wybrane przez współpracowników na ich reprezentantów (oraz osoby samoistnie wychodzące z inicjatywą - „naturalnych" liderów), jak również osoby formalnie mianowane przez dyrektorów do pełnienia (społecznej) funkcji jego

9. Drugi ze stylów przywództwa, określany mianem "transakcyjnego", odwołuje się do potrzeb „niższego rzędu", jest oparty na motywacji zewnętrznej i ma na względzie głównie podporządkowanie podwładnych.

10. Określenie za Małgorzatą Żytko (2009) będące przeciwieństwem „szkoła to ja". 
zastępcy bądź koordynatora (przewodniczącego) powołanego przez niego zespołu zadaniowego. Jest to pewna rozbieżność definicyjna wymagająca jeszcze doprecyzowania.

Badana grupa nauczycieli, odwołując się do swoich subiektywnych odczuć ("Lubię to"; „Dobrze czuję się w roli lidera”; „Uważam, że potrafię to robić"; "Mam nadzieję posiadanych cech/predyspozycji liderskich") oraz zrealizowanych przez siebie konkretnych zadań, wskazała na szereg cech osobowości i nabytych kompetencji, które ich zdaniem świadczą o byciu liderem w szkole. Są to: poczucie własnej wartości, pewność celu („wiem, czego chcę"), wewnętrzna gotowość i chęć do przewodzenia oraz chęć podejmowania decyzji, umiejętność kierowania innymi i przewodzenie grupie, odpowiedzialność za siebie i innych, gotowość do nauki, własna aktywność (włączanie się do zadań, które samemu się proponuje, podawanie własnych pomysłów), charyzma i facylitacja (inspirowanie i motywowanie innych), bycie przykładem do naśladowania dla innych, umiejętność przekonywania innych do swojego pomysłu, kreatywność, komunikatywność i umiejętność słuchania innych, tolerancyjność, dobra znajomość szkoły i środowiska wychowawczego, promowanie rozwoju wokół siebie oraz reprezentowanie innych (na przykład jako przewodniczący zespołu).

Ankietowani nauczyciele często utożsamiali przywództwo (ang. leadership) z zarządzaniem (ang. management), podczas gdy są to dwa różne (choć - jak zauważa Madalińska-Michalak, 2015, s. 175 - komplementarne) obszary aktywności. Najczęściej wskazywanym obszarem uwidaczniania się zdolności przywódczych było dla nich posiadanie zdolności organizacyjnych. Respondenci wymieniali takie zadania, jak: opracowanie planów i harmonogramów, koordynowanie działań, monitorowanie efektów czy analizowanie wyników (na przykład na polu ewaluacji wewnętrznej). Nieco rzadziej pojawiały się wskazania dotyczące przywództwa sensu stricto, czyli pracy zespołowej i budowania sieci współpracy. Na tym polu wyszczególniono następujące obszary działania: motywowanie, facylitowanie, konsultowanie, prowadzenie szkoleń wewnętrznych, planowanie doskonalenia, „obserwacje lekcji, wypracowanie strategii, wizji szkoły, planowanie pracy SU - razem z uczniami, wdrażanie nowych n-li; OK (szkolenia, lekcje koleżeńskie)", rozwiązywanie problemów wychowawczych (na przykład: „analiza zachowania uczniów, ich problemów, sposobów pomocy"), a także: „KO (organizacja i moderowanie życia kulturalnego grona ped.)". Jedna z na- 
uczycielek napisała: „w zespole laboratorium organizuję obserwacje uczniów, a później prowadzę spotkanie, na którym opracowujemy działania (...), prowadzę mini szkolenia, dzieląc się z koleżankami wiedzą z różnych szkoleń".

Respondenci sami zwrócili uwagę, że aby być liderem, nie potrzeba oficjalnego, odgórnego mianowania - często wystarczy uznanie w oczach innych ludzi. Owo uznanie może być jednak zarówno dużą nobilitacją, jak i próbą zrzucenia odpowiedzialności za zadanie na osobę bardziej aktywną i/lub mniej asertywną, która niekoniecznie musi cieszyć się z tego "wyróżnienia” ("ludzie współpracujący ze mną oczekują ode mnie pomysłów - czekają, aż ja coś wymyślę, zaproponuję [określają mnie mianem lidera], jeśli potrzeba pomocy"). Związany z przywództwem wymóg bycia zaangażowanym i rozliczanym za efekty pracy może zniechęcać niektórych do podjęcia się tej roli (zwłaszcza, jeśli jest ona niejako narzucona przez innych). Niemniej, wielu nauczycieli odczuwa potrzebę robienia czegoś więcej, niż przyjęło się od nich oczekiwać, i wychodzi z własnymi propozycjami zmian na różnych polach.

\section{Zmiany proponowane przez nauczycieli}

Nauczyciel jako nieformalny przywódca, niezależnie od formalnego zwierzchnictwa osoby dyrektora, może mieć wpływ na kierunek, w jakim zmierza jego szkoła. Nawet nie mając prawnie zagwarantowanej władzy, może wysuwać własne postulaty i proponować projekty zmian prorozwojowych i próbować je wdrożyć we współpracy z innymi zainteresowanymi osobami (sojusznikami zmian), na przykład opracowywać własne rozwiązania dydaktyczne i dzieląc się nimi, służyć uczeniu się całej społeczności szkolnej. Innymi słowy, wychodząc z własną inicjatywą, może sam zapoczątkować zmiany "oddolne", a następnie upowszechnić je w swojej szkole i środowisku lokalnym. Wspomniane już badania nad przejawami i obszarami nieformalnego przywództwa w szkołach i przedszkolach (Kaczyńska, 2015) pokazały, że zmiany te mogą odbywać się na dwóch poziomach, mieć różny charakter i obejmować różne wymiary pracy szkoły, co pokazuje poniższa rycina. 
Rycina 1. Zakres i różnorodność proponowanych zmian przez badanych nauczycieli

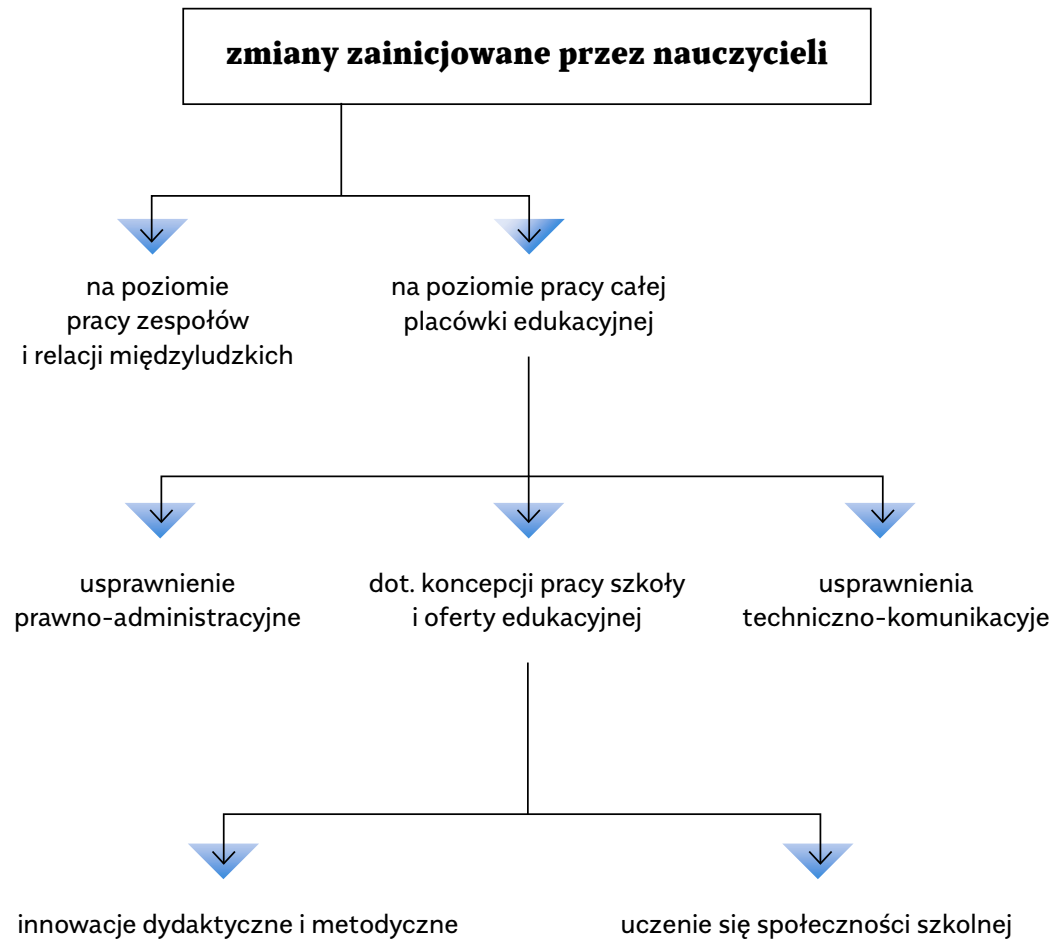

Źródło: opracowanie własne (za Kaczyńska, 2015, s. 28; Dorczak i in., 2016, s. 63).

Część zmian proponowanych przez grupę badanych nauczycieli miała wymiar organizacyjny, zadaniowy. Zmiany te były tym samym związane z kierowaniem bieżącą pracą szkoły, czyli zarządzaniem nią (ang. management). Nauczyciele wskazali na dwa główne typy usprawnień na tym polu, które można określić mianem: prawno-administracyjnych oraz techniczno-komunikacyjnych. W ramach pierwszego z nich pojawiały się odpowiedzi związane ze zmianą obowiązujących w szkole/przedszkolu regulacji, takich jak: procedury („interwencyjne; zmiany statutowe - organizacja pracy zespołowej"), plany pracy, lekcji oraz wyjść („wszystkie godziny wychowawcze na danym poziomie są w tym samym czasie - możliwość spotkania całego poziomu bez zmiany organizacji pracy szkoły"), zasady dotyczące wdrażania programów, 
przeprowadzania egzaminów/testów kompetencji, systemu oceniania, udzielania pomocy psychologiczno-pedagogicznej czy zarządzania funduszem socjalnym, jak też „realnego kształtowania wyglądu danych projektów". Można również wspomnieć o propozycji częstszej pracy zespołowej „ze wsparciem zewnętrznym i wspólnego organizowania sprawdzianów klas III z rodzicami, na boisku szkolnym". W ramach drugiego typu pisano o informatyzacji placówki, czyli o wyposażeniu jej w niezbędny do efektywnego zarządzania informacją sprzęt komputerowy, oraz wskazywano na „opracowanie, wdrożenie i prowadzenie dokumentacji elektronicznie; gromadzenie dokumentacji w »chmurze «; ułatwienie komunikacji między członkami rady pedagogicznej; montaż monitorów na szkolnych holach do projekcji prezentacji edukacyjnych na przerwach; sposób zbierania informacji dotyczący wyboru lub nie klas szóstych".

Innym obszarem zmian był ten związany z koncepcją pracy szkoły i jej oferty edukacyjnej. Badani nauczyciele pisali między innymi o: „nowych profilach" szkół lub klas, „otwarciu placówki/poszerzeniu oferty; zaproszeniu uczniów gimnazjum do uczestnictwa w kółkach zainteresowań w obszarze przedzawodowym" czy też "stałej formule święta szkoły i propozycji spotkań indywidualnych z uczniami i ich rodzicami".

Wiele propozycji inicjowanych przez nauczycieli dotyczyło dydaktyki i metodyki, w tym innowacji pedagogicznych („»Nauczanie ekspedycyjne « i więcej nauki poza klasą; wprowadzenie zajęć indywidualizacji (...) według planu daltońskiego; wspólne warsztaty dzieci - rodzice dla różnych grup"). Niektórzy z nich wskazywali na swoje osiągnięcia, takie jak na przykład: „programy ogólnopolskie”, autorskie programy, projekty i eksperymenty pedagogiczne („szkolny program wspierania uzdolnień; opracowanie dwóch eksperymentów do wprowadzenia w LO; cykliczny projekt z zakresu edukacji globalnej, który realizują uczniowie; doprowadzenie szkoły do uzyskania w powiecie (10-krotnie) tytułu "Ekologicznej szkoły «"). Jedna osoba zachęciła innych do pracy z programem "Gramy w piktogramy", inna wskazała na zmianę ustawienia ławek, jeszcze inna organizuje w swojej szkole "spotkania autorskie" i "międzyszkolne konkursy". Wśród odpowiedzi pojawiła się też inicjatywa dzielenia się wiedzą i doświadczeniem poprzez stworzenie „zbioru pomocy - scenariuszy zajęć itp.".

Poza kwestiami organizacyjnymi oraz zmianami dydaktycznymi ankietowani wskazywali na działania o charakterze przywódczym, podkre- 
ślając rolę pracy zespołowej, jak również uczenia się całej społeczności szkolnej. Nauczyciele wymieniali takie inicjatywy, jak: „lekcje otwarte, spacer edukacyjny, zespoły samokształceniowe w postaci Laboratoriów Praktyki Edukacyjnej, World Cafe" czy nawet "filmowanie zajęć lekcyjnych". Niektórzy wzorowali się na Ocenianiu Kształtującym i programie Szkoła Ucząca się („włączenie SU do prac zespołów przedm. (...); szkolenia dla nowych n-li o OK"). Nauczyciele zapytani o to, czy postrzegają siebie w roli lidera stwierdzali, że mogą o tym świadczyć takie ich aktywności, jak: inspirowanie i motywowanie innych, gotowość do współpracy („Podążamy w przyszłość razem”), doradzanie, dzielenie się wiedzą, doświadczeniem i pomysłami oraz korzystanie z pomysłów innych. Pisali także o samej zmianie: jej inicjowaniu i wdrażaniu, przekonywaniu do niej innych i pozyskiwaniu sojuszników do jej realizacji. W jednej z ankiet zwrócono uwagę na zabieganie o „zmianę mentalną" u innych nauczycieli.

Z udzielonych odpowiedzi wynika także, że zainicjowane zmiany nie muszą obejmować swym zasięgiem całej placówki. Mogą one dotyczyć jedynie wybranych grup/zespołów współpracujących ze sobą nauczycieli. Przykładowo, wypracowują oni nowe formy wewnętrznej komunikacji, takie jak: „zmiana formuły spotkań zespołów klas, ”robocze « spotkania RP" [Rady Pedagogicznej - dop. autora], „wprowadzenie pracy w oparciu o ligi-zespoły-zadania, wprowadzenie zeszytów informacji, czy zmiana charakteru działań zespołu z indywidualnego na zespołowe". Na tym obszarze ankietowani podkreślali znaczenie działań integrujących grono pedagogiczne oraz troskę o dobre relacje międzyludzkie i atmosferę w pracy. Jednym z podanych rozwiązań było wspieranie „żywotności grupy pedagogów poprzez akcje, wyjścia, spotkania, wspólne świętowanie".

W tym miejscu warto jeszcze podkreślić, że zaproponowane przez nauczycieli zmiany mogłyby nie wejść $w$ życie, gdyby nie wsparcie ze strony dyrektora szkoły/przedszkola. Aż $2 / 3$ ankietowanych znalazło w swoim przełożonym poparcie dla swoich pomysłów, z czego połowa tej grupy określiła postawę dyrektora mianem „akceptującej”, a druga połowa stwierdziła, że ten aktywnie pomagał im przy jej wdrażaniu. Nikt nie przyznał, że całkowicie zabroniono mu wprowadzić zmianę, natomiast kilka osób wskazało, że "góra" generowała pewne przeszkody lub częściowo utrudniała realizację pomysłów. Ciekawe jest, że jednej osobie pomimo jawnego sprzeciwu dyrektora udało się osiągnąć zamierzony cel (czym jednak: „naraziła się na duże niezadowolenie!”). 


\section{Postrzeganie i intepretowanie przywództwa nauczycieli}

Z omówionych wyżej badań eksploracyjnych nad sposobami rozumienia nieformalnego przywództwa edukacyjnego nauczycieli przez samych nauczycieli i osoby zajmujące się ich profesjonalizacją wynika, że termin "przywództwo nauczycieli" nasuwa wiele różnych, nieraz skrajnych skojarzeń i interpretacji (zob. Madalińska-Michalak, Kołodziejczyk, 2015). Uzasadnieniem dla takiego stanu rzeczy może być brak lub niedostateczny stan badań z tego obszaru na gruncie polskim, jak również społeczna świadomość braku rzeczywistej autonomii nauczycieli w polskich szkołach.

Ową niejednoznaczność pojęciową potwierdzają także inne, przeprowadzone przeze mnie badania internetowe na małej próbie 24 osób. Tym razem badani (osoby czynnie związane z edukacją na wszystkich jej szczeblach) zostali poproszeni o odpowiedź na dwa pytania otwarte: Z czym kojarzy się Panu/Pani określenie "nauczyciel-nieformalny przywódca edukacyjny"? Jaką rolę może pełnić w szkole? Ankietowani utożsamiali wspomnianą osobę z kimś, kto: dąży do zmian lub innowacji (6 osób), "nadaje kierunek” (kieruje przebiegiem procesu edukacyjnego) (6 osób), jest kompetentny w tym, co robi (5 osób), posiada autorytet (4 osoby), wyróżnia się charyzmą (3 osoby), inspiruje innych (3 osoby), może wpływać/oddziaływać na innych (3 osoby), a także wykazuje entuzjazm i "chce robić więcej". Do jego scharakteryzowania badani posłużyli się zamiennymi określeniami, takimi jak: lider uczenia się, lider zmiany, lokomotywa zmian, wizjoner, inicjator, innowator, drogowskaz, latarnia morska, mistrz, wzór, autorytet, osobowość, przewodnik (w procesie edukacyjnym), coach, nauczyciel-ambasador, pasjonat, praktyk, ciekawy człowiek i przyjaciel. Dla kilku badanych osób nauczyciel jest przywódcą przede wszystkim dla uczniów, niekoniecznie dla innych nauczycieli - trudno im było dostrzec $w$ jego pracy działania nieformalne, niewynikające bezpośrednio z funkcji nauczyciela klasowego.

Respondenci wyszczególnili także szereg zadań, za których wykonanie nauczyciel-przywódca edukacyjny może ich zdaniem odpowiadać w szkole. Zadania te wpisują się w trzy główne obszary działania: wspieranie współpracowników w rozwoju, pracę z uczniami oraz przewodzenie zmianie w szkole (zob. rycina 2.). W pierwszym obszarze znalazły się takie zadania, jak: uczenie innych nauczycieli, służenie im radą i pomocą oraz inspirowanie swoją osobą i swym działaniem (także nauczycieli innych przedmiotów), np. poprzez wprowadzanie nowych 
metod pracy i przekonywanie do innowacji, zachęcanie do wprowadzania i udoskonalania warsztatu pracy, pokazywanie nowych ścieżek i możliwości, jak również stanie na czele grupy i dodawanie jej poczucia pewności siebie i siły. Do drugiego obszaru można zaliczyć takie działania, jak: kształtowanie ścieżek edukacyjnych uczniów, pomaganie im w znalezieniu "właściwej drogi rozwoju", zaszczepianie i rozbudzanie ciekawości i pasji, angażowanie do wytężonej pracy, budowanie emocjonalnej więzi oraz bycie oparciem dla uczniów. $Z$ kolei trzeci obszar dotyczy takich zadań, jak: zachęcanie innych do zmian, wyznaczanie kierunku zmian oraz wprowadzanie/prowadzenie zmian. Badani wskazali także na inne role pełnione ich zdaniem przez nauczycieli-przywódców w szkole: szef zespołu przedmiotowego, szef szkoleń, osoba rekrutująca uczniów, metodyk, edukator, jak również człowiek dyrekcji (przywódca rzekomo nieformalny).

Rycina 2. Obszary działania nauczycieli-przywódców edukacyjnych

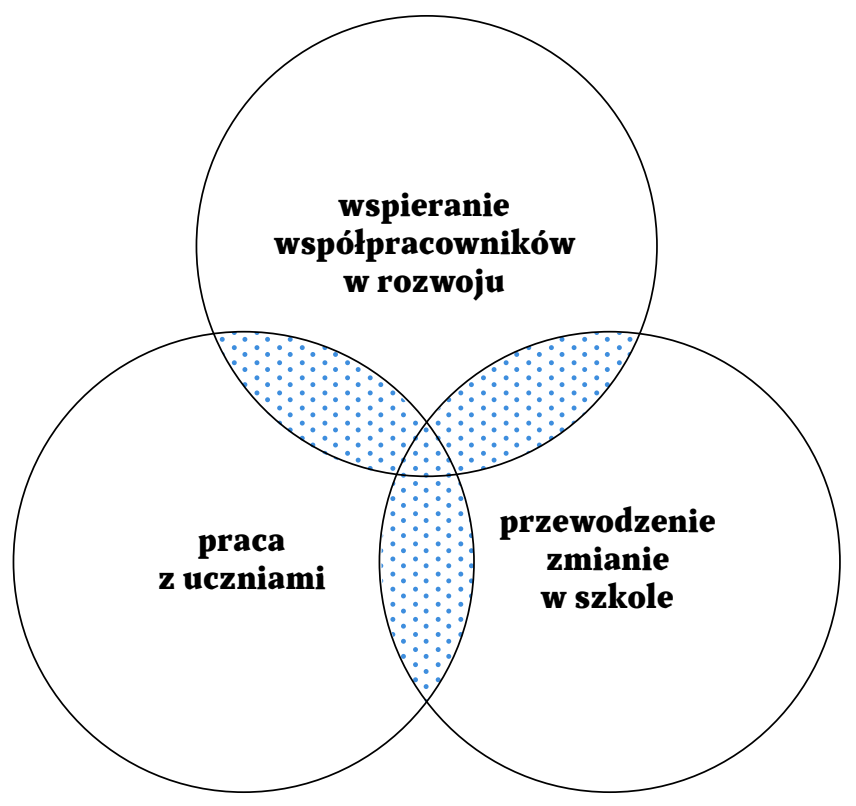

Źródło: opracowanie własne.

Ciekawe jest, że niektórzy ankietowani dostrzegli również negatywny wymiar przywództwa nauczycieli: powodowanie regresu lub stagnacji, 
spowalnianie zmian w sytuacji kryzysu, buntowanie na zmiany, wprowadzanie złych zmian, a nawet „zniechęcanie do otwartego podejścia do samodoskonalenia i rozwoju". Osoby te nie wyjaśniły jednak, na czym konkretnie miałyby polegać te działania w edukacyjnym kontekście, który w założeniu służy przecież rozwojowi. Inni zwrócili uwagę na to, że nauczyciele-przywódcy mogą w jakimś stopniu kontestować zewnętrzne wymogi i pracować według własnej wizji, niekoniecznie akceptowanej przez współpracowników i dyrektora („pracować w oderwaniu od narzuconych programów”, ,wychodzić poza ramy”, „uczyć myśleć niestandardowo", nie być kimś „bezrefleksyjnie odtwarzającym” wytyczne).

\section{Podsumowanie}

Przywództwo bardziej niż na bieżących zadaniach skupia się na kreśleniu wizji i wyznaczaniu dalekosiężnych celów - pozwala znaleźć punkt zaczepienia, którego poszukują "Restauratorzy". Fakt, że podkreśla ono wartość współpracy i że poszukuje nowych, nieraz innowacyjnych rozwiązań, powinni docenić "Dekoratorzy". Z kolei zwolenników „jakości" i "Rekonstruktorów" powinien ucieszyć argument zapisany w raporcie OECD (Pont, Nusche, Moorman, 2008, s. 9): „skuteczne przywództwo edukacyjne jest niezbędne dla (...) równego dostępu do edukacji". Wydaje się, że badani nauczyciele bardziej niż na zmianach społecznych i sposobach myślenia o edukacji (jej istocie i fundamentach), koncentrują się na dydaktyce i na praktycznych (organizacyjnych) aspektach pracy szkoły. Jednakże ich działania skierowane ku budowaniu kultury współpracy i wzajemnego uczenia się już same w sobie stanowią krok w stronę oddolnej przemiany systemu edukacji o społecznym, a wręcz fundamentalnym znaczeniu. Kultura „zamkniętej klasy” powoli przemienia się we wspólnotę autonomicznych osób, które są gotowe "stanąć za sterem", by pokierować rozwojem społeczności szkolnej. Skuteczność podejmowanych przez nauczycieli działań może z kolei wywoływać u nich refleksję nad jego sensem i nad znaczeniem edukacji w ogóle. Nauczyciele tacy nie muszą być wcale "bohaterami" o niezwykłych zdolnościach, a ich przywództwo nie musi być sformalizowane, na co zwraca uwagę Donaldson (2007, s. 27), lecz może mieć relacyjny charakter, a więc dziać się niejako „w przestrzeni” między osobami będącymi członkami szkolnej społeczności.

Przywództwo edukacyjne tworzy warunki do rozwoju dzieci, gdyż „jest drugim najważniejszym czynnikiem po nauczaniu w klasie na- 
uczania wpływającym na uczenie się uczniów" (Leithwood, Harris, Hopkins, 2008, s. 27). Ponieważ "klimat" klasy odzwierciedla "klimat" szkoły, aby móc skutecznie przewodzić, sami nauczyciele również potrzebują wspierającego środowiska, które umożliwi im realizację ich potencjału, wizji i pomysłów oraz dzielenie się nimi z innymi. Dystrybucja przywództwa, czyli poszerzanie strefy wpływu i autonomii (rozumianej także jako empowerment - upoważnianie, wzmacnianie za: Blanchard, 2013, s. 58), daje nauczycielom poczucie sprawczości. Wciąż trudno jednoznacznie stwierdzić, jak duże znaczenie przy realizacji oddolnych inicjatyw ma poparcie ze strony dyrektora szkoły (odwołując się do wcześniejszych porównań - owo dopuszczenie nauczyciela do "mostka kapitańskiego"). Wydaje się jednak, że zdeterminowany i odporny na niesprzyjające okoliczności nieformalny przywódca edukacyjny może mieć szansę na przekonanie innych do realizacji swojej wizji (w opisanym wcześniej badaniu zdecydowanej większości osób udało się pozyskać sojuszników wśród współpracowników oraz wprowadzić w życie zaproponowane zmiany). Niemniej, potrzebne są też wewnętrzne dyspozycje, które pomogą mu poradzić sobie z oporem wobec zmiany i pozwolą zachować początkową motywację, zaangażowanie i spełnienie zawodowe (Kaczyńska, 2016b). Nauczyciel bez owych dyspozycji, któremu jednocześnie odmawia się prawa do wewnątrzsterownego działania oraz przejęcia za nie odpowiedzialności, może odczuwać frustrację i stracić początkowe poczucie sensu własnej pracy (tamże).

Niezależnie od tego, który dyskurs („jakości" czy "nadawania znaczenia"), i którą z wyszczególnionych wizji zmian edukacyjnych przyjmiemy, planując kolejne, nie powinniśmy zapominać o nauczycielach - ich głównych realizatorach. Skoro powierzamy im dzieci, a z nimi przyszłość kraju i świata, dlaczego nie uczynić ich także współtwórcami owych zmian? Tworząc im optymalne warunki pracy oparte na zaufaniu do ich kompetencji, gotowości do współpracy oraz dzielenia się wiedzą i władzą, możemy pomóc nauczycielom - pasjonatom utrzymać ich entuzjazm i zaangażowanie lub rozbudzić je u tych, którym ich brakuje. Patrząc na wielość i różnorodność zmian inicjowanych przez nauczycieli, można z przekonaniem stwierdzić, że warto szukać wśród nich (potencjalnych) nieformalnych przywódców i że warto ich wspierać, gdyż działają oni na korzyść nie tylko swoich uczniów, ale także całej społeczności szkolnej. 


\section{Bibliografia}

$\rightarrow$ Anderson, K.D. (2004), The nature of teacher leadership in schools as reciprocal influences between teacher leaders and principals, School Effectiveness and School Improvement, 15(1), 97-113.

$\rightarrow$ Blanchard, K. i in. (2013), Przywództwo wyższego stopnia, tłum. A. Bekier, Warszawa: Wydawnictwo Naukowe PWN.

$\rightarrow$ Burns, J.M. (1978), Leadership, New York: Harper \& Row.

$\rightarrow$ Bruner, J.S. (2006), Kultura edukacji, tłum. T. Brzostowska-Tereszkiewicz, Kraków: Universitas.

$\rightarrow$ Curtis R. (2013), Findings a new way: Leveraging teacher leadership to meet unprecedented demands, Washington, DC: Aspen Institute.

$\rightarrow$ Dahlberg, G., Moss, P., Pence, A. (2013), Poza dyskursem jakości w instytucjach wczesnej edukacji i opieki. Języki ocen, tłum. K. Gawlicz, Wrocław: Wydawnictwo Naukowe Dolnośląskiej Szkoły Wyższej.

$\rightarrow$ Day, Ch. (2014), Budowanie i podtrzymywanie sukcesu w przywództwie szkolnym: perspektywy międzynarodowe, tłum. i oprac. nauk. J. Madalińska-Michalak [w:] S.M. Kwiatkowski, J. Madalińska-Michalak (red.), Przywództwo edukacyjne. Współczesne wyzwania, s. 119-155, Warszawa: Wolters Kluwer.

$\rightarrow$ Donaldson, G.A. Jr. (2007), What Do Teachers Bring to Leadership?, Educational Leadership, 65(1), 26-29.

$\rightarrow$ Dorczak, R., Dobrowolski, Z., Gansiniec-Lenart, R., Hesse-Gawęda, A., Kałużyńska, M., Łagodzińska, M., Szczudlińska-Kanoś, A., Słuszko-Ciapińska, M. (red.) (2016), Wyzwania przywództwa i zarządzania edukacyjnego, Kraków: Monografie i Studia Instytutu Spraw Publicznych Uniwersytetu Jagiellońskiego.

$\rightarrow$ Flores, M.A. (2014), Przywództwo nauczycieli w czasach pełnych wyzwań, tłum. i oprac. nauk. J. Madalińska-Michalak [w:] S.M. Kwiatkowski, J. Madalińska-Michalak (red.), Przywództwo edukacyjne. Współczesne wyzwania, s. 167-186, Warszawa: Wolters Kluwer. 
$\rightarrow$ French, J.R.P., Raven, B. (1959), The Basis of Social Power [w:] D. Cartwright (red.), Studies in Social Power, s. 150-167, Michigan: ANN Arbor, University of Michigan Press.

$\rightarrow$ Fullan, M. (2006), Odpowiedzialne i skuteczne kierowanie szkoła, tłum. K. Kruszewski, Warszawa: Wydawnictwo Naukowe PWN.

$\rightarrow$ Frost, D. (2011), Supporting teacher leadership in 15 countries. International Teacher Leadership project. Phase 1. A report, Cambridge: University of Cambridge.

$\rightarrow$ Griffin, R.W. (2004), Podstawy zarzq̨dzania organizacjami, tłum. M. Rusiński, Warszawa: Wydawnictwo Naukowe PWN.

$\rightarrow$ Gutek, G.L. (2003), Filozoficzne i ideologiczne podstawy edukacji, tłum. A. Kacmajor, Gdańsk: Gdańskie Wydawnictwo Psychologiczne.

$\rightarrow$ Hattie, J. (2015), Widoczne uczenie się dla nauczycieli. Jak maksymalizować siłę oddziaływania na uczenie się, tłum. Z. Janowska, M. Pater, Warszawa: Centrum Edukacji Obywatelskiej.

$\rightarrow$ Holly, R. (2000), „Przywództwo” [w:] W. Kwaśniewicz (red. zespół pod kierunkiem), Encyklopedia socjologii, t. III, s. 244-252, Warszawa: Oficyna Naukowa.

$\rightarrow$ Juul, J. (2014), Kryzys szkoły. Co możemy zrobić dla uczniów, nauczycieli i rodziców, tłum. D. Syska, Podkowa Leśna: Wydawnictwo MiND.

$\rightarrow$ Kaczyńska, M. (2015), Przejawy i obszary nieformalnego przywództwa nauczycieli w szkołach i przedszkolach, niepubl. praca dyplomowa napisana pod kierunkiem R. Dorczaka, Kraków: Instytut Spraw Publicznych UJ.

$\rightarrow$ Kaczyńska, M. (2016a), Dokq̨d płynie współczesny nauczyciel? Obrazy nauczycieli w dziennikach doświadczeń zawodowych [w:] M. Kamińska, Z.P. Kruszewski, ks. A. Gretkowski, B. Skałbania (red. nauk.), Nauczyciel we współczesnej edukacji. Diagnoza - rozwój - zmiana, s. 239-253, Płock-Warszawa: Oficyna Wydawnicza Szkoły Wyższej im. P. Włodkowica.

$\rightarrow$ Kaczyńska, M. (2016b), Nauczyciele wczesnej edukacji-między pasją a cierpiętnictwem [w:] M. Żytko (red.), Skąd przyszliśmy - dokq̨d idziemy? Pedagogika wobec wyzwań współczesności, s. 125-142, Warszawa: Wydawnictwo Naukowe Katedra.

$\rightarrow$ Kopciewicz, L. (2011), Nauczycielskie poniżanie. Szkolna przemoc wobec dziewcząt, Warszawa: Engram i Difin.

$\rightarrow$ Kwiatkowska, H. (1997), Edukacja nauczycieli. Konteksty-Kategorie-Praktyki, Warszawa: Instytut Badań Edukacyjnych.

$\rightarrow$ Kwiatkowska, H. (2005), Tożsamość nauczycieli. Między anomiq a autonomiq̨, Gdańsk: GWP.

$\rightarrow$ Legowicz, J. (1993), O nauczycielu mistrzu samego siebie [w:] A.A. Kotusiewicz, H. Kwiatkowska, W.P. Zaczyński (red. nauk.), Pedeutologia. Badania 
i koncepcje metodologiczne, s. 15-25, Warszawa: Wydawnictwo Uniwersytetu Warszawskiego.

$\rightarrow$ Leithwood, K. (2005), Teacher leadership: it's nature, development, and impact on schools and students [w:] M. Brundnett, N. Burton, R. Smith (red.), Leadership in Education, s. 103-117, London: Thousend Oaks, New Delhi: SAGE Publications.

$\rightarrow$ Leithwood, K., Harris, A., Hopkins, D. (2008), Seven strong claims about successful school leadership. School Leadership \& Management, 28 (1), 27-42.

$\rightarrow$ Lewartowska-Zychowicz, M. (2009), Nauczyciel (wczesnej edukacji) w relacjach wolności i przymusu [w:] D. Klus-Stańska, M. Szczepska-Pustkowska (red.), Pedagogika wczesnoszkolna. Dyskursy - problemy - rozwiqzania, s. 158-184, Warszawa: Wydawnictwa Akademickie i Profesjonalne.

$\rightarrow$ Little, J.W. (2003), Constructions of teacher leadership in three periods of policy and reform activism, School Leadership and Management, 23(4), 401-419.

$\rightarrow$ Madalińska-Michalak, J. (2015), Dyrektor szkoły liderem: inspiracje i perspektywy, Warszawa: Wydawnictwo Wolters Kluwer SA.

$\rightarrow$ Madalińska-Michalak, J., Kołodziejczyk, J. (2015), Przywództwo i zarzq̨dzanie w szkole: w poszukiwaniu równowagi [w:] G. Mazurkiewicz (red.), Przywództwo edukacyjne. Zaproszenie do dialogu, s. 121-134, Kraków: Wydawnictwo Uniwersytetu Jagiellońskiego.

$\rightarrow$ Mazurkiewicz, G. (2011), Przywództwo edukacyjne. Odpowiedzialne zarządzanie edukacją wobec wyzwań współczesności, Kraków: Wydawnictwo Uniwersytetu Jagiellońskiego.

$\rightarrow$ Michalak, J.M. (2010), Przywództwo w zarzq̨dzaniu szkołą, Warszawa: ORE.

$\rightarrow$ Muijs, D., Harris, A. (2006), Teacher led school improvement: Teacher leadership in the UK, Teaching and Teacher Education, 22(8), 961-972.

$\rightarrow$ Pont, B., Nusche, D., Moorman, H. (red.) (2008), Improving School Leadership, volume 1: Policy and Practice, OECD Publishing Paris.

$\rightarrow$ Schratz, M. (2014), Tworzenie zmiany od wewnq̨trz. Przywództwo jako uczenie się z wyłaniającej się przyszłości, tłum. i oprac. nauk. J. Madalińska-Michalak [w:] S.M. Kwiatkowski, J. Madalińska-Michalak (red.), Przywództwo edukacyjne. Współczesne wyzwania, s. 11-36, Warszawa: Wydawnictwo Wolters Kluwer.

$\rightarrow$ Sikorski, C. (2006), Organizacje bez wodzów. Od przywództwa emocjonalnego do koordynacji demokratycznej, Warszawa: C.H. Beck.

$\rightarrow$ Smyth, W.J. (1986), Leadership and Pedagogy, Geelong.

$\rightarrow$ Steffy, B.E. (1993), Top-down-bottom-up: systemic change in Kentucky, Educational Leadership, 51(1), 42-44. 
$\rightarrow$ Teacher Leadership Exploratory Consortium (2011), Model Standards Advance the Profession, 32(3), 16-24.

$\rightarrow$ Tołwińska, B. (2011), Kierowanie szkołą: rola dyrektora-partycypacja nauczycieli [w:] S.M. Kwiatkowski, J.M. Michalak, I. Nowosad (red.), Przywództwo edukacyjne w szkole i jej otoczeniu, s. 105-113, Warszawa: Wydawnictwo Difin.

$\rightarrow$ Wenner, J.A., Campbell, T. (2016), The theoretical and empirical basis of teacher leadership: A review of the literature, Review of Educational Research, 86(4), 1-38.

$\rightarrow$ York-Barr, J., Duke, K. (2004), What do we know about teacher leadership? Findings from two decades of scholarship, Review of Educational Research, 74(3), 255-316.

$\rightarrow$ Zellermayer, M., Margolin, I. (2005), Teacher educators' professional learning described through the lens of complexity theory, Teachers College Record, 107(6), 1275-1304.

$\rightarrow$ Żylińska, M. (2013), Neurodydaktyka. Nauczanie i uczenie się przyjazne mózgowi, Toruń: Wydawnictwo Naukowe Uniwersytetu Mikołaja Kopernika.

$\rightarrow$ Żytko, M. (2009), Szkoła to ja? - wywiady z dyrektorami [w:] M. Dagiel, M. Żytko (red.), Badanie umiejętności podstawowych uczniów trzecich klas szkoły podstawowej. Nauczyciel kształcenia zintegrowanego 2008 - wiele różnych światów?, s. 98-125, Warszawa: CKE. 


\title{
Przywództwo dyrektorów szkół \\ i klimat szkoły jako podłoże dla \\ rozwoju przywództwa nauczycieli
}

\author{
Jakub Kołodziejczyk
}

W artykule skoncentrowano się na analizie wzajemnego związku stylów przywództwa i klimatu szkoły, które mogą wpływać facylitująco lub hamująco na warunki dla rozwoju przywództwa nauczycieli. Badanie wymiarów przywództwa przeprowadzono, opierając się na skali GLOBE, natomiast klimat szkoły badano za pomocą kwestionariusza klimatu szkoły wykorzystanego w ramach projektu "Zdrowa szkoła”. Badanie przeprowadzono w 28 wielkomiejskich gimnazjach (28 dyrektorów szkół 521 nauczycieli). Przeprowadzona analiza nie dostarcza mocnych argumentów w postaci silnych korelacji między współwystępowaniem badanych stylów przywództwa a elementami klimatu szkoły, jednak dostarcza podstaw do wyciągnięcia wniosków o kierunku oddziaływania stylów przywództwa sprawowanego przez dyrektorów szkół. Wyniki analizy wskazują na pozytywny związek trzech wymiarów przywództwa: zorientowanego na zespół, charyzmatycznego i partycypacyjnego z klimatem szkoły i negatywny związek stylu autonomicznego z klimatem szkoły.

\section{__ Słowa kluczowe: \\ przywództwo nauczycieli \\ klimat szkoły \\ style przywódcze}




\title{
School principals' leadership and school climate as a ground for teachers' leadership development
}

\author{
Jakub Kołodziejczyk
}

The article concentrates on the analysis of the mutual connections between leadership styles and the school climate that can facilitate or impair the conditions for teachers' leadership development. The analysis of leadership dimensions was conducted on the basis of the GLOBE scale and the school climate was studied with the use of the school climate questionnaire developed in the project 'Healthy School.' The study was carried out in 28 middle schools in large cities ( 28 school heads and 521 teachers). The conducted analysis does not provide strong arguments in the form of strong correlates between the co-occurrence of the analysed leadership styles and elements of the school climate, it does provide grounds for drawing conclusions as to the direction of the influence of leadership styles exercised by the school heads though. The results of the analysis indicate a positive relation of three dimensions of leadership: team-oriented, charismatic and participative with the school's climate and a negative relation of autonomic style with the school climate.

\section{Keywords \\ teachers' leadership \\ school climate \\ leadership styles}




\section{Wprowadzenie}

Przegląd definicji przywództwa nauczycieli przedstawianych w literaturze ostatniej dekady wskazuje na występowanie pięciu elementów, na które kładą nacisk badacze. I tak, przywództwo nauczycieli: (1) wykracza poza przewodzenie uczniom i nauczanie w klasie, (2) wspiera profesjonalne uczenie się w szkole, na przykład przez przewodzenie różnym formom doskonalenia nauczycieli, (3) powinno być włączone w politykę i podejmowanie decyzji na niektórych poziomach zarządzania, (4) związane jest z doskonaleniem procesu uczenia się uczniów i odnoszeniem przez nich sukcesów, (5) powinno działać w kierunku doskonalenia i zmiany organizacji szkoły jako całości (Wenner, Campbell, 2017).

Początkowo badania przywództwa nauczycieli prowadzone były bez odwoływania się do założeń teoretycznych (York-Barr, Duke, 2004). Współcześnie badacze $w$ większym stopniu wykorzystują różne ramy koncepcyjne, z których najczęściej znaleźć można odwołania do koncepcji przywództwa rozproszonego (ang. distributed leadership), rzadziej do innych koncepcji, takich jak przywództwo demokratyczne/konstruktywistyczne, przywództwo równoległe (ang. paralel leadership), przywództwo transakcyjne (ang. transactional leadership) (Wenner, Campbell, 2017).

Ważnym elementem, któremu poświęca się wiele miejsca $w$ badaniach nad przywództwem nauczycieli, są warunki wpływające na nie. York-Barr i Duke (2004) na podstawie przeglądu literatury wskazali trzy obszary mające wpływ na przywództwo nauczycieli:

$\rightarrow$ kulturę szkoły i kontekst,

$\rightarrow$ role i relacje (między nauczycielami oraz między nauczycielami a dyrektorami), oraz

$\rightarrow$ strukturę organizacyjną szkoły.

Badacze podkreślają, że obszary te są ze sobą powiązane na przykład strukturą szkoły i że relacje mogą wywierać wpływ na przywództwo nauczycieli, ale mogą także być uzależnione od kultury szkoły. Wenner i Campbell (2017), dokonując przeglądu literatury przedmiotu pochodzącej z ostatniej dekady, wyodrębnili szereg czynników, które wspierają przywództwo nauczycieli w szkole, a także takie, które je hamują. W publikacjach naukowych wśród czynników facylitujących przywództwo nauczycieli wymieniane są: zewnętrzne szkolenia i udzielanie wsparcia 
nauczycielom liderom, wsparcie dla administracji, klimat szkoły i czynniki strukturalne, które pozwalają nauczycielom liderom lepiej wykonywać ich pracę, a także wyraźne określenie ich odpowiedzialności za wykonywaną pracę oraz wyrażanie uznania, za ich wypełnianie. Wśród czynników hamujących pojawiają się: brak czasu, złe relacje z innymi nauczycielami i/lub administracją szkoły, klimat i czynniki strukturalne oraz cechy osobiste (Wenner, Campbell, 2017).

W niniejszym opracowaniu szczególna uwaga zostanie poświęcona dwóm czynnikom, które oddziałują na przywództwo nauczycieli, a mianowicie: (1) stylowi przywództwa dyrektorów szkół, który może odgrywać rolę dla tworzenia relacji między nauczycielami a dyrektorami, oraz (2) klimatowi szkoły, w aspektach, które mogą wiązać się z warunkami sprzyjająco lub hamująco wpływającymi na przywództwo nauczycieli. Interesować nas będzie przede wszystkim współwystępowanie stylu przywództwa dyrektorów szkół i nasilenia czynników klimatu szkoły, które mogą być podstawą dla rozwijania przywództwa nauczycieli.

Styl przywództwa praktykowany przez dyrektorów może odgrywać ważną rolę $w$ tworzeniu się relacji między nauczycielami a dyrektorami i szeroko rozumianym klimatem szkoły, jak pisał Schein (1986) „jedyną rolą, jaką przywódcy odgrywają, jest tworzenie i zarządzanie kulturą" (za Leithwood i in., 1999, s. 82). Wsparciem tego stanowiska są badania modeli przywództwa sprawowanego przez dyrektorów szkół, które przekonują do przyjęcia stanowiska, że wpływ dyrektorów na wyniki edukacyjne odbywa się w sposób pośredni (Hallinger, Heck, 1998) i jest on zależny od innych osób, zdarzeń i czynników organizacyjnych (Leithwood, Anderson, Mascall i Strauss, 2010). Działania dyrektorów wpływają na specyficzny dla konkretnych szkół klimat, który rozumiany jest jako subiektywny sposób postrzegania życia szkolnego przez członków jej społeczności (uczniów, nauczycieli, rodziców, dyrektorów, pracowników) ${ }^{1}$, co wskazuje na percepcyjny (psychologiczny) charakter tego zjawiska (Kulesza, 2011; Van Houtte, 2005 za: Ostaszewski 2012).

\section{Badania wlasne}

W przedstawionej analizie wykorzystano dane pochodzące $z$ badania wpływu przywództwa w szkole na zachowania agresywne i przemoc

1. Oxford Research Encyclopedia of Education, www.education.oxfordre.com/view/10.1093/ acrefore/9780190264093.001.0001/acrefore-9780190264093-e-89 
wśród uczniów². W badaniu tym poza pomiarem wymiarów przywództwa, zgromadzono dane dotyczące postrzegania przez nauczycieli różnych aspektów klimatu szkoły.

Dla potrzeb artykułu przeprowadzono analizę korelacji między sześcioma wymiarami przywództwa postrzeganymi przez dyrektorów a klimatem szkoły postrzeganym przez nauczycieli. Założenie to posłuży odpowiedzi na pytanie o wzajemny związek dwóch czynników, które mogą wpływać facylitująco lub hamująco na warunki dla rozwoju przywództwa nauczycieli w szkołach.

\section{Pomiar stylów przywództwa}

Najszerzej zakrojone badanie kultur organizacyjnych i przywództwa ostatnich lat przeprowadzone zostało w ramach projektu Global Leadership and Organizational Behavior Effectiveness Research Project (GLOBE).

Celem projektu GLOBE było zwiększenie dostępnej wiedzy, która może być ważna dla międzykulturowych interakcji. Badania, w których uczestniczyli menedżerowie przeprowadzone były w bez mała tysiącu organizacji z 62 krajów. Badania te dostarczają wiedzy o dziewięciu wymiarach kultur organizacyjnych i sześciu wymiarach zachowań przywódców.

W projekcie GLOBE przywództwo zostało zdefiniowane jako zdolność jednostki do wpływania, motywowania i umożliwiania innym przyczyniania się do skuteczności i sukcesu organizacji, której są członkami (House, Hanges, Javidan, Dorfman, Gupta, 2004, s. 15). W badaniu tym zidentyfikowano 21 cech lub zachowań liderów, które powszechnie postrzegane są jako wpływające na skuteczność przywództwa, 8 powszechnie postrzeganych jako utrudniające sprawowanie przywództwa oraz 35 cech lub zachowań liderów, które w jednych kulturach uważane są jako wspierające, a w innych jako utrudniające przywództwo (tamże, s. 14). Ostatecznie wyodrębniono sześć wymiarów przywództwa:

2. Projekt badawczy „Wpływ przywództwa w szkole na zachowania agresywne i przemoc wśród uczniów" realizowany jest w ramach badań statutowych Instytutu Spraw Publicznych UJ. Celem badania jest określenie wpływu przywództwa sprawowanego przez dyrektorów szkół na efekty działania szkoły w odniesieniu do innych wskaźników niż te, które dominują we współczesnych badaniach (osiągnięcia akademickie) - zachowania społeczne (agresja i przemoc). Badania przeprowadzone były w gimnazjach wielkomiejskich, w których uczestniczyli dyrektorzy, nauczyciele i uczniowie. 
$\rightarrow$ Przywództwo charyzmatyczne/oparte na wartościach (charismatic/value-based) - ten wymiar przywództwa odzwierciedla zdolność do inspirowania, motywowania i stawiania wysokich oczekiwań przy odwołaniu się do podstawowych wartości. Wymiar przywództwa charyzmatycznego składa się z sześciu podskal: (a) wizjonerstwo, (b) inspiracja, (c) poświęcenie, (d) rzetelność, (e) decyzyjność, (f) orientacja na zadania.

$\rightarrow$ Przywództwo zorientowane na zespół (team oriented) - wymiar ten podkreśla rolę budowania zespołu i ustalania wspólnych celów przez członków zespołu. Wymiar przywództwo zorientowane na zespół zawiera pięć podskal: (a) orientacja na współpracę, (b) integracja zespołu, (c) dyplomacja, (d) wrogość (odwrócone), (e) kompetencje administracyjne.

$\rightarrow$ Przywództwo partycypacyjne (participative) - ten wymiar przywództwa odnosi się do stopnia, w jakim lider włącza innych do podejmowania i wdrażania decyzji. Wymiar przywództwa partycypacyjnego składa się z dwóch podskal: (a) autokratyzm (odwrócona), (b) niepartycypacyjność (odwrócona).

$\rightarrow$ Przywództwo zorientowane na ludzi (humane oriented) - wymiar ten odnosi się przywództwa wspierającego i taktownego, ale zawiera również współczucie i hojność. Wymiar przywództwa zorientowanego na ludzi składa się z dwóch podskal: (a) orientacja na człowieka, (b) skromność.

$\rightarrow$ Przywództwo autonomiczne (autonomous) - wyodrębniony wymiar przywództwa odnosi się do niezależności i indywidualistycznych cech przywództwa. Wymiar ten mierzony jest za pomocą jednej podskali: (a) autonomia.

$\rightarrow$ Przywództwo samo-chroniące (self-protective) - nowo zdefiniowany wymiar przywództwa odgrywa rolę w zachodniej perspektywie i określa zachowania lidera zorientowane na zapewnienie bezpieczeństwa i chronienie siebie i grupy przez wzmocnienie statusu i wizerunku. Wymiar przywództwa samo-chroniącego zawiera pięć podskal: (a) koncentracja na dobrym wizerunku, (b) świadomość statusu społecznego, (c) konfliktowość, (d) koncentracja na sobie, (e) biurokratyzm.

W badaniu wykorzystano Kwestionariusz ankiety badania kulturowego kontekstu grup społecznych i organizacji, narzędzia zaadaptowa- 
nego na podstawie projektu GLOBE przez R. Porzaka, M. Sagana i M. Zuba (Porzak, Sagan, Zub, 2011; Porzak, Sagan, 2015), który został wykorzystany za zgodą autorów.

Badanie stylów przywódczych polegało na przedstawieniu w kwestionariuszu listy zachowań i cech charakteryzujących przywódcę, do której dołączone były krótkie ich opisy (np. godny zaufania - można na nim polegać, dotrzymuje słowa). Do każdego itemu dołączone zostało pole, w którym respondent wpisywał wybrany przez siebie poziom z siedmiostopniowej skali (między 1 - "ta cecha wyjątkowo przeszkadza w zostaniu wybitnym liderem", a 7 - „ta cecha wyjątkowo pomaga w zostaniu wybitnym liderem").

\section{Badanie klimatu szkoły}

W badaniu wykorzystano wybrane pytania pochodzące $z$ kwestionariusza klimatu szkoły wykorzystanego w ramach projektu "Zdrowa szkoła" (Woynarowska, Sokolowska, Lutze, Woynarowska-Soldan, 2007). Pytania dotyczące wpływu nauczycieli na życie szkoły powiązane były w głównej mierze z rolą, jaką odgrywa dyrektor, zaś przykładowe itemy brzmiały następująco: „Dyrekcja szkoły pyta nauczycieli o opinie w sprawach dotyczących życia i pracy szkoły”, „Moje zdanie na temat życia i pracy szkoły jest brane pod uwagę", "Dyrekcja jest otwarta na propozycje i pomysły nauczycieli". Kolejne trzy pytania dotyczyły relacji między nauczycielami. I tutaj przykładowe itemy: „Relacje między nauczycielami są dobre”, "Mam zaufanie do większości nauczycieli w mojej szkole", "Czuję się akceptowany przez innych nauczycieli".

Itemy użyte do badania klimatu szkoły mierzone były na pięciostopniowej skali Likerta.

\section{Osoby badane}

Badania zostały przeprowadzone w 28 gimnazjach z dwóch wielkomiejskich lokalizacji (miasto powyżej 200 tys. mieszkańców i powyżej 800 tys. mieszkańców). W badaniu uczestniczyli dyrektorzy każdej ze szkoły $(n=28)$ i nauczyciele $(n=521)$. Wśród dyrektorów szkół $w$ badaniu wzięło udział 18 kobiet (64\%) i 10 mężczyzn (36\%). Wśród badanych nauczycieli większość stanowiły kobiety $83,5 \%$, mężczyźni stanowili $16,5 \%$. Szkoły różniły się wskaźnikiem zwrotności ankiet, który kształtował się na poziomie od 9 do 56 wypełnionych kwestionariuszy. 


\section{Wyniki badań}

Według dyrektorów cechy liderów zapewniające sukces związane są przede wszystkim ze stylem przywództwa zorientowanym na zespół (średnia 6,0) i charyzmatycznym (średnia 5,79), a w mniejszym stopniu z przywództwem zorientowanym na ludzi (średnia 4,88). Na podobnym poziomie dyrektorzy oceniają przydatność cechy przywództwa autonomicznego (średnia 4,34) i partycypacyjnego (średnia 4,32). Najniżej dla sukcesu przywództwa cenione są cechy związane ze stylem samochroniącym (średnia 3,53). Porównanie średnich poszczególnych stylów przywództwa przedstawione są na rysunku 1.

Rysunek 1. Średnie stylów przywództwa

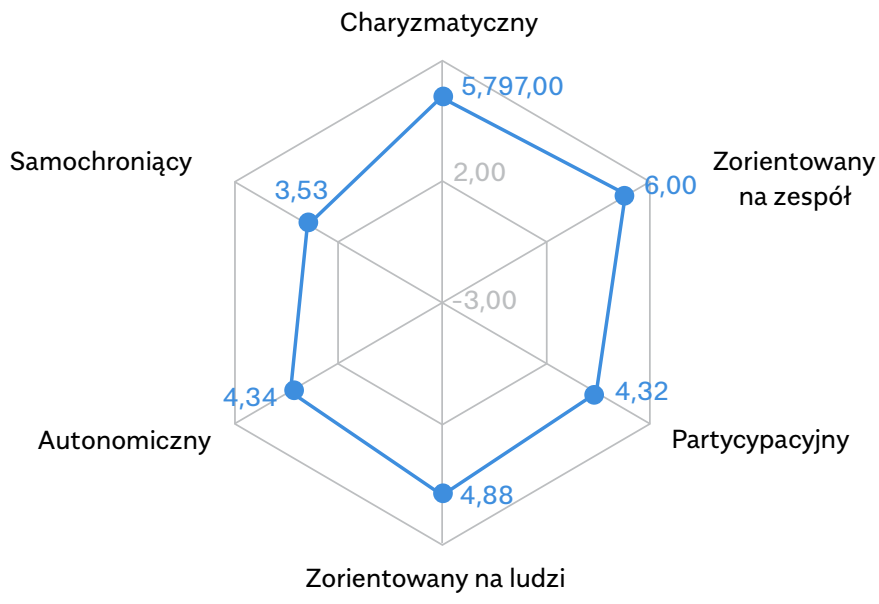

Źródło: opracowanie własne.

Bliższe przyjrzenie się statystykom opisowym (por. tabela 1.) pokazuje, że najbardziej zróżnicowane poglądy mają dyrektorzy w odniesieniu do przywództwa zorientowanego na zespół i przywództwa autonomicznego, które charakteryzują się największym rozstępem i rozproszeniem wyników wokół średniej.

W bardziej spójny sposób dyrektorzy postrzegają znaczenie stylów przywódczych, które osiągnęły średnie wyższe (przywództwo charyzmatyczne i zorientowane na zespół) i niższe (przywództwo partycypacyjne i samo-chroniące). 
Tabela 1. Statystyki opisowe stylów przywództwa

\begin{tabular}{l|r|r|r|r|r}
\multicolumn{1}{c|}{ STYL PRZYwódZTWA } & N & MIN. & MAKS. & \multicolumn{1}{c}{ ŚRED. } & \multicolumn{2}{c}{$\begin{array}{c}\text { ODCHYLENIE } \\
\text { STANDARDOWE }\end{array}$} \\
\hline Zorientowany na zespół & 28 & 5,01 & 6,75 & 6,00 & 0,551 \\
\hline Charyzmatyczny & 28 & 4,57 & 6,61 & 5,79 & 0,448 \\
\hline Zorientowany na ludzi & 28 & 1,50 & 6,63 & 4,88 & 1,141 \\
\hline Autonomiczny & 28 & 2,00 & 6,25 & 4,34 & 1,354 \\
\hline Partycypacyjny & 28 & 2,54 & 5,46 & 4,32 & 0,716 \\
\hline Samochroniący & 28 & 2,43 & 5,07 & 3,53 & 0,666
\end{tabular}

Źródło: opracowanie własne.

Większość nauczycieli pozytywnie ocenia użyte w analizie elementy klimatu szkoły (por. tabela 2.). W opisie wyników wzięte zostały pod uwagę dwa skrajne, pozytywne elementy skali: w dużym stopniu prawdziwe i całkowicie prawdziwe.

Pierwsza grupa pytań dotyczyła relacji między nauczycielami a dyrektorami. Uczestniczący w badaniu nauczyciele są zdania, że dyrektorzy szkół są wobec nich życzliwi (72,3\%), zainteresowani nimi (60,9\%). Większość nauczycieli ma też poczucie, że jest w szkole doceniana $58 \%$. Inne pytania dotykały kwestii wpływu nauczycieli na życie szkoły. Dwie trzecie badanych nauczycieli wyraziła opinię, że dyrektorzy pytają ich o zdanie w sprawach dotyczących życia i pracy szkoły. Taki sam odsetek uważa, że ich zdanie jest brane pod uwagę. Nieco mniej badanych dostrzega otwartość dyrektorów na propozycje i pomysły przedstawiane przez nauczycieli $(59,4 \%)$.

Badania pokazują, że wysoko oceniane są przez nauczycieli różne elementy klimatu związane z relacjami między nauczycielami. Nauczyciele mają poczucie, że są akceptowani przez innych nauczycieli (73\%), od których mogą otrzymać w razie potrzeby pomoc (69,6\%). Pozytywnie oceniają też relacje między sobą $(64,8 \%)$ i chęć podejmowania współpracy $(61,2 \%)$. Najniżej (choć nadal pozytywnie przez większość badanych) nauczyciele oceniają chęć uczestniczenia we wspólnych spotkaniach i imprezach oraz posiadanie zaufania do innych nauczycieli $(57,7 \%)$. 


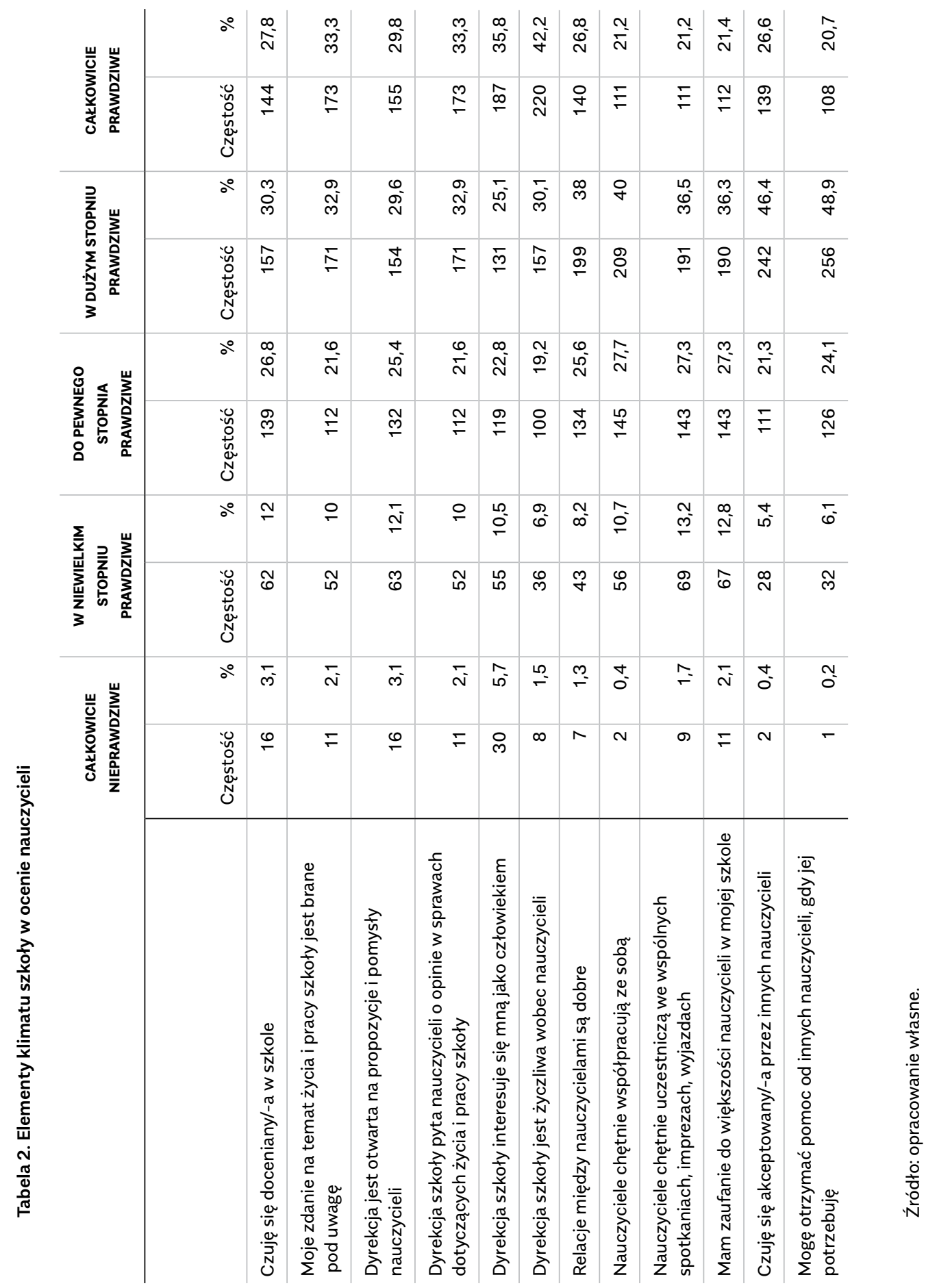


Analizę korelacji przeprowadzono w oparciu o dane pochodzące od nauczycieli, którym przypisano odpowiednio wyniki skal przywództwa dyrektora szkoły, w której pracują. Siła korelacji między elementami klimatu szkoły postrzeganymi przez nauczycieli a skalami przywództwa jest niska, mieści się $w$ przedziale między $r=-0,199$ a $r=0,260$ (por. tabela 3.).

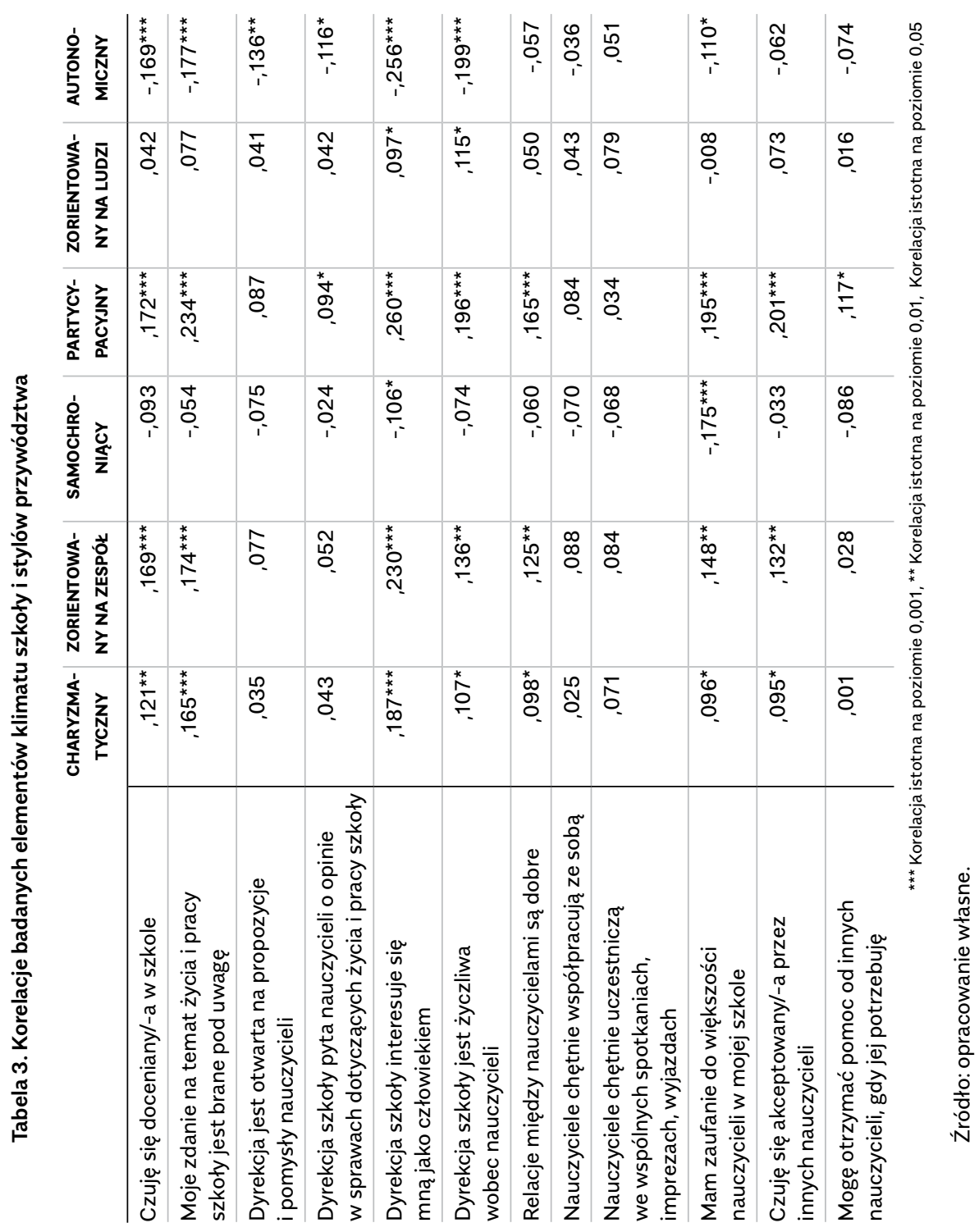


Spośród badanych stylów przywództwa przyczyniających się zdaniem dyrektorów do sukcesu osiąganego przez liderów najsilniej oraz z największą liczbą elementów klimatu szkoły postrzeganego przez nauczycieli w istotnie statystycznie sposób koreluje partycypacyjny styl przywództwa. Najsilniej ten styl przywództwa koreluje z poczuciem nauczycieli, że dyrekcja szkoły interesuje się nimi $(r=0,260)$ i przekonaniem, że ich zdanie na temat życia szkoły jest brane pod uwagę $(r=0,234)$. We wszystkich przypadkach korelacja jest dodatnia, co oznacza, że partycypacyjny styl przywództwa dyrektorów towarzyszy bardziej pozytywnemu klimatowi szkoły.

Podobnie do partycypacyjnego stylu przywództwa choć z mniejszą siłą współwystępowania i w mniejszej liczbie badanych elementów klimatu szkoły, przywództwo zorientowane na zespół i charyzmatyczne pozytywnie koreluje $z$ większością użytych $w$ analizie itemów klimatu szkoły. Przywództwo zorientowane na zespół najsilniej koreluje z poczuciem nauczycieli, że dyrekcja szkoły interesuje się nimi $(r=0,230)$ i poczuciem, że ich zdanie na temat życia szkoły jest brane pod uwage $(r=0,174)$. $Z$ podobnymi elementami klimatu szkoły najsilniej koreluje styl charyzmatyczny, lecz na nieco niższym poziomie (odpowiednio: $r=0,187$ i $r=0,165)$.

Najmniejszy związek z klimatem szkoły mają przywództwo zorientowane na ludzi i styl samochroniący, istotnie statystycznie korelacje występują w dwóch przypadkach.

Występuje jednak między tymi stylami zasadnicza różnica dotycząca kierunku korelacji. Przywództwo zorientowane na ludzi koreluje pozytywnie z takimi elementami klimatu szkoły, jak zainteresowanie dyrektora nauczycielami $(r=0,097)$ i życzliwością wobec nich $(r=0,115)$, natomiast styl samochroniący koreluje ujemnie z zainteresowaniem dyrektora nauczycielami $(r=-0,106)$ i zaufaniem między nauczycielami $(r=-0,175)$.

Wyraźnie inny charakter ma współwystępowanie autonomicznego stylu przywództwa i postrzeganych przez nauczycieli cech klimatu szkoły. W większości przypadków korelacja autonomicznego stylu przywództwa z elementami klimatu szkoły postrzeganego przez nauczycieli przybiera kierunek ujemny. Oznacza to, że z wyższym poziomem tego stylu przywództwa współwystępuje gorsze postrzeganie klimatu szkoły. Najsilniej przywództwo autonomiczne w sposób istotny statystycznie koreluje z zainteresowaniem dyrektora nauczycielami jako ludźmi 
$(r=-0,256)$, postrzeganiem dyrektora jako życzliwego wobec nauczycieli $(r=-0,199)$ i przekonaniem, że zdanie nauczycieli na temat życia i pracy szkoły jest brane pod uwage $(r=-0,177)$.

Zauważyć należy, że aktywności podejmowane wspólnie z innymi nauczycielami (współpraca i uczestnictwo we wspólnych spotkaniach) nie korelują na istotnym statystycznie poziomie z żadnym ze stylów przywództwa.

\section{Wnioski}

Przeprowadzona analiza, pomimo że nie dostarcza mocnych argumentów w postaci silnych korelacji między współwystępowaniem badanych stylów przywództwa a elementami klimatu szkoły, które mogą być związane z przywództwem nauczycieli, dostarcza jednak podstaw do wyciągania wniosków o kierunku oddziaływania stylów przywództwa sprawowanego przez dyrektorów szkół. Pierwszy z wniosków dotyczy trzech stylów przywództwa: zorientowanego na zespół, charyzmatycznego i partycypacyjnego, które wspierają klimat szkoły sprzyjający przywództwu nauczycieli.

Oznacza to, że takie cechy i zachowania liderów, jak: wizjonerstwo, inspiracja, poświęcenie, rzetelność, decyzyjność, orientacja na zadania, orientacja na współpracę, integracja zespołu, dyplomacja, przyjacielskość, kompetencje administracyjne, partycypacyjność i brak autokratyzmu sprzyjają tworzeniu klimatu dla przywództwa nauczycieli w szkołach. Zauważyć należy, że najsilniej współwystępujący z klimatem szkoły wspierającym warunki dla przywództwa nauczycieli jest styl partycypacyjny, który nie jest wskazywany przez dyrektorów jako ten, który należy do najsilniej przyczyniających się do sukcesu szkolnych liderów.

Wyniki badań wskazują również, że autonomiczny styl przywództwa negatywnie wpływa na tworzenie warunków dla przywództwa nauczycieli. Oznacza to, że niezależność oraz indywidualistyczne zachowania i cechy dyrektora przeszkadzają rozwojowi przywództwa nauczycieli. Podobnie, choć w znacznie mniejszej liczbie badanych elementów klimatu szkoły, oddziałuje styl samo-chroniący, zorientowany na zachowanie bezpieczeństwa i chronienie siebie i grupy przez wzmocnienie statusu i wizerunku.

Jedną z istotnych kwestii dla przywództwa nauczycieli, zwłaszcza w kontekście wykraczania poza rolę lidera w klasie szkolnej, jest 
współpraca między nauczycielami. Z przeprowadzonej analizy wynika, że przywództwo partycypacyjne, charyzmatyczne i zorientowane na zespół w pozytywny sposób wiąże się z relacjami między nauczycielami, wzajemną akceptacją i zaufaniem, jednocześnie samo-chroniący i autonomiczny styl przywództwa negatywnie wiążą się z zaufaniem między nauczycielami. Na tym tle żaden z badanych stylów przywództwa nie wiąże się $w$ istotny sposób z postrzeganiem przez nauczycieli chęci współpracy i wspólnego uczestnictwa w spotkaniach, imprezach i wyjazdach.

\section{Zakończenie}

W świetle przedstawionych wyników badań zrozumiałe jest łączenie przez badaczy różnych konceptualizacji przywództwa sprawowanego przez dyrektorów szkół (np. rozproszonego, demokratycznego, równoległego) z przywództwem nauczycieli (Wenner, Campbell, 2017). Wydaje się, że dla przywództwa nauczycieli niezbędne jest tworzenie sprzyjających warunków, które są inspirowane i w pewnym zakresie kształtowane przez działania podejmowane przez dyrektorów szkół. W tej perspektywie przedstawione wyniki wskazują na potrzebę brania pod uwagę nie tylko poszczególnych czynników wpływających na sprawowanie przywództwa w szkołach przez nauczycieli, ale także interakcji pomiędzy tymi czynnikami.

Na zakończenie - refleksja dotycząca relacji i współpracy między nauczycielami, które mogą być czynnikami wspierającymi lub hamującymi rozwój przywództwa nauczycieli. Wiele badań pokazuje istnienie pozytywnych relacji między nauczycielami w szkołach i dobrej między nimi współpracy (Tłuściak-Deliowska, Dernowska, 2016), a także przekonanie o zaangażowaniu w pracę zespołową (Wlazło, 2010; Kołodziejczyk, 2013, 2013a). Warto jednak zauważyć, że są również badania ukazujące negatywne zjawiska związane $z$ relacjami między nauczycielami $i$ ich współpracą, zwykle prowadzone są z innych perspektyw badawczych niż przywództwo lub klimat organizacji, np. stresory w środowisku pracy nauczyciela (Pyżalski, 2010), ewaluacji własnej pracy (Kołodziejczyk, Kołodziejczyk, 2015). Badanie przywództwa nauczycieli w kontekście współpracy i pracy zespołowej powinny w większym stopniu uwzględniać tę krytyczną perspektywę. 


\section{Bibliografia}

$\rightarrow$ Hallinger, P., Heck, R.H. (1998), Exploring the Principal's Contribution to School Effectiveness: 1980-1995, School Effectiveness and School Improvement, 9(2), 157-191.

$\rightarrow$ House, R.J., Hanges, P.J., Javidan, M., Dorfman, P.W., Gupta, V. (Eds.) (2004), Culture, leadership, and organizations: The GLOBE study of 62 societies, Thousand Oaks: Sage Publications.

$\rightarrow$ Kołodziejczyk, J. (2013), Analiza danych dotyczących wymagania "Procesy edukacyjne sq efektem współdziałania nauczycieli" [w:] G. Mazurkiewicz (red.), Jakość edukacji. Dane i wnioski z ewaluacji zewnętrznych prowadzonych w latach 2010-2011, s. 109-122, Kraków: Wydawnictwo Uniwersytetu Jagiellońskiego.

$\rightarrow$ Kołodziejczyk, J. (2013a), The Cooperation of Teachers to Improve Educational Processes. Official Conference Proceedings IAFOR, s. 716-723, The European Conference on Education, Brighton UK, July 11-14, 2013.

$\rightarrow$ Kołodziejczyk, J., Kołodziejczyk, J. (2015), Ewaluacja własnej pracy nauczycieli - obszary, rozumienie, współpraca, Forum Oświatowe, 2(54), 115-130.

$\rightarrow$ Kulesza, M. (2011), Klimat szkoły a zachowania agresywne i przemocowe uczniów, Łódź: Wydawnictwo Uniwersytetu Łódzkiego.

$\rightarrow$ Leithwood, K., Anderson, S.E., Mascall, B., Strauss, T. (2010), School leaders' influences on student learning: The four paths [w:] T. Bush, L. Bell, D. Middlewood (red.), The principles of educational leadership and management, s. 1330, London: Sage.

$\rightarrow$ Ostaszewski, K. (2012), Pojęcie klimatu szkoły w badaniach zachowań ryzykownych młodzieży, Edukacja, 4(120), 22-38.

$\rightarrow$ Porzak, R., Sagan, M. (2015), Kultura organizacyjna polskich uczelni w percepcji studentów studiów ekonomicznych, Organizacja i Kierowanie, 4, 129-145.

$\rightarrow$ Porzak, R., Sagan, M., Zuba, M. (2011), Kulturowe uwarunkowania rozwoju Polski Wschodniej-próba identyfikacji kulturowych węzłów gordyjskich, Zeszyty Naukowe WSEI seria: EKONOMIA, 3(1), 37-52. 
$\rightarrow$ Pyżalski, J. (2010), Stresory w środowisku pracy nauczyciela [w:] J. Pyżalski, D. Merecz (red.), Psychospołeczne warunki pracy polskich nauczycieli, s. 53-74, Kraków: Oficyna Wydawnicza "Impuls".

$\rightarrow$ Schein, E.H. (1985), Leadership and Organizational Culture, San Fracisco CA: Jossey-Bass.

$\rightarrow$ Tłuściak-Deliowska, A., Dernowska, U. (2016), Kultura współpracy w szkole w percepcji nauczycieli szkół gimnazjalnych, Studia Edukacyjne, 40, 127-148.

$\rightarrow$ Van Houtte, M. (2005), Climate or culture? A plea for conceptual clarity in school effectiveness research, School Effectiveness and School Improvement, 16(1), 71-89.

$\rightarrow$ Wenner, J.A., Campbell, T. (2017), The theoretical and empirical basis of teacher leadership: A review of the literature, Review of Educational Research, 87(1), 134-171.

$\rightarrow$ Wlazło, S. (2010), Nauczyciele działajq zespołowo?, Wrocław: Wydawnictwo Naukowe Dolnośląskiej Szkoły Wyższej.

$\rightarrow$ Woynarowska, B., Sokolowska, M., Lutze, I., Woynarowska-Soldan, M. (2007), Narzędzia do autoewaluacji w szkole promującej zdrowie, Edukacja Zdrowotna i Promocja Zdrowia w Szkole, 11, 49-159.

$\rightarrow$ York-Barr, J., Duke, K. (2004), What do we know about teacher leadership? Findings from two decades of scholarship, Review of Educational Research, 74(3), 255-316. 


\title{
Klimat szkoły i jego znaczenie dla podejmowania przez nauczycieli ról oraz zadań liderskich
}

\author{
Karolina Malinowska
}

Klimat szkoły, a w szczególności dwie jego składowe: styl przywództwa, jaki prezentuje dyrektor szkoły, a także relacje interpersonalne między dyrektorem a nauczycielami oraz w gronie pedagogicznym, mają znaczenie dla podejmowania lub niepodejmowania przez nauczycieli rozmaitych liderskich ról i zadań w szkole. Badania pokazują, że w polskich szkołach dyrektorzy niezbyt chętnie dzielą się z nauczycielami przywództwem. Z kolei zarówno relacje z dyrektorem, jak i relacje w gronie pedagogicznym są przez polskich nauczycieli oceniane bardzo dobrze. Pewne problemy widać jedynie w zakresie możliwości otwartego dyskutowania o problemach, ujawniania trudności, zarówno pedagogicznych, jak i wychowawczych. Zatem barierą dla wyłaniania się szkolnych liderów może być tak niechęć dyrektora do dzielenia się przywództwem, jak też opór nauczycieli i dyrektora przed dzieleniem się z innymi swoimi trudnościami w pracy. Dla wzmocnienia przywództwa nauczycieli ważny jest zatem zarówno styl kierowania przyjęty przez dyrektora szkoły, jak i większy niż dotychczas nacisk położony na budowanie zaufania we wzajemnych relacjach.

\section{Słowa kluczowe:}

\section{klimat szkoły}

przywództwo nauczycieli

dzielenie się przywództwem 


\title{
School climate and its importance for teachers' roles and leadership tasks
}

\author{
Karolina Malinowska
}

School climate and especially its two components: the leadership style presented by the principal and principal-teacher and teacher-teacher relationships are important for the teacher's leadership in school. The data indicate that Polish principals are not very willing to share leadership with teachers. In turn, almost all Polish teachers positively assess both principal-teacher and teacher-teacher relations at school. Certain problems can be seen only in terms of open discussion of problems, disclosure of difficulties, both pedagogical and educational. Thus, the barrier to the emergence of school leaders can be the reluctance of the principal to share leadership with teachers as well as resistance of teachers and principal to share his or her working difficulties with others. Therefore, to empower teacher's leadership, both the principal leadership style and the emphasis placed on building trust in relationships are important.

\section{Keywords:}

school climate

teacher leadership

shared leadership 


\section{Wprowadzenie}

Rola nauczyciela jest w samej swej istocie rolą liderską. To nauczyciel przewodzi uczniom, kieruje pracą na lekcji, inspiruje uczniów do rozwoju, określa zasady wspólnych działań itd. Jednak w szkole możliwe jest również pełnienie przez nauczycieli innych niż jedynie w odniesieniu do uczniów ról i zadań liderskich. Uwarunkowań przyjmowania na siebie tego typu ról i obowiązków przez nauczycieli można szukać zarówno w czynnikach prawnych, instytucjonalnych, organizacyjnych, jak i psychospołecznych, w tym również indywidualnych, leżących tak po stronie samych nauczycieli, jak i innych członków społeczności szkolnej, w szczególności po stronie dyrektora szkoły.

Poszukując adekwatnej perspektywy, która ujmuje tę wielowątkową kwestię, wybrałam analizę klimatu szkoły i jego znaczenia dla procesu wyłaniania się szkolnych liderów. Warto już na wstępie zauważyć, że tego typu analiza może dać jedynie częściową odpowiedź na pytanie, w jakich warunkach możliwe jest podejmowanie przez nauczycieli ról i zadań liderskich oraz pełniejsze wydobywanie z grona pedagogicznego potencjału przywódczego.

\section{Klimat szkoły i jego wymiary w kontekście przywództwa nauczycieli}

Klimat szkoły jest pojęciem, jak wiele innych w naukach społecznych, definiowanym na różne sposoby przez badaczy i teoretyków zagadnienia. W ramach tej analizy będę się posługiwać definicją spójną z definicjami klimatu organizacji, z których wywodzą się rozważania nad klimatem szkoły. Pojęcie to oznacza podzielaną przez różne osoby percepcję obiektywnej rzeczywistości, środowiska społecznego, warunków szkolnych, kultury szkoły, a nie samą obiektywną rzeczywistość, w której uczniowie i nauczyciele funkcjonują (Przewłocka, 2015a, s. 3).

Klimat szkoły obejmuje wiele wymiarów w różnym stopniu uwzględnianych przez badaczy. Wśród nich są:

$\rightarrow$ Jakość relacji społecznych (stosunki nauczyciel - uczeń, troska o dobro ucznia, stosunki między uczniami, związki przyjacielskie, relacje między nauczycielami oraz między nauczycielami i dyrektorem szkoły, relacje między szkołą i rodzicami oraz między szkołą i społecznością lokalną).

$\rightarrow$ Bezpieczne i zadbane środowisko (stan budynku, klas lekcyjnych, dostępność pomocy edukacyjnych, stan bezpieczeństwa w szko- 
le, tolerowanie agresji lub innych form dokuczania słabszym, bezpieczeństwo emocjonalne na lekcjach, akceptacja dla twórczych poszukiwań, poszanowanie odmienności, np. religijnych, równość w przestrzeganiu zasad i regulaminów szkolnych).

$\rightarrow$ Środowisko kształcenia (nastawienie na osiągnięcia w nauce szkolnej, wysokie oczekiwania przy jednoczesnym wsparciu dla uczniów, atrakcyjna interaktywna metodyka nauczania).

$\rightarrow$ Udział w życiu szkoły (styl zarządzania, warunki do aktywnego uczestniczenia nauczycieli, uczniów i rodziców w życiu szko$ł y$, autonomia nauczyciela, podział obowiązków i kompetencji, udział uczniów w zajęciach pozalekcyjnych i nieformalnej edukacji) (Blum, 2007, cyt. za: Ostaszewski, 2012, s. 27).

Wydaje się, że spośród wymienionych wymiarów klimatu szkoły dla podejmowania przez nauczycieli różnych ról i zadań liderskich szczególnie istotne mogą być: jakość relacji społecznych oraz udział w życiu szkoły. Analizę zacznę od kwestii roli dyrektora szkoły, a więc jego stylu przywództwa, tworzenia lub nie warunków dla nauczycieli do aktywnego uczestnictwa w podejmowaniu decyzji.

\section{Dzielenie się przywództwem w szkołach}

W ostatnich latach popularna w literaturze dotyczącej przywództwa edukacyjnego stała się koncepcja dzielenia się przywództwem, przywództwa rozproszonego, czy partycypacyjnego (Michalak, 2011; Madalińska-Michalak, 2015; Elsner, 2015; Mazurkiewicz, 2010; Hernik i in., 2012; Tołwińska, 2011a). Niezależnie od przyjętej definicji i nazwy w wymienionych koncepcjach istotą jest partycypacja nauczycieli w przywództwie w szkole, a więc tzw. dystrybucja przywództwa (Michalak, 2010).

W literaturze przedmiotu postuluje się rozszerzenie systemu awansu zawodowego nauczycieli o liderskie ścieżki rozwoju zawodowego, na przykład formą awansu poziomego może być między innymi tworzenie takich funkcji, jak: mentor (istniejąca w Polsce, ale wymagająca dowartościowania funkcja opiekuna stażu), mediator szkolny, promotor młodych talentów czy szkolny koordynator projektów (Hernik i in., 2014, s. 149). W wielu szkołach w Polsce są nauczyciele pełniący tego typu funkcje. Praca zespołowa jest dziś przecież w szkołach nie tylko pożądana, ale jest również wymogiem prawnym, a co za tym idzie, istnieje potrzeba wyłaniania się liderów rozmaitych zespołów, takich jak: zespoły przedmio- 
towe, nauczyciele uczący w jednej klasie, zespoły wychowawcze, zespoły mające na celu wypracowanie indywidualnych form pomocy dla uczniów ze specjalnymi potrzebami edukacyjnymi czy też inne zespoły zadaniowe. Ponadto nauczyciele mogą pełnić wiele nieformalnych ról przywódczych.

Warto zauważyć, że, jak wynika z badań, włączenie nauczycieli w proces przywództwa w szkole pozytywnie wpływa na ich efektywność i zaangażowanie uczniów (Harris, 2011). Ten typ przywództwa zakłada bowiem dużą możliwość wyzwalania potencjału nauczycieli, wspierania ich rozwoju, wzmacniania poczucia odpowiedzialności, co przekłada się również na pracę z uczniami. Ponadto dzielenie się przywództwem może wspierać współpracę w gronie pedagogicznym.

Trudno jednak ocenić, na ile w polskich szkołach ten stosunkowo nowy styl przywództwa stanowi obowiązującą praktykę, na ile zaś wciąż to jedynie bardziej postulat. W Międzynarodowym Badaniu Nauczania i Uczenia się TALIS 2013 starano się uchwycić to, na ile dyrektor decyzje podejmuje sam, a na ile odpowiedzialność za poszczególne sprawy ponoszą też inne podmioty lub osoby. $Z$ badania wyłonił się obraz polskich dyrektorów jako osób z jednej strony przeciążonych swoimi obowiązkami, bez wystarczającego wsparcia i zaangażowania ze strony rodziców, borykających się z problemami niewystarczających środków finansowych i innych zasobów szkoły, a z drugiej strony liderów, którzy biorą na siebie coraz więcej zadań, nie dzieląc się odpowiedzialnością i władzą z innymi (Hernik, 2015). Kamila Hernik, analizując wyniki badania TALIS 2013, wskazuje na widoczne w postawie dyrektorów napięcie między chęcią utrzymania kontroli, tam gdzie to jest możliwe, i niemożnością poradzenia sobie z tym, a co za tym idzie, trudnością w skupianiu się na działaniach przywódczych. Wydaje się, że rozwiązaniem w tej sytuacji mogłoby być przynajmniej częściowe podzielenie się zadaniami z innymi podmiotami, w tym w szczególności z nauczycielami.

Badanie TALIS 2013 pokazało również, że w Polsce nieco ponad trzy czwarte nauczycieli deklaruje, że dyrektor "stwarza im możliwość aktywnego uczestnictwa w podejmowaniu decyzji dotyczących szkoły", ale tylko ok. $12 \%$ zgodziło się z tym stwierdzeniem zdecydowanie (Przewłocka, 2015b).

Zatem wśród czynników wspierających podejmowanie przez nauczycieli rozmaitych ról i zadań liderskich, z pewnością należy wymienić postawę dyrektora szkoły, w tym styl przywództwa, jaki reprezentuje. Jeśli dyrektor jest mocno przywiązany do hierarchicznej struktury władzy i wykazuje się 
bardzo dużą odpowiedzialnością za większość szkolnych spraw, może to stwarzać warunki, w których nauczycielom brakuje motywacji do brania na siebie większej odpowiedzialności. Może być również tak, że dyrektor szkoły jest po prostu niechętny, by nauczyciele partycypowali w podejmowaniu pozaklasowych działań czy decyzji i wtedy taka inicjatywa ze strony nauczycieli wymagałaby od nich bardzo dużej siły i motywacji.

\section{Relacje nauczycieli i dyrektora szkoły}

Zarówno styl przywództwa, jak również relacje interpersonalne panujące w szkole są częścią klimatu szkoły i mają znaczenie w omawianej kwestii. Jak wskazuje Bożena Tołwińska (2011b), szkoła jest specyficzną organizacją, której główną wartością są ludzie, a oddziaływania realizowane są w bezpośrednich codziennych kontaktach między nimi. Dlatego stosunki międzyludzkie są jednym z ważniejszych czynników wspierających lub utrudniających rozwój szkół.

Podejmowanie przez nauczycieli ról i zadań liderskich zależeć będzie między innymi od tego, jak będą się czuli w gronie innych nauczycieli i jakie stosunki będą ich łączyć z dyrektorem szkoły. Relacje w gronie pedagogicznym oraz między dyrektorem a nauczycielami, w tym: poziom zaufania i otwartości, podejmowanie współpracy, wzajemne wsparcie wpływają na zaangażowanie i satysfakcję zawodową nauczycieli, a co za tym idzie, również na gotowość do podejmowania dodatkowych ról i zadań, np. liderskich.

Danych w tym zakresie dostarcza między innymi przeprowadzone przez Instytut Badań Edukacyjnych badanie „Bezpieczeństwo uczniów i klimat społeczny w polskich szkołach" (Przewłocka, 2015c). Badanie obejmowało uczniów, wychowawców, pedagogów i psychologów szkolnych, pozostałych nauczycieli oraz dyrektorów ze szkół: podstawowych (od klasy IV), gimnazjów, liceów, techników oraz zasadniczych szkół zawodowych. Jak się okazuje, zdecydowana większość nauczycieli bardzo wysoko ocenia dyrektora i jego relacje z gronem pedagogicznym (wykres 1.), przy czym dyrektorzy w niewielkich szkołach są oceniani lepiej niż ci w szkołach większych. Ponad $80 \%$ ogółu badanych nauczycieli deklaruje, że dyrektor ich szkoły traktuje nauczycieli z szacunkiem, pomaga im $w$ trudnych sytuacjach $i$ jest otwarty na ich propozycje. Podobny odsetek uważa, że dyrektor pozostawia nauczycielom decyzje dotyczące pracy z uczniami, przy czym w tej kwestii odpowiedzi badanych nie są już tak bardzo zdecydowane: o ile w przypadku poprzednich 
stwierdzeń po ok. $40 \%$ wybierało odpowiedzi „zdecydowanie tak" i „raczej tak", o tyle w kwestii pozostawiania decyzji tylko $20 \%$ wybrało opcję zdecydowaną. Około $70 \%$ nauczycieli potwierdza, że dyrektor docenia pracę nauczycieli, traktuje ich sprawiedliwie i ufa im. Jednocześnie, co warto podkreślić, niemal jedna czwarta nauczycieli wskazuje na problem niechętnego przyznawania się przed dyrekcją do problemów dydaktycznych i wychowawczych (Przewłocka, 2015c).

Wykres 1. Odsetek nauczycieli zgadzających i niezgadzających się z podanymi stwierdzeniami dotyczącymi relacji z dyrektorem

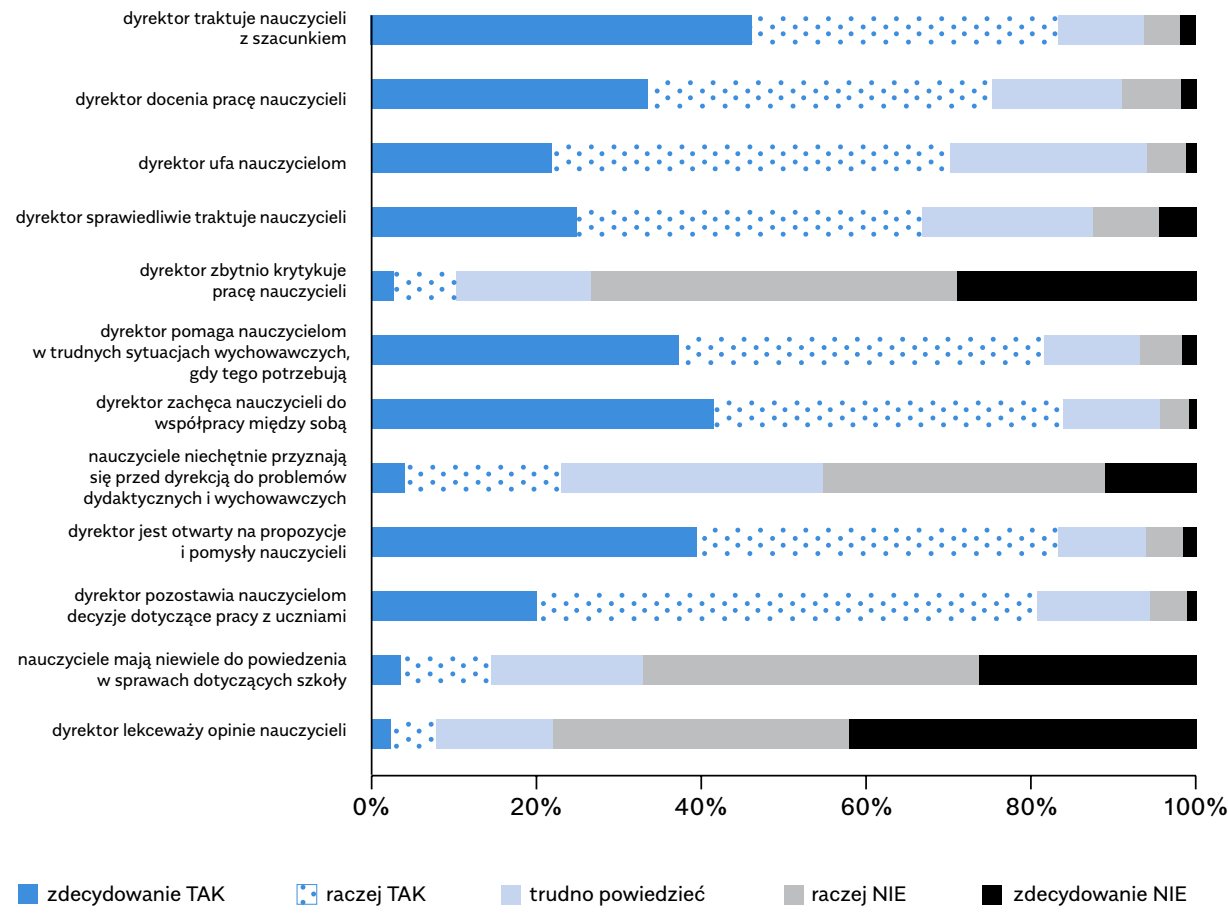

Źródło: Przewłocka, J. (2015), Bezpieczeństwo uczniów i klimat społeczny w polskich szkołach, Warszawa: Instytut Badań Edukacyjnych, s. 100.

\section{Relacje w gronie nauczycieli}

Podobnie relacje w gronie pedagogicznym zdecydowana większość nauczycieli ocenia pozytywnie. Ponad $80 \%$ nauczycieli potwierdza, że 
nauczyciele często pomagają sobie w rozwiązywaniu trudności wychowawczych (wykres 2.). Jednocześnie co czwarty badany twierdzi, że nauczyciele niechętnie przyznają się przed innymi nauczycielami do problemów. A 30\% nie ma w tej kwestii zdania. Zatem kłopot w przyznawaniu się do trudności istnieje, zdaniem znaczącego odsetka nauczycieli, zarówno w relacjach z dyrektorem szkoły, jak i innymi nauczycielami.

Większość nauczycieli pozytywnie ocenia możliwość uzyskania pomocy kolegów w sytuacji konieczności wykonania większej pracy. Gorzej niż wsparcie oceniany jest natomiast poziom zaufania: niewiele ponad połowa potwierdza, że nauczyciele ufają sobie wzajemnie, a tylko co dziesiąty respondent wybrał odpowiedź „zdecydowanie tak". Niewiele jest negatywnych opinii wskazujących na rywalizację czy niedobrą atmosferę; jednak ponad $40 \%$ nauczycieli potwierdza, że grono jest podzielone i są wyraźne grupy trzymające się razem. Jak wskazuje Jadwiga Przewłocka, zarówno poziom wsparcia, jak i zaufania, jest najwyższy w małych szkołach. W dużych szkołach z kolei większa jest rywalizacja między nauczycielami (Przewłocka, 2015c).

Wykres 2. Odsetek nauczycieli zgadzających i niezgadzających się z podanymi stwierdzeniami dotyczącymi relacji w gronie pedagogicznym

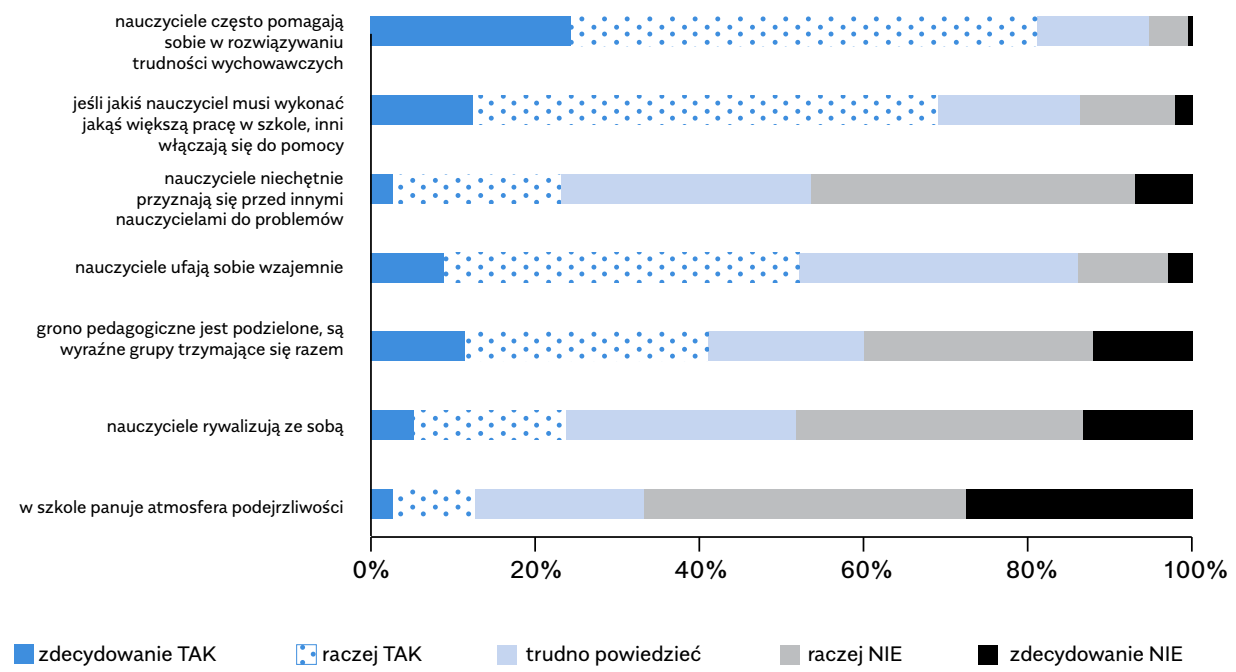

Źródło: Przewłocka, J. (2015), Bezpieczeństwo uczniów i klimat społeczny w polskich szkołach, Warszawa: Instytut Badań Edukacyjnych, s. 99. 
Możliwość otwartego dyskutowania o problemach, ujawniania trudności zarówno pedagogicznych, jak i wychowawczych oraz uzyskiwania wsparcia przez nauczycieli to ważne składowe pozytywnego klimatu szkoły. Badanie TALIS 2013 potwierdza pewne problemy polskiej szkoły w tym zakresie. Mimo że niemal wszyscy dyrektorzy szkół (93\%) deklarują, iż „pracownicy szkoły otwarcie rozmawiają o trudnościach", to stosunkowo rzadko w porównaniu do swoich dyrektorów z innych krajów są w pełni przekonani co do tej odpowiedzi. Wśród dyrektorów gimnazjów tylko $18 \%$ wybrało odpowiedź „zdecydowanie tak", a np. w Słowacji i Rumunii odsetek ten wyniósł $41 \%$, natomiast średnia TALIS dla dyrektorów ze wszystkich badanych krajów wynosi $26 \%$. Badanie pokazało podobny wynik w zakresie odpowiedzi o "wzajemnym szacunku dla pomysłów innych nauczycieli" - jego obecność w szkole potwierdzają niemal wszyscy dyrektorzy, jednak tylko 13\% zdecydowanie wyraża swoje zdanie, podczas gdy średnia dla dyrektorów ze wszystkich krajów wyniosła 23\% (Przewłocka, 2015b).

Wracając do badania dotyczącego klimatu szkoły, analizy pokazują, że relacje z kolegami z pracy mają duży wpływ na satysfakcję i samopoczucie nauczycieli (Przewłocka, 2015c). Jeszcze większy wpływ zanotowano w wypadku relacji z dyrektorem szkoły. Większość nauczycieli deklaruje zadowolenie z pracy w swojej szkole, ponad trzy czwarte deklaruje, że w swojej szkole "czuje się u siebie", tyle samo poleca ją jako dobre miejsce pracy. Jedynie jeden na sześciu nauczycieli często czuje się zestresowany w swojej szkole (wykres 3.).

Wykres 3. Odsetek nauczycieli zgadzających i niezgadzających się z podanymi stwierdzeniami dotyczącymi zadowolenia z pracy

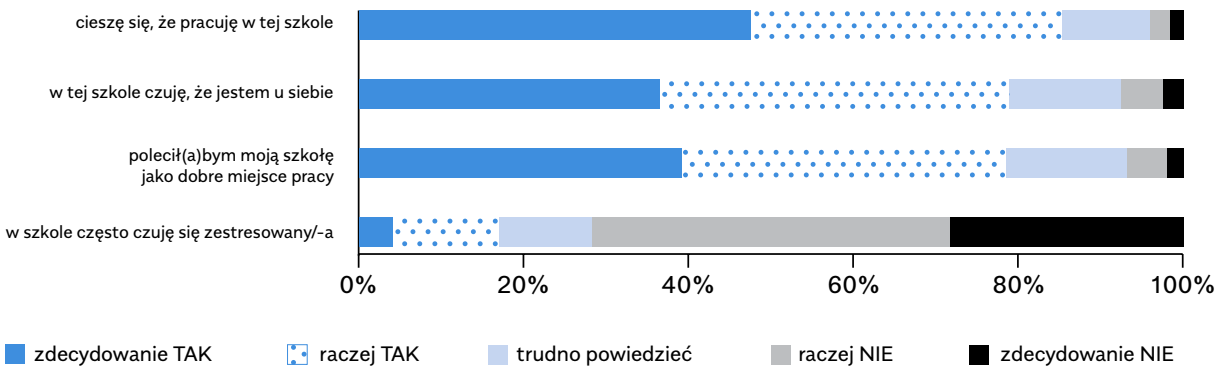

Źródło: Przewłocka, J. (2015), Bezpieczeństwo uczniów i klimat społeczny w polskich szkołach, Warszawa: Instytut Badań Edukacyjnych, s. 101. 
Uzupełnieniem danych dotyczących klimatu szkoły w kontekście podejmowania przez nauczycieli ról i zadań liderskich mogą być wyniki Badania Czasu i Warunków Pracy Nauczycieli (Federowicz i in., 2013), które pokazują, że ci nauczyciele, którzy pełnią rolę liderów zespołów przedmiotowych lub innych zespołów zadaniowych w szkole (stanowili oni $1 / 4$ wszystkich badanych nauczycieli), są jednocześnie znacznie częściej niż inni nauczyciele wychowawcami klas. Co więcej, nauczyciele pełniący funkcję lidera zespołu należą do tych, którzy na przygotowanie zajęć lekcyjnych i pozalekcyjnych poświęcają więcej czasu niż pozostali. Autorzy raportu wskazują możliwe wyjaśnienia tej sytuacji: być może właśnie dlatego ci nauczyciele wybierani są na liderów zespołów albo na odwrót, jako liderzy czują się zobowiązani do głębszych przygotowań. Tak czy inaczej, generalnie poświęcają więcej czasu na codzienne przygotowanie zajęć czy sprawdzanie prac (Federowicz i in., 2013). Wynik ten może wskazywać, że szkolni liderzy to osoby o szczególnym podejściu do pracy, bardziej niż inni zaangażowane w swoją pracę i odpowiedzialne za szkołę, zarówno jej edukacyjną, jak i wychowawczą funkcję. Wydaje się jednak, że nie można tych postaw rozumieć jedynie jako pewnych indywidualnych cech tkwiących $w$ danym nauczycielu. Na rozwój takiej aktywnej postawy może mieć również wpływ klimat szkoły. John Fischer i Jeff Taylor (2012), dowodzą, że nauczyciele, którzy lubią swoją pracę, czują satysfakcję z jej wykonywania i mają poczucie własnego znaczenia, zazwyczaj bardziej się angażują i osiągają lepsze wyniki. Pozytywne nastawienie i energia sprawiają, że tacy nauczyciele mogą zrealizować więcej zadań, a co za tym idzie - celów. Wzmacnianie tego typu postaw wśród nauczycieli zarówno przez samo grono nauczycieli, jak i dyrektora szkoły, a także uczniów, ich rodziców czy przedstawicieli samorządów lokalnych może dać wiele korzyści społecznościom szkolnym.

\section{Zakończenie}

Podsumowując, wydaje się, że w bardzo wielu polskich szkołach istnieje potencjał dzielenia się przez dyrektorów przywództwem z nauczycielami wynikający między innymi z pozytywnych relacji interpersonalnych i ogólnie dobrej atmosfery panującej w gronie pedagogicznym.

Barierą może być jednak opór nauczycieli przed dzieleniem się z innymi swoimi trudnościami w pracy. Przyznanie się do tego, że coś nie wychodzi, jest trudne, stanowi problem, naraża nauczycieli na ocenę. 
Z kolei przyjmowanie na siebie ról i zadań liderskich wymaga dużego zaufania do kolegów w pracy i przełożonego oraz, co ważne, możliwości sięgania po wsparcie, gdy to konieczne. Inną barierą może być postawa dyrektora szkoły i brak chęci lub umiejętności przekazywania odpowiedzialności za sprawy szkoły na nauczycieli. Nie wystarczy więc, by w szkołach była dobra atmosfera. Nie bez powodu fundamentem wielu koncepcji przywództwa jest zaufanie w relacjach międzyludzkich (Tołwińska, 2010). To przywódca ma tworzyć takie środowisko, w którym członkowie organizacji mogą czuć się bezpiecznie, bo to jest warunkiem zaufania i angażowania się w jakiekolwiek działania. Brak zaufania niszczy chęć do takich działań, stanowi poważną barierę w porozumiewaniu się nawet wtedy, gdy kompetencje pracowników są wysokie (tamże). 


\section{Bibliografia}

$\rightarrow$ Federowicz, M., Haman, J., Herczyński, J., Hernik, K., Krawczyk-Radwan, M., Malinowska, K., Pawłowski, M., Strawiński, P., Walczak, D. i Wichrowski, A. (2013), Czas pracy i warunki pracy w relacjach nauczycieli. Raport tematyczny z badania, Warszawa: Instytut Badań Edukacyjnych.

$\rightarrow$ Fischer, J.M., Taylor, J. (2012), Wspieranie zespołów nauczycieli w procesie podejmowania decyzji [w:] G. Mazurkiewicz (red.), Jakość edukacji. Różnorodne perspektywy, s. 235-249, Kraków: Wydawnictwo Uniwersytetu Jagiellońskiego.

$\rightarrow$ Harris, A. (2011), Distributed leadership: implications for the role of the principal, Journal of Management Development, 31(1), s. 7-17.

$\rightarrow$ Hernik, K., Wasilewska, O., Kasprzak, T. (2012), Kierunki rozwoju przywództwa szkolnego w Europie, Polityka Społeczna, nr tematyczny 1, 10-15.

$\rightarrow$ Hernik, K., Przewłocka, J., Smak, M., Piwowarski, R. (2014), Rozwój kompetencji nauczycieli [w:] M. Federowicz, J. Choińska-Mika, D. Walczak (red.), Raport o stanie edukacji. Liczq się nauczyciele, s. 129-156, Warszawa: Instytut Badań Edukacyjnych.

$\rightarrow$ Hernik, K. (2015), Przywództwo szkolne: rola i zadania dyrektorów [w:] K. Hernik (red.), Polscy nauczyciele i dyrektorzy w Międzynarodowym Badaniu Nauczania i Uczenia się TALIS 2013, s. 72-92, Warszawa: Instytut Badań Edukacyjnych.

$\rightarrow$ Michalak, J.M. (2010), Przywództwo edukacyjne w budowaniu potencjału szkoły [w:] S.M. Kwiatkowski, J.M. Michalak (red.), Przywództwo edukacyjne w teorii i praktyce, s. 63-81, Warszawa: Fundacja Rozwoju Systemu Edukacji.

$\rightarrow$ Michalak, J.M. (2011), Przywództwo w zarządzaniu szkołą, Warszawa: Ośrodek Rozwoju Edukacji.

$\rightarrow$ Madalińska-Michalak, J. (2015), Dyrektor szkoły liderem - perspektywy i inspiracje, Warszawa: Wolters Kluwer.

$\rightarrow$ Ostaszewski, K. (2012), Pojęcie klimatu szkoły w badaniach zachowań ryzykownych młodzieży, Edukacja, 4(120), s. 23-38. 
$\rightarrow$ Przewłocka, J. (2015a), Klimat szkoły i jego znaczenie dla funkcjonowania uczniów w szkole. Raport o stanie badań, Warszawa: Instytut Badań Edukacyjnych.

$\rightarrow$ Przewłocka, J. (2015b), Klimat szkoły [w:] K. Hernik (red.), Polscy nauczyciele i dyrektorzy w Międzynarodowym Badaniu Nauczania i Uczenia się TALIS 2013, s. 59-63, Warszawa: Instytut Badań Edukacyjnych.

$\rightarrow$ Przewłocka, J. (2015c), Bezpieczeństwo uczniów i klimat społeczny w polskich szkołach, Warszawa: Instytut Badań Edukacyjnych.

$\rightarrow$ Tołwińska, B. (2010), Kompetencje społeczne dyrektorów szkół a przywództwo [w:] S.M. Kwiatkowski, J.M. Michalak (red.), Przywództwo edukacyjne w teorii i praktyce, s. 159-174, Warszawa: Fundacja Rozwoju Systemu Edukacji.

$\rightarrow$ Tołwińska, B. (2011a), Kierowanie szkołą: rola dyrektora - partycypacja nauczycieli [w:] S.M. Kwiatkowski, J.M. Michalak, I. Nowosad (red. nauk.), Przywództwo edukacyjne w szkole i jej otoczeniu, s. 105-113, Warszawa: Wydawnictwo Difin.

$\rightarrow$ Tołwińska, B. (2011b), Relacje międzyludzkie w kulturze szkoły sprzyjającej uczeniu się [w:] A. Cudowska (red.), Kierunki rozwoju edukacji w zmieniającej się przestrzeni społecznej. Księga Jubileuszowa dedykowana profesorowi doktorowi habilitowanemu Michałowi Balickiemu, s. 536-543, Białystok: Trans Humana Wydawnictwo Uniwersyteckie. 



\section{Rozwijanie kompetencji przywódczych nauczycieli w trakcie ponadnarodowej mobilności w projektach edukacyjnych programu Erasmus+}

Liliana Budkowska

Artykuł podejmuje problematykę rozwijania kompetencji przywódczych nauczycieli realizujących ponadnarodowe mobilności edukacyjne, które związane są z realizacją międzynarodowych projektów edukacyjnych w ramach programu Erasmus+.

Słowa kluczowe:

ponadnarodowa mobilność edukacyjna

kompetencje

przywództwo nauczycieli 


\title{
Developing teachers' leadership competences during transnational learning mobility in educational projects of programme Hrasmus+
}

\author{
Liliana Budkowska
}

The article presents the issues of developing the leadership competences of teachers implementing transnational learning mobility, which are related to the implementation of the international educational projects, within the programme Erasmus+.

Keywords:

transnational learning mobility

competences

teacher leadership 


\section{Wprowadzenie}

W niniejszym artykule podejmuję problematykę rozwijania kompetencji przywódczych nauczycieli realizujących ponadnarodowe mobilności edukacyjne. Uczestnictwo nauczycieli w międzynarodowych projektach edukacyjnych sprzyja rozwojowi szkół, co przejawia się w poszerzeniu oferty edukacyjnej szkoły, większej integracji zespołu nauczycielskiego, wzbogaceniu bazy dydaktycznej oraz w podejmowaniu współpracy z szeroko rozumianym środowiskiem lokalnym, w którym funkcjonuje dana placówka edukacyjna. Jakkolwiek projekty są w zasadniczej mierze realizowane przez nauczycieli, to postawa i zaangażowanie koordynatora projektu, będącego również nauczycielem, ma ogromny wpływ na efektywność podejmowanych $w$ trakcie realizacji projektu działań oraz na wypracowanie rezultatów końcowych, zarówno w postaci produktów takich, jak publikacje, scenariusze zajęć, jak i ukształtowania kompetencji kluczowych.

Na tekst składają się rozważania odnośnie do metody projektów we współczesnej Europie, rodzajów projektów oraz kompetencji nauczycieli, a zwłaszcza postawy przywódczej kadry edukacyjnej w odniesieniu do mobilności ponadnarodowych realizowanych podczas międzynarodowych projektów edukacyjnych.

\section{Metoda projektów w kontekście mobliności}

Jak słusznie zauważa Stefan M. Kwiatkowski, „problemy edukacyjne nie znają granic. Dlatego też celowe jest rozpatrywanie rodzimych priorytetów w tej dziedzinie - i uwarunkowań ich realizacji - na szerszym, europejskim tle" (2006, s. 10).

Przy czym, warto zauważyć, że Unia Europejska wyznacza jedynie cele, ramy i kierunki polityki edukacyjnej, zaś państwa członkowskie indywidualnie kształtują swoje krajowe polityki edukacyjne i to one podejmują odpowiednie działania. Wspólnota Europejska zachęca państwa członkowskie do współpracy w dziedzinie edukacji, wspierania działań z zakresu organizacji systemów kształcenia, przy uwzględnianiu ich różnorodności kulturowej i językowej. Zapis art. 149 Traktatu o Unii Europejskiej i Traktatu ustanawiającego Wspólnotę Europejską wyraźnie stwierdza, iż "Wspólnota przyczynia się do rozwoju edukacji o wysokiej jakości, poprzez zachęcanie do współpracy między państwami członkowskimi oraz - jeśli jest to niezbędne - poprzez wspieranie i uzupełnianie ich działalności, w pełni szanując odpowiedzialność państw człon- 
kowskich za treść nauczania i organizację systemów edukacyjnych, jak również ich różnorodność kulturową i językową" (2006, s. 112). Pozostawienie tak dużej części tworzenia oraz realizacji polityki edukacyjnej w gestii państw członkowskich jest wyrazem uznania ich różnorodności i potrzeby jej zachowania. Określono to najpełniej w jednym z dokumentów wspólnotowych „Edukacja w Europie”, który odzwierciedla bogactwo języków, kultur i systemów będące nieodłącznym elementem tożsamości należących do niej krajów i regionów. Systemy edukacyjne rozwijały się przez długie lata w specyficznych warunkach społecznych i kulturowych danych krajów. Dlatego w poszczególnych państwach i regionach istnieją rozmaite instytucje edukacyjne, obowiązują odmienne zasady naboru, nauka rozpoczyna się i kończy w innym czasie, a przyznawane kwalifikacje, tytuły i stopnie naukowe odzwierciedlają różnorodność programów nauczania, systemów kształcenia i szkolenia. Wszystkie państwa bardzo wysoko cenią sobie tę różnorodność; jest ona także wspólnym dobrem Europejczyków. Należy więc umożliwić im korzystanie z tej różnorodności bez ograniczeń - to zaś wymaga rozszerzenia współpracy i zwiększenia mobilności.

\section{Rodzaje projektów edukacyjnych}

Metoda projektów ze swojego założenia daje nauczycielowi i uczniom dużą swobodę działania, zarówno jeśli chodzi o rodzaj i zakres projektu, jak i sposób zorganizowania pracy. W literaturze przedmiotu nie pojawia się zatem jeden podział na rodzaje projektów. Ze względu na fakt, że projekt może przybierać różne formy, a tym samym być realizowany w różnoraki sposób, kryteriami podziału są najczęściej: cel i charakter działania, wiek i liczba uczestników, czas realizacji czy też umiejętności metodyczne nauczyciela.

Zdaniem Mirosława S. Szymańskiego możliwe jest współistnienie różnorodnych rodzajów metody projektów. Zaproponował on trzy możliwe warianty o różnym "stopniu swobody" (2010, s. 89):

$\rightarrow$ wramu nauczania, to taki, w ramach którego uczniowie wspólnie z nauczycielem, po zapoznaniu z programem nauczania danego przedmiotu, poszukują interesujących zagadnień i problemów, które mogą przyjąć właśnie postać projektów. W tego typu projektach cała klasa wykonuje projekt przedmiotowy podzielony na "podprojekty", realizowane przez mniejsze grupy uczniowskie. 
$\rightarrow$ Projekt typu "wykonujemy konkretne zlecenia", który może być wykonywany na zlecenie zewnętrzne, na przykład innej szkoły, przedszkola czy jednostki samorządu terytorialnego, lub zlecenie wewnętrzne - szkolne, na przykład związane z przygotowaniem uroczystości, przedsięwzięcia.

Nieco inny podział rodzajów projektów zaproponowała Krystyna Chałas, za kryterium obierając charakter działania. Wyróżniła dwie grupy projektów:

$\rightarrow$ zorientowane na działalność poznawczą,

$\rightarrow$ zorientowane na działalność praktyczną.

Wśród projektów nakierowanych na działalność poznawczą, rozumianą jako opis rzeczywistości przyrodniczej, społecznej czy technologicznej, będą projekty typu "opisać", w których podstawowym źródłem danych jest obserwacja oraz literatura, a także projekty typu badawczego, polegające na zebraniu i usystematyzowaniu informacji na drodze postępowania badawczego. Rezultatem tego rodzaju projektów są opracowania prezentowane przez uczniów.

Wśród projektów zorientowanych na działalność praktyczną znajdują się projekty mające charakter służebny wobec społeczności szkolnej czy lokalnej oraz projekty techniczne, mające na celu usprawnienie działania. Autorka podkreśla jednak, że najczęściej projekty nie występują w czystej postaci. Często bowiem projekty nakierowane na działalność praktyczną poprzedzone są realizacją projektów poznawczych typu "opisać" (Chałas, 2000, s. 17-18). Podobne spojrzenie na rodzaje projektów przedstawia w poradniku Jak zorganizować i prowadzić gimnazjalne projekty edukacyjne Jacek Strzemieczny, który wyróżnia projekty o profilu badawczym oraz projekty o profilu zadaniowym. Projekty o profilu badawczym, z problemem w formie otwartego pytania, uczą szukania informacji i analizowania ich, krytycznego myślenia, stawiania hipotez i ich sprawdzania, a także przedstawiania i obrony wybranych rozwiązań. Dzięki temu uczniowie podejmą prawdziwy intelektualny wysiłek i w pogłębiony sposób poznają fragment rzeczywistości, który jest dla nich ważny i przez to ciekawy. Zdaniem autora wspomnianego poradnika inny charakter mają projekty zadaniowe, w których większą wagę uzyskują praktyczne działania uczniów, a nie badania i analiza. Zagadnienie, którym wtedy zajmują się uczniowie, nakierowane jest na 
rozwiązanie realnego problemu poprzez podjęcie konkretnych działań (Strzemieczny, 2010, s. 27-28).

Podsumowując, można stwierdzić, iż metoda projektów daje niezwykle dużo możliwości działania oraz aranżacji czasu i przestrzeni edukacyjnej, determinuje wiele różnorodnych podziałów na rodzaje projektów, uwzględniające zarówno kryteria ilościowe, na przykład liczbę zaangażowanych w ich realizację osób, jak i jakościowe, dotyczące ich treści i tematyki.

\section{Kompetencje nauczycieli}

Pojęcie kompetencji używane jest zazwyczaj w dwóch znaczeniach: po pierwsze, kompetencje utożsamiane są z kwalifikacjami, po drugie, termin kompetencje oznacza zakres uprawnień. W artykule poprzez kompetencje nauczycieli rozumieć będziemy kwalifikacje niezbędne do efektywnego wykonywania tego zawodu.

W literaturze nie pojawia się jedna, precyzyjna definicja kompetencji (zob. np. Czerepaniak-Walczak, 1999; Madalińska-Michalak, Góralska, 2012; Jurgiel-Aleksander, Jagiełło-Rusiłowski, 2013; Madalińska-Michalak, 2015, 2016). Mówiąc o kompetencji, najczęściej odnosimy się do cech i właściwości danej osoby. Można zatem powiedzieć, że jest to rozwinięta umiejętność robienia rzeczy dobrze, sprawności niezbędne do radzenia sobie z problemami. Wydaje się, że najpełniejszym opisem tego pojęcia jest ten, według którego kompetencja to harmonijna kompozycja wiedzy, sprawności, rozumienia oraz pragnienia (Czerepaniak-Walczak, 1999). Jest to zatem kombinacja różnych atrybutów nauczyciela, które są podstawą jego skutecznej pracy - wykorzystania wiedzy profesjonalnej i umiejętności w określonych warunkach pracy oraz kierowanie się wartościami zawodowymi.

Robert Kwaśnica (2003, s. 298-302) dokonał podziału kompetencji na dwie grupy. Pierwszą z nich stanowią kompetencje praktyczno-moralne, na które składają się takie kompetencje, jak: komunikacyjne, moralne. Druga grupa to kompetencje techniczne. W odróżnieniu od poprzednich od nich zależy instrumentalnie rozumiana efektywność działania i mają one przedmiotowo określony zakres zastosowań. Zawierają się $w$ nich zatem kompetencje postulacyjne (normatywne), kompetencje metodyczne, a także kompetencje realizacyjne, rozumiane jako umiejętność doboru środków i tworzenia warunków sprzyjających osiąganiu celów. Podział ten wyodrębnia sprawności natury 
etycznej i odróżnia je od kompetencji związanych ze sferą dydaktyczną. Zwraca uwagę fakt wyraźnego podkreślenia przez autora praktycznego wymiaru tych sprawności, co upewnia w przekonaniu nie tylko o ich wadze, ale i związku z pedagogicznym działaniem.

W badaniu kompetencji, według J. Madalińskiej-Michalak (2016), jako pojęcia pedagogicznego warto zwrócić uwagę na następujące jego cechy:

$\rightarrow$ podmiotowy charakter - kompetencje są własnością podmiotu indywidualnego (jednostki) lub podmiotu zbiorowego (np. społeczeństwo, grupa osób, organizacja);

$\rightarrow$ złożoną strukturę - kompetencje mają różną strukturę w zależności od ich rodzaju, o budowie kompetencji decydują takie ich wyznaczniki, jak chociażby: wiedza, umiejętności, cechy osobowościowe, systemy wartości, do- świadczenie, motywacja do pracy;

$\rightarrow$ stopniowalność - podmiot osiąga kompetencje na różnym poziomie, co rzutuje na przykład na sprawność i zdolność do wykonania określonego zadania, przy czym określony poziom kompetencji podmiotu jest wyznaczony przez stopień rozwoju poszczególnych elementów tworzących daną kompetencję (np. poziom wiedzy czy umiejętności w danym zakresie);

$\rightarrow$ dynamikę - wyraża się w zmianie kondycji poszczególnych korelatów kompetencji, a w rezultacie może prowadzić do zmiany całej kompetencji, co z kolei mówi o możliwości jej rozwijania;

$\rightarrow$ możliwość rozwoju - kompetencje traktujemy jako rezultat procesu uczenia się podmiotu w toku nabywania i wytwarzania znaczących dla podmiotu doświadczeń edukacyjnych w toku jego życia;

$\rightarrow$ ujawnianie się kompetencji w określonym kontekście sytuacyjnym (sytuacyjność kompetencji) - kompetencje uwidaczniają się, gdy podmiot podejmuje się wykonania zadań w określonych warunkach;

$\rightarrow$ interaktywność kompetencji wobec warunków, w jakich funkcjonuje dany podmiot - ustawiczne aktualizowanie kompetencji stosownie do kontekstu (nowe doświadczenia rzutują na rozwijanie wiedzy, doskonalenie umiejętności i postaw podmiotu, które to postawy uwidaczniają się w działaniu); 
$\rightarrow$ możliwość przeniesienia kompetencji na inne sytuacje, inne układy odniesienia - prowadzi to do poszerzania pola wolności i odpowiedzialności, a wraz z tym do zdolności do wykonywania nowych zadań (Madalińska-Michalak, 2016, s. 12).

Obecnie Komisja Europejska współpracuje z krajami członkowskimi w celu wzmocnienia "kluczowych kompetencji” - wiedzy, umiejętności i postaw, które pomogą uczniom znaleźć osobiste spełnienie, a później w życiu znaleźć pracę i uczestniczyć w życiu społecznym. Głównym celem niniejszego przeglądu jest aktualizacja zalecenia obejmującego kompetencje kluczowe, aby upewnić się, że od 2006 roku odzwierciedla ona zmiany polityczne, społeczne, gospodarcze, ekologiczne i technologiczne. Może zatem zaproponować zmiany w celu lepszego odzwierciedlenia ostatnich wydarzeń w dziedzinach, takich jak: wielojęzyczność, różnorodność kulturowa i różnorodne sposoby komunikacji, migracji, obywatelstwa i kwestii związanych ze zrównoważonym rozwojem. Kolejnym celem przeglądu jest lepsze zrozumienie potrzeb zainteresowanych stron dla przyszłego wykorzystania ram i identyfikacja przydatnych narzędzi i procesów, które mogą pomóc decydentom i praktykom w ich pracy. Ponadto przegląd ma na celu zapewnienie, że zalecenie w sprawie kluczowych kompetencji pozostaje ważnym narzędziem rozwoju systemów edukacji i szkoleń w Europie, również jedenaście lat po jego przyjęciu. Poprzez aktualizację i opracowanie zalecenia dotyczącego kluczowych kompetencji Komisja Europejska zamierza w całej Europie nadal promować nauczanie i uczenie się na podstawie kompetencji. Zaktualizowane zalecenie będzie nadal wspierać wysiłki na rzecz rozwoju kompetencji kluczowych dla wszystkich - na poziomie krajowym, regionalnym i lokalnym oraz $w$ formalnych, pozaformalnych i nieformalnych formach uczenia się, dla obywateli w każdym wieku.

Odnosząc te zapisy do nauczycieli, należy pamiętać, że aby móc je rozwijać u uczniów, sami nauczyciele powinni je posiadać. W Polsce jednym z dokumentów opisujących kompetencje nauczycieli, jest rozporządzenie Ministra Nauki i Szkolnictwa Wyższego z 17 stycznia 2012 r. w sprawie standardów kształcenia przygotowującego do wykonywania zawodu nauczyciela ${ }^{1}$, które określa wizerunek absolwenta, po 
zakończeniu kształcenia przygotowującego do wykonywania zawodu nauczyciela. Zawarte $w$ tym akcie prawnym regulacje opisują umiejętności, będące podstawą kompetencji nauczycielskich. Opis umiejętności nauczyciela przedstawia się zatem następująco:

$\rightarrow$ posiada wiedzę psychologiczną i pedagogiczną pozwalającą na rozumienie procesów rozwoju, socjalizacji, wychowania i nauczania-uczenia się;

$\rightarrow$ posiada wiedzę z zakresu dydaktyki i szczegółowej metodyki działalności pedagogicznej, popartą doświadczeniem w jej praktycznym wykorzystywaniu;

$\rightarrow$ posiada umiejętności i kompetencje niezbędne do kompleksowej realizacji dydaktycznych, wychowawczych i opiekuńczych zadań szkoły, w tym do samodzielnego przygotowania i dostosowania programu nauczania do potrzeb i możliwości uczniów;

$\rightarrow$ wykazuje umiejętność uczenia się i doskonalenia własnego warsztatu pedagogicznego, z wykorzystaniem nowoczesnych środków i metod pozyskiwania, organizowania i przetwarzania informacji i materiałów;

$\rightarrow$ umiejętnie komunikuje się przy użyciu różnych technik, zarówno z osobami będącymi podmiotami działalności pedagogicznej, jak i z innymi osobami współdziałającymi w procesie dydaktyczno-wychowawczym oraz specjalistami wspierającymi ten proces;

$\rightarrow$ charakteryzuje się wrażliwością etyczną, empatią, otwartością, refleksyjnością oraz postawami prospołecznymi i poczuciem odpowiedzialności;

$\rightarrow$ jest praktycznie przygotowany do realizowania zadań zawodowych (dydaktycznych, wychowawczych i opiekuńczych) wynikających z roli nauczyciela.

Pośród tych siedmiu grup umiejętności można wyróżnić również te, odnoszące się do kompetencji przywódczych. Zatem należy założyć, że skoro nauczyciel rozpoczynający pracę jest wyposażony $w$ te umiejętności, to realizacja międzynarodowych projektów, a szczególnie mobilności edukacyjnych w trakcie ich trwania, sprzyja rozwojowi wielu z nich, a zwłaszcza tych odnoszących się do postaw przywódczych. 


\section{Kompetencje przywódcze nauczycieli realizujących ponadnarodowe mobilności edukacyjne}

Nauczyciel, tak jak każdy, kto chciałby pełnić rolę przywódczą, powinien rozpocząć od autodiagnozy w obszarze własnego profesjonalnego przygotowania merytorycznego, pedagogicznego, psychologicznego i metodycznego.

Warto również pamiętać o refleksji, że droga do zwycięstwa publicznego wiedzie przez zwycięstwo prywatne. Zatem przyjąć należy, że zwycięstwo publiczne wynikające z przywództwa opiera się na nieustannym rozwoju człowieka i jego udanych kontaktach z innymi, co oznacza rozpoczynanie działania z wizją jego końca, bycie proaktywnym oraz wykonywanie najważniejszych rzeczy w pierwszej kolejności (Covey, 2007).

Wielowymiarowość przywództwa, w tym przywództwa nauczycielskiego, wymaga od nauczyciela odpowiedzialności pedagogicznej, która zawiera poziom etycznego postępowania i stanowi rezultat kierowania przez nauczyciela-wychowawcę własnym działaniem w stosunku do uczniów i wychowanków (Madalińska-Michalak, 2015). Odpowiedzialność ta to relacja między pedagogiem a efektem jego oddziaływań, umożliwiająca ocenę jego pracy. W odpowiedzialności tej wyłaniają się trzy poziomy: odpowiedzialność prawna za przestrzeganie przepisów prawnych obowiązujących w nauczaniu i wychowaniu, odpowiedzialność zawodowa za należyte wypełnianie obowiązków i powinności fachowych, tzn. pedagogicznych umiejętności działania, oraz odpowiedzialność etyczna przejawiająca się w postawie realizacji interesów, potrzeb i dobra dziecka oraz poczuwania się do odpowiedzialności za niego i jego rozwój (Michalak, 2004, s. 785-786).

Mówiąc o kompetencjach przywódczych nauczycieli, należy przyjąć, że na kompetencje przywódcze, powinny składać się co najmniej trzy rodzaje kompetencji, a mianowicie: kompetencje strategiczne, kompetencje społeczne i kompetencje osobiste (Madalińska-Michalak, 2016). Kompetencje strategiczne - bazujące na wiedzy i umiejętności holistycznego spojrzenia na proces uczenia się, nauczania - mówią o umiejętności podporządkowania działań określonym celom. Kompetencje społeczne wskazują na umiejętności budowania relacji z innymi, bycia zorientowanym na potrzeby innych, radzenia sobie z sytuacjami kryzysowymi i z rozwiązywaniem konfliktów. Ważną rolę odgrywają takie składowe kompetencje, jak chociażby kompetencje związane 
z komunikowaniem, zarządzaniem konfliktem oraz pracą zespołową. Kompetencje osobiste są powiązane $z$ indywidualnym sposobem realizacji zadań, co jest równoznaczne z takimi cechami, jak: otwartość, wiara we własne możliwości, dalekowzroczność, umiejętność mobilizowania innych, empatia, zaangażowanie, wytrwałość, silna wewnętrzna motywacja, zdolność adaptacji do zmian, optymizm, innowacyjność w podejściu do problemów, kreatywna postawa życiowa. Poziom tych kompetencji wpływa na ogólną jakość i skuteczność wykonywanych zadań, decyduje o szybkości i zaangażowaniu w podejmowane działania. W kompetencje te wpisują się kompetencje osobiste zewnętrzne i kompetencje osobiste wewnętrzne (tamże).

Analiza raportów końcowych projektów edukacyjnych, zawierających ponadnarodowe mobilności nauczycieli, realizowanych ze środków programu Erasmus +2 (akcja 1, sektor edukacja szkolna) potwierdza, że ponadnarodowe mobilności sprzyjają umiędzynarodowieniu szkół w Polsce. Kadra zarządzająca oraz nauczyciele mają możliwość poznawania nowoczesnych i innowacyjnych metod pracy oraz zarządzania placówką oświatową, w tym kształtowania postaw przywódczych, co pozwala na osiągnięcie głównego celu, jakim jest poprawa jakości pracy placówki w określonych przez nią obszarach wymagających zmian oraz pogłębienie współpracy międzynarodowej.

Każda szkoła czy placówka edukacyjna przedstawia plan rozwoju szkoły (School Development Plan), określający obszary wymagające poprawy, zgodność działań w projekcie z potrzebami i specyfiką placówki oraz długofalowe korzyści wynikające z udziału w projekcie. Cele projektu są określane wspólnie przez nauczycieli i dyrektora na podstawie analizy potrzeb szkoły i jej pracowników, dzięki czemu korzyści z wyjazdu odnosi nie tylko sam uczestnik wyjazdu, ale cała placówka. Wśród najczęściej pojawiających się, znajdują się również te z obszaru przywództwa, jak: efektywne komunikowanie się, rozwiązywanie trudności w twórczy sposób czy współpraca i współdziałanie z innymi.

2. Program Erasmus + jest unijną inicjatywą wspierającą edukację na obszarze Unii Europejskiej, państw ubiegających się o członkostwo w UE oraz krajów stowarzyszonych w ramach EFTA/ EOG. Program został powołany na mocy rozporządzenia Parlamentu Europejskiego i Rady nr 1288/2013 z 11 grudnia 2013 r., a jego oferta przeznaczona dla kadry edukacji szkolnej dotyczy m.in. różnych kursów doskonalenia zawodowego oraz daje możliwość obserwacji pracy i prowadzenia zajęć dydaktycznych w zagranicznych placówkach edukacyjnych. 
W ramach projektów uczestnicy otrzymują dofinansowanie na udział w takich formach wsparcia, jak: działalność dydaktyczna (teaching assignment) - działania pozwalające nauczycielom na prowadzenie zajęć dydaktycznych w szkołach partnerskich; szkolenia kadry - uczestnictwo w zorganizowanych zajęciach lub szkoleniach za granicą, job shadowing oraz udział w konferencjach czy seminariach. Nauczyciele przejawiają postawy liderskie, które warunkują zaangażowanie w proces zmian całej kadry edukacyjnej szkoły czy placówki oświatowej oraz interesariuszy szkoły - szeroko pojęte środowisko lokalne.

W trakcie ponadnarodowych mobilności nauczyciele rozwijają zatem kompetencje przywódcze. Od nauczycieli koordynujących projekty oczekuje się bowiem odpowiedzialności, umiejętności wytyczania i osiągania założonych celów oraz zachęcania i motywowania innych do wspólnej pracy na rzecz realizacji projektu. Skuteczne koordynowanie międzynarodowym projektem obejmuje wdrożenie i utrzymywanie sprawnego systemu komunikacji, wdrożenie i przestrzeganie ustalonych zasad postępowania podczas realizacji działań o kluczowym znaczeniu dla osiągnięcia celów projektu oraz wprowadzanie zmian, potrzebnych dla osiągnięcia celów i spełnienia postawionych wymagań, z zachowaniem integralności projektu.

Fundacja Rozwoju Systemu Edukacji prowadziła badania w obszarze efektów realizacji ponadnarodowych projektów (Pachocki, 2016). Wyniki badania wskazały, że postawy liderskie wśród nauczycieli biorących udział w mobilnościach ujawniają się już na etapie planowania, bowiem sama decyzja o przystąpieniu do projektu stanowi często przejaw indywidualnej inicjatywy i wynika bezpośrednio z potrzeb deklarowanych przez konkretnych nauczycieli. Jednocześnie wybór tematyki form doskonalenia za granicą jest najczęściej odpowiedzią na bieżące problemy oraz diagnozę potrzeb całej szkoły. Konieczny do przygotowania na etapie składania wniosku, europejski plan rozwoju szkoły sprzyja wspólnym działaniom kadry edukacyjnej nad planowaniem rozwoju, co równocześnie wyłania szkolnych liderów już na etapie przygotowania uczestników do realizacji wyjazdu. W procesie tym ważne są takie aspekty, jak uzgodnienie merytorycznego programu pobytu oraz poznanie kontekstu i systemu edukacji kraju i regionu, w którym realizowana będzie ponadnarodowa mobilność edukacyjna.

Postawy liderskie uczestników są widoczne przede wszystkim w deklarowanych nowych propozycjach zmian na rzecz poprawy jakości 
pracy szkoły, a jednocześnie do zachęcania nauczycieli do podejmowania działań na rzecz własnego rozwoju zawodowego oraz rozwoju szkół i placówki edukacyjnej, w której nauczyciel jest zatrudniony. Po powrocie z zagranicznej mobilności nauczyciele często inspirują innych do wprowadzania nowych pomysłów w codziennej pracy zawodowej, a także tworzą lub współtworzą grupy podejmujące inicjatywy na rzecz podnoszenia jakości pracy szkoły. Wynika to najczęściej z faktu, że podczas ponadnarodowej mobilności nauczyciele mają możliwość poznania specyfiki pracy kolegów w różnych krajach europejskich.

\section{Podsumowanie}

Można uznać, że oferta programu Erasmus+, dotycząca mobilności edukacyjnych (akcja 1, sektor Edukacja szkolna), poprzez swoją specyfikę może stać się również wsparciem w zakresie realizacji założeń reformy systemu edukacji. Bez wątpienia bowiem mamy do czynienia z pracą metodą projektów, poszerzoną o aspekt wielokulturowości, realizacji wyjazdów zagranicznych kadry pedagogicznej, kształtowania kompetencji kluczowych, przede wszystkim tych związanych ze znajomością języków obcych oraz technologiami informacyjno-komunikacyjnymi (Budkowska, 2011, s. 102). Ponadto główne cele, jakie stawiają sobie uczestnicy, to nabycie wiedzy w zakresie możliwości wykorzystania nowych metod, podejść, technik nauczania oraz pracy z uczniem; podniesienie kompetencji w zakresie języka obcego i poprawa znajomości nauczanego przedmiotu.

Dzięki udziałowi w zagranicznych mobilnościach nauczyciele poznają nowe metody i techniki pracy, które mogą wykorzystywać na co dzień na swoich lekcjach, dzięki czemu, lekcje są bardziej urozmaicone. Prowadzone zajęcia mogą w większym stopniu odpowiadać potrzebom i indywidualnym sposobom uczenia się uczniów. Nauczyciele wykorzystują interaktywne i aktywizujące metody pracy. Udział w mobilności ma także wpływ na wzrost świadomości konieczności ciągłego podnoszenia kompetencji zawodowych. Uczestnicy ponadnarodowej mobilności w ramach projektów doceniają przede wszystkim możliwość doskonalenia zawodowego i językowego za granicą, ze względu na możliwość poznania przedstawicieli innych krajów, w których funkcjonują różne systemy edukacji.

Dzięki upowszechnianiu osiągniętych rezultatów i nabytych umiejętności udział w międzynarodowych mobilnościach pomaga również 
zainteresować nauczycieli z innych szkół możliwością doskonalenia zawodowego poza granicami naszego kraju. Korzyści płynące z doskonalenia zawodowego nauczycieli za granicą mają bezpośrednie przełożenie na instytucję macierzystą. Dzięki zastosowaniu innowacyjnych technik i metod nauczania przez nauczycieli będącymi uczestnikami projektu, uczniowie doskonalą umiejętności, kompetencje w różnorodny i aktywny sposób. Wprowadzenie sposobu uczenia stawiającego ucznia w centrum uwagi i opartego na jego stylu uczenia się, podnosi atrakcyjność zajęć, rozwija motywację wewnętrzną i zapewnia edukację wysokiej jakości. Może stać się ponadto gwarantem trwałości rezultatów.

Doświadczenia ponadnarodowych mobilności pokazują zatem, że kluczową rolę w procesie zmian mogą odegrać właśnie szkolni liderzy, których aktywność i zaangażowanie ma niewątpliwie duży wpływ na powodzenie reform w obszarze systemów edukacji nie tylko w Polsce, ale i w innych krajach europejskich. 


\section{Bibliografia}

$\rightarrow$ Budkowska, L. (2011), Dyrektor szkoły liderem międzynarodowych projektów edukacyjnych. Implikacje dla rozwoju szkoły [w:] S.M. Kwiatkowski, J.M. Michalak, I. Nowosad (red.), Przywództwo edukacyjne w szkole i jej otoczeniu, s. 132-142, Warszawa: Wydawnictwo Difin.

$\rightarrow$ Chałas, K. (2000), Metoda projektów i jej egzemplifikacja w praktyce. W poszukiwaniu strategii edukacyjnych zreformowanej szkoły, Warszawa: Nowa Era.

$\rightarrow$ Covey, S.R. (2007), 7 nawyków skutecznego działania, tłum. I. Majewska-Opiełka. Poznań: REBIS.

$\rightarrow$ Czerepaniak-Walczak, M. (1999), Kompetencja: słowo kluczowe czy „wytrych” w edukacji, Neodidagmata, nr XXIV, 53-66.

$\rightarrow$ Czerepaniak-Walczak, M. (2006), Pedagogika emancypacyjna, Gdańsk: Gdańskie Wydawnictwo Psychologiczne.

$\rightarrow$ Dylak, S. (2004), Nauczyciel-kompetencje i kształcenie zawodowe [w:] T. Pilch (red.), Encyklopedia pedagogiczna XXI wieku, t. III, s. 553-567, Warszawa: Wydawnictwo Akademickie "Żak".

$\rightarrow$ Jurgiel-Aleksander, A., Jagiełło-Rusiłowski, A. (2013), Dyskurs uczenia się przez całe życie: administrowanie kompetencjami czy pytanie o ich sens i znaczenie?, Rocznik Andragogiczny, t. 20, 65-73.

$\rightarrow \quad$ Kwaśnica, R. (2003), Wprowadzenie do myślenia o nauczycielu [w:] Z. Kwieciński, B. Śliwerski (red.), Pedagogika. Podręcznik akademicki, t. II, s. 291-325, Warszawa: PWN.

$\rightarrow$ Kwiatkowski, S.M. (2006), Młodzież - praca-perspektywy. Kontekst badawczy [w:] S.M. Kwiatkowski, Z. Sirojć (red.), Młodzież na rynku pracy: od badań do praktyki, s. 89-92, Warszawa: Ochotnicze Hufce Pracy Komenda Główna.

$\rightarrow$ Michalak, J.M. (2004), Odpowiedzialność nauczyciela [w:] T. Pilch (red.), Encyklopedia Pedagogiczna XXI wieku, t. III, s. 781-791, Warszawa: Wydawnictwo Akademickie "Żak". 
$\rightarrow$ Madalińska-Michalak, J. (2016), Kompetencje przywódcze dyrektora szkoły - wyzwania wobec teorii i praktyki edukacyjnej, Kwartalnik Pedagogiczny, 4(242), 9-28.

$\rightarrow$ Madalińska-Michalak, J., Góralska, R. (2012), Kompetencje emocjonalne nauczyciela, Warszawa: Wolters Kluwer.

$\rightarrow$ Madalińska-Michalak, J. (2015), Dyrektor szkoły liderem - inspiracje i perspektywy, Warszawa: Wolters Kluwer.

$\rightarrow$ Pachocki, M. (2016), Mobilni nauczyciele zmieniajq swoje szkoły, Warszawa: Fundacja Rozwoju Systemu Edukacji.

$\rightarrow$ Rozporządzenie Ministra Nauki i Szkolnictwa Wyższego z 17 stycznia 2012 r. w sprawie standardów kształcenia przygotowującego do wykonywania zawodu nauczyciela (Dz. U. z 2012 r. poz. 131).

$\rightarrow$ Strzemieczny, J. (2010), Jak zorganizować i prowadzić gimnazjalne projekty edukacyjne. Poradnik dla dyrektorów, szkolnych organizatorów i nauczycieli opiekunów, Warszawa: ORE.

$\rightarrow$ Strykowski, W., Strykowska, J., Pielachowski, J. (2007), Kompetencje nauczyciela szkoły współczesnej, Poznań: Wydawnictwo eMPi².

$\rightarrow$ Szymański, M.S. (2010), O metodzie projektów, Warszawa: Wydawnictwo Akademickie "Żak".

$\rightarrow$ Traktat o Unii Europejskiej i Traktat ustanawiający Wspólnotę Europejską, Dz. Urz. UE C 321E 2006. 


\section{Znaczenie postaw liderskich dla rozwoju polskich szkół. Doświadczenia zagranicznych mobilności szkolnej kadry edukacyjnej}

Michał Pachocki

Artykuł przedstawia wyniki międzynarodowego badania efektów zagranicznych szkoleń kadry nauczycielskiej. Stanowi również próbę odpowiedzi na pytanie, w jakim stopniu udział w zagranicznej mobilności wpływa na kształtowanie postaw liderskich oraz w jakim stopniu przywództwo nauczycieli warunkuje zmiany zachodzące w macierzystych szkołach uczestników projektów.

\section{Słowa kluczowe:}

przywództwo nauczycieli

umiędzynarodowienie szkół

mobilność 


\section{The significance of leaders' attitudes in the development of polish schools. Experiences of transnational mobilities of educational school staff}

Michał Pachocki

The article provides overview on results of transnational impact study concerning school staff mobility projects. It is also an attempt to deliver diagnosis to what extent of extent the participation in mobility has an impact on teacher leadership and how it reflects on changes in sending schools of project participants.

\section{Keywords:}

teacher leadership

internationalisation of schools

mobility 


\section{Wprowadzenie}

We współczesnych rozważaniach na temat roli, jaką odgrywają liderzy w funkcjonowaniu szkoły, wiele uwagi poświęca się głównie przejawom postaw liderskich $w$ codziennej pracy dydaktycznej oraz relacjom grona pedagogicznego z kierownictwem. Kwestie związane z przywództwem nauczycieli pojawiają się rzadziej w kontekście umiędzynarodowienia szkoły oraz możliwości podnoszenia kompetencji, jakie daje uczestnictwo w zagranicznych szkoleniach kadry pedagogicznej.

W artykule przedstawiono wyniki badania dotyczącego projektów zagranicznych mobilności szkolnej kadry edukacyjnej, realizowanych ze środków programu Erasmus+1. Badanie zrealizowano w ramach wspólnego międzynarodowego projektu koordynowanego przez instytucje odpowiedzialne za realizację tego programu w sektorze edukacji szkolnej na Litwie, w Estonii, Finlandii, Niemczech oraz Polsce.

Aktywności badawcze zostały zrealizowane we wszystkich wymienionych wyżej krajach, zgodnie z zestandaryzowaną, metodologią (Balčiūnas, Damkuvienè, Valuckienė, 2015). W artykule przedstawione zostały wyniki ponad 5200 ankiet oraz 17 wywiadów grupowych zrealizowanych $w$ krajach objętych badaniem. Łącznie w badaniu uczestniczyło 288 szkół, które otrzymały dofinansowanie na realizację projektu i w momencie realizacji aktywności badawczych zakończyły już realizację wszystkich zaplanowanych szkoleń za granicą.

Badanie ilościowe zostało zrealizowane za pomocą ankiety, skierowanej do czterech głównych grup respondentów: uczestników zagranicznych szkoleń; innych pracowników dydaktycznych, którzy nie brali udziału w wyjazdach; uczniów (w wieku powyżej 15 lat), którzy uczestniczyli w lekcjach prowadzonych przez uczestników mobilności oraz rodziców, którzy na co dzień aktywnie uczestniczą w życiu szkoły. Tak szeroka grupa docelowa respondentów wynikała z założenia, że uczestnictwo w kursach doskonalenia zawodowego nauczycieli ma sens przede wszystkim wtedy, gdy prowadzi do refleksji nad jakością pracy dydaktycznej, zarówno w kontekście realizacji nauczania, jak i w od-

1. Program Erasmus + jest unijną inicjatywą wspierającą edukację na obszarze Unii Europejskiej, państw ubiegających się o członkostwo w UE oraz krajów stowarzyszonych w ramach EFTA/ EOG. Program został powołany na mocy rozporządzenia Parlamentu Europejskiego i Rady nr 1288/2013 z 11 grudnia 2013 r., a jego oferta przeznaczona dla kadry edukacji szkolnej dotyczy m.in. różnych kursów doskonalenia zawodowego oraz daje możliwość obserwacji pracy i prowadzenia zajęć dydaktycznych w zagranicznych placówkach edukacyjnych. 
niesieniu do jakości funkcjonowania szkoły jako instytucji (Postholm, 2012). Analiza jakościowa dotyczyła przede wszystkim danych pozyskanych podczas wywiadów grupowych oraz materiału badawczego, który zebrano $w$ ramach realizacji studiów przypadku wybranych dobrych praktyk².

Badania dotyczyły odpowiedzi na pytanie, o to, czy zagraniczne szkolenia zawodowe mają wpływ nie tylko na wyjeżdżających nauczycieli, ale także na ich macierzystą instytucję oraz jej otoczenie. W badaniach zwrócono uwagę na to, czy oferowana forma podnoszenia kompetencji ma rzeczywisty wpływ na zmianę postaw zawodowych przy założeniu, że rozwój zawodowy nauczycieli przekłada się nie tylko na przyrost wiedzy, ale przede wszystkim na umiejętność jej praktycznego zastosowania w nauczaniu (Avalos, 2011).

Chociaż kluczowe cele badania dotyczyły przede wszystkim określenia, na ile rezultaty zagranicznych mobilności kadry są trwałe i stanowią potencjalnie istotny czynnik w procesie rozwoju placówek edukacyjnych, okazało się, że istotna w procesie zmian zachodzących w szkołach po zakończeniu projektu jest także rola, jaką uczestnicy mobilności pełnią w społeczności szkolnej. Szczególnie ważne w tym kontekście okazało się to, w jakim stopniu uczestnicy wyjazdów przejawiają postawy liderskie, będące często warunkiem zaangażowania w proces zmian całego grona pedagogicznego oraz innych osób funkcjonujących w otoczeniu szkoły.

\section{Rola liderów w diagnozie potrzeb rozwojowych szkoły}

Wyniki badania pokazują, że w realizacji szkoleń zagranicznych, postawy liderskie wśród nauczycieli biorących udział w mobilnościach ujawniają się już na etapie planowania założeń wyjazdu. Często sama decyzja o przystąpieniu do projektu stanowiła przejaw indywidualnej inicjatywy i wynikała bezpośrednio z potrzeb deklarowanych przez konkretnych nauczycieli. Jednak nawet $w$ takich sytuacjach sam wybór tematyki szkoleń był poprzedzony dodatkową analizą bieżących problemów i diagnozą potrzeb całej instytucji. Dopiero po przeprowadzeniu takiej

2. W przypadku Estonii, Finlandii, Litwy oraz Polski w badaniu kwestionariuszowym uczestniczyły wszystkie założone grupy docelowe. W przypadku Niemiec badanie ograniczono do nauczycieli (zrezygnowano $z$ badania uczniów oraz ich rodziców). W ramach niemieckiej części badania nie zrealizowano również komponentu jakościowego (grupy fokusowe oraz studia przypadków wybranych dobrych praktyk). 
analizy kierownictwo szkoły lub całe grono pedagogiczne przystępowało do poszukiwania interesującego obszaru, którego mogłoby dotyczyć zagraniczne szkolenie. Zgodnie z deklaracjami uczestników badania, obszar merytoryczny projektów wynikał bowiem głównie z dotychczasowych potrzeb rozwojowych macierzystej placówki, a zagraniczne mobilności traktowano jak potencjalne remedium na konkretne zdefiniowane problemy albo stojące przed szkołą nowe wyzwania.

Nie bez znaczenia okazała się również silna obecność szkolnych liderów na etapie przygotowania uczestników do realizacji wyjazdu. Zgodnie z wytycznymi programu Erasmus+, jest to niezwykle istotny element projektu, stanowiący warunek jakościowej realizacji mobilności ${ }^{3}$. Potwierdzają to deklaracje zdecydowanej większości respondentów badania, którzy jako szczególnie ważne wymieniali chociażby takie aspekty, jak uzgodnienie merytorycznego programu pobytu oraz poznanie kontekstu systemowego kraju lub regionu, w którym realizowano mobilność (ponad dwie trzecie respondentów przed wyjazdem zapoznało się z systemem nauczania w kraju partnerskim). Niemal każdy badany uczestnik starał się pogłębić swoją wiedzę ogólną na temat kraju docelowego wyjazdu (w Polsce tylko mniej niż jeden procent badanych zadeklarowało, że nie zrealizowało żadnych aktywności o charakterze przygotowawczym przed wyjazdem za granicę). Badanie wykazało również, że to właśnie ci nauczyciele, którzy więcej wysiłku wkładają w jakościowe przygotowanie do wyjazdu, częściej przejawiają później postawy liderskie, dzieląc się zdobytą wiedzą i upowszechniając wypracowane $w$ projekcie rezultaty.

3. Zasady formalnej i jakościowej realizacji projektu zostały wyrażone zarówno w Przewodniku po programie, jak i w dodatkowych wytycznych przekazywanych beneficjentom podczas spotkań dla wnioskodawców oraz szkoleń dla beneficjentów, którzy otrzymali granty na realizację zaplanowanych mobilności. 
Wykres 1. Działania podejmowane przed realizacją mobilności edukacyjnej - ankieta dla uczestników mobilności [pytanie pozwalało na wybranie więcej niż jednej odpowiedzi]

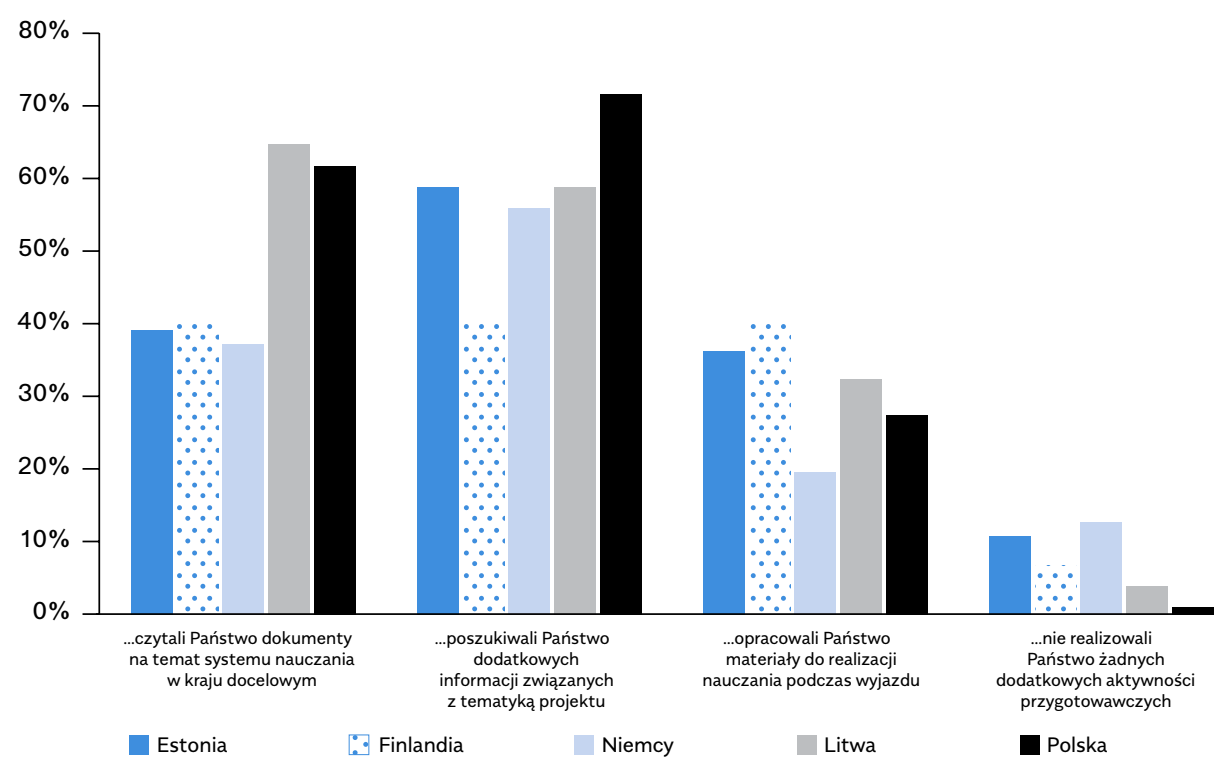

Źródło: opracowanie własne.

Jakościowe przygotowanie do realizacji mobilności determinuje nie tylko jakość realizacji projektu, ale przede wszystkim pomaga w późniejszym nabywaniu przez uczestników nowych kompetencji, co przekłada się na realne zmiany, jakie zachodzą w macierzystych placówkach uczestników wyjazdów. Lepsze i bardziej rzetelne przygotowanie do realizacji mobilności sprzyjało pełniejszej obserwacji i recepcji zagranicznych rozwiązań organizacyjnych i systemowych, co w opinii respondentów wywiadów często oznaczało wyższy poziom uzyskanych kompetencji oraz wyraźniejsze zmiany w funkcjonowaniu macierzystych instytucji wysyłających uczestników.

\section{Liderzy w obliczu zmiany}

Wyniki badania pokazują, że pomimo odmiennego kontekstu systemowego oraz specyfiki funkcjonowania placówek edukacyjnych, liderzy odgrywają ważną rolę w procesie zmian zachodzących w szkołach we 
wszystkich krajach objętych badaniem. Jeśli w szkole wyłania się lider, to szansa na pojawienie się oddolnych inicjatyw na rzecz poprawy funkcjonowania szkoły jest zdecydowanie większa, a przez to większe jest prawdopodobieństwo zidentyfikowania obszarów, które można zmienić lub poprawić. Wielu respondentów wywiadów deklarowało, że gdyby nie szkolny lider, to nie tylko zmiany w szkole, ale i sam wyjazd, który je zapoczątkował, prawdopodobnie nigdy nie doszedłby do skutku.

Postawy liderskie uczestników są widoczne przede wszystkim w deklarowanych nowych inicjatywach na rzecz poprawy jakości funkcjonowania i organizacji pracy szkoły, poprawy jakości nauczania oraz inspirowania innych do podejmowania nowych aktywności i większego angażowania się w życie macierzystej placówki dydaktycznej.

W niektórych krajach (np. w Estonii) w wyniku mobilności zdecydowanie zwiększyła się liczba szkoleń organizowanych przez nauczycieli danej placówki dla pozostałych członków grona pedagogicznego. Dzięki własnej inicjatywie uczestnicy wyjazdu często przyczyniali się do upowszechniania wiedzy, prowadząc szkolenia nie tylko dla innych pracowników dydaktycznych w swojej szkole, ale również poza nią. Realizowane projekty sprzyjały uzyskaniu korzyści nie tylko w obszarze rozwoju uczestników mobilności, ale również w kontekście całej placówki.

Wykres 2. Upowszechnianie rezultatów szkoleń przez uczestników mobilności [na wykresie wskazano odsetek respondentów z obu grup, którzy zgodzili się z danym stwierdzeniem]

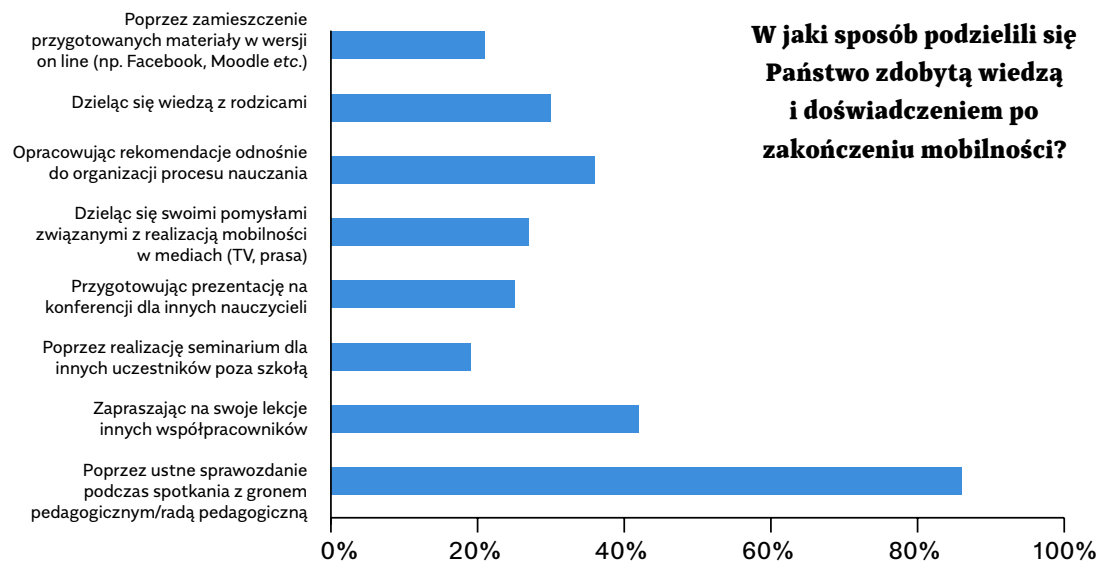

Źródło: opracowanie własne. 
Warto podkreślić, że we wszystkich krajach objętych badaniem uczestnicy wyjazdów pozytywnie ocenili swoje kompetencje liderskie. Średnio $70 \%$ uczestników badania - uczestników mobilności uznało, że ich działania inspirują innych do wprowadzania nowych pomysłów w codziennej pracy zawodowej, a średnio jedna trzecia respondentów zadeklarowała, że działa również na rzecz tworzenia grup inicjatywnych, aby ułatwić wprowadzanie w życie nowych rozwiązań. Nieco mniejsza grupa badanych zadeklarowała również, że stara się aktywnie uczestniczyć w planowaniu działań szkoleniowych w placówce, wspierając rozwój kompetencji swoich współpracowników.

Wykres 3. Doświadczenie w realizacji mobilności (odsetek nauczycieli, którzy brali już udział w szkoleniu zawodowym za granicą - ankieta dla uczestników mobilności)

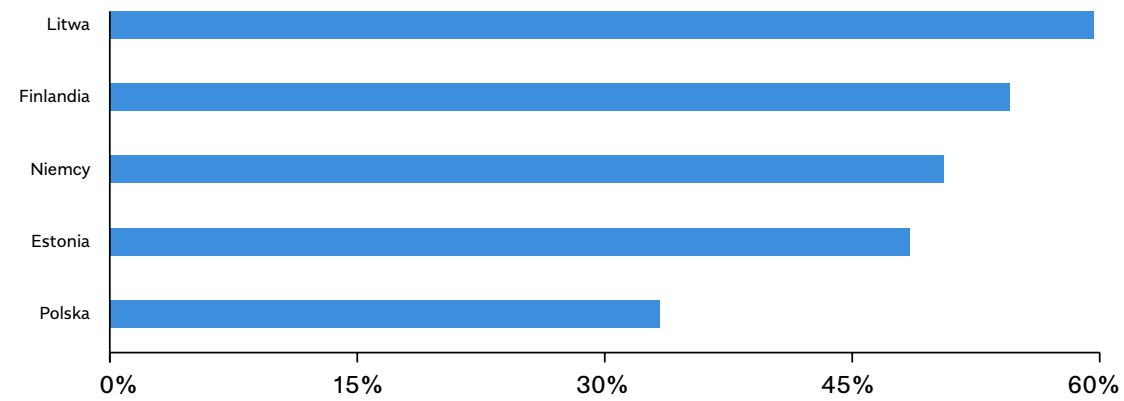

Źródło: opracowanie własne.

Należy dodać, że postawy liderskie przejawiają się w różny sposób, w zależności od lokalnych kontekstów systemu kształcenia i funkcjonowania szkół. O ile deklaracje dotyczące budowania zespołów działających na rzecz wprowadzania zmian są częstsze w Niemczech i na Litwie, o tyle polscy nauczyciele zdecydowanie częściej angażują do współpracy rodziców i szukają różnych form wsparcia dla takich procesów poza szkołą. Z pewnością wynika to chociażby ze specyfiki systemowej (włączenie w proces podejmowania strategicznych decyzji Organów Prowadzących). Duża aktywność polskich uczestników w procesie upowszechniania rezultatów może wynikać również z mniejszego doświadczenia w realizacji podobnych projektów. Podczas gdy w pozo- 
stałych krajach prawie lub ponad połowa respondentów deklarowała wcześniejszy udział w zagranicznych szkoleniach kadry, to w Polsce $z$ takiej formy podnoszenia kompetencji zawodowych skorzystał tylko co trzeci respondent.

\section{Rola liderów w zapewnieniu trwałości rezultatów}

Badanie pozwoliło również na ocenę, w jaki sposób przejawy postaw liderskich uczestników zagranicznych wyjazdów wpływają na trwałość wypracowanych efektów projektu.

Wyniki pokazują, że im silniejsze deklaracje postaw liderskich wyjeżdżających nauczycieli, tym silniejsze okazywały się również deklaracje w odniesieniu do zmian, jakie w wyniku projektu wprowadzano w placówkach macierzystych uczestników mobilności.

We wszystkich krajach objętych badaniem najczęstszym sposobem upowszechniania rezultatów i dzielenia się wiedzą zdobytą z innymi są ustne relacje z pobytu za granicą, podczas spotkań z innymi pracownikami dydaktycznymi szkoły (np. na radach pedagogicznych lub podczas bieżących spotkań i rozmów w pokoju nauczycielskim). Dwie piąte badanych respondentów zaprosiło swoich współpracowników do udziału w otwartych lekcjach, a jedna trzecia uczestników mobilności podzieliła się zdobytą wiedzą, umieszczając opracowane materiały dydaktyczne w internecie.

Wykres 4. Wpływ projektu na uczestników - ankieta dla uczestników

mobilności [na wykresie wskazano odsetek respondentów z obu grup, którzy zgodzili się z danym stwierdzeniem]

Po powrocie z mobilności wykorzystuję nowe pomysły w swojej pracy

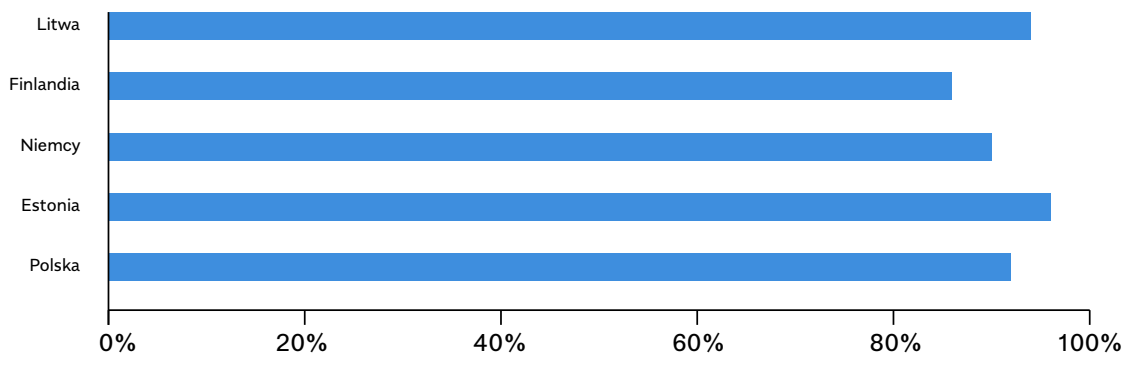

Źródło: opracowanie własne. 
Badanie wykazało jednak istotne różnice w wykorzystywaniu efektów mobilności po zakończeniu projektu. Zebrane wyniki pokazują, że sposób wykorzystania rezultatów zależy w dużej mierze od własnej inicjatywy nauczycieli. Zgodnie z deklaracjami respondentów wywiadów ten proces często przekracza również granice szkoły (uczestnicy projektów organizują szkolenia dla nauczycieli innych placówek i piszą artykuły, w których dzielą się zdobytą wiedzą i doświadczeniem). Takie działania przyczyniają się także do zwiększenia popularności zagranicznych szkoleń w środowisku zawodowym uczestników, a pozytywne relacje z wyjazdów nakłaniają liderów z innym placówek do decyzji o podjęciu podobnych inicjatyw w swojej szkole.

Wykres 5. Przejawy postaw liderskich wśród uczestników mobilności [na wykresie wskazano odsetek respondentów z obu grup, którzy wybrali podane odpowiedzi]

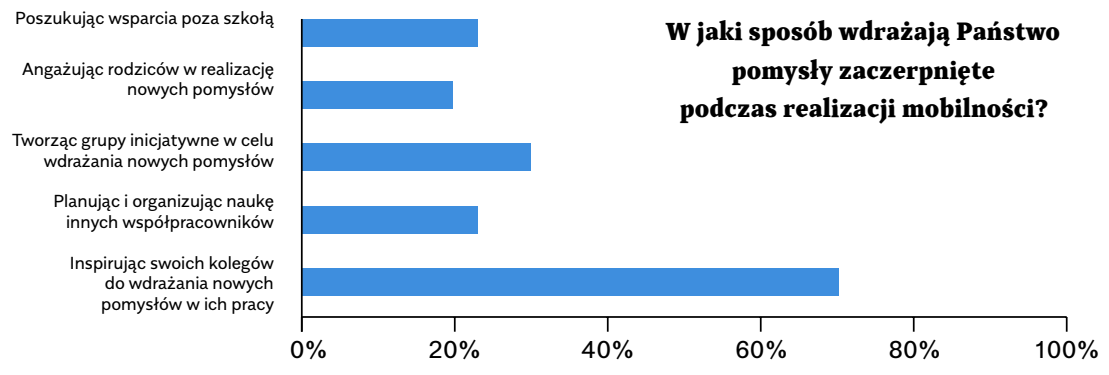

Źródło: opracowanie własne.

Należy podkreślić, że w poszczególnych krajach objętych badaniem obserwowano wiele wzorców zmian i recepcji postulowanych rozwiązań. O tym, jak różne są potrzeby, zarówno szkół, jak i samych uczestników wyjazdów, świadczą nie tylko odmienne obszary wprowadzania zmian, ale i różne podejście do dzielenia się zdobytą wiedza. O ile w nowych państwach członkowskich UE, które wciąż jeszcze przechodzą transformację ustrojową (Estonia, Litwa, Polska), wśród respondentów zdecydowanie częściej pojawiały się deklaracje związane z realizacją różnego typu działań upowszechniających, o tyle w przypadku Finlandii i Niemiec działania upowszechniające wydają się być realizowane nieco rzadziej. Różnice w tym obszarze są szczególnie zauważalne w odnie- 
sieniu do deklarowanych działań włączających w proces zmian rodziców, a w przypadku Niemiec, również w odniesieniu do inspirowania innych nauczycieli oraz współorganizowania procesu kształcenia w macierzystych placówkach dydaktycznych. Przyczyny tych różnic można upatrywać w poziomie rozwoju systemu edukacji w poszczególnych krajach oraz w poziomie zadowolenia z jakości pracy szkoły. Wydaje się, że fińscy i niemieccy nauczyciele częściej traktują szkolenie za granicą jako sposób na podniesienie własnych kompetencji zawodowych niż jako okazję do transferu innowacji na poziomie instytucjonalnym czy też systemowym, ponieważ nie widzą szczególnej konieczności wprowadzania takich zmian. To drugie podejście wydaje się być charakterystyczne raczej dla uczestników z tych krajów, gdzie zmiany zachodzące w szkole w wyniku realizacji projektów europejskich są postrzegane jako element szerszej zmiany systemowej, związanej z rozwojem gospodarczym i społecznym po upadku komunizmu.

Szczególnie aktywni na polu działań upowszechniających okazali się uczestnicy z Polski. Zgodnie z deklaracją respondentów, wiedzą zdobytą podczas mobilności podzieliło się z innymi ponad 95\% uczestników wyjazdów. Niemal wszyscy respondenci potwierdzili również, że doświadczenia zdobyte podczas pobytu za granicą wykorzystują w swojej codziennej pracy zawodowej. Zdecydowana większość ankietowanych stara się również zachęcić do wdrażania nowych idei swoich szkolnych współpracowników oraz inspirować do realizacji nowych pomysłów nie tylko na rzecz podnoszenia kompetencji uczniów, ale również rozwoju macierzystej placówki edukacyjnej. Ponad dwie piąte polskich respondentów w realizację nowych pomysłów stara się angażować także rodziców.

\section{Rola kierownictwa w kreowaniu postaw liderskich}

Dla powodzenia projektu ważne okazały się także dobre relacje pomiędzy gronem pedagogicznym a kierownictwem szkoły. Takie relacje okazują się szczególnie istotne już na etapie opracowywania założeń projektu, sprawiając, że wyjazd spełni nie tylko potrzeby szkoleniowe nauczycieli, ale również przyczyni się do spełnienia potrzeb rozwojowych szkoły. Nie można pominąć roli kierownictwa we wspieraniu postaw liderskich, ponieważ zmiany wdrażane w szkołach (nawet te inicjowane oddolnie) wymagają pozytywnej decyzji ze strony dyrekcji danej placówki. 
Wyniki zebrane we wszystkich krajach objętych badaniem jednocześnie pokazały, że często o tym, w jaki sposób oraz w jakim stopniu są wykorzystywane rezultaty projektu, decyduje rola formalna, jaką pełni na co dzień w szkole dany uczestnik zagranicznej mobilności. Dyrektorzy szkół biorący udział w zagranicznych szkoleniach zdecydowanie częściej deklarowali, że podzielili się doświadczeniem zdobytym podczas wyjazdu zarówno w swojej macierzystej placówce, jak i poza nią. Zdecydowanie rzadziej takie deklaracje pojawiały się natomiast u pozostałych respondentów, bez względu na to, czy pełnili oni funkcję wicedyrektora, szeregowego nauczyciela, czy też inne funkcje dydaktyczne.

Wykres 6. Rola kierownictwa w procesie zmian po zakończeniu zagranicznych mobilności w opinii nauczycieli. Zestawienie obejmuje odpowiedzi udzielone przez respondentów z Polski [na wykresie wskazano odsetek respondentów z obu grup, którzy zgodzili się z danym stwierdzeniem]

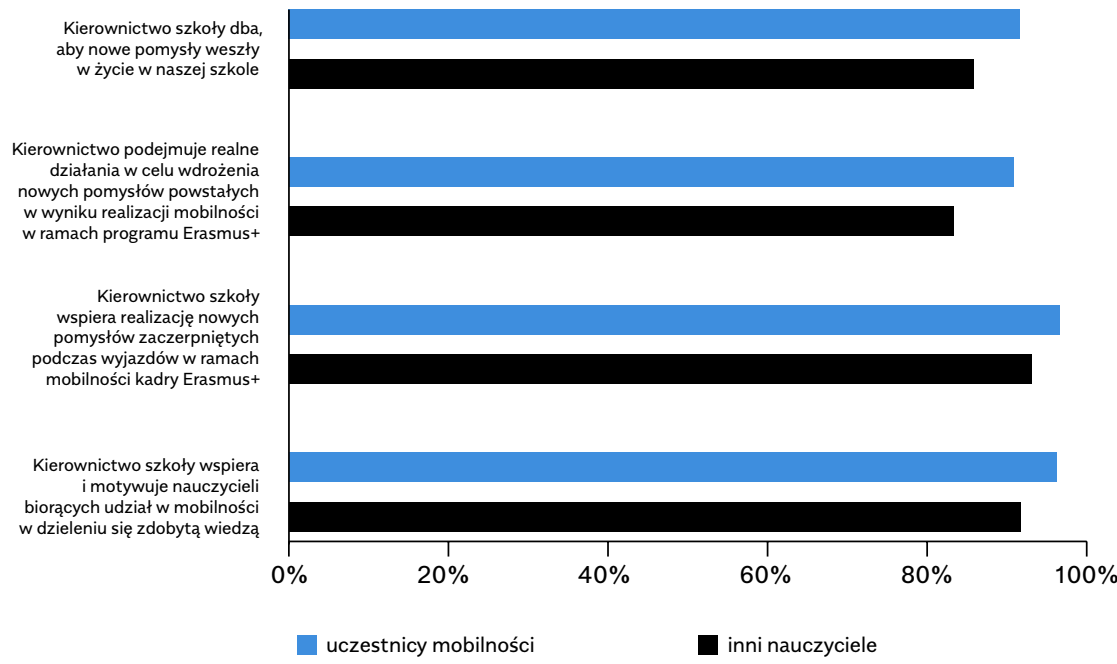

Źródło: opracowanie własne.

Badanie pozwoliło na porównanie deklaracji respondentów odnośnie do roli, jaką kierownictwo szkoły odgrywa w procesie wdrażania zmian postulowanych przez uczestników mobilności po zakończeniu zagranicznej mobilności. 
W opinii respondentów dyrektorzy szkół zasadniczo wspierają nowe pomysły nauczycieli i starają się je urzeczywistniać. Badani nauczyciele doceniali również starania dyrekcji związane z tworzeniem dobrego klimatu dla potencjalnych zmian, chociażby poprzez motywowanie swoich pracowników do dalszych działań na rzecz zwiększenia jakości kształcenia uczniów i poprawy funkcjonowania szkoły.

Odpowiedzi udzielone przez respondentów wydają się w dużej mierze także potwierdzać fakt, że kierownictwo badanych instytucji często angażuje się nie tylko $w$ realizację projektu, ale i w proces opracowywania jego założeń. Warto podkreślić, że w opinii respondentów wymagająca postawa dyrekcji w odniesieniu do zapewnienia wysokiej jakości działań projektowych często w znacznym stopniu wpływała równocześnie na jakość i poziom wdrażanych później zmian. Taka zależność okazała się być szczególnie widoczna w takich aspektach, jak rzetelny proces rekrutacji uczestników (spełniających kryteria formalne i jakościowe projektu) oraz właściwe przygotowanie do realizacji mobilności, które - jak wspomniano wyżej - ma często niezwykle istotny wpływ na trwałość efektów realizowanych mobilności.

\section{Lider w środowisku i otoczeniu szkoły}

Respondenci badania podkreślali wpływ projektów na środowisko szkolne, jego bezpośrednie otoczenie, ale także na zmianę nastawienia i postaw osób zaangażowanych w życie i kulturę szkoły.

Wielu respondentów zauważyło, że im bardziej dany projekt angażuje merytorycznie nauczycieli, tym bardziej korzystają na tym uczniowie (poznane metody są wówczas chętniej wykorzystywane podczas realizowanych zajęć dydaktycznych), a niekiedy i inne osoby, które funkcjonują w bezpośrednim otoczeniu placówki. 
Wykres 7. Percepcja korzyści instytucjonalnych z realizowanych mobilności. Zestawienie odpowiedzi uczestników wyjazdów oraz pozostałych nauczycieli, którzy nie uczestniczyli w zagranicznych szkoleniach [na wykresie wskazano, ile procent respondentów zgodziło się z danym stwierdzeniem]

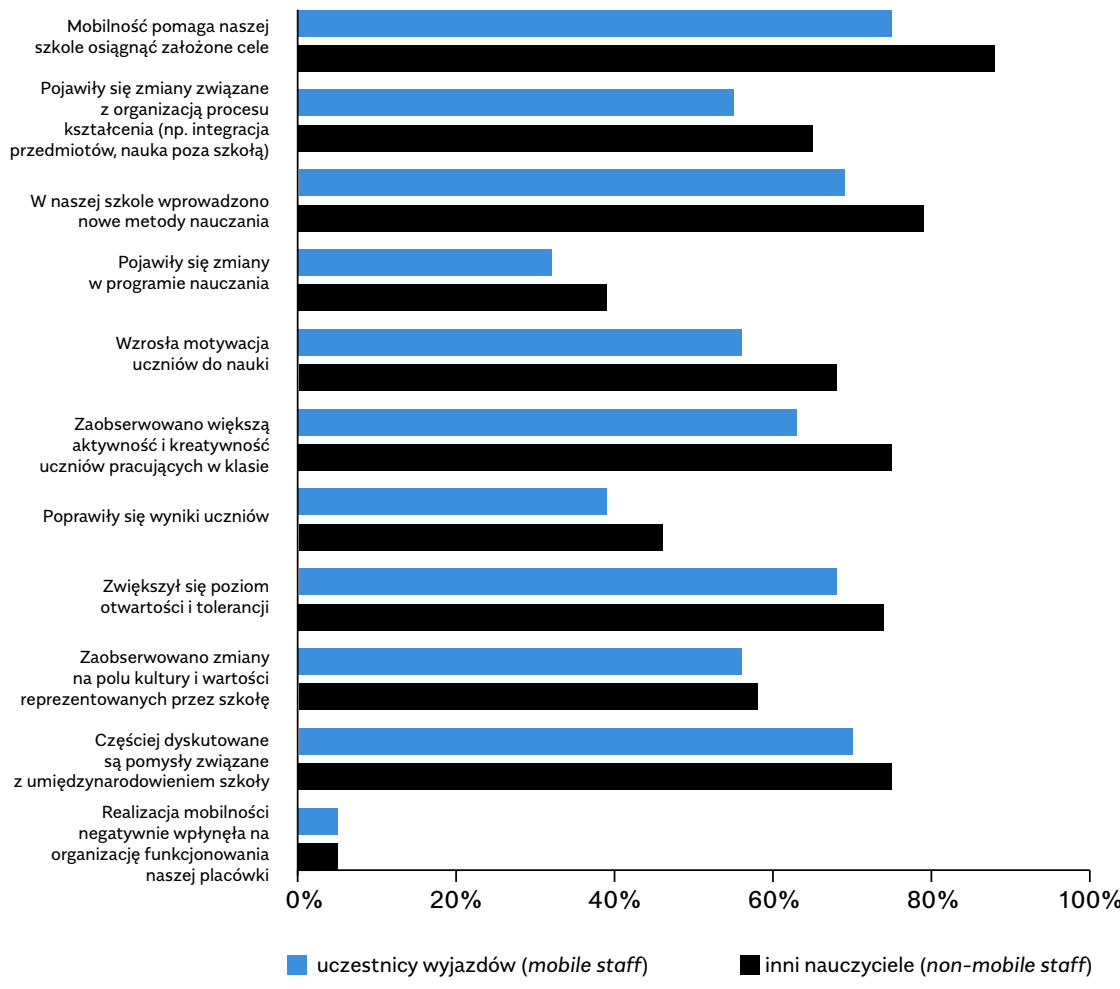

Źródło: opracowanie własne.

Wyniki badania kwestionariuszowego pokazują, że zarówno uczestnicy mobilności, jak i pozostali nauczyciele w podobny sposób postrzegają korzyści wynikające z realizacji projektu. Oznacza to, że rezultaty wyjazdów szkoleniowych znajdują odzwierciedlenie w jakościowej poprawie pracy szkoły i są realnie dostrzegane nie tylko przez samych uczestników projektów, ale i pozostałych członków grona pedagogicznego. Należy jednak dodać, iż niektórzy uczestnicy wywiadów deklarowali, że rola, jaką pełnią szkolni liderzy w projektach, jest trudna, a ich zapał i inicjatywa do pracy nie zawsze spotyka się ze wsparciem innych osób w szkole. 
Informacje pozyskane w ramach wywiadów z uczestnikami mobilności potwierdziły, że respondenci zwracali także uwagę na różnice w specyfice pracy nauczycieli w różnych krajach europejskich, a realizacja zagranicznych mobilności kadry często sprzyjała refleksji zarówno nad kondycją zawodu nauczyciela, jak i nad warunkami pracy dydaktyków w polskich szkołach. Takie obserwacje dotyczyły również kontekstu społecznego, w jakim występuje odgrywanie roli społecznej przez nauczycieli w szkole i w jej otoczeniu, chociażby zupełnie innego postrzegania pracy nauczyciela, który w wielu krajach jest traktowany z większym niż w Polsce szacunkiem, a jego zawód charakteryzuje o wiele większy prestiż, co wpływa nie tylko na proporcjonalnie wyższe wynagrodzenie, ale przede wszystkim na o wiele większy komfort pracy.

Deklarowany brak autorytetu roli nauczyciela w Polsce, prymat ocen nad rzeczywistymi efektami kształcenia czy też brak zewnętrznej motywacji uczniów do nauki nie sprzyjają, w opinii respondentów, ani wzmacnianiu cech przywódczych kierownictwa szkoły, ani odkrywaniu postaw liderskich grona pedagogicznego.

Dodać należy, że powyższe refleksje były w dużej mierze konsekwencją bezpośredniej obserwacji całkowicie odwrotnych tendencji w szkołach w innych krajach europejskich. Badani nauczyciele zwracali uwagę, że szkoły w krajach partnerskich wspierają zarówno najdrobniejsze przejawy postaw liderskich, jak i oddolne inicjatywy na rzecz zmian tak w kształceniu, jak i w organizacji pracy szkoły.

Wykres 8. Rola grona pedagogicznego w procesie zmian zachodzących po zakończeniu projektu mobilności (zestawienie opinii uczestników wyjazdów oraz pozostałych nauczycieli). Zestawienie obejmuje odpowiedzi udzielone przez respondentów z Polski [na wykresie wskazano odsetek respondentów z obu grup, którzy zgodzili się z danym stwierdzeniem]

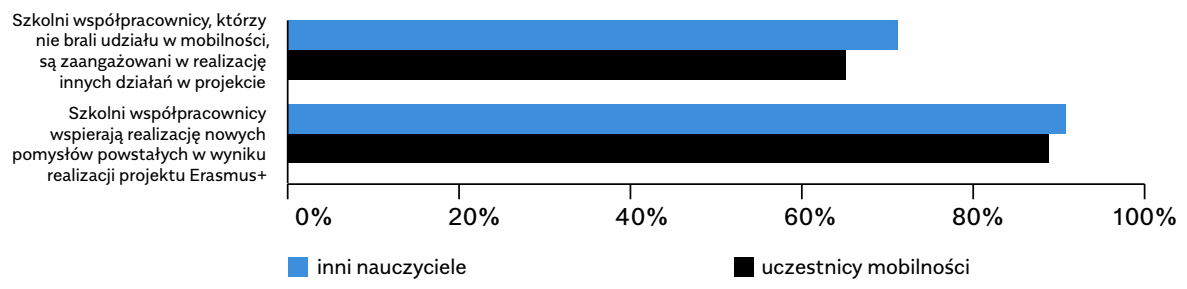

Źródło: opracowanie własne. 
Polscy respondenci badania deklarowali również, że jednym z najszybciej zauważanych efektów zagranicznych mobilności jest poprawa relacji pomiędzy nauczycielami a uczniami. Poznanie odmiennych standardów pracy dydaktycznej sprawia, że nauczyciele stają się bardziej otwarci na potrzeby uczniów i zdecydowanie chętniej korzystają z niekonwencjonalnych metod prowadzenia lekcji.

Należy zaznaczyć, że w opinii respondentów sami uczniowie dużo chętniej angażują się w zajęcia lekcyjne oraz w życie szkolne, jeśli czują, że są motywowani przez nauczycieli nowymi, ciekawymi pomysłami i technikami pracy. Potwierdzają to również wyniki badania ankietowego, w którym uczestniczyli uczniowie szkół realizujących projekty. Niemal wszyscy respondenci tej grupy deklarowali, jak ważne jest wykorzystywanie przez nauczycieli nowych pomysłów dydaktycznych z zagranicy. Często pojawiały się deklaracje związane z chęcią uczestnictwa w projektach z uczniami z innych krajów, a także w uczniowskich wymianach zagranicznych. Ważna dla uczniów okazała się współpraca pomiędzy nauczycielami z różnych krajów.

Opinie uczniów odnośnie do istoty umiędzynarodowienia placówek potwierdzają deklaracje ich rodziców. Wśród tej grupy przeważała opinia, że realizowane mobilności przynoszą szkole zdecydowanie więcej korzyści niż potencjalnych strat. Należy jednak zaznaczyć, że to właśnie w tej grupie relatywnie częściej wskazywano na ryzyko zaniedbywania funkcji edukacyjnej szkoły z powodu wyjazdu nauczycieli na szkolenia. Badani rodzice potwierdzili, że ważne jest zdobywanie przez dzieci kompetencji związanych ze współpracą międzynarodową.

Respondenci zauważyli również związek pomiędzy mobilnościami i rozwojem szkoły, a przede wszystkim poprawą wyników osiąganych przez uczniów. Dostrzegli także rolę, jaką odgrywają w szkołach aspekty związane z umiędzynarodowieniem placówek edukacyjnych. Potwierdzili także, że szkoła sama angażuje ich w takie działania. 
Wykres 9. Ocena korzyści z realizacji mobilności dla otoczenia szkoły wysyłającej z perspektywy rodziców (rozkład odpowiedzi na pytanie: Jaka jest Państwa opinia na temat poziomu umiędzynarodowienia szkoły, w której uczy się Państwa dziecko?). Zestawienie obejmuje odpowiedzi udzielone przez respondentów z Polski [na wykresie wskazano odsetek respondentów z obu grup, którzy zgodzili się z danym stwierdzeniem]

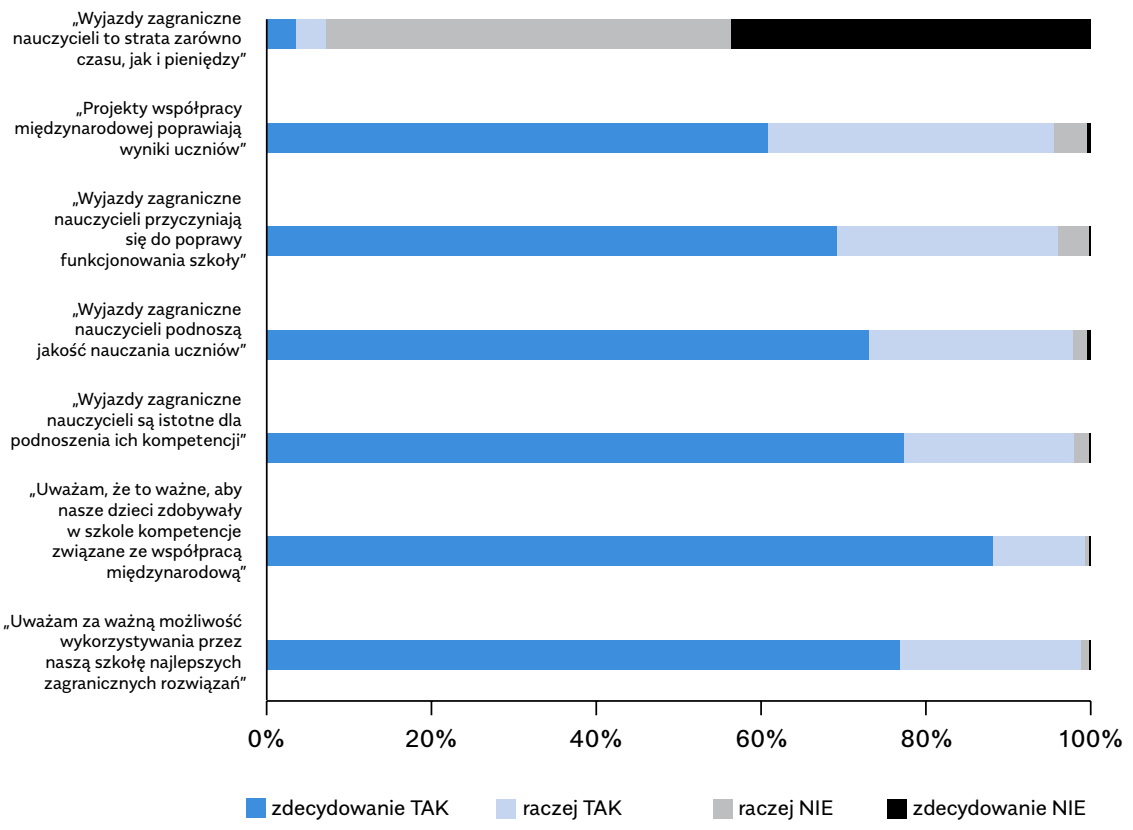

Źródło: opracowanie własne.

Badani nauczyciele jako istotny obszar problemów we wprowadzaniu zmian wskazywali również współpracę z organami prowadzącymi szkoły (był to problem szczególnie trudny dla tych osób, które wcześniej składały podobne wnioski indywidualnie i nie miały do czynienia z przeszkodami biurokratycznymi). W opinii części respondentów organ prowadzący nie zawsze dostatecznie wspiera szkolnych liderów tak na etapie realizacji projektu, jak i w procesie wdrażania wypracowanych rezultatów. Pojawiły się także głosy, że urzędnikom odpowiedzialnym za nadzór nad projektami unijnymi ze strony organu prowadzącego nierzadko brakuje dostatecznej wiedzy, aby wyjaśnić zaistniałe wątpliwości czy też sprostać wymogom formalnym. Co więcej, utrudnienia biurokra- 
tyczne często okazują się być również głównym czynnikiem utrudniającym dyrekcji szkół podjęcie decyzji o przystąpieniu do projektu oraz zaangażowaniu szkoły w działania o charakterze międzynarodowym.

\section{Podsumowanie}

W obliczu trwającej obecnie dyskusji o konieczności zmian w polskim systemie oświaty, warto podkreślić działania na rzecz poprawy jakości nauczania oraz funkcjonowania szkół stanowią często konsekwencję systematycznych szkoleń kadry, a realizacja projektów ze środków europejskich pozwala ich uczestnikom dzielić się nową wiedzą przywiezioną z zagranicy.

Większość badanych uczestników projektów postrzega możliwość zdobywania doświadczeń w innych krajach europejskich nie tylko w kontekście osobistych korzyści, ale przede wszystkim w wymiarze instytucjonalnym, ponieważ rezultaty takich projektów wzmacniają potencjał całego grona pedagogicznego.

Co ważne, przedstawiciele niemal wszystkich badanych szkół potwierdzili, że zaistniałe zmiany nie byłyby możliwe, gdyby nie szkolni liderzy. Respondenci często deklarowali, że gdyby nie ich inicjatywa, to nie tylko pozytywne zmiany, ale prawdopodobnie same projekty nigdy nie doszłyby do skutku.

Z poczynionych obserwacji wynika także i to, że przede wszystkim aktywność liderów gwarantuje, iż wypracowane w ramach projektu rezultaty mają szansę okazać się trwałe i tym samym przyczynić się nie tylko do rozwoju kompetencji nauczycieli, ale i w znacznym stopniu wpływać na jakość pracy szkół nie tylko w Polsce, a także w innych krajach europejskich. Pozwala to żywić nadzieję, że środki przeznaczone na realizację indywidualnych wyjazdów okażą się dobrą inwestycją nie tylko na poziomie szkoły, ale i w kontekście zmian systemowych w polskiej oświacie.

Doświadczenia zagranicznych mobilności pokazują, że kluczową rolę w tym procesie mogą odegrać właśnie szkolni liderzy, których aktywność i zaangażowanie warunkuje zmiany, jakie zachodzą w szkołach w Polsce i w innych krajach europejskich. 


\section{Bibliografia}

$\rightarrow$ Avalos, B. (2011), Teacher Professional Development in Teaching and Teacher Education over ten years, Teaching and Teacher Education, 1(27), 10-20.

$\rightarrow$ Balčiūnas, S., Damkuvienė, M., Valuckienè, J. (2015), Impact and Sustainability of the Erasmus+ Programme Key Action 1 Mobility Projects for School Education Staff, Research Report, Vilinus.

$\rightarrow$ European Commission (2014), Erasmus+ Programme Guide. Valid as of 1 January 2014. Version 3: 09/04/2014, Brussels: European Commission.

$\rightarrow$ Pachocki, M. (2016), Mobilni nauczyciele zmieniajq swoje szkoły, Warszawa: Fundacja Rozwoju Systemu Edukacji.

$\rightarrow$ Postholm, M.B. (2012), A completed research and development work project in school: The teachers' learning and possibilities, premises and challenges for further development, Teaching and Teacher Education, 27(3), 560-568. 



\title{
Nauczyciel akademicki - przywódca, ekspert, mistrz czy przewodnik?
}

\author{
Mirosław J. Szymański
}

Szkoły wyższe są dużymi organizacjami. Ich funkcjonowanie wymaga zatrudniania wielu nauczycieli akademickich o zróżnicowanych kwalifikacjach. W takich zbiorowościach konieczne jest wyłanianie liderów. Są oni powoływani oficjalnie, ale bywają też liderzy nieformalni. Autor artykułu charakteryzuje cztery grupy wyróżniających się nauczycieli akademickich. Są nimi: przywódcy, eksperci, mistrzowie i przewodnicy. Uznaje, że wszyscy odgrywają znaczącą rolę w uczelni. Są wręcz niezbędni do właściwego funkcjonowania instytucji i zespołów nauczycieli akademickich oraz kształcenia studentów. Mimo osiągnięć wielu nauczycieli akademickich, nie powinno być jednak zbyt dużego dystansu między nimi a studentami. Oni bowiem także uczestniczą w badaniach, rozwijają postawy twórcze. Korzystne jest wspólne budowanie kapitału społecznego. Jest to możliwe, gdy między nauczycielami akademickimi a studentami istnieją dobrze pojęte relacje partnerskie.

\section{Słowa kluczowe:}

nauczyciel akademicki

przywódca

ekspert

mistrz

przewodnik 


\section{Academic teacher - leader, \\ expert, master or guide?}

Mirosław J. Szymański

Higher education institutions are large organizations. In order to function, they need to employ a substantial number of academic teachers of varying qualifications. It is necessary for such communities to have their leaders. They are appointed formally, although there can be informal leaders as well. The author of the article characterizes four distinguishing groups of academic teachers. These are: leaders, experts, masters and guides. He considers all of them to play an important role at a higher education institution. In fact, they are essential for the proper functioning of institutions and groups of academic teachers, and for educating students. However, regardless of the accomplishments of many academic teachers, there should not be too much distance between them and their students. After all, they also participate in studies and foster creativity. Working together to build social capital is beneficial. What makes is possible is the existence of well-understood partnership relations between academic teachers and students.

\section{Keywords:}

academic teacher

leader

expert

master

guide 


\section{Wprowadzenie}

Nauczycielami akademickimi nazywamy nauczycieli szkół wyższych. Właściwie można by przyjąć, że nazwa ta przysługuje tylko części tych nauczycieli i jest ograniczona do grupy nauczycieli, którzy pracują w uczelniach mających uprawnienia do prowadzenia studiów pierwszego (licencjackich), drugiego (magisterskich) i trzeciego stopnia (doktorskich). Właściwie byłoby to zasadne, gdyż tylko te uczelnie mają pełne uprawnienia akademickie. W praktyce przyjęło się jednak szersze rozumienie tego określenia. Obejmuje nauczycieli zatrudnionych w szkołach wyższych na stanowiskach naukowo-dydaktycznych, naukowych i dydaktycznych. Są to nauczyciele, którzy mają ukończone studia magisterskie, mogą też mieć stopnie naukowe doktora lub doktora habilitowanego, a także tytuły profesorskie. W zależności od tego, a także innych warunków są zatrudniani na stanowiskach asystenta, adiunkta, profesora, a także wykładowcy lub starszego wykładowcy. W sumie ich liczebność przekracza 100 tysięcy osób. Jest to więc niemała grupa zawodowa.

$W$ tradycyjnych uniwersytetach stanowiących organizacje hierarchiczne rządzili profesorowie. Był wprawdzie w średniowieczu także inny model uniwersytetów, w których władza należała do studentów; to oni zatrudniali profesorów, a także ze swego grona wybierali rektora. Upowszechnił się jednak inny ówczesny model uniwersytetu, zwany paryskim. W takim uniwersytecie dominowali profesorowie. Spośród nich wybierano najwyższe władze uczelni: rektora, prorektorów, członków senatu. Dziś profesorowie dzielą się władzą z przedstawicielami innych grup nauczycieli akademickich i innych pracowników uczelni, choć nadal kierownicze funkcje (rektora, dziekana, dyrektora instytutu, kierownika katedry) w silnych uczelniach powierzane są tylko profesorom. W takich uczelniach nikt przypadkowo nie zostaje profesorem i zapewne również w związku z tym profesorów obdarza się szacunkiem i należnym poważaniem.

W swojej pracy akademickiej odnotowałem przypadek, który miał miejsce, kiedy zostałem wybrany dyrektorem instytutu. Za kilka dni miałem zaproponować dwie osoby na stanowiska swoich zastępców. Przyszedł wówczas do mnie student z propozycją, abym jego kandydaturę zgłosił na stanowisko wicedyrektora. Pod względem prawnym było to możliwe, ale przed głosowaniem, w którym mieli brać udział wszyscy pracownicy i przedstawiciele studentów, ów młody człowiek wycofał się, gdyż oszacował zapewne, że jego szanse są niewielkie. 
Także obecnie, choć szkoły wyższe mają charakter bardziej demokratyczny i zarówno przedstawiciele tzw. młodszej kadry, pracowników obsługi, jak i studentów wchodzą w skład kolegialnych organów uczelni (senat, rada wydziału, rada instytutu itp.), jednak zwłaszcza w grupie nauczycieli akademickich formalnymi i nieformalnymi liderami są niemal zawsze profesorowie mający tytuły profesorskie i/lub stopień naukowy doktora habilitowanego. Oczywiście nie wszyscy z nich są lub mogą stać się takimi liderami. Co zatem decyduje o tym, że nauczyciel akademicki może stać się przywódcą w gronie swoich kolegów, a także pełnić tę rolę w środowisku studentów i w całej społeczności uczelni?

Moim zdaniem, trudno o jednoznaczną odpowiedź. Decydujące znaczenie mają tu: wzór osobowy określonego człowieka, a także powody, cechy sprawiające, że właśnie on bywa obdarzony charyzmą i autorytetem. Wiąże się to z tym, co wyróżnia nauczyciela akademickiego spośród innych, mianowicie w oczach innych członków społeczności akademickiej jest przywódcą, ekspertem lub przewodnikiem. W dalszej części artykułu spróbuję przybliżyć te typy liderów akademickich.

\section{Przywództwo nauczyciela akademickiego w środowisku uczelni}

Termin "przywództwo" pochodzi od słowa "wódz". Eksponuje jego czynności, które polegają na sprawowaniu funkcji kierowniczej, dowodzeniu, kierowaniu innymi. Łączy się zatem z problematyką sprawowania władzy. W analizach naukowych rozważania na temat przywództwa występują w różnych dyscyplinach: socjologii, psychologii społecznej, politologii, w naukach o zarządzaniu i innych. Przywództwo może być rozpatrywane jako proces oddziaływań na inne osoby lub jako właściwość lidera. W pierwszym wypadku uwaga skoncentrowania jest na prawidłowościach działania i jego efektywności, począwszy od etapu formułowania celów i wyboru strategii działania, aż do oceny uzyskiwanych wyników. Drugi aspekt dotyczy cech osobowych przywódcy i jego kompetencji społecznych, zwłaszcza interpersonalnych, które sprzyjają skutecznemu oddziaływaniu na innych.

Zdaniem Burnsa (1995) o przywództwie można mówić wówczas, gdy pod wpływem lidera inne osoby angażują się w proces osiągania wyznaczonego celu w ramach jakiegoś systemu lub otoczenia. W takim ujęciu centralne miejsce zajmuje problematyka wpływu społecznego. Istotne są tu wzajemne związki między przywódcą, jego zwolennikami 
oraz sytuacją społeczną, w której zachodzą interakcje społeczne. Nie każdy bowiem menedżer czy kierownik zasługuje na miano przywódcy. Andrzej K. Koźmiński i Dariusz Jemielniak (2008, s. 18) sądzą, że wynika to z rzadko występujących cech osobistych, którymi muszą się charakteryzować przywódcy. Stwierdzają więc: „Przywództwo to zdolność "prowadzenia za sobą" mniej lub bardziej licznych grup zwolenników. Zdolność taka polega na umiejętności wskazania i zakomunikowania wizji stanów przyszłych, do których grupa ma wspólnie dążyć. Wizja ta musi być na tyle atrakcyjna, by wyzwolić u zwolenników przywódcy emocjonalny stan silnego pragnienia jej realizacji. Pragnienie to tylko w pewnym stopniu opiera się na racjonalnej kalkulacji przyszłych korzyści. Musi ono odwoływać się do »wyższych « motywacji, takich jak chęć wyróżnienia siebie i swojej grupy, niekiedy »odegrania się « za poniesione w przeszłości porażki, pragnienie realizacji jakiejś misji ideologicznej, dokonania czegoś «niezwykłego» i innowacyjnego".

Pojawia się interesujące zagadnienie charyzmy przywódcy. Aby jego obecność i działanie wywoływały taki efekt, zwolennicy przywódcy "muszą być przekonani o jego »niezwykłości«, czyli nadzwyczajnych talentach, umiejętności, wiedzy, zdolnościach przewidywania, wyższości moralnej nad innymi itp." (tamże, s. 17). Zwłaszcza w okresie gwałtownej zmiany, a z taką mamy obecnie do czynienia, kiedy u wielu osób zwiększa się subiektywne poczucie niepewności, zagrożenia, chaosu i ryzyka, ludzie poszukują charyzmatycznych przywódców. Wraz z pojawianiem się okresów stabilizacji, prestiż takich przywódców znacznie się zmniejsza (Kwiatkowski, 2010).

W ostatnich dziesięcioleciach badania naukowe przywództwa cechuje podejście kompleksowe. Badania te wykazały, że skuteczność przywódcy zależy od jego osobowości, doświadczenia, uznawanych przez niego wartości, oczekiwań i zachowań podwładnych, charakteru podejmowanego zadania oraz kultury organizacyjnej. Ten ostatni czynnik szczególnie silnie eksponowany jest w najnowszych badaniach (Michalak, 2006; Madalińska-Michalak, 2012, 2015). Pożądane jest, aby przywództwo oparte było na trwałych zasadach. Jak twierdzi Alicja Korzeniecka-Bondar (2011, s. 97), zapewnia ono nie tylko uczciwość, życzliwość i wydajność, ale także skuteczność.

Można zastanawiać się, czy przywództwo w działaniach edukacyjnych, kształceniu i wychowaniu ma swoją specyfikę. Edukacja jest dziedziną, w której relacje, procesy i podejmowane działania mają cha- 
rakter społeczny. Zarówno ich inicjatorami, jak i beneficjentami są ludzie. Działalność edukacyjna nie ogranicza się jednak tylko do układów: "dawca - biorca”, „ekspert - klient", które zresztą nie są dziś układami jednostronnymi. Coraz bardziej widoczne jest to, że nauczyciel w szkole podstawowej i średniej, a w szkole wyższej - profesor to nie tylko potencjalny przywódca, ale też $\mathrm{w}$ wielu zakresach ekspert, przewodnik i partner studentów.

W procesie nauczania - uczenia się aktywnymi podmiotami są w szkołach wyższych: nauczyciele akademiccy i studenci. Aktywne jest także otoczenie społeczne, które stanowi ważny kontekst społeczny każdej szkoły. Tworzony jest całe społeczeństwo, naród, grupy wyznaniowe, społeczność lokalną, grupy towarzyskie, administrację terenową. Duże znaczenia mają wpływy kultury popularnej, w jej różnych zakresach i wymiarach, a także oddziaływania mediów i świata wirtualnego, który nabiera coraz większego znaczenia. W szkołach wyższych znaczącą rolę odgrywają ponadto politycy, prezesi lub dyrektorzy instytucji i korporacji gospodarczych, ludzie świata biznesu, reprezentanci fundacji i stowarzyszeń, przedstawiciele zakładów pracy. Wynika stąd, że nawet wzorowe wykonywanie zawodu nauczyciela, a w szkole wyższej - nauczyciela akademickiego zwykle nie wystarcza do tego, by być przywódcą. Przywódca musi umieć elastycznie i selektywnie wykorzystywać oddziaływania zewnętrzne do realizacji swoich celów i zamierzeń, być aktywnym na wielu polach, mobilizując nie tylko siebie, ale też współpracowników i studentów, a także włączać do podejmowanych działań różne instytucje, organizacje i siły społeczne.

Przywództwo edukacyjne w szkole wyższej ma znaczenie nie tylko dla pracy tej szkoły. Ze względu na specyficzne funkcje edukacji, do których należy wspomaganie rozwoju człowieka, przygotowanie i doskonalenie kadr dla gospodarki oraz obywateli do życia społecznego, ma ona znaczenie dla całokształtu funkcjonowania społeczeństwa. Jednym z jej zadań szkolnictwa wyższym, jest kształtowanie elit społecznych. Jest to zadanie tradycyjnie już podejmowane przez szkoły wyższe. Dziś wymaga nowego ujęcia ze względu na zachodzące zmiany społeczne oraz zmiany funkcji uniwersytetów i innych szkół wyższych. Na pewno nie ogranicza się do zadań związanych z kształtowaniem i rozwojem człowieka. Coraz większej wagi nabierają zadania związane z przygotowaniem kadr dla instytucji funkcjonujących na zasadach gospodarki rynkowej, a także z przygotowaniem nowocześnie wykształconej inte- 
ligencji do działania w społeczeństwie demokratycznym. O ile pierwsze z wymienionych zadań czasem nawet nazbyt silnie odbija się na pracy szkół wyższych, drugie jest w naszym kraju słabo dostrzegane, niekiedy bardzo mało widoczne.

Głęboka zmiana społeczna, z którą obecnie mamy do czynienia, powoduje, że przywódcy i współdziałające z nimi osoby powinny mieć umiejętność odczytywania istoty zmiany, przewidywania jej bliższych i dalszych skutków, posiadania wizji przyszłości. Dotyczy to w szczególności przywództwa edukacyjnego, gdyż uczniowie i studenci pełną aktywność społeczną i zawodową podejmą po kilku lub kilkunastu latach, a w tym czasie i świat człowieka, i cały otaczający go kontekst gospodarczy i społeczny bardzo się zmienią. Dlatego trzeba zgodzić się zarówno z argumentacją Michaela Schratza (2014, s. 11-36), że przywództwo powinno być dziś pojmowane jako uczenie się z wyłaniającej się przyszłości, jak i ze słowami Grzegorza Mazurkiewicza (2014, s. 37): "Nasza przyszłość decyduje się dzisiaj. Ku temu niezbędne jest rozumienie - siebie, innych ludzi, całych społeczeństw i przeróżnych zjawisk, czyli rozumienie świata. Prawdopodobnie musimy zaakceptować fakt, że rozumienie to nigdy nie będzie pełne, a jego poszukiwanie nigdy nie ustanie. Jednak to właśnie chęć porozumienia, wymiany, gotowość uczenia się i rozwoju jest naszą szansą na zmianę".

Czy jest tak w praktyce? Jak dotąd, o wyborze liderów w środowiskach akademickich częściej decydują ich dokonania, nie zaś to, jak postrzegają przyszłość, jak ją analizują, jakie z tego wyciągają wnioski. W uczelniach wyższych przywódcami zostają przede wszystkim ludzie, którzy wyróżniają się, osiągnęli mistrzostwo przynajmniej w niektórych dziedzinach działalności zawodowej. Dawniej każdy absolwent szkoły wyższej, zostając magistrem, zgodnie z tym określeniem mógł być uznawany za mistrza. Dziś już tak nie jest. Jest to spowodowane upowszechnianiem kształcenia, tym, że kształcenie wyższe nie jest już elitarne. Znacznie wzrósł poziom wykształcenia ludności, toteż absolwent szkoły wyższej nie góruje już tak nad innymi pod względem wiedzy, umiejętności i kompetencji, jak to było jeszcze pół wieku temu i wcześniej. Obecnie nawet profesorom nie zawsze udaje się zyskać opinię, że są mistrzami. Wiąże się to też z gwałtownym przyrostem wiedzy, pojawieniem się nowych rodzajów umiejętności (np. informatycznych), a jednocześnie $z$ wysokimi wymaganiami, których spełnienie staje się niezbędne, by uznać kogoś za mistrza. 


\section{Mistrz wśród nauczycieli akademickich}

Mistrzostwo - według definicji zawartej w Słowniku języka polskiego (red. M. Szymczaka, t. II, 1979, s. 186) - to "najwyższy stopień biegłości w wykonywaniu czegoś, biegłość, artyzm, kunszt". Mistrz to z kolei "człowiek przewyższający innych umiejętnością czegoś, biegłością w czymś, niedościgniony w jakiejś dziedzinie" (tamże). Mistrz imponuje zatem tym, którzy go obserwują lub się od niego uczą, staje się dla nich niekwestionowanym autorytetem i godnym naśladowania wzorem.

„Jasne jest - powiada Witkowski (2000, s. 365) - że zasada promująca "bycie tym pierwszym" ma wiele plusów i niesie pożytki dydaktyczno-wychowawcze. Nieprzypadkowo idea mistrzostwa i walory autorytetu (nie mylonego $z$ autorytaryzmem) są doceniane w pedagogice od dawna. Pozwala ona na dookreślenie i stopniowanie kompetencji w zakresie promocji konkretnych ról. Ta zasada najprościej daje się przekładać na czytelne schematy metodyki, na kryteria organizowania czasu lekcji i egzekwowania przyswojenia wiedzy (choćby i jej tylko odtwarzania)".

Można dodać także i inne plusy, jak choćby wartość przekazu, jednoznaczność oczekiwań i wymagań, jasne określenie wzoru, omijanie wielu rozterek i dylematów związanych z wyborem drogi poszukiwań i oceną rozwiązań. Prawdziwi mistrzowie we współczesnym uniwersytecie są bardzo potrzebni, gdyż bez nich trudno wyobrazić sobie wiodącą rolę uczelni w budowaniu społeczeństwa opartego na wiedzy (Szymański, 2002, s. 235-242). Przypominają się tu słowa Sergiusza Hessena: „profesor jest tym lepszy, im więcej stoi jako uczony" i Jerzego Kmity, który wyraził opinię, iż "nauczaniu uniwersyteckiemu jest potrzebny »uczony-twórca «, który będzie oddziaływał na słuchaczy posługując się przykładem własnym" (podaję za: Brzeziński, 1997).

Oddziaływanie mistrza ma też słabsze strony. Nieprzypadkowo z pracowni wybitnych malarzy wywodziło się mnóstwo sprawnych kopistów, a niewielu twórców. Mistrz może przytłaczać siłą oddziaływania swego wzoru, ograniczać rozwój indywidualności i postaw twórczych swych podopiecznych, utrudniać przełamywanie przyjętych konwencji i schematów. Minusem jest - znowu odwołajmy się do Witkowskiego (tamże) - to, że idea mistrzostwa oznacza "wmontowanie w funkcjonowanie szkoły poziomu kompetencji, także moralnej, opisywanego przez Kohlberga i także Habermasa w terminach sięgających co naj- 
wyżej »konwencjonalności « $i$ »tożsamości roli«. Sytuacyjnie daje to także efekty z poziomu anomii, o ile strach i nagroda stają się sposobem utrwalania nieodwracalności wspomnianego pierwszeństwa nauczyciela w każdej sytuacji".

Mistrz - w przypadku uczelni profesor lub inny nauczyciel akademic$\mathrm{ki}$ - może być, choć nie musi przewodnikiem dla studentów. Czynnikiem decydującym o spełnianiu roli przewodnika są - oprócz walorów intelektualnych i bogactwa wiedzy - cechy osobowości konkretnej osoby. Należą do nich - jak sądzę - ujmujące podopiecznych cechy charakteru, umiejętności tworzenia właściwych kontaktów interpersonalnych oraz uzdolnienia pedagogiczne niezbędne do rozwijania zainteresowań studentów i skutecznego przekazywania wiedzy.

Mistrz musi prezentować doskonałość przynajmniej w niektórych ważnych dziedzinach pracy. W odniesieniu do nauczycieli akademickich są to: twórczość naukowa, praca dydaktyczna, działalność organizacyjna i kierownicza. Można być uznanym za mistrza w całej uprawianej dyscyplinie (np. w filozofii, socjologii, fizyce czy automatyce) bądź jej częściach składowych (np. socjologii rodziny lub fizyce kwantowej), a także w metodologii nauk społecznych czy przyrodniczych, $w$ badaniach ilościowych lub jakościowych.

\section{Nauczyciel akademicki jako ekspert}

Coraz większa specjalizacja zbliża pozycję mistrza do roli eksperta, specjalisty lub biegłego, który może być autorem ekspertyz, opinii naukowych, konsultantem, rzeczoznawcą. Ekspertyza może być rozumiana jako czynność wykonywana przez eksperta lub ekspertów (np. ustalanie przyczyny wypadku lotniczego lub możliwości usytuowania wieżowca na danym terenie). Mianem ekspertyzy określa się też wynik pracy eksperta, np. w przypadku ustalania stanu psychicznego człowieka w momencie popełnienia przestępstwa lub badania nastrojów społecznych w przededniu wyborów.

Ekspert w środowisku uczelnianym jest uczonym i nauczycielem akademickim o formalnie lub nieformalnie uznanej biegłości w określonej dziedzinie, która znajduje wyraz zarówno w opanowaniu teorii, jak i praktycznym działaniu. Ekspertami są więc profesorowie, którym powierza się opiniowanie rozpraw doktorskich, a także dorobku naukowego kandydatów do stopnia naukowego doktora habilitowanego i tytułu profesora. Podobną rolę, choć w innym zakresie, pełnią też 
u nas członkowie Polskiej Komisji Akredytacyjnej, która ocenia i opiniuje $w$ danej uczelni całokształt działalności na określonym kierunku studiów, bada też związane z tym organizacyjno-prawne aspekty dotyczące funkcjonowania uczelni, wydziału i poszczególnych osób. Choć działania eksperta polegają na zbieraniu informacji niezbędnych do wydania opinii i ocen, a ekspertyzy je zawierają, praca eksperta także podlega ocenom. W ich wyniku pozycja eksperta albo się wzmacnia, albo słabnie, co może prowadzić do utrzymywania się, wzmacniania lub utraty tej roli.

Jest oczywiste, że ekspert ma lub powinien mieć autorytet. W uczelni wyższej jest to autorytet naukowy lub autorytet nauczyciela akademickiego jako dydaktyka, oparty na ocenach przełożonych, współpracowników i studentów, często też powiększany przez absolwentów, czytelników publikacji autorskich, a także przez wystąpienia na zjazdach i konferencjach, działania popularyzatorskie, prezentacje w mediach. Jeśli nauczyciel pełni funkcje kierownicze, odgrywa dużą rolę w zarządzaniu uczelnią, pełniąc funkcje rektora lub prorektorów, dziekana lub prodziekana, kierownika katedry lub zakładu, członka różnych organów kolegialnych (senat, rada wydziału, rada instytutu, komisja rektorska itp.), także ten rodzaj działalności może przyczyniać się do pozyskiwania (lub nie) autorytetu.

W coraz bardziej skomplikowanym społeczeństwie, nazywanym społeczeństwem ponowoczesnym, społeczeństwem sieci czy społeczeństwem ryzyka, ludziom coraz trudniej zdobywać orientację w świecie. Wzrasta więc rola intelektualistów, $w$ tym elity nauczycieli akademickich z różnych dziedzin w ostrzeganiu szerokich kręgów społecznych przed nowymi, nieznanymi wcześniej niebezpieczeństwami wywołanymi przez globalizację, kolejne fazy rewolucji naukowo-technicznej, gospodarkę rynkową, konsumpcjonizm, agresywną i niejednokrotnie szkodliwą politykę, ekspansję mediów oraz złudy i pułapki świata wirtualnego. Oczekuje się od nich także wskazywania prawidłowej drogi, na której umiejętność korzystania z dobrodziejstw zawdzięczanych ogromnym postępom naukowo-technicznym będzie harmonizowana z opartym na zasadach demokracji i humanizmu ładzie społecznym, w którym prawa człowieka i normy etyczne staną się podstawą istniejącego porządku. W ten sposób nowe zobowiązanie tych, „którzy więcej wiedzą", sprowadza się do częstszego podejmowania roli przewodników obok innych form naukowej i dydaktycznej działalności. 


\section{Nauczyciel akademicki w roli przewodnika}

Przewodnik jest liderem, musi więc umieć podejmować role przywódcze, mieć odwagę ponoszenia odpowiedzialności za podejmowane decyzje, wybór wartości, wyznaczanie dróg poznania naukowego, rozstrzyganie spornych kwestii. Potrzebne są mu więc pewne umiejętności eksperta, jego roli sprzyja posiadanie autorytetu i cech przywódczych. Gdy łączy je skutecznie, efekty są widoczne w tym, że zarówno on sam, jak i podążający jego śladami młodsi pracownicy nauki, nauczyciele akademiccy i studenci odnoszą sukcesy, mają obiektywne świadectwa i subiektywne poczucie swoich postępów. Taki nauczyciel akademicki może cieszyć się zasłużoną estymą i dużym autorytetem.

Przewodnik powinien być jednak przygotowany na trudne chwile, jeśli jego wiedza lub strategia okazuje się błędna (wiele takich przypadków wystąpiło w okresie przełomu po rozpadzie Związku Radzieckiego i całego bloku państw komunistycznych), gdy radykalnie zmienia się sposób postrzegania świata i potrzebne stają się nowe wartości oraz nowe sposoby rozumienia sensu życia.

Biorąc pod uwagę ogromne trudności, jakie są związane z wypełnianiem roli mistrza i przewodnika, coraz więcej nauczycieli akademickich, zwłaszcza młodszych, przyjmuje rolę życzliwego partnera studentów w ich dążeniu do poznawania wartości i zdobywania wiedzy. Są otwarci na dialog, służą radą i pomocą, ale nie pretendują do posiadania monopolu na prawdę i słuszność aksjologicznych wyborów. Starając się zachować własne "ja”, w pełni respektują podmiotowość studentów, ich odmienne osobowości, sposoby myślenia, racje światopoglądowe, style życia. Układy partnerskie dobrze przystają do ogólnych stosunków kształtujących się w demokratycznym społeczeństwie. Sprzyjają autentycznemu studiowaniu, motywowanemu przez zainteresowania poznawcze osoby prowadzącej zajęcia i uczestniczących w nich studentów, a nie wymuszanemu przez rygory zewnętrzne, sztucznie powiększaną dyscyplinę czy zwykły strach przed egzaminem i represjami ze strony nauczyciela akademickiego.

Partnerski styl pracy w uczelni wyższej jest jednak - wbrew pozorom - również bardzo trudny. W tym przypadku także niezbędny jest niekwestionowany autorytet nauczyciela akademickiego, aby w atmosferze stosunków demokratycznych ze studentami mógł osiągnąć założone cele i zadania pracy dydaktyczno-wychowawczej. W przeciwnym razie układy partnerskie mogą dryfować w stronę źle pojętego koleżeństwa, 
powodować spadek poczucia obowiązku i dyscypliny młodzieży akademickiej, oznaczać trudności egzekwowania wymagań i odpowiedniego rytmu pracy. Takie stany rzeczy w rezultacie muszą prowadzić do niskich efektów dydaktycznych, a czasem też do niewłaściwych postaw i zachowań studentów.

Trudno jest zatem jednoznacznie rozstrzygnąć, jaki powinien być współczesny nauczyciel akademicki. Tradycyjny model mistrza powoli się przeżywa, gdyż często związany z nim autorytaryzm i chęć ustawicznego narzucania znaczeń nie przystają do potrzeb demokratyzującego się społeczeństwa. Rola przewodnika, choć chwalebna i wartościowa z pedagogicznego punktu widzenia, bywa trudna do wypełnienia, zwłaszcza w okresie gwałtownej zmiany społecznej i równie szybko wzrastającego poziomu wiedzy. Z kolei pozycja partnerska w stosunku do studentów, choć dobrze wkomponowana w realia społeczeństwa obywatelskiego, w niektórych przypadkach może zawodzić.

Być może zatem w warunkach złożonego i zmieniającego się społeczeństwa nie ma jednego pożądanego wzoru nauczyciela akedemickiego. Przywódcy są potrzebni w każdym środowisku, a więc także w społeczności akademickiej nastawianej na wytyczone, ale też ciągle modyfikowane cele. Nawet jeśli krytykujemy pedagogikę dyrektywną i autorytarną, trudno wykluczyć, że części młodzieży potrzebne są i takie oddziaływania. Propagując podmiotowość wszystkich obywateli, a więc oczywiście również studentów, nie można kwestionować, że zadania, a także wiedza, umiejętności i kompetencje osób uczestniczących w życiu uniwersytetu nie są jednakowe, więc dobrze byłoby, gdyby nauczyciele akademiccy odgrywali rolę przewodników czy też liderów studentów na tyle, na ile jest to możliwe. Podobną rolę odgrywają eksperci - ich wiedza i umiejętności mogą imponować i zachęcać do intensywnych studiów. Nie powinno być jednak zbyt dużego dystansu między nauczycielami akademickimi i studentami, gdyż oni także powinni czynnie uczestniczyć w badaniach. Trudno więc negować znaczenie dobrze pojętych układów partnerskich między kadrą nauczającą i studentami. Rzecz tylko w tym, iż muszą one wynikać z potrzeb i możliwości obu grup społeczności akademickiej, a jednocześnie służyć celom wyznaczonym w programach studiów.

Zatem we współczesnym uniwersytecie potrzebni są przywódcy, eksperci i mistrzowie, a także przewodnicy młodzieży akademickiej oraz nauczyciele akademiccy będący partnerami studentów. Możliwe jest 
również integrowanie cech wszystkich wymienionych typów nauczycieli akademickich w działaniach tej samej osoby. Niełatwo to jednak osiągnąć. Niektórzy wszak mówią, iż prawdziwymi przywódcami mogą być tylko nieliczni, ludzie, których otacza charyzma, od obecnych ekspertów z czasem okażą się lepsi inni, mistrzem tylko czasem się bywa, rolę przewodnika wypełniamy niejednokrotnie, ale przecież nie zawsze jest to możliwe. Partnerstwo ze studentami jest pożądane, jednak też ma swoje uwarunkowania i granice. 


\section{Bibliografia}

$\rightarrow$ Brzeziński, J. (1997), Trwałe wartości uniwersytetu, Forum Oświatowe, 1-2, 203-218.

$\rightarrow$ Burns MacGregor, J. (1995), Władza przywódcza [w:] J. Szczupaczyński (red.), Władza i społeczeństwo. Antologia tekstów z zakresu socjologii polityki, s. 265269, Warszawa: Wydawnictwo Naukowe Scholar.

$\rightarrow$ Korzeniecka-Bondar, A. (2011), Przywództwo w szkole: „powierzchowna retoryka" czy konieczny warunek zmian? [w:] S.M. Kwiatkowski, J.M. Michalak, I. Nowosad (red.), Przywództwo edukacyjne w szkole i jej otoczeniu, s. 95-104, Warszawa: Wydawnictwo Difin.

$\rightarrow$ Koźmiński, A.K., Jemielniak, D. (2008), Zarzq̨dzanie od podstaw. Podręcznik akademicki, Warszawa: Wydawnictwa Akademickie i Profesjonalne.

$\rightarrow$ Kwiatkowski, S.M. (2010), Miejsce i rola przywództwa w edukacji [w:] S.M. Kwiatkowski, J. Madalińska-Michalak (red.), Przywództwo edukacyjne w teorii i praktyce, s. 13-24, Warszawa: Fundacja Rozwoju Systemu Edukacji.

$\rightarrow$ Mazurkiewicz, G. (2014), Przywództwo edukacyjne - ambitny projekt zmiany [w:] S.M. Kwiatkowski, J. Madalińska-Michalak (red.), Przywództwo edukacyjne. Współczesne wyzwania, s. 37-64, Warszawa: Wolters Kluwer.

$\rightarrow$ Madalińska-Michalak, J. (2015), Dyrektor szkoły liderem - inspiracje i perspektywy, Warszawa: Wolters Kluwer.

$\rightarrow$ Madalińska-Michalak, J. (2012), Skuteczne przywództwo w szkołach na obszarach zaniedbanych społecznie. Studium porównawcze, Łódź: Wydawnictwo Uniwersytetu Łódzkiego.

$\rightarrow$ Michalak, J.M. (2006), Istota i modele przywództwa szkolnego [w:] J.M. Michalak (red.), Przywództwo w szkole, s. 63-80, Kraków: Oficyna Wydawnicza "Impuls".

$\rightarrow$ Schratz, M. (2014), Tworzenie zmiany od wewnq̨trz. Przywództwo jako uczenie się z wyłaniajq̨cej się przyszłości, tłum. i oprac. nauk. J. Madalińska-Michalak [w:] S.M. Kwiatkowski, J. Madalińska-Michalak (red.), Przywództwo edukacyjne. Współczesne wyzwania, s. 11-36, Warszawa: Wolters Kluwer. 
$\rightarrow$ Szymczak, M. (red.) (1979), Słownik języka polskiego, t. II, Warszawa: Państwowe Wydawnictwo Naukowe.

$\rightarrow$ Szymański, M.J. (2002), Kryzys i zmiana. Studia nad przemianami edukacyjnymi w Polsce w latach dziewięćdziesiątych, Kraków: Wydawnictwo Naukowe Akademii Pedagogicznej.

$\rightarrow$ Witkowski, L. (2000), Alternatywy myślenia o/dla edukacji, Warszawa: Instytut Badań Edukacyjnych. 



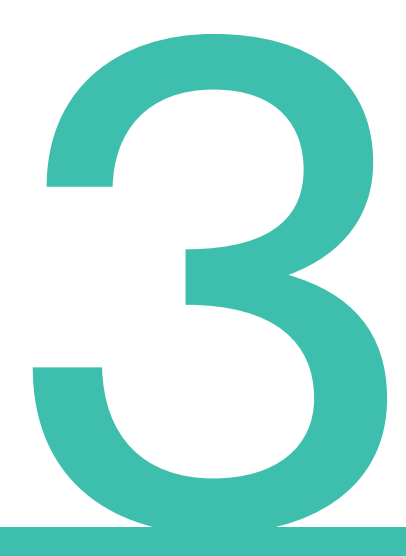




\section{Przywództwo nauczycieli \\ - perspektywa międzynarodowa}




\title{
Przywództwo edukacyjne nauczycieli
}

\author{
Maria Assunção Flores
}

W niniejszym artykule prezentuję sposoby postrzegania przez portugalskich nauczycieli warunków i możliwości sprawowania przywództwa, szczególnie w kontekście coraz większego obciążenia ich pracą i biurokracją, jak również pogarszających się warunków zatrudnienia, w tym ich społeczno-ekonomicznego statusu. W pierwszej części rozdziału dokonuję przeglądu istniejącej literatury dotyczącej przywództwa edukacyjnego nauczycieli w celu wyjaśnienia tego pojęcia, które podlega różnym interpretacjom. Następnie przedstawiam metodologię projektu badawczego, którego dotyczy druga część tego artykułu. Rezultaty badania przedstawione są według kluczowych tematów wypływających zarówno z danych ilościowych, jak i jakościowych. Rozdział zamyka podsumowanie wyników badania oraz ich wpływu na rozwój zawodowy nauczycieli.

\section{Słowa kluczowe: \\ przywództwo nauczycieli \\ zawód nauczyciela \\ warunki pracy}




\title{
Perspectives on teacher leadership
}

\author{
Maria Assunção Flores
}

In this chapter, I address the ways in which Portuguese teachers look at conditions and opportunities for them to exercise leadership, particularly at a time marked by an increase of the workload and bureaucracy and the deterioration of their working conditions including their social economic status. In the first part of the chapter I look at international literature on teacher leadership in order to clarify the concept which subject to different interpretations. Then, I address the methodological features of the research project on which the second part of the chapter is based. Findings are presented according to the key themes emerging from both quantitative and qualitative data. The chapter ends with a discussion of the findings and their implications for teacher professional development.

\section{Keywords:}

teacher leadership 


\section{Wprowadzenie}

W kontekście europejskim, podstawowe elementy programów kształcenia nauczycieli obejmują: kompetencje przedmiotowe; kompetencje pedagogiczne; integrację teorii i praktyki; współpracę; zapewnianie jakości; mobilność; przywództwo edukacyjne; kształcenie ustawiczne i uczenie się przez całe życie.

Raport oparty na dokumentach Komisji Europejskiej w kontekście umiędzynarodowienia kształcenia nauczycieli w Europie wskazuje znaczenie takich zagadnień, jak: uczenie się oparte na badaniach, rozwój własny, wymiana uczniów, nauka języków europejskich, rozumienie różnych kultur europejskich etc. Jednakże w dokumentach państw członkowskich często brakuje odwołań do następujących elementów: mobilność, przywództwo edukacyjne oraz kształcenie ustawiczne i uczenie się przez całe życie (Piesanen i Valijarvi, 2010).

W wydanej w ostatnim czasie publikacji Huang (2016, s. 222-223) twierdzi, że „związek pomiędzy przywództwem edukacyjnym nauczycieli a ich kształceniem do zawodu jest często pomijany" i że należy dążyć do wzmocnienia tych powiązań, ponieważ „rozwój zawodowy ma bardzo duże znaczenie, a umiejętność podejmowania działań staje się stopniowo ważną cechą zachodzących w nauczycielach zmian" [oryginalny zapis]. Również Flores (2017, artykuł prasowy), bazując na badaniach empirycznych, wskazuje cztery kluczowe elementy wpływające na jakość pracy nauczyciela. Pierwszy element to pojęcie nauczyciela jako lidera procesu uczenia się, co konstytuuje zawód nauczyciela, włączając w to takie zagadnienia, jak: motywacja, innowacyjna praktyka, zaangażowanie oraz elastyczność. W swojej ostatniej książce Frost (2017) twierdzi, że praca nauczycieli jest określana przez kierunki polityki i dlatego też wymaga się od nich, by nie tylko kierowali procesem wprowadzania zmian, ale również odgrywali rolę $w$ kształtowaniu samych kierunków polityki. W tym kontekście Frost (2017, s. 174) zauważa, że "upodmiotowienie nauczycieli i wyposażenie ich w możliwości wprowadzania zmian jest pilną koniecznością".

W niniejszym rozdziale prezentuję sposoby postrzegania przez portugalskich nauczycieli warunków i możliwości określających sprawowanie przez nich przywództwa, szczególnie w kontekście coraz większego obciążenia ich pracą i biurokracją, jak również pogarszających się warunków zatrudnienia, w tym ich społeczno-ekonomicznego statusu (patrz: Flores, 2014). W pierwszej części artykułu dokonuję przeglądu 
międzynarodowej literatury na temat przywództwa edukacyjnego nauczycieli w celu wyjaśnienia pojęcia, które nie ma jednej uzgodnionej definicji. Następnie przedstawiam metodologię projektu badawczego, którego dotyczy druga część tego artykułu. Rezultaty badania przedstawione są według kluczowych tematów wypływających zarówno z danych ilościowych, jak i jakościowych. Rozdział zamyka podsumowanie wyników badania oraz ich wpływu na rozwój zawodowy nauczycieli

\section{Dlaczego przywództwo edukacyjne nauczycieli jest ważne?}

Literatura dotycząca przywództwa edukacyjnego nauczycieli (PEN) jest obszerna, ale brakuje jej konsensu. Istnieje wiele różnorodnych podejść i definicji PEN (Davis, Leon, 2009; Alexandrou, Swaffield, 2012). Jednakże, mimo tego zróżnicowania w zakresie użycia tego terminu, PEN postrzegane jest jako kluczowy element poprawy jakości edukacji.

Stevenson $(2012$, s. 345) uważa, że większość literatury na temat przywództwa edukacyjnego nauczycieli „jest zakorzeniona w głównym nurcie dyskusji dotyczącej przywództwa i zarządzania w edukacji oraz nie udziela odpowiedzi na bardziej fundamentalne pytania o naturę przywództwa w kontekście edukacyjnym". Autor wskazuje dwa główne problemy dotyczące tych opracowań: i) przywództwo edukacyjne nauczycieli nadal jest postrzegane z perspektywy zarządczej zakorzenionej w tradycji i hierarchii powiązanej z pewnymi rolami i strukturami, w pełni konserwatywnej i ortodoksyjnej; ii) literatura ta kładzie nacisk na wkład nauczycieli liderów w edukacyjną zmianę, ale, jak twierdzi autor, rzadko odpowiada na pytanie o "fundamentalną naturę tych zmian" (2012, s. 345). Podobnie uważają Fairman i Mackenzie (2012, s. 244), którzy sugerują, że odnoszenie się do aspektów praktyki nauczycielskiej jako „przywództwa” może być problematyczne: „Określanie pracy nauczycieli jako »przywództwo « może faktycznie zniechęcać nauczycieli do angażowania się w działania przywódcze, gdyż rozumienie pojęcia »przywództwo « przez nauczycieli wywodzi się z bardziej tradycyjnego modelu formalnie przypisanych ról i zakresów odpowiedzialności. Przyczyną tego stanu rzeczy mogą też być utrzymujące się w nauczaniu egalitarne normy".

W dużej mierze można $w$ istniejącej literaturze na temat PEN wyróżnić zarówno wymiar formalny jak i nieformalny, w tym różne poziomy interwencji i różnych interesariuszy. Na przykład York-Barr i Duke $(2004,288)$ twierdzą, że przywództwo edukacyjne nauczycieli stanowi 
„Wszechstronne pojęcie obejmujące różne aspekty pracy w wielorakich obszarach systemów edukacji, w tym pracę z uczniami, kolegami i administracją oraz pracę związaną z nauczaniem jak również z rozwojem zawodowym i organizacyjnym".

Huang (2016) wyróżnia tradycyjne postrzeganie przywództwa i przywództwo nieformalne, przy czym to pierwsze skupia się na posiadającej władzę jednostce (zazwyczaj jest to dyrektor lub kierownictwo szkoły), a drugie - wskazuje osoby, które nie piastują formalnych stanowisk w danej organizacji. Formalne i nieformalne przywództwo edukacyjne nauczycieli jest różnie przedstawiane $w$ istniejącej literaturze przedmiotu. Formalni nauczyciele-liderzy, to ci, którzy odgrywają rolę w strukturze organizacyjnej szkoły (np. szefowie działów, koordynatorzy programów nauczania, mentorzy etc.), podczas gdy nieformalni nauczyciele-liderzy, to ci, którzy nie piastują żadnej formalnej funkcji w szkole, ale wpływają na innych (uczniów, kolegów, rodziców) w środowisku, w którym pracują. Dlatego też nieformalne przywództwo kojarzone jest z różnymi działaniami, dzięki którym nauczyciele dokonują zmiany $w$ swoim miejscu pracy poprzez wchodzenie $w$ interakcje $z$ innymi, wpływanie na innych i kierowanie nimi w różnorodny sposób. Na przykład Katzenmeyer i Moller (2001, s. 5) definiują nauczycieli-liderów jako tych, którzy "przewodzą w klasie i poza nią, utożsamiają się ze społecznością nauczycieli uczących się i liderów oraz wnoszą do niej swój wkład, jak również wywierają na innych wpływ w celu doskonalenia praktyki edukacyjnej". Podobne zdanie prezentuje Frost (2012), który optuje za postrzeganiem przywództwa edukacyjnego nauczycieli jako zjawiska niepowiązanego z piastowaniem stanowisk oraz "nie zakłada, że przywództwo jest automatycznie powiązane ze stanowiskiem w hierarchii organizacyjnej szkoły" (Frost, 2012 , s. 210). Bardziej tradycyjne postrzeganie przywództwa opiera się na podejściu odgórnym, hierarchicznym i zindywidualizowanym, które nie dostrzega kolektywnego, opartego na współpracy wymiaru przywództwa (Harris, 2003).

W szkołach postrzeganych jako środowiska uczące się (Forte, Flores, 2014), nauczyciele są zachęcani do bycia przywódcami oraz angażowania się $\mathrm{w}$ doskonalenie swoich miejsc pracy poprzez prowadzenie projektów, wpływanie na innych i mobilizowanie ich zarówno w klasie, szkole, jak i poza nimi. W tym kontekście Poekert (2012, s. 171) podkreśla znaczenie tej definicji, zwracając uwagę na centralny wymiar 
przywództwa, które opiera się na "wywieraniu wpływu i wchodzeniu w interakcje, a nie na sile i władzy".

Fairman i Mackenzie (2012) wskazują na dynamiczny i zależny od kontekstu charakter przywództwa edukacyjnego nauczycieli. Określono również wiele warunków, które muszą zostać spełnione, aby przywództwo edukacyjne nauczycieli mogło się pomyślnie rozwijać: kultura zaufania i wsparcie, struktury wspierające przywództwo edukacyjne nauczycieli, jasne, transparentne i silne przywództwo, zaangażowanie w innowacyjne formy doskonalenia zawodowego (Muijs, Harris, 2006). Również według Durranta (2004, s. 27) ważne jest, by „wizje i wartości nauczycieli były wyrażane i żeby nauczyciele byli angażowani zarówno w ustalanie programu zmian, jak i sprawowali przywództwo w ich wdrażaniu". Huang (2016) mówi o podejściu opartym na upodmiotowieniu, omawiając naturę nieformalnego przywództwa sprawowanego przez osoby, które nie piastują formalnych stanowisk w szkolnej strukturze. Jak twierdzą Hanuscin, Rebello oraz Sinha (2012, s. 17), „istnieje wiele nieformalnych możliwości, dzięki którym nauczyciele wywierają wpływ i wprowadzają pozytywną zmianę w szkołach".

Huang (2016) uważa, że w przypadku nieformalnych liderów można promować bardziej autonomiczne działania realizowane przez ich zwolenników. Ten sam autor, na podstawie badania przeprowadzonego na Tajwanie, konkluduje, że PEN jest szeroko zakrojonym procesem, który obejmuje zarówno głównych liderów, jak i kluczowych członków społeczności oraz ogólnych zwolenników. To samo badanie wskazuje na szczególne cechy głównych liderów, takie jak ich silna i autonomiczna wola, która wydaje się nie być w żaden sposób powiązana z jakimkolwiek rodzajem intencji organizacyjnych lub związanych ze stanowiskiem. Ponadto kluczowi liderzy skłonni są do stosowania w swoich wypowiedziach "tonu zapraszajq̨cego" [oryginalny zapis] w celu budowania relacji opartych na współpracy i profesjonalnym dialogu (Huang, 2016). Podobnie uważa Hunzicker (2012, s. 268), który twierdzi, że „najlepsze przygotowanie nauczycieli liderów to połączenie rozwoju zawodowego z doświadczeniem współpracy". Zagadnienia współpracy i strategicznego przywództwa edukacyjnego nauczycieli również występuje w literaturze (Frost, Roberts, 2004).

Potencjał PEN, by zmieniać szkoły i praktykę edukacyjną, został udokumentowany na wiele sposobów (np. Flores, 2013, Flores i in., 2016), czego przykładem może być ostatnio wydana książka Frosta (2017). W publikacji tej teorię przywództwa edukacyjnego nauczycieli, 
które nie wynika z zajmowanego stanowiska, ilustrują historie i wypowiedzi nauczycieli pochodzących z różnych środowisk. Umożliwia to zrozumienie, dlaczego PEN jest ważne i dlaczego sprawdza się w szkołach, na przykład poprzez włączenie technologii do procesu uczenia się w pewnej szkole w Kairze (Elfouly, Eltemamy, 2017), opracowanie strategii mających na celu poprawę umiejętności matematycznych w Anglii (Sakatis, Wootton, 2017) lub kultywowanie nadziei w trudnej sytuacji panującej w Portugali (Flores, Richmond, 2017).

\section{Badanie}

Niniejszy rozdział bazuje na danych pochodzących z trwającego trzy lata (od stycznia 2011 r. do czerwca 2014 r.) projektu finansowanego przez Fundação para a Ciência e a Tecnologia (Narodowa Fundacja na rzecz Nauki i Technologii) (PTDC/CPE-CED/112164/2009). Projekt został opracowany $\mathrm{w}$ bardzo ważnym dla zawodu nauczyciela okresie oszczędności ekonomicznych i kryzysu gospodarczego. Zagadnienia, takie jak: intensyfikacja, wzrost obciążenia pracą, biurokracja, pogarszające się warunki pracy nauczycieli, w tym ich statusu społeczno-ekonomicznego, to tylko kilka z wielu przykładów. Opierając się na wynikach głównego projektu badawczego, w niniejszym rozdziale postaramy się odpowiedzieć na następujące pytania:

$\rightarrow$ Jak nauczyciele postrzegają przywództwo edukacyjne nauczycieli?

$\rightarrow$ Jak inni interesariusze w szkole, głównie uczniowie, kierownictwo szkoły, postrzegają przywództwo edukacyjne nauczycieli?

$\rightarrow$ W jakich warunkach nauczyciele mogą sprawować przywództwo?

Wykorzystano mieszane metody badań. Dane zbierane były w trzech etapach. W I fazie przeprowadzono krajowe badanie opinii, w którym wzięło udział 2702 nauczycieli. W celu szczegółowego przeanalizowania głównych wyników ze zgromadzonych danych ilościowych, 11 szkół usytuowanych w różnych regionach kraju wzięło udział w II fazie projektu, która składała się z częściowo ustrukturyzowanych wywiadów przeprowadzonych z 11 dyrektorami oraz grup fokusowych obejmujących uczniów ( $n=108$ ) i nauczycieli $(n=99)$. Trzecia faza obejmowała program rozwoju zawodowego realizowany w pięciu szkołach znajdujących się na północy Portugalii, w który wzięło udział 66 nauczycieli (faza III). W niniejszym rozdziale omówione zostaną dane z fazy I i II. Więcej in- 
formacji na temat fazy III można znaleźć na stronie internetowej: www. teachersexercisingleadership.com.

Łącznie 2702 nauczycieli z kontynentalnej części Portugalii wzięło udział w badaniu przeprowadzonym online. $78,5 \% \mathrm{z}$ nich stanowiły kobiety; $42,8 \%$ było $w$ wieku $40-49$ lat, 28,6\% w wieku 50-59 lat, a $25,5 \%$ w wieku 30-39 lat. Tylko 1,7\% miało 20-29 lat. Pozostaje to w zgodzie z najnowszym "Ogólnym profilem nauczycieli 2014/2015" opublikowanym przez Ministerstwo Edukacji (Direção-Geral de Estatísticas da Educação e Ciências, lipiec 2016). Zawarte w tej publikacji statystyki potwierdzają, że mniej niż $2 \%$ portugalskich nauczycieli ma 30 lub mniej lat. Jeśli chodzi o kwalifikacje nauczycieli, to większość z nich posiada licencjat (Licenciatura) $(59,3 \%)$, a 21,4\% - tytuł magistra. Większość nauczycieli ma od 11 do 20 lat doświadczenia zawodowego (37,6\%), a 34,9\% - pomiędzy 21 a 30 lat. Duża większość z nich jest na stałe zatrudniona w szkole (83,3\%). Ponadto większość uczy w szkołach miejskich $(51,1 \%)$ we wszystkich sektorach nauczania (od przedszkola do szkoły średniej: uczniowie w wieku od 3 do 18 lat).

W przypadku 99 nauczycieli biorących udział w grupach fokusowych (w sumie 22), większość stanowiły kobiety $(76,8 \%)$. Jeśli chodzi o ich wiek, to $31,3 \%$ miało od 51 do 60 lat, a $27,3 \%$ miało pomiędzy 41 a 50 lat. Uczestnicy badania pochodzili ze wszystkich sektorów edukacji, od przedszkola do szkoły średniej i nauczali różnych przedmiotów. Biorąc pod uwagę ich doświadczenie zawodowe: $36,4 \%$ miało za sobą od 21 do 30 lat pracy, 26,3\% pomiędzy 31 a 40 lat, a 22,2\% miało doświadczenie zawodowe wynoszące od 11 do 20 lat.

Spośród 11 uczestniczących w badaniu dyrektorów szkół, 54,5\% stanowiły kobiety pracujące we wszystkich sektorach edukacji, $w$ tym w dużych zespołach szkół (od przedszkola do szkoły średniej) (63,6\%); jedynie 36,4\% pracowało w sektorze szkół średnich.

W przypadku 108 uczniów biorących udział w grupach fokusowych (w sumie 23), większość stanowiły dziewczęta $(52,8 \%)$ w wieku od 11 do 15 lat $(39,8 \%)$ i w wieku od 16 do 20 lat $(30,6 \%)$. Uczestnicy pochodzili ze wszystkich sektorów nauczania, przedszkoli, szkół podstawowych i szkół średnich. 32,4\% spośród 108 uczniów uczyło się w szkołach średnich, a 25,9\% w szkołach podstawowych (uczniowie w wieku od 10 do 15 lat).

Dane ilościowe zostały przeanalizowane pod względem statystycznym z wykorzystaniem systemu SPSS (wersja 20). Proces analizy 
danych jakościowych był dwufazowy: analiza danych zebranych w każdej szkole w postaci wypowiedzi nauczycieli, uczniów i dyrektorów. Druga faza miała formę analizy komparatywnej lub horyzontalnej (analiza krzyżowa) (Miles, Huberman, 1994). W tej fazie możliwe było poszukiwanie wspólnych wzorców, jak również różnic. Zespół badaczy wykorzystał kryterium semantyczne do wyszukania kluczowych tematów wynikających z danych jakościowych.

\section{Glówne rezultaty badania}

W ramach projektu uzyskano wiele wartościowych danych. Z uwagi na ograniczenia odnośnie obszerności niniejszego tekstu, wyniki zostaną przedstawione według trzech głównych tematów: współistnienie w szkole różnych liderów; dobrzy nauczyciele liderami uczenia się; klasa szkolna jako kluczowy kontekst sprawowania przywództwa edukacyjnego nauczycieli.

\section{Współistnienie różnych liderów w szkole}

Kiedy zadaliśmy pytanie: „Kto jest liderem w twojej szkole?”, uczestnicy badania wskazywali różnorodne role przywódcze. Innymi słowy, przywództwo opisywane jest jako wielorakie działania podejmowane przez różne osoby. Poza tym, najpopularniejszy punkt widzenia nauczycieli związany był z wymiarem formalnym przywództwa, w szczególności przypisanym do tych osób, które odgrywają rolę w strukturze zarządzania szkołą, jak dzieje się to w przypadku dyrektora szkoły lub starszego kierownictwa. Nauczyciele wspominali również o roli, jaką odgrywa szef działu lub koordynator danego przedmiotu.

„Dyrektor szkoły odgrywa w niej kluczową rolę w zakresie przywództwa".

(Nauczyciel ze szkoły średniej, 23 lata doświadczenia w nauczaniu)

"Dyrektor szkoły jest kluczową osobą, jeśli chodzi o przywództwo". (Nauczyciel ze szkoły podstawowej, 20 lat doświadczenia w nauczaniu)

„Moim zdaniem kluczowym liderem jest dyrektor szkoły. Ona jest najważniejszą osobą w szkole. Oczywiście, jest grupa ludzi, którzy ją wspierają i jej pomagają (...) i w rezultacie również kierują szkołą". (Nauczyciel ze szkoły podstawowej, 18 lat doświadczenia w nauczaniu) 
Inni nauczyciele podkreślali role szefów działów i tutorów, jak również koordynatorów projektów w szkole:

„Myślę, że przywództwo w szkole jest wstępnie zdefiniowane. Są koordynatorzy poszczególnych działów, to oni wnoszą pewien rodzaj dynamiki do szkoły. W czasie spotkań prowadzone są dyskusje, ludzie zabierają głos, komunikują się...".

(Nauczyciel ze szkoły podstawowej, 28 lat doświadczenia w nauczaniu)

„Przywództwo w szkole to nie tylko jej dyrektor. Można mówić o przywództwie również na poziomie pośrednim, na przykład w odniesieniu do szefów działów, tutorów, ich koordynatorów etc. Oni wszyscy są ważni...".

(Nauczyciel ze szkoły podstawowej, 34 lata doświadczenia w nauczaniu)

„Myślę, że to koordynatorzy sprawiają, że szkoła jest dynamiczna. Oczywiście kadra kierownicza jest ważna, ale to koordynatorzy radzą sobie z codziennymi sprawami...".

(Nauczyciel ze szkoły średniej, 32 lata doświadczenia w nauczaniu)

"Koordynator pracy nauczycieli odgrywa kluczową rolę. On/ona próbuje wypracować pewną dynamikę w szkole, zbudować pracę zespołową, on/ona ułatwia nauczycielom współpracę. Życie w szkole jest trudne w obecnych czasach i to koordynator jest elementem łączącym, zdejmującym z nauczycieli presję i wspierającym ich. Nauczyciele potrzebują poczucia, że koordynator koncentruje się na nich i że on/ona jest dobry/a w tym, co robi i wie, co należy zrobić".

(Nauczyciel ze szkoły podstawowej, 26 lat doświadczenia w nauczaniu)

Rola tutorów nauczycieli w ustanawianiu powiązań pomiędzy szkołą a rodzinami również jest podkreślana w odpowiedziach osób biorących udział w badaniu. Uczestnicy badania mówili o ich przywódczej roli w odniesieniu do interakcji z uczniami, rodzicami i innymi nauczycielami. Podobnie postrzegani są koordynatorzy projektów w szkołach, których traktuje się jak głównych graczy w odniesieniu do przywództwa edukacyjnego nauczycieli w szkole. 
„Tutorzy odgrywają w szkole kluczową rolę ... są zaangażowani w ustanawianie powiązań pomiędzy pracą w szkole a rodzinami, pracują z uczniami, nauczycielami i rodzicami. Opiekują się dziećmi i ich praca wykracza poza kontekst klasy szkolnej. Ich praca jest ważna w kontekście wspierania zachowań i osiągnięć uczniów...". (Nauczyciel ze szkoły podstawowej, 18 lat doświadczenia w nauczaniu)

Mimo iż w odpowiedziach nauczycieli dominuje formalny wymiar przywództwa, to można wyróżnić również szersze rozumienie przywództwa edukacyjnego nauczycieli, nawet jeśli ten pogląd jest rzadziej reprezentowany. Uczestnicy mówili również o nauczycielach, którzy wprowadzają zmianę w ich szkołach, wskazując na nieformalne przywództwo edukacyjne nauczycieli i jego wymiar nie związany z piastowanym stanowiskiem (Frost, 2012). W przypadku tego rodzaju przywództwa w szkole, odpowiedzi udzielane przez nauczycieli są bardzo obszerne. Odnoszą się do wywierania wpływu, mobilizacji, motywacji, innowacji i działania. Jest to widoczne w takich wyrażeniach, jak: „prawdziwe przywództwo”, „zdolność angażowania i mobilizowania ludzi”, "umiejętność kierowania ludźmi i motywowania ich oraz angażowania w szkole", „podejmowanie inicjatywy" oraz "sprawianie, że inni zaczynają wierzyć, że coś jest możliwe":

"Moim zdaniem, w szkole są ludzie, którzy, mimo iż nie odgrywają formalnej roli, mają posłuch i są szanowani przez wszystkich. Pyta się ich o opinie na temat danych spraw, to ludzie, którzy wiedzą, o czym mówią (...), to jest prawdziwe przywództwo".

(Nauczyciel ze szkoły średniej)

„W mojej grupie znam ludzi, którzy potrafią motywować i mobilizować innych. Kierują innymi w projektach i w czasie innych działań. (...) kiedykolwiek mam wątpliwości, albo napotykam na problemy, pytam ich o zdanie".

(Nauczyciel ze szkoły średniej)

"Zdaję sobie sprawę z tego, że to nie formalne stanowiska sprawiają, że szkoła działa sprawnie. To zasługa tych dwustu kilkudziesięciu innych nauczycieli...".

(Nauczyciel ze szkoły średniej, 20 lat doświadczenia w nauczaniu) 
"Czasem czuję się jak lider, kiedy myślę o jakiejś idei. Chcę ją rozwinąć i prezentuję ją mojej grupie i kiedy uda mi się ich zaangażować $w$ dany projekt, to wtedy mam poczucie, że jestem liderem. Jestem w stanie ich zaangażować w projekt i sprawić, by uwierzyli, że można coś zrobić dla uczniów i dla szkoły".

(Nauczyciel ze szkoły podstawowej, 25 lat doświadczenia w nauczaniu)

Dlatego też przywództwo edukacyjne nauczycieli nie odnosi się tylko do odgrywania formalnych ról. W opinii niektórych uczestników badania w szkole są obecni nieformalni liderzy i to oni są promotorami zmian, przewodząc innym, dzięki swojej wiedzy, doświadczeniu i mądrości. Są to nauczyciele, którzy wpływają na swoich kolegów, opracowują innowacyjne projekty, angażują się w działania, które wprowadzają zmiany w środowisku, w którym pracują.

\section{Dobrzy nauczyciele liderami uczenia się}

Nauczyciele uczestniczący w badaniu podkreślali swoją rolę jako liderów procesu uczenia się, szczególnie w kontekście klasy szkolnej. Mówili też o różnych sposobach wprowadzania zmian przez nauczycieli w środowisku szkolnym, kiedy mogą wywierać wpływ i mobilizować innych, poprzez realizację projektów, kontakty z rodzicami i środowiskiem lokalnym etc. Nauczyciele postrzegani są zatem jako promotorzy zmian, liderzy procesu uczenia się uczniów, jak również własnego uczenia się.

„W klasie postrzegam siebie jako lidera".

(Nauczyciel ze szkoły podstawowej, 27 lat doświadczenia w nauczaniu)

„Będąc nauczycielem, musisz być liderem w klasie, nieprawdaż? Każdy jest liderem na swój sposób...".

(Nauczyciel ze szkoły podstawowej, 26 lat doświadczenia w nauczaniu)

Uczestnicy badania podkreślają, że nauczyciele są liderami nauczania i uczenia się w klasie, kiedy proponują lub realizują działania pedagogiczne. Ten rodzaj przywództwa jest również widoczny w pedagogicznych interakcjach z uczniami i jest związany z ich umiejętnością mobilizowania innych, wpływania na nich i wprowadzania zmian w ich życiu. 
„Jako nauczyciel możesz wpływać na swoich kolegów i uczniów. Możesz być też prowadzony przez nich. (...) Musisz być liderem w klasie...".

(Nauczyciel ze szkoły średniej, 33 lata doświadczenia w nauczaniu)

„Uważam, że jestem liderem. Lubię kierować działaniami, w które wierzę".

(Nauczyciel ze szkoły średniej, 17 lat doświadczenia w nauczaniu)

W podobnym duchu wypowiadają się biorący udział w badaniu dyrektorzy szkół, którzy podkreślają rolę nauczycieli-liderów, ich zdolność do wywierania wpływu na innych i mobilizowania ich oraz motywowania ludzi do przewodzenia innym w swoim miejscu pracy:

„Nauczyciele-liderzy potrafią motywować, angażować ludzi, na przykład w projekt, lub skupiać nauczycieli w grupę (...) umieją włączać ludzi do działania i zrobienia czegoś dla szkoły".

(Dyrektor szkoły, 19 lat doświadczenia w nauczaniu)

"Nauczyciel-lider potrafi związać ludzi ze sobą i wprowadzić w szkole dobrą atmosferę. Angażujesz ludzi w życie szkoły".

(Dyrektor szkoły, 23 lata doświadczenia w nauczaniu)

Uczniowie również potrafili mówić o przywództwie jako kluczowym elemencie pracy ich nauczycieli. Takie zagadnienia, jak: inspiracja, motywacja i pasja, przewijają się w ich wypowiedziach:

"Lider to ktoś, kto umie cię zmotywować, ktoś, kogo szanujesz, a on szanuje ciebie. Czujesz, że powinieneś zrobić to, co oni mówią...". (Uczeń, 16 lat)

"Inspiruje cię i czujesz, że z nim pracujesz...."

(Uczeń, 12 lat)

„Nauczyciele-liderzy są kompetentni. Wiele ich cech związanych jest z byciem dobrym nauczycielem, nawiązują dobre relacje i potrafią utrzymywać formalne, ale nie sztywne relacje ze swoimi uczniami". (Uczeń, 16 lat) 


\section{Klasa szkolna jako kluczowy kontekst sprawowania przywództwa przez nauczycieli}

Klasa szkolna powiązana jest z pojęciem nieformalnego przywództwa. Według uczestników badania, nauczyciele są liderami uczenia się i nauczania w klasie szkolnej dzięki prowadzeniu działań pedagogicznych. Ten rodzaj przywództwa jest również widoczny w pedagogicznych relacjach z uczniami, w tym umiejętności ich mobilizowania, wywierania na nich wpływu i wprowadzania zmian w ich życie.

"Nauczyciel musi być liderem w oczach uczniów, prawda? Każdy nauczyciel jest liderem na swój sposób...".

(Nauczyciel ze szkoły podstawowej, 26 lat doświadczenia w nauczaniu)

„Można postrzegać przywództwo nauczycieli przez pryzmat tego, jak motywują swoich uczniów i/lub, w jaki sposób są prowadzeni przez uczniów. Myślę, że kluczowe zagadnienie przywództwa w tej szkole nie wiąże się z liderem szkoły. Jako nauczyciel musisz być liderem w klasie. Nie ma alternatywy".

(Nauczyciel ze szkoły średniej, 33 lata doświadczenia w nauczaniu)

„To Ty jesteś liderem w klasie szkolnej. Jesteś liderem w takim stopniu, w jakim jesteś z nimi powiązany. Możesz na nich wywierać wpływ".

(Nauczyciel ze szkoły podstawowej, 25 lat doświadczenia w nauczaniu)

„Jestem liderem. Lubię prowadzić sprawy, w które wierzę. Ale nie lubię, jak mi ktoś mówi, co mam robić. Tak, w klasie mamy do czynienia z przywództwem".

(Nauczyciel ze szkoły średniej, 27 lat doświadczenia w nauczaniu)

„W klasie możesz sprawić, że uczniowie czują, iż są odpowiedzialni za szkołę. Będąc nauczycielem jesteś liderem w klasie. Co to znaczy być liderem? Musisz umieć motywować uczniów, prowadzić ich, angażować ich w działanie, ale przede wszystkim musisz ich znać".

(Nauczyciel ze szkoły podstawowej) 
Podczas gdy uczestnicy badania uznają wagę sprawowania przywództwa, jednocześnie podkreślają, że ich przywództwo podlega atakom z powodu zmian zachodzących w edukacji w ciągu ostatnich lat. Nauczyciele uczestniczący w badaniu prezentują różne opinie odnośnie do wyrażenia: "Jestem zachęcany, by sprawować przywództwo": $27,6 \%$ zgadza się z tym stwierdzeniem, 30,8\% nie ma zdania, a 22,5\% nie zgadza się. Ilustrują to poniższe cytaty:

"Nie czuję się zachęcany do sprawowania przywództwa. Mimo iż czujesz, że musisz coś zrobić dla uczniów, nie czujesz się zachęcany do bycia liderem".

(Nauczyciel ze szkoły podstawowej, 14 lat doświadczenia w nauczaniu)

"Nie czuję się zachęcany do sprawowania przywództwa, ponieważ centralna administracja mi to uniemożliwia (...) nie masz autonomii, nie czujesz się wspierany, by angażować się w pewną dynamikę szkoły".

(Nauczyciel ze szkoły podstawowej, 27 lat doświadczenia w nauczaniu)

"Szkoła przechodzi potężny kryzys (...) czasami wydaje się, że wyhodowano potwora w obliczu sprzecznych wytycznych, zarządzania taką dużą różnorodnością ludzi, wielu zadań administracyjnych etc. Taki ciężar zaburza nasze zdolności przywódcze w klasie szkolnej z powodu braku wiedzy. Przywództwo w klasie oparte jest na kompromisie z powodu liczby zadań i wyzwań, z którymi jako nauczyciel musisz sobie radzić. Jako nauczyciel musisz panować nad wieloma sprawami: zdarzeniami edukacyjnymi, zagadnieniami emocjonalnymi etc. A przecież nad wszystkim nie zapanujesz...".

(Nauczyciel ze szkoły podstawowej).

Dane z krajowego badania wskazują również, że nauczyciele prezentują ambitną postawę wobec najważniejszych wyzwań, jakie niesie ze sobą ich praca. 
Tabela 1. Wyzwania w pracy nauczyciela

\begin{tabular}{|c|c|c|}
\hline \multirow{5}{*}{ 崖 } & współpraca z kolegami & $63,4 \%$ \\
\hline & wspieranie uczniów & $58,7 \%$ \\
\hline & refleksyjna praktyka & $51,1 \%$ \\
\hline & planowanie nauczania & $49,1 \%$ \\
\hline & kształcenie ustawiczne & $45,1 \%$ \\
\hline \multirow{5}{*}{ 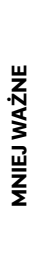 } & wypełnianie obowiązków administracyjnych & $7,5 \%$ \\
\hline & angażowanie się w życie społeczności lokalnej & $14,5 \%$ \\
\hline & rozwój pracy zespołowej & $18,7 \%$ \\
\hline & wykorzystanie TIK & $19,7 \%$ \\
\hline & uczestnictwo w procesie podejmowania decyzji & $19,7 \%$ \\
\hline
\end{tabular}

Źródło: opracowanie własne.

Tabela 2. Powody udziału w programie INSET oraz korzystania z możliwości rozwoju zawodowego

\begin{tabular}{|c|c|c|}
\hline \multirow{4}{*}{ 岁 } & doskonalenie praktyki zawodowej & $83,1 \%$ \\
\hline & poszerzenie wiedzy dziedzinowej & $81,1 \%$ \\
\hline & opracowanie innowacyjnych strategii nauczania & $60,5 \%$ \\
\hline & dzielenie się pomysłami i doświadczeniem z kolegami & $52,4 \%$ \\
\hline \multirow{4}{*}{ 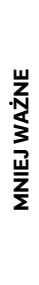 } & $\begin{array}{l}\text { wdrażanie polityki/inicjatyw opracowanych } \\
\text { przez administrację centralną }\end{array}$ & $4,8 \%$ \\
\hline & rozwijanie umiejętności przywódczych & $6,3 \%$ \\
\hline & piastowanie pewnych funkcji i stanowisk w szkole & $6,8 \%$ \\
\hline & $\begin{array}{l}\text { refleksja nad wartościami stanowiącymi } \\
\text { fundament funkcjonowania szkoły }\end{array}$ & $13,2 \%$ \\
\hline
\end{tabular}

Źródło: opracowanie własne.

Te ambiwalentne opinie można wytłumaczyć na różne sposoby, między innymi, zdaniem nauczycieli na temat współpracy, rozumienia po- 
jęcia przywództwa, koncepcji nauczania jako zawodu, profesjonalizmu etc. Należy do tego dodać środowisko szkolne i jego etos jako element wyróżniający doświadczenie nauczycieli związane z wykonywaną pracą w obliczu inicjatyw politycznych i presji istniejącej w ich miejscu pracy. Dlatego też kadra kierownicza szkół i kultura szkoły to dwa kluczowe elementy pozwalające na wyjaśnienie i zrozumienie opinii i doświadczenia nauczycieli w odniesieniu do możliwości współpracy i zachęty do sprawowania przywództwa. Jest to zgodne z poprzednimi badaniami empirycznymi, które wskazywały na mediacyjną rolę kadry kierowniczej szkół we wprowadzaniu w życie inicjatyw politycznych (Tuytens, Devos, 2010; Flores, 2012).

To w tym kontekście przywództwo edukacyjne nauczycieli ma wartość zarówno w klasie szkolnej, jak i poza nią. Zaangażowanie nauczycieli w tworzenie bardziej sprzyjających uczeniu się warunków jest elementem powtarzającym się w wypowiedziach nauczycieli biorących udział w badaniu. W swoich odpowiedziach nauczyciele odnosili pojęcie nieformalnego przywództwa do odpowiedzialności nie tylko za podnoszenie jakości uczenia się, rozwój uczniów i ich dobre samopoczucie, ale też za tworzenie wraz z kolegami odpowiedniej atmosfery w szkole oraz ustanawianie związków pomiędzy szkołą a rodzinami i wspólnotami, jak również za swój rozwój zawodowy. Wypowiedzi uczestników badania wskazują na waloryzację dynamiki pracy i zawodowych relacji, które określa dzielenie się doświadczeniem i wymiana wiedzy, jak również wspólna praca w celu rozwiązywania problemów ich codziennego życia. Podkreślają też współpracę w zakresie nauczania (współuczenia, ang.: co-teaching) oraz opracowywania projektów i inicjatyw w szkole jako kluczowe elementy przywództwa szkolnego i edukacyjnego nauczycieli.

Wypowiedzi uczniów są również interesujące. Mimo iż przyznają oni, że najważniejszą rolę odgrywa dyrektor jako lider szkoły, to wskazują także na przywództwo nauczycieli. Postrzegają ich jako kluczowe osoby w swoim życiu. Podkreślają, że nauczyciele-liderzy dobrze pracują, ale również potrafią wpływać na dynamikę szkoły poprzez opracowywanie projektów.

„Z perspektywy biurokratycznej, liderem jest dyrektor szkoły. Ale biurokracja niszczy szkołę...".

(Uczeń, 16 lat) 
„Tak, nauczyciele to prawdziwi liderzy w szkole (...). To znaczy, w mojej opinii, nie jestem pewien, czy ci sami liderzy wywierają wpływ na całą szkołę...".

(Uczeń, 15 lat)

Podobnie uczestniczący w badaniu dyrektorzy szkół pytani o wskazanie: „kim są ludzie, którzy przyczyniają się do rozwoju szkoły?" oraz "kto sprawuje przywództwo w szkole?" - wskazywali liczne elementy i osoby, zarówno indywidualne, jak i grupy ludzi. Mówili o "spójności zespołu liderów”, "tutorach i koordynatorach działów" oraz "nauczycielach, którzy prowadzą różnego rodzaju działania w szkole". Jednakże, dyrektorzy szkół podkreślają znaczenie tutorów w ustanawianiu związków pomiędzy uczniami, nauczycielami i rodzinami. Ponadto niektórzy dyrektorzy szkół kładli nacisk na relacje pomiędzy przywództwem edukacyjnym nauczycieli a ich "umiejętnością kierowania", zdolnością "podejmowania inicjatyw", ich "siłą i odpowiedzialnością" oraz ich „zaufaniem, jakie otrzymali, by przewodzić":

"Zaufanie. Myślę, że nauczyciele czują, że im ufamy. W mojej szkole ludzie mogą podejmować inicjatywę. Ludzie czują, że mogą podejmować ryzyko i że jeśli coś pójdzie nie tak, jesteśmy w stanie zaakceptować porażkę. Czują, że jeśli coś się wydarzy, mają się do kogo zwrócić".

(Dyrektor szkoły, 23 lata pracy)

Niektórzy dyrektorzy szkół doceniają też ideę „rozproszonego przywództwa" i tego, co określają, jako "zdecentralizowaną, opartą na odpowiedzialności, rozproszoną władzę" w swoich szkołach. Uznają działania strategiczne i przywództwo nauczycieli w różnorodnych kontekstach i sytuacjach, w tym w środowisku klasy szkolnej:

"Myślę, że każdy może odgrywać rolę przywódcy: nauczyciele w klasie, personel wspierający etc., nawet uczniowie mogą to robić w szkole".

(Dyrektor szkoły, 21 lat pracy)

„Przywództwo w szkole jest w sposób naturalny sprawowane przez tych ludzi, którzy pełnią formalne funkcje w strukturze 
szkolnej. Ale nauczyciele również mogą sprawować przywództwo i podejmować działania w szkole".

(Dyrektor szkoły, 18 lat pracy)

\section{Wnioski}

Celem niniejszego artykułu było dokonanie analizy zagadnienia przywództwa edukacyjnego nauczycieli w Portugalii na podstawie wyników ogólnokrajowego projektu badawczego. Można tu wyciągnąć trzy główne wnioski. Po pierwsze, istnieje potrzeba dekonstrukcji pojęcia przywództwa. Nawet jeśli w wypowiedziach uczestników badania (nauczycieli, dyrektorów szkoły i uczniów) pojawia się nieformalne przywództwo edukacyjne nauczycieli, to większość z nich wskazuje na silne powiązanie przywództwa z piastowaniem formalnych stanowisk w strukturze szkoły. Innymi słowy, na pytanie o to, kto w szkole sprawuje przywództwo, większość uczestników badania odpowiadała, że są to: dyrektor szkoły, koordynatorzy działów, tutorzy etc. Istnieje wyraźna dominacja formalnych liderów, nawet jeśli w niektórych wypowiedziach pojawia się rola nieformalnych liderów. Dlatego też bardzo ważne jest, by dokonać dekonstrukcji pojęcia przywództwa i przypisać mu znaczenie niewynikające z piastowanego stanowiska (Frost, 2012) oraz podkreślić potrzebę stworzenia nauczycielom warunków i możliwości do sprawowania przywództwa oraz podejmowania działań. Było to jednym z celów III fazy projektu badawczego opisanego w niniejszym artykule. Jednakże szczegóły budowania sieci nauczycieli i szkół w celu wzmocnienia przywództwa edukacyjnego nauczycieli w ramach rozwoju zawodowego wykracza poza zakres tematyczny tej pracy. Ogólnie III faza projektu stanowiła ilustrację możliwości nauczycieli w zakresie dzielenia się doświadczeniem i budowania sieci w kontekście opracowywania przez nauczycieli projektów jako przestrzeni umożliwiającej im odkrywanie i zrozumienie znaczenia nieformalnego przywództwa.

Drugi wniosek dotyczy świadomości roli nauczycieli jako promotorów zmian. W grupach fokusowych, pomimo krytycznych warunków pracy, w kontekście wprowadzanych środków oszczędnościowych, obniżek płac, rosnącej biurokracji i kontroli, zarówno nauczyciele, jak i dyrektorzy szkół oraz uczniowie byli w stanie wskazać nauczycieli, którzy w różny sposób wprowadzają zmiany w ich środowiskach. W czasie grup fokusowych nauczyciele mogli porównać i zestawić ze sobą swoje poglądy. W niektórych przypadkach dyskusja stanowiła ogromną szan- 
sę, by podnieść świadomość siły ich oddziaływania dla dobra uczniów, nawet $w$ trudnych warunkach pracy. Dlatego też klasa szkolna stanowi dla nauczycieli, jako liderów procesu uczenia się, kluczowe środowisko sprawowania przywództwa.

Po trzecie, istnieje potrzeba kształcenia umiejętności przywódczych nie tylko w ramach programu INSET i innych programów rozwoju zawodowego praktykujących nauczycieli, lecz również w kontekście przygotowania nauczycieli do zawodu. Dlatego też bardzo ważne jest, by stwarzać tak nauczycielom, jak i przyszłym nauczycielom możliwości do refleksji na temat bycia nauczycielem, nauczania i uczenia się. Innymi słowy, zagadnienia profesjonalizmu i tożsamości mają kluczowe znaczenie, by lepiej zrozumieć nieformalne przywództwo edukacyjne nauczycieli w danym kontekście. Dlatego też, istotne jest, by prowadzić dalsze badania na temat nauczycieli-liderów, a w szczególności nauczycieli jako nieformalnych przywódców. Kim są nauczyciele-liderzy w szkole? Co robią? Jakie są rezultaty podejmowanych przez nich działań? Zagadnienia, takie jak kultura zawodowa nauczycieli, mikropolityka w miejscu pracy, szczególnie w zakresie przywództwa, mogą stanowić jedną z możliwości lepszego zrozumienia i wzmocnienia rozwoju nauczycieli jako promotorów zmian w środowiskach, w których pracują. 


\section{Bibliografia}

$\rightarrow$ Alexandrou, A., Swaffield, S. (2012), Teacher leadership and professional development: perspectives, connections and prospects, Professional Development in Education, 38(2), 159-167.

$\rightarrow$ Davis, S.H., \& Leon, R.J. (2009), Teaching Gil to lead. Journal of School Leadership, 19, 266-298.

$\rightarrow$ Durrant, J. (2004), Teachers leading change: frameworks and key ingredients for school improvement, Leading and Managing, 10:2, 10-29.

$\rightarrow$ Elfouly, A., Eltemamy, A. (2017), Integrating technology in learning at a school in Cairo [w:] D. Frost (Ed.), Empowering Teachers as Agents of Change: A non-positional approach to teacher leadership, s. 44-50, Cambridge: University of Cambridge Press.

$\rightarrow$ Fairman, J.C., Mackenzie, S.V. (2012), Spheres of teacher leadership action for learning, Professional Development in Education, 38(2), 229-246.

$\rightarrow$ Flores, M.A. Richmond, M.S. (2017), Cultivating hope through teacher leadership in Portugal [w:] D. Frost (Ed.), Empowering teachers as agents of change: a non-positional approach to teacher leadership, s. 125-130, Cambridge: University of Cambridge Press.

$\rightarrow$ Flores, M.A. (2012), The implementation of a new policy on teacher appraisal in Portugal: How do teachers experience it at school?, Educational Assessment Evaluation and Accountability, 24, 351-368.

$\rightarrow$ Flores, M.A. (2013), Przywództwo nauczycieli w czasach pełnych wyzwań [Teacher leadership in Challenging Times], tłum. J. Madalińska-Michalak [w:] S.M. Kwiatkowski, J. Madalińska-Michalak (Eds.), Przywództwo Edukacyjne Współczesne wyzwania, s. 167-186, Warszawa: Wolters Kluwer.

$\rightarrow$ Flores, M.A. (2014) (Coord), Profissionalismo e Liderança dos Professores, Santo Tirso: De Facto Editores.

$\rightarrow$ Flores, M.A. (in press) (2017), Unpacking Teacher Quality: Key Issues for Early Career Teachers [w:] A. Sullivan, B.R. Johnson and M. Simons (Eds.), Attracting 
and Keeping the Best Teachers - Problems and Possibilities, London-New York: Springer.

$\rightarrow$ Flores, M.A., Fernandes, E., Flores, M. e Forte, A. (2016), Conditions for teacher leadership and professional development in challenging circumstances [w:] B. de Wever, R. Vanderlinde, M. Tuytens, A. Aelterman (Eds.), Professional Learning in Education. Challenges for Teacher Educators, Teachers and Student Teachers, s. 113-133, Gent: Academia Press.

$\rightarrow$ Forte, A., Flores, M.A. (2014), Teacher collaboration and professional development in the workplace: A study of Portuguese teachers, European Journal of Teacher Education, 37(1), 91-105.

$\rightarrow$ Frost, D. (2012) (Eds.), Empowering Teachers as Agents of Change: A non-positional approach to teacher leadership, Cambridge: University of Cambridge Press.

$\rightarrow$ Frost, D. (2012), From professional development to system change: teacher leadership and innovation, Professional Development in Education, 38(2), 205$-227$.

$\rightarrow$ Frost, D., Roberts, A. (2004), From Teacher Research to Teacher Leadership: the case of the Hertfordshire Learning Preferences Project, Teacher Development, 8 (2-3), 181-199.

$\rightarrow$ Hanuscin, D.L., Rebello, C.M., Sinha, S. (2012), Supporting the development of science teacher leaders: where do we begin?, Science Educator, 21(1), 12-18.

$\rightarrow$ Harris, A. (2003), Teacher leadership as distributed leadership: Heresy, fantasy or possibility, School Leadership \& Management: Formerly School Organisation 23 (3), 313-324.

$\rightarrow$ Huang, T. (2016), Linking the private and public: teacher leadership and teacher education in the reflexive modernity, European Journal of Teacher Education, 39(2), 222-237.

$\rightarrow$ Hunzicker, J. (2012), Professional development and job-embedded collaboration: how teachers learn to exercise leadership, Professional Development in Education, 38(2), 267-289.

$\rightarrow$ Katzenmeyer, M., Moller, G. (2001), Awakening the Sleeping Giant: helping teachers develop as leaders, Thousand Oaks: Corwin Press.

$\rightarrow$ Miles, M., Huberman, M. (1994), Qualitative Data Analysis. London: Sage.

$\rightarrow$ Muijs, D., Harris, A. (2006), Teacher led school improvement: teacher leadership in the UK, Teaching and Teacher Education, 22, 961-972.

$\rightarrow$ Piesanen, E., Välijärvi, J. (2010), Lot 2: Teacher Education Curricula in the EU, Final Report, Finish Institute for Educational Research. A study commissioned 
by the European Commission's Directorate-General for Education and Culture, Helsinki: Finnish Institute for Educational Research.

$\rightarrow$ Poekert, P.E. (2012), Teacher leadership and professional development examining links between two concepts central to school improvement, Professional Development in Education, 38(2), 169-188.

$\rightarrow$ Sakatis, L., Wootton, H. (2017), Developing strategies to improve mindset in mathematics [w:] D. Frost (Eds.), Empowering teachers as agents of change: a non-positional approach to teacher leadership, s. 37-43, Cambridge: University of Cambridge Press.

$\rightarrow$ Stevenson, H. (2012), Teacher leadership as intellectual leadership: creating spaces for alternative voices in the English school system, Professional Development in Education, 38(2), 345-360.

$\rightarrow$ Tuytens, M., Devos, G. (2010), The influence of school leadership on teachers' perception of teacher evaluation policy, Educational Studies, 36, 521-536.

$\rightarrow$ York-Barr, J., Duke, K. (2004), What do we know about teacher leadership? Findings from two decades of scholarship, Review of Educational Research, 74(3), 255-316.

Uwaga: Niniejsza praca została sfinansowana przez FEDER Funds w ramach programu COMPETE oraz ze środków krajowych w ramach FCT - Fundação para a Ciência e a Tecnologia (Narodowa Fundacja na rzecz Nauki i Technologii) w ramach projektu PTDC/MHCCED/2703/2014. 



\title{
Przywództwo na rzecz uczenia się. Nauczyciele-liderzy mediatorami innowacji i zmian w szkole
}

\author{
Livia Rößler, Michael Schratz
}

\begin{abstract}
Na nauczycieli-liderów czeka szerokie spektrum zadań: wdrażanie w życie nowych zasad polityki, tworzenie środowiska dla partycypacji, pośredniczenie między dyrekcją szkoły a pozostałym personelem oraz tworzenie warunków dla profesjonalnego uczenia się. W ten sposób nauczyciele są mediatorami zmian i innowacji. W artykule omówiono teoretyczne podstawy takiego podejścia i działań oraz ukazano na zasadzie przykładu dwie konkretne role nauczycieli-liderów w austriackim systemie oświaty. Są to: projektanci uczenia się, którzy działają jako promotorzy zmian w każdej szkole, dzieląc się przywództwem z dyrektorem w celu poprawy procesów nauczania i uczenia się, oraz szkolni koordynatorzy ds. jakości, którzy przewodzą usprawnieniom w szkole z uwzględnieniem wymagań systemowych. Łącząc zarówno teoretyczne, jak i praktyczne perspektywy, autorzy przedstawiają całościowe rozumienie tego, co jest potrzebne nauczycielom-liderom do wspierania innowacji i zmian o charakterze systemowym.
\end{abstract}

\section{__ Słowa kluczowe: \\ role nauczyciela-lidera \\ przywództwo na rzecz uczenia się \\ projektant uczenia się \\ przywództwo strategiczne \\ mediatorzy zmiany}




\title{
Leadership for learning. \\ Teacher leaders as mediators for \\ school-wide innovation and change
}

\author{
Livia Rößler, Michael Schratz
}

Teacher leaders have a wide range of tasks: they translate new policies into the prevailing practice, they create an environment for participation, they mediate between school leaders and staff, they establish relationships for professional learning. In doing so, they are mediators for change and innovation. The chapter discusses the theoretical underpinnings for such endeavors, and, by means of example, presents two specific teacher leader roles in the Austrian school system: Learning Designers, who work as change agents in each school sharing leadership with the principal with a view to improve teaching and learning, and School Quality Coordinators, who orchestrate school improvement in accordance with systems requirements. Weaving together both theoretical and practical perspectives, the authors provide a comprehensive understanding of what is needed for teacher leaders to support innovation and systemic change.

\section{Keywords:}

teacher leader roles

leadership for learning

learning designer

strategic leadership

mediators for change 


\section{Wstęp}

Systematyczne inicjowanie formalnych ról przywódczych nauczycieli stanowi względnie nową formę interwencji w austriackim systemie edukacji. Chociaż nauczyciele-liderzy byli obecni w austriackim systemie edukacji od stuleci, to ich formalne obowiązki i role nie były postrzegane jako katalizator zmian i innowacji.

W pierwszej części niniejszego artykułu omówiono ogólną sytuację nauczycieli-liderów w Austrii, natomiast w drugiej części opisano dwie role nauczycieli-liderów, a mianowicie szkolnych koordynatorów jakości kształcenia oraz projektantów uczenia się. Zostaną tu zdefiniowane i omówione czynniki wspierające i utrudniające realizację formalnych ról nauczycieli-liderów, poparte przykładami z projektu badawczego. W drugim etapie ustalenia te zostaną powiązane z potencjałem nauczycieli-liderów pod względem ich zdolności do inicjowania innowacji i zmian w szkołach i w całym systemie edukacji.

\section{Przywództwo w szkołach austriackich}

\section{Krótka historia przywództwa}

Podobnie jak w innych krajach europejskich, przez długi czas rola lidera szkolnego w Austrii charakteryzowała się hierarchicznym usytuowaniem $w$ ramach centralnie zarządzanego systemu szkolnego i dlatego przywództwo na ogół kojarzono z „formalnym zakresem obowiązków lub odpowiedzialności, które jest generalnie postrzegane jako wysiłek indywidualny, a nie zbiorowy" (Harris, Mujis, 2005, s. 15). Rola dyrektora szkoły w dużej mierze była uzależniona od koncepcji zarządzania szkołą przyjętej przez administrację szkoły, w ramach której dyrektor szkoły był podporządkowany władzom administracyjnym. Dyrektor szkoły, jako primus inter pares, miał realizować przepisy urzędowe w możliwie najbardziej sprawny sposób (Schratz, 2005; Hall i in. 2017, s. 315) i był częścią tego, co Lortie (2002) nazywa "wzorem autonomii-równości”. "Kryteria kwalifikacyjności” na to ważne stanowisko zazwyczaj obejmowały długi staż pracy, sukcesy w pracy w systemie edukacji i nieposzlakowaną opinię. Rozwój miał miejsce w drodze konsultacji z przełożonymi. Taka forma przywództwa w szkołach w Austrii nadal odzwierciedlała kulturę polityczną, która nawiązywała do monarchii Habsburgów, była silnie zhierarchizowana i charakteryzowała się wszechobecnym formalizmem (Schratz, 2012). 
Wraz z rosnącym wpływem ocen na dużą skalę (np. TIMSS, PIZA), austriacki system edukacji podążył za globalnym ruchem propagującym zarządzanie szkołami oparte na wynikach (Altrichter Maag, Merki, 2010; Schratz, 2011). Taka zmiana systemu zarządzania wiązała się z różnorakimi koncepcjami dotyczącymi reformy oświaty, takimi jak: „autonomia szkoły”, „jakość w szkole”, „odpowiedzialność liderów”, „efektywność i skuteczność", „odpowiedzialność" i „standardy pracy".

Z powyższymi zmianami wiążą się cztery trendy, które zostały podsumowane $w$ tabeli 1.

Tabela 1. Model zbieżności badań w zakresie przywództwa w edukacji

\begin{tabular}{|c|c|c|c|c|c|c|}
\hline TREND & PARADYGMAT & KONCEPCJA & PRZYWÓDZTWO & UCZĄCY SIĘ & RELACJA & ZARZĄDZANIE \\
\hline 1.0 & $\begin{array}{l}\text { Podnosze- } \\
\text { nie jakości } \\
\text { i zarządzanie } \\
\text { jakością, } \\
\text { odpowie- } \\
\text { dzialność }\end{array}$ & $\begin{array}{l}\text { Style } \\
\text { przywódz- } \\
\text { twa, teoria } \\
\text { organizacji }\end{array}$ & $\begin{array}{l}\text { Zoriento- } \\
\text { wane na } \\
\text { zwierzchnic- } \\
\text { two, optyma- } \\
\text { lizuje }\end{array}$ & Odbiorca & $\begin{array}{l}\text { Zoriento- } \\
\text { wana na } \\
\text { nauczyciela, } \\
\text { instrukta- } \\
\text { żowa }\end{array}$ & $\begin{array}{l}\text { Zoriento- } \\
\text { wane na } \\
\text { nauczanie }\end{array}$ \\
\hline 2.0 & Skuteczność & $\begin{array}{l}\text { Wyniki } \\
\text { zasadzające } \\
\text { się na danych, } \\
\text { badania } \\
\text { empiryczne }\end{array}$ & $\begin{array}{l}\text { Zorientowa- } \\
\text { ne na eksper- } \\
\text { tów }\end{array}$ & Realizator & Transakcyjna & $\begin{array}{l}\text { Zoriento- } \\
\text { wane na } \\
\text { egzaminy }\end{array}$ \\
\hline 3.0 & $\begin{array}{l}\text { Interwencja, } \\
\text { rozwój }\end{array}$ & $\begin{array}{l}\text { Upodmio- } \\
\text { towienie, } \\
\text { zmieniające } \\
\text { się wzory }\end{array}$ & $\begin{array}{l}\text { Kształtuje } \\
\text { i stwarza } \\
\text { odpowiednie } \\
\text { warunki }\end{array}$ & Respondent & $\begin{array}{l}\text { Oparta } \\
\text { na dialogu, } \\
\text { poszerza } \\
\text { horyzonty }\end{array}$ & $\begin{array}{l}\text { Zoriento- } \\
\text { wane na } \\
\text { uczenie się }\end{array}$ \\
\hline 4.0 & $\begin{array}{l}\text { Orientacja } \\
\text { na wartość } \\
\text { i znaczenie, } \\
\text { salutogeneza }\end{array}$ & $\begin{array}{l}\text { Orientacja na } \\
\text { trwały rozwój } \\
\text { i odporność }\end{array}$ & $\begin{array}{l}\text { Wychowuje } \\
\text { i służy }\end{array}$ & $\begin{array}{l}\text { Korespon- } \\
\text { dent }\end{array}$ & $\begin{array}{l}\text { Żywa, pełna } \\
\text { szacunku }\end{array}$ & $\begin{array}{l}\text { Z perspekty- } \\
\text { wy uczenia } \\
\text { się }\end{array}$ \\
\hline
\end{tabular}

Źródło: opracowanie na podstawie Wiesner i in., 2015; Schratz i in., 2016.

Poszczególne trendy zostały przypisane do określonych słów kluczowych stosowanych w przeważających dyskursach dotyczących zarządzania, które przeniosły przywództwo na wyższy poziom od 1.0 (zorientowane na zwierzchnictwo) do 2.0 (zorientowane na ekspertów) i 3.0 (upodmiotowienie) do 4.0 (wychowuje i służy). Przechodzenie 
na wyższe poziomy skali nie oznacza, że wcześniejsze trendy stają się przestarzałe, lecz raczej zbiegają się wraz z upływem czasu, jak przedstawiono na rysunku 1.

Rysunek 1. Ilustracja paradygmatów modelu zbieżności

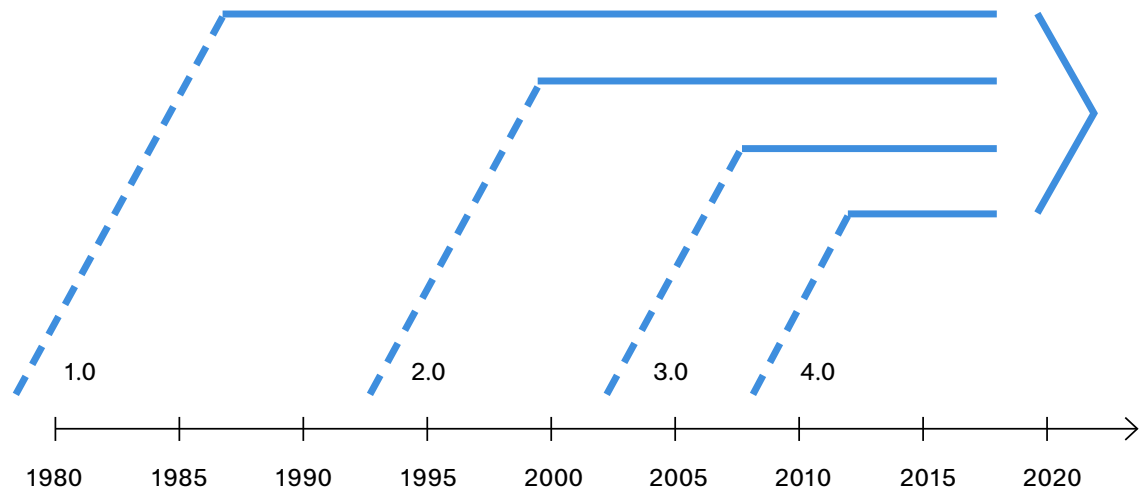

Źródło: opracowanie na podstawie: Wiesner i in., 2015; Schratz i in., 2016.

Szczególnie trendy 3.0 i 4.0 pozytywnie wpływają na kulturę rozwoju nauczycieli-liderów: „Jedyne przywództwo, które może spowodować zmianę, to przywództwo nauczycieli. Tylko w przypadku nauczycieli wszystkie kluczowe elementy promują zmianę. Tylko oni znają codzienne problemy i wiedzą, jak można je rozwiązać. To nauczyciele, a nie dyrektorzy szkół powinni zatrudniać nowych nauczycieli. Mają oni wiedzę na temat tego, co jest potrzebne, a jeśli popełniają błędy, muszą ponieść ich konsekwencje. Nauczyciele powinni kierować szkołami oraz prowadzić zajęcia szkolne i pozaszkolne. Ale niestety poddano ich praniu mózgów, są bojaźliwi i zależni od innych" (Buchen, 2000, s. 36).

Wyłaniające się trendy potwierdzają zmianę akcentu w modelu przywództwa $z$ interwencji jednego lidera na współdzielone przywództwo w szkole. Dlatego rola nauczycieli-liderów „pojawiła się w wyniku połączenia ruchu na rzecz odpowiedzialności i chęci poprawy sytuacji w szkołach" (Tomal, Schilling, Wilhite, 2014, s. 4) i przywództwo nauczycieli stało się bardziej widoczne w badaniach empirycznych, a w wielu z tych badań założono, że nauczyciele-liderzy mają kluczowe znaczenie dla powodzenia reformy szkolnej (Frost i in., 2000; Katzenmeyer, Moller, 2009). 


\section{Rozwój przywództwa nauczycieli}

Conley i Muncey (1999) zauważyli, że poważne zadanie, jakim jest stawienie czoła wyzwaniom w szkołach, wymaga, by nauczyciele przejęli role i obowiązki, które wcześniej były zarezerwowane dla członków kierownictwa szkół (patrz: Katzenmeyer, Moller, 2009, s. 2). Ponieważ niedawne reformy w Austrii spowodowały powstanie nowych zawiłości systemu, którymi poszczególni dyrektorzy szkół nie są już w stanie zarządzać, wyłoniły się nowe, wiodące role, które należy promować. $\mathrm{Na}$ początku nie było jasne, które kompetencje były niezbędne, aby stać się nauczycielem-liderem. Według niektórych źródeł, nauczyciele-liderzy "często mają rozległe doświadczenie pedagogiczne i wykazują się wiedzą, współpracą, przemyśleniami oraz poczuciem upodmiotowienia. Nauczyciele-liderzy szukają wyzwań i możliwości rozwoju i mają odwagę poszukiwać nowatorskich i ambitnych programów mających na celu rozwój wiedzy uczniów i kolegów. Zapewniają oni możliwości działania innym oraz podejmują ryzyko i współpracę. Opisy w badaniach poświęconych tym nauczycielom w zestawie atrybutów obejmują pożądane cechy osobiste, takie jak bycie godnym zaufania, oddanym i nieformalne wspieranie kolegów" (Tomal, Schilling, Wilhite, 2014, s. 22-23). Określenie takich ambitnych kompetencji to jedna rzecz, a osiągnięcie ich - to zupełnie inne zagadnienie. Członkowie kadry kierowniczej szkół mogą na wiele sposobów wspierać nauczycieli w tym, by stali się liderami, ale rozwój przywództwa zawsze zasadza się na samorozwoju.

Nauczyciele-liderzy przekraczają granice w szkołach, ponieważ pełnią oni tam różne role (Schley i in., 2009): jako współpracownicy są oni takimi samymi nauczycielami jak wszystkie inne osoby pracujące w systemie oświaty. Jako promotorzy zmian pełnią oni dodatkową rolę polegającą na podejmowaniu odpowiedzialności za reformę lub ważną kwestię (np. monitorowanie jakości, kierowanie uczeniem się). Realizując te zadania, pracują nad systemem i pełniąc funkcję kierowniczą dzięki temu, że stali się „liderami zmiany", wspierają dyrektora szkoły w jego/jej zwierzchniej roli (patrz: rysunek 2.). 
Rysunek 2. Różne role nauczycieli-liderów

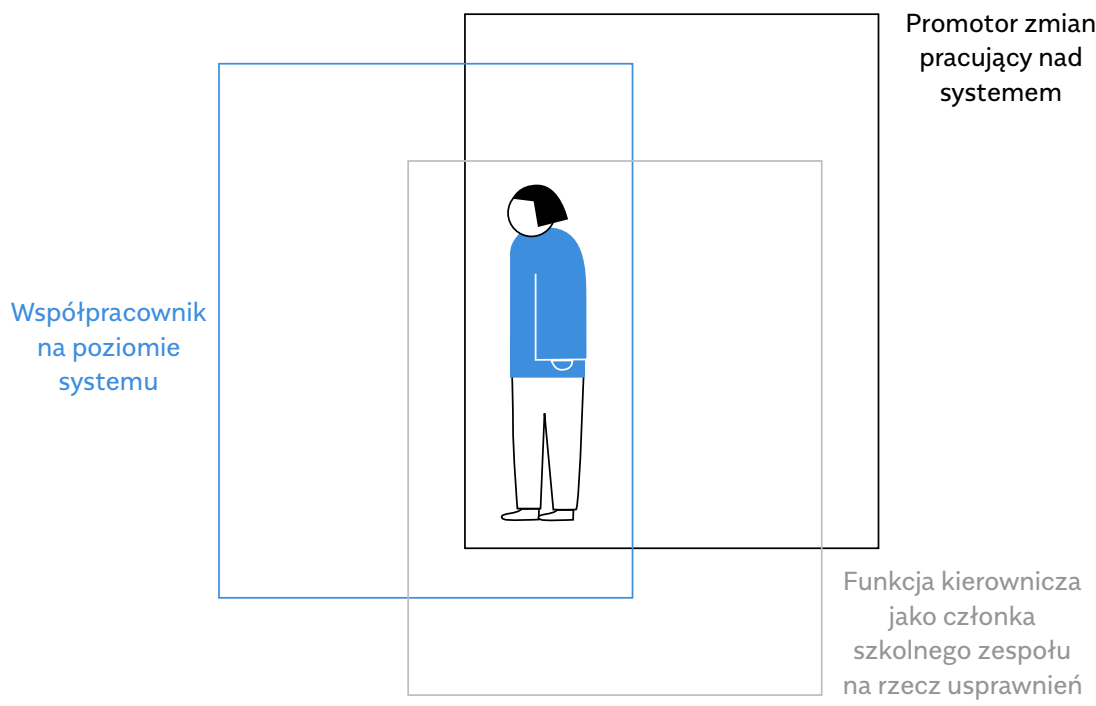

Źródło: opracowanie na podstawie Schley, Schratz, 2010, s. 286.

Inicjowanie przywództwa nauczycieli w płaskim systemie hierarchicznym otwiera nowe możliwości: taka inicjatywa może wpływać na upodmiotowienie i stać się ważną interwencją w szkołach, a tym samym może stać się impulsem do zmian. Ponieważ nauczyciele-liderzy tworzą silne ogniwo pomiędzy dyrektorem szkoły a nauczycielami, tworzy się nowa dynamika, która prowadzi do uczenia się we współdziałaniu (ang. collaborative learning), co jest pomocne w przechodzeniu od tradycyjnego pojęcia, jakim jest "Moja klasa i ja" do pojęcia "My i nasza szkoła” promującego współpracę. Odejście od prywatności zamkniętej klasy jest możliwe tylko wtedy, gdy istnieje wzajemne zrozumienie znaczenia pracy we „wspólnocie praktyków" (Wenger, 1998), co wymaga wzajemnego zaufania. Strategie budowania zaufania przez współpracowników obejmują: "utrzymanie otwartego dialogu, znalezienie czasu na budowanie zespołu oraz na zapoznawanie nowego zespołu, nowej grupy zaszeregowania lub nowych członków wydziału ze szkołą, jej kulturą i obowiązującymi normami" (Mayers, Zepeda, Benson, 2013, s. 28). Tworzenie kultury jest celem długofalowym, ale musi ono zostać zapoczątkowane w trybie współpracy. Jeżeli nauczyciele naruszają hierarchię, 
podejmując zadania przywódcze, mogą napotkać opór. W takich przypadkach muszą oni być wyposażeni w niezbędne kompetencje i mieć na względzie szerszy kontekst. Przy wprowadzaniu polityki w życie „.... nauczyciele są odpowiedzialni za jej objaśnianie". Chociaż nauczyciele przejmują role przywódcze, to postrzegają siebie jako „przedstawicieli" zmian, a nie "liderów", którzy wdrażają lub inicjują zmianę" (Harris, Mujis, 2005, s. 16). Przy zmianie tego wzorca, najważniejszym celem jest zainicjowanie elementu kreatywności, zaangażowania i entuzjazmu do wprowadzania polityki w życie, natomiast kreatywność i zaangażowanie polegają na zaangażowaniu indywidualnym, zaangażowaniu współpracowników i uczniów, aby "realizować politykę" i aby "robić to dobrze" (Ball i in., 2012, s. 138).

\section{Przywództwo i ograniczenia prawne}

Kolejnym wyzwaniem, wobec jakiego stają nauczyciele-liderzy w Austrii, jest różnorodność uregulowań prawnych (np. oficjalna funkcja, polityka rekrutacji). Podczas gdy nieformalne role są często sytuacyjne, większość formalnych ról jest obowiązkowa i obejmuje takie same struktury ramowe w każdej szkole. Jeżeli rola nauczyciela-lidera jest uregulowana prawnie, wiąże się ona z odrębną funkcją, która z kolei wiąże się z określonymi dodatkami. Jednak często występują nieformalne role przywódcze, które nie są prawnie uregulowane, lecz są konieczne do wprowadzenia w życie nowych reform. Fakt, że tylko kilka ról jest uregulowanych prawnie, prowadzi do sytuacji, w której powstaje "społeczeństwo dwupartyjne" w sferze formalnych ról nauczycieli-liderów. To również może znaleźć odzwierciedlenie w skuteczności danej roli i w sposobie, w jaki dyrektor szkoły odnosi się do niektórych ról nauczycieli-liderów w praktyce, co niekiedy może prowadzić do arbitralnych interpretacji.

Istnieją także wymogi prawne, które wyjaśniają procedury kwalifikacji i procesy rekrutacji w odniesieniu do niektórych ról nauczycieli-liderów. Przy takim postępowaniu sformułowania te są niejasne i często pozostawiają wiele miejsca na interpretację. Tomal, Schilling i Wilhite sugerują, że "[d]yrektorzy szkół powinni mądrze korzystać z pomocy nauczycieli-liderów, którzy znani są z tego, że mają dobre stosunki i pozytywne relacje z kolegami" $(2014$, s. 13). Jeśli to stwierdzenie weźmie się sobie do serca, mianowanie nauczycieli-liderów wymaga pewnego poziomu wrażliwości i wiedzy o mocnych i słabych stronach członków 
personelu. Innym ważnym aspektem jest związek pomiędzy przywództwem nauczycieli a kierowaniem szkołą. Nauczyciele-liderzy są niejako wciśnięci pomiędzy pionowe i poziomie potrzeby (rysunek 3.). Z jednej strony istnieje potrzeba stworzenia synergii pomiędzy kadrą kierowniczą szkoły a nauczycielami w rozwijaniu ich umiejętności zawodowych, a z drugiej strony nauczyciele-liderzy muszą godzić różne wymagania i oczekiwania.

Rysunek 3. Pozycja nauczycieli-liderów

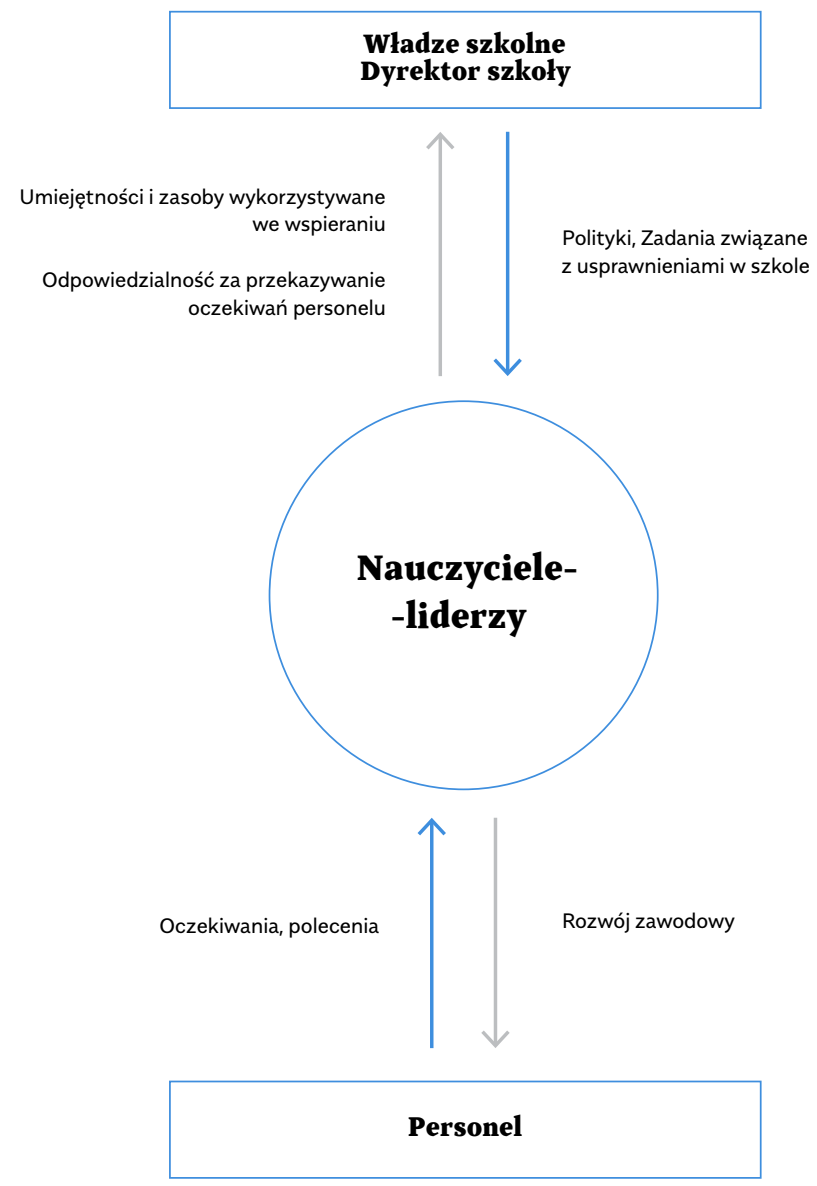

Źródło: opracowanie na podstawie Tomal, Schilling, Wilhite, 2014. 
Poza kwestiami zatrudnienia nauczycieli-liderów należy zadać pytanie, w jaki sposób są oni przygotowywani do wyzwań zawodowych. Zarówno z doświadczenia, jak i z literatury wynika, że w kontekście rzeczywistości szkolnej lider musi być przygotowany na opór wobec zmian i sam musi rozwinąć odporność, aby móc realizować swoje zadanie (Gabriel, 2005; Tomal, Schilling, Wilhit, 2014). Nauczyciele-liderzy muszą mieć umiejętność dostosowywania się do kontekstu i określonych ról podczas komunikacji z innymi graczami (patrz: EPNoSL1). $Z$ tego powodu rozwój zawodowy nauczycieli-liderów powinien obejmować model dynamicznych szkoleń, w ramach którego mają oni możliwość stale zmieniać kontekst własnych postępów. Snoek i Volman zwracają uwagę na to, że program szkoleniowy dla nauczycieli-liderów nie „powinien określać »transferu « jako przenoszenia wyraźnych elementów wiedzy i umiejętności na potrzeby nowych sytuacji, lecz raczej [należy go rozumieć] jako proces przekraczania granicy między systemami aktywności, który obejmuje ponowną interpretację sytuacji w miejscu pracy i dostosowanie zdobytych kompetencji" $(2014$, s. 92) w celu możliwie najlepszego zaspokojenia potrzeb. Powinno to być uwzględnione i wspominane we wprowadzeniu do programów doskonalenia zawodowego i działaniach podejmowanych w ramach profesjonalizacji nauczycieli-liderów.

Podsumowując, można powiedzieć, że różne czynniki tworzą środowisko, w którym nauczyciele-liderzy mogą rozwinąć swój potencjał. Na poziomie szkoły duże znaczenie ma wyjaśnienie własnej roli - zwłaszcza w kontekście nowych reform i ich wprowadzenia w życie, jak również współpracy z kolegami i dyrektorem szkoły. Szczególnie w Austrii potrzebne jest nowe rozumienie kultury (współdzielonego) przywództwa, podczas gdy ramy legislacyjne na poziomie systemu definiują funkcje nauczycieli-liderów i jednocześnie zapewniają stabilność dzięki podstawom prawnym. Ogólnikowy charakter wymagań dotyczących rekrutacji i profesjonalizacji umożliwia zastosowanie zakresu działania, który zapewnia elastyczność i otwartość, a tym samym promuje podejmowanie autonomicznych decyzji. 


\section{Należy mieć na względzie cel końcowy, jakim jest przywództwo na rzecz uczenia się}

Terminy "przywództwo" i "uczenie się" należą do różnych dziedzin dyskursu pedagogicznego i są kojarzone z różnymi podmiotami na arenie oświatowej. Przywództwo charakteryzuje się tym, że ludzie są "prowadzeni" do interakcji w określonym środowisku, tak aby działali zgodnie z pożądanymi celami lub podejmowali określone zadania. $Z$ drugiej strony nauka jest procesem, który powinien prowadzić do zdobywania nowej wiedzy lub umiejętności. Liderzy, nauczyciele i osoby uczące się są protagonistami, którzy muszą skutecznie współdziałać, aby osiągnąć pożądane rezultaty. Prowadzi to do następujących pytań: $W$ jaki sposób przywództwo wchodzi w interakcję z nauczaniem i uczeniem się? W jaki sposób dyrekcja szkoły wchodzi w interakcję z nauczycielami i uczniami? W praktyce na te pytania nie można odpowiedzieć osobno, ponieważ przywództwo mieści się "w zbiorowych relacjach, gdzie uczestnicy zarówno kształtują, jak i są kształtowani przez siebie nawzajem" (Donaldson, 2001, s. 41).

W ostatnim czasie poczyniono wiele wysiłków, aby przybliżyć przywództwo do uczenia się przez uczniów (MacBeath, Moos, 2004; Mróz, Swaffield, 2004). I właśnie w tym miejscu pojęcie "przywództwo na rzecz uczenia się" nabiera znaczenia: $u$ jego podstaw leży najważniejsze pytanie, które ma daleko idące znaczenie: W jaki sposób przywództwo może mieć zrównoważony wpływ na nauczanie? Wyniki międzynarodowych badań potwierdzają, że działania kadry kierownicznej szkół mają głównie pośredni wpływ na procesy uczenia się przez uczniów, jako że wpływają one na wewnętrzne procesy w szkole. Niektóre badania (np. Scheerens, 2012) wykazują mały, ale także umiarkowany wpływ (np. Marzano i in., 2005) dyrekcji szkoły. Ponadto Hattie (2009) stwierdza, że istnieje umiarkowany średni związek pomiędzy działaniami dyrekcji szkoły a wynikami uczniów. Wpływ dyrektorów szkół określony przez Hattiego (2009) może się wydawać większy niż np. wpływ pracy domowej, lecz jest mniejszy niż wpływ czasu aktywnej nauki.

Powodem tych pozornie sprzecznych zjawisk w szkołach jest fakt, że zazwyczaj dyrektorzy szkół głównie koncentrują się na przywództwie (i czasem również na nauczaniu), nauczyciele zajmują się nauczaniem, a zadaniem uczniów jest uczenie się. Tylko w rzadkich przypadkach działania te są koordynowane w systematyczny sposób. Ze względu na to, że poszczególni aktorzy realizują różne funkcje (i zachowania) na 
różnych poziomach, realizacja polityki nie jest kaskadowym procesem odgórnym, ponieważ polityki są „złożonymi procesami dyskursywnymi, które są uzależnione od kontekstu i realizowane na poziomie instytucjonalnym. Polityka jest prowadzona przez i na rzecz nauczycieli, którzy są aktorami i podmiotami, podlegają i są celem realizacji polityki. Polityka jest wpisana w podmioty i wpływa na konkretne stanowiska" (Ball i in., 2012, s. 3). Dlatego działania skierowane na reformę przywództwa w szkołach i zmiany na poziomie całego systemu wymagają innego podejścia, dzięki czemu system oświaty ulegnie transformacji wskutek przyjęcia jakości przywództwa jako punktu wyjściowego dla innowacji systemowych.

Natomiast jeśli dyrektorzy szkół przyjmą odpowiedzialność wyłącznie za przywództwo, procesy reform nie będą mieć wpływu na szkoły jako całe instytucje. Mając na względzie połączenie przywództwa z uczeniem się, Fullan ukuł termin "myśliciele systemowi w działaniu" (ang. system thinkers in action), którzy są liderami, „którzy aktywnie i naturalnie uwzględniają i wchodzą w interakcję z większymi elementami systemu, podczas gdy doprowadzają oni do głębszej reformy i pomagają w kształtowaniu innych liderów pracujących nad tymi samymi zagadnieniami. Są oni teoretykami i jednocześnie praktykami, których teorie są na co dzień realizowane w praktyce. Ich pomysły są uwzględniane w codziennych interakcjach, co sprawia dużą różnicę" (Fullan, 2005, s. 11).

Mając na względzie złożoność planów reform, ważna będzie dystrybucja przywództwa i ukształtowanie wielu myślicieli systemowych w działaniu, którzy zaangażują się w działania na rzecz zmiany całego systemu. Natomiast nie mogą oni z powodzeniem działać w izolacji, lecz potrzebują „poczucia związku, przynależności, współzależności i rozwoju", który sprawi, że "grupa będzie bardziej spójna i zostanie zbudowana społeczność" (Gabriel, 2005, s. 108). Dlatego budowanie wspólnoty i budowanie systemów stanowią istotne składniki udanego przywództwa nauczycieli.

\section{Analiza dwóch ról nauczycieli-liderów w Austrii}

W Austrii, „reforma oświaty na poziomie systemowym doprowadziła do powstania kilku nowych ról w 2008 r., które mają wpływ na architekturę społeczną szkół" (Westfall-Greiter, Hofbauer, 2015, s. 129). Reforma utworzyła różne ścieżki dla nowo powstałych ról nauczycieli-liderów. 
Pierwsza kategoria to nauczyciele-liderzy, którzy z jednej strony są trenerami lub mentorami, a co za tym idzie, działają na rzecz dobra wspólnego, a druga to ta, w której pełnią bardziej formalne funkcje pedagogiczne i mają uprawnienia nadzorcze (Tomal, Schilling, Wilhite, 2014, s. 8).

Niemniej większość z tych ról nie jest uregulowana na poziomie federalnym: niektóre z nich wchodzą w zakres oficjalnych obowiązków, a inne są realizowane wyłącznie na polecenie i nie wynikają z przepisów prawa pracy. Aby zilustrować tę konkretną sytuację, przedstawiamy dwie nowo wprowadzone role nauczycieli-liderów w austriackim systemie oświaty. Pierwsza: rola projektanta uczenia się, funkcja, która miała kluczowe znaczenie dla reformy nowych gimnazjów i która stanowi formalną rolę nauczyciela-lidera. Druga: rola szkolnego koordynatora ds. jakości kształcenia, który zajmuje się koordynacją kształcenia w szkołach ogólnokształcących i działa na polecenie. Obie role są silnie związane z przywództwem na rzecz uczenia się, ale ich genezy i teorie działania różnią się. Prezentując obie role, koncentrujemy się na początkowych fazach, na tym, w jaki sposób system wspiera te role, oraz na wyzwaniach związanych $z$ ich realizacją.

\section{Projektant uczenia się}

W fazie wdrażania każde nowe gimnazjum musiało wybrać nauczyciela, który miał stać się „projektantem uczenia się". Jako że rola ta nie istniała wcześniej, możliwe było zaprezentowanie jej jako nowego zadania, które przesuwa nacisk z nauczania na uczenie się. Odgrywając rolę "projektanta uczenia się", nauczyciel-lider bierze na siebie dodatkowe obowiązki i pomaga dyrektorowi szkoły opracować nową kulturę nauczania, w ramach której potencjał każdego dziecka jest traktowany jako punkt wyjścia dla uczenia się. Ponieważ nowa rola powinna mieć wpływ na kulturę szkoły oraz na nauczanie i uczenie się, w dużej mierze została ona zaprojektowana jako rola nadrzędna.

Ustanowienie heterogenicznych grup zorientowanych na nauczanie i uczenie się wymaga krytycznego dialogu dotyczącego indywidualizacji i personalizacji uczenia się. Szkoła musi mieć świadomość tego, że tworzy różnice, które powodują różnice. Kluczowe znaczenie ma to, by projektant uczenia się przejął rolę przywódczą i współpracował z heterogenicznymi grupami. Wymaga to współdzielonego przywództwa dyrekcji szkół i projektantów uczenia się. Proces określania 
ról i rozumienia różnych obszarów zawodowych w szkole to kluczowy pierwszy krok wiodący do zmiany samoświadomości i odpowiedzialności, tak by wszyscy uczniowie uczęszczający do Neue Mittelschule byli wspierani i by stawiano przed nimi wyzwania umożliwiające im rozwijanie talentów i uzdolnień. W celu wspierania reform, zainicjowano sieci i wspólnoty praktyków, które zostały wdrożone na poziomie całego kraju i na wszystkich poziomach systemu. Powód tych działań był wyraźny i jasno określony: Reforma szkolnictwa, aby była skuteczna, musi być realizowana na poziomie szkół, a promotorzy zmian muszą współpracować w ramach sieci i wspólnot praktyków. Utworzono wirtualną sieć uczenia się profesjonalistów (Rößler, Westfall-Greiter) pod nazwą NMS-Vernetzung. Podstawowym celem sieci projektantów uczenia się jest wspieranie rozwoju skutecznych środowisk uczenia się w każdej szkole, z przestrzeganiem zasad reformy szkół (Marzano, 2003) i koncentrowanie się na osiągnięciu celu, jakim jest sprawiedliwość. Strategia polega na pogłębianiu umiejętności zawodowych nauczycieli, aby mogli oni stać się nauczycielami-liderami, a tym samym umożliwienie im i ich szkołom realizacji skutecznego przywództwa współdzielonego. Bardziej niż kiedykolwiek, kadra kierownicza szkół musi koncentrować się na osiągnięciach uczniów i promowaniu kultury uczenia się w całej szkole.

\section{Szkolni koordynatorzy ds. jakości}

W celu podniesienia jakości pracy szkół w Austrii podjęto inicjatywę pn. Jakość szkół w kształceniu ogólnym (SQA) (Kemethofer, Altrichter, 2015). Inicjatywa ta koncentruje się na zapewnieniu możliwie najlepszych doświadczeń uczenia się i efektów uczenia się na wszystkich poziomach, przy jednoczesnym wspieraniu rozwoju zawodowego pracowników szkół, budowaniu partnerstw i nacisku na przywództwo i zarządzanie (Altrichter i in., 2012). Szkoły są proszone o opracowanie planów rozwoju w określonych obszarach (następujących kategoriach: doświadczenie uczenia się i efekty uczenia się, uczenie się i nauczanie, przestrzeń w klasie i szkole, przywództwo i zarządzanie szkołą, profesjonalizm i rozwój zawodowy personelu, partnerstwa szkół i partnerstwa zewnętrzne) obejmujących okres około trzech lat. Mają one na celu opisanie najważniejszych wskaźników służących do mierzenia usprawnień, gdy osiągną już zamierzone cele. Na początku i na końcu każdego semestru dyrektorzy szkół prowadzą rozmowy na temat rozwoju 
z przedstawicielami władz szkolnych. Nowa rola nauczyciela-lidera, tj. szkolnego koordynatora ds. jakości (SQC) - została wprowadzona w celu wspierania dyrektorów szkół. Krajowe ramy odniesienia, które podsumowują najważniejsze obowiązki i zadania koordynatorów, zostały opublikowane przez ministerstwo:

Szkolni koordynatorzy ds. jakości realizują następujące obowiązki:

$\rightarrow$ informują pracowników dydaktycznych i pozadydaktycznych oraz partnerów szkoły o SQG,

$\rightarrow$ są kluczowymi osobami, do których należy zwracać się z zapytaniami lub wątpliwościami dotyczącymi SQGE,

$\rightarrow$ służą jako punkty kontaktu dla powiatowych koordynatorów SQGE,

$\rightarrow$ regularnie uczestniczą $w$ kursach doskonalenia zawodowego dla SQGE,

$\rightarrow$ wspierają szkolne inicjatywy związane z SQGE,

$\rightarrow$ są członkami zespołu liderów średniego szczebla (jeżeli taki istnieje),

$\rightarrow$ wspierają dyrektora szkoły w przygotowaniu rozmów z władzami szkoły na temat rozwoju,

$\rightarrow$ prowadzą prace redakcyjne nad planem rozwoju,

$\rightarrow$ wspierają procesy ewaluacji i przekazywania informacji zwrotnych,

$\rightarrow$ zbierają, analizują i znajdują nowy kontekst dla istotnych danych dotyczących SQGE.

Mając na względzie powyższe zadania, szkolni koordynatorzy ds. jakości są przede wszystkim postrzegani jako wsparcie administracyjne dla dyrektora szkoły. Porównując te zadania do struktur ramowych przywództwa nauczycieli opracowanych przez Tomal, Schilling i Wilhite (2014, s. 38, tabela 2.), dostrzec można, iż obejmują one tylko niektóre kompetencje. Jak sugerują struktury ramowe, zdolności przywódcze szkolnych koordynatorów ds. jakości polegają na "organizowaniu, analizowaniu i wspieraniu". Zwłaszcza te wybrane umiejętności przywódcze są istotne, ponieważ określają one rodzaje wskaźników potrzebnych do osiągnięcia mierzalnych usprawnień. 
Tabela 2. Struktury ramowe przywództwa nauczycieli

\begin{tabular}{l|l|l}
\multicolumn{1}{c|}{ KOMPETENCJE } & \multicolumn{1}{|c}{ PRZYwóDZTwo } & \multicolumn{1}{c}{ EFEKTY } \\
\hline Promowanie kultury współpracy & Rozwijanie & \\
\hline $\begin{array}{l}\text { Uzyskanie dostępu do i korzystanie } \\
\text { z badań }\end{array}$ & Organizowanie & $\begin{array}{l}\text { Podnoszenie jakości } \\
\text { uczenia się przez uczniów }\end{array}$ \\
\hline $\begin{array}{l}\text { Promowanie społeczności na rzecz } \\
\text { rozwoju zawodowego }\end{array}$ & Mentoring & $\begin{array}{l}\text { Wzrost umiejętności peda- } \\
\text { gogicznych nauczycieli }\end{array}$ \\
\hline $\begin{array}{l}\text { Promowanie usprawnień w zakresie } \\
\text { nauczania i uczenia się }\end{array}$ & Coaching & \\
\hline $\begin{array}{l}\text { Promowanie stosowania ocen } \\
\text { i danych }\end{array}$ & Analizowanie & \\
\hline $\begin{array}{l}\text { Zwiększenie zasięgu działań i rozwój } \\
\text { współpracy }\end{array}$ & Modelowanie & \\
\hline $\begin{array}{l}\text { Wspieranie uczenia się przez } \\
\text { uczniów i zawodu }\end{array}$ & Wspieranie & $\begin{array}{l}\text { Podnoszenie jakości pracy } \\
\text { szkoły }\end{array}$
\end{tabular}

Źródło: na podstawie Tomal, Schilling, Wilhite, 2014, s. 38.

Niemniej jednak, jeśli porównamy te dwie role nauczycieli-liderów, wyraźnie widać jedną istotną różnicę: podczas gdy projektant uczenia się ściśle współpracuje z dyrektorem szkoły, z którym tworzy dynamiczny duet, szkolni koordynatorzy ds. jakości są wzywani jako wsparcie operacyjne i nie ponoszą oni odpowiedzialności strategicznej² za rozwój szkoły. W tym przypadku umiejętności nauczyciel-liderów, takie jak „rozwijanie, mentoring, coaching i modelowanie", są słabo reprezentowane.

W przeciwieństwie do roli projektanta uczenia się, reforma dotycząca szkolnych koordynatorów ds. jakości nie była realizowana na poziomie krajowym. Powiaty były odpowiedzialne za szkolenie i doskonalenie zawodowe koordynatorów. $Z$ tego powodu, kompetencje i opisy zadań są zróżnicowane. Jednak niedawno przeprowadzone badanie empiryczne (Rößler, Kraler, mające się wkrótce ukazać) przeprowadzone w siedmiu nowych gimnazjach pokazało, że rola szkolnych koordynatorów ds. 
jakości uległa zmianie. Nawet jeśli rola ta koncentruje się na ewaluacji $i$ analizie, synergie są wykorzystywane w celu doskonalenia nauczania i uczenia się. Ponieważ niektóre z obszarów jakości SQA pokrywają się z wymogami reformy nowych gimnazjów, projektanci uczenia się i szkolni koordynatorzy ds. jakości współpracują ze sobą. Zwłaszcza przy formułowaniu konkretnych celów planów rozwoju szkolni koordynatorzy ds. jakości współpracują z koordynatorami przedmiotu i projektantami uczenia się. Dzięki takiemu współdzielonemu przywództwu odnotowano trwałe podniesienie jakości pracy w tych siedmiu szkołach.

\section{Ustalenia na temat roli nauczycieli-liderów}

Obie role zostały powiązane $\mathrm{z}$ reformami realizowanymi na poziomie krajowym, tak więc stały się obowiązkowe we wszystkich powiatach. Jak wskazano powyżej, jedna z tych dwóch ról była wspierana za pomocą ogólnokrajowych kursów doskonalenia zawodowego (odbywały się w ośmiu edycjach) i dodatkowo została wzmocniona przez sieć wirtualną. W odniesieniu do drugiej nowej roli odbywały się szkolenia w ramach doskonalenia zawodowego na poziomie powiatów oraz jednorazowe kontakty z profesjonalnymi sieciami edukacyjnymi działającymi poza szkołami. W naszym rozumieniu, doskonalenie zawodowe w obu przypadkach było pomocne w profesjonalizacji nowych nauczycieli-liderów, zwłaszcza sieć wirtualna i projektowanie generacyjne w ramach profesjonalnych sieci edukacyjnych zapewniły trwałe, profesjonalne rozumienie tematu. Sieć ta nadal stanowi aktywną wspólnotę, gdzie nauczyciele-liderzy wzajemnie się wspierają (Kahlhammer 2012; Rößler, Westfall-Greiter, 2018).

Podobnie obie role nauczycieli-liderów kierowały się rozumieniem różnorodności, a nie uniformizmu (Westfall-Greiter, Hofbauer, 2010, 2015). Rola nauczyciela-lidera dopasowana do każdego środowiska lokalnego nie może być realizowana, ponieważ każda szkoła i każdy proces rozwoju wymagają odmiennych form wsparcia i koncentrują się na indywidualnych wyzwaniach. Ogólnie znany jest fakt, że nauczyciele-liderzy, którzy mają możliwość tworzenia i kształtowania własnych ról, otrzymują więcej wsparcia i odnoszą większy sukces. Jak Hofbauer i Schwarz (2016) wskazują na podstawie swojej pracy z nauczycielami-liderami, „odgrywanie i tworzenie ról stanowi istotne procesy, które zmieniają kulturę szkół i zawodu nauczyciela". Doświadczenia austriackie pokazały, że najlepszym sposobem na rozwój 
tych niezdefiniowanych ról jest profesjonalizacja zawodu nauczyciela i stwarzanie im odpowiednich warunków do codziennej pracy (Cooper i in., 2016; York-Barr, Duke, 2004). Aby odnosić sukcesy w środowisku, nauczyciele-liderzy muszą być przede wszystkim wiarygodni i muszą posiadać wiedzę ekspercką.

Na koniec, wpływ nauczycieli-liderów „w dużym stopniu zależy od dynamiki przywództwa w (...) szkołach i stopnia, w jakim kultura izolacji hamuje wzrost" (Hofbauer, Schwarz, 2016). Zatem profilowanie nauczycieli-liderów zależy od wprowadzenia, wsparcia i gotowości do dzielenia się obowiązkami z dyrektorami szkół. Ponieważ doskonalenie zawodowe projektantów uczenia się było skierowane nie tylko do nowych nauczycieli-liderów, lecz także do dyrektorów szkół, zapewniono wspólne rozumienie tematu i wsparcie. Nauczyciele-liderzy i dyrektorzy szkół współpracują ze sobą - sukces profesjonalizacji i trwałego rozwoju nowych ról nauczycieli-liderów zawsze wymaga udziału dyrektorów szkół w ich rozwoju zawodowym, ponieważ to oni określają oczekiwania oraz tworzą ścieżki prowadzące do sukcesu nauczycieli-liderów (Mangin, 2007; Cooper i in., 2016).

\section{Wnioski: Innowacyjność wymaga strategicznego przywództwa}

Innowacje systemowe zasadzają się na ludziach i procesach z jednej strony, a z drugiej - na ruchach oddolnych, takich jak rozwój zawodowy i systemowy na poziomie regionalnym, jak również zaangażowanie na poziomie szkół. Inteligentne wykorzystanie kapitału intelektualnego i społecznego ma kluczowe znaczenie dla rozwoju systemu. Ponieważ ludzie są różni oraz sytuacje i kultury różnią się między sobą, zmiana kulturowa wymaga zmiany mentalności, która opiera się na strategicznych obszarach przywództwa. Przywództwo strategiczne tworzy wizję, jest skierowane na przyszłość i przekształca poczucie niepewności w wyraziste i atrakcyjne cele.

Przywództwo strategiczne jako interwencje na poziomie całego systemu jest bardzo złożonym procesem i wymaga zmiany paradygmatu, jak przedstawiono $w$ tabeli 3 . 
Tabela 3. Zmiana paradygmatu reformy oświaty

\begin{tabular}{l|l|l} 
NAUKA SZKOLNA & uczenie się & $\begin{array}{l}\text { zasadnicza zmiana w rozumieniu } \\
\text { roli nauczycieli }\end{array}$ \\
\hline $\begin{array}{l}\text { PODZIAŁ UCZNIÓW } \\
\text { NA GRUPY }\end{array}$ & $\begin{array}{l}\text { spersonalizowane } \\
\text { uczenie się }\end{array}$ & $\begin{array}{l}\text { strukturalna zmiana w podejściu } \\
\text { do różnorodności }\end{array}$ \\
\hline $\begin{array}{l}\text { OCENA } \\
\text { PODĄŻANIE }\end{array}$ & informacje zwrotne & $\begin{array}{l}\text { różne sposoby koncentrowania się } \\
\text { na osiągnięciach uczniów }\end{array}$ \\
\hline "MOJA KLASA I JA" & pośrednictwo & $\begin{array}{l}\text { nowe hipotezy dotyczące } \\
\text { współdzielonego przywództwa }\end{array}$ \\
\hline REALIZACJA KONCEPCJI & rozwój systemu & $\begin{array}{l}\text { podejście do szkoły jako systemu } \\
\text { społecznego }\end{array}$ \\
\hline $\begin{array}{l}\text { PIONOWE DOWODZENIE } \\
\text { I KONTROLA }\end{array}$ & integracja lateralna & $\begin{array}{l}\text { zwrot w organizowaniu procesu } \\
\text { zmian }\end{array}$ \\
\hline
\end{tabular}

Źródło: opracowanie własne.

Taka zmiana paradygmatu tworzy świadomość hiper-złożoności, co uniemożliwia realizację za pomocą tradycyjnych strategii odgórnych. Dlatego też struktura sieci i wspólnoty uczenia się profesjonalistów na wszystkich poziomach systemu zostały wprowadzone w celu wzmocnienia zdolności przywództwa w poszczególnych szkołach. Biorąc pod uwagę powyższe założenia, poszukując podejścia systemowego, które pozwoliłoby różnym interesariuszom na zapoznanie się i działanie na podstawie powstającej całości oraz powiązanie ich z przywództwem jako czynnikiem skutecznego wywierania nacisku, uzyskuje się coś, czego brakowało w austriackiej kulturze szkolnej, a mianowicie „zdolność do zbiorowego odczuwania, kształtowania i tworzenia naszej przyszłości" (Scharmer, 2007, s. 352). Matryca przedstawiona w tabeli 3. może więc służyć jako lista kontrolna dostosowywania zbiorowego podejścia do tego, co implikuje zmiana systemu. $W$ tym procesie nauczyciele-liderzy odgrywają istotną rolę jako mediatorzy innowacji na poziomie szkoły i zmian w całym kraju.

Podsumowując, podejście teoretyczne, jak również praktyczne doświadczenia dotyczące dwóch austriackich przykładów pokazują, 
w jaki sposób nauczyciele-liderzy mogą stać się mediatorami innowacji w szkole i procesów zmiany. Nauczyciele-liderzy mają szeroki zakres zadań: transponują nowe polityki, tworzą warunki do uczestnictwa, pośredniczą pomiędzy dyrekcją a pracownikami szkoły, ustanawiają relacje na rzecz profesjonalnego uczenia się (Harris, 2003). Wszystko to wymaga korzystania z ich zasobów i atutów oraz dodatkowo skutecznego rozwoju zawodowego i wsparcia dla zawodu nauczyciela. Wszystkie prezentowane tu role nauczycieli-liderów kładą nacisk na przywództwo na rzecz uczenia się. Podział odpowiedzialności na wszystkich nauczycieli, którzy są wspierani przez nauczycieli-liderów mogących przyczynić się do profesjonalizacji na szczeblu lokalnym, promuje zmiany skierowane na tworzenie środowisk edukacyjnych, które podnoszą jakość uczenia się przez uczniów. Ponadto przywództwo nauczycieli wydaje się skuteczne jedynie w przypadku, gdy dyrektorzy szkół są zaangażowani, a członkowie personelu są skłonni zaakceptować nowe role jako zapewniające im wsparcie.

Zdecydowanie podkreśliliśmy tu fakt, że projektowanie realizacji ról nauczycieli-liderów ma miejsce na poziomie lokalnym i nie może być odgórnie administrowane, jako że wymaga ono kontekstowego uwrażliwienia na lokalne potrzeby i możliwości. Równoważenie różnych potrzeb i oczekiwań prowadzi nas do ugruntowania funkcji i ról, które zmieniają wspólne podejście do szkoły i prowadzą do zmiany paradygmatu w myśleniu o uczeniu się i nauczaniu. Nauczyciele-liderzy odgrywają główną rolę w tym procesie. 


\section{Bibliografia}

$\rightarrow$ Altrichter, H., Maag Merki, K. (2010), Handbuch neue Steuerung im Schulsystem, Wiesbaden: VS Verlag für Sozialwissenschaften.

$\rightarrow$ Altrichter, H., Helm, C., \& Kanape-Willingshofer, A. (2012), Unterrichts-und Schulqualität, http://www.sqa.at/pluginfile.php/988/coursecat/description/ qualitaet_von_unterricht_und_schule.pdf [dostęp: 19.10.2017].

$\rightarrow$ Ball, S.J., Maguire, M. \& Braun, A. (2012), How Schools do Policy. Policy Enactments in Secondary Schools, London: Routledge.

$\rightarrow$ Buchen, I.H. (2000), The myth of school leadership. Education Week, 19(38), 35-36.

$\rightarrow$ Conley, S., Muncey, D.E. (1999), Teachers talk about teaming and leadership in their work, Theory Into Practice, 38(1), 46-55.

$\rightarrow$ Cooper, K.S., Stanulis, R.N., Brondyk, S.K., Hamilton, E.R., Macaluso, M., Meier, J.A. (2016), The teacher leadership process: Attempting change within embedded systems, Journal of Educational Change, 17(1), 85-113.

$\rightarrow$ Crowther, F., Kaagen, S., Ferguson, M. \& Hann, L. (2002), Developing Teacher Leaders: How Teacher Leadership Enhances School Success, Thousend Oaks: Corwin Press.

$\rightarrow$ Donaldson, L. (2001), The Contingency Theory of Organizations, Thousend Oaks: Sage.

$\rightarrow$ Frost, D., Durrant, J., Head, M., Holden, G. (2000), Teacher-led School Improvement, London, New York: Falmer Press.

$\rightarrow$ Frost, D., Swaffield, S. (2004, January), The Leadership for Learning (Carpe Vitam) project: an eclectic and emerging methodology. In 17th International Congress for School Effectiveness and Improvement, Rotterdam, Netherlands.

$\rightarrow$ Fullan, M. (2005), Leadership \& sustainability: System thinkers in action, Corwin Press.

$\rightarrow$ Gabriel, J.G. (2005), How to Thrive as a Teacher Leader, Alexandria: Association for Supervision and Curriculum Development. 
$\rightarrow$ Hall, D., Møller, J., Schratz, M., Serpieri, R. (2017), From Welfarism to Neo-Liberalism: Conceptualizing the Diversity of Leadership Models in Europe [w:] D. Waite, I. Bogotch (Eds.), The Wiley international handbook of education leadership, s. 311-334, Hoboken, NJ: John Wiley \& Sons.

$\rightarrow$ Harris, A. (2003), School Improvement. What's in it for Schools?, London: RoutledgeFalmer.

$\rightarrow$ Harris, A., Muijs, D. (2005), Teacher Leadership: Principles and Practice, London: National College for School Leadership.

$\rightarrow$ Hattie, J.A. (2009), Visible Learning: A synthesis of 800+ Meta-analyses on Achievement, Abingdon: Routledge.

$\rightarrow$ Hofbauer, C. \& Schwarz, J.E. (2016), Posterpresenation at Austrian Showcase, Glasgow: International Conference for School Effectiveness and Improvement. http://www.nmsvernetzung.at/pluginfile.php/22141/mod_resource/content/1/ ICSEI_Poster_Teacher_Leadership_final.pdf

$\rightarrow$ Kahlhammer, M. (2012), Lernateliers als Professionelle LerngemeinschaftenDie Wahrnehmungen und Einschätzungen der beteiligten Lerndesigner zur eigenen, gemeinsamen und systemischen Professionalisierung im Rahmen von Lernateliers der Entwicklungsbegleitung der Neuen Mittelschule, Master Thesis, Weingarten, $\mathrm{PH}$ Weingarten - internationale Bodenseehochschule.

$\rightarrow$ Katzenmeyer, M., Moller, G. (2009), Awaking the Sleeping Giant. Helping Teachers Develop as Leaders, Thausand Oaks: Corwin Press.

$\rightarrow$ Kemethofer, D., Altrichter, H. (2015), Schulqualität Allgemeinbildung (SQA) in der Einschätzung von Schulleitungen allgemeinbildender Pflichtschulen, Erziehung und Unterricht, 165(7-8), 675-690.

$\rightarrow$ Lortie, D.C. (2002), Schoolteacher. A Sociological study. Chicago: University of Chicago Press.

$\rightarrow$ MacBeath, John E.C., Moos, L. (Eds.) (2004), Democratic Learning. The Challenge to School Effectiveness, London: RoutledgeFalmer.

$\rightarrow$ Mangin, M.M. (2007), Facilitating elementary principals' support for instructional teacher leadership, Educational Administration Quarterly, 43(3), 319-357.

$\rightarrow$ Marzano, R.J. (2003), What Works in Schools: Translating Research into Action, Alexandria: Association for Supervision and Curriculum Development.

$\rightarrow$ Marzano, R.J., Waters, T., McNulty, B.A. (2005), School leadership that works: From research to results, Alexandria: Association for Supervision and Curriculum Development.

$\rightarrow$ Mayers, R.S., Zepeda, S.J., Benson, B. (2013), Call to Teacher Leadership, Hoboken: Taylor and Francis. 
$\rightarrow$ Rößler, L., Westfall-Greiter, T. (in print), Austria's Lerndesigner Network: The Dynamics of Virtual Professional Learning in Interschool Networks [w:] C. Brown, C. Poortman (Eds.), Networks for Learning: Effective collaboration for teacher, school and system improvement, New York: Routledge.

$\rightarrow$ Rößler, L., Kraler, Ch. (forthcoming), 2. Zwischenbericht Modellregion Bildung Zillertal, Innsbruck.

$\rightarrow$ Scheerens, J. (2012), Summary and conclusion: Instructional leadership in schools as loosely coupled organizations [w:] J. Scheerens (Ed.), School Leadership Effects Revisited. Review and Metaanalysis of Emprical Studies, s. 131-152, Springer Netherlands.

$\rightarrow$ Schley, W., Schratz, M. (2010), Developing Leaders, building networks, changing schools through system leadership [w:] J. MacBeath, T. Townsend (Eds.), International Handbook on Leadership for Learning, s. 267-296, New York: Springer.

$\rightarrow$ Schley, W., Schratz, M., Hofbauer, C., Westfall-Greiter, T. (2009), Das Konzept der NMS- Entwicklungsbegleitung als Transformationsprozess, Erziehung und Unterricht, 7-8, 686-689.

$\rightarrow$ Schratz, M. (2005), Abschied vom primus inter pares - Schulleitung zwischen Beruf und Berufung [w:] X. Büeler, A. Buholzer, M. Roos (Eds.), Schulen mit Profil. Forschungsergebnisse - Brennpunkte - Zukunftsperspektiven, s. 181-192, Innsbruck: StudienVerlag.

$\rightarrow$ Schratz, M. (2011), Die Internationalisierung von Bildung im Zeitalter der Globalisierung [w:] M. Ruep (Eds.), Bildungspolitische Trends und Perspektiven, s. 19-53, Baltmannsweiler: Schneider Hohengehren.

$\rightarrow$ Schratz, M. (2012), Austria's Balancing Act: Walking the Tightrope between Federalism and Centralization [w:] K. Seashore Louis, B. van Velzen (Eds.), Educational Policy in an International Context. Political Culture and its Effects, s. 95-104, New York: Palgrave Macmillan.

$\rightarrow$ Schratz, M., Wiesner, C., Kemethofer, D., George, A.C., Rauscher, E., Krenn, S. i in. (2016), Schulleitung im Wandel: Anforderungen an eine ergebnisorientierte Führungskultur [w:] M. Bruneforth, F. Eder, K. Krainer, C. Schreiner, A. Seel, C. Spiel (Eds.), Nationaler Bildungsbericht Österreich 2015 Band 2. Fokussierte Analysen bildungspolitscher Schwerpunktthemen, s. 221-262, Graz: Leykam.

$\rightarrow$ Snoek, M., Volman, M. (2014), The impact of the organizational transfer climate on the use of teacher leadership competences developed in a post-initial Master's program, Teaching and Teacher Education, 37, 91-100.

$\rightarrow$ Tomal, D., Schilling, C. \& Wilhite, R. (2014), The Teacher Leader. Core Competencies and Strategies for Effective Leadership, Lanham: Rowman \& Littlefield. 
$\rightarrow$ Wenger, E. (1998), Communities of Practice: Learning, Meaning, and Identity, Cambridge: Cambridge University Press.

$\rightarrow$ Westfall-Greiter, T., Hofbauer, C. (2010), Shared Leadership setzt Teacher Leaders voraus: Lerndesigner/innen im Feld der Neuen Mittelschule, Journal für Schulentwicklung, 4, 8-14.

$\rightarrow$ Westfall-Greiter, T., Hofbauer, C. (2015), Fostering teacher leaders for sustainable school reform: system-wide strategies in Austria's lower secondary school reform, Ricercazione, 7(2), 125-144.

$\rightarrow$ Wiesner, C., George, A.C., Kemethofer, D., Schratz, M. (2015), School leadership in German speaking countries with an emphasis on Austria: A Re-Vision, Ricercazione, 7(2), 65-90.

$\rightarrow$ York-Barr, J., Duke, K. (2004), What do we know about teacher leadership? Findings from two decades of scholarship, Review of Educational Research, 74(3), 255-316. 


\title{
Argumenty za upodmiotowieniem: brakujący element kluczowy
}

\author{
Christopher Bezzina
}

\begin{abstract}
Na przestrzeni ubiegłych 20 lat na Malcie falowo przeprowadzono wiele reform. Podczas gdy dokumenty urzędowe mówią o potrzebie odejścia od podejmowania decyzji w ramach hierarchicznej struktury w kierunku bardziej zdecentralizowanych form zarządzania, rzeczywistość okazuje się odmienna. Dane z licznych badań dotyczących dyrektorów szkół pokazują, że według nich przyjęte podejście odgórne ogranicza przestrzeń do rozproszonych form zarządzania. Kwestia władzy i kontroli pozostaje wciąż kością niezgody, jako że to władze centralne wciąż określają politykę dotyczącą okręgów szkolnych/szkół. W rzeczywistości, obecne doświadczanie można opisać jako kolegialność ukierunkowaną mandatem politycznym. W artykule przedstawiono wyniki badania, w ramach którego przeprowadzono zogniskowane wywiady grupowe z dyrektorami i nauczycielami maltańskich szkół publicznych. Artykuł wskazuje na obawy, jakie mają dyrektorzy szkół w związku ze sposobami wdrażania reform oświatowych, na stałe odniesienia do przeciążenia pracą i stresem, na potrzebę większego wsparcia na poziomie jednostkowym i zbiorowym, a także na konieczność zapewnienia szkołom możliwości przejmowania inicjatywy.
\end{abstract}

\section{_ Słowa kluczowe:}

zarządzanie, upodmiotowienie

nauczyciel

budowanie sieci

tworzenie polityki

Malta 


\title{
Making a case for empowerment: The missing key ingredient
}

\author{
Christopher Bezzina
}

Over the past 20 years or so, Malta has been witnessing wave after wave of reforms. Whilst the official documents speak of the need to move away from a top-down hierarchical structure of decision making to more decentralised forms of governance the reality shows otherwise. Data from a series of studies involving school leaders show that they still feel that a top-down approach is being adopted leaving limited space for distributed forms of governance. The issue of power and control remains a bone of contention with the centre identified as still determining College/school policies. In fact, what is being experienced can be described as policy-mandated collegiality. This paper presents findings of one such study that involved interviews with a number of focus groups involving school leaders in a number of Maltese state schools. This study highlights the concern that heads feel towards the way reforms are being introduced and implemented; the constant reference to work overload and stress; the need for greater support at the personal and collective level, and the need to start letting go so that schools can take the initiative.

\section{Keywords:}

governance

empowerment

teacher

networking

policy making

Malta 


\section{Wstęp}

Struktura społeczna w moim kraju ulega zmianom. Realia, w jakich żyjemy, są zupełnie odmienne od tych, w jakich dorastaliśmy. Stare i obecne sposoby myślenia i działania powinny zostać zrewidowane, abyśmy mogli sprostać wyzwaniom, przed jakimi stoimy. W mojej opinii, sprostanie tym wyzwaniom jest uzależnione od umiejętności naszego społeczeństwa w zakresie wykorzystania zbiorowego geniuszu naszych obywateli. W tym rozdziale chciałbym zadać następujące pytanie: co w naszym systemie oświaty sprawia, że nie potrafimy wykorzystać zbiorowego geniuszu wszystkich naszych obywateli? Sposób, w jaki zaprojektowaliśmy i na przestrzeni lat wdrożyliśmy reformy edukacji, wpływa na odpowiedź, jakiej możemy udzielić na to pytanie. Ponadto musimy pamiętać, że potrzebny nam jest system edukacji, który ma charakter ewolucyjny, a nie reakcyjny.

Dzięki odbytym wizytom w instytucjach w kraju i poza jego granica$\mathrm{mi}$, rozmowom i lekturze znalazłem odpowiedź na powyższe pytanie. Z moich poszukiwań i uzyskanych odpowiedzi wyłoniły się dwa odrębne zagadnienia: potrzeba transformacyjnego przywództwa i skoncentrowania się na jasno określonym celu.

\section{Zwartość przywództwa}

Różni ludzie, z którymi rozmawiałem, przedstawiali ciekawe, świeże i nietypowe definicje przywództwa. Twierdzili oni, że przywództwo jest umiejętnością, którą wszyscy musimy posiąść i wykorzystywać na co dzień. Większość uważała, że przywództwo nie zasadza się na zajmowanym stanowisku, lecz na sposobie postępowania wszystkich osób w systemie oświaty. Innymi słowy, wszyscy powinni wziąć na siebie odpowiedzialność za całość systemu i zapewnić, że kierują swoje działania na priorytety organizacyjne. Zaangażowanie wszystkich w przywództwo jako sposób na tworzenie zwartego przywództwa w organizacji, które przynosi korzyści dla całej organizacji ma duże znaczenie. Dobrym przykładem na to może być grupa nauczycieli, którzy byli rozczarowani wynikami uczniów w naukach ścisłych i postanowili coś z tym zrobić. Samodzielnie przeprowadzili ankietę wśród uczniów na temat jakości programu i stosowanych metod nauczania nauk ścisłych. Nikt nie polecił nauczycielom, żeby to zrobili. Nauczyciele wiedzieli, że tak należy postąpić i zrobili to. Mieli świadomość tego, że było to najlepsze działanie, jakie mogli podjąć, aby poprawić wyniki w nauce swoich uczniów. 
W rezultacie dowiedzieli się z pierwszej ręki, że obowiązujący program był dla uczniów nudny i demotywujący. Poprosili ekspertów o poradę w zakresie pedagogiki, oceniania, zrozumienia i interpretacji uzyskanych wyników. Takie podejście pozwoliło nauczycielom zrewidować obowiązujące treści i praktyki oraz stworzyć bardziej rygorystyczny, zorientowany na praktyczne cele program nauczania, który stanowił wyzwanie dla wszystkich uczniów i sprawił, że nauczane treści były bliższe ich doświadczeniom.

\section{Jasno określony cel}

Rozmowy na temat przywództwa sprawiły również, że nacisk został położony na jasno określony cel. Jeśli chcemy wykorzystać zbiorowy geniusz wszystkich członków systemu szkolnego, musimy zmienić postrzeganie zarządzania, władzy i sprawowania kontroli. Potrzebujemy bardziej rozproszonych form przywództwa. Musimy podejmować trudne wybory dotyczące naszego działania. Dlatego wyznaczenie jasnego celu wpasowuje się w koncepcję zwartości przywództwa: jeśli każdy członek systemu ma świadomość celów/wyzwań, którym należy sprostać, przywództwo realizowane przez wszystkich powinno skupiać się z celnością lasera na najważniejszych zagadnieniach.

Podczas wizyty w Szwecji odkryłem, że nauczyciele i dyrekcja szkoły podstawowej zgodnie twierdzili, że umiejętności czytania, pisania i liczenia to najważniejsze cele, jakie muszą osiągnąć uczniowie. Wszyscy byli zgodni co do tego, że dziecko, które nie posiada takich umiejętności, będzie skazane na życie w ubóstwie we współczesnym społeczeństwie opartym na wiedzy. Natomiast w szkole, w której pracuję na Malcie, kierujemy się czterema głównymi zasadami, jakimi są: współpraca, personalizacja, ocena zasadzająca się na wynikach i przydatność. Wysiłki skierowane są na przegląd zarówno treści, jak i samego programu nauczania oraz na przegląd struktur i procesów planowania i podejmowania decyzji, w celu odzwierciedlenia tych zasad.

\section{Bazowanie na mocnych stronach}

Istnieją liczne przykłady z różnych krajów, w których w codziennej praktyce stosowane są te dwie podstawowe umiejętności polegające na przywództwie i koncentrowaniu się na jasno określonych celach. Warto odnotować fakt, że niewielkie szkoły zazwyczaj nie realizują programów nauczania zakrojonych na szeroką skalę lub też realizują alternatywne 
programy i ścieżki kształcenia, a także aktywne, dogłębne formy uczenia się. Wspierają one zarówno proces uczenia się przez uczniów, jak i kształcenia dorosłych w ramach wysiłków zmierzających do stworzenia kultury, w której uczenie się i przywództwo stanowią części systemu, których wszyscy mogą doświadczyć. Reformy z całego świata, szczególnie te przeprowadzone w ostatnim dwudziestoleciu, kładą nacisk na przekazywanie szkołom coraz większego zakresu władzy (Chapman, Aspin, 2003; DuFour, 2014; Rose, 2010) w celu umożliwienia większego zaangażowania nauczycieli, gdyż to oni zapewniają możliwości „zmiany poglądów, głośnego ich wyrażania i zapewnienia, że wszyscy są widoczni" (Swaffield, 2017, s. 493). Różne badania pokazują znaczenie wspierania nauczycieli na różnych etapach kariery i zapewnienia im możliwości doskonalenia zawodowego w szkole (Bates, 2007; Goodwin, Kosnik, 2013; Lunenberg i in., 2017; Madalińska-Michalak, Niemi, Chong, 2012; Schleicher, 2012). Jak wspomniano w jednym z ostatnich dokumentów Komisji Europejskiej, kraje podejmują działania zmierzające do podniesienia jakości nauczania dzięki wprowadzeniu lepszych programów kształcenia i doskonalenia zawodowego nauczycieli. Trend obecnie obserwowany w Europie skierowany jest na wymaganie wyższych kwalifikacji i zwiększenie zakresu szkoleń praktycznych, w tym praktyk szkolnych i podniesienie jakości doskonalenia zawodowego nauczycieli (Komisja Europejska, 2015, s. 2).

Dyrektorzy szkół nie są już w stanie samodzielnie kierować szkołami. Będą oni musieli odstąpić od koncepcji, wedle której przywództwo jest hierarchicznie rozłożone, i zaangażować się w rozwijające się przywództwo w szkołach będące współdzielonym doświadczeniem. Oznacza to potrzebę opracowania bardziej złożonego podejścia do natury przywództwa, które jest współdzielone, i czynników, które wpływają na podejście nauczycieli do współdzielenia (Duignan, Bezzina, 2006). Aby osiągnąć takie warunki, muszą oni ułatwić ludziom zdobywanie wiedzy na temat tego, jak uczyć się razem w celu rozwijania wspólnych modeli i znaczeń mentalnych na rzecz współpracy, wiążących ich ze sobą jako zespoły w społecznościach uczących się. Główny nacisk kładzie się na wspólną naukę, dzielenie się i tworzenie procesów i warunków, które zachęcają wszystkich członków społeczności szkolnej, aby byli źródłami nauki dla siebie nawzajem. Zasadniczo, właśnie to oznacza współdzielone przywództwo w społeczności szkolnej. Takie współdzielone przywództwo musi aktywnie angażować nauczycieli w podejmowanie 
decyzji w zakresie uczenia się i nauczania. Jak twierdzi Muscat, „tworzenie takiego środowiska wymaga pasji, cierpliwości i wytrwałości" (2017, s. 27). Rolą lidera jest dążenie do, koncentrowanie się na, uwalnianie, upodmiotowienie i dostosowanie wspólnego celu, a takie postępowanie rozwija i uwalnia potencjał ludzki (Hopkins, Jackson, 2005).

Są to istotne kwestie związane z polityką. O ile nie przyjrzymy się uważnie temu, w jaki sposób reformy są realizowane i zarządza się zmianą, nie będziemy w stanie podjąć takich kroków. Nie ma wątpliwości, że jeśli bylibyśmy w stanie wykorzystać zbiorową energię wszystkich edukatorów, uczniów i pracowników szkoły, moglibyśmy dokonać niezbędnych zmian w zakresie kształcenia wszystkich naszych dzieci. Zwartość przywództwa i wyznaczenie jasnego celu to idealne elementy, od których należy zacząć.

Jednakże musimy postępować ostrożnie. Zgadzam się z Duignan i Bezzina, którzy twierdzą, że „Podczas gdy język przywództwa jest przepełniony żargonem dotyczącym dzielenia się i współpracy (np. inkluzywność, wychowywanie, wspólne podejmowanie decyzji, upodmiotowienie szeregowych członków organizacji, wspólna wizja i cele), zbyt często język stanowi pustą retorykę, która nigdy nie jest uaktualniana. Istnieje potrzeba sprawienia, by retoryka ta stała się rzeczywistością dla wszystkich członków szkoły, szczególnie dla nauczycieli. Współdzielenie przywództwa z innymi wymaga redefinicji tego, co stanowi realną filozofię i struktury ramowe dla przywództwa w szkołach oraz tego, w jaki sposób umożliwić wszystkim pracownikom szkoły, zwłaszcza nauczycielom, uzyskanie głębokiego poczucia zaangażowania i przynależności. Nie ma wątpliwości, że zmieniająca się złożoność i niepewność życia i pracy w szkołach zmusza kadrę kierowniczą szkół do ściślejszej współpracy z coraz większą liczbą osób. Obejmuje to tworzenie nowych społeczności uczących się, zasadzających się na współpracy, które są gotowe do stawienia czoła niepewności i paradoksom (2006, s. 3-4).

\section{Scenariusz krajowy}

Mając na względzie powyższy kontekst i przekonanie, że rozwój jest uzależniony od liderów - na wszystkich poziomach - przyjęcie bardziej rozproszonego stylu przywództwa może przyczynić się do wprowadzenia usprawnień. W jaki sposób władze lokalne pojmują przywództwo? Jaki jest kierunek polityki realizowanej przez maltańskie władze oświatowe i jakie wyzwania przynosi nasza rzeczywistość? Są to dwa 
bardzo istotne pytania, które należy zadać i na które należy znaleźć odpowiedź, jeśli zamierzamy poczynić postępy we wprowadzaniu usprawnień w szkole. Zaczniemy od wymienienia głównych zasad kierujących procesem reform na Malcie, a następnie omówimy kontekst, w którym te reformy są realizowane.

Reformy realizowane od połowy lat dziewięćdziesiątych zostały podjęte z myślą o zwiększeniu udziału sieci jako środka wspierającego procesy realizacji polityki w czasie zmian w zakresie centralizacji/ decentralizacji. Przedstawiono argument, że jeżeli chcemy podnieść standardy w edukacji, istnieje konieczność powiązania polityki zarówno w płaszczyźnie poziomej, jak i pionowej (Education Act z 2006 r.). Sieci, za pośrednictwem systemu okręgów szkolnych, zostały zidentyfikowane jako sposób na osiągnięcia takiego powiązania. Działania te miały na celu przejście od wysoce scentralizowanego i elitarnego systemu edukacji w kierunku demokratyzacji i umieszczenia dziecka na pierwszym planie (MEYE, 2005). Bezzina $(2010$, s. 6) argumentował, że bodźcem było "utworzenie modelu uczenia się, który przenika cały system". Nie obyło się tu bez trudności. Różne badania wykazały, że po ośmiu latach od rozpoczęcia wprowadzania reform zachęcanie do i promowanie kultury współpracy oraz podejścia polegającego na współdzielonym zarządzaniu i odpowiedzialności zbiorowej nadal stanowią istotne kwestie problemowe (Bezzina, 2012; Bezzina, Vella, 2013).

Rok szkolny 2005-2006 okazał się przełomowym dla edukacji na Malcie. Doniosłe znaczenie w tym względzie miał dokument pt. For All Children to Succeed - A New Network Organisation for Quality Education in Malta (FACTS) (MEYE, 2005) (Aby wszystkie dzieci odniosły sukces - nowa organizacja sieciowa na rzecz wysokiej jakości edukacji na Malcie), w którym przedstawiono projekty reformy oświaty. Z dokumentu wynikało, że zmiany i reformy miały na celu pełną restrukturyzację maltańskiego systemu edukacji. Obejmował on następujące projekty:

$\rightarrow$ Utworzenie dziesięciu autonomicznych okręgów szkolnych (ang. Colleges), w których skład wchodziłyby wszystkie szkoły podstawowe i średnie, w ramach trójstopniowego procesu wdrażania;

$\rightarrow$ Wszystkie okręgi szkolne mogłyby generować nowe możliwości dzięki sprawowaniu kontroli nad programem nauczania i zasobami oraz większemu wsparciu technicznemu i administracyjnemu;

$\rightarrow$ Podział wydziału edukacji na dwie uzupełniające się dyrekcje: jedną sprawującą funkcje wspierające głównie szkoły państwowe 
i drugą pełniącą funkcje regulacyjne i związane z zapewnieniem jakości we wszystkich szkołach na Malcie;

$\rightarrow$ Najbardziej gruntowna przebudowa programów nauczania w historii oświaty na Malcie;

$\rightarrow$ Wyposażenie społeczności szkolnych w najnowocześniejsze udogodnienia umożliwiające realizację holistycznej edukacji skoncentrowanej na uczeniu się w szkołach/okręgach szkolnych.

W rezultacie, w 2007 r. rząd i Maltański Związek Nauczycieli (MUT) podpisali umowę w sprawie nowej reformy oświaty. Postanowienia umowy miały na celu wprowadzenie nowych struktur zarządzania, uelastycznienie relacji pomiędzy instytucjami a wydziałami, zaangażowanie nowych pracowników w udzielanie wsparcia i podnoszenie jakości usług oraz wprowadzenie elementów odpowiedzialności niezbędnych do uruchomienia okręgów szkolnych (Ministerstwo Edukacji, Młodzieży i Zatrudnienia, 2007).

Niniejsze badanie zostało przeprowadzone w powyższym kontekście. Za pomocą badania zamierzamy przedstawić punkt widzenia umożliwiający lepsze zrozumienie wpływu maltańskich okręgów szkolnych na przywództwo edukacyjne i zarządzanie oświatą. Perspektywa ta nie ma charakteru nakazowego, lecz przybiera formę wizji, która stanowić będzie przyczynek do pozyskania wiedzy, szczególnie w dziedzinie edukacji. Wyniki badania są uzależnione od pytania badawczego: „Jakie są implikacje dla przywództwa i zarządzania instytucjami zaangażowanymi we współpracę w kontekście polityki, która wymaga współdziałania poszczególnych szkół?".

Przedstawione w 2006 r. polityki w zakresie tworzenia sieci, które zostały przedstawione $w$ ramach propozycji zawartych w FACTS (MEYE, 2005), mające na celu wprowadzenie zasadniczych zmian w sposobie współpracy i utrzymywania kontaktów przez praktyków w szkołach i okręgach szkolnych, zostały zatwierdzone w Act to Amend the Education Act, Cap. 327 (Laws of Malta, 2006) (ustawie o zmianie ustawy o edukacji). Oba dokumenty urzędowe mogą być postrzegane jako prekursorzy reform rozpoczętych w 2006 r. które są nadal realizowane. Władze oświatowe uznały, że organizacja sieci w sektorze edukacji to zjawisko, jakie można zaobserwować niemal na całym świecie, i stwierdziły, że „obecnie wiele szkół, zarówno w Wielkiej Brytanii, jak i za granicą, odnosi korzyści ze współpracy w ramach sieci" (MEYE, 2005, s. 38). 
Jest zrozumiałe, że niezwykle innowacyjny charakter reformy zaproponowanej przez FACTS (MEYE, 2005) spowodował mieszane reakcje. Datnow, Hubbard i Melan (2002, s. 29) twierdzą, że „w wyniku zmian w rozmieszczeniu władzy, definicja i interpretacja wydarzeń przez poszczególne podmioty mogą być kwestiami spornymi. Różne opinie mogą zostać przedstawione w toku realizacji działań prowadzących do reformy". Z jednej strony byli zwolennicy i propagatorzy reformy, w tym osoby odpowiedzialne za tworzenie polityki, przedstawiciele władz oświatowych, dyrektorzy okręgów szkolnych oraz osoby niezależne. Natomiast inne osoby i instytucje publicznie wyrażały swój sceptycyzm, krytykę oraz powątpiewanie $w$ to, że cele sieci zostaną rzeczywiście osiągnięte. Sceptycy z różnych kręgów społeczeństwa maltańskiego - nauczyciele akademiccy, przedstawiciele MUT i parlamentarzyści - wyrażali zastrzeżenia co do reformy sieci innowacji na rzecz maltańskiego systemu edukacji. Autor (Bezzina, 2005, 2006) dość wyraźnie stwierdził przed powstaniem systemu sieciowego, że takie podejście wymaga zmiany sposobu myślenia na wszystkich poziomach i trwałego wsparcia. W innych badaniach zalecano ostrożność (Bezzina, Cutajar, 2013; Borg, Giordmaina, 2012; Mifsud, 2015) oraz podkreślano potrzebę przeprowadzenia przeglądu realizacji procesu.

\section{Reforma oświaty}

W chwili pisania tego artykułu decentralizacja i autonomia zostały tylko częściowo osiągnięte. Mając na względzie bieżący scenariusz edukacyjny w kraju, przedstawiciele maltańskich okręgów szkolnych i dyrektorzy szkół mogą być zmuszeni do balansowania pomiędzy scentralizowanym systemem nadzoru a zdecentralizowanym systemem zarządzania instytucjami. W literaturze (Leithwood, Hallinger, 2002) można znaleźć stwierdzenia, że taka sytuacja ma bardzo często miejsce, gdy rząd centralny aktywnie angażuje się $w$ opracowywanie polityki oświatowej. Maltańskie okręgi szkolne i wchodzące w ich skład szkoły doświadczyły zarządzania na poziomie instytucji (ang. site-based management - SBM), jako że otrzymały pewną swobodę w zarządzaniu finansami i zasobami technologicznymi, podczas gdy wdrażanie reform pozostało w gestii władz centralnych. Było to zgodne z niektórymi przepisami ustawy (Laws of Malta, 2006), które usankcjonowały częściową decentralizację, gdzie władze centralne zostały uznane za pomysłodawców zmian i rozwoju na wszystkich poziomach. Ustawa 
(Laws of Malta, 2006) również określała funkcje i powołanie Komitetu Stałego ds. Edukacji, któremu przewodniczy minister. Zadaniem Komitetu Stałego ds. Edukacji było nadanie kierunku polityce oświatowej na Malcie, przy zachowaniu przez niego prawa do podejmowania decyzji. W związku z tym, taka sytuacja pokazała, że decentralizacji zarządzania szkołami towarzyszyły scentralizowane systemy obejmujące zasoby ludzkie, program nauczania i nadzór nad ocenianiem.

\section{Metodologia prowadzenia badania}

W tej części wyjaśniono, uzasadniono i przeprowadzono krytyczną ocenę metodologii prowadzenia niniejszego badania na małą skalę. Skupiono się tutaj na aspektach związanych z metodologią i przedstawiono proces decyzyjny zastosowany do udzielenia odpowiedzi na pytanie badawcze, które brzmi następująco: „Jakie są implikacje dla przywództwa i zarządzania instytucjami zaangażowanymi we współpracę $w$ kontekście polityki, która wymaga kolaboracji poszczególnych szkół?".

Ogólnym celem badania było wzbogacenie wiedzy i zrozumienie narracji poszczególnych interesariuszy i postrzegania przez nich wprowadzonych reform dzięki syntezie perspektyw teoretycznych uzyskanych z zebranych dowodów, uzupełnionych o przegląd istniejącej powiązanej literatury. Dane uzyskano za pomocą badań empirycznych obejmujących badania przypadków z czterech okręgów szkolnych wybranych przy użyciu wygodnych i celowych metod doboru próby. Zastosowanie nieprobabilistycznego doboru próby implikuje, że z całkowitej populacji potencjalnych uczestników badania tylko w przypadku niektórych respondentów występowało większe prawdopodobieństwo ich wyboru niż w przypadku pozostałych (Bryman, 2004), co sugeruje, że badacz nie mógł sformułować uogólnionego wniosku na temat tej populacji (Cohen, Manion, Morrison, 2003). Jednakże można twierdzić, że celowy dobór próby umożliwił zbadanie i przedstawienie charakterystyki pełnej gamy doświadczeń respondentów w różnych instytucjach, co w pewien sposób umożliwiło przeprowadzenie pewnych uogólnień. Można również stwierdzić, że informacje zebrane na podstawie nieprobabilistycznego doboru próby nie mogą zostać użyte do wyciągnięcia wniosków na temat populacji, z której dokonano doboru próby (Bryman, 2004). Ponadto zastosowano proces triangulacji metodologii, ponieważ dane zostały zebrane za pomocą wywiadów częściowo ustrukturyzowanych w formie bezpośredniej rozmowy z po- 
szczególnymi respondentami, obserwacji spotkań Rady Dyrektorów i analizy dokumentów.

Zastosowano podejście jakościowe, ponieważ ułatwiło to dogłębne zrozumienie pojedynczych przypadków. Badania jakościowe wykorzystują naturalistyczne podejście i mają na celu zrozumienie faktów w określonych sytuacjach. (Cohen, Manion, Morrison, 2003; Filmer i in., 1998, cyt. za: Seale, 2000; Patton, 2002). Strauss i Corbin (1990, s. 17) definiują badania jakościowe jako „wszelkiego rodzaju badania, które zapewniają wyniki niedostępne przy stosowaniu procedur statystycznych lub innych sposobów kwantyfikacji". Ponadto zastosowanie podejścia jakościowego pozwoliło na uzyskanie dogłębnego zrozumienia poglądów edukatorów w tym zakresie i zapewniło bezpośredni i osobisty kontakt $z$ respondentami w ich własnym środowisku. Jako że badanie dotyczyło postrzegania przez respondentów wydarzeń w ich codziennej pracy, zastosowano technikę etnometodologii sytuacyjnej.

\section{Obraz ogólny}

Podjęto decyzję, by przeprowadzić wywiady z osobami odpowiedzialnymi za tworzenie polityki, dyrektorami okręgów szkolnych, dyrektorami szkół i nauczycielami, ponieważ uznaliśmy, że osoby te mogłyby dostarczyć informacji, jakich szukaliśmy, ze względu na to, że były one bezpośrednio zaangażowane we wdrażanie, realizację i zapewnienie trwałości reform. W tabeli 1. przedstawiono 37 szkół na trzech różnych poziomach obowiązkowego kształcenia wchodzących w skład czterech okręgów szkolnych, które zostały wybrane do udziału w badaniu. Wybrani czterej dyrektorzy okręgów szkolnych mieli ogromne doświadczenie w zakresie przywództwa na różnych poziomach kształcenia, jak przedstawiono $w$ tabeli 2. 
Tabela 1. Liczba szkół wchodzących w skład czterech

okręgów szkolnych uczestniczących w badaniu

\begin{tabular}{|c|c|c|}
\hline $\begin{array}{l}\text { ODDZIAtY PRZEDSZKOLNE* } \\
\text { (uczniowie w wieku 3-6 lat) }\end{array}$ & & 28 \\
\hline $\begin{array}{l}\text { SZKOŁY PODSTAWOWE } \\
\text { (uczniowie w wieku 6-11 lat) }\end{array}$ & & 28 \\
\hline \multirow{2}{*}{$\begin{array}{l}\text { GIMNAZJA } \\
\text { (uczniowie w wieku 11-16 lat) }\end{array}$} & Chłopcy & 3 \\
\hline & Dziewczęta & 1 \\
\hline \multirow{2}{*}{$\begin{array}{l}\text { GIMNAZJA I SZKOŁY PONADGIMNAZJALNE MIESZCZĄCE SIĘ } \\
\text { W TYM SAMYM BUDYNKU } \\
\text { (ucZniowie w wieku 11-16 lat) }\end{array}$} & Chłopcy & 1 \\
\hline & Dziewczęta & 3 \\
\hline \multirow{2}{*}{$\begin{array}{l}\text { SZKOŁY PONADGIMNAZJALNE (ANG. AREA SECONDARY SCHOOLS) } \\
\text { (uczniowie w wieku 11-16 lat) }\end{array}$} & Chłopcy & 2 \\
\hline & Dziewczęta & 2 \\
\hline
\end{tabular}

" Oddział przedszkolny znajduje się w każdej szkole podstawowej.

Źródło: opracowanie własne.

Tabela 2. Dyrektorzy okręgów szkolnych objętych badaniem

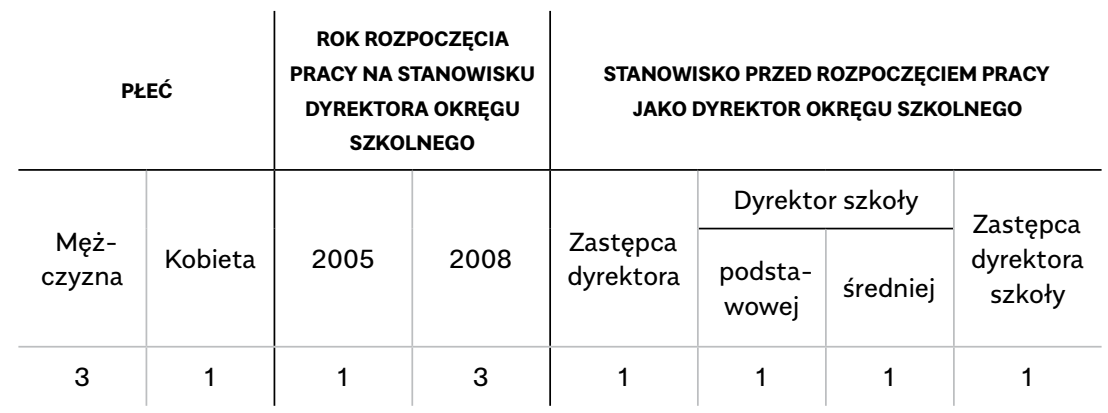

Źródło: opracowanie własne.

Stosunek mężczyzn do kobiet wynoszący 3:1 w przypadku dyrektorów, z którymi przeprowadzono wywiady, stanowił odzwierciedlenie zestawienia przedstawionego $w$ tabeli 2. Doświadczenie dyrektorów w zakresie kierowania szkołami wynosiło od 2 miesięcy do 12 lat. Większość z nich posiada dyplom z administracji i zarządzania 
instytucjami oświatowymi (wymagany przy ubieganiu się o pracę na stanowisku dyrektora szkoły od 1995 r.), niektórzy z nich posiadają tytuł magistra, a kilkoro $z$ nich jest $w$ trakcie studiów magisterskich. Jedna osoba ma doktorat, a kilkoro $z$ nich realizuje studia doktoranckie. Wszyscy dyrektorzy szkół, z którymi przeprowadzono wywiady, byli doświadczonymi nauczycielami, którzy nauczali w szkołach podstawowych lub średnich lub w szkołach na obu poziomach. Ich doświadczenie w zakresie nauczania wynosiło od 12 do 20 lat. Wszyscy dyrektorzy szkół, z którymi przeprowadzono wywiady, pięli się po szczeblach kariery w hierarchicznej strukturze zgodnie z tradycyjnym modelem awansu w służbie cywilnej opartym na stażu pracy. Oznacza to, że najpierw pracowali jako nauczyciele, następnie zastępcy dyrektora wydziału, dyrektorzy wydziału, aż doszli do stanowiska dyrektora szkoły.

Kryteria doboru próby nauczycieli, z którymi przeprowadzono wywiady, zasadzały się na czynnikach, takich jak płeć i doświadczenie pedagogiczne. W doborze kohorty starano się zapewnić równowagę płci i zróżnicowaną próbę początkujących i doświadczonych nauczycieli, gdyż oba te czynniki mogły zapewnić pełny i dystynktywny zbiór danych. Dzięki pomocy dyrektorów szkół, którzy zapewnili listę nauczycieli i inne informacje, zidentyfikowaliśmy kohorty nauczycieli z każdego okręgu szkolnego, z którymi mieliśmy przeprowadzić wywiady, z zastosowaniem wyżej wymienionych kryteriów. W rezultacie, zakres doświadczenia zawodowego nauczycieli, z którymi przeprowadzono wywiady, wynosił od 2 do 40 lat, a ich kwalifikacje zawodowe wahały się od świadectwa ukończenia kolegium nauczycielskiego do dyplomu ukończenia studiów drugiego stopnia.

\section{Zbieranie danych}

Bryman (2004) argumentuje, że częściowo ustrukturyzowane wywiady pozwalają na elastyczność i często są postrzegane jako wywiady pogłębione lub jakościowe. Wybraliśmy częściowo ustrukturyzowane wywiady, ponieważ umożliwiają one „respondentom przedstawienie własnych sposobów definiowania świata" (Cohen, Manion, Morrison, 2003, s. 146-147). Częściowo ustrukturyzowane wywiady w formie bezpośredniej rozmowy (oprócz obserwacji i przeglądu dokumentów urzędowych) okazały się sposobem na zbieranie danych do badania. Wywiady były nagrywane. Dzięki zapisowi na taśmie odpowiedzi re- 
spondentów są mniej ulotne (Denscombe, 2007) i możliwe jest sporządzenie ich transkrypcji. Co więcej, transkrypcja wywiadów zmniejsza wszelki możliwy wpływ z góry przyjętych osądów przeprowadzającego wywiad oraz umożliwia respondentom autoryzację i potwierdzenie informacji przekazanych podczas wywiadu. Wywiady zapewniły szczegółowe dane na temat skuteczności reformy, powiązanych zagadnień i wyzwań, ponieważ relacje respondentów to „... rzeczywistość" (Cuff, Sharrock, Francis, 1990, s. 185).

Wywiady z osobami odpowiedzialnymi za podejmowanie decyzji zawsze miały miejsce w godzinach wieczornych, ze względu na obowiązki służbowe i urzędowe respondentów. Nie było trudności z organizacją wywiadów z dyrektorami okręgów szkolnych i dyrektorami szkół, ponieważ zgodzili się oni na to, by sesje miały miejsce głównie w godzinach popołudniowych. Wywiady z nauczycielami zostały zaprojektowane we współpracy z dyrektorami szkół.

Tak dalece jak to możliwe, przyjąłem podrzędną rolę, aby uzyskane informacje były wynikiem końcowym niezmanipulowanego modelu. Pytania do wywiadu, opracowane w ramach badania, zostały skonstruowane w taki sposób, by zmotywować respondentów do udzielenia odpowiedzi. W związku z tym pytania nie były zbyt szczegółowe, aby nie zachęcać respondentów do przyjęcia taktyki unikania odpowiedzi na nie. Ponadto pytania zostały skonstruowane w jasny sposób i były otwarte (Cohen, Manion, 1997).

Oprócz tego przeprowadzono dwanaście sesji obserwacyjnych comiesięcznych spotkań Rady Dyrektorów Szkół w Okręgach Szkolnych. Uczestniczyłem w tych spotkaniach w charakterze obserwatora bez praw uczestnika, gdzie miałem możliwość obserwować dyrektorów okręgów szkolnych i dyrektorów szkół w innym środowisku pracy i odgrywających inną rolę - członków zespołu, który współpracował na rzecz danego okręgu szkolnego. Uczestnicy czuli się swobodnie w mojej obecności, która podczas spotkań w charakterze obserwatora bez praw uczestnika nie stanowiła dla nich problemu.

\section{Analiza danych}

Na etapie analizy danych pozyskanych podczas wywiadów podjęto wiele wstępnych kroków prowadzących do procesu transkrypcji. Kroki te były niezbędne, aby utworzyć system klasyfikacji zarejestrowanych danych. System klasyfikacji przedstawiono w tabeli 3. 
Tabela 3. Klasyfikacja danych uzyskanych od respondentów

\begin{tabular}{|c|c|}
\hline $\begin{array}{c}\text { ZESTAW } \\
\text { A }\end{array}$ & Osoby odpowiedzialne za tworzenie polityki \\
\hline $\begin{array}{l}\text { ZESTAW } \\
\text { B }\end{array}$ & Dyrektorzy okręgów szkolnych nr 1, 5, 6 i 7 \\
\hline \multirow{2}{*}{$\begin{array}{l}\text { ZESTAW } \\
\text { C }\end{array}$} & Dyrektorzy szkół podstawowych w okręgu szkolnym nr 1, 5, 6 i 7 \\
\hline & $\begin{array}{l}\text { Dyrektorzy szkół ponadgimnazjalnych i gimnazjów } \\
\qquad \text { w okręgu szkolnym } \mathrm{nr} 1,5,6 \text { i } 7\end{array}$ \\
\hline \multirow{2}{*}{$\begin{array}{c}\text { ZESTAW } \\
\text { D }\end{array}$} & Nauczyciele szkół podstawowych w okręgu szkolnym nr 1, 5, 6 i 7 \\
\hline & $\begin{array}{l}\text { Nauczyciele szkół ponadgimnazjalnych i gimnazjów } \\
\text { w okręgu szkolnym nr 1, 5, } 6 \text { i } 7\end{array}$ \\
\hline
\end{tabular}

Źródło: opracowanie własne.

Do analizy wybranych danych z wywiadów zastosowano metodę określoną przez Thomasa (2011, s. 198) jako analiza sieciowa. Podkreślił on użyteczność takiej analizy dla badaczy, koncentrujących się na głównym zagadnieniu, z którym powiązane są liczne kwestie poboczne. Metoda ta podkreśla również zależność pomiędzy zagadnieniami. W konsekwencji, zagadnienia o podobnej problematyce zostały sklasyfikowane $w$ ramach kategorii tematycznych.

Dane na podstawie notatek $z$ obserwacji terenowych zostały umieszczone w folderach "Okręgi szkolne" (odpowiednio okręg szkolny nr jeden, cztery, pięć, sześć i siedem) oraz w czterech podkatalogach pn. "Klaster do każdego folderu” pn. „Okręg szkolny”, jak przedstawiono $w$ tabeli 4. Taka procedura klasyfikacji miała na celu zwiększenie przystępności i czytelności dystrybucji danych, ułatwienie analizy oraz zapewnienie pełnego obrazu i gruntownego zrozumienia danych obserwacyjnych ze wszystkich spotkań Rady Dyrektorów Szkół w czterech Okręgach Szkolnych (Creswell, 2009; Miles, Huberman, 1994). 
Tabela 4. Dane obserwacyjne - Okręg szkolny nr 1, 5, 6 i 7

\begin{tabular}{c|c}
$\begin{array}{c}\text { KLASTER } \\
\text { A }\end{array}$ & Dane demograficzne \\
\hline $\begin{array}{c}\text { KLASTER } \\
\text { B }\end{array}$ & $\begin{array}{c}\text { Informacje na temat tego, w jaki sposób uczestnicy } \\
\text { wchodzili w interakcje podczas spotkań }\end{array}$ \\
\hline KLASTER \\
C
\end{tabular}

Źródło: opracowanie własne.

\section{Wyniki i ich omówienie}

Wyniki badania przedstawione w tej części podkreślają szersze implikacje, jakie reformy, mające główne znaczenie dla nowego modelu współpracy w kontekście tworzenia polityki, mogłyby mieć dla przywództwa edukacyjnego i zarządzania instytucjami oświaty. W badaniu podkreślono spostrzeżenia respondentów dotyczące następujących pięciu głównych zagadnień: skutecznych umiejętności przywódczych, które mogą być pomocne w zapewnieniu jakości nauczania i uczenia się oraz wspólnych wysiłków; sprawstwa zmian; budowania zaufania; wykazywania się odwagą przywódczą; bycia wizjonerem i posiadania zdolności do kształtowania i kierowania innymi w ramach podtrzymywania relacji w szkole i pomiędzy szkołami. Ustalenia wskazywały także na style przywództwa, szczególnie przywództwo kolegialne i zorientowane na personel.

Zebrane dane uwzględniały również spostrzeżenia respondentów dotyczące kwestii godzenia napięć pomiędzy centralizacją a decentralizacją, co okazało się kontrowersyjnym zagadnieniem. Dyrektorzy szkół i nauczyciele uważali, że dyrekcje powinny więcej ingerować w tym obszarze i stworzyć bardziej demokratyczny system w okręgach szkolnych/na poziomie szkół. Z drugiej strony, osoby odpowiedzialne za tworzenie polityki twierdziły, że nie była to kwestia przejścia od systemu scentralizowanego do zdecentralizowanego, lecz tego, że na Malcie ist- 
niała konieczność znalezienia równowagi pomiędzy scentralizowanymi i zdecentralizowanymi strukturami zarządzania. Ustalenia potwierdziły również występowanie napięć wokół rozproszonego przywództwa oraz, że potrzebni są przywódcy transformacji i kultura, która promuje i wspiera rozwój zawodowy pracowników. Liderzy, z którymi przeprowadzono wywiady, potwierdzili istnienie potrzeby zapewnienia przestrzeni rozwoju dla nauczycieli. Zagadnienia dodatkowe dotyczące charakterystyki przywództwa w kontekście i znaczenia tego, by liderzy koncentrowali się na wymiarze ludzkim, okazały się bardzo istotne, zwłaszcza dla nauczycieli, z którymi przeprowadzono wywiady. Problemy i wyzwania, wobec jakich staje zróżnicowana grupa respondentów, były ewidentne i wydawały się dotyczyć czterech głównych zagadnień: motywowania innych; nadmiaru obowiązków zarządczych; mikro-polityki okręgów szkolnych, oraz dużej roli, jaką związki zawodowe odgrywają w państwie.

W niniejszym artykule przeprowadzono analizę następujących pięciu zagadnień: przywódcy będący wizjonerami, utrzymywanie współpracy, umiejętności przywódcze, ludzki wymiar liderów oraz wyzwania i obawy związane z przywództwem. Zagadnienia te zostały omówione w odniesieniu do literatury i postawionego pytania badawczego.

Wielu respondentów (osoby odpowiedzialne za tworzenie polityki i nauczyciele) uznaje, że wybitni i skuteczni dyrektorzy okręgów szkolnych i dyrektorzy szkół odgrywają kluczową rolę we wprowadzaniu usprawnień w szkołach. Jeden z dyrektorów szkoły podstawowej stwierdził:

"Lider musi służyć jako wzór do naśladowania dla wszystkich członków instytucji oraz umożliwić im realizację wspólnej wizji szkoły lub okręgu szkolnego. Jeśli jest dobrym liderem, członkowie personelu pójdą za nim z powodu jego wpływu. Lider będzie pomagać innym rozwijać się poprzez dawanie dobrego przykładu i wyznaczanie odpowiednich standardów".

(Dyrektor szkoły nr 1, szkoła podstawowa, okręg szkolny nr 1)

Powyższa obserwacja znajduje potwierdzenie w badaniach przeprowadzonych między innymi przez Bennett, Cartwright i Crawford (2006) oraz Dean (2007, za Rosenholtz, 1989). Dyrektorzy okręgów szkolnych i dyrektorzy szkół odgrywają kluczową i ważną rolę w tworzeniu wizji wysokiej jakości edukacji dla każdego ucznia oraz we wdra- 
żaniu i wspieraniu środowiska uczenia się, która jest opracowywana i wyznawana przez kluczowych interesariuszy. Stąd jednym z następstw przywództwa edukacyjnego wynikającym z formy współpracy określonej w ustawie (Laws of Malta, 2006) jest to, że dyrektorzy okręgów szkolnych i dyrektorzy szkół muszą koncentrować się na budowaniu kultury kolegialności i współpracy pomiędzy uczniami, edukatorami i interesariuszami. Ponadto niektórzy respondenci postulowali odejście od ducha izolacji, który otacza działania praktyków w szkołach maltańskich, na rzecz współpracy. Jedna z osób odpowiedzialnych za tworzenie polityki powiedziała:

„Współpraca ma kluczowe znaczenie dla ustawy o (zmianie ustawy) o edukacji [Education (Amendment) Act, 2006]. Przywództwo kolegialne będące naturalnym skutkiem współpracy charakteryzuje się współdzielonym podejmowaniem decyzji. Badania, a nawet doświadczenia wykazały, że taki styl przywództwa promuje pracę zespołową i motywuje innych dzięki uczestnictwu i uznawaniu wartości każdej osoby. Nasze wyobrażenia na temat przywództwa muszą ulec zmianie, jeśli mamy osiągnąć cel, jakim jest transformacja maltańskiego systemu edukacji i dostosowanie go do wymogów XXI wieku. Musimy wykorzystać pełny potencjał przywództwa".

(Osoba odpowiedzialna za tworzenie polityki nr 1)

Jednak musimy być ostrożni i postępować z rozwagą, zwłaszcza biorąc pod uwagę to, że próba ustalenia koncepcji współpracy jako zasadniczej kwestii, pozostaje podejściem „złożonym i kwestionowanym" (Morrison i Arthur, 2013, s. 179). Crowther, Hann i Andrews (2002) oraz Reeves (2010) twierdzą, że członkowie kierownictwa szkół muszą motywować swoich pracowników, tak by została zachowana wizja instytucji, którą kierują, co z kolei stanowi pewien rodzaj wyzwania. Grupy muszą współpracować ze sobą w celu określenia swoich mocnych stron, opierając się na wiedzy i doświadczeniu, aby w rezultacie przejść od indywidualnej autonomii do zbiorowej autonomii i odpowiedzialności, jak przedstawiono w "teorii aktywności” (ang. activity theory) (Engeström, 1988, cyt. przez Holt, Morris, 1993). Oczywiście, działania grup muszą być kształtujące i rozwojowe, co umożliwi ich członkom zarówno rozwijanie mocnych stron, jak i eliminację słabości. Ponadto 
wszyscy musimy być skoncentrowani, ponieważ pracując nad realizacją reformy, stosunkowo łatwo jest stracić z oczu jej główny cel, jakim jest podniesienie jakości edukacji szkolnej dla zapewenia warunków, w których wszystkie dzieci odniosą sukces. Kolejna osoba odpowiedzialna za tworzenie polityki powiedziała:

"Oczekuję, że wszyscy liderzy edukacyjni będą promotorami zmian. Dyrektorzy okręgów szkolnych i dyrektorzy szkół muszą być gotowi na nieszablonowe myślenie, kwestionowanie tradycyjnego systemu, motywowanie innych i dawanie przykładu, by realizowane reformy okazały się trwałe. Muszą oni być nastawieni na działanie i charakteryzować się pozytywną postawą [nacisk położony przez respondenta]. Oczekuję, że liderzy ci wykażą się wieloma umiejętnościami i będą umieli utrzymać kulturę zarządzania zmianami".

(Osoba odpowiedzialna za tworzenie polityki nr 2)

Takie przywództwo wymaga przywódców transformacji. Obecność przywódców transformacji jest kolejną implikacją wynikającą z modelu współpracy określonego w ustawie (Laws of Malta, 2006). W rezultacie, dyrektorzy okręgów szkolnych i dyrektorzy szkół, liderzy i kierownicy państwowych okręgów szkolnych i szkół, muszą sobie radzić i rozumieć zarówno zagadnienia praktyczne, jak i podstawowe konsekwencje kultury zmiany, wobec jakich stają edukatorzy, którymi kierują. Dla wielu praktyków szkolnych, głównym powodem do obaw, którym należy się zająć, jest przejście od modelu narzucania woli do współpracy i uczestnictwa, co implikuje, że ludzie będą musieli się zmienić. Jak przedstawiono w literaturze (Fullan, 2007; Hadfield, Chapman, 2009), wielu ludzi może mieć trudności z proszeniem o pomoc. Jedna z nauczycielek pracujących w szkole podstawowej stwierdziła:

"Wydaje się, że nadal walczymy o terytorium, zasoby i kompetencje. Dyrektorzy szkół muszą poczynić więcej wysiłków, aby wprowadzić kulturę współpracy i kolegialności. Poważniejsza refleksja i planowanie będą wstępem do stanowczego zaangażowania w budowanie i wzmacnianie, w płaszczyźnie poziomej i pionowej, kultury przywództwa kolegialnego i rozproszonego". (Nauczyciel nr 10, szkoła podstawowa, okręg szkolny nr 6) 
Zdając sobie sprawę z faktu, że zmiana będzie stwarzać trudności, jestem zdania, że równie ważne jest, aby zapewnić, że problemy związane ze zmianami będą rozwiązywane. Zrozumienie i rozwiązywanie problemów, jak argumentuje Fullan (1995) będzie pomocne w znalezieniu rozwiązań i pomoże odnieść sukces. Tylko wówczas gdy dyrektorzy okręgów szkolnych i szkół oraz liderzy edukacyjni będą w stanie w pełni zrozumieć znaczenie budowania kultury współpracy w szkole, będą oni mogli znaleźć sposoby zaangażowania się w życie szkoły jako społeczności uczenia się, co zapewni przestrzeń do dyskusji. $Z$ tego wynika, że maltańscy liderzy edukacyjni muszą wprowadzić zmiany w zakresie kultury, a to oznacza, że muszą przyczynić się do zmiany postaw, norm, umiejętności i postrzegania współpracy, aby doprowadzić do przekształcenia obecnej formy współpracy, tam gdzie jest ona nieformalnie realizowana, i promować nowy sposób pracy w zespole (Bezzina, Calleja, 2017; Calleja, Bezzina, 2017).

Ponadto dyrektorzy maltańskich okręgów szkolnych i szkół muszą mieć na względzie nie tylko swoje zalety, lecz także muszą być świadomi i muszą akceptować swoje słabości. Dlatego dyrektorzy okręgów szkolnych i szkół, a nawet liderzy edukacyjni muszą odejść od przyjętego założenia, że odgrywają oni najważniejszą rolę w okręgu szkolnym, w szkole lub w klasie. Przyjęcie takiego podejścia sprawi, że nie będą oni mieć problemu z przekazywaniem obowiązków innym, którzy okażą się być bardziej kompetentni w określonych dziedzinach. Kiedy kierownictwo szkół koncentruje się na budowaniu silnych relacji kolegialnych wśród członków personelu i prowadzi ich w kierunku pracy w zespołach, jak uważa Chapman (2005, s. 150), wypracują oni „profesjonalne społeczności uczenia się, które promują generowanie i dzielenie się wiedzą przez wszystkich". Zapewnią oni potwierdzenie profesjonalnego wymiaru swojego przywództwa. Jednakże przy podziale obowiązków i promowaniu rozproszonego przywództwa należy działać ostrożnie, ponieważ może się ono przerodzić w swego rodzaju mikro politykę pomiędzy liderami a ich pracownikami na poziomie okręgu szkolnego lub szkoły (Law, 2010), szczególnie jeżeli liderzy starają się rozdzielić obowiązki, lecz jednocześnie pragną zachować władzę absolutną.

Dane wskazują na to, że reformy będą również stanowić wyzwanie i będą powodem do obaw dla dyrektorów okręgów szkolnych i kierownictwa szkół. Dowody wskazują na to, że z powodu przeciążenia obowiązkami niezwiązanymi z nauczaniem dyrektorzy szkół i nauczyciele 
doświadczają wypalenia zawodowego. W rezultacie ma to wpływ na ich obowiązki w szkole i w klasie oraz sprawia, że czują się zniechęceni i brak im motywacji. Podobne obserwacje poczynili również Fullan (1995) i Hargreaves (2004). Dyrektorzy szkół uważają, że czasami muszą oni podejmować wybory niepożądane dla szkoły i nauczycieli, co ma wpływ na ogólne wyniki pracy szkoły. Jeden z dyrektorów zespołu szkół gimnazjalnych i średnich, który wydawał się wyrażać opinię niemal wszystkich dyrektorów szkół w okręgu szkolnym nr 1, stwierdził, że:

„Jesteśmy zasypywani e-mailami, okólnikami i zadaniami przez różnych kierowników i dyrektorów oraz prośbami o udzielenie informacji, które zostały już przekazane do innych wydziałów Dyrekcji ds. Oświaty w takim stopniu, że nie mamy już czasu na pracę w charakterze mentorów naszych nauczycieli".

(Dyrektor szkoły nr 1, Zespół szkół gimnazjalnych i średnich, okręg szkolny nr 5)

Dyrektorzy szkół uważają, że decentralizacja ról przywódczych jest w najlepszym razie grą pozorów. Dyrektorzy szkół twierdzą, że mają ograniczoną władzę, ponieważ muszą prosić dyrektora okręgu szkolnego o zatwierdzenie wszystkich działań. Podzielają oni obawy, że ich przełożeni żyją w wieży z kości słoniowej. Dyrektorzy szkół również odnieśli się do kwestii związanych z Radą Liderów Edukacyjnych (ang. Education Leaders Council - ELC). Dyrektorzy szkół uważają, że działanie ELC tylko wzmacnia przekonanie, że decentralizacja jest w najlepszym razie grą pozorów. Szczególnie ma to miejsce, gdy bardzo często uczestniczą w spotkaniach Rady Dyrektorów, których agenda jest opracowywana przez dyrektora okręgu szkolnego. Jeśli podczas spotkań Rady Dyrektorów dyrektorzy mają możliwość przedstawienia problemów, z jakimi borykają się szkoły, mogą oni zapoznać się z pomysłami i rozwiązaniami stosowanymi przez kolegów. Aktualna sytuacja wskazuje na to, że rzadko mają taką okazję. Jeden z niezadowolonych dyrektorów szkoły podstawowej stwierdził:

„Dyrektorzy szkół czują się zagrożeni tym, co odbieramy jako narzucanie nam woli przez dyrektorów okręgów szkolnych. Powinien zostać zdefiniowany dokładniejszy podział ról. Dyrektorzy okręgów szkolnych powinni angażować dyrektorów szkół w opracowywanie agendy spotkań Rady Dyrektorów, 
a nie przychodzić na spotkanie z narzuconym z góry programem, który prawdopodobnie zasadza się na decyzjach podjętych podczas ich comiesięcznych spotkań z dyrektorem generalnym i innymi dyrektorami".

(Dyrektor szkoły nr 7, szkoła podstawowa, okręg szkolny nr 1)

Powyższa opinia potwierdza obawy wyrażone w ramach innego lokalnego badania (Mifsuda, 2015), gdzie stwierdzono, że chociaż możliwe jest odniesienie korzyści ze współpracy sieciowej, dyrektorzy zauważyli, że ich autonomia została naruszona i że są ofiarami tego, co Hargreaves (1994) trafnie opisał jako "naciągana kolegialność". Chociaż występują ruchy skierowane na modele współpracy partnerskiej, istnieją wątpliwości co do rzeczywistego udziału pracowników w podejmowaniu decyzji.

Nauczyciele są zdania, że dyrektorzy szkół pokazują swoją prawdziwą wartość w sposobie, w jaki zachowują się w decydujących momentach i przy ważnych okazjach, gdy mają do czynienia z ludźmi. Zatem, jak twierdzi Hoerr (2005), przywództwo polega na budowaniu relacji. I nie chodzi tu tylko o przedstawienie wizji i uzyskanie rezultatów, lecz także o traktowanie ludzi z szacunkiem, przy zachowaniu przyzwoitości i człowieczeństwa. Dyrektor gimnazjum i szkoły średniej stwierdziła:

„Przy opracowywaniu planów pracy szkoły i realizacji polityk musimy zawsze wykazać naszym pracownikom, że przede wszystkim mamy na względzie ich dobro. Prawdą jest, że ponosimy odpowiedzialność wobec rządu, który jest naszym pracodawcą, i musimy realizować odgórne zalecenia, ale zawsze pamiętamy o naszych pracownikach dydaktycznych i ich potrzebach. Musimy im udowadniać, że naszym zadaniem jest praca z nimi [nacisk położony przez respondentkę]".

(Dyrektor szkoły nr 2, zespół szkół gimnazjalnych i średnich, okręg szkolny nr 7)

Procesy i procedury mogą świadczyć o realizacji obowiązków kierowniczych, ale postępowanie z ludźmi ujawnia prawdę o posiadanych cechach i umiejętnościach przywódczych. Dyrektorzy szkół powinni postrzegać przywództwo jako rezultat relacji międzyludzkich, opartych na zaufaniu i otwartości, i z takim stwierdzeniem zgadzają się Bush (2011), Greenfield (1991) i Hoerr (2005). 


\section{Wnioski}

Analiza zebranych danych dotyczących pytania badawczego, jakim jest przywództwo edukacyjne i zarządzanie instytucjami oświaty, przyniosła wiele interesujących wniosków mających istotne znaczenie dla implikacji, jakie nowo zatwierdzony sposób współpracy w sektorze edukacji będzie mieć dla przywództwa edukacyjnego i zarządzania oświatą.

Dyrektorzy okręgów szkolnych i szkół muszą mieć odpowiednie umiejętności, aby móc wspierać i utrzymywać praktyki współpracy i kolegialności, jakich znaczenie podkreślono w nowych reformach i politykach. Muszą oni budować poczucie zaufania wśród pracowników, dzięki któremu będą oni w stanie kształtować i kierować innymi. Odwaga i wizjonerstwo związane z przywództwem to bardzo ważne umiejętności, jakie dyrektorzy okręgów szkolnych i szkół muszą posiadać i które są uznawane za mające znaczenie dla współpracy na poziomie szkoły, a także $z$ instytucjami zewnętrznymi.

Ta część badania wykazała, że przywództwo kolegialne musi zasadzać się na szacunku, zgodności, zrozumieniu, współpracy i empatii oraz że liderzy muszą włożyć więcej wysiłku w budowanie kultury zespołu i kolegialności, co będzie pomocne w utrzymaniu ducha współpracy. Transformacyjny styl przywództwa jest uważany za korzystny, ponieważ może pomóc maltańskim liderom edukacyjnym stawić czoła wyzwaniom związanym z obecnymi i przyszłymi reformami, szczególnie w zmianie nastawienia pracowników, co może być pomocne w praktycznej realizacji reform.

Pogodzenie stanu rzeczy z rzeczywistymi potrzebami i przekucie retoryki w rzeczywistość okazuje się dość trudne, ponieważ ma to negatywny wpływ na działania przywódcze dyrektorów okręgów szkolnych i szkół. Dyrektorzy czują się przeciążeni pracą administracyjną związaną z infrastrukturą i prozaicznymi potrzebami szkoły. Liderzy edukacyjni nie są w stanie skupić się na pełnieniu i rozwijaniu ról przywódczych, w ramach których mogliby służyć jako mentorzy i w ten sposób wspierać swoich pracowników przy jednoczesnym zapewnieniu rozwoju szkoły, która realizuje założenia ustawy (Laws of Malta, 2006).

Dyrektorzy szkół twierdzą, że mają ograniczoną władzę, ponieważ muszą prosić dyrektora okręgu szkolnego o zatwierdzenie wszystkich działań. Wydaje się, że za retoryką decentralizacji kryje się scentralizowane i tradycyjnie hierarchiczne podejście do pracy. Takie odgórne zarządzanie uniemożliwia realizację współpracy, która, aby była owocna, 
wymaga współdziałania na poziomie szkoły i współpracy szkoły z innymi instytucjami. To potwierdza obawy wyrażone $w$ ramach niedawnych badań lokalnych (Cutajar, 2015; Debono, 2014), w których podkreślono, że dyrektorzy nadal są zbyt mocno zaangażowani w realizację obowiązków administracyjnych i wykonywanie prac zleconych, a nie w realizację tego, co Hartley (2007), określił jako „zbiorowe wysiłki”.

Wielu dyrektorów okręgów szkolnych, dyrektorów szkół, a nawet urzędników pracujących w instytucjach oświaty wydaje się być mało wyrozumiałymi, gdy wydają polecenia lub przekazują wytyczne, zwłaszcza gdy w ich postawie dominuje władczość, brak zrozumienia i empatii. Dyrektorzy okręgów szkolnych i dyrektorzy szkół wydają się nie mieć wrażliwości w stosunku do osób odpowiedzialnych za tworzenie fizycznego środowiska szkół.

Niniejsze badanie może służyć jako podstawa do dyskusji i przyczynek do debaty. Dyskusja powinna skupić się na sposobie przejścia w kierunku zrównoważonego systemu, który pozwala na realizację określonych scentralizowanych praktyk i jednocześnie pozostawia odpowiednią swobodę dla działań sieci i szkół, które się różnią. Określenie tego, co jest właściwe, jest kluczową kwestią, która umożliwia okręgom szkolnym i szkołom wprowadzenie pożądanych usprawnień, zapewniając spełnienie wymagań edukacji XXI wieku.

Podsumowując, przedstawię główne punkty, które moim zdaniem pomogą nam zmienić sposób postrzegania i zarządzania wspólnymi działaniami zarówno na poziomie makro, jak i mikro. Powinno to pomóc czytelnikowi docenić fakt, że podczas gdy koncepcje przedstawione w dokumentach określających politykę promują bliższą współpracę i modele kolegialne, to rzeczywistość, co potwierdza niniejsze badanie na małą skalę, pokazuje, że - jak dowodzi Morrison i Arthur (2013) - na wielu poziomach obecnie próby pozostają „złożonym i kwestionowanym" podejściem.

$\rightarrow$ Przechodzenie od wysoce scentralizowanego i nakazowego modelu podejmowania decyzji do bardziej demokratycznego i kolegialnego jest powolnym i żmudnym procesem, który wymaga zaangażowania i poświęceń zarówno ze strony jednostek, jak i grup.

$\rightarrow$ Postulowany model demokratyczny zasadzający się na współpracy wymaga zmian w sposobie myślenia i działania na poziomie intelektualnym i rozwojowym. Wiąże się to z potrzebą, aby 
edukatorzy na wszystkich poziomach dokonali rewizji sposobu, $w$ jaki angażują się $w$ relacje $z$ innymi.

$\rightarrow$ Przywództwo kolegialne musi zasadzać się na szacunku, zgodności, zrozumieniu, współpracy i empatii.

$\rightarrow$ Aby te wartości mogły zostać przekształcone w zachowania, przywódcy muszą być gotowi na zmiany i poświęcenia, tak by członkowie społeczności szkolnej nauczyli się angażować we wspólne działania.

$\rightarrow$ Badanie wykazało, że chociaż postulujemy kolegialność, mamy tendencję do niedostrzegania znaczenia faktu, iż w centrum naszego dyskursu powinien znajdować się człowiek.

$\rightarrow$ Musimy zapewnić, że dyrektorzy szkół mają zagwarantowane wsparcie, ponieważ wielu z nich przejawia oznaki wypalenia zawodowego.

$\rightarrow$ Przekazanie władzy i przejście od władzy nad innymi do wspólnego podejmowania decyzji i wspólnych działań wymaga zaangażowania na poziomie indywidualnym i zbiorowym.

Powyższe punkty powinny pomóc nam zrozumieć nie tylko kontekst, w jakim działamy, lecz także wartości, na których zasadza się przywództwo zorientowane na współpracę, oraz zdać sobie sprawę z tego, że podróż, w którą wyruszyliśmy, będzie długa i uciążliwa. Jednak przyświecają nam słowa amerykańskiego poety Roberta Frosta:

Zdarzyło mi się niegdyś ujrzeć w lesie rano

Dwie drogi: pojechałem tą mniej uczęszczaną,

Reszta wzięła się z tego, że to ją wybrałem.

Droga nie wybrana (tłum. St. Barańczak)

Będziemy kontynuować nasze wysiłki skierowane na realizację praktyk zasadzających się na współpracy, które mają wpływ na życie poszczególnych osób. Tylko w taki sposób możemy upodmiotowić ludzi, aby dali z siebie to, co najlepsze, aby podtrzymali lub na nowo rozpalili w sobie zamiłowanie do edukacji. 


\section{Bibliografia}

$\rightarrow$ Bates, R. (2007), Australian Teacher Education in the New Millennium [w:] M. Valencic Zuljan, J. Vogrinc (Eds.), Professional Inductions of Teachers in Europe and Elsewhere, s. 19-31, Ljublijana: University of Ljubljana.

$\rightarrow$ Bennett, N., Cartwright, M., Crawford, M. (Eds.) (2006), Effective Educational Leadership, London: Sage.

$\rightarrow$ Bezzina, C. (2012), Contending with Governance and Leadership as Critical Issues within the Maltese Education System, The Open Education Journal, No. 5, 23-31.

$\rightarrow$ Bezzina, C. (2010), School Improvement through school networks: The Malta Experience [w:] F. Fabri, C. Bezzina (Eds.), School Improvement through School Networks: The Malta Experience, s. 15-23, Malta: MEEF.

$\rightarrow$ Bezzina, C. (2006), From Centralisation to Decentralisation: The real challenges facing Educational Reforms in Malta, Journal of Maltese Education Research, Vol. 4(1), 80-95.

$\rightarrow$ Bezzina, C. (2005), Networks for Nurturing Professional Learning Communities, Keynote address at the EXCEL Network Conference, Learning through Peer Collaboration, Mgarr Primary School, Malta, 17th-18th May.

$\rightarrow$ Bezzina, C., Calleja, J. (2017), Leading Change in a Time of Unrest, The Sunday Times of Malta, 5th March 2017.

$\rightarrow$ Bezzina, C., Cutajar, M. (2013), The Educational Reforms in Malta: The Challenge of Shared Governance, International Studies in Educational Administration, Vol. 41(1), 3-19.

$\rightarrow$ Bezzina, C., Vella, K. (2013), The Leadership Imperative: a journey where people matter, Print It: Malta.

$\rightarrow$ Borg, M., Giordmaina, J. (2012), Towards a Quality Education for All: Every Teacher Counts. The College System in the State School Sector: A study of its impact as perceived by College Principals, members of school senior management teams, and personnel in the various teaching grades, Malta: Malta Union of Teachers. 
$\rightarrow$ Bryman, A. (2004), Social Research Methods, 2nd ed. Oxford: Oxford University Press.

$\rightarrow$ Bush, T. (2011), Theories of Educational Leadership and Management, 4th ed. London: SAGE.

$\rightarrow$ Calleja, J. and Bezzina, C. (2017), Teachers Supporting Teachers, The Sunday Times of Malta, 19th March 2017.

$\rightarrow$ Chapman, C. (2005), Building the leadership capacity for school improvement: a case study [w:] A. Harris, C. Day, M. Hadfield, D. Hopkins, Hargreaves, A. and C. Chapman (Eds.), Effective Leadership for School Improvement, s. 137-153, Reprint. London: RoutledgeFalmer.

$\rightarrow$ Chapman, J., Aspin, D. (2003), Networks of learning: a new construct for educational provision and a new strategy for reform [w:] B. Davies and J. West-Burnham (Eds.), Handbook of Educational Leadership and Management, s. 653-659, London: Pearson and Longman.

$\rightarrow$ Cohen, L., Manion, L. (1997), Research Methods in Education, 4th ed. London: RoutledgeFalmer.

$\rightarrow$ Cohen, L., Manion, L. and Morrison, K. (2003), Research Methods in Education, 5 th ed. London: RoutledgeFalmer.

$\rightarrow$ Creswell, J.W. (2009), Research Design: Qualitative, Quantitative and Mixed Methods Approaches, 3rd ed. Thousand Oaks, CA: SAGE.

$\rightarrow$ Crowther, F., Hann, L., Andrews, D. (2002), Rethinking the Role of the School Principal: Successful School Improvement in the Post-industrial Era, The Practicing Administrator, Australia.

$\rightarrow$ Cuff, E.C., Sharrock, W.W. and Francis, D.W. (1990), Perspectives in Sociology, 3rd ed. London: Routledge.

$\rightarrow$ Cutajar, M. (2015), An analysis of inter-school working in state-maintained colleges in the Maltese Islands. Unpublished PhD thesis presented at the Department of Education, University of Bath.

$\rightarrow$ Datnow, A., Hubbard, L., Melan, H. (2002), Extending Educational Reform - From one school to many, London: RoutledgeFalmer.

$\rightarrow$ Dean, R.D. (2007), Thinking Globally: The National College of School Leadership: A Case Study in Distributed Leadership Development [online], available from www.ucea.org/storage/JRLE/pdf/Vol2_issue 1 [dostęp: 23.02.2008].

$\rightarrow$ Debono, D. (2014), Effective leadership: A model for schools in Malta in the light of recent changes in the educational system, University of Leicester: Unpublished M.Sc. Dissertation.

$\rightarrow$ Denscombe, M. (2007), The Good Research Guide for Small-Scale Social Research Projects, 3rd ed. Maidenhead: Open University Press. 
$\rightarrow$ DuFour, R. (2014), Harnessing the power of PLCS, Educational Leadership, 71(8), 30-35.

$\rightarrow$ Duignan, P., Bezzina, M. (2006), Building a Capacity for Shared Leadership in Schools Teachers as Leaders of Educational Change. Educational Leadership Conference, University of Wollongong, Australia, Available from: https://www. uow.edu.au/content/groups/public/@web/@educ/documents/doc/uow037796. pdf [dostęp: 23.09.2017].

$\rightarrow$ Engeström, Y. (1988), How to do Research on Activity?, The Quarterly Newsletter of the Laboratory of Comparative Human Cognition, 10, 30-31.

$\rightarrow$ Filmer, P., Jenks, C., Seale, C., Walsh, D. (1998), Developments in social theory [w:] C. Seale (Ed.), Researching Society and Culture, s. 23-36, London: SAGE.

$\rightarrow$ Fullan, M. (1995), Change Forces - Probing the depths of educational reform, Reprint. UK: Falmer Press.

$\rightarrow$ Fullan, M. (2007), The new meaning of educational change, 4th ed. Teachers College Press: New York.

$\rightarrow$ Goodwin, A.L., Kosnik, C. (2013), Quality teacher educators = quality teachers? Conceptualizing essential domains of knowledge for those who teach teachers, Teacher Development, 17(3), 334-346.

$\rightarrow$ Greenfield, T. (1991), Re-forming and re-valuing educational administration: whence and when cometh the Phoenix?, Educational Management and Administration, 19(4), 200-217.

$\rightarrow$ Hadfield, M., Chapman, C. (2009), Leading School-based Networks, London: Routledge.

$\rightarrow$ Hargreaves, A. (2004), Inclusive and exclusive educational change: emotional responses of teachers and implications for leadership, School Leadership and Management, 24(2), 8-13.

$\rightarrow$ Hartley, D. (2007), The emergence of distributed leadership in education: why now?, British Journal of Educational Studies, 55 (2), 202-214.

$\rightarrow$ Hoerr, R.T. (2005), The Art of School Leadership, Alexandria VA: ASCD.

$\rightarrow$ Holt, R., Morris, A.W. (1993), Activity Theory and the Analysis of Organizations, Human Organization, 52(1), 97-109.

$\rightarrow$ Hopkins, D., Jackson, D. (2005), Building the Capacity for Leading and Learning [w:] A. Harris, C. Day, D. Hopkins, M. Hadfield, A. Hargreaves, C. Chapman, Effective Leadership for School Improvement, s. 84-104, London: Routledge Falmer.

$\rightarrow$ Laws of Malta (2006), An Act to Amend the Education Act, Cap.327, Valletta: DOI.

$\rightarrow$ Leithwood, K., Hallinger, P. (Eds.) (2002), Second International Handbook of Educational Leadership and Administration, London: Kluwer Academic Publishers. 
$\rightarrow$ Lunenberg, M., Murray, J., Smith, K. and Vanderlinde, R. (2017), Collaborative teacher educator professional development in Europe: different voices, one goal, Professional Development in Education, 43(4), 556-572.

$\rightarrow$ Madalińska-Michalak, J., Niemi, H., Chong, S. (Eds.) (2012), Research, Policy, and Practice in Teacher Education in Europe, Lodz: University of Lodz.

$\rightarrow$ MEYE (2005). For All Children to Succeed: A New Network Organisation for Quality Education in Malta, Floriana: MEYE.

$\rightarrow$ Mifsud, D. (2015), Distribution. Delegation. Empowerment. Direction. Collaboration. Control, Deregulation. Centralization... The presence of a tension between democracy and autocracy within a distributed leadership scenario?, Paper presented at the BELMAS Annual Conference, Democracy: Time for Renewal or Retreat in Educational Leadership, 10th-12th July, Wokefield Park, Reading, UK.

$\rightarrow$ Miles, M.B. and Huberman, M. (1994), Qualitative Data Analysis: An Expanded Sourcebook, 2nd ed. London SAGE.

$\rightarrow$ Ministry of Education, Youth and Employment (2007), Agreement between the Government and the Malta Union of Teachers, Floriana: MEYE.

$\rightarrow$ Morrison, M. and Arthur, L. (2013), Leadership for Inter-service Practice: Collaborative Leadership Lost in Translation? An Exploration, Educational Management, Administration and Leadership, 41(2), 179-198.

$\rightarrow$ Muscat, M. (2017), The Journey into Leadership - Listening to the Educational Leader's Voice in Gozo, Unpublished Master of Arts in Educational Leadership and Management, Faculty of Education, University of Malta.

$\rightarrow$ Patton, M. (2002), Qualitative Evaluation and Research Methods, 3rd ed. London: SAGE.

$\rightarrow$ Reeves, D.B. (2010), Transforming Professional Development into Student Results, Alexandria, Virginia: Association for Supervision and Curriculum Development.

$\rightarrow$ Rose, M. (2010), Reform: To What End?, Educational Leadership, 67(7), 6-11.

$\rightarrow$ Rosenholtz, S. (1989), Teachers Workplace, the Social Organization of Schools, New York: Longman.

$\rightarrow$ Schleicher, A. (2012), Preparing Teachers and Developing School Leaders for the 21st Century: Lessons from around the World, OECD Publishing.

$\rightarrow$ Seale, C. (Ed.) (2000), Researching Society and Culture, London: SAGE.

$\rightarrow$ Strauss, A. and Corbin, J. (1990), Basics of Qualitative Research: Grounded Theory Procedures and Techniques, London: SAGE.

$\rightarrow$ Swaffield, S. (2017), Reframing views, lifitng up voices and ensuring everyone is visible? Editorial, Professional Development in Education, 43(4), 493-496.

$\rightarrow$ Thomas, G. (2011), How to do your research project, London: SAGE. 



\title{
Przywództwo zorientowane na nauczanie. Dylematy wspierające badania nad prak- tyką zawodową nauczycieli w warunkach wysokiej rozliczalności za wyniki
}

\author{
Pete Boyd, Lesley Curtis
}

W niniejszym artykule jako profesor i dyrektor szkoły podejmujemy - ponad powszechnie przyjętymi granicami między szkołą a uniwersytetem - namysł nad miejscem profesjonalnego dociekania nauczycieli jako elementu instruktażowego przywództwa w ich szkołach. W szczególności koncentrujemy się na potencjale profesjonalnego dociekania w erze wysokiej rozliczalności za wyniki, w której neoliberalne ramy polityki wpływają silnie na szkoły, nauczycieli i dyrektorów szkół, szczególnie w Anglii, ale też na arenie międzynarodowej. Nasze rozumienie profesjonalnego dociekania, szereg podejść do systematycznego badania i rozwoju praktyki, które sytuują nauczyciela jako badacza, wywodzi się z prac L. Stenhousea i pojęcia „dociekania jako postawy" M. Cochran-Smith i S. Lytle. Wartość wielu badań prowadzonych przez nauczycieli została w swoim czasie zakwestionowana przez S. Kemmisa, który wskazał, że nauczyciele prowadzący badania biorą pod uwagę jedynie sposoby nauczania, nie odnoszą się zaś krytycznie do edukacji i nie mają odwagi stawiać trudnych pytań dotyczących edukacji. Wskazujemy sześć dylematów i proponujemy je jako praktyczne narzędzie, które nauczyciele i inni przywódcy szkół mogliby wykorzystać w ocenie swoich wzorów w zakresie profesjonalnego namysłu i jego wdrażania.

\section{Słowa kluczowe:}

przywództwo instruktażowe

dociekanie nauczyciela

profesjonalne dociekanie

kolektywne przywództwo

doskonalenie szkoły 


\title{
Instructional leadership. Dilemmas for professional inquiry in high accountability context
}

\author{
Pete Boyd, Lesley Curtis
}

In this paper, as a Professor and a Principal, we reflect across the boundary between school and university on the place of professional inquiry by teachers as an element of instructional leadership in schools. In particular, we focus on the potential of professional inquiry within a high accountability era in which neoliberal policy frameworks strongly influence schools, teachers and head teachers - especially in England but also internationally. Our understanding of professional inquiry, a range of approaches to systematic investigation and development of practice that position the teacher as researcher, is founded on the thinking of L. Stenhouse and the concept of 'inquiry as stance' by M.Cochran-Smith and S. Lytle. However, the value of much teacher inquiry activity has previously been challenged by $\mathrm{S}$. Kemmis, who asks if these teacher researchers are merely evaluating the techniques of schooling rather than adopting a critical stance and daring to ask challenging questions about education. We identify six dilemmas and offer them as a practical tool with which teachers and other school leaders might review their design and implementation of professional inquiry. 


\section{Wstęp}

W niniejszym artykule przedstawiamy krytyczne podejście do potencjału badań nad praktyką zawodową nauczyciela, prowadzonych przez nauczycieli, jako elementu przywództwa zorientowanego na nauczanie (ang. instructional leadership) i zbiorowego w systemie oświaty, który został zdominowany przez politykę rozliczalności za wyniki. Nie przedstawiamy tu łatwych odpowiedzi, lecz opisujemy zestaw dylematów służących jako narzędzie do rozważań na temat wykorzystania badań nad praktyką zawodową nauczyciela prowadzonych przez nauczycieli lub badań przez praktyków jako formy doskonalenia zawodowego, opracowywania programów nauczania i zbiorowego przywództwa. Będąc dyrektorem szkoły i opiekunem badań naukowych, współpracowaliśmy wcześniej jako współautorzy projektu badawczego zasadzającego się na współpracy nauczyciela i badacza, którego cele obejmowały tworzenie wiedzy, doskonalenie zawodowe oraz doskonalenie środowiska szkolnego. Projekt zatytułowany „Rozmowy o uczeniu się" (Learning conversations) koncentrował się na interakcji pomiędzy dorosłym a dzieckiem $w$ dwóch instytucjach wczesnej edukacji w centrum Liverpoolu (Boyd, 2014; Boyd i in., 2015). Będziemy cytować ten projekt jako konkretny przykład ilustrujący dylematy, które zidentyfikowaliśmy.

Anglia jest przykładem systemu oświaty, który działa w warunkach wysokiego poziomu rozliczalności za wyniki. Od lat osiemdziesiątych ubiegłego wieku kolejne rządy w Anglii podejmowały się doskonalenia szkół w ramach prowadzonej polityki neoliberalnej, gdzie nacisk położono na zapewnienie rodzicom możliwości wyboru szkół (Ball, 2013; Day, Smethem, 2009). Takie ramy polityczne miały na celu zapewnienie, że szkoły ponoszą odpowiedzialność wobec rodziców, a rząd centralny dba o realizację ustalonej podstawy programowej, prowadzi kontrole w szkołach, opracowuje tabele rankingowe na podstawie wyników egzaminów, promuje performatywność nauczycieli i stopniowe rozdrobnienie zarządzania szkołami. Niektórzy twierdzą, że w Anglii można zaobserwować stopniową prywatyzację szkół państwowych wynikającą ze zmniejszenia kontroli władz lokalnych i kontroli nad sieciami szkół sprawowanej przez nowe niezależne organizacje. W tym kontekście nie dziwi fakt, że większość dyrektorów i członków kierownictwa szkół odczuwa ogromną presję, aby skupiać się na tym, „czego szukają kontrolerzy", i koncentrują swoje działania na maksymalizowaniu mierzalnych rezultatów, takich jak wyniki testów i egzaminów, które mają wpływ na 
miejsce szkoły w tabeli rankingowej i jej prestiż. Wszystko to sprawia, że Anglia stanowi raczej ekstremalny przykład systemu oświaty, który został ukształtowany przez politykę neoliberalną, natomiast zainteresowane strony $w$ wielu krajach rozpoznają tu pewne cechy charakterystyczne dla systemu o wysokim poziomie rozliczalności za wyniki.

Opracowując artykuł, mieliśmy na celu zainspirowanie do przemyśleń nad przywództwem w szkole, jednak ze względu na skupienie się na dalszym udziale badań nad praktyką zawodową nauczyciela, prowadzonych przez nauczycieli, kierujemy dyskusję w stronę przywództwa zorientowanego na nauczanie. Poprzez podkreślenie znaczenia środowiska pracy, relacji i kultury, które umożliwiają rozwój krytycznych badań prowadzonych przez nauczycieli, skoncentrujemy się na zbiorowym przywództwie w szkole, a nie na indywidualnych liderach edukacyjnych. Członkowie kadry kierowniczej szkół, którzy stosują podejście „przywództwa zorientowanego na nauczanie", mogą wspierać przemyślenia nauczycieli poprzez dialog, modelowanie i coaching oraz zachęcać do współpracy, opracowywania programów nauczania i prowadzenia badań w działaniu (Blasé, Blasé, 1999; Southworth, 2002). Tacy przywódcy, stosujący styl zarządzania zorientowany na nauczanie, mogą wspomagać działania na rzecz rozwoju przywództwa, które będą pomocne nauczycielom w zwiększeniu ich udziału w zbiorowym przywództwie oraz w wykorzystaniu ich pośrednictwa do ograniczania presji wysokiego poziomu rozliczalności za wyniki (Terosky, 2016). Natomiast Terosky odnalazł dyrektorów szkół w Nowym Jorku, którzy już stosują podejście przywództwa zorientowanego na nauczanie, podczas gdy Kalman i Arslan odkryli, że wielu dyrektorów szkół w Turcji czuło się ograniczonych wpływami na szerszym systemowym poziomie governmentality i nie było w stanie przyjąć pewnych cech przywódcy stosującego styl zarządzania zorientowany na nauczanie (2016).

W ramach badania opinii na temat skutecznego przywództwa w sektorze usług dla dzieci w Anglii zidentyfikowano dwa główne wyzwania dla przywódców, a mianowicie związane z projektowaniem systemów uczenia się oraz związane z rozwojem zdolności. Stwierdzono także, iż skuteczni przywódcy stosowali elastyczny zestaw strategii rozwiązywania problemów (Daniels, Edwards, 2012). To badanie, przeprowadzone na małą skalę, koncentrowało się na przywódcach, którzy byli skuteczni. $W$ rezultacie liderzy stanęli przed kluczowym wyzwaniem, jakim jest znalezienie odpowiedzi na pytanie: „w jaki sposób przywódcy umoż- 
liwiają poszerzanie odpowiedzialności zawodowej w ramach kultury ukierunkowanej na rozliczalność za wyniki?". Natomiast w ramach badania nie przeprowadzono dogłębnej analizy w tym zakresie i potwierdzono podstawowe założenie, że „przywódcy muszą być przekonani o tym, że profesjonalna ocena doprowadzi do najlepszych możliwych rezultatów z punktu widzenia korzyści dla dzieci..." (2012, s. 36). Pozostaje pytanie, w jaki sposób niektórzy przywódcy mogą stosować podejście polegające na umiejętnym budowaniu zdolności, które łagodzi wpływ polityki zasadzającej się na wysokim poziomie rozliczalności za wyniki, podczas gdy inni w tym samym kontekście stosują podejście menedżerskie, w ramach którego wymagają stosowania narzuconych odgórnie "najlepszych" praktyk.

Do celów niniejszego artykułu zdefiniujemy badania nad praktyką zawodową nauczyciela (ang. professional inquiry) jako systematyczną ocenę praktyki, która łączy krytyczne zainteresowanie istotnymi teoriami i badaniami naukowymi z praktyczną wiedzą nauczycieli i stosowanymi przez nich metodami pracy. Badania poświęcone danej profesji obejmują analizę danych, zazwyczaj łącznie z dowodami naukowymi i mogą być umiejscowione pomiędzy pragmatyczną ewaluacją a badaniami naukowymi prowadzonymi przez praktyków (Boyd, White, 2017). Wydaje się, że istnieje ryzyko, iż badania nad praktyką zawodową nauczyciela prowadzone przez nauczycieli mogą być ograniczone, jeżeli będą one traktowane jedynie jako kolejna strategia "ewaluacji” w ramach organizacji uczącej się, a nie zostaną zachowane niektóre istotne cechy działalności badawczej. Na przykład "badania naukowe” są realizowane z przestrzeganiem ram etycznych, jakie badacze stosują, aby nie wyrządzić krzywdy uczestnikom ani samym sobie. Jest to istotne zagadnienie, ponieważ badania nad praktyką zawodową nauczyciela lub te prowadzone przez praktyków (również często określane jako "badania w działaniu" - ang. action research) są często stosowane przez władze krajowe, regionalne oraz szkoły w ramach sprawowania przywództwa, polityki edukacyjnej i strategii doskonalenia funkcjonowania szkół.

W tym artykule będziemy analizować cztery łączące się elementy związane z badaniami prowadzonymi przez nauczycieli w warunkach rozliczalności za wyniki, jakimi są: wiedza ogólna i fachowa nauczycieli; koncepcja organizacji uczącej się; skuteczne ustawiczne doskonalenie zawodowe nauczycieli oraz znaczenie nagrań wideo zajęć w klasie dla 
prowadzenia badań przez nauczycieli. Dyskusja skupi się na kwestii "krytycznych" analiz prowadzonych przez nauczycieli. Następnie zostaną przedstawione dylematy związane $z$ badaniami nad praktyką zawodową nauczyciela jako elementem przywództwa nauczyciela zorientowanego na nauczanie. Stanowi to niejako narzędzie służące refleksji, z uwzględnieniem doświadczeń autorów w ramach projektu współpracy pomiędzy nauczycielem a badaczem, pn. „Rozmowy o uczeniu się". Będziemy przekonywać, że badania prowadzone przez nauczycieli nadal mają potencjał jako istotny element przywództwa zorientowanego na nauczanie. Zmiana modelu takich badań od pragmatycznej oceny menedżerskiej do badań prowadzonych przez praktyków, przy zastosowaniu podejścia etycznego i krytycznego, przyczyni się do zapewnienia efektywności badań w kontekście systemu edukacji opartego na wysokim poziomie rozliczalności za wyniki.

\section{Wiedza ekspercka nauczycieli}

Jako dyrektor szkoły oraz nauczyciel akademicki jesteśmy w pełni świadomi różnic w wartościowaniu różnych rodzajów wiedzy dostępnej w szkołach i na uniwersytetach. Jako inspirację dla modelu projektu pn. "Rozmowy o uczeniu się" celowo wybrano metaforę przedstawiającą doskonalenie zawodowe nauczycieli jako "Wzajemną zależność" pomiędzy wiedzą publiczną a wiedzą praktyczną (Boyd, Bloxham, 2014; Boyd, Hymer, Lockney, 2015). Przez wiedzę praktyczną (a właściwie "mądrość praktyczną" - ang. practical wisdom) rozumiemy poziomą domenę ugruntowanej i społecznie rozpoznawalnej wiedzy fachowej nauczycieli i zespołów dydaktycznych, z jakiej korzystają oni w miejscu pracy, którą można opisać jako "metody pracy" lub "to, co się u nas sprawdza". Przez wiedzę publiczną (ang. public knowledge) rozumiemy pionową domenę opublikowanej wiedzy, która została zhierarchizowana, a jej zakres obejmuje teorię uczenia się, dowody naukowe, profesjonalne doradztwo i politykę oświatową. Ta metaforyczna struktura wzajemnych oddziaływań stanowi alternatywę dla mylącej metafory przepaści pomiędzy teorią a praktyką, która jest rozpowszechniona w środowisku oświatowym. Metafora doskonalenia zawodowego jako wzajemnej zależności została opracowana w ramach społeczno-kulturowej perspektywy uczenia się poprzez praktykę w miejscu pracy, w ramach której praktyka i tożsamość stale ulegają zmianom (Lave, Wenger, 1991; Wenger, 1998), a profesjonalna "wiedza" pozostaje przedmiotem dyskusji, 
jest umieszczana w kontekście, ma wymiar społeczny, podlega dynamicznym zmianom i jest nieustannie kwestionowana (Blackler (1995). Kluczowym aspektem metafory wzajemnej zależności jest to, że uznaje ona wartość wiedzy eksperckiej nauczycieli i dostrzega przewagę praktyków podczas współtworzenia nowej wiedzy w ramach doskonalenia zawodowego zasadzającego się na prowadzonych badaniach, jako że $w$ tych ramach tworzą oni i oceniają zmiany w praktyce dydaktycznej.

Metafora wzajemnej zależności jest szczególnie przydatna, ponieważ niektórzy obserwatorzy i osoby odpowiedzialne za tworzenie polityki lubią porównywać edukację do medycyny, ze względu na stosowane podejście oparte na dowodach. Będziemy zdecydowanie sprzeciwiać się temu, że odpowiednim podejściem jest porównanie multidyscyplinarnej i wieloparadygmatowej dziedziny, jaką jest edukacja, do "opieki zdrowotnej" czy nawet do ochrony zdrowia psychicznego (Philpott, 2017). Priorytety przywódców stosujących styl zarządzania zorientowany na nauczanie oczywiście mogą zasadzać się na "rozmiarach efektów" interwencji postulowanych w meta-recenzjach randomizowanych badań kontrolowanych (EEF, 2017), jednakże doskonalenie szkoły i zmiany w klasie są dużo bardziej skomplikowane. Zanim przystąpimy do rozważań na temat charakterystyki skutecznego doskonalenia zawodowego nauczycieli, warto spojrzeć na szkoły jako organizacje uczące się.

\section{Organizacja ucząca się}

Koncepcja organizacji uczącej się ewoluowała wraz z literaturą poświęconą rozwojowi organizacji i miejscu pracy i oznacza instytucję, w której praca, nauka i innowacje są wzajemnie powiązane w sposób komplementarny (Brown, Duguid, 1991, s. 40). Garvin podkreśla, że organizacja nie tylko musi opracowywać nowe pomysły, lecz także zmieniać swoje metody pracy, aby odzwierciedlały one nową wiedzę (Garvin, 1993). Chociaż koncepcja organizacji uczącej się w przeważającej mierze jest stosowana w sektorze przedsiębiorstw, to stanowi ona podstawę rozwoju "profesjonalnych społeczności uczących się" w szkołach. Badanie przeprowadzone w Wielkiej Brytanii za pomocą kwestionariusza na dużą skalę i badań przypadku miało na celu określenie ośmiu kluczowych cech skutecznych, profesjonalnych społeczności uczących się w szkołach, w tym „współpracy skoncentrowanej na uczeniu się" $i$ „refleksyjnych badań nad praktyką zawodową nauczyciela" (Bolam i in., 2005). Analiza krytyczna koncepcji organizacji uczącej się wskazuje, że 
zasadza się ona na mało uzasadnionym założeniu, że stały postęp ma miejsce, kładzie nacisk na wiedzę instrumentalną mającą wartość dla organizacji, prowadzi do „przywłaszczenia” krytycznej refleksji przez organizację, oraz zakłada, że „otwarty" dialog jest użyteczny dla uczenia się w grupie, pomimo że kierownictwo i edukatorzy mają dużą władzę wynikającą z piastowanych przez nich stanowisk (Fenwick, 2001). Profesjonalne społeczności uczące się również zostały poddane krytyce ze względu na ryzyko związane z tym, iż wspólnota taka może niekiedy narzucać wąski punkt widzenia i zbiór wartości, zamiast pomagać w tworzeniu kultury stawiania pytań, eksplorującej i profesjonalnego uczenia się skoncentrowanego na badaniach (Watson, 2014). Przyjmowanie odgórnego, ograniczonego punktu widzenia wydaje się być bardziej prawdopodobne w warunkach rozliczalności za wyniki.

Rozważania o wiedzy i władzy w instytucjach miały miejsce niezależnie od rozwoju "heroicznego" modelu przywództwa, który zasadza się na idei przywództwa sprawowanego przez osoby posiadające odpowiednie cechy, zalety czy też podejmujące określone działania. W ramach alternatywnych modeli powstał pogląd na przywództwo, które jest rozproszone, współdzielone, relacyjne lub zbiorowe (D'Innocenzo, Mathieu, Kukenberger, 2014). W ramach przywództwa, które jest bardziej rozproszone i silniej koncentruje się na tożsamości, uznaje się, że również szeregowi członkowie organizacji posiadają władzę (Haslam, Reicher, Platow, 2011). Patrząc z tej perspektywy, osoba pełniąca rolę formalnego lidera może rozwijać wspólną tożsamość społeczną z szeregowymi członkami organizacji i dzięki temu zwiększać swój wpływ oraz wykorzystywać władzę za pośrednictwem innych osób w celu zdobycia kontroli nad zasobami (Turner, 2005). Perspektywa rozproszonej wiedzy i władzy jest zbliżona do sposobu myślenia Foucaulta przedstawionego w ramach jego historii o wiedzy i władzy (Foucault, 1972). Model tożsamości społecznej zaproponowany przez Haslama i jego współpracowników został opracowany na podbudowie koncepcji rozproszonego przywództwa, jednakże wyróżnia go perspektywa teoretyczna obejmująca trzy dystynktywne etapy (Haslam i in., 2014). Na pierwszym etapie, jakim jest sprawowanie przywództwa obejmujące refleksję, główny akcent jest położony na kulturę słuchania i rozumienia w obrębie grupy oraz na rozwój identyfikacji z grupą. Na drugim etapie, jakim jest sprawowanie przywództwa obejmujące reprezentację, podejmowane są działania, które odzwierciedlają i promują wartości 
wyznawane przez grupę. Na trzecim etapie, jakim jest sprawowanie przywództwa obejmujące realizację, nacisk kładzie się na spełnianie obietnic i pokazanie, że proponowane zmiany, które mają znaczenie dla grupy, zostały wprowadzone. $Z$ naszego doświadczenia możemy powiedzieć, że etapy te odzwierciedlają niektóre fazy wspierania ważnych i trwałych projektów obejmujących wspólne prowadzenie przez nauczycieli badań nad praktyką zawodową nauczyciela i sposób, w jaki rozproszona wiedza może zostać wykorzystana do celów zapewnienia zbiorowej, wspólnej gotowości na zmiany w praktyce. W rozważaniach na temat roli dyrektorów szkół, Niesche zapożycza od Foucaulta koncepcję trójstronnego układu sił obejmującego szerszy poziom systemowy ("rządomyślność" - ang. governmentality), poziom szkoły (władza dyscyplinarna) oraz poziom indywidualny (etyka) (2015). Również ta struktura ramowa wydaje się być pomocna we wspieraniu nauczycieli i innych przywódców edukacyjnych przy przyjmowaniu bardziej krytycznej perspektywy w procesie uzgadniania głównego przedmiotu i modelu projektu badań nad praktyką zawodową nauczyciela.

\section{Skuteczne doskonalenie zawodowe nauczycieli}

Charakterystyka badań nad praktyką zawodową nauczyciela jest zgodna z wymaganiami dotyczącymi skutecznego, ustawicznego doskonalenia zawodowego nauczycieli określonymi w recenzjach badań naukowych (TDT, 2015). Charakterystyka ta obejmuje rozwój współpracy i wzrost zaufania, krytyczne zainteresowanie zewnętrzną wiedzą, trwały projekt realizowany $w$ tempie, które zapewnia możliwości prowadzenia eksperymentów i ewaluacji w klasie oraz wyraźne wsparcie ze strony kierownictwa szkoły. Z perspektywy badań nad praktyką zawodową nauczyciela charakterystyka ta uwzględniałaby jeszcze aspekty badań prowadzonych przez praktyków, takie jak ramy etyczne, systematyczne gromadzenie i analizę danych oraz rozpowszechnianie badań poddanych recenzji naukowej (Baumfield Akademiki, Wall, 2013).

Prowadzenie badań nad praktyką zawodową nauczyciela przez nauczycieli wymaga od nich krytycznego zainteresowania teorią i dowodami z przeprowadzonych badań oraz ich oceny pod względem przydatności w miejscu pracy oraz implikacji dla stosowanych praktyk. Proces ten zyskał różne miana, takie jak: wymiana wiedzy, mobilizacja wiedzy i praktyka poparta badaniami (Lewin, 2011; 2013; Nutley, Young \& Walter, 2008). Od wielu lat na arenie międzynarodowej prowadzona jest 
debata na temat rozwoju nauczania popartego badaniami naukowymi (Hammersley, 1997; Oancea, 2005). Nutley przedstawia recenzję tej debaty i proponuje klasyfikację podejść do badań związanych z doskonaleniem zawodowym, jak przedstawiono $w$ tabeli 1. (Nutley i in., 2008).

Tabela 1. Typologia modeli projektów badawczych realizowanych przez nauczycieli

\begin{tabular}{c|l|l} 
& \multicolumn{1}{|c|}{ RACJONALNO-LINIOWY } & \multicolumn{1}{|c}{ INTERAKTYWNY } \\
\hline $\begin{array}{c}\text { PRAKTYK KORZYSTAJĄCY } \\
\begin{array}{c}\text { Z WYNIKÓW BADAN } \\
\text { NAUKOWYCH }\end{array}\end{array}$ & $\begin{array}{l}\text { Rozpowszechnianie wśród } \\
\text { praktyków na pierwszej linii }\end{array}$ & $\begin{array}{l}\text { Aktywna interpretacja } \\
\text { na poziomie lokalnym }\end{array}$ \\
\hline $\begin{array}{c}\text { MODEL EMBEDDED } \\
\text { RESEARCH }\end{array}$ & $\begin{array}{l}\text { Wyniki badań przełożone } \\
\text { na wskazówki i narzędzia }\end{array}$ & $\begin{array}{l}\text { Wspólne opracowywanie } \\
\text { wytycznych }\end{array}$ \\
\hline $\begin{array}{c}\text { MODEL DOSKONAŁOŚcI } \\
\text { ORGANIZACYJNEJ }\end{array}$ & $\begin{array}{l}\text { Transfer wyników na poziomie } \\
\text { lokalnym }\end{array}$ & $\begin{array}{l}\text { Wyniki interpretowane } \\
\text { na poziomie lokalnym, } \\
\text { instytucjonalnym lub } \\
\text { poszczególnych wydziałów }\end{array}$
\end{tabular}

Źródło: na podstawie Nutley i in., 2008.

W tabeli 1. podsumowano sposób, w jaki Nutley klasyfikuje podejścia do doskonalenia zawodowego nauczycieli na podstawie założeń dotyczących wiedzy. Model racjonalno-liniowy zakłada w miarę bezpośrednią ścieżkę od opracowania nowych wyników badań do wdrożenia istotnych zmian przez nauczycieli w ramach praktyki dydaktycznej. Termin "transfer wiedzy" jest często używany w sektorze szkolnictwa wyższego, jako że opisuje on "moc", którą posiadają badacze. Model interaktywny podkreśla potrzebę krytycznego zainteresowania praktyków wynikami badań i dzielenia się ich implikacjami w środowisku pracy. Termin "wymiana wiedzy" jest bliższy temu poglądowi i uwzględnia współtworzenie nowej wiedzy oraz bardziej równomierny rozkład sił pomiędzy naukowcami (którzy propagują wiedzę publiczną) a nauczycielami prowadzącymi badania (którzy promują wiedzę praktyczną).

Typologia taka jak przedstawiona w tabeli 1., jest przydatna, jednak istnieje ryzyko, że przy zbyt prostym przedstawieniu dychotomii pomiędzy modelem racjonalno-liniowym a interaktywnym możliwe jest ukrycie różnic w tych podejściach. Może wydawać się, że model projektu doskonalenia szkoły opartego na badaniach naukowych mieści 
się w podejściu interaktywnym, natomiast podejście menedżerskie i stosunki panujące w w miejscu pracy mogą w praktyce wskazywać, że lepiej on odpowiada modelowi racjonalno-liniowemu. Na przykład, w projektach obejmujących badania przypadku rozległa literatura badawcza poświęcona dialogowi pomiędzy dorosłym a dzieckiem ma silną pozycję w pionowej domenie wiedzy publicznej ze względu na to, że przedstawia dowody naukowe. Tak rozległa wiedza może być interpretowana w ramach projektu jako wiedza określająca "doskonałą praktykę", którą po prostu należy przenieść do lub narzucić jej stosowanie w praktyce $w$ danym środowisku. Jednakże ta perspektywa pomija poziomą domenę wiedzy praktycznej nauczycieli na temat sposobu promowania dialogu z dziećmi w określonym środowisku lokalnym. Aby móc zakwestionować i poddać krytycznej ewaluacji rozległą wiedzę publiczną, która została opublikowana, potrzebna jest pewność co do słuszności stosowanego podejścia i racjonalnie uzasadnione pojmowanie badań edukacyjnych i wiedzy nauczycieli. Stąd nasze obawy co do wpływów, jakim ulega kierownictwo szkoły w dobie rozliczalności za wyniki. W szczególności przywódcy edukacyjni pełniący funkcje kierownicze, którzy są poddawani naciskom, mogą prowadzić ewaluacje w ramach paradygmatu pragmatycznego, lecz określają je mianem badań nad praktyką zawodową nauczyciela lub nawet badań prowadzonych przez praktyków.

\section{Przydatność nagrań wideo}

Kwestionowanie wykorzystania nagrań zajęć w klasie w naszej polemice może wydawać się prozaiczne. Jednakże nasze doświadczenie i liczne badania potwierdzają pogląd, że korzystanie z nagrań wideo z zajęć w klasie jest korzystne dla rozwoju zawodowego nauczycieli w ramach stosowanego przez nich podejścia obejmującego badania, które przyczyniają się do upowszechniania dyskusji (Borko i in., 2008). Niestety, wiele dowodów na przydatność takich nagrań dla nauczycieli pochodzi z badań na małą skalę, które często obejmowały początkujących nauczycieli, a nie doświadczonych praktyków. Na podstawie przeglądu piśmiennictwa i własnego badania z wykorzystaniem filmów wideo dokumentujących pracę 15 nauczycieli nagranych w okresie jednego roku, Osipova i współpracownicy (2011) twierdzą, że nauczyciele uważają, iż oglądanie i omawianie nagrań wideo praktyki dydaktycznej jest wartościowym doświadczeniem związanym z rozwojem zawodowym. 
Podobne wnioski wyciągnięto również w przypadku nauczycieli nauczania początkowego (Cherrington, Loveridge, 2014). Badanie obejmujące 10 nauczycieli matematyki, którzy korzystali z nagrań wideo do celów rozwoju zawodowego zauważyło różnice pomiędzy analizą nagrań pracy innych nauczycieli a filmów dokumentujących ich własną praktykę zawodową (Kleinknecht, Schneider, 2013). Badanie wykazało, że nauczyciele byli bardzo mocni zaangażowani emocjonalnie podczas analizy nagrań wideo. W ramach badania zasugerowano, że nauczyciele potrzebują lepszego przygotowania i wsparcia podczas analizy nagrań własnej pracy niż w przypadku obserwacji praktyki innych nauczycieli. Nagrania zajęć lekcyjnych mogą być wykorzystywane jako "dane do analiz" w ramach badań prowadzonych przez praktyków lub alternatywnie mogą po prostu sprawić, że badanie zajęć lekcyjnych stanie się łatwiejsze, ponieważ umożliwiają one obserwację lekcji przez inne osoby po jej odbyciu oraz pozwalają nauczycielom odpowiedzialnym za stworzenie korzystnych warunków w klasie przeprowadzenie bardziej skutecznej i szczegółowej analizy obserwacji. Analiza nagrań wideo dokumentujących złożoność zajęć lekcyjnych nie jest prosta, ale - przestrzegając ram etycznych i bazując na metodach badawczych odświeżających pamięć - uważamy, że ta praktyczna sposobność jest nieocenionym narzędziem dla nauczycieli prowadzących badania poświęcone ich profesji (Lyle, 2003).

\section{Podejście krytyczne}

Prowadzenie badań nad praktyką zawodową nauczyciela sprawia, że nauczyciele zmuszeni są prowadzić krytyczną analizę tego, co się dzieje w klasach i szkołach w formie kwestionowania wiedzy publicznej, a także muszą być skłonni do prowadzenia oceny silnie ugruntowanych i być może pozornie skutecznych lokalnych praktyk. Jednakże niektórzy komentatorzy wskazują na ryzyko, że badania prowadzone przez praktyków lub badania w działaniu prowadzone przez nauczycieli mogą zostać "udomowione", w tym znaczeniu, że ich głównym przedmiotem staną się procedury zapewniania jakości i zabraknie w nich odwagi do zadawania najważniejszych pytań. Można stwierdzić, że konieczność zastosowania "krytycznego podejścia" przez praktyków prowadzących badania dotyczy nie tylko "analizy krytycznej", co oznacza zastosowanie krytycznego podejścia do literatury i do danych, lecz także przyjęcia postawy "teorii krytycznej". Kemmis poddaje krytyce badania w działaniu, 
które "mają na celu jedynie usprawnienie technik nauczania (...) bez postrzegania ich jako działań związanych z bardziej ogólnymi pytaniami o kształcenie uczniów na rzecz lepszego społeczeństwa" $(2006,460)$. Kemmis dokonuje rozróżnienia pomiędzy ewaluacją technik nauczania, czyli techniczną analizą skuteczności strategii nauczania, a badaniami w zakresie edukacji, czyli zadawaniem trudnych pytań na temat ogólnego rozwoju dzieci jako obywateli tworzących lepsze społeczeństwo.

Taka potrzeba szerszego spojrzenia jest dalej rozwijana przez Ponte (2007), który proponuje trzy obszary wiedzy w ramach badań prowadzonych przez nauczycieli:

$\rightarrow$ Wiedza ideologiczna skupiająca się na pożądanych efektach - szersze cele edukacyjne

$\rightarrow$ Wiedza technologiczna skupiająca się na pożądanych zjawiskach - strategie nauczania

$\rightarrow$ Wiedza empiryczna skupiająca się na rzeczywistych efektach - wpływ prowadzenia zajęć lekcyjnych

Ponte (2007) twierdzi, że nauczyciele prowadzący badania naukowe muszą połączyć te trzy dziedziny wiedzy, aby ich działania nie służyły jedynie instrumentalnym celom. Cochran-Smith i Lytle, którzy mają istotny wkład w ruch "nauczycieli jako badaczy", wzywają nauczycieli, aby traktowali „prowadzenie badań jako postawę" oraz współpracowali z rodzicami i lokalnymi agencjami opieki socjalnej, aby pomóc w osiągnięciu perspektywy teorii krytycznej i zapewnić bardziej znaczący wpływ ich projektów badawczych (2009). W ramach dominującego systemu szkolnictwa opartego na rozliczalności za wyniki w systemie oświaty występuje możliwość "udomowienia" profesjonalnych badań nad praktyką zawodową nauczyciela, co oznacza, że mogą one zostać "wchłonięte" przez podejście menedżerskie i utracą swój krytyczny charakter (Kemmis, 2006). Takie udomowione badania nad praktyką zawodową nauczyciela mogą jedynie oceniać techniki nauczania i będą unikać teorii krytycznej, która podaje w wątpliwość zagadnienia sprawiedliwości społecznej, szersze cele edukacji lub organizację szkolnictwa (Cochran-Smith, Lytle, 2009; Biesta, 2011).

\section{Dylematy nauczycieli prowadzących badania}

W ramach rozważań nad naszym projektem pn. „Rozmowy o uczeniu się" oraz nad pięcioma zagadnieniami omówionymi powyżej, tj.: wiedzą 
nauczycieli, organizacjami uczącymi się, skutecznym doskonaleniem zawodowym nauczycieli, przydatnością nagrań wideo oraz podejściem krytycznym, zidentyfikowaliśmy 6 dylematów, wobec jakich stają nauczyciele i inni przywódcy zamawiający i uczestniczący w badaniach porównawczych nad nauczaniem. Przedstawiamy owych sześć dylematów jako użyteczne narzędzie dla nauczycieli prowadzących badania i przywódców edukacyjnych przy projektowaniu i recenzowaniu badań porównawczych poświęconych profesji nauczyciela oraz projektów badań prowadzonych przez praktyków.

Dylematy dotyczące projektowania i recenzowania projektów badań nad praktyką zawodową nauczyciela prowadzonych przez nauczycieli

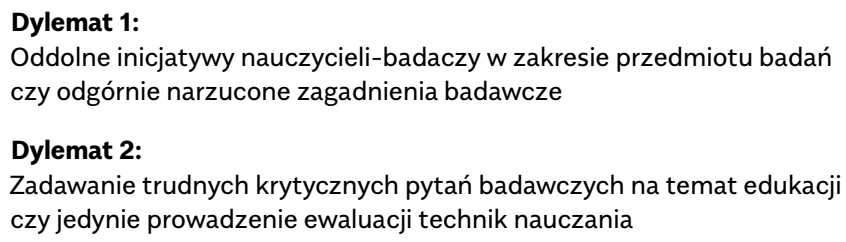

\section{Dylemat 4:}

Przestrzeganie etyki badań, aby zapewnić bezpieczeństwo czy prowadzenie ewaluacji z zapewnieniem przejrzystości i rozliczalności jednostek

\section{Dylemat 5:}

Eksperymentowanie i ewaluacja w klasie czy wdrażanie "praktyki popartej dowodami” (lub „dobrych praktyk" pod wpływem tego, „czego według nas inspektorzy oczekują")

\section{Dylemat 6:}

Krytyczne zainteresowanie wiedzą praktyczną nauczycieli czy akceptacja lokalnych sposobów pracy i niepisanych zasad w miejscu pracy

Źródło: opracowanie własne.

\section{Rozmowy o uczeniu się}

Aby zilustrować zastosowanie 6 dylematów do celów badań nad praktyką zawodową nauczyciela, w tym punkcie przedstawimy nasze refleksje 
na temat projektu badania pn. „Rozmowy o uczeniu się”. Oczywiście dylematy te są wzajemnie powiązane i częściowo się pokrywają, ale chcieliśmy wypróbować proponowany zestaw dylematów jako praktyczne narzędzie, zatem poniżej prezentujemy krótkie uwagi na temat każdego z nich:

Dylemat 1: Oddolne inicjatywy nauczycieli-badaczy w zakresie przedmiotu badań czy odgórnie narzucone zagadnienia badawcze

Wybór przedmiotu badań przez nauczyciela-badacza wiąże się z kilkoma potencjalnymi korzyściami, w tym: nauczyciele mogą mieć większą motywację do realizacji projektu; pytanie badawcze może być bardziej interesujące i przydatne dla nauczycieli; potwierdza uznanie dla wiedzy fachowej nauczycieli; poziom etyki zawodowej wymaga jasno określonego prawa do nieuczestniczenia, a w przypadku uczestników - do wycofania swoich danych w dowolnym momencie. Główny przedmiot badawczy projektu pn. „Rozmowy o uczeniu się" został uzgodniony na podstawie rozmów poświęconych priorytetom i wyzwaniom, wobec jakich staje szkoła, przeprowadzonych przez uczelnianego opiekuna naukowego z członkami wyższego kierownictwa szkoły, którzy chcieli zlecić projekt badawczy realizowany przez praktyków. Obie szkoły są usytuowane w obszarze zamieszkałym przez dużą liczbę defaworyzowanych rodzin, gdzie występuje wysoki odsetek dzieci w wieku 4-6 lat o niskim poziomie rozwoju mowy i języka w porównaniu do normy dla dzieci w tej grupie wiekowej. Ostatecznego wyboru przedmiotu badawczego, jakim były interakcje pomiędzy dorosłym a dzieckiem, dokonano podczas wstępnych spotkań z kierownictwem szkoły, które uznało, że pracujący w szkole nauczyciele są w stanie przeprowadzić badania i mogą mieć wpływ na rozwój tego obszaru pracy. Ze względu na to, że przedmiot badawczy został ustalony odgórnie, co zapewne jest typowe dla wielu podobnych projektów badań nad praktyką zawodową nauczyciela realizowanych w szkołach, byliśmy zmuszeni rozważyć to, w jaki sposób z projektem tym mogą utożsamiać się nauczyciele i jakie podejście etyczne do udziału powinno zostać zastosowane. Postanowiliśmy postawić nauczycieli w roli badaczy i członków zespołu badawczego, a nie jedynie uczestników, dostarczając danych do projektu. Po utworzeniu zespołu badawczego opracowanie modelu badania przyjęło formę projektu współpracy, w ramach którego nauczyciele mogli mocniej się z nim utożsamić i zy- 
skać nad nim większą kontrolę. Inne istotne podjęte kroki dotyczące etyki i zamierzonych rezultatów projektu zostały omówione w ramach opisu dylematu 3. i 5., jak poniżej.

Opracowanie przedmiotu badawczego i projektowanie modelu badania można opisać jako negocjacje pomiędzy zainteresowanymi stronami i dobrze jest, jeśli wszystkie zaangażowane strony wezmą pod uwagę trzy poziomy, jakimi są: rządomyślność, szkoła i jednostka (Niesche, 2015). Nasz projekt był złożony, a to ze względu na fakt, że nasi nauczyciele-badacze pracowali $w$ dwóch współpracujących ze sobą szkołach, dlatego też sugerujemy dodanie dodatkowego poziomu, jakim jest „zespół” (zespół pedagogiczny i/lub zespól badawczy), który może stanowić łącznik pomiędzy szkołą a poszczególnymi poziomami.

Dylemat 2: Zadawanie trudnych krytycznych pytań badawczych na temat edukacji czy jedynie prowadzenie ewaluacji technik nauczania

Po ustanowieniu zespołu badawczego złożonego z nauczycieli w ramach projektu pn. „Rozmowy o uczeniu się", na wczesnym etapie została podjęta kluczowa decyzja, aby nie angażować rodziców bezpośrednio w proces badawczy. Stoi to w pewnym sensie w sprzeczności z dowodami popartymi badaniami, jako że rodzice oczywiście mają ogromny wpływ na dialog pomiędzy dorosłymi a dziećmi i stanowią potencjalny zasób dla rozwoju języka u małych dzieci, co również obejmuje zagadnienia klas społecznych i sprawiedliwości społecznej (Tizard \& Hughes, 1984). Zamiast bezpośredniego udziału rodziców w badaniu, jednym z zaplanowanych rezultatów projektu było przeprowadzenie warsztatów dla nich zorganizowanych z wykorzystaniem wyników badania. Powody decyzji, by nie angażować rodziców bezpośrednio, miały charakter pragmatyczny i były uzasadnione, obejmowały one kwestie, takie jak czas, złożoność i etyka, lecz, patrząc na to z perspektywy czasu, była to kluczowa decyzja, która przesądziła o kształcie projektu, który silniej koncentrował się na ewaluacji technik nauczania, a nie na bardziej ambitnej perspektywie krytycznej i zainteresowaniu kwestiami sprawiedliwości społecznej (Kemmis, 2006; Cochran-Smith i Lytle, 2009). Podejmując decyzję o nieangażowaniu rodziców, wykluczyliśmy ich jako źródło danych, a także jako potencjalne źródło wiedzy na temat prowadzenia dialogu z małymi dziećmi. Ogólnie rzecz biorąc, wydaje się, że Kemmis działał trochę zbyt pochopnie, twierdząc, że badania $\mathrm{w}$ działaniu prowadzone przez nauczycieli zostały udomowione. Projekt 
mógłby być postrzegany jako przydatny, a nawet niezbędny pierwszy krok w kierunku współpracy $z$ rodzicami w celu prowadzenia dialogu pomiędzy dorosłym a dzieckiem dzięki oparciu się na wiedzy fachowej i pewności siebie nauczycieli.

Przy projektowaniu projektów badawczych i dopracowywaniu pytań badawczych nauczyciele i kierownictwo szkoły powinni przeprowadzić dogłębne rozważania i dyskusje. Zanim odejdziemy od kwestii zadawania trudnych pytań edukacyjnych, a także mając na względzie kontekst wysokiego poziomu rozliczalności za wyniki, należy zwrócić uwagę na ryzyko, jakie podejmuje kierownictwo szkoły, zlecając badanie naukowe nad praktyką zawodową nauczyciela, które może, ze względu na poziom autonomii i krytyczne podejście, ujawnić niewygodne prawdy.

Dylemat 3: Doskonalenie zawodowe i budowanie potencjału nauczycieli-badaczy czy wnoszenie wkładu $w$ dowody z badań naukowych

W wielu projektach badawczych będących blisko praktyki zawodowej i w badaniach w działaniu nauczycielom-badaczom zapewniono by większą samodzielność i wspierano by ich w zadawaniu własnych pytań badawczych i w opracowywaniu modeli badania w ramach ogólnie uzgodnionego przedmiotu badawczego. Takie podejście może zapewnić doskonalenie zawodowe nauczycieli na dobrym poziomie, ale mniej prawdopodobnym jest stworzenie nowej wiedzy i solidnych badań wymaganych do celów publikacji w czasopiśmie naukowym. W projekcie pn. „Rozmowy o uczeniu się" uzgodniliśmy wspólne pytanie badawcze i model badania. Uzgodniono, że rezultatem projektu będzie artykuł opublikowany w czasopiśmie naukowym (Boyd, 2014) i ten zamierzony rezultat stanowił priorytet dla opiekuna naukowego projektu, chociażby ze względu na presję ze strony kierownictwa, jaka występuje w szkolnictwie wyższym. Częścią z zamierzeń projektu było współtworzenie solidnej wiedzy kontekstowej (Nowotny, Scott, Gibbons, 2001) poprzez analizę porównawczą danych z udziałem nauczycieli i uczelnianego opiekuna naukowego projektu. Tymczasem w projekcie pn. „Rozmowy o uczeniu się" głównym rezultatem projektu było doskonalenie zawodowe nauczycieli-badaczy. Jego celem było wzmocnienie roli nauczycieli-badaczy jako doradców i konsultantów dla nauczycieli, którzy są w stanie wspierać rozwój doświadczonych współpracowników w szkole. Na podstawie informacji zwrotnych od nauczycieli-badaczy można stwierdzić, że uznali oni analizę porównawczą danych z wykorzystaniem 
nagrań wideo jako narzędzie bardzo przydatne do celów doskonalenia zawodowego. Natomiast w ramach procesu badawczego znacznie mniej uwagi poświęcono prowadzeniu eksperymentów w klasie i coachingowi, ze względu na to, że członkini rady szkoły, posiadająca odpowiednią wiedzę i doświadczenie w charakterze doradcy nauczycieli, uczestniczyła w projekcie jako doradca i trener pedagogiczny przez dwa lata jego trwania. Przez ten czas pracowała z nauczycielami, obserwując praktykę zawodową i analizując nagrania wideo w celu wspierania doskonalenia zawodowego. Po zastanowieniu, opiekun naukowy projektu pn. „Rozmowy o uczeniu się" jest nieco zawiedziony faktem, że nauczyciele nie zdobyli bardziej pogłębionej wiedzy i umiejętności w zakresie prowadzenia badań naukowych w dziedzinie edukacji. Chociaż byli oni zaangażowani w procesy badawcze w charakterze współpracowników, ze względu na ograniczenia czasowe i obowiązki zawodowe nauczyciele ci koncentrowali swoje wysiłki na doskonaleniu zawodowym w zakresie interakcji pomiędzy dorosłymi a dziećmi, nie angażowali się jednak $w$ dodatkową lekturę na temat prowadzenia badań, co nie jest zaskoczeniem.

Zapewnienie równowagi pomiędzy celami badań naukowych poświęconych nauczaniu, takimi jak rezultaty doskonalenia zawodowego i solidne prace naukowe nadające się do publikacji, to nie tylko kwestia założeń projektu badawczego. Mają na to wpływ decyzje w zakresie projektowania, poczucia zaangażowania i etyki, podejmowane przez cały czas trwania projektu, a to wymaga starannego rozważenia i refleksyjnego monitorowania.

Dylemat 4: Przestrzeganie etyki badań, aby zapewnić bezpieczeństwo czy prowadzenie ewaluacji z zapewnieniem przejrzystości i rozliczalności jednostek

Po ustanowieniu zespołu badawczego w ramach projektu pn. „Rozmowy o uczeniu się", rozpoczęto rozmowy na temat etyki prowadzenia badań i uzgodnienia dotyczące pytań badawczych i modelu badania. Zespół przedłożył wniosek badawczy, który został zatwierdzony w procesie zatwierdzenia kwestii etycznych przeprowadzonym na uniwersytecie. Zagadnienia etyczne dotyczyły dzieci, rodziców i szkoły, lecz w niniejszym artykule, który koncentruje się na przywództwie, omówimy głównie kwestie etyczne związane nauczycielami prowadzącymi badania naukowe. Rozpatrzenie kwestii etycznych wydawało się szcze- 
gólnie przydatne w przypadku badań prowadzonych przez nauczycieli zleconych przez dyrektora szkoły, ponieważ dzięki temu zespół badawczy mógł postulować uzasadniony poziom kontroli i anonimowości nauczycieli-badaczy udostępniających dane do celów realizacji projektu. Takie podejście zapewniło nauczycielom możliwość zadecydowania o tym, aby nie udostępniać nagrań wideo. Nagrania wideo oznaczają, że nie było możliwe zapewnienie anonimowości w obrębie zespołu badawczego, jednak nauczyciele-badacze mogli sami zdecydować o liczbie dokonanych nagrań i o wyborze tych, które zostały przekazane jako dane do celów prowadzenia badań. Zapewne obniżyło to w pewnym stopniu jakość danych, co zostało odnotowane w publikacji, natomiast przyczyniło się do zapewnienia kontroli etycznej zagrożeń, przed jakimi stali nauczyciele uczestniczący w badaniu. Krok ten przyczynił się do zmniejszenia potencjalnego stresu związanego z dzieleniem się nagraniami zajęć lekcyjnych, który może być bardzo silny, ze względu na wgląd w praktykę zawodową, co może zostać odebrane przez nauczycieli jako ingerencja $w$ ich pracę. Okazało się to szczególnie realne w przypadku nieformalnych rozmów z dziećmi przeprowadzanych twarzą w twarz, które mają bardziej prywatny charakter niż nauczanie całej klasy.

Zbieranie danych do celów prowadzenia badań nad praktyką zawodową nauczyciela, zwłaszcza nagrań wideo, stwarza poważne zagrożenie dla reputacji zawodowej poszczególnych nauczycieli, która ma kluczowe znaczenie w warunkach rozliczalności za wyniki. Zasady etyki prowadzenia badań i powiązane z nimi procesy mogą być pomocne w tworzeniu bezpiecznej przestrzeni dla prowadzenia badań przez nauczycieli i z pewnością jest to obszar, w którym traktowanie prowadzenia badań nad nauczaniem jako badań prowadzonych przez praktyków jest szczególnie pomocne.

Dylemat 5: Eksperymentowanie i ewaluacja w klasie czy wdrażanie "praktyki popartej dowodami" (lub "dobrych praktyk" pod wpływem tego, "Czego według nas inspektorzy oczekujq")

W ramach projektu pn. „Rozmowy o uczeniu się", pomimo celu, jakim była poprawa wyników dzieci w nauce, poza zwykłą oceną i systemami monitorowania stosowanymi w obu szkołach, nie podejmowano konkretnych prób zmierzenia postępów w zakresie efektów związanych z mówieniem i nauką języka. Występują pewne naciski na nauczycieli- 
-badaczy, aby ich badania koncentrowały się na opracowywaniu „twardych danych" potwierdzających postępy w uczeniu się dzieci. Wydają się one uzasadnione, ale należy też zapewnić, że badania prowadzone przez praktyków koncentrują się na zrozumieniu procesu uczenia się. Badania interwencyjne na dużą skalę prowadzone w schemacie RCT oraz dostępne meta-recenzje takich badań (EEF, 2017) odgrywają ważną rolę w określaniu priorytetów i możliwości dla kierownictwa szkół, natomiast badania jakościowe na małą skalę pomagają nauczycielom zrozumieć dowody z badań dzięki prowadzeniu eksperymentów podczas zajęć i pomagają skoncentrować się na tym, dlaczego i w jaki sposób interwencje wspierają dzieci w nauce. Na wczesnym etapie realizacji projektu pn. „Rozmowy o uczeniu się" pracownik akademicki posiadający specjalistyczną wiedzę zapewnił pomoc opiekunowi naukowemu projektu i sporządził zwięzły przegląd literatury na temat interakcji dorosły-dziecko, co pomogło nauczycielom zapoznać się z teoriami i danymi naukowymi. Miało to wpływ na wstępne ramy analityczne, które zastosowano do transkrypcji nagrań wideo na początkowych etapach analizy porównawczej. Proces ten umożliwił nauczycielom przeprowadzenie krytycznej analizy wiedzy publicznej oraz bezpośrednie porównanie jej z praktyką zawodową i wiedzą praktyczną. Alternatywne struktury ramowe analizy interakcji dorosły-dziecko zostały przedstawione przez opiekuna naukowego, co pozwoliło na poszerzenie zakresu analizy (Boyd, 2014). Jednym z głównych wniosków było wykorzystanie „przenośnej tożsamości" (ang. transportable identity) jako strategii prowadzenia dialogu z małymi dziećmi. Polega ona tym, że w miarę rozwoju dialogu nauczyciel przyjmuje tożsamość członka rodziny lub towarzysza zabaw dzieci w celu odegrania roli innej niż rola nauczyciela. Strategia ta wydawała się pomocna nauczycielom, aby mogli unikać tematów koncentrujących się na programie nauczania podczas rozmów z dziećmi. W ten sposób, w ramach projektu, choć częściowo możliwe było przyjęcie krytycznej perspektywy, która łączy sposób myślenia na poziomie centralnym z poziomem szkoły $i$ jednostki oraz stawianie oporu przez nauczycieli wobec podstawy programowej obowiązującej na poziomie kraju oraz wobec struktur ramowych kontroli.

Opublikowane dowody naukowe są przekonujące i kwestionowanie ich może sprawiać trudność nauczycielom. Sokratejskie podejście, w ramach którego zadamy pytanie: „co opublikowane dowody naukowe oznaczają dla naszej praktyki dydaktycznej i naszych dzieci?", może być 
pomocne w sprowokowaniu krytycznego myślenia i dialogu pomiędzy opiekunem naukowym jako pośrednikiem a nauczycielami-badaczami. W szkołach w Anglii, gdzie obowiązuje wysoki poziom rozliczalności za wyniki, gra toczy się o wysoką stawkę i istnieje ryzyko publicznego wytknięcia błędu, agencja rządowa odpowiedzialna za kontrolę ma tendencję do wypaczania priorytetów szkoły i może odwracać uwagę dyrektorów szkół od realizacji działań na podstawie dowodów naukowych. Skoncentrowanie się na dowodach badawczych może pomóc dyrekcji i ich szkołom w stawianiu oporu tym niezamierzonym konsekwencjom systemu kontroli.

Dylemat 6: Krytyczne zainteresowanie wiedzq praktycznq nauczycieli czy akceptacja lokalnych sposobów pracy i niepisanych zasad w miejscu pracy

Krytyczne podejście do stosowanych sposobów pracy może być trudniejsze do osiągnięcia niż krytyczne podejście do lub może nawet ignorowanie opublikowanych dowodów naukowych. W ramach projektu pn. „Rozmowy o uczeniu się", opiekun naukowy poczynił starania, aby zapewnić uznanie dla wiedzy fachowej i wiedzy praktycznej, jaką nauczyciele-badacze zdobyli w miejscu pracy. Do pewnego stopnia podejście krytyczne do wiedzy praktycznej nauczycieli było stosowane podczas wywiadów z nauczycielami, podczas których omawiano nagrania wideo. W tym przypadku podczas wywiadu proszono ich, aby podzielili się refleksjami na temat wybranego nagrania i przeanalizowali swoje strategie prowadzenia dialogu. Wywiady poświęcone nagraniom wideo również były nagrywane i stanowiły dodatkowe źródło danych, chociaż w praktyce nauczycielom trudno rozmawiało się na ten temat i wspólna analiza nagrań była bardziej udana, jako że rozmawialiśmy o kodowaniu segmentów rozmów prowadzonych przez dorosłych i dzieci. Podczas oglądania nagrań wideo nauczyciele komentowali swoje zachowanie i czasami tłumaczyli, że dobierali określone strategie do potrzeb danego dziecka lub na podstawie wcześniejszych doświadczeń, ponieważ te elementy miały wpływ na ich wybór strategii konwersacyjnych. Poza prowadzeniem wspólnej analizy, ewaluacja prowadzona przez nauczycieli-badaczy obejmowała opracowanie i prezentację wyników badań podczas konferencji naukowych dla nauczycieli, co stanowiło istotny impuls dla doskonalenia zawodowego i budowania pewności siebie, wynikających z uczestnictwa w projekcie. Nauczyciele-badacze zauważyli 
również, że dużo nauczyli się podczas opracowywania materiałów szkoleniowych do celów doskonalenia zawodowego, które stanowiły drugi rezultat projektu pn. „Rozmowy o uczeniu się" (Boyd i in., 2015). Materiały te obejmowały profesjonalne nagrania wideo pokazujące, jak nauczyciele-badacze rozmawiają z dziećmi oraz prezentujące ich przemyślenia na temat praktyki zawodowej. Upowszechnianie rezultatów prowadzonych badań wśród współpracowników w formie prezentacji nt. badania i zajęć $w$ ramach doskonalenia zawodowego to bodaj najważniejsze elementy badań nad praktyką zawodową nauczyciela, jeżeli chcemy zapewnić ich maksymalny wpływ na uczenie się przez nauczycieli-badaczy.

Budowanie zaufania ma kluczowe znaczenie, jeżeli w ramach prowadzonych badań chcemy przeprowadzić wspólną analizę praktyki zawodowej i poddać krytyce stosowane metody pracy. Budowanie takiego poziomu zaufania jest procesem relacyjnym i dynamicznym, nad którym należy pracować i który jest możliwy do osiągnięcia w ramach każdego projektu. Przestrzeganie struktur ramowych etyki badań naukowych jest pomocne w osiągnięciu tego celu, nawet w środowisku o wysokim poziomie rozliczalności za wyniki. Wykorzystanie nagrań wideo jest obusieczną bronią, gdyż wymaga wysokiego poziomu zaufania, lecz jeżeli zostanie on osiągnięty wówczas możemy stwierdzić, że mogą one okazać się niezwykle przydatnym narzędziem doskonalenia zawodowego nauczycieli. Ogólnie rzecz biorąc, w naszym projekcie osiągnęliśmy wysoki poziom zaufania pomiędzy nauczycielami, opiekunem naukowym projektu, trenerem i kierownictwem przedszkola. Korzystanie z nagrań wideo z jednej strony wymagało zaufania, a z drugiej pomagało jego wzrastaniu.

\section{Omówienie}

Jako że po 30 latach dominacji era neoliberalizmu w Anglii ma się ku końcowi, jej ostatni zwolennicy odpowiedzialni za tworzenie polityki uparcie nie dostrzegają wyraźnie widocznych błędów tej polityki (Heffernan, 2011). W sektorze oświaty miały miejsce powolne rozdrobnienie i prywatyzacja, które sprawiły, że można twierdzić, iż „polityka ta przyczyniła się do rozpadu, lub do początku końca, państwowej oświaty" (Exley, Ball, 2013, s. 26). Musimy opracować podejścia do przywództwa, które zapewnią dobre alternatywy dla oparcia się na "heroicznych" przywódcach oraz siłach rynkowych i które sprawdzą się w środowisku o wysokim poziomie rozliczalności za wyniki. 
W artykule przedstawiliśmy narzędzie składające się z sześciu prowokujących do dyskusji dylematów, z jakimi mogą borykać się nauczyciele i inni przywódcy edukacyjni, jak również opiekunowie naukowi projektów badawczych pracujący na uniwersytetach w ramach przeglądu metod opracowywania projektów badawczych i realizacji takich projektów.

$\rightarrow$ Dylemat 1: Oddolne inicjatywy nauczycieli-badaczy w zakresie przedmiotu badań czy odgórnie narzucone zagadnienia badawcze

$\rightarrow$ Dylemat 2: Zadawanie trudnych krytycznych pytań badawczych na temat edukacji czy jedynie prowadzenie ewaluacji technik nauczania

$\rightarrow$ Dylemat 3: Doskonalenie zawodowe i budowanie potencjału nauczycieli-badaczy czy wnoszenie wkładu w dowody z badań naukowych i szersze zmiany w praktyce zawodowej

$\rightarrow$ Dylemat 4: Przestrzeganie etyki badań, aby zapewnić bezpieczeństwo czy prowadzenie ewaluacji z zapewnieniem przejrzystości i rozliczalności jednostek

$\rightarrow$ Dylemat 5: Eksperymentowanie i ewaluacja w klasie czy wdrażanie "praktyki popartej dowodami" (lub "dobrych praktyk" pod wpływem tego, "czego według nas inspektorzy oczekują")

$\rightarrow$ Dylemat 6: Krytyczne zainteresowanie wiedzą praktyczną nauczycieli czy akceptacja lokalnych sposobów pracy i niepisanych zasad w miejscu pracy

Rozważenie tych dylematów oznacza dostrzeżenie niuansów i wzajemnych zależności pomiędzy wiedzą a władzą występujących w uczeniu się w miejscu pracy przez nauczycieli, podczas opracowywania programu nauczania i doskonalenia środowiska szkolnego. Uważamy, że badania nad nauczaniem prowadzone wspólnie przez nauczycieli i stanowiące element przywództwa zorientowanego na nauczanie mogą stanowić bardzo skuteczną strategię. Mamy nadzieję, że inni również uznają, iż przedstawione przez nas dylematy mogą być przyczynkiem do refleksji nad zagadnieniem opracowywania projektów badań nad praktyką zawodową nauczyciela w warunkach wysokiego poziomu rozliczalności za wyniki. Przywództwo zorientowane na nauczanie, w ramach którego prowadzone są badania nad nauczaniem, wymaga pogodzenia się z niepewnością, prowadzenia eksperymentów i po- 
dejmowania ryzyka. Sprawowanie przywództwa w szkołach w sposób, który promuje niezależność nauczycieli, współzależność, skuteczność zbiorowych działań, eksperymentowanie i podejmowanie ryzyka, wymaga zaangażowania we współczesne formy przywództwa zbiorowego w warunkach rozliczalności za wyniki. W takiej sytuacji prowadzenie wspólnych badań przez nauczycieli nad ich zawodem traktowane jako forma doskonalenia środowiska szkolnego i doskonalenia zawodowego nauczycieli wymaga od wszystkich zainteresowanych stron, by uwierzyły w stwierdzenie: „Nie ma ryzyka, nie ma uczenia się" i powtarzały je jak mantrę. 


\section{Bibliografia}

$\rightarrow$ Ball, S. (2013), The Education Debate, Bristol: Policy Press.

$\rightarrow$ Baumfield, V., Hall, E. \& Wall, K. (2013), Action Research in Education, London: Sage.

$\rightarrow$ Biesta, G. (2011), Good Education in an Age of Measurement: Ethics, politics, democracy, Boulder: Paradigm.

$\rightarrow$ Blackler, F. (1995), Knowledge, knowledge work and organizations: An overview and interpretation, Organization Studies, 16(6), 1021-104.

$\rightarrow$ Blasé, J., Blasé, J. (1999), Principals' instructional leadership and teacher development: Teachers' perspectives, Educational Administration Quarterly 35(3), 349-378.

$\rightarrow$ Bolam, R., McMahon, A., Stoll, L., Thomas, S., Wallace, M. (2005), Creating and Sustaining Professional Learning Communities. Department for Education and Skills Research Report 637. Retrieved on 04 October 2017 from http://dera.ioe. ac.uk/5622/1/RR637.pdf

$\rightarrow$ Borko, H., Jacobs, J., Eitljorg, E., Pittman, M.E. (2008), Video as a tool for fostering productive discussions in mathematics professional development, Teaching and Teacher Education, 24(2), 417-436.

$\rightarrow$ Boyd, P. (2014), Learning Conversations: teacher researchers evaluating dialogic strategies in early years settings, International Journal of Early Years Education, 22(4), 441-456.

$\rightarrow$ Boyd, P., Bloxham, S. (2014), A situative metaphor for teacher learning: the case of university tutors learning to grade student coursework, British Educational Research Journal, 40(2), 337-352.

$\rightarrow$ Boyd, P., Cox, E., Curtis, L., Doyle, K., Guy, E., Leslie, P., O'Connor, F., Roberts, L., Surrey, C., Wilson, J. (2015), Learning Conversations Teacher Toolkit: Developing practice in early years through practitioner inquiry, Liverpool: Everton Nursery School and Family Centre. 
$\rightarrow$ Boyd, P., Hymer, B., Lockney, K. (2015), Learning Teaching: Becoming an inspirational teacher, St Albans: Critical Publishing.

$\rightarrow$ Brown, J.S., Duguid, P. (1991), Organizational learning and communities of practice: towards a unified view of working, learning and innovation, Organization Science, 2(1), 40-57.

$\rightarrow$ Boyd, P., White, E. (2017), Teacher and Teacher Educator Professional Inquiry in an Age of Accountability [w:] P. Boyd, A. Szplit (Eds.), Teachers and Teacher Educators Learning Through Inquiry: International Perspectives, Retrieved on 08 October 2017 from: https://goo.gl/RtPwQ5

$\rightarrow$ Cherrington, S., Loveridge, J. (2014), Using video to promote early childhood teachers' thinking and reflection, Teaching and Teacher Education, 41, 42-51.

$\rightarrow$ Cochran-Smith, M., Lytle, (2009), Inquiry as Stance: Practitioner Research for the Next Generation, New York: Teachers College Press.

$\rightarrow$ Daniels, H., Edwards, A. (2012), Leading for Learning: How the intelligent leader builds capacity, Nottingham: National College for School Leadership.

$\rightarrow$ Day, C., Smethem, L. (2009), The effects of reform: Have teachers really lost their sense of professionalism?, Journal of Educational Change, 10, 141-157.

$\rightarrow$ D'Innocenzo L., Mathieu, J.E., Kukenberger, M.R. (2014), A meta-analysis of different forms of shared leadership - team performance relations, Journal of Management. Retrieved on 08 October 2017 from: DOI 10.1177/0149206314525205

$\rightarrow$ Education Endowment Fund (EEF) (2017), Teaching and Learning Toolkit: An accessible summary of the international evidence on teaching 5-16 year-olds, Retrieved on 08 October 2017 from: https://educationendowmentfoundation. org.uk/resources/teaching-learning-toolkit

$\rightarrow$ Exley, S., Ball, S. (2013), Neoliberalism and Education in England [w:] D.A. Turner, H. Yolcu (Eds.), Neo-Liberal Reforms: A Critical Analysis, s. 13-31, London: Routledge.

$\rightarrow$ Fenwick, T. (2001), Questioning the Concept of the Learning Organisation [w:] C. Paechter, M, Preedy, D., Scott, J. Soler (Eds.), Knowledge, Power and Learning, s. 74-88, London: Paul Chapman.

$\rightarrow$ Foucault, M. (1972), The Archaeology of Knowledge, London: Tavistock.

$\rightarrow$ Hammersley, M. (1997), Educational Research and Teaching: A response to David Hargreaves' TTA lecture, British Educational Research Journal, 23(2), 141-161.

$\rightarrow$ Haslam, S.A., Reicher, S.D., Platow, M.J. (2011), The New Psychology of Leadership: Identity, influence and power, New York: Psychology Press.

$\rightarrow$ Heffernan, M. (2011), Wilful Blindness: Why We Ignore the Obvious at Our Peril, London: Simon \& Schuster. 
$\rightarrow$ Kalman, M., Arslan, M.C. (2016), School principals' evaluations of their instructional leadership behaviours: realities vs. ideals. School Leadership \& Management, 36(5), 508-530.

$\rightarrow$ Kemmis, S. (2006), Participatory action research and the public sphere, Educational Action Research, 14(94), 459-476.

$\rightarrow$ Kleinknecht, M., Schneider, J. (2013), What do teachers think and feel when analyzing videos of themselves and other teachers teaching?, Teaching and Teacher Education, 33, 13-23.

$\rightarrow$ Lave, J., Wenger, E. (1991), Situated Learning, Cambridge: Cambridge University Press.

$\rightarrow$ Levin, B. (2011), Theory, research and practice in mobilizing research knowledge in education, London Review of Education, 9(1), 15-26.

$\rightarrow$ Levin, B. (2013), To know is not enough: research knowledge and its use, Review of Education, 1(1), 2-31.

$\rightarrow$ Lyle, J. (2003), Stimulated Recall: A report on its use in naturalistic research, British Educational Research Journal, 29(6), 861-878.

$\rightarrow$ Niesche, R. (2015), Governmentality and my school: school principals in societies of control, Educational Philosophy and Theory, 47(2), 133-145.

$\rightarrow$ Nowotny, H. Scott, P., Gibbons, M. (2001), Rethinking Science: Knowledge and the public in an age of uncertainty, Cambridge: Polity Press.

$\rightarrow$ Nutley, S., Jung, T., Walter, I. (2008), The many forms of research-informed practice: A framework for mapping diversity, Cambridge Journal of Education, 38(1), 53-71.

$\rightarrow$ Oancea, A. (2005), Criticisms of educational research: Key topics and levels of analysis, British Educational Research Journal, 31(2), 157-183.

$\rightarrow$ Osipova, A., Prichard, B., Boardman, A.G., Kiely, M.T., Carroll, P. (2011), Refocusing the Lens: enhancing elementary special education reading instruction through video self-reflection, Learning Disabilities Research \& Practice, 26(3), 158-171.

$\rightarrow$ Philpott, C. (2017), Medical models for teachers' learning: asking for a second opinion. Journal of Education for Teaching, 43(1), 20-31.

$\rightarrow$ Ponte, P. (2007), Action research, pedagogy and human development [w:] A. Campbell, S. Groundwater-Smith (Eds.), An Ethical Approach to Practitioner Research, s. 144-161, New York: Routledge.

$\rightarrow$ Southworth, G. (2002), Instructional leadership in schools: reflections and empirical evidence, School Leadership \& Management, 22(1), 73-91.

$\rightarrow$ Teacher Development Trust (TDT) (2015), Developing Great Teaching, Retrieved on 08 October 2017 from: http://tdtrust.org/about/dgt 
$\rightarrow$ Terosky, A.L. (2016), Enacting instructional leadership: perspectives and actions of public K-12 principals, School Leadership \& Management, 36(3), 311-332.

$\rightarrow$ Tizard, B., Hughes, M. (1984), Young Children learning: Talking and Thinking at Home and at School, London: Fontana.

$\rightarrow$ Turner, J.C. (2005), Explaining the nature of power: a three-process theory, European Journal of Social Psychology, 35, 1-22.

$\rightarrow$ Watson, C. (2014), Effective professional learning communities? The possibilities for teachers as agents of change in schools, British Educational Research Journal, 40(1), 18-29.

$\rightarrow$ Wenger, E. (1998), Communities of Practice: Learning, meaning, and identity, Cambridge: Cambridge University Press. 


\section{Przywództwo nauczycieli na Ukrainie. Rola nauczycieli w zarządzaniu szkołą i rozwoju zawodowym}

Oksana Zabolotna, Svitlana Shchudlo, Olena Kovalchuk

W artykule przedstawiono obecną sytuację przywództwa edukacyjnego nauczycieli na Ukrainie. Autorki skupiają się na powiązaniach pomiędzy przywództwem nauczycieli a autonomią szkoły oraz pomiędzy kształtowaniem kultury szkoły a rozwojem zawodowym nauczycieli. Rozwój zawodowy odnosi się do działań, które sprzyjają rozwijaniu umiejętności i wiedzy w kontekście dążenia do osiągnięcia zasadniczego celu, jakim jest wzmacnianie przywództwa nauczycieli. Prezentowane tutaj badania, przeprowadzone przez Ukraińskie Stowarzyszenie Badań Edukacyjnych, stanowią część Ogólnoukraińskich Badań Kwestionariuszowych Nauczycieli i Dyrektorów Szkół Średnich z wykorzystaniem metodologii badania TALIS. Badania te były realizowane przez ukraińską fundację pn. "Krok po kroku" przy wsparciu Ministerstwa Edukacji i Nauki na Ukrainie i organizacji Porticus w ramach szeroko zakrojonego projektu "Reforma Edukacyjna: Ocena jakości w kontekście międzynarodowym". W celach porównawczych wykorzystano średnie wyniki z badania TALIS 2013. W końcowej części artykułu zamieszczono omówienie wyników badań, które może być użyteczne dla osób odpowiedzialnych za tworzenie polityki, przywódców szkolnych i nauczycieli. Zebrane dane ukazują złożoność przywództwa edukacyjnego nauczycieli i jednocześnie siłę wpływu tego zjawiska na wszystkie aspekty życia szkoły. 


\title{
Teacher leadership in Ukraine. The role of teachers in school management and professional development
}

\author{
Oksana Zabolotna, Svitlana Shchudlo, Olena Kovalchuk
}

This article presents the current situation with teacher leadership in Ukraine. The authors focus on the connection of teacher leadership with shool autonomy, forming school culture and professional development experiences of teachers. Professional development refers to activities that advance teachers' skills and knowledge, with the ultimate aim of fostering teacher leadership. The presented research was based on the results of the All-Ukrainian Monitoring Survey of Secondary School Teachers and Principals with the use of TALIS methodology. Research was conducted by the Ukrainian Educational Research Association. The monitoring survey was a part of the Teacher Project within the big scale project "Educational Reform: Quality Assessment in the International Context" realized by Ukrainian Step by Step Foundation with the support of Ministry of Education and Science of Ukraine and Porticus. For comparison, the average data of the international TALIS 2013 survey was given. The article concludes with a discussion useful for policy makers, school leaders and teachers. The material demonstrates how complex teacher leadership is and how powerfully it can influence all the aspects of school life.

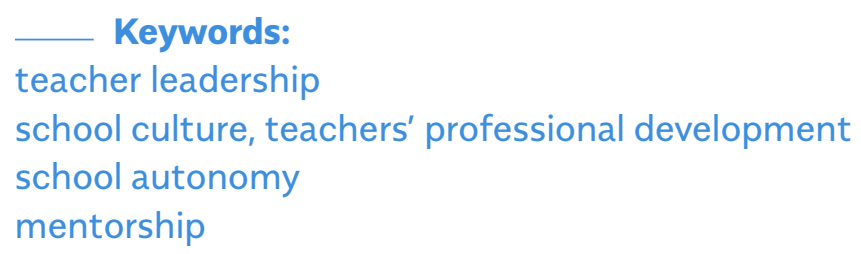




\section{Pojmowanie przywództwa edukacyjnego nauczycieli w ukraińskich szkołach średnich oraz ujęcie tego tematu w badaniach}

W dobie szybkich zmian, jakie zachodzą obecnie w świecie, zarówno społeczeństwa, jak i jednostki stają w obliczu nowych wyzwań wynikających z procesów modernizacji i globalizacji. Być może największym dylematem, przed którym stoją edukatorzy w XXI wieku, jest nowe zapotrzebowanie na umiejętności i wiedzę, jakie sami nauczyciele muszą nabyć, aby móc nauczać swoich uczniów w sposób efektywny. Właściwie w nowym świecie digitalizacji, automatyzacji i outsourcingu wysokie wymagania edukacyjne w zakresie pracy i życia codziennego wymagają od nauczycieli, by byli wysoko wykwalifikowanymi pracownikami, doskonalącymi swoje kompetencje zawodowe, jak również demonstrowali swoje umiejętności przywódcze. Ukraińscy nauczyciele starają się dostosować do zmian zainicjowanych w nowej "Ustawie o edukacji”. Ustanawia ona wyższe wymagania dotyczące zawodu nauczyciela oraz doskonalenia zawodowego w perspektywie uczenia się przez całe życie (Supreme Soviet of Ukraine, 2017).

Przegląd literatury dotyczącej tego zagadnienia pokazuje różnorodne koncepcje i praktyki w zakresie przywództwa edukacyjnego nauczycieli w okresie ostatnich dwudziestu lat (Lyniov, 2016). Obejmuje on wiele prowadzonych na małą skalę badań jakościowych, które opisują wymiary przywództwa edukacyjnego nauczycieli w praktyce, cechy charakterystyczne i warunki sprawowania przywództwa, które zarazem promują i podważają przywództwo edukacyjne nauczycieli. Jednakże badania dotyczące przywództwa edukacyjnego nauczycieli opisane w ukraińskiej literaturze przedmiotu różnią się od opisu tego zjawiska z perspektywy międzynarodowej.

W ukraińskich szkołach średnich przywództwo edukacyjne nauczycieli jest postrzegane głównie jako formalne zarządzanie pracownikami szkoły $i$ jest reprezentowane w osobach dyrektora i wicedyrektora danej placówki (Shchudlo, Kovalchuk, 2014). Takie ujęcie tego zagadnienia nie obejmuje przywództwa edukacyjnego nauczycieli. Większość przeprowadzonych na Ukrainie badań dotyczyła efektywnego zarządzania szkołą i jedynie kilka z nich koncentrowało się na nauczycielach, którzy nie wchodzą w skład oficjalnego zespołu administracyjnego. Może to prowadzić do konkluzji, że role nauczycieli oraz ich wpływ na różne aspekty życia szkoły są niedoceniane. Zagadnienia badane obecnie na 
Ukrainie w pewnym stopniu przypominają zjawiska, które były przedmiotem międzynarodowych badań w latach osiemdziesiątych XX wieku. Skupiają się one wokół takich tematów, jak: rozwój cech związanych z przywództwem edukacyjnym nauczycieli, gdzie nauczyciel postrzegany jest jako przywódca w relacjach nauczyciel-uczeń lub nauczyciel-klasa w edukacji. Na przykład, N. Semchenko i N. Marahovska analizowali uwarunkowania pedagogiczne, które pomagają przyszłym nauczycielom w nabywaniu i rozwijaniu ich umiejętności przywódczych w czasie zajęć pozalekcyjnych (Semchenko, 2005; Marahovska, 2009). D. Zerbino podjął próbę opisania umiejętności badawczych nauczyciela - przywódcy oraz relacji nauczyciel-uczeń w tym kontekście. Aby stać się skutecznym przywódcą naukowym, nauczyciel musi tworzyć nowe idee (Zerbino, 2011), być skoncentrowanym kulturowo (Moskovets, 2012) oraz kompetentnym zawodowo (Osovska, 2012). Inną cechą skutecznego nauczyciela przywódcy jest umiejętność działania w charakterze facylitatora, która nie tylko pozwala przyciągać ludzi, wspierać ich i inspirować, ale również przewodzić im dzięki sile argumentów i perswazji (Zavalevsky, 2008).

Joellen Killion i Cindy Harrison w swojej książce pt.: Taking the Lead: New Roles for Teachers and School-Based Coaches definiują dziesięć głównych ról nauczycieli-liderów: osoba odpowiedzialna za zapewnienie zasobów, specjalista w zakresie nauczania, specjalista w dziedzinie programu nauczania, osoba wspierająca klasę szkolną, facylitator uczenia się, mentor, przywódca w szkole, opiekun danych, katalizator zmian, osoba ucząca się (Killion, Harrison, 2006).

Wymienione wyżej role pokazują, jak złożone jest przywództwo edukacyjne nauczycieli i jak silnie może wpływać na wszystkie aspekty życia szkoły. W niniejszym artykule nauczyciele liderzy postrzegani są przez pryzmat ich zdolności do wywierania wpływu na kulturę szkoły oraz rozwój zawodowy nauczycieli.

\section{Kontekst ukraiński: nauczyciele i szkoły, w których pracują}

Aby zrozumieć, co oznacza przywództwo edukacyjne nauczycieli na Ukrainie, bardzo ważne jest, by czytelnik uzyskał pełen obraz ukraińskiej edukacji reprezentowanej przez nauczycieli i szkoły, w których pracują. Tabela 1. przedstawia profil nauczycieli ukraińskich z uwzględnieniem podziału według płci, wieku, doświadczenia zawodowego, poziomu wykształcenia oraz specjalistycznych szkoleń. Podane poniżej dane 
pochodzą z raportu przygotowanego dla Ministerstwa Edukacji Ukrainy przez Ukraińskie Stowarzyszenie Badań Edukacyjnych (Shchudlo, Zabolotna, Lisova, 2017).

\section{Profil nauczycieli}

Jeśli chodzi o rozkład płci wśród ukraińskich nauczycieli, to $84 \%$ z nich stanowią kobiety. $\mathrm{W}$ ujęciu regionalnym podział procentowy waha się od $76,7 \%$ kobiet nauczycieli pracujących w centralnej części Ukrainy, do $87,7 \%$ w stolicy.

Średni wiek nauczycieli pracujących w ukraińskich szkołach średnich to 44,7 lat. Większości ukraińskich nauczycieli mieści się w przedziale wiekowym 40-49 lat (29\%). Ponad $12 \%$ ukraińskich nauczycieli ma ponad 60 lat, przy czym najstarsi nauczyciele pracują w stolicy.

Jeśli chodzi o doświadczenie zawodowe, to, średnio, ukraińscy nauczyciele mają za sobą 21,7 lat pracy. Co więcej, średnio, ukraińscy nauczyciele pracują w tej samej szkole od 17,8 lat, co wskazuje na niski poziom mobilności nauczycieli w obrębie systemu edukacji.

$\mathrm{Na}$ Ukrainie 96,3\% nauczycieli posiada tytuł zawodowy licencjata lub wyższy (specjalista, magister lub kandydat nauk). Jednakże procent nauczycieli, którzy posiadają stopień kandydata nauk, doktora lub habilitację jest stosunkowo niski $(0,2 \%)$.

Wysoki odsetek nauczycieli ukraińskich posiada przygotowanie specjalistyczne do pracy w sektorze edukacji $(98,3 \%)$. Większość nauczycieli twierdzi również, że ich kształcenie zawierało wszystkie następujące elementy: wiedzę dziedzinową z zakresu nauczanego/-ych przedmiotu/-ów (82,5\%), pedagogikę nauczanego/-ych przedmiotu/-ów (82,9\%), praktykę szkolną w zakresie nauczanego/-ych przedmiotu/-ów (79,9\%). Nauczyciele ukraińscy czują się dobrze lub bardzo dobrze przygotowani do wykonywania tych wszystkich zadań. W stolicy procent nauczycieli, którzy nie czują się przygotowani w pewnym stopniu lub w ogóle, jest wyższy niż w innych regionach. Niektórzy nauczyciele, szczególnie nauczyciele przedmiotów artystycznych $(4,3 \%)$, nie byli specjalnie szkoleni do nauczania przedmiotu/-ów, którego/-ych uczą.

\section{Podział procentowy nauczycieli w szkołach ukraińskich}

Innym aspektem ułatwiającym zrozumienie przywództwa edukacyjnego ukraińskich nauczycieli jest ich podział procentowy w szkołach. 
Zgodnie z raportem UERA 7,1\% ukraińskich nauczycieli pracuje w szkołach, gdzie dla ponad 10\% dzieci język ukraiński nie jest językiem ojczystym. Mniej niż 1\% ukraińskich nauczycieli przyznaje, że pracują w szkołach, gdzie więcej niż $10 \%$ uczniów posiada specjalne potrzeby edukacyjne. W porównaniu z innymi krajami dane przekazane przez ukraińskich nauczycieli mogą rodzić pytanie o niewystarczający stopień uwagi poświęcanej diagnozowaniu specjalnych potrzeb edukacyjnych. $64,9 \%$ ukraińskich nauczycieli podaje, że w ich klasach nie ma dzieci ze specjalnymi potrzebami edukacyjnymi. Jednakże 6,5\% ukraińskich nauczycieli pracuje w szkołach, gdzie ponad $30 \%$ dzieci pochodzi z rodzin o niskim dochodzie.

\section{Metodologia badania}

Większość badań edukacyjnych prowadzonych do lat osiemdziesiątych XX wieku. miała charakter pozytywistyczny i dotyczyła opisu stanowisk administracyjnych oraz cech osobowych. Jednakże nie odkrywała związków pomiędzy przywództwem a kulturą szkoły, przywództwem a rozwojem zawodowym lub bardziej ogólnie rozumianym przywództwem. W rezultacie w naszych badaniach przechodzimy od skutków bezpośrednich do skutków pośrednich i efektów poprzedzających. Zastosowaliśmy wielowymiarową analizę danych, która umożliwia skonstruowanie modelu skutków w ramach modelu przywództwa edukacyjnego nauczycieli. Ten naukowy statystyczny obraz wpływu nauczycieli liderów na kulturę szkoły i rozwój zawodowy nauczycieli pozwolił na wyciagnięcie istotnych wniosków dotyczących skutecznego przywództwa.

Podstawą badania były rezultaty Ogólnoukraińskiego badania monitorującego/kwestionariuszowego nauczycieli i dyrektorów szkół średnich (opartego na metodologii badania TALIS) przeprowadzonego przez Ukraińskie Stowarzyszenie Badań Edukacyjnych z zastosowaniem kwestionariuszy skierowanych do nauczycieli i dyrektorów szkół wykorzystanych w realizowanym przez OECD w roku 2013 Międzynarodowym badaniu w zakresie nauczania i uczenia się (ang. Teaching and Learning International Survey - TALIS).

Badanie monitorujące stanowiło część inicjatywy pt.: Projekt Nauczyciel (ang. The Teacher Project) realizowanego w ramach zakrojonego na dużą skalę projektu pt.: Reformy edukacyjne: Ocena jakości w kontekście międzynarodowym (ang.: Educational Reform: Quality 
Assessment in the International Context) prowadzonego przez Ukraińską Fundację "Krok po Kroku" przy wsparciu Ministerstwa Edukacji i Nauki Ukrainy i organizacji „Porticus". Projekt realizowany był pod kierunkiem prof. Svitlany Shchudlo, a koordynowany był przez prof. Oksanę Zabolotną i doc. Tetianę Lisovą.

Dwie pierwsze edycje Badania w zakresie nauczania i uczenia się (TALIS) przeprowadzone były przez OECD w latach 2008 i 2013. Ukraina nie uczestniczyła $w$ tych edycjach badania TALIS ani w roku 2008, ani 2013; nie będzie też brać udziału w nowej edycji w roku 2018. Pozbawia to Ukrainę wartościowych danych, które mogłyby przyczynić się do zrozumienia obecnej sytuacji dzięki porównaniu danych otrzymanych z UE i innych krajów. Mając powyższe na uwadze, Ukraińskie Stowarzyszenie Badań Edukacyjnych otrzymało z OECD zgodę na wykorzystanie kwestionariuszy badania TALIS 2013 Dyrektorzy szkół i nauczyciele w celu przeprowadzenia na Ukrainie badania wzorowanego na badaniu TALIS.

Ogólnoukraińskie badanie miało na celu pozyskanie porównywalnych danych dotyczących charakterystyki społecznej, demograficznej i zawodowej nauczycieli oraz środowiska szkolnego. Dane powinny być wykorzystane do sformułowania odpowiedzi na następujące pytania badawcze:

$\rightarrow$ Jakie są powiązania pomiędzy autonomią szkoły a przywództwem edukacyjnym nauczycieli na Ukrainie?

$\rightarrow$ Jaką rolę odgrywają nauczyciele liderzy w kształtowaniu kultury szkoły?

$\rightarrow$ W jakim stopniu programy doskonalenia zawodowego nauczycieli wspierają przywództwo edukacyjne nauczycieli?

Ukraińskie Stowarzyszenie Badań Edukacyjnych prowadziło to badanie od lutego do sierpnia 2017 r. Populacja badanych szkół obejmowała 201 dyrektorów z 201 szkół oraz 3600 nauczycieli (ISCED 2). Badanie było prowadzone we wszystkich regionach Ukrainy z wyjątkiem Krymu oraz terytoriów objętych konfliktem. W badaniu wykorzystano dwuetapowy wzór doboru próby (S.E. - 1,6\%, wskaźnik uczestnictwa nauczycieli - 97\%). Uczestnicy wypełniali kwestionariusze w wersji papierowej.

W celu pokazania tego zagadnienia w ujęciu komparatystycznym autorzy wykorzystali rezultaty ogólnoukraińskiego monitoring prze- 
prowadzonego przez UERA w roku 2017 oraz wyniki badania TALIS przeprowadzonego przez OECD w 2013 r.

\section{Wyniki badania}

\section{Wzajemne powiązania między autonomią szkoły a przywództwem edukacyjnym nauczycieli}

Kwestionariusz badania TALIS skierowany do dyrektorów szkół (OECD, 2014a) zawierał pytania dotyczące stopnia autonomii szkół oraz pytania dotyczące odpowiedzialności za podejmowanie niektórych decyzji na poziomie szkoły (dyrektor, księgowy, szefowie wydziałów, nauczyciele, przedstawiciel/e szkoły, rodzice lub opiekunowie i uczniowie).

Jak pokazały wyniki badania TALIS 2013, w niektórych sferach szkoły mogą być bardziej autonomiczne, a w innych mniej. Na przykład mogą mieć prawo do mianowania nauczycieli, ale nie mogą ustalać ich wyjściowych wynagrodzeń, w tym siatek płac etc. Mogą mieć różny stopień wpływu na: kształtowanie zasad i procedur dotyczących dyscypliny uczniów, wybór materiałów dydaktycznych, opracowywanie treści programowych etc. Szkoły w większości europejskich systemów oświaty cieszą się coraz większą autonomią; jednakże nie ma wielu badań dotyczących wzajemnych powiązań między autonomią szkoły a przywództwem edukacyjnym nauczycieli.

Tabela 1. pokazuje podział procentowy nauczycieli w szkołach, gdzie, zgodnie z odpowiedziami udzielonymi przez dyrektorów tych szkół, to szkoły ponoszą kluczową odpowiedzialność za podejmowanie decyzji w zakresie niektórych aspektów. Ponieważ wywieranie wpływu stanowi sedno przywództwa edukacyjnego nauczycieli, ważne jest, aby poznać ich zdolność do wpływania na różne aspekty życia szkoły. 
Tabela 1. Podział procentowy nauczycieli w szkołach, które-zgodnie z odpowiedziami udzielonymi przez ich dyrektorów - ponoszą kluczową odpowiedzialność za podejmowanie decyzji w zakresie niektórych aspektów

\begin{tabular}{|c|c|c|c|}
\hline \multirow{2}{*}{ ZADANIA } & \multicolumn{2}{|c|}{$\begin{array}{c}\text { ODPOWIEDZIALNOŚĆ SZKOŁY (WSZYSTKIE } \\
\text { OSOBY DECYZYJNE W SZKOLE, W TYM } \\
\text { NAUCZYCIELE) }\end{array}$} & \multirow{2}{*}{$\begin{array}{c}\text { ODPOWIEDZIALNOŚĆ } \\
\text { NAUCZYCIELI } \\
\begin{array}{c}\text { ŚREDNIA Z BADANIA } \\
\text { NA UKRAINIE }\end{array}\end{array}$} \\
\hline & $\begin{array}{l}\text { ŚREDNIA Z BADANIA } \\
\text { NA UKRAINIE }\end{array}$ & $\begin{array}{c}\text { ŚREDNIA Z BADANIA } \\
\text { TALIS }\end{array}$ & \\
\hline $\begin{array}{l}\text { Mianowanie lub } \\
\text { zatrudnianie nauczycieli }\end{array}$ & 65,7 & 74,7 & 1,2 \\
\hline $\begin{array}{l}\text { Zwalnianie lub } \\
\text { zawieszanie nauczycieli }\end{array}$ & 54,1 & 68,4 & 3,0 \\
\hline $\begin{array}{l}\text { Ustalanie wyjściowych } \\
\text { wynagrodzeń nauczycieli, } \\
\text { w tym ustalanie siatki płac }\end{array}$ & 23,5 & 35,9 & 1,2 \\
\hline $\begin{array}{l}\text { Ustalanie podwyżek } \\
\text { wynagrodzenia nauczycieli }\end{array}$ & 20,3 & 37,1 & 4,2 \\
\hline $\begin{array}{l}\text { Decydowanie o podziale } \\
\text { budżetu w ramach szkoły }\end{array}$ & 45,4 & 82,5 & 5,5 \\
\hline $\begin{array}{l}\text { Określanie zasad } \\
\text { i procedur dotyczących } \\
\text { dyscypliny uczniów }\end{array}$ & 98,8 & 95,8 & 50,9 \\
\hline $\begin{array}{l}\text { Określanie zasad } \\
\text { oceny uczniów, } \\
\text { z uwzględnieniem praktyk } \\
\text { krajowych/regionalnych }\end{array}$ & 75,1 & 79,1 & 50,3 \\
\hline $\begin{array}{l}\text { Wybór wykorzystywanych } \\
\text { materiałów } \\
\text { dydaktycznych }\end{array}$ & 100,0 & 81,2 & 2,4 \\
\hline $\begin{array}{l}\text { Opracowywanie } \\
\text { treści nauczania } \\
\text { z uwzględnieniem } \\
\text { krajowych/regionalnych } \\
\text { programów nauczania }\end{array}$ & 94,0 & 94,0 & 88,5 \\
\hline $\begin{array}{l}\text { Decydowanie o ofercie } \\
\text { programowej }\end{array}$ & 86,9 & 64,6 & 68,5 \\
\hline
\end{tabular}

Źródło: OECD, 2014a; Baza danych UERA, 2017 r. 
Z badania jasno wynika, że wszyscy ukraińscy nauczyciele pracują w szkołach, gdzie decyzje dotyczące przyjęcia uczniów do danej szkoły leżą w gestii szkoły (średnia badania TALIS 2013 wynosi 81,2\%). Prawie wszystkie ukraińskie szkoły $(98,8 \%)$ cieszą się swobodą w opracowaniu zasad i procedur dotyczących dyscypliny uczniów (średnia badania TALIS 2013 to $95,8 \%$ ). 94\% ukraińskich nauczycieli pracuje w szkołach, które posiadają prawo wyboru materiałów dydaktycznych (wyniki badania TALIS 2013 są podobne). Opracowywanie zasad oceny uczniów oraz treści programowych również należy do decyzji szkół, które są miejscem pracy $75 \%$ ukraińskich nauczycieli.

Jednakże mniej niż 40\% nauczycieli uczestniczących w badaniu TALIS 2013 pracuje w szkołach, które mogą wpływać na sprawy finansowe dotyczące ustalania wyjściowych pensji nauczycieli, podwyżek wynagrodzeń i alokacji budżetu w ramach szkoły. Na Ukrainie wyniki badania wskazują nawet mniejszy wpływ na zagadnienia finansowe, biorąc pod uwagę fakt, że jedynie $23,5 \%$ nauczycieli pracuje w szkołach, które mają wpływ na ustalanie wyjściowych pensji nauczycieli, 20,3\% nauczycieli jest zatrudnionych w szkołach, które mają wpływ na określanie wysokości podwyżek wynagrodzeń.

Zgodnie z niektórymi odpowiedziami dyrektorów szkół udzielonymi w ramach badania TALIS 2013, w niektórych krajach (Republice Czeskiej, Estonii, Holandii, na Słowacji i w Zjednoczonym Królestwie) szkoły cieszą się dużą autonomią w większości obszarów. Na Ukrainie jednakże szkoły mają ograniczoną autonomię. Poprzez ograniczoną autonomię rozumiemy zdolność szkoły do ponoszenia odpowiedzialności, chyba że podejmowane decyzje mają wpływ na zagadnienia finansowe.

Biorąc pod uwagę obecną sytuację w zakresie autonomii szkół na Ukrainie, powinniśmy pamiętać, że sfera odpowiedzialności nauczycieli zależy od obszaru odpowiedzialności szkoły. W związku z tym, że odpowiedzialność w szkole jest podzielona pomiędzy dyrektora, księgowego, szefów wydziałów, rodziców i nauczycieli, sfera odpowiedzialności tych ostatnich jest dużo węższa niż odpowiedzialność ponoszona przez szkołę.

Przedstawione dowody prowadzą do logicznej konkluzji, że ukraińscy nauczyciele nie mają wystarczającego wpływu na politykę edukacyjną, szkolną administrację, standardy państwowe i inne zagadnienia. 


\section{Rola nauczycieli liderów w kształtowaniu kultury szkoły}

W artykułach i książkach naukowych można znaleźć wiele różnych opisów kultury szkoły. Niektóre publikacje koncentrują się na kulturze szkoły, która przyczynia się do rozkwitu przywództwa edukacyjnego nauczycieli. Autorzy opinii w nich zawartych zgodnie przyznają, że produktywna w tym zakresie kultura szkoły powinna czerpać ze środowiska kolegialnego, być zorientowana na rozwiązywanie problemów, opierać się na zaufaniu i jasnej komunikacji (Educator Effectiveness, 2015). Prowadzono badania dotyczące roli nauczycieli liderów w kształtowaniu kultury szkoły. Na przykład w badaniu opisanym przez Roby'ego wyciągnięto następujące wnioski: „Zainicjowanie otwartego dialogu w celu zajęcia się kluczowymi zagadnieniami, które zostały potwierdzone przez rezultaty badania, umożliwiłoby nauczycielom liderom zmianę negatywnych aspektów kultury szkoły. Budowanie zaufania, zarządzanie zmianą oraz wzmocnienie relacji pomiędzy edukatorami w miejscu pracy stanowią kluczowe elementy, którymi, zgodnie z wynikami badania, powinni zająć się nauczyciele liderzy i administracja szkoły" (Roby, 2017).

Część kwestionariuszy badania TALIS 2013 skierowanych do dyrektorów szkół i nauczycieli (OECD, 2014a; OECD, 2014b) zawierała pytania dotyczące przywództwa rozproszonego, czyli sposobu, w jaki delegowane są obowiązki. W celu uzyskania informacji w kwestionariuszu poproszono zarówno dyrektorów, jak i nauczycieli, o udzielenie odpowiedzi, w jakim stopniu zgadzają się z następującymi twierdzeniami:

$\rightarrow$ Szkoła umożliwia kadrze aktywne uczestnictwo w podejmowaniu decyzji dotyczących szkoły.

$\rightarrow$ W szkole istnieje kultura podziału odpowiedzialności za sprawy szkoły.

$\rightarrow$ W szkole istnieje kultura współpracy, którą charakteryzuje wzajemne wsparcie.

Tabela 2. zawiera informacje, które mogą być wykorzystane do dokonania porównania podejść stosowanych w odniesieniu do tych samych zagadnień z punktu widzenia dyrektorów szkół i nauczycieli. 
Tabela 2. Decyzje dotyczące szkoły i kultura szkoły oparta na współpracy: procent dyrektorów szkół i nauczycieli, którzy „zdecydowanie nie zgadzajq się”, „nie zgadzajq̨ się', „zgadzaja się” lub „zdecydowanie zgadzają się" z następującymi twierdzeniami na temat swoich szkół

\begin{tabular}{|c|c|c|c|c|c|}
\hline & & $\begin{array}{c}\text { UKRAIŃSCY } \\
\text { DYREKTORZY } \\
\text { SZKÓt }\end{array}$ & $\begin{array}{c}\text { DYREKTORZY } \\
\text { SZKÓ } \text { (ŚREDNIA } \\
\text { Z BADANIA } \\
\text { TALIS) }\end{array}$ & $\begin{array}{l}\text { UKRAIŃSCY } \\
\text { NAUCZYCIELE }\end{array}$ & $\begin{array}{c}\text { NAUCZYCIELE } \\
\text { (ŚREDNIA } \\
\text { Z BADANIA TALIS) }\end{array}$ \\
\hline \multirow{4}{*}{$\begin{array}{l}\text { Szkoła umożliwia } \\
\text { kadrze aktywne } \\
\text { uczestnictwo } \\
\text { w podejmowaniu } \\
\text { decyzji } \\
\text { dotyczących } \\
\text { szkoły }\end{array}$} & $\begin{array}{l}\text { Zdecydowanie } \\
\text { nie zgadzam się }\end{array}$ & 3,5 & 0,3 & 2,9 & 6,3 \\
\hline & Nie zgadzam się & 0,0 & 1,8 & 13,6 & 20,4 \\
\hline & Zgadzam się & 70,6 & 64,6 & 67,8 & 61,9 \\
\hline & $\begin{array}{l}\text { Zdecydowanie } \\
\text { zgadzam się }\end{array}$ & 25,9 & 33,2 & 15,6 & 11,4 \\
\hline \multirow{4}{*}{$\begin{array}{l}\text { Samodzielnie } \\
\text { podejmuję ważne } \\
\text { decyzje }\end{array}$} & $\begin{array}{l}\text { Zdecydowanie } \\
\text { nie zgadzam się }\end{array}$ & 10,4 & 18,3 & - & - \\
\hline & Nie zgadzam się & 62,2 & 47,1 & - & - \\
\hline & Zgadzam się & 23,9 & 28 & - & - \\
\hline & $\begin{array}{l}\text { Zdecydowanie } \\
\text { zgadzam się }\end{array}$ & 3,5 & 6,6 & - & - \\
\hline \multirow{4}{*}{$\begin{array}{l}\text { W szkole } \\
\text { istnieje kultura } \\
\text { współdzielonej } \\
\text { odpowiedzialności } \\
\text { za sprawy szkoły }\end{array}$} & $\begin{array}{l}\text { Zdecydowanie } \\
\text { nie zgadzam się }\end{array}$ & - & - & 2,0 & 4,4 \\
\hline & Nie zgadzam się & - & - & 10,7 & 21,1 \\
\hline & Zgadzam się & - & - & 69,4 & 62,8 \\
\hline & $\begin{array}{l}\text { Zdecydowanie } \\
\text { zgadzam się }\end{array}$ & - & - & 18,0 & 11,7 \\
\hline \multirow{4}{*}{$\begin{array}{l}\text { W szkole } \\
\text { istnieje kultura } \\
\text { współpracy, którą } \\
\text { charakteryzuje } \\
\text { wzajemne } \\
\text { wsparcie }\end{array}$} & $\begin{array}{l}\text { Zdecydowanie } \\
\text { nie zgadzam się }\end{array}$ & 2,0 & 0,5 & 1,8 & 4,3 \\
\hline & Nie zgadzam się & 11,0 & 4,3 & 9,5 & 18,3 \\
\hline & Zgadzam się & 72,0 & 62,7 & 67,9 & 62,1 \\
\hline & $\begin{array}{l}\text { Zdecydowanie } \\
\text { zgadzam się }\end{array}$ & 15,0 & 32,5 & 20,8 & 15,3 \\
\hline
\end{tabular}

"-“ kwestionariusz nie zawierał tego pytania

Źródło: OECD, 2014a; Baza danych UERA, 2017 r.

Jak wynika z tabeli 2., większość ukraińskich dyrektorów szkół, jak również dyrektorów biorących udział w badaniu TALIS 2013, uważa, 
że w ich szkołach istnieje kultura współpracy, którą charakteryzuje wzajemne wsparcie $(87 \%$ i $95,2 \%)$ oraz że umożliwiają swojej kadrze aktywne uczestnictwo w podejmowaniu decyzji dotyczących szkoły $(96,5 \%$ i $97,8 \%)$.

Jeśli jednak dokonamy porównania odpowiedzi dyrektorów szkół i nauczycieli, zobaczymy, że różnią się one w pewnym sensie pod względem opisu kultury szkoły. Na przykład 33,2\% badanych dyrektorów szkół zdecydowanie twierdzi, że umożliwiają swojej kadrze aktywne uczestnictwo w podejmowaniu decyzji dotyczących szkoły, podczas gdy jedynie $15,6 \%$ nauczycieli podziela ten sam pogląd. Kolejny przykład dotyczy twierdzenia, że w szkole istnieje kultura współpracy, którą charakteryzuje wzajemne wsparcie. Tylko $15 \%$ dyrektorów szkoły potwierdza taki stan rzeczy, podczas gdy 20,8\% nauczycieli wierzy, że jest to prawda. Przykłady te pokazują różne podejścia kierownictwa szkół i nauczycieli do rozumienia tego, czym jest "kultura szkoły oparta na współpracy" oraz ich różne oczekiwania odnośnie tego, co to może dla nich oznaczać. Dyrektorzy szkół mogą uważać, że kultura szkoły oparta na współpracy polega na delegowaniu zadań, podczas gdy w mniemaniu nauczycieli może to oznaczać więcej praw i wolności w podejmowaniu ważnych decyzji.

Inne zagadnienie dotyczy sfery odpowiedzialności nauczycieli. $\mathrm{Na}$ Ukrainie dyrektorzy szkół nie odpowiadają za kadrę i zagadnienia finansowe, natomiast nauczyciele są głównie odpowiedzialni za nauczanie. Takie podejście pozbawia nauczycieli możliwości sprawowania przywództwa w ramach odgrywania innych ról w obszarach wykraczających poza nauczanie.

\section{Nauczyciele liderzy i ich wpływ na rozwój zawodowy nauczycieli}

Ponieważ główną cechą nauczycieli liderów jest ich zdolność do wpływania na doskonalenie szkoły, ważne jest znalezienie dowodów potwierdzających również ich umiejętność wpływania na rozwój zawodowy nauczycieli. W celu zbadania tego zagadnienia na potrzeby badania TALIS przyjęto szeroką definicję rozwoju zawodowego nauczycieli: "rozwój zawodowy jest definiowany jako działania, które mają na celu rozwój umiejętności, wiedzy, wiedzy fachowej i innych cech jednostki jako nauczyciela" (OECD, 2009, s. 49).

Najbardziej wyraźne sposoby potwierdzenia zdolności nauczycieli do wpływania na rozwój zawodowy przedstawiają się następująco: 
$\rightarrow$ Obecne zaangażowanie nauczycieli w działania związane z mentoringiem

$\rightarrow$ Rozwój zawodowy i wsparcie nauczycieli

$\rightarrow$ Nauczyciele jako ewaluatorzy przekazujący formalną i nieformalną informację zwrotną innym nauczycielom

\section{Obecne zaangażowanie nauczycieli w działania związane z mentoringiem}

Prowadzone były szeroko zakrojone badania nad tym, w jaki sposób mentoring może wpływać na różne aspekty kształcenia i polityki edukacyjnej. Mentoring Leadership and Resource Network to sieć ASCD, która koncentruje się na wspieraniu edukatorów w zakresie mentoringu i programach wprowadzających do zawodu nauczyciela oraz zapewnia dobre praktyki w tym zakresie. Od sześciu lat sieć udziela pomocy i darmowych porad zarówno mentorom, jak i w zakresie programów mentoringu (MLRN: The Mentoring Leadership And Resource Network, 2017).

W literaturze przedmiotu proces mentoringu jest rozumiany na różne sposoby. Koki uważa, że "mentoring jest złożonym i wielowymiarowym procesem prowadzenia, nauczania, wpływania na i wspierania początkującego nauczyciela na początku jego drogi zawodowej. Jest ogólnie przyjętym, że nauczyciel mentor prowadzi, przewodzi i doradza mniej doświadczonemu nauczycielowi w środowisku pracy opartym na wzajemnym zaufaniu i wspólnych przekonaniach" (Koki, 2015, s. 3). Proces mentoringu może być pomocny w wychodzeniu "daleko poza wspieranie programów wprowadzania młodych nauczycieli w system szkolny poprzez doradztwo zawodowe i wsparcie" (tamże). Chodzi tu o przekonania, wartości i przywództwo edukacyjne nauczycieli. Idea ta została udowodniona przez wielu badaczy, według których mentoring jest ściśle powiązany z koncepcją przywództwa szkolnego.

Na Ukrainie mentoring jest bardziej kojarzony z doradztwem zawodowym. Różnice terminologiczne powodowały pewne trudności w wypełnianiu kwestionariusza i wymagały dodatkowych wyjaśnień. W rezultacie odpowiedzi mogą dotyczyć połączenia różnych typów wspierania nauczycieli: tutoringu, mentoringu i coachingu, jako że w ukraińskiej literaturze przedmiotu nie ma różnicy między tymi terminami. Oficjalnie, mentorzy są przydzielani każdemu początkującemu nauczycielowi, czyli nauczycielowi, który pracuje w zawodzie krócej niż trzy lata. Istnieją na 
Ukrainie szkoły, w ramach których funkcjonują formalne Szkoły dla Początkujących Nauczycieli. Są to instytucje prowadzące doradztwo i upowszechniające wiedzę fachową bardziej doświadczonych nauczycieli.

W kwestionariuszu TALIS mentoring jest definiowany jako struktura wsparcia w szkołach, w ramach której bardziej doświadczeni nauczyciele wspierają tych mniej doświadczonych. Struktura ta może obejmować wszystkich nauczycieli lub tylko początkujących. Zgodnie z wynikami badania TALIS 2013 w większości krajów programy mentoringu stają się dominującą formą wprowadzania nauczycieli do zawodu. Mają one na celu ułatwianie startu rozwoju zawodowego nauczycielom rozpoczynającym karierę (oraz szerszej społeczności nauczycielskiej).

Kwestionariusz badania TALIS adresowany do dyrektorów szkół miał na celu zdobycie informacji na temat zaangażowania nauczycieli w programy mentoringu. Jak pokazują odpowiedzi dyrektorów szkół, jedynie 10,8\% ukraińskich nauczycieli pracuje w szkołach, w których nie są obecnie prowadzone takie programy (tabela 3.). W krajach biorących udział w badaniu TALIS 2013 prawie jedna czwarta nauczycieli nie ma dostępu do mentoringu. Istnieją też kraje, w których programy mentoringu w ogóle nie funkcjonują (Chile, Finlandia, Meksyk, Portugalia, Hiszpania), podczas gdy w innych programy mentoringu są dostępne dla szerokiej społeczności nauczycieli (Australia, Chorwacja, Holandia, Zjednoczone Królestwo, Serbia etc.).

Tabela 3. Programy mentoringu w ukraińskich szkołach (\%)

\begin{tabular}{|c|c|c|c|}
\hline & & $\begin{array}{l}\text { ŚREDNIA Z BADANIA } \\
\text { NA UKRAINIE }\end{array}$ & $\begin{array}{l}\text { ŚREDNIA Z BADANIA } \\
\text { TALIS }\end{array}$ \\
\hline \multirow{4}{*}{$\begin{array}{c}\text { DOSTĘP DO } \\
\text { PROGRAMÓW } \\
\text { MENTORINGU } \\
\text { (ODPOWIEDZI } \\
\text { DYREKTORÓW } \\
\text { SZKÓŁ) }\end{array}$} & Początkujący nauczyciele & 47,1 & 27,0 \\
\hline & $\begin{array}{l}\text { Nauczyciele z doświadczeniem } \\
\text { zawodowym krótszym niż } 5 \text { lat }\end{array}$ & 19,3 & 22,2 \\
\hline & Wszyscy nauczyciele w szkole & 22,8 & 24,9 \\
\hline & Programy mentoringu nie istnieją & 10,8 & 25,8 \\
\hline \multirow{2}{*}{$\begin{array}{c}\text { DOSTĘP DO } \\
\text { PROGRAMÓW } \\
\text { MENTORINGU } \\
\text { (ODPOWIEDZI } \\
\text { NAUCZYCIELI) }\end{array}$} & Nauczyciele, którzy mają mentorów & 15,9 & 12,8 \\
\hline & Nauczyciele, którzy są mentorami & 25,8 & 14,2 \\
\hline
\end{tabular}


Na Ukrainie większość nauczycieli (90,7\%) pracuje w szkołach, w których mentorzy uczą tych samych przedmiotów co początkujący nauczyciele (środkowa kolumna tabeli 5.). Jednakże istnieją kraje (Holandia i Belgia), gdzie w ramach prowadzonych programów mentoringu nauczany przedmiot niekoniecznie jest brany pod uwagę. Cechą wyróżniającą badanie TALIS jest to, że dane zbierane są z dwóch różnych perspektyw, jako że na to samo pytanie odpowiadają zarówno dyrektorzy szkół, jak i nauczyciele. Ostatnia kolumna tabeli pokazuje odpowiedzi nauczycieli na pytania dotyczące mentoringu. 25,8\% ukraińskich nauczycieli odpowiedziało, że są mentorami dla jednego lub kilku nauczycieli. 15,9\% ukraińskich nauczycieli posiada mentora, który ich wspiera na początkowym etapie kariery zawodowej. W większości krajów procent nauczycieli posiadających mentorów jest znacznie niższy niż procent nauczycieli, którzy (jak można wnioskować na podstawie odpowiedzi dyrektorów szkół) pracują w szkołach, w których obecnie realizowane są programy mentoringu. Powodem może być to, że niektórzy nauczyciele pełnią role mentorów. Jednakże sytuacje, w których mamy do czynienia z uderzającymi różnicami, mogą być powodem do obaw, mogą bowiem one oznaczać, że niektórzy nauczyciele nie są zainteresowani posiadaniem mentora lub w niektórych szkołach nie istnieje kultura oparta na partnerstwie. Na przykład w Holandii $71 \%$ nauczycieli pracuje w szkołach, gdzie jest zapewniony dostęp do programów mentoringu, podczas gdy jedynie $17 \%$ nauczycieli posiada własnego mentora; w Rumunii liczby te wynoszą odpowiednio $53 \%$ i $8 \%$. Na Ukrainie różnica wynosi pomiędzy $22,8 \%$ a $15,9 \%$, co jest całkiem akceptowalne.

Tabele 4. i 5. pokazują pewne cechy charakterystyczne (płeć, doświadczenie zawodowe, status zatrudnienia oraz godzinowy wymiar pracy) nauczycieli, którzy odpowiedzieli, że mają mentorów oraz nauczycieli, którzy pracują w charakterze mentorów. 
Tabela 4. Nauczyciele posiadający mentorów - podział na płeć, doświadczenie zawodowe, status zatrudnienia oraz godzinowy wymiar pracy (dane w proc.)

\begin{tabular}{|c|c|c|c|}
\hline & & $\begin{array}{c}\text { ŚREDNIA Z BADANIA } \\
\text { NA UKRAINIE }\end{array}$ & $\begin{array}{c}\text { ŚREDNIA Z BADANIA } \\
\text { TALIS }\end{array}$ \\
\hline \multirow{2}{*}{ PŁEĆ } & Mężczyzna & 18,2 & 13,3 \\
\hline & Kobieta & 15,4 & 12,5 \\
\hline \multirow{2}{*}{$\begin{array}{l}\text { DOŚWIADCZENIE } \\
\text { ZAWODOWE }\end{array}$} & $\begin{array}{l}\text { W sumie od } 0 \text { do } 5 \text { lat } \\
\text { doświadczenia w pracy } \\
\text { jako nauczyciel }\end{array}$ & 62,1 & 24,8 \\
\hline & $\begin{array}{l}\text { W sumie ponad } 5 \text { lat } \\
\text { doświadczenia w pracy } \\
\text { jako nauczyciel }\end{array}$ & 10,0 & 9,6 \\
\hline \multirow{2}{*}{$\begin{array}{c}\text { STATUS } \\
\text { ZATRUDNIENIA }\end{array}$} & Stałe zatrudnienie & 15,1 & 11,0 \\
\hline & Umowa na czas określony & 34,6 & 24,2 \\
\hline \multirow{2}{*}{$\begin{array}{c}\text { GODZINOWY } \\
\text { WYMIAR PRACY }\end{array}$} & $\begin{array}{l}\text { Pracował/-a mniej niż } 30 \text { godzin } \\
\text { w ciągu ostatniego pełnego } \\
\text { kalendarzowego tygodnia }\end{array}$ & 20,7 & 12,6 \\
\hline & $\begin{array}{l}\text { Pracował/-a } 30 \text { lub więcej godzin } \\
\text { w ciągu ostatniego pełnego } \\
\text { kalendarzowego tygodnia }\end{array}$ & 15,0 & 12,8 \\
\hline
\end{tabular}

Źródło: OECD, 2014b; Baza danych UERA, 2017 r.

Tabela 5. Nauczyciele pełniący funkcję mentorów - podział na płeć, doświadczenie zawodowe, status zatrudnienia oraz godzinowy wymiar pracy (dane w proc.)

\begin{tabular}{c|l|r|r} 
& & $\begin{array}{c}\text { ŚREDNIA Z BADANIA } \\
\text { NA UKRAINIE }\end{array}$ & $\begin{array}{c}\text { ŚREDNIA Z BADANIA } \\
\text { TALIS }\end{array}$ \\
\hline \multirow{2}{*}{ PŁEĆ } & Mężczyzna & 18,4 & 14,0 \\
\cline { 2 - 4 } & Kobieta & 27,2 & 14,0 \\
\hline \multirow{2}{*}{$\begin{array}{c}\text { ZośWIADCZENIE } \\
\text { ZaWODOWE }\end{array}$} & $\begin{array}{l}\text { W sumie od 0 do 5 lat } \\
\text { doświadczenia pracy } \\
\text { jako nauczyciel }\end{array}$ & $\begin{array}{l}\text { W sumie ponad 5 lat } \\
\text { doświadczenia pracy } \\
\text { jako nauczyciel }\end{array}$ & 3,8 \\
\hline
\end{tabular}




\begin{tabular}{|c|c|c|c|}
\hline \multirow{2}{*}{$\begin{array}{c}\text { STATUS } \\
\text { ZATRUDNIENIA }\end{array}$} & Stałe zatrudnienie & 26,4 & 15,6 \\
\hline & Umowa na czas określony & 14,4 & 6,4 \\
\hline \multirow{2}{*}{$\begin{array}{l}\text { GODZINOWY } \\
\text { WYMIAR PRACY }\end{array}$} & $\begin{array}{l}\text { Pracował/-a mniej niż } 30 \text { godzin } \\
\text { w ciągu ostatniego pełnego } \\
\text { kalendarzowego tygodnia }\end{array}$ & 21,5 & 12,7 \\
\hline & $\begin{array}{l}\text { Pracował/-a } 30 \text { lub więcej godzin } \\
\text { w ciągu ostatniego pełnego } \\
\text { kalendarzowego tygodnia }\end{array}$ & 26,5 & 14,7 \\
\hline
\end{tabular}

Źródło: OECD, 2014b; Baza danych UERA, 2017 r.

Dane pokazują, że wśród ukraińskich nauczycieli, którzy mają mentorów, 18,2\% stanowią mężczyźni, a 15,4\% - kobiety. To, co różni ukraińskich respondentów od średniej z badania TALIS, to fakt, że dużo więcej nauczycielek $(27,2 \%)$ niż nauczycieli $(18,4 \%)$ pełni funkcję mentora dla innych nauczycieli. W badaniu TALIS 2013 procent ten jest prawie identyczny.

Jest to całkowicie naturalne, że nauczyciele z pięcioletnim lub dłuższym stażem częściej pełnią funkcję mentorów $(28,7 \%)$ niż sami posiadają mentorów (10,0\%). Jak twierdzą uczestnicy badania, na Ukrainie 62,1\% nauczycieli mających 5-letnie lub krótsze doświadczenie ma przydzielonych mentorów (średnia z badania TALIS 2013 to 24,8\%). Jednakże kwestionariusz nie przedstawia zagadnień związanych z naturą programów mentoringu, nie pokazuje też stopnia ich efektywności. Potrzebne są dalsze badania w zakresie natury programów mentoringu na Ukrainie, ponieważ sam fakt posiadania mentora nie oznacza otrzymania wsparcia eksperckiego na starcie zawodowym i w ramach dalszego rozwoju zawodowego.

W większości krajów uczestniczących w badaniu TALIS nauczyciele posiadający stałe zatrudnienie częściej pełnią funkcje mentorów $(26,4 \%)$, niż sami ich posiadają (15,1\%). Jak pokazują wyniki badania, wśród nauczycieli, którzy pracują mniej niż 30 godzin tygodniowo, prawie ten sam procent pełni funkcję mentora $(21,5 \%)$, co ich posiada $(20,7 \%)$. Ci, którzy twierdzą, że pracują więcej niż 30 godzin tygodniowo, częściej pełnią funkcję mentora $(26,5 \%)$. 


\section{Rozwój zawodowy i wspieranie nauczycieli}

Zespół badania TALIS przyznaje, że rozwój zawodowy nauczycieli wywiera długoterminowe pozytywne skutki na osiągnięcia uczniów (OECD, 2014). Istnieją też nowe badania, które analizują przywództwo edukacyjne nauczycieli i ich rozwój zawodowy z różnych perspektyw. Pokazuje to, że wielu nauczycieli-liderów wywodzi się z różnorodnych działań i inicjatyw realizowanych $w$ ramach doskonalenia zawodowego (Alexandrou, Swaffield, 2016). W rezultacie osoby odpowiedzialne za tworzenie polityki wiążą rozwój zawodowy nauczycieli bezpośrednio z szansami na doskonalenie systemu edukacji. W tym zakresie, przywództwo edukacyjne nauczycieli odgrywa jedną z najważniejszych ról.

W badaniu TALIS poszukiwano dowodów rozwoju zawodowego nauczycieli, zadając pytania dotyczące udziału nauczycieli w różnorodnych działaniach $w$ zakresie doskonalenia zawodowego oraz czasu trwania takich inicjatyw (w okresie ostatnich 12 miesięcy), w tym udziału w działaniach organizowanych w weekend, wieczorami lub poza godzinami pracy. Na Ukrainie $98,2 \%$ nauczycieli twierdzi, że uczestniczyli w przynajmniej jednej inicjatywie w zakresie rozwoju zawodowego w ciągu 12 miesięcy poprzedzających wypełnienie kwestionariusza. Średnia w badaniu TALIS 2013 wynosi 88,4\%, co dowodzi, że do doskonalenia zawodowego nauczycieli przykładana jest duża waga.

Tabela 6. pokazuje wskaźnik uczestnictwa nauczycieli szkół średnich I stopnia oraz poniesione przez nich koszty indywidualne za udział w działaniach w zakresie rozwoju zawodowego w czasie 12 miesięcy poprzedzających badanie. Druga kolumna przedstawia informacje dotyczące procentu nauczycieli, którzy przyznali, że uczestniczyli w przynajmniej jednym działaniu w zakresie doskonalenia zawodowego bez żadnego wsparcia ze strony szkoły $(18,2 \%$ z badania na Ukrainie i 5,7\% - średnia z badania TALIS). Ostatnie trzy kolumny tabeli pokazują procent nauczycieli, którzy nie musieli zapłacić za żadne działania podejmowane w zakresie rozwoju zawodowego oraz tych, którzy musieli zapłacić za niektóre lub wszystkie. W rzeczywistości dwie trzecie badanych przyznało, że nie płaciło za udział w działaniach związanych $z$ doskonaleniem zawodowym. 
Tabela 6. Rozwój zawodowy nauczycieli i poniesione przez

nich koszty indywidualne (dane w proc.)

\begin{tabular}{|c|c|c|c|}
\hline & & $\begin{array}{l}\text { ŚREDNIA Z BADANIA } \\
\text { NA UKRAINIE }\end{array}$ & $\begin{array}{c}\text { ŚREDNIA Z BADANIA } \\
\text { TALIS }\end{array}$ \\
\hline \multicolumn{2}{|c|}{$\begin{array}{l}\text { Nauczyciele, którzy podjęli działania w ramach rozwoju } \\
\text { zawodowego w ciągu ostatnich } 12 \text { miesięcy }\end{array}$} & 98,2 & 88,4 \\
\hline \multicolumn{2}{|c|}{$\begin{array}{l}\text { Nauczyciele, którzy podjęli działania w ramach rozwoju } \\
\text { zawodowego w ciągu ostatnich } 12 \text { miesięcy bez żadnego } \\
\text { rodzaju wsparcia }\end{array}$} & 18,2 & 5,7 \\
\hline \multirow{3}{*}{$\begin{array}{l}\text { Nauczyciele, którzy nie } \\
\text { musieli zapłacić za żadne } \\
\text { działania podejmowane } \\
\text { w zakresie rozwoju } \\
\text { zawodowego oraz ci, } \\
\text { którzy musieli zapłacić } \\
\text { za niektóre lub wszystkie }\end{array}$} & Nie płacili za żadne działania & 73,6 & 66,1 \\
\hline & Płacili za niektóre działania & 17,7 & 25,2 \\
\hline & Płacili za wszystkie działania & 8,7 & 8,6 \\
\hline
\end{tabular}

Źródło: OECD, 2014b; Baza danych UERA, 2017 r.

Na Ukrainie procent nauczycieli, którzy podali, że płacili za program rozwoju zawodowego $(8,7 \%)$, jest prawie taki sam, jak średnia z badania TALIS (8,6\%). Dane zebrane w badaniu TALIS 2013 jasno dowodzą, że procent nauczycieli aktywnie uczestniczących w programach rozwoju zawodowego jest wyższy w krajach udzielających nauczycielom wsparcia. Programy prowadzone przez uniwersytety i kolegia mające na celu wyposażenie nauczycieli w wysokie kwalifikacje zazwyczaj wykorzystują więcej materiałów i dlatego są pełno- lub częściowo płatne (OECD, 2014). Na Ukrainie jest to całkiem powszechna sytuacja, gdyż placówki szkolnictwa średniego i wyższego są finansowane z różnych źródeł.

Tabela 7. ilustruje zależność wskaźnika uczestnictwa badanych nauczycieli w programach doskonalenia zawodowego od pewnych ich cech, w tym płci, doświadczenia zawodowego, statusu zatrudnienia oraz tygodniowego wymiaru pracy.

Dowody pokazują, że procent nauczycielek, które uczestniczyły w działaniach w zakresie rozwoju zawodowego $(98,3 \%)$, jest nieco wyższy niż procent nauczycieli (97,9\%), aczkolwiek różnica ta jest bardzo niewielka. Znaczną różnicę $w$ krajach uczestniczących $w$ badaniu TALIS 2013 można zaobserwować w Czechach i we Włoszech, gdzie 
liczba nauczycielek jest wyższa o około $9 \%$. Jeśli chodzi o korelację doświadczenia zawodowego i uczestnictwa $w$ działaniach w zakresie doskonalenia zawodowego, należy zauważyć, że ukraińscy nauczyciele posiadający więcej niż 5 lat doświadczenia zawodowego częściej biorą udział $w$ doskonaleniu zawodowym niż nauczyciele pracujący w edukacji 5 lub mniej lat $(95,9 \%)$.

Tabela 7. Rozwój zawodowy nauczycieli w ostatnim czasie - podział na: status zatrudnienia, doświadczenie zawodowe i płeć (dane w proc.)

\begin{tabular}{|c|c|c|c|}
\hline & & $\begin{array}{l}\text { ŚREDNIA Z BADANIA } \\
\text { NA UKRAINIE }\end{array}$ & $\begin{array}{c}\text { ŚREDNIA Z BADANIA } \\
\text { TALIS }\end{array}$ \\
\hline \multirow{2}{*}{ PŁEĆ } & Mężczyzna & 97,9 & 86,8 \\
\hline & Kobieta & 98,3 & 88,9 \\
\hline \multirow{2}{*}{$\begin{array}{l}\text { DOŚWIADCZENIE } \\
\text { ZAWODOWE }\end{array}$} & $\begin{array}{l}5 \text { lat lub mniej doświadczenia } \\
\text { w pracy jako nauczyciel }\end{array}$ & 95,9 & 86,5 \\
\hline & $\begin{array}{l}\text { Ponad } 5 \text { lat doświadczenia } \\
\text { w pracy jako nauczyciel }\end{array}$ & 98,6 & 88,8 \\
\hline \multirow{2}{*}{$\begin{array}{c}\text { STATUS } \\
\text { ZATRUDNIENIA }\end{array}$} & Stałe zatrudnienie & 98,4 & 89,1 \\
\hline & Umowa na czas określony & 94,7 & 84,6 \\
\hline \multirow{2}{*}{$\begin{array}{l}\text { TYGODNIOWY } \\
\text { WYMIAR PRACY }\end{array}$} & Mniej niż 30 godzin tygodniowo & 94,6 & 84,2 \\
\hline & 30 lub więcej godzin tygodniowo & 98,9 & 89,6 \\
\hline
\end{tabular}

Źródło: OECD, 2014b; Baza danych UERA, 2017 r.

Podobnie jak w krajach uczestniczących w badaniu TALIS 2013, ukraińscy nauczyciele zatrudnieni na czas nieokreślony $(98,4 \%)$ wydają się być bardziej zainteresowani rozwojem zawodowym niż nauczyciele pracujący na podstawie umów na czas określony $(94,7 \%)$. Taką samą sytuację można zaobserwować w przypadku nauczycieli pracujących 30 lub więcej godzin tygodniowo $(98,9 \%)$ w porównaniu do nauczycieli pracujących mniej niż 30 godzin tygodniowo $(94,6 \%)$. Średnio w krajach uczestniczących w badaniu TALIS nauczyciele, którzy pracują 
w szkołach publicznych bardziej aktywnie uczestniczą w programach doskonalenia zawodowego niż ci pracujący w szkołach prywatnych. Niemniej jednak są kraje, gdzie wskaźnik uczestnictwa w rozwoju zawodowym jest wyższy wśród nauczycieli ze szkół prywatnych (na przykład w Portugalii, na Słowacji, w Hiszpanii różnica ta wynosi prawie 6\%). Błędem byłoby wyciąganie wniosku dotyczącego sytuacji na Ukrainie na podstawie opisanego badania, ponieważ próba obejmowała tylko jedną szkołę prywatną. Ogólnie rzecz biorąc, na Ukrainie większość szkół to szkoły państwowe, a szkoły prywatne stanowią mniej niż $1 \%$.

W czasie badania poszukiwano informacji o rodzajach programów doskonalenia zawodowego najczęściej oferowanych ukraińskim nauczycielom i przez nich podejmowanych. Kwestionariusz badania TALIS (OECD, 2014b) obejmował listę zarówno formalnych, jak i nieformalnych działań, a przeprowadzone badanie dostarcza informacji na temat uczestnictwa ukraińskich nauczycieli w obu formach szkoleń. Ponadto badanie dostarczyło też danych, które mogą być wykorzystane w celu porównania sytuacji na Ukrainie ze specyficzną sytuacją w niektórych krajach uczestniczących w badaniu TALIS 2013.

Wyniki badania pokazują, że najbardziej popularnymi formami doskonalenia zawodowego wśród ukraińskich nauczycieli są konferencje lub seminaria poświęcone edukacji ( $w$ czasie których nauczyciele i/lub badacze prezentują wyniki swoich badań i omawiają zagadnienia z dziedziny edukacji) oraz uczestnictwo w sieciach nauczycieli, które są tworzone specjalnie w celu rozwoju zawodowego nauczycieli.

Z odsetkiem nauczycieli, którzy podają, że uczestniczą w edukacyjnych konferencjach i seminariach, wynoszącym 86,4\%, Ukraina plasuje się bardzo wysoko wśród krajów uczestniczących w badaniu TALIS, w których to średnia wynosi 43,6\%. Najwyższy wskaźnik uczestnictwa odnotowuje Chorwacja (79\%), podczas gdy w niektórych krajach wskaźnik ten spada poniżej 25\%: Czechy (22\%), Francja (20\%), Słowacja (25\%), Hiszpania (24\%) i Belgia (Flandria) (23\%). Nie popadając w zbytni optymizm, zakładamy, że w poszczególnych krajach istnieje inne rozumienie tego, czym są konferencje/seminaria poświęcone edukacji. Na Ukrainie osoby uczestniczące $w$ badaniu mogły mieć na myśli dowolne spotkanie, w czasie którego dyskutowane są zagadnienia edukacyjne, które nie wymagało ani wcześniejszego przygotowania, ani zaprezentowania badań prowadzonych przez nauczycieli. 
Inną powszechną formą uczestnictwa ukraińskich nauczycieli w doskonaleniu zawodowym jest ich udział w specjalnie tworzonych sieciach nauczycieli $(85,4 \%)$. Wskaźnik ten jest dużo wyższy niż średnia z badania TALIS która wynosi 36,9\%. Skala wyników badania TALIS w tym względzie jest całkiem szeroka - od najniższego wyniku - $17 \%$ (Czechy) do najwyższego - 63\% (Chorwacja). Tak duża rozpiętość skali może oznaczać różne rozumienie koncepcji sieci rozwoju zawodowego nauczycieli oraz różny stopień ich formalnej działalności w poszczególnych krajach. Na Ukrainie nauczyciele są członkami tzw. stowarzyszeń metodycznych, które są formalnymi strukturami mającymi na celu dzielenie się najlepszą praktyką $w$ dziedzinie edukacji.

Zebrane dane pokazują, że 65,4\% ukraińskich nauczycieli uczestniczyło w kursach lub warsztatach (np. dotyczących danego zagadnienia lub metody i/lub innych tematów związanych z edukacją), których średni czas trwania wynosił 10,6 dni. Średnia z badania TALIS wynosi $70,9 \%$ i 8,5 dnia. Najniższy poziom uczestnictwa pokazują dane uzyskane $z$ Włoch (51\%), Rumunii (52\%) i Słowacji (39\%).

Jak wynika z odpowiedzi (patrz: rysunek 1.), mentoring i/lub wzajemne obserwacje i coaching, jako część formalnych rozwiązań stosowanych w szkołach, są udziałem 67,9\% ukraińskich nauczycieli, przy czym średnia ta jest naprawdę wysoka, biorąc pod uwagę średnią z badania TALIS, która wynosi 29,5\%. Jak już wspomniano powyżej, mniej niż jedna czwarta ukraińskich nauczycieli pracuje w szkołach jako mentorzy, co może oznaczać, że tak wysoki wskaźnik może być rezultatem aktywnego udziału we wzajemnych obserwacjach w ukraińskich szkołach. Dowodzi tego fakt, że 69,6\% ukraińskich nauczycieli potwierdza udział w hospitacjach prowadzonych w innej szkole.

$Z$ drugiej strony 55,9\% ukraińskich nauczycieli twierdzi, że bierze udział $w$ badaniach prowadzonych indywidualnie lub we współpracy $z$ innymi nauczycielami na temat zgodny $z$ ich zawodowymi zainteresowaniami, a 43,8\% uczestniczy w programach podnoszących kwalifikacje (np. studia wyższe), z drugiej strony na Ukrainie najmniejsza liczba nauczycieli posiada stopień doktora lub wyższy.

Inne zagadnienie, które wymaga przeprowadzenia dalszych badań, to społeczność szkoły oparta na partnerstwie, stwarzająca możliwości wspierania nauczycieli liderów poprzez ich rozwój zawodowy. Badanie jasno pokazuje, że nie istnieje prawdziwe partnerstwo szkół z biznesem, organizacjami publicznymi i pozarządowymi. Fakt ten może potwier- 
dzić również argument, że niewielu ukraińskich nauczycieli uczestniczy w obserwacjach prowadzonych na terenie tych instytucji $(20,2 \%)$ lub w kursach doskonalenia zawodowego organizowanych przez biznes, organizacje publiczne lub pozarządowe.

Rysunek 1. Rodzaj doskonalenia zawodowego podejmowanego w ostatnim czasie przez nauczycieli: wskaźnik uczestnictwa w każdej formie rozwoju zawodowego, w której uczestniczyli biorący udział w badaniu nauczyciele ze szkół średnich I stopnia w ciągu 12 miesięcy poprzedzających badanie

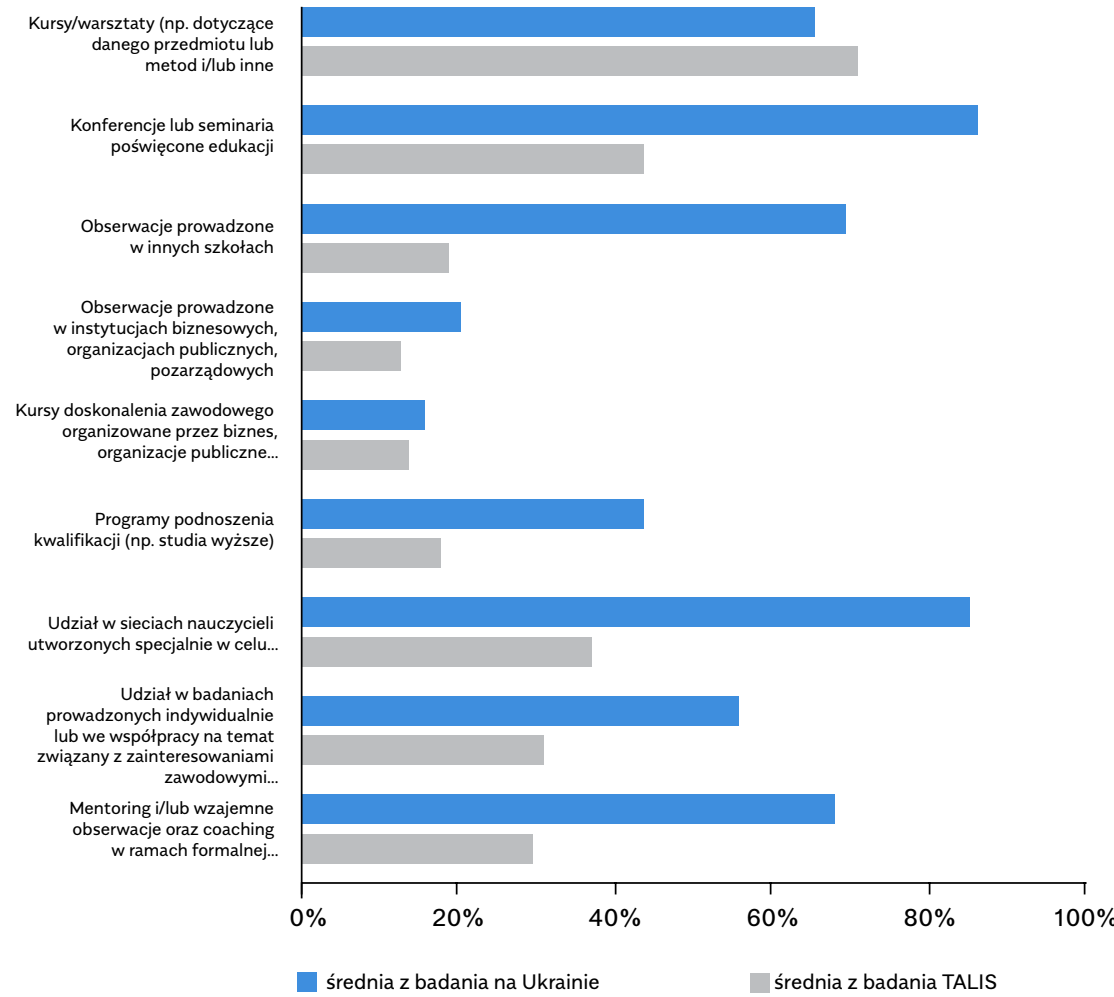

Źródło: OECD, 2014b; Baza danych UERA, 2017 r.

W kwestionariuszu pytano nauczycieli o pozytywny wpływ działań w zakresie doskonalenia zawodowego związanych z różnymi aspektami. Uczestniczący w badaniu ukraińscy nauczyciele wskazywali na 
różny stopień wpływu, wahający się od 16,7\% (nauczanie w środowisku wielokulturowym lub wielojęzycznym) do $92 \%$ (kompetencje pedagogiczne w nauczaniu przedmiotu/-ów dziedzinowego/-ych) (patrz: rysunek 2.). Ponad $75 \%$ potwierdziło pozytywny wpływ na następujące aspekty: wiedza i rozumienie nauczanego/-ych przedmiotu/-ów $(90,9 \%)$; ewaluacja uczniów i praktyki oceniania $(78,5 \%)$; nowe technologie w miejscu pracy $(76,9 \%)$. We wszystkich tych aspektach obserwuje się wyższą średnią ukraińskich nauczycieli niż średnia z badania TALIS 2013. Jednakże procent ukraińskich nauczycieli, którzy potwierdzili pozytywny wpływ zarządzania szkołą i administracji (17,2\%) oraz nauczania uczniów posiadających specjalne potrzeby edukacyjne $(22,2 \%)$ na ich doskonalenie zawodowe, jest znacznie niższy niż średnia z badania TALIS 2013.

Rysunek 2. Wpływ programów rozwoju zawodowego w ocenie nauczycieli

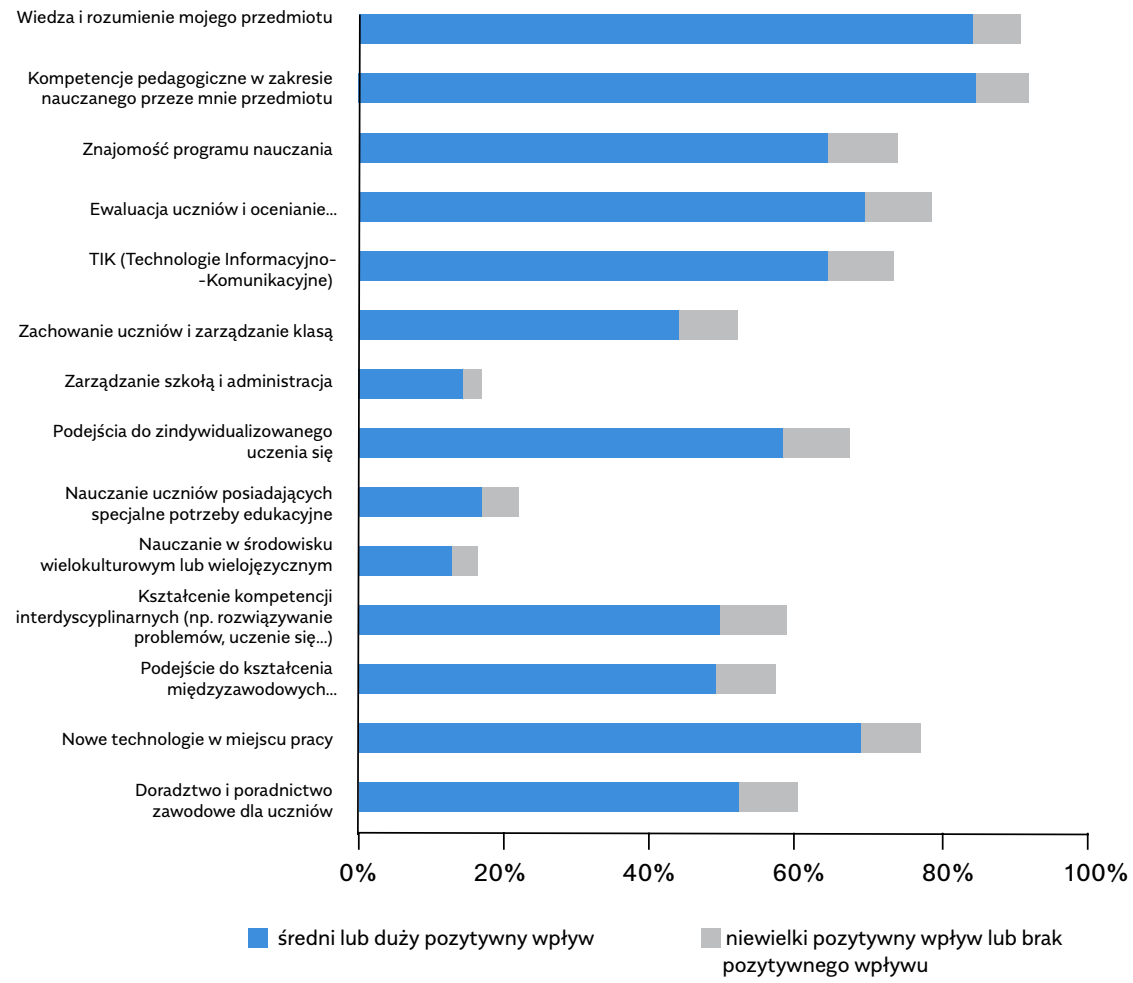

Źródło: OECD, 2014b; Baza danych UERA, 2017 r. 
Nauczanie uczniów posiadających specjalne potrzeby edukacyjnie jest na całym świecie wymieniane jako jedno z najważniejszych zagadnień, któremu należy poświęcić uwagę $\mathrm{w}$ trakcie doskonalenia zawodowego. Jednakże tylko 5,6\% ukraińskich nauczycieli wskazało, że temat ten powinien być włączony do programów rozwoju zawodowego. Nauczyciele na Ukrainie najbardziej zainteresowani są umiejętnościami w zakresie wykorzystania w nauczaniu TIK (Technologie Informacyjno-Komunikacyjne) $(14,1 \%)$ oraz zastosowania nowych technologii w miejscu pracy $(16,8 \%)$ (patrz: rysunek 3.$)$.

Rysunek 3. Potrzeby nauczycieli w zakresie rozwoju zawodowego

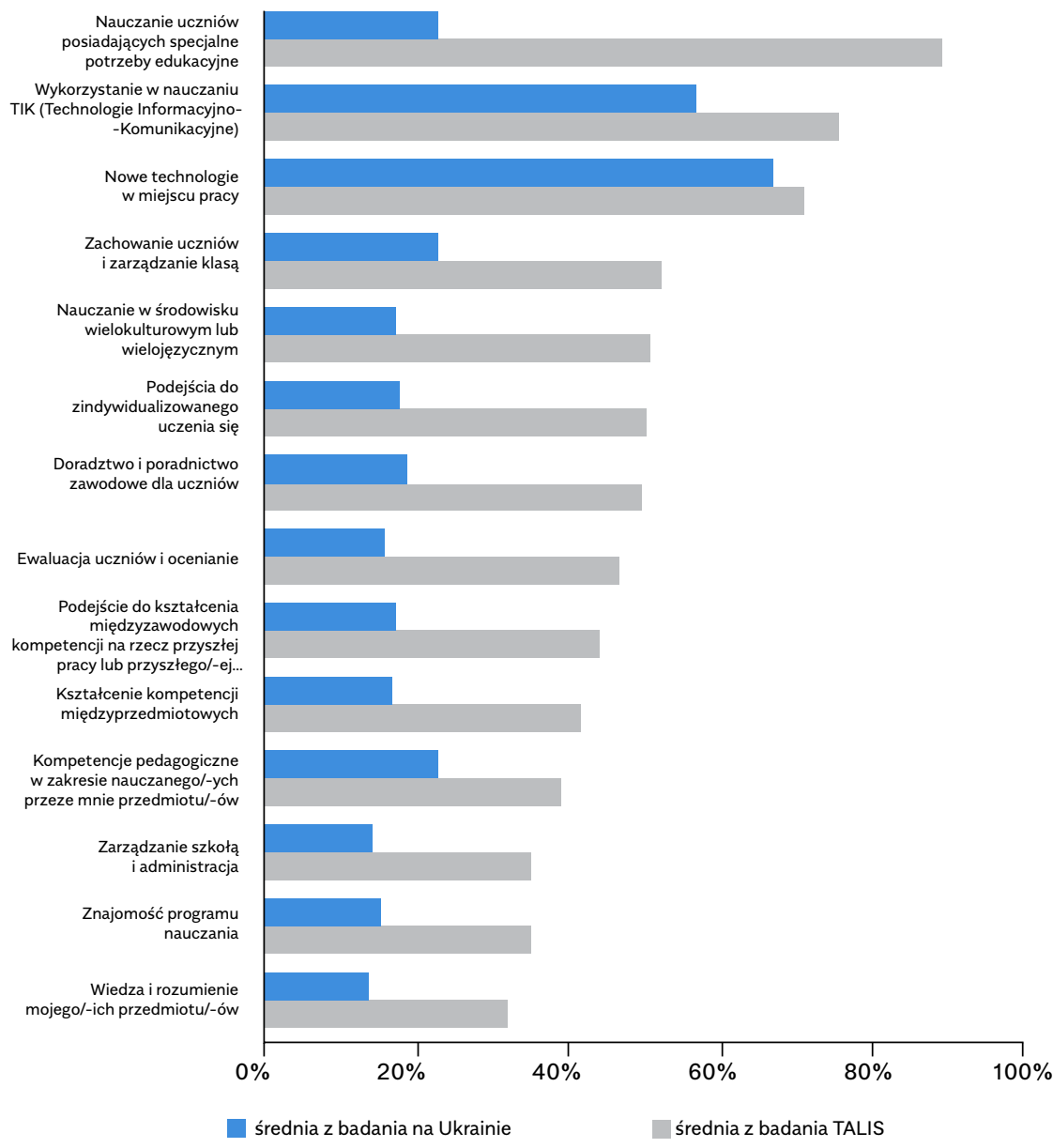

Źródło: OECD, 2014b; Baza danych UERA, 2017 r. 
Jak pokazują wyniki badania (tabela 8.), główną barierą w doskonaleniu zawodowym nauczycieli na Ukrainie oraz w krajach uczestniczących w badaniu TALIS jest fakt, że działania związane z rozwojem zawodowym kolidują z godzinami pracy w szkole ( $54 \%$ nauczycieli na Ukrainie oraz średnio 50,6\% nauczycieli z krajów uczestniczących w badaniu TALIS 2013). Kolejną ważną przeszkodą dla pomyślnego doskonalenia zawodowego jest brak zachęt do udziału w takich działaniach $(50,2 \%$ w przypadku Ukrainy i $48 \%$ w przypadku krajów uczestniczących w badaniu TALIS 2013). Należy podkreślić, że mniej niż 23,8\% ukraińskich nauczycieli uważa, że doskonalenie zawodowe jest zbyt drogie/że ich na nie stać. Procent ten jest znacznie wyższy we Włoszech (83\%), Portugalii ( $85 \%$ ) i Hiszpanii $(80 \%)$, co pokazuje, że jest to poważny problem w krajach, gdzie nauczyciele muszą w pełni lub częściowo pokrywać koszty swojego udziału w programach doskonalenia zawodowego.

Tabela 8. Bariery uczestnictwa nauczycieli w doskonaleniu zawodowym.

Odsetek nauczycieli ze szkół średnich I stopnia, którzy: „zgadzają się” lub „zdecydowanie zgadzają się", że następujące powody stanowią istotne przeszkody dla ich uczestnictwa w rozwoju zawodowym

\begin{tabular}{l|r|r}
\multicolumn{1}{c|}{$\begin{array}{c}\text { BARIERY DLA UCZESTNICTWA NAUCZYCIELI } \\
\text { W DOSKONALENIU ZAWODOWYM }\end{array}$} & $\begin{array}{c}\text { ŚREDNIA Z BADANIA } \\
\text { NA UKRAINIE }\end{array}$ & $\begin{array}{c}\text { ŚREDNIA } \\
\text { Z BADANIA TALIS }\end{array}$ \\
\hline $\begin{array}{l}\text { Niespełnianie wymagań (wymagane kwalifikacje, } \\
\text { doświadczenie, staż pracy) }\end{array}$ & 4,9 & 11,1 \\
\hline Zbyt wysoki koszt doskonalenia zawodowego & 23,8 & 43,8 \\
\hline Brak wsparcia ze strony pracodawcy & 16,5 & 31,6 \\
\hline Brak możliwości pogodzenia z godzinami pracy & 54,0 & 50,6 \\
\hline Brak czasu ze względów rodzinnych & 11,5 & 35,7 \\
\hline Brak ofert odpowiedniego rozwoju zawodowego & 18,8 & 39,0 \\
\hline Brak zachęt do uczestnictwa w takich działaniach & 50,2 & 48,0
\end{tabular}

Źródło: OECD, 2014b; Baza danych UERA, 2017 r.

\section{Nauczyciele jako ewaluatorzy udzielający formalnej i nieformalnej informacji zwrotnej innym nauczycielom}

Ocena nauczycieli i informacja zwrotna stanowią ważny komponent przywództwa edukacyjnego nauczycieli. Ich podstawowym celem jest 
przekazanie nauczycielom wartościowych informacji, aby lepiej rozumieli i udoskonalali swoją praktykę zawodową. Jednakże ocena nauczycieli i informacja zwrotna mogą być również wykorzystane do określenia możliwości rozwoju zawodowego i kariery nauczycieli. Mogą znacznie poprawić postrzeganie przez nauczycieli stosowanych przez nich metod, praktyki nauczania oraz uczenia się uczniów (Santiago, Benavides, 2009). Mogą też pomóc nauczycielom w doskonaleniu ich umiejętności nauczania, dzięki wskazaniu i rozwijaniu jego poszczególnych aspektów oraz mogą poprawić relacje nauczycieli z uczniami (Gates Foundation, 2010). Zgodnie z definicją zawartą w badaniu TALIS, z oceną nauczycieli i informacją zwrotną mamy do czynienia podczas oceny pracy nauczyciela przez dyrektora szkoły, zewnętrznego inspektora lub współpracowników (OECD, 2009). W szerokim rozumieniu tych pojęć, takie ewaluacje stwarzają nauczycielom ważne i często unikalne możliwości otrzymania informacji zwrotnej na temat ich pracy i służą jako środek wskazania, co się sprawdza w klasie, a co nie i dlaczego (Behn, 2003).

Tabela 9. pokazuje procent nauczycieli, którzy twierdzą, że otrzymują informację zwrotną z różnych źródeł lub nie otrzymali takiej informacji. W celu wskazania osób lub instytucji zewnętrznych, jak zostało to ujęte w Tabeli poniżej, badanie TALIS odnosi się do inspektorów, przedstawicieli gmin lub innych osób spoza szkoły (OECD, 2014b).

Tabela 9. Źródła ewaluacji dostarczające formalnej i nieformalnej informacji zwrotnej innym nauczycielom (dane w proc.)

\begin{tabular}{|c|c|c|c|}
\hline & & $\begin{array}{l}\text { ŚREDNIA Z BADANIA } \\
\text { NA UKRAINIE }\end{array}$ & $\begin{array}{l}\text { ŚREDNIA Z BADANIA } \\
\text { TALIS }\end{array}$ \\
\hline \multirow{5}{*}{$\begin{array}{l}\text { Nauczyciele } \\
\text { otrzymali } \\
\text { informację } \\
\text { zwrotną } \\
\text { odnośnie do } \\
\text { swojej pracy od: }\end{array}$} & osoby lub instytucji z zewnątrz & 62,2 & 28,9 \\
\hline & dyrektora szkoły & 84,4 & 54,3 \\
\hline & $\begin{array}{l}\text { członka/członków zespołu } \\
\text { zarządzającego szkołą }\end{array}$ & 93,9 & 49,3 \\
\hline & wyznaczonych mentorów & 24,4 & 19,2 \\
\hline & $\begin{array}{l}\text { innych nauczycieli (spoza } \\
\text { zespołu zarządzającego szkołą) }\end{array}$ & 44,8 & 41,9 \\
\hline \multicolumn{2}{|c|}{$\begin{array}{l}\text { Nauczyciele nigdy nie otrzymują informacji zwrotnej } \\
\text { na temat swojej pracy }\end{array}$} & 0,6 & 12,5 \\
\hline
\end{tabular}


Zgodnie z wynikami badania TALIS 2013 średni wskaźnik w krajach biorących udział w badaniu wskazuje, że 87,5\% nauczycieli otrzymuje informację zwrotną w szkole. Pod tym względem Ukraina plasuje się znacznie powyżej średniej, z wynikiem 99,4\% nauczycieli, którzy otrzymują informację zwrotną na temat swojej pracy. Jednocześnie istnieją różnice w zakresie głównych źródeł informacji zwrotnej na Ukrainie i w pozostałych państwach biorących udział w badaniu. Tym samym ukraińscy nauczyciele częściej otrzymują informację zwrotną od instytucji lub osób z zewnątrz niż ich koledzy z krajów biorących udział w badaniu TALIS 2013 (62,2\% i 28,9\%), od pracowników administracji szkoły (93,9\% i 49,3\%) oraz od dyrektora szkoły (84,4\% i 54,3\%). Wskaźnik informacji zwrotnej otrzymywanej od kolegów nauczycieli lub mentorów jest bliski międzynarodowej średniej.

Celem wywiadów prowadzonych z ukraińskimi nauczycielami było uzyskanie informacji dotyczących metod wykorzystywanych do przekazywania informacji zwrotnej. Metody te obejmują informację zwrotną przekazywaną na podstawie bezpośrednich obserwacji nauczania w klasie, badań prowadzonych wśród uczniów na temat nauczania, oceny wiedzy dziedzinowej, analizy wyników testów uczniów, samooceny nauczycieli na temat ich pracy (np. prezentacja portfolio w zakresie oceny) oraz badań i dyskusji prowadzonych wśród rodziców lub opiekunów. Tabela 10. pokazuje odsetek nauczycieli, którzy twierdzą, że otrzymali informację zwrotną z wykorzystaniem powyższych form i metod.

Tabela 10. Formy i metody uzyskiwania informacji zwrotnej przez nauczycieli (dane w proc.)

\begin{tabular}{l|r|r} 
& $\begin{array}{c}\text { ŚREDNIA Z BADANIA } \\
\text { NA UKRAINIE }\end{array}$ & $\begin{array}{c}\text { ŚREDNIA } \\
\text { Z BADANIA TALIS }\end{array}$ \\
\hline Bezpośrednie obserwacje nauczania w klasie & 98,7 & 78,8 \\
\hline Badania prowadzone wśród uczniów na temat nauczania & 90,8 & 53,3 \\
\hline Ocena wiedzy dziedzinowej & 92,1 & 54,8 \\
\hline Analiza wyników testów uczniów & 93,1 & 63,6 \\
\hline Samoocena nauczycieli na temat ich pracy & 92,1 & 52,7 \\
\hline $\begin{array}{l}\text { Badania i dyskusje prowadzone wśród rodziców } \\
\text { lub opiekunów }\end{array}$ & 84,2 & 53,4
\end{tabular}


Biorąc pod uwagę każdą metodę przekazywania informacji zwrotnej, na Ukrainie występuje wyższy procent nauczycieli, którzy twierdzą, że otrzymują informację zwrotną przy wykorzystaniu takich metod, niż średnia w krajach uczestniczących w badaniu TALIS, członków OECD i liderów badania PISA. Informacja zwrotna przekazywana po bezpośrednich obserwacjach praktyki nauczania w klasie jest uznana na Ukrainie za najbardziej powszechną metodę przekazywania informacji zwrotnej nauczycielom na temat ich pracy $(98,7 \%)$. Większość nauczycieli ukraińskich uważa, że najpopularniejszą metodą przekazywania informacji zwrotnej jest analiza wyników testów uczniów (93,1\%), ocena wiedzy dziedzinowej $(92,1 \%)$ oraz wyniki prowadzonych wśród uczniów badań na temat nauczania $(90,8 \%)$. Najniżej plasują się dyskusje prowadzone z rodzicami lub opiekunami.

Oprócz zebrania danych na temat metod przekazywania informacji zwrotnej, badanie TALIS miało na celu zebranie informacji o takich obszarach, które podlegają informacji zwrotnej. Kwestionariusz zawiera jedenaście zagadnień związanych ze szkolnictwem, które były zaprezentowane nauczycielom.

Tabela 11. pokazuje jedenaście kluczowych obszarów, których dotyczy przekazywana nauczycielom na Ukrainie informacja zwrotna, zaprezentowanych w porządku rosnącym. Pod uwagę wzięto procent nauczycieli, którzy kładli nacisk na następujące obszary, wskazując je jako "ważne" lub "bardzo ważne" dla otrzymania informacji zwrotnej. Dla porównania podano średnie dane z międzynarodowego badania TALIS.

Tabela 11. Obszary, których dotyczy informacja zwrotna (dane w proc.)

\begin{tabular}{l|r|r} 
& $\begin{array}{c}\text { UKRAIŃSCY } \\
\text { NAUCZYCIELE }\end{array}$ & $\begin{array}{c}\text { ŚREDNIA } \\
\text { Z BADANIA } \\
\text { TALIS }\end{array}$ \\
\hline Wyniki uczniów & 87,3 & 87,5 \\
\hline Wiedza i zrozumienie obszaru/-ów dziedzinowych & 88,7 & 83,5 \\
\hline $\begin{array}{l}\text { Kompetencje pedagogiczne w nauczaniu mojego/ich } \\
\text { przedmiotu/-ów }\end{array}$ & 89,6 & 86,8 \\
\hline $\begin{array}{l}\text { Praktyki oceniania uczniów } \\
\text { Zachowanie uczniów i zarządzanie klasą szkolną }\end{array}$ & 85,0 & 83,0 \\
\hline $\begin{array}{l}\text { Nauczanie uczniów posiadających specjalne potrzeby } \\
\text { edukacyjne }\end{array}$ & 77,5 & 86,9 \\
\hline
\end{tabular}




\begin{tabular}{l|c|c}
\hline $\begin{array}{l}\text { Nauczanie w środowisku wielokulturowym } \\
\text { i wielojęzycznym }\end{array}$ & 19,2 & 43,7 \\
\hline $\begin{array}{l}\text { Informacja zwrotna przekazywana innym nauczycielom } \\
\text { w celu udoskonalenia ich praktyki nauczania }\end{array}$ & 40,7 & 57,4 \\
\hline Informacja zwrotna od rodziców lub opiekunów & 48,2 & 70,8 \\
\hline Informacja zwrotna otrzymywana od uczniów & 56,1 & 79,1 \\
\hline Współpraca lub praca z innymi nauczycielami & 73,6 & 80,7
\end{tabular}

Źródło: OECD, 2014b; Baza danych UERA, 2017 r.

Informacje przekazane przez te dwie grupy nauczycieli pokazują, że obie grupy przykładają taką samą wagę do wyników uczniów jako informacji zwrotnej na temat ich pracy $(87,3 \%$ oraz $87,5 \%)$. Istnieje też niewielka różnica pomiędzy średnią odpowiedzi udzielonych przez ukraińskich respondentów i uczestników badania TALIS na temat kompetencji pedagogicznych dotyczących nauczania przedmiotu/-ów (odpowiedni $89,6 \%$ i $86,8 \%$ ). Podobnie małe różnice pomiędzy krajami można odnotować w takich obszarach, jak: wiedza i rozumienie obszaru/-ów dziedzinowego/-ych (88,7\% oraz $83,5 \%)$, a także ocena umiejętności uczniów $(85,0 \%$ i 83,0\%). W pewnym stopniu wskaźniki dotyczące takich obszarów, jak: zachowanie uczniów i zarządzanie klasą $(77,5 \%$ oraz $86,9 \%)$, informacja zwrotna przekazywana innym nauczycielom w celu udoskonalenia ich nauczania $(40,7 \%$ i $57,4 \%)$, ocenianie nauczycieli przez uczniów $(56,1 \%$ oraz $79,1 \%)$, jak również ocena nauczycieli dokonywana przez rodziców lub opiekunów $(48,2 \%$ i 70,8\%), są mniej cenione przez ukraińskich nauczycieli w czasie otrzymywania informacji zwrotnej.

Bez wątpienia, niezależnie od danej formy oceniania nauczycieli i przekazywania im informacji zwrotnej, są to bardzo sprawiedliwe i odpowiednie sposoby dokonywania oceny. Mimo iż obserwacje w klasie postrzegane są jako najbardziej powszechne narzędzie oceny we wszystkich wyżej wymienionych krajach (Ukraina, kraje uczestniczące w badaniu TALIS), to badania prowadzone wśród nauczycieli, portfolia rozwoju zawodowego nauczycieli oraz wyniki uczniów mogą również stanowić pożyteczny sposób doskonalenia zawodowego nauczycieli, w zależności od kontekstu. Niezależnie od szczególnych sposobów 
przekazywania informacji zwrotnej, o czym była mowa powyżej, jasne jest, że narzędzia te mają potencjał, by wpływać na przywództwo edukacyjne nauczycieli poprzez ich rozwój zawodowy.

\section{Podsumowanie}

Jak wykazano w niniejszym artykule, przywództwo edukacyjne nauczycieli ma duży potencjał w zakresie wprowadzania zmian w edukacji. Jednakże na Ukrainie ta szansa jest czasami niedoceniana i nie poświęca się jej należytej uwagi. Przede wszystkim jest ona postrzegana poprzez pryzmat powiązania przywództwa edukacyjnego nauczycieli z autonomią szkoły. Dopóki szkoła posiada autonomię tylko w wybranych obszarach, bez prawdziwego wpływu na wszystkie sfery życia szkoły, dopóty nie możemy mówić o przywództwie edukacyjnym nauczycieli we wszystkich jego wymiarach. Jeśli szkoła poddawana jest głęboko sięgającej kontroli państwa oraz narzuca się jej wartości i przekonania, przywództwo edukacyjne nauczycieli nie może rozkwitać. Zagadnienia edukacyjne, administracyjne i finansowe są ze sobą ściśle powiązane w edukacji, dlatego też bez możliwości wpływania na nie wszystkie, nauczyciele nie mogą cieszyć się autonomią podejmowania decyzji dotyczących życia społeczności szkolnej. Naszym zdaniem, to bardziej zagadnienie zaufania, kiedy państwo nie jest gotowe, by dać nauczycielom wolność decydowania o podstawowych zagadnieniach w obszarze ich ekspertyzy. Z drugiej strony, bez uzyskania autonomii, nauczyciele nie nauczą się brania na siebie odpowiedzialności, co stanowi fundament przywództwa edukacyjnego nauczycieli.

W zgodzie z pierwszym zagadnieniem pozostaje rola przywództwa edukacyjnego nauczycieli w kształtowaniu kultury szkoły, która jest oparta na środowisku kolegialnym, podejściu ukierunkowanym na rozwiązywanie problemów, zaufaniu i klarownej komunikacji. Całe doświadczenie zdaje się pokazywać, że wielu początkujących nauczycieli wchodzi do szkoły, wierząc, że mogą zmienić świat edukacji na lepszy. Następnie, gdy znajdą się w wąskim narożniku życia szkoły, z którego nie mogą zobaczyć pełnego obrazu i nie mogą podejmować nawet pomniejszych decyzji, mogą się rozczarować i doświadczyć wypalenia zawodowego.

W naszej opinii realizacja ważnych długofalowych zadań dotyczących administracji szkoły może prowadzić do przywództwa edukacyjnego nauczycieli. To, co ma nawet większe znaczenie w tym względzie, 
to fakt, że nauczyciele powinni mieć jasną wizję przyszłości swojej szkoły. Jeśli będą mieć wspólną wizję, będą mogli uczestniczyć w opracowaniu strategii, jak również wykonywaniu pionierskiej pracy w szkole. Przez "wspólną wizję" rozumiemy obraz rozwoju szkoły stworzony przez nauczycieli i administrację szkoły zgodnie z zasadą wzajemnego szacunku i współpracy. Jak pokazują wyniki badania, nauczyciele i kierownictwo szkół postrzegają kulturę swojej szkoły w różny sposób. Ponownie odwołujemy się do zapewnienia nauczycielom autonomii i odpowiedzialności jako głównej przesłanki wspierającej przywództwo edukacyjne nauczycieli.

Innym bardzo ważnym elementem przywództwa edukacyjnego nauczycieli jest aktywne uczestnictwo i uczciwa informacja zwrotna na temat wszystkiego, co dzieje się w ich szkole. Nauczyciele powinni wypowiadać swoje opinie, a nie wskazywać jedynie, czego oczekują od nich inni. Zagadnienie integralności ma podstawowe znaczenie nie tylko dla współczesnych teoretyków edukacji, ale również dla praktyków. Ponieważ zagadnienie informacji zwrotnej jest ważnym tematem, którym należy się zająć, nauczyciele-liderzy powinni nauczyć się przekazywać ją swoim uczniom i kolegom. Jest to również istotne dla ustawicznego doskonalenia zawodowego nauczycieli. Na Ukrainie nauczyciele mają wystarczająco dużo możliwości, by uczestniczyć w działaniach w zakresie rozwoju zawodowego. Ważne jest, by również aktywnie uczestniczyli w organizowaniu tych działań oraz decydowaniu, co jest dla nich ważne. W ten sposób nauczyciele-liderzy mogą prowadzić innych do pozytywnej zmiany w swoich szkołach i edukacji w ogóle.

Podsumowując, nasze wnioski prowadzą do konkluzji, że chociaż na Ukrainie istnieje duże zapotrzebowanie na nauczycieli liderów, istnieją pewne ważne problemy, które należy rozwiązać, zanim będą oni mogli wnieść swoją energię i kreatywność we wszystkie sfery życia szkoły.

Potrzebna jest dalsza praca, by lepiej zrozumieć, w jaki sposób nauczyciele-liderzy mogą pomóc swoim kolegom we wdrażaniu efektywnych strategii nauczania, jak mogą zapewnić realizację spójnego programu nauczania w całej szkole, w jaki sposób mogą zachęcać swoich współpracowników, by korzystali z danych w celu wzmocnienia nauczania, jak również, w jaki sposób mogą uczestniczyć w opracowywaniu wspólnej wizji w procesie przełamywania status quo i poszukiwania lepszych rozwiązań. 


\section{Bibliografia}

$\rightarrow$ Alexandrou, A., Swaffield, S. (2016), Teacher Leadership and Professional Development, New York: Routledge.

$\rightarrow$ Behn, R.D. (2003), Why Measure Performance? Different Purposes Require Different Measures, Public Administration Review, 63, 586-606.

$\rightarrow$ Educator Effectiveness (2015), Building a School Culture that Supports Teacher Leadership, Massachutes: Massachusets Department of Elementary and Secondary Education.

$\rightarrow$ Gates Foundation (2010), Learning about Teaching: Initial Findings from the Measures of Effective Teaching Project, Seattle, WA.: Bill and Melinda Gates Foundation.

$\rightarrow$ Hilton, A., Hilton, G., Dole, S., Goos, M. (2015), School Leaders as Participants in Teachers' Professional Development: The Impact on Teachers' and School Leaders' Professional Growth, Australian Journal of Teacher Education, 40(12), 104-125.

$\rightarrow$ Killion, J., Harrison, C. (2006), Taking the Lead: New Roles for Teachers and School-Based Coaches Ten Roles for Teacher Leaders, Oxford, OH: National Staff Development Council.

$\rightarrow$ Koki, S. (2015), The Role of Teacher Mentoring in Educational Reform, Honolulu: Pacific Resources for Education and Learning.

$\rightarrow$ Lyniov, K. (2016), Upravlinnya zakladom seredn'oyi osvity na osnovi paradyhmy liderstva (School Management based on Leadership Paradigm), Osvitologiia, (5), 50-55, dostęp: http://elibrary.kubg.edu.ua/17101/1/K_Lynov_O_5_FITU.pdf

$\rightarrow$ Marahovskaya, N.V. (2009), Pedahohichni umovy formuvannia liderskih yakostei maibutnih uchyteliv u prosesi navchannia dystsiplin humanitarnoho tsyklu [Pedagogical conditions helping future teachers to form their leadership skills during teaching humanitarian cycle disciplines] (abstrakt autora, praca doktorska), dostęp: ProQuest Dissertations \& Theses database [w j. ukraińskim].

$\rightarrow$ MLRN: The Mentoring Leadership And Resource Network (2017). Mentors.net, dostęp: 25 września 2017 r., na stronie: http://www.mentors.net/ 
$\rightarrow$ Moskovets, L. (2012), Profesijno-osoby`stisna kul'tura suchasnogo vchy`telya-lidera [Professional and Personal Culture of the Teacher Leader] [w:] Kultura i kompetentnist suchasnogo vchy telya-lidera [Culture and Proficiency of Modern Teacher Leader] (s. 54), Poltava.

$\rightarrow$ OECD (2014), TALIS 2013 Results: An International Perspective on Teaching and Learning, Paris: OECD Publishing.

$\rightarrow$ OECD (2014a), Teaching and Learning International Survey (TALIS) 2013. Principal Questionnaire, (2013).

$\rightarrow$ OECD (2014b), Teaching and Learning International Survey (TALIS) 2013. Teacher Questionnaire, (2013).

$\rightarrow$ OECD (2009), Creating Effective Teaching and Learning Environments: First Results from TALIS, Paris: OECD Publishing.

$\rightarrow$ Osovska, S. (2012), Kultura i kompetentnist suchasnogo vchy telya-lidera [Culture and Proficiency of Modern Teacher Leader] [w:] Kul tura i kompetentnist`suchasnogo vchy telya-lidera [Culture and Proficiency of Modern Teacher Leader], Poltava.

$\rightarrow$ Roby, D. (2017), Teacher leaders impacting school culture, Education, 131(4), 782-790.

$\rightarrow$ Santiago, P., Benavides, F. (2009), Teacher Evaluation: A Conceptual Framework and Examples of Country Practices, Paris: OECD Publishing.

$\rightarrow$ Semchenko, N.O. (2005), Pedahohichni umovy formuvannia liderskih yakostei maibutnih uchyteliv u pozaaudytorni diyalnosti [Pedagogical conditions helping future teachers to form their leadership skills during extra-curricular activities] (abstrakt autora, praca doktorska), dostęp: ProQuest Dissertations \& Theses database [w j. ukraińskim].

$\rightarrow$ Shchudlo, S., Kovalchuk, S. (2014), Reworking of School Principals' Roles in the Context of Educational Privatization: A View from Ukraine, European Education, 46(2), 32-52.

$\rightarrow$ Shchudlo, S., Zabolotna, O., Lisova, T. (2017), Ukrayins`ki vchy'teli ta navchaIne seredovy shhe [Ukrainian Teachers and School Environment]. All-Ukrainian Monitoring by TALIS Methodology conducted by Ukrainian Educational Research Association. Drohobych: UADO; TzOV TREK LTD.

$\rightarrow$ Supreme Soviet of Ukraine [Verkhovna Rada Ukrayiny]. (2017), Law of Education, Supreme Soviet of Ukraine [Verkhovna Rada Ukrayiny].

$\rightarrow$ Zavalevskyi, Y. (2008), Suchasny’j vchy tel': vy`mir chasu [Modern Teacher: Time Dimension], Kyiv: Bukrek.

$\rightarrow$ Zerbino, D. (2011), Naukova shkola: lider i uchni [Research School: Leader and Students], Lviv: Yevrosvit. 



\section{Przywództwo nauczycieli \\ w szkolnictwie wyższym w Laosie. \\ Wyzwania i szanse}

Bouakhong Keo Asa, Joanna Madalińska-Michalak

W artykule przedstawiono wyniki badań nad skutecznymi strategiami przywództwa w zakresie doskonalenia jakości kształcenia nauczycieli w Laosie. Szczególną uwagę zwraca się na kwestię przywództwa nauczycieli w szkolnictwie wyższym w Laosie oraz wyzwania i możliwości tego przywództwa. Pierwsza część artykułu poświęcona jest opisowi systemu edukacji w Laosie, ze szczególnym uwzględnieniem szkolnictwa wyższego oraz struktury administracji i zarządzania edukacją, w tym ministerstwa i lokalnych struktur zarządzania. Druga część przedstawia wybrane ustalenia dotyczące przywództwa nauczycieli w szkolnictwie wyższym w Laosie, jego wyzwania i możliwości. Sformułowano zalecenia dotyczące kluczowych zagadnień w zakresie kształtowania polityki na rzecz rozwoju przywództwa nauczycieli w ich organizacjach i sukcesu organizacyjnego.

\section{_ Słowa kluczowe: \\ przywództwo nauczycieli \\ reforma oświaty \\ szkolnictwo wyższe \\ edukacja nauczycieli




\section{Teacher leadership in higher education in Laos. Challenges and opportunities}

Bouakhong Keo Asa, Joanna Madalińska-Michalak

The paper presents the derived findings from the study on successful leadership strategies in improving quality of teacher education in Laos. The special attention is paid to the issue of teacher leadership in higher education in Laos and the challenges and opportunities of this leadership. The first part of the paper is devoted to the description of the educational system in Laos with focus on higher education and structures of education administration and management, including the ministry and local governance. The second part presents the chosen findings on teacher leadership in higher education in Laos and its challenges and opportunities. The recommendations on key policy issues for teacher leadership in their organizations for organizational success are formulated.

\section{Keywords: \\ teacher leadership \\ education reform \\ higher education \\ teacher education




\section{Wstęp}

Przywództwo jest złożonym pojęciem i niemal niemożliwe jest przestawienie jednej, poprawnej, ogólnie akceptowanej definicji (Madalińska-Michalak, 2015, s. 33). Może być postrzegane jako proces i relacje, w ramach których jednostka (lub grupa osób) wywiera wpływ na grupę osób, aby osiągnąć wspólny cel. Jedną z form przywództwa może być przywództwo nauczycieli w instytucjach oświaty. Odgrywa ono istotną rolę w zapewnianiu jakości kształcenia i równych możliwości edukacyjnych dla wszystkich osób uczących się (raport Trade Union Committee for Education, 2012). Przywództwo edukacyjne nauczycieli tworzy warunki dla efektywnego nauczania i uczenia się w szkołach, zapewnia niezbędne zasoby, wspiera i motywuje nauczycieli i uczniów. Nauczyciele jako przywódcy pomagają tworzyć i utrzymywać klimat pozytywnej instytucji i kultury pokoju, współpracy, ciężkiej pracy, porządku i dyscypliny w instytucji na rzecz całej wspólnoty instytucji (raport Trade Union Committee for Education, 2012).

Bardzo interesującą formą przywództwa jest przywództwo nauczycieli w instytucjach szkolnictwa wyższego. Przywódcy, którzy są odpowiedzialni za sprawowanie przywództwa nad współpracownikami na uniwersytetach, wydziałach i w biurach, zwani są przywódcami akademickimi. Wywierają oni wpływ na współpracowników, którzy są pracownikami naukowymi, nauczycielami i przedstawicielami innych zawodów, a także na studentów w celu osiągnięcia celów instytucji (Trash, 2012; OECD, 2013). Zwykle, choć nie zawsze, zajmują oni takie stanowiska administracyjne, jak: kierownik wydziału, koordynator programu, dyrektor lub wicedyrektor, kierownik przedmiotu lub zastępca kierownika przedmiotu, dziekan, zastępca dziekana, zastępca rektora i rektor.

Przywódcy akademiccy piastują wiele różnych stanowisk kierowniczych i sprawują funkcje przywódcze w instytucjach. Rektorzy i dziekani odgrywają kluczowe role przywódcze ze względu na ich pozycję w strukturze władzy w instytucji szkolnictwa wyższego, jaką jest uniwersytet. Są oni odpowiedzialni za realizację różnych obowiązków. $\mathrm{Na}$ przykład w hierarchii uniwersyteckiej dziekani kontrolują informacje, gromadzą i przydzielają zasoby i oceniają pracę swoich wydziałów, kolegiów i pracowników. Odgrywają zarówno rolę kierowników średniego szczebla w strukturze uniwersytetu, jak i szefów biur akademickich działających w ramach danego wydziału (Wood, 2004; Trash, 2012). 
Ponadto odgrywają ważną rolę jako interesariusze organizacji, ponieważ sprawują przywództwo w ramach wydziału, jak również w innych obszarach działalności uniwersytetu (Qablan, 2005). Możemy zaobserwować niewłaściwe przygotowanie osób obejmujących stanowisko dziekana - wiele z nich jest wyłanianych spośród nauczycieli akademickich. Często dziekani są wybierani w wyniku sprawowania przywództwa w środowisku akademickim, realizowanych obowiązków, doświadczenia zawodowego, rekomendacji kolegów, wykształcenia i sposobu bycia (Kolb, Kolb, 2005). Dziekani pracujący na uczelniach muszą działać w charakterze menedżerów i przywódców. Podobnie jak inni menedżerowie, muszą zajmować się planowaniem, organizacją i sprawowaniem kontroli. W ramach tych typowych kompetencji kierowniczych dziekani muszą przekazywać swoje obowiązki bezpośrednim podwładnym i przy ich pomocy wyznaczać cele oraz określać metody ich realizacji przez wydział (Trash, 2012; Gmelch, 2004). Skuteczni dziekani muszą być przedstawicielami swojego wydziału, cechującymi się wysokim poziomem kultury, posiadać umiejętności komunikacyjne, być wykwalifikowanymi menedżerami, umieć planować przyszłe działania, promować uczelnię i posiadać umiejętności zarządzania zmianą (Del Favero, 2006).

Przywódcy będący członkami kierownictwa średniego szczebla realizują funkcje przywódcze powiązane z pięcioma wymiarami lub aspektami organizacji, takimi jak: program nauczania, zarządzanie rozwojem operacyjnym i zasobami, stosunki interpersonalne, symbole i kultura oraz podejmowanie decyzji (Busher, Harris, Wise, 2000). Podobne poglądy głoszą Partington i Stainton (2003), którzy utrzymują, że kierownicy średniego szczebla angażują się w ramach organizacji w szereg działań, takich jak: organizowanie, planowanie, monitorowanie, zarządzanie zasobami, sprawowanie kontroli i prowadzenie oceny oraz sprawowanie przywództwa.

W niniejszym artykule przedstawiono wyniki badania na temat skutecznych strategii przywództwa w kształceniu nauczycieli w Laosie1. Szczególną wagę przywiązuje się tutaj do kwestii przywództwa nauczycieli w szkolnictwie wyższym w Laosie oraz wyzwań i szans związanych

1. B. Keo Asa (2017), Successful Leadership Strategies in Improving Teacher Education for Prospective Primary Teachers in Laos (Skuteczne strategie przywódcze na rzecz podnoszenia jakości kształcenia przyszłych nauczycieli szkół podstawowych w Laosie). Niepublikowana rozprawa doktorska napisana pod nadzorem prof. Joanny Madalińskiej-Michalak, Warszawa, Wydział Pedagogiczny Uniwersytetu Warszawskiego. 
z takim przywództwem. W badaniu, które przeprowadzono w latach 2015-2017, zastosowano metody badania jakościowego. Badanie to zasadza się na metodzie zbiorowego studium przypadku. W celu uzyskania zróżnicowanych materiałów zastosowano wywiady jakościowe, obserwacje i analizę dokumentów. Przeprowadzono analizę wielu tekstów istotnych dla celów badania, zarówno w języku laotańskim, jak i angielskim, w tym: odnośnej literatury, artykułów opublikowanych w czasopismach, dokumentów rządowych, raportów sporządzonych przez konsultantów i sponsorów badań, raportów rocznych, programów, dokumentów administracyjnych i akademickich oraz wybranych badań przeprowadzonych $w$ Laosie $w$ ramach szeregu sponsorowanych badań porównawczych. Kluczowe obszary analizy literatury obejmowały politykę i struktury oświatowe w Laosie, przywództwo edukacyjne, przywództwo w kolegiach i szkołach oraz decentralizację.

Przedmiotem badania są wyzwania i szanse w przywództwie nauczycieli w szkolnictwie wyższym. Dostrzec można, iż coraz większą wagę przywiązuje się do podsumowywania i syntetyzowania wyników badań, aby wyłonić $z$ ich zbioru te, które są obiecujące i znaczące w tej dziedzinie.

\section{Edukacja w Laosie - sytuacja ogólna}

Laos jest państwem śródlądowym w Azji Południowo-Wschodniej. Graniczy z pięcioma krajami: z Chinami od północy, Wietnamem od wschodu, Kambodżą od południa, Tajlandią od zachodu i Birmą od północnego zachodu. Laos jako państwem zróżnicowanym etnicznie. Populacja wynosi $6,5 \mathrm{mln}$ osób. Ponad $80 \%$ ludności żyje w obszarach wiejskich. Większość z nich prowadzi produkcję rolną na własne potrzeby. Laos jest jednym z najsłabiej rozwiniętych krajów na świecie. Niedawno zaobserwowano gwałtowny rozwój gospodarczy na średnim poziomie $7,1 \%$ w skali kraju, jednak około $34 \%$ populacji utrzymuje się za mniej niż 1,25 USD dziennie. Kraj ten ma jedne z najsłabszych wskaźników edukacyjnych w Azji. Laosem rządzi ta sama partia od 1975 r.

W ramach laotańskiej reformy oświaty wprowadzono zmiany $w$ systemie edukacji, również w sektorze szkolnictwa wyższego, a zwłaszcza w odniesieniu do kolegiów kształcenia nauczycielski. Zmiany w szkolnictwie wyższym wyraźnie odzwierciedlają dane dotyczące zmniejszenia liczby instytucji, takich jak kolegia kształcenia nauczycieli, oraz utworzenia nowych filii uniwersytetów we wszystkich częściach Laosu. 
W 1991 r. działało 59 kolegiów kształcenia nauczycieli, a w 2000 r. ich liczba spadła do 10 (z uwzględnieniem Laotańskiego Uniwersytetu Państwowego). Działania te zostały podjęte w odpowiedzi na sytuację finansową kraju, priorytety polityki i zarządzania szkolnictwem wyższym. Obecnie w kraju działa osiem kolegiów kształcenia nauczycieli i cztery uniwersytety. Na uczelniach tych studiuje 18756 studentów, w tym 10467 kobiet. Spośród nich można wyróżnić 1939 przyszłych nauczycieli (w tym 1938 kobiet) wychowania przedszkolnego, 2688 przyszłych nauczycieli (w tym 1302 kobiety) szkół podstawowych, 9872 przyszłych nauczycieli (w tym 5055 kobiet) szkół średnich pierwszego stopnia i 4257 przyszłych nauczycieli (w tym 2172 kobiety) szkół wyższych pierwszego stopnia. Jeśli chodzi o personel, obejmuje on 979 nauczycieli i 147 pracowników administracyjnych (MOE, DTE Annual summary report 2016-2017).

\section{System oświaty}

Kształcenie formalne w Laosie obejmuje pięć poziomów: szkolnictwo podstawowe (nauka trwa 5 lat), szkolnictwo pierwszego stopnia (cztery lata), szkolnictwo średnie drugiego stopnia (trzy lata), szkolnictwo zawodowe i techniczne (rok lub trzy lata) oraz szkolnictwo wyższe (trzy do siedmiu lat, w zależności od obszarów tematycznych).

Szkolnictwo ponadpodstawowe lub szkolnictwo średnie przeznaczone jest dla dzieci i nastolatków w wieku 11-16 lat, i dzieli się na dwa etapy: szkolnictwo średnie pierwszego stopnia i szkolnictwo średnie drugiego stopnia. Do szkół średnich pierwszego stopnia uczęszczają uczniowie w wieku 11-13 lat (klasy 6-8), natomiast do szkół średnich drugiego stopnia uczęszczają uczniowie w wieku 14-16 lat (klasy 9-11). Podział szkolnictwa średniego na dwa trzyletnie etapy jest wynikiem procesu reform realizowanych od $2007 \mathrm{r}$. w ramach krajowej strategii reform systemu edukacji (NESRS). Po zakończeniu reform nauka w szkole średniej pierwszego stopnia została wydłużona do czterech lat i uczęszczają do niej uczniowie w wieku 11-14 lat. Szkoły średnie drugiego stopnia zostały podzielone na szkoły ogólnokształcące i zawodowe (w tym kształcenie nauczycieli).

\section{Polityka oświatowa}

Rząd Laosu traktuje edukację jako jeden z kluczowych priorytetów, obok rolnictwa, ochrony zdrowia, infrastruktury (szczególnie dróg 
w obszarach wiejskich) i jako jeden z filarów strategii redukcji ubóstwa. Rząd określił podstawowy poziom wykształcenia, jaki powinni osiągnąć wszyscy obywatele Laosu, którzy muszą ukończyć szkołę podstawową niezależnie od rasy, religii, płci, pochodzenia etnicznego i statusu społeczno-ekonomicznego. Wszyscy uczniowie muszą ukończyć szkołę podstawową. Usługi edukacyjne mogą być świadczone w szkołach publicznych lub prywatnych. Jednak treści kształcenia muszą mieć na celu rozwój fizyczny i psychiczny dzieci i być zgodne z programem nauczania opracowanym przez Ministerstwo Edukacji. Rząd i obywatele muszą połączyć wysiłki w ramach odpowiedzialności za zarządzanie oświatą i usługami we wszystkich publicznych szkołach podstawowych.

\section{Wsparcie finansowe edukacji}

Od ustanowienia Lao, Laotańskiej Republiki Ludowo-Demokratycznej w 1975 r., rząd laotański zwraca dużą uwagę na usprawnienia w sektorze edukacji: od kształcenia w przedszkolach aż do poziomu szkół wyższych. Na podstawie rocznych planów rozwoju edukacji i raportów Ministerstwa Edukacji rząd laotański opracowuje budżet finansowy dla sektora edukacji na poziomie od $10 \%$ do $16 \%$ wydatków budżetu państwa. Jednak zasoby finansowe przeznaczone na oświatę są nadal niewystarczające $w$ stosunku do potrzeb edukacyjnych lokalnych społeczności. Środki przeznaczone dla dystryktów są niewystarczające do zapewnienia odpowiedniego poziomu finansowania usług publicznych na tym poziomie. W większości przypadków potrzebne jest wsparcie dla budżetów poszczególnych prowincji, jednakże nie jest ono zagwarantowane. W rezultacie budżety przeznaczone na zarządzanie szkołami są niskie, szkoły są wspierane przez wspólnoty, które nie są w stanie przeznaczyć odpowiednich kwot na działalność szkół i wypłatę wynagrodzeń dla nauczycieli, a zaległości w tym zakresie zazwyczaj są kilkumiesięczne.

Decentralizacja fiskalna i przekazanie obowiązków operacyjnych prowincjom i dystryktom sprawiły, że sektory socjalne pozostały bez odpowiedniej ochrony zabezpieczającej zaspokojenie minimalnych potrzeb w najbiedniejszych regionach kraju i wśród najbiedniejszych grup ludności. Jeśli chodzi o tworzenie sieci, brak jest przepływu informacji pomiędzy władzami oświatowymi na poziomem centralnym a tymi w prowincjach, co osłabia użyteczność planów rządowych. Inne problemy zidentyfikowane przez rząd laotański wykryto na szczeblu lokalnym, 
tj. władz oświatowych w prowincjach i kuratoriach okręgowych, gdzie brak jest planowania finansowego i monitorowania wydatków i tym samym brak możliwości realizacji zadań określonych w przepisach. Brak też prób połączenia planowania budżetu z planowaniem rozwoju edukacji. Chociaż wydaje się, że wdrożono odpowiedni system kontroli rachunkowości finansowej, to jego stosowanie nie gwarantuje skuteczności i zasadności wykorzystania zasobów, jak również dysproporcji pomiędzy wydatkami stałymi a nakładami inwestycyjnymi. Jednakże nie ma mechanizmu zapewniającego odpowiednią równowagę pomiędzy inwestycjami uwzględnionymi w budżecie a wydatkami stałymi na poziomie lokalnym.

Łączny budżet inwestycyjny samorządów jest ponad 3-krotnie wyższy niż wydatki stałe i znacznie przekracza budżet inwestycyjny zatwierdzony przez Zgromadzenie Narodowe. Taki poziom inwestycji jest nierealny w stosunku do dostępnych zasobów i są symptomy wskazujące na to, że inwestycje wypierają lokalne wydatki stałe w ramach realizacji budżetu, na dużą niekorzyść sektorów społecznych. Aby rozwiązać te problemy, rząd laotański musiał podzielić wydatki na edukację w stosunku do całkowitej kwoty wydatków publicznych, która wzrosła z 8\% w 2004 r. do 18\% w 2015 r. (MOES, 2008, 3). Taki wzrost był potrzebny, aby pokryć wydatki stałe konieczne do utrzymania inwestycji w jakość zasobów ludzkich, które mają związek z pracą naukową, a także przydatnością programu nauczania/materiałów dydaktycznych, podręczników i niezbędnym wyposażeniem. Dodatkowo, większość pomocy międzynarodowej została ukierunkowana na wzmocnienie szkół podstawowych, Narodowego Uniwersytetu Laotańskiego i kolegiów nauczycielskich. Szkolnictwo średnie, jak dotąd, otrzymało niewielkie wsparcie zewnętrzne, głównie z budżetu państwa i ze strony rodziców.

\section{Administracja oświatowa}

Ministerstwo Edukacji (ME) zarządza największą grupą pracowników cywilnych w Laosie. Sektor edukacji zatrudniał ponad 56000 pracowników w roku szkolnym 2006-2007 (Ministerstwo Edukacji, 16 kwietnia 2008 r.). Ministerstwo Edukacji jest złożoną instytucją ze względu na różne linie komunikacji i uprawnień; ma strukturę hierarchiczną, zarówno na szczeblu centralnym, jak i prowincji i dystryktów. Jest ono centralnym urzędem oświatowym. Pełni rolę sekretariatu dla Komitetu Centralnego Partii i rządu w sprawach związanych z edukacją, 
planowaniem i opracowywaniem polityki, jak również z nadzorowaniem, kierowaniem, wdrażaniem i kontrolowaniem zadań oświatowych w całym kraju. Dlatego Ministerstwo Edukacji jest odpowiedzialne za kształcenie formalne i pozaformalne na wszystkich poziomach, zarówno w sektorze publicznym, jak i prywatnym, nad którymi Ministerstwo to pełni nadzór.

W szczególności obowiązki Ministerstwa Edukacji i związanych z nim organizacji obejmują: rekrutację i zatrudnianie nauczycieli, opracowywanie programów nauczania, pisanie i publikację podręczników, kształcenie nauczycieli, kształcenie i szkolenie zawodowe, szkolnictwo wyższe, planowanie i współpracę, finansowanie edukacji ( $w$ tym opracowywanie krajowego budżetu na edukację poprzez ustalanie ram budżetowych i regulacyjnych, tak by władze prowincji i dystryktów mogły funkcjonować w tych ramach) oraz ogólne zarządzanie personelem w systemie, jak również ustanawianie standardów dla szkół i zapewnianie jakości edukacji.

W 2008 r. Ministerstwo Edukacji przeprowadziło audyt organizacyjny i restrukturyzację swoich struktur na podstawie dekretu premiera o organizacji i funkcjonowaniu Ministerstwa Edukacji Nr 62/PM/07 (MOESa, 7 kwietnia 2008 r.). Reorganizacja administracji i zarządzania oświatą składa się z dwóch poziomów: makro (ME) i lokalnego (kuratoria na poziomie prowincji i regionów - bez wzmianki o poziomie wspólnot).

W 2008 r. Ministerstwo Edukacji przeprowadziło audyt organizacyjny i restrukturyzację swoich struktur na podstawie dekretu premiera o organizacji i funkcjonowaniu Ministerstwa Edukacji nr 2239/MOE. CB.08 (MOESb, 7 września 2008 r.). Reorganizacja administracji i zarządzania oświatą składa się z dwóch poziomów: makro (ME) i lokalnego, prowincjonalne służby oświatowe (PSO) i Kuratoria oświaty na poziomie dystryktów (KOD). Struktura organizacyjna została przedstawiona poniżej (rysunek 1.). 
Rysunek 1. Organizacja administracji i zarządzania edukacją w Laosie

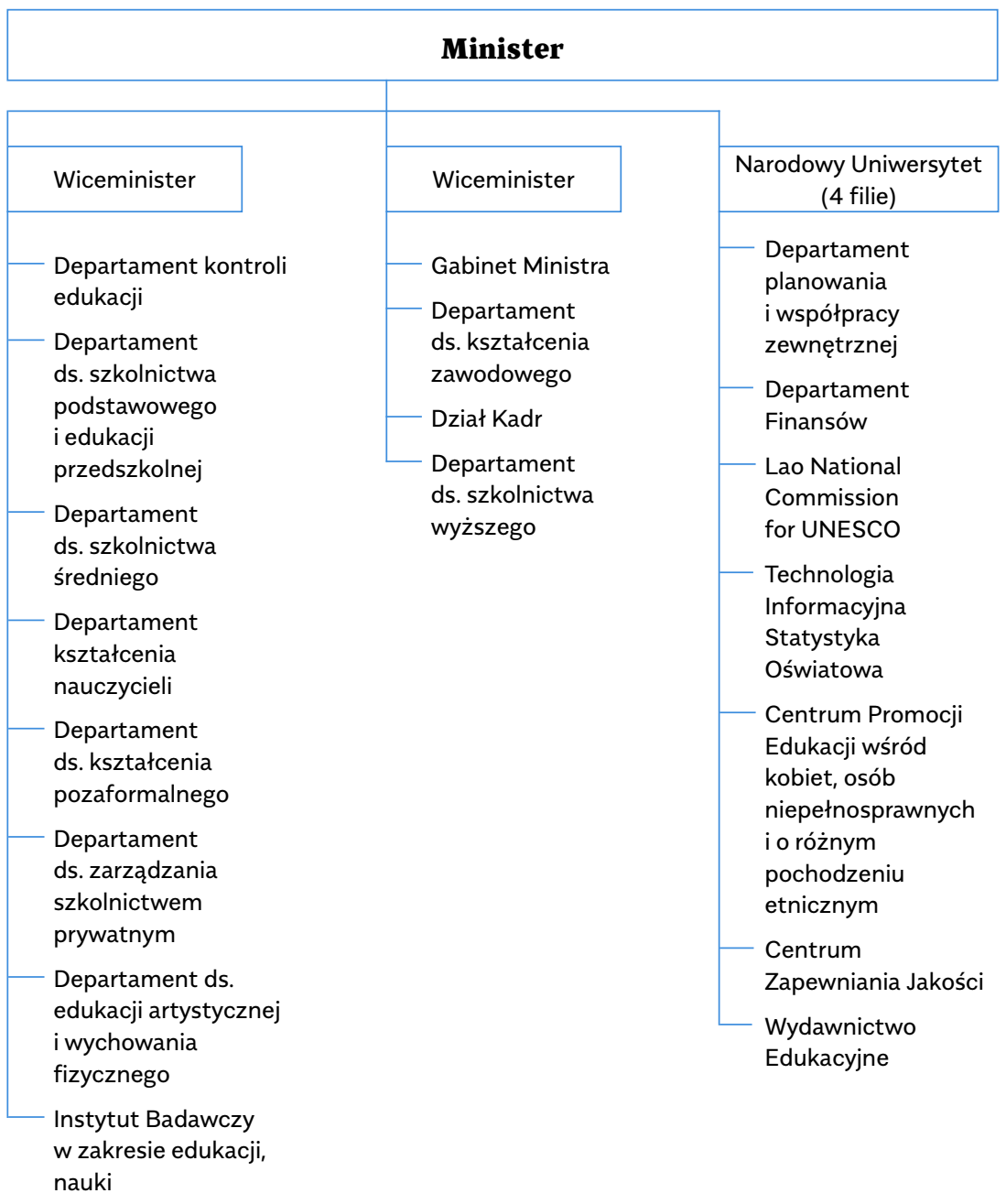

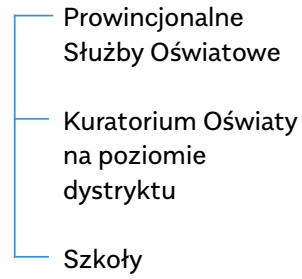

Źródło: Dekret ME nr 2239/MOE.CB.08 z dnia 7 września 2008 r. 
W skład ministerstwa wchodzi 12 departamentów, jeden gabinet, jedna komisja i jedna instytucja. Działają również centra i przedsiębiorstwa, które podlegają nadzorowi ministerstwa (patrz schemat organizacyjny ME powyżej). Każdy departament ma określony własny zakres obowiązków, porozumienia administracyjne oraz relacje ze służbami na poziomie prowincji i dystryktów. Chociaż uczelnie uważane są za autonomiczne instytucje, to wciąż znajdują się pod nadzorem ME na poziomie makro.

Departament kształcenia nauczycieli jest jedną z jednostek organizacyjnych ME. Jednostka ta jest odpowiedzialna za techniczne i finansowe wsparcie dla ośmiu instytucji kształcenia nauczycieli w Laosie. Każdą instytucją kształcenia nauczycieli kieruje zarząd (dyrektor i trzech wicedyrektorów), który współpracuje z Radą Zarządzającą i Radą Nauczycieli. Ich role przywódcze obejmują: opracowywanie planu rozwoju instytucji, planu budowania zdolności kadry akademickiej, zarządzanie, budżetowanie, wspieranie i kontrolę każdego biura w ramach instytucji lub kolegiów. Inne role obejmują współpracę z organizacjami zewnętrznymi, takimi jak SEP-y, KOR-y, szkoły i społeczności, w celu rozwijania procesu nauczania-uczenia się. W ramach każdej instytucji kształcenia nauczycieli działa 10 biur: Akademickie Biuro Promocji, Biuro ds. Nauk Przyrodniczych, Biuro ds. Nauk Społecznych, Biuro ds. Kształcenia Nauczycieli Szkół Podstawowych, Biuro ds. Znajomości Języków Obcych, Biuro ds. Rozwoju Zawodowego Nauczycieli, Biuro Spraw Studenckich, Biuro ds. Zarządzania Finansami, Biuro Kadr i Biuro ds. Oceny i Ewaluacji. Biura te składają się z 34 jednostek.

Biuro ds. Kształcenia Nauczycieli Szkół Podstawowych jest głównie odpowiedzialne za kształcenie przyszłych nauczycieli szkół podstawowych. Biurem ds. Kształcenia Nauczycieli Szkół Podstawowych kieruje zarząd (biuro kierownika i biuro zastępcy kierownika) oraz kierownicy jednostek, którzy współpracują na rzecz doskonalenia nauczania z dyrektorami kolegiów nauczycielskich i kierownikami innych biur w ramach instytucji, a także $z$ organizacjami zewnętrznymi. Ich role przywódcze obejmują: obserwację procesu nauczania-uczenia się na poziomie biura, badanie i rozwój nauczania-uczenia się, obserwację kształcenia przyszłych nauczycieli, organizację warsztatów w ramach biura, gromadzenie danych o nauczaniu. Inne role biura kierownika to współpraca z organizacjami zewnętrznymi, szczególnie z kuratoriami oświaty w regionach i szkołami podczas praktyk przyszłych nauczycieli 
i ich wspieranie, udzielanie informacji zwrotnej, dostarczanie materiałów i metod nauczania (opracowanie na podstawie zarządzenia Ministra nr 814/MOE.PO/10 z dnia 9 kwietnia 2010 r.).

Rysunek 2. Struktura organizacyjna instytucji kształcenia nauczycieli

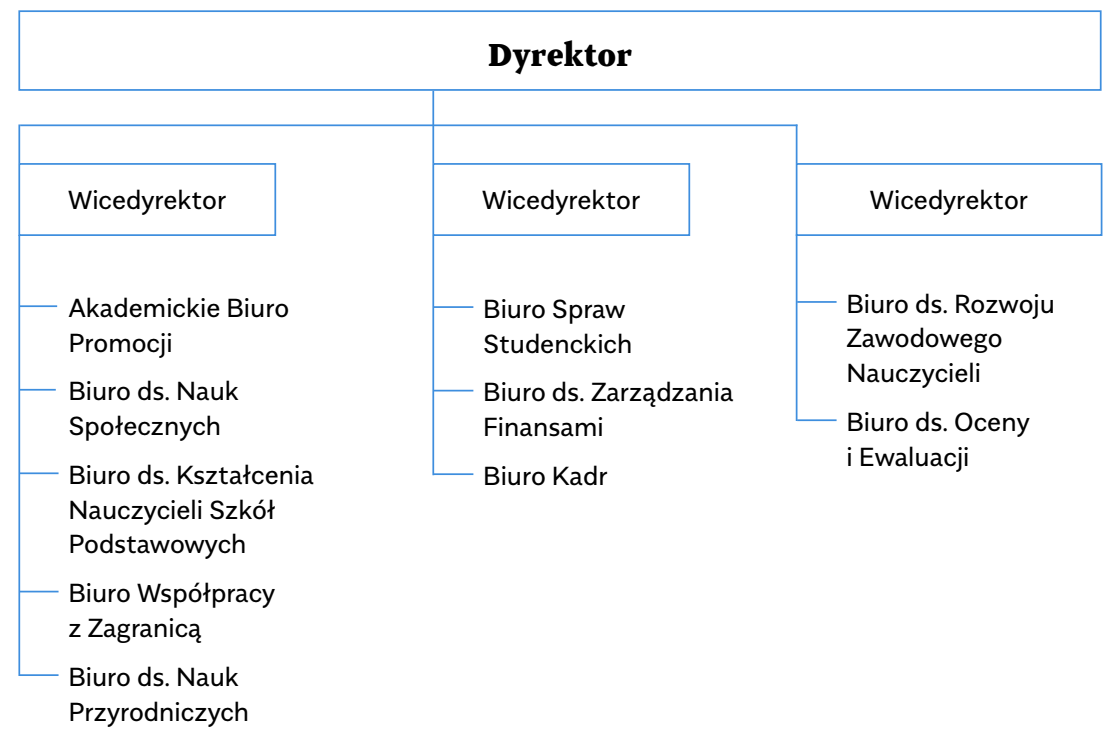

Źródło: Dekret ME nr 814/MOE.PO/10 z dnia 9 kwietnia 2010 r.

MEiS (2006) zaproponowało politykę doskonalenia sieci instytucji kształcenia nauczycieli w jego regionie, gdzie każda instytucja kształcenia nauczycieli powinna przeprowadzić reorganizację swojej Rady Doradczej. W skład Rady Doradczej powinni wchodzić przedstawiciele społeczności i organizacji biznesowych, Departamentu Kształcenia Nauczycieli (DKN), Służb Oświatowych na poziomie Prowincji (PSO) i kuratoriów oświaty na poziomie dystryktu (KOD). Doskonalenie zawodowe nauczycieli w szkołach podstawowych jest wspierane przez profesjonalne sieci koordynacji obejmujące instytucje kształcenia nauczycieli, doradców pedagogicznych i innych pracowników PSO i KOD, Centrów Doskonalenia Nauczycieli i klasterów szkół w celu wspierania nauczania. 
Na poziomie lokalnym są to Prowincjonalne Służby Oświatowe (PSO) i Kuratoria Oświaty na poziomie Dystryktu (KOD). Instytucje te w dużej mierze ponoszą odpowiedzialność operacyjną za realizację kształcenia na poziomie szkół podstawowych i ponadpodstawowych. Jednak $w$ ramach procesu decentralizacji prowadzonego przez rząd od 2000 r. ME przekazało część obowiązków PSO i KOD, jak określono w art. 62 nowej ustawy oświatowej z 2007 r. w sprawie administrowania oświatą i organizacji zarządzania: Rząd pełni obowiq̨zki na poziomie centralnym w zakresie zarządzania oświatą i zapewnia, że system edukacji narodowej działa na poziomie całego kraju. ME ponosi bezpośredniq̨ odpowiedzialność za administrowanie i zarzq̨dzanie oświatą. Organizacje odpowiedzialne za administrowanie i zarządzanie oświatq to ME, SPO, stołeczne służby oświatowe, KOD i prefektury (tłumaczenie sporządzone przez badacza na podstawie art. 62 ustawy oświatowej przyjętej przez Zgromadzenie Narodowe Nr. 25/NA z dnia 6 maja 2003 r.).

PSO stanowią na poziomie prowincji pionową organizację odpowiedzialną za administrowanie i zarządzanie na rzecz ME. Rolą PSO jest sprawowanie doradztwa i przywództwa, wdrażanie, kontrola i ewaluacja administrowania, zarządzania i rozwoju oświaty w danej prowincji, zgodnie z polityką rządu. PSO są postrzegane jako ekspozytury ME, lecz także podlegają gubernatorom lub burmistrzom w przypadku gmin. Gubernator, który technicznie stanowi odpowiednik ministra, posiada dużą władzę w zakresie określania priorytetów międzysektorowych i mianowania personelu SEP-ów. PSO są odpowiedzialne za (i) szkoły średnie, oraz (ii) technika i szkoły zawodowe, które nie znajdują się pod kontrolą ME. W skład PSO wchodzi 11 działów, z których każdy ma inny zakres obowiązków, odrębne porozumienia administracyjne i relacje z departamentami ME i jednostkami KOD (opracowanie na podstawie Dekretu ME nr 1584/MOE.DoP.09 z dnia 3 lipca 2009 r.). 
Rysunek 3. Struktura organizacyjna Służb Oświatowych i ds. Sportu na poziomie prowincji

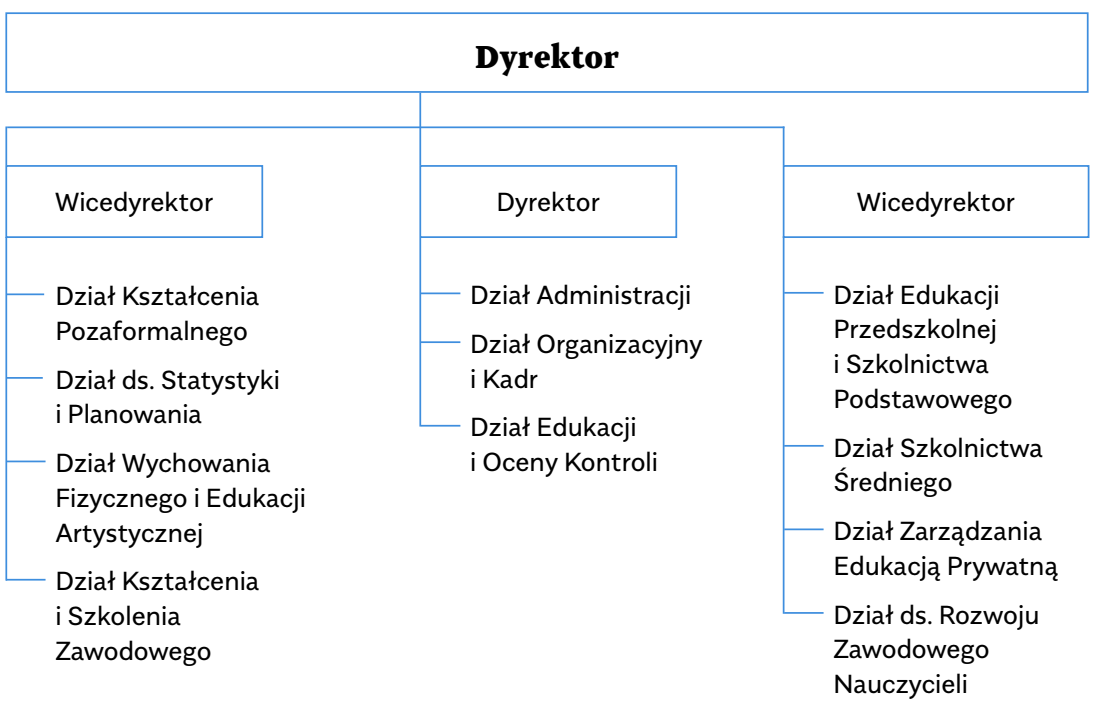

Źródło: Dekret ME nr 2239/MOE.DoP.09 z dnia 3 lipca 2009 r.

Kuratorium Oświaty na poziomie dystryktu (KOD) jest lokalnym biurem na najniższym poziomie administracji oświatowej. Zgodnie z Dekretem nr 1572/MoE.DoP.09 (MOE, 3 lipca 2009b), KOD to pionowa organizacja odpowiedzialna za administrowanie i zarządzanie na rzecz ME na poziomie dystryktu. Rolą KOD jest zapewnianie wytycznych i sprawowanie przywództwa, wdrażanie, kontrola, monitorowanie i ocena rozwoju edukacji w danym dystrykcie. KOD-y są postrzegane jako ekspozytury SPO, lecz także podlegają szefowi dystryktu. Szef dystryktu ma dużą władzę w zakresie określania priorytetów międzysektorowych i mianowania personelu KOD-ów. W skład KOD-u wchodzi 8 jednostek (patrz struktura organizacyjna KOD-u poniżej). Każda jednostka ma odrębny zakres obowiązków, porozumienia administracyjne i relacje z działami PSO i ze szkołami. KOD wspiera szkoły i społeczności w planowaniu kształcenia podstawowego i edukacji przedszkolnej oraz przygotowuje plan na każdy rok akademicki i każdy semestr szkolny w danym dystrykcie. KOD jest odpowiedzialne za przedszkola, szkoły podstawowe i instytucje kształcenia pozaformalnego $\mathrm{w}$ danym dystrykcie. 
Rysunek 4. Struktura organizacyjna Kuratorium Oświaty

i ds. Sportu na poziomie dystryktu

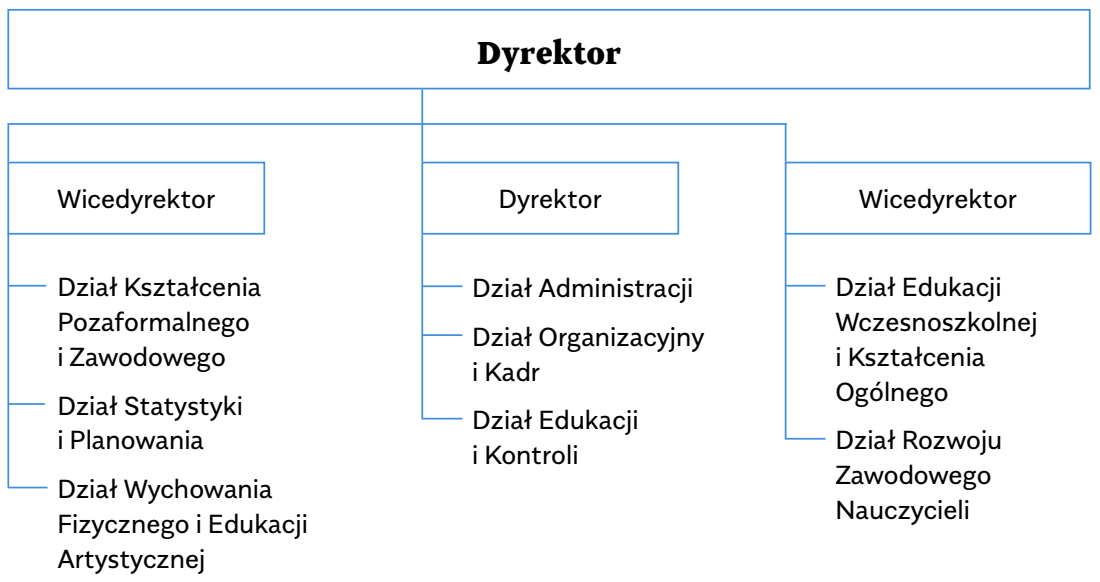

Źródło: Dekret ME nr 2584/MOE.DoP.09 z dnia 3 lipca 2009 r.

Podsumowując, przywództwo w zakresie organizacji edukacji, zarówno na poziomie centralnym, jak i lokalnym, jest hierarchicznie uporządkowane. Liderzy w każdej instytucji posiadają odrębny zakres obowiązków określony przez ME, które jest odpowiedzialne za planowanie, określanie polityki, jak również nadzorowanie, prowadzenie. wdrażanie i kontrolowanie zadań edukacyjnych w całym kraju. Natomiast liderzy na poszczególnych poziomach pełnią swoje odpowiednie funkcje, w związku z czym przywódca każdej organizacji wydaje się odgrywać ważną rolę w sprawowaniu przywództwa i budowaniu zdolności danej organizacji, aby mogła osiągnąć zamierzone cele.

\section{Monitorowanie i kontrola}

Odpowiedzialność za zapewnienie jakości nauczania w laotańskiej oświacie jest rozłożona głównie na trzech poziomach obejmujących Kuratoria Oświaty na poziomie dystryktu, Prowincjonalne Służby Oświatowe i Centra Zapewniania Jakości.

KOD-y są odpowiedzialne za kontrolę jakości nauczania w szkolnictwie podstawowym. Urząd ten prowadzi kontrolę nauczania zgodnie 
z wytycznymi PSO, a jednocześnie odpowiedzialność za zapewnienie jakości nauczania i działanie szkół na poziomie szkoły średniej ponoszą PSO, które zatrudniają dwóch lub trzech inspektorów odpowiedzialnych za zapewnienie przestrzegania rozporządzeń ME przez szkoły. Jednakże inspektorzy rzadko wizytują szkoły podstawowe i średnie, ponieważ fundusze na pokrycie kosztów transportu i wydatków inspektorów są ograniczone.

System doradztwa pedagogicznego na poziomie szkolnictwa podstawowego i średniego został uruchomiony $w$ roku szkolnym 1995/1996 dzięki wsparciu z Banku Światowego. W rzeczywistości owi doradcy pedagogiczni nie są odpowiedzialni za monitorowanie zgodności, lecz próbują wspierać nauczycieli w korzystaniu z nowego programu nauczania. W ramach systemu decentralizacji zarządzania odpowiedzialność za działania szkół w dużej mierze leży w gestii dyrektorów tychże szkół.

Natomiast Centrum Zapewniania Jakości (CZJ), nowo utworzone w 2013 r., jest odpowiedzialne za zapewnienie jakości nauczania i działalność kolegiów kształcenia nauczycieli. Trzej inspektorzy odpowiadają za zapewnienie zgodności działań kolegiów z rozporządzeniami Departamentu ds. Kształcenia Nauczycieli i ME. Jednakże CZJ jeszcze nie działa prawidłowo ze względu na ograniczenia finansowe i braki w umiejętnościach pracowników, stąd też inspektorzy rzadko prowadzą kontrole w kolegiach.

\section{Kształcenie nauczycieli w Laosie}

W 1975 r. sytuacja polityczna w Indochinach uległa drastycznej zmianie. Obywatele Kambodży, Laosu i Wietnamu odnieśli zwycięstwo w walce o socjalistyczne społeczeństwo. Po okresie niezależności, zgodnie z zobowiązaniem rządu Laotańskiej Republiki Ludowo-Demokratycznej do zapewnienia rozwoju obywateli czy zasobów ludzkich, w całym kraju otworzono więcej instytucji kształcenia nauczycieli w celu zaspokojenia rosnącego popytu na nauczycieli, który spowodowany był wyższymi poziomami naborów w szkołach.

W rezultacie kształcenie nauczycieli w Laosie było realizowane w ramach różnych programów przygotowawczych trwających jeden rok, dwa, trzy lub cztery lata - oferowanych przez kolegia kształcenia nauczycieli, i 4-letnich programów kształcenia - na uniwersyteckich wydziałach pedagogicznych. Kursy mogą być realizowane w kolegiach 
kształcenia nauczycieli wspieranych przez rząd i na uniwersytetach akredytowanych przez Ministerstwo Edukacji i Sportu (MEiS).

\section{Charakterystyka ogólna kształcenia nauczycieli}

W ramach reformy oświaty, liczba instytucji kształcenia nauczycieli spadła z 59 w 1991 r. do 10 (w tym Uniwersytet Laotański) w 2000 r. Działanie to zostało podjęte $w$ reakcji na realny stan finansowy, rzeczywiste zarządzanie i zapewnianie jakości kształcenia. W 2003 r. w kraju działało osiem kolegiów kształcenia nauczycieli. Pod względem technicznym i finansowym, owe osiem kolegiów pozostawało pod kierownictwem i stosowało się do wytycznych Departamentu Kształcenia Nauczycieli edukacji w MEiS. Jednakże, pod względem ideologicznym i politycznym, instytucje te znajdowały się pod nadzorem Prowincjonalnego Biura ds. Edukacji i Sportu. Ponieważ wprowadzono zmiany w szkolnictwie średnim, programy kształcenia nauczycieli szkół podstawowych w kolegiach kształcenia nauczycieli również uległy zmianie i rozwojowi.

Obecnie kształcenie nauczycieli szkół podstawowych jest realizowane poprzez trzy programy: system $9+3,12+2 \mathrm{i} 12+4$. W ramach tych programów kształceni są nauczyciele szkół podstawowych, którzy mają kwalifikacje do nauczania wszystkich przedmiotów na tym poziomie kształcenia.

Programy kształcenia nauczycieli szkół średnich pierwszego stopnia pozostają w systemie $12+4$. Po ukończeniu tego programu absolwenci studiów stają się wykwalifikowanymi nauczycielami szkół średnich pierwszego stopnia.

W 2006 r. Ministerstwo Edukacji i Sportu wprowadziło reformy kształcenia ogólnego polegające na wydłużeniu o jeden rok kształcenia średniego pierwszego stopnia, z cyklu trzyletniego na czteroletni. Obecnie kształcenie ogólne $w$ Laosie jest realizowane $w$ systemie 5+4+3 (12-letnie kształcenie ogólne). Ponieważ wprowadzono zmiany w kształceniu ogólnym, instytucje kształcenia nauczycieli w całym kraju również zostały zreformowane i każda szkoła kształcąca nauczycieli uzyskała status instytucji kształcenia nauczycieli. Opracowano nowe programy kształcenia nauczycieli i pozostały tylko trzy z nich w systemie $9+3,12+2$ i $12+4$. 
Tabela 1. Osiem kolegiów nauczycielskich w Laosie

\begin{tabular}{|c|c|c|}
\hline $\begin{array}{l}\text { NAZWA KOLEGIUM } \\
\text { NAUCZYCIELSKIEGO }\end{array}$ & $\begin{array}{l}\text { TYPY SZKÓŁ, DLA KTÓRYCH } \\
\text { KSZTAŁCENI SĄ NAUCZYCIELE }\end{array}$ & POZIOM ZARZĄDZANIA \\
\hline Bankeun & $\begin{array}{l}\text { szkoły średnie pierwszego stopnia, } \\
\text { szkoły podstawowe, przedszkola }\end{array}$ & ME i władze prowincji \\
\hline Dong Kham Xang & szkoły podstawowe, przedszkola & ME \\
\hline Luang Nam Tha & $\begin{array}{l}\text { szkoły średnie pierwszego stopnia, } \\
\text { szkoły podstawowe, przedszkola }\end{array}$ & ME i władze prowincji \\
\hline Luang Prabang & $\begin{array}{l}\text { szkoły średnie pierwszego stopnia, } \\
\text { szkoły podstawowe, przedszkola }\end{array}$ & ME i władze prowincji \\
\hline Paske & $\begin{array}{l}\text { szkoły średnie pierwszego stopnia, } \\
\text { szkoły podstawowe, przedszkola }\end{array}$ & ME i władze prowincji \\
\hline Savannakhet & $\begin{array}{l}\text { szkoły średnie pierwszego stopnia, } \\
\text { szkoły podstawowe, przedszkola }\end{array}$ & ME i władze prowincji \\
\hline Saravan & szkoły podstawowe, przedszkola & ME i władze prowincji \\
\hline Xieng Khouang & $\begin{array}{l}\text { szkoły średnie pierwszego stopnia, } \\
\text { szkoły podstawowe, przedszkola }\end{array}$ & ME i władze prowincji \\
\hline
\end{tabular}

Źródło: ME, 2012.

\section{Struktura kształcenia nauczycieli i system rekrutacji}

Zawód nauczyciela w Laosie nie wydaje się być popularny wśród młodych obywateli, zwłaszcza młodych mieszkańców miast. Zgodnie z raportem Kształcenie i zatrudnianie nauczycieli (Teacher Training and Recruitment into the Teaching Profession, TTEST, 2004), 76\% studentów kierunków kształcących nauczycieli pochodzi z biednych rodzin rolniczych i nie mają oni możliwości uczęszczania na inne uczelnie.

Rekrutacja kandydatów na studia opiera się na różnych zasadach i politykach. Jedna z podstawowych zasad, na których zasadza się proces selekcji, wynika z regulacji opublikowanych przez MEiS. Jednakże rzeczywisty proces selekcji na poziomie realizacji (prowincja) nie został jednoznacznie określony. Wybór kandydatów mających rozpocząć kształcenie prowadzące do uzyskania kwalifikacji pedagogicznych jest skomplikowanym procesem, który obejmuje głównie dwie ścieżki: kandydaci kwotowi i pozostali kandydaci (niekwotowi). Procesem rekrutacji kandydatów niekwotowych zarządzają kolegia nauczycielskie, podczas 
gdy kwotowy system rekrutacji obejmuje kilka poziomów hierarchicznych, począwszy od MEiS do poziomu prowincji, dystryktu i kolegium.

Na kwotowy system rekrutacji składa się kilka procesów. Po pierwsze, Departament Administracji w Kancelarii Premiera określa liczbę studentów na podstawie liczby pracowników, którzy przechodzą na emeryturę i przesyła taką liczbę (kwotę) do MEiS. Po drugie, MEiS wskazuje kwotę studentów w odniesieniu do każdego z Prowincjonalnych Biur ds. Edukacji i Sportu (PBES) w całym kraju. Po trzecie, PBES określa kwotę studentów dla każdego Biura ds. Edukacji i Sportu na poziomie dystryktu (BESD), BESD wybiera studentów z lokalnego obszaru w zależności od lokalnych potrzeb i odsyła ich do PBES, a następnie instytucje kształcenia nauczycieli otrzymują studentów wysłanych przez PBES, jak pokazano na rysunku 5.

Rysunek 5. Kwotowy system rekrutacji studentów w Laosie

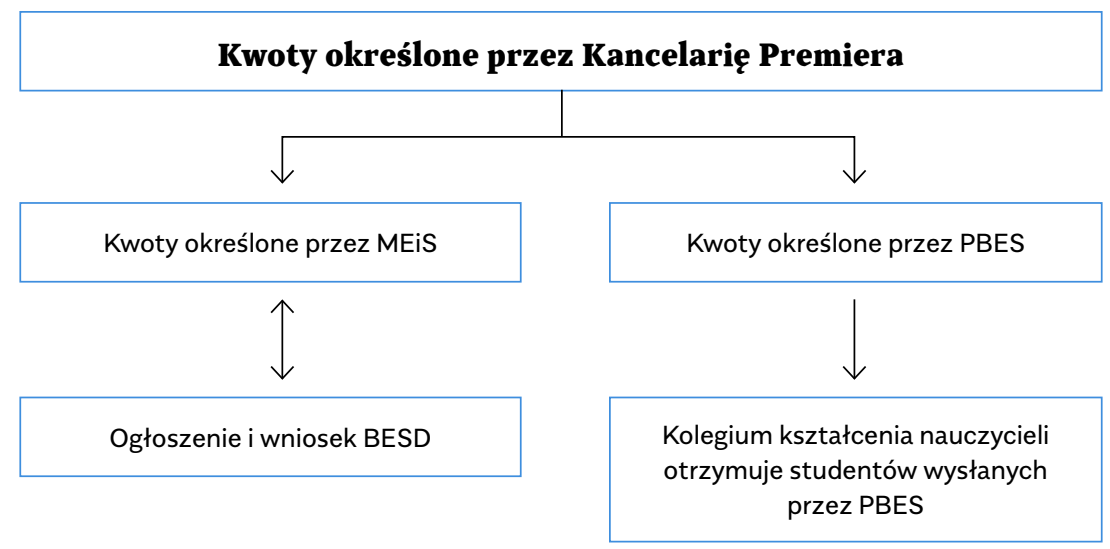

Źródło: TTEST, 2004, 8.

Podsumowując, obecne reformy kształcenia nauczycieli zasadzają się na zmianach w systemie kształcenia ogólnego, trzy systemy: $5+3$, $5+4$ i $8+1$ zostały wyeliminowane, natomiast dwa systemy: $9+3,12+2$ nadal istnieją (wcześniej zwane 8+3 i 11+2, obecnie zwane 9+3 i 12+2; jest to spowodowane tym, że dodano jeden rok kształcenia na poziomie szkolnictwa średniego) oraz wprowadzono nowy system $12+4$. 


\section{Główne zasady}

Kształcenie nauczycieli na poziomie akademickim odbywa się w kolegiach. Obejmuje ono zarówno przedmioty ogólne, przedmiot specjalizacyjny, jak i metodykę nauczania. Nauki psychologiczne i społeczne również stanowią ważne przedmioty. Teoria jest nauczana w klasie, natomiast praktyki są organizowane na ostatnim roku studiów, aby pomóc studentom połączyć teorię z praktyką i ułatwić rozwiązywanie codziennych problemów związanych z nauczaniem. Studia pedagogiczne i nauczanie treści przedmiotowych są blisko powiązane.

Nacisk kładzie się na rolę nauczyciela w kontekście społecznym. Nauczyciele są uprawnieni do podjęcia studiów magisterskich. Otrzymują świadectwo ukończenia kolegium potwierdzające uzyskanie 96 punktów zaliczeniowych (po dwóch latach kształcenia, świadectwo kwalifikacji do nauczania w szkołach podstawowych), 110 punktów zaliczeniowych (po trzech latach kształcenia, świadectwo kwalifikacji do nauczania w wiejskich szkołach podstawowych) oraz 145 punktów zaliczeniowych (po czterech latach kształcenia, dyplom licencjacki uprawniający do nauczania w szkołach podstawowych). Studia pedagogiczne organizowane są w kolegiach nauczycielskich pod nadzorem departamentu kształcenia nauczycieli. Szkoły, w których duża część studenckich praktyk pedagogicznych jest realizowana, są związane organicznie z departamentem kształcenia nauczycieli. Praktyki nauczycielskie odbywają się w zwykłych szkołach w całym kraju. Po ukończeniu kolegium, studenci otrzymują świadectwo i uprawnienia do nauczania i tym samym mogą ubiegać się o zatrudnienie w szkołach podstawowych.

\section{Wyzwania przywództwa edukacyjnego nauczycieli w kształceniu nauczycieli}

Odnośnie do sytuacji w Laosie, można powiedzieć, że przywódcy edukacyjni na szczeblu krajowym i lokalnym w Laosie mierzą się z licznymi wyzwaniami. Obejmują one ograniczenie liczby wykwalifikowanych zasobów ludzkich i nieskuteczne zespoły przywódcze, niskie poziomy finansowania ze źródeł publicznych, nieefektywność systemu zapewniania jakości, trudności w wykonywaniu ustaw, przepisów i rozporzq̨dzeń, niski poziom dostępności danych edukacyjnych, konflikty pomiędzy liniami podejmowania decyzji a koordynacji na szczeblu lokalnym i centralnym, słabe zaangażowanie społeczno- 
ści lokalnych w rozwój edukacji (MOES, 2006; MOES, 2008c; MOES, MOES 2012a).

Na poziomie centralnym (tj. MEiS, uniwersytetów i kolegiów, jednym z wyzwań jest ograniczona liczba kompetentnych i sprawnych zasobów ludzkich w MEiS. Ministerstwo to cierpi na poważny niedobór dobrze wyszkolonych, wykwalifikowanych i zaangażowanych pracowników administracyjnych. Zauważono również, że wielu z najlepiej wykształconych i najbardziej kompetentnych pracowników jest w wieku powyżej 50 lat. Niektórzy z pracowników w tej grupie przejdą na emeryturę w ciągu kilku najbliższych lat. Dlatego bardzo ważnym zagadnieniem jest przygotowanie pracowników do pracy i wymiana personelu na dobrze wykształconych młodych pracowników, którzy przejmą zadania tych, którzy wkrótce przejdą na emeryturę (Kittiphanh, 2011). Jak zauważył Ogawa (2009), pracownicy Departamentu Szkolnictwa Wyższego w Ministerstwie Edukacji i Sportu posiadają niewystarczającą wiedzę i umiejętności niezbędne do tworzenia polityki, poprawy programu nauczania w szkolnictwie wyższym i opracowania standardów ewaluacji i monitorowania systemu szkolnictwa wyższego.

Drugie duże wyzwanie dla przywództwa wynika z ograniczonych zasobów finansowych, z jakimi boryka się sektor oświaty $w$ kraju. Laos w dużej mierze polega na zewnętrznych źródłach finansowania budżetu na edukację (UNESCO, 2012). Na przykład wydatki publiczne na edukację osiągnęły tylko $15 \%$ całkowitej kwoty wydatków publicznych i 3,2\% produktu krajowego brutto (PKB) w latach 2006-2007. Natomiast poprawa ta wynika z silnego wzrostu budżetu inwestycyjnego, który w większości jest finansowany przez partnerów rozwoju i nie oznacza jakiegokolwiek wzrostu udziału krajowych środków finansowych we wskaźniku budżetu na wydatki stałe i inwestycyjne. Stosunek wydatków stałych do kapitałowych wyniósł 46:53, a fundusze zagraniczne stanowiły ponad 90\% wydatków kapitałowych w latach 2004-2005. Ponadto większość budżetu została przeznaczona na wynagrodzenia nauczycieli i inne koszty stałe i tylko niewielka część budżetu może być przeznaczona na doskonalenie i rozwój oświaty, a budżet na rozwój kształcenia w latach 2012-2013 wynosił zaledwie 16,7\% wydatków rządowych i 4,47\% PKB (MOES, 2013). Doprowadziło to do braku regularnego monitorowania, nadzoru i ewaluacji w całym sektorze oświaty (MOES, 2008c; MOES, MOES 2012b). Kolejny problem, przed którym staje przywództwo, jest związany z systemem zapewniania jakości 
w każdej dziedzinie edukacji. Ogólnie rzecz ujmując, system nie jest wystarczający i nie spełnia oczekiwań współczesnego społeczeństwa.

Centrum Zapewniania Jakości (CZJ) działające w ramach MEiS jest obecnie odpowiedzialne za opracowywanie polityki i procedur zapewniania jakości we wszystkich sub-sektorach edukacji, w tym w sektorze publicznego i prywatnego szkolnictwa wyższego, jak również szkolnictwa średniego, technicznego i zawodowego. CZJ jest stosunkowo młodą jednostką i jego zdolności powinny zostać wzmocnione (MOES, 2006; MOES, 2008c; UNESCO, 2008). Kolejnym problemem jest działanie Systemu Informacji o Zarządzaniu Edukacją (SIZE) w nieprzychylnym środowisku. Zasoby Ludzkie SIZE są niewystarczające do jego prawidłowego działania, szczególnie na poziomie centralnym (ME) i dystryktów. Na poziomie centralnym, infrastruktura SIZE jest niewystarczająca, natomiast na poziomie dystryktów nadal działa 25 Kuratoriów Oświaty, które nie mają dostępu do energii elektrycznej, a ponad połowa z nich nie posiada komputera. Obecnie rezultaty działania SIZE są ograniczone i dublowane z powodu istnienia kilku równoległych systemów gromadzenia danych przez różne departamenty MEiS, które są zbierane z tego samego źródła w tym samym czasie (UNESCO, 2008).

W związku z wyższym poziomem wykształcenia na uniwersytetach i w kolegiach, MEiS twierdzi, że system zarządzania edukacją w ośmiu instytucjach kształcenia nauczycieli w całym kraju jest nieskuteczny (MOES, 2006; UNESCO, 2008).

Pierwszy powód do obaw jest wspólny dla większości zespołów przywódczych w instytucjach kształcenia nauczycieli (IKN). Nie odbyły one specjalistycznych szkoleń w zakresie przywództwa i zarządzania. Większość dyrektorów IKN zazwyczaj uczy się, jak prowadzić i zarządzać instytucją w ramach wykonywania obowiązków zawodowych. Zdolności przywódcze i umiejętności zarządzania dyrektorów i administratorów oświaty w kolegiach i na uniwersytetach są ograniczone (MOES, 2006; UNESCO, 2008).

Druga poważna kwestia jest związana z jakością kadry nauczającej w kolegiach i na uniwersytetach. Większość nauczycieli pracujących w instytucjach szkolnictwa wyższego posiada tylko tytuł zawodowy licencjata. Istnieje niedobór pracowników z wykształceniem magisterskim i posiadających stopień doktora (MOES, 2012a). Powoduje to problemy w opracowywaniu programu nauczania i materiałów dydaktycznych, które muszą być stale adaptowane, korygowane i zmieniane, aby były 
ściśle powiązane z szybkim międzynarodowym postępem nauki i technologii oraz aby podnosiły jakość szkolnictwa wyższego (MOES, 2008b). Jak podaje Europe AID Cooperation Office (2009), jakość kształcenia w szkolnictwie wyższym pozostaje na niskim poziomie, a rząd nie potraktował rozwoju edukacji jako zagadnienia priorytetowego. Nakłady na badania i rozwój edukacji również kształtują się na bardzo niskim poziomie. Ponadto niektórzy pracownicy, osoby kształcące nauczycieli i wykładowcy nie są mocno zaangażowani w swoją pracę (MOES, 2008d).

Trzecia kwestia jest związana z warunkami społeczno-ekonomicznymi i słabą kondycją finansową. W rezultacie, kierownictwa IKN muszą poświęcać dużą część swojego czasu na rozwiązywanie codziennych problemów dotyczących warunków życia osób odpowiedzialnych za kształcenie studentów i samych studentów. Zespoły kierownicze nie są w stanie w pełni przyczyniać się do podnoszenia jakości pracy w instytucjach kształcących nauczycieli. Procedury pracy, delegowanie zadań i decentralizacja obowiązków na różnych poziomach IKN nie są jeszcze zadowalające (UNESCO, 2008; MOES, 2006).

Czwarte wyzwanie dotyczy regulacji, zasad i innych przepisów prawa dotyczących zarządzania szkolnictwem wyższym. Nie są one adekwatne do istoty i specyfiki problemów z zarządzaniem tym związanych. Wprowadzenie zasad i regulacji dotyczących kontroli jakości było trudne - po części z powodu braku poczucia odpowiedzialności za ten mechanizm, po części w związku z brakiem systemu zapewnienia jakości w IKN (MOES, 2006; MOES, 2008b; UNSCO, 2008). Kolegiom i uniwersytetom nadal brak jasnej wizji, polityki i strategii oraz planu działania skierowanych na osiągnięcie regionalnych i międzynarodowych standardów w zakresie dostępu, jakości, przydatności i konkurencyjności. Co więcej, poza powyższym, brakuje kompleksowego planowania, zarządzania i monitorowania na poziomie kształcenia pomaturalnego i w sektorze szkoleń (UNESCO, 2008; MOES, 2012 a).

Na szczeblu władz lokalnych (tj. Prowincjonalnych Biur ds. Edukacji i Sportu oraz Kuratoriów Oświaty na poziomie dystryktu, szkół i społeczności), PBES jest odpowiedzialne za (techniczna odpowiedzialność operacyjna) szkolnictwo średnie oraz za doradzanie Kuratoriom Oświaty na poziomie dystryktu (KOD) oraz za kolegia kształcenia nauczycieli i szkoły techniczne, natomiast Kuratoria Oświaty na poziomie dystryktu są odpowiedzialne (odpowiedzialność operacyjna) za szkolnictwo podstawowe i współpracę ze społecznościami. 
W 2000 r. rząd laotański zainicjował decentralizację struktury politycznej, przekazując odpowiedzialność za planowanie edukacji, alokację budżetu i świadczenie usług władzom administracyjnym prowincji i dystryktów (UNESCO, 2008). W wyniku wprowadzenia decentralizacji zarządzania edukacją pojawiło się wiele nowych wyzwań na różnych poziomach.

Po pierwsze, brak jest jasnych procesów planowania, systemów, ról i podziału obowiązków w zakresie zdecentralizowanego zarządzania pomiędzy szczeblem centralnym a lokalnym, poczynając od MEiS, przez PSO, KOD aż po szkoły. MEiS utraciło kontrolę nad kluczowymi elementami, w tym nad ogólnym przygotowaniem budżetu i wydatków, zarządzaniem oraz monitorowaniem i ewaluacją edukacji publicznej (Azjatycki Bank Rozwoju, 2003, cyt. w Kittiphanh, 2011, 28). Problem ten wskazuje na niejasne struktury odpowiedzialności pomiędzy PSO, KOD oraz relacje pomiędzy administracją na poziomie prowincji i dystryktów. Zaobserwowano, że gubernatorzy prowincji odgrywają kluczową rolę w zarządzaniu finansami publicznymi, a przydzielone środki budżetowe zależą w głównej mierze od negocjacji pomiędzy gubernatorami prowincji a rządem centralnym, nie zaś od klarownych przepisów (Bank Światowy, 2008, cyt. w Kittiphanh, 2011; MOES, 2012b).

Po drugie, przepływ środków finansowych na poziomie władz prowincji jest bardzo ograniczony od chwili rozpoczęcia decentralizacji. Utrudnia to PSO i KOD wspieranie doradców pedagogicznych w monitorowaniu początkujących nauczycieli, ocenianie pracy nauczycieli i systematyczne nadzorowanie dyrektorów szkół w zakresie realizacji procesu nauczania-uczenia się. Na przykład wymaga się, by dyrektorzy szkół, administratorzy i nauczyciele byli regularnie nadzorowani i wspierani przez ekspertów ds. edukacji z kolegiów, uniwersytetów, PBES i KOD w celu podniesienia jakości nauczania. Jednakże brak jest regularnego monitorowania, nadzoru i wsparcia dla pracowników szkół ze strony PBES i KOD (MOES, 2008c). Jak spostrzeżono w jednym z ostatnich raportów:

$\rightarrow$ Brak wystarczającej liczby pracowników technicznych na poziomie prowincji i dystryktów, którzy mogliby zapewnić wsparcie,

$\rightarrow$ Wiedza i umiejętności pracowników technicznych na poziomie prowincji i dystryktów jest nieodpowiednia, oraz 
$\rightarrow$ Pracownicy techniczni na poziomie prowincji i dystryktów mają utrudnioną pracę z powodu niedoboru środków na monitorowanie i nadzór (MOES, 2008c, s. 107).

Po trzecie, zdolności zespołów przywódczych PBES i KOD (tj. dyrektorów szkół, dyrektorów wicedyrektorów, kierowników biur, kierowników działów) oraz członków kadry akademickiej na tych poziomach są nieskuteczne i niedostateczne, a także brak jest personelu i szkoleń z zarządzania. Większość urzędników PSO i KOD to byli nauczyciele i niektórzy z nich ukończyli tylko szkołę podstawową i średnią pierwszego stopnia (Azjatycki Bank Rozwoju, 2003, cyt. w Kittiphanh, 2011). Mają oni niewielkie możliwości uczestnictwa w efektywnych szkoleniach umożliwiających im podjęcie nowych obowiązków w ramach decentralizacji. Stwarza to bariery w angażowaniu się w dialog polityczny lub działanie na rzecz zwiększenia budżetu.

Kolejny problem, z jakim borykają się SPO i KOD, związany jest z przepływem wykwalifikowanych pracowników, na przykład na poziomie prowincji, gdzie pracownicy po odbyciu szkoleń, zwłaszcza w obszarach technicznych, często odchodzą, aby podjąć bardziej lukratywne finansowo zatrudnienie, co prowadzi do niedoboru wykwalifikowanych pracowników technicznych. Podobna sytuacja może występować na poziomie dystryktów (Kittiphanh, 2011).

Wyzwania związane z przywództwem edukacyjnym na poziomie szkół są stosunkowo podobne do tych obserwowanych na poziomie prowincji i dystryktu. Zdolności zespołów przywódczych (tj. dyrektorów szkół, wicedyrektorów, kadry akademickiej, nauczycieli) są niewystarczające. Większość dyrektorów i wicedyrektorów, którzy kierują swoimi organizacjami, jest powoływana na te stanowiska bez udziału w specjalnych szkoleniach z dziedziny zarządzania. W rezultacie, jak twierdzi MEiS (2011 r.), brakuje im ważnych umiejętności, gdy idzie o zarządzanie placówkami szkolnymi, kadra kierownicza na poziomie szkoły dysponuje ograniczonymi umiejętnościami w zakresie mobilizowania i angażowania społeczności lokalnych w przywództwo i zarządzanie szkołami za pośrednictwem Wiejskich Komitetów Rozwoju Edukacji (WKRE), a także brak jest koordynacji działań pomiędzy władzami na szczeblu prowincji, dystryktu a WKRE, opiekunem uczniów - na rzecz podnoszenia jakości edukacji (MOES, 2008d; MOES, 2011). Dodatkowo, od czasu decentralizacji zapoczątkowanej w 2000 r., alokacje środków 
z budżetu dla każdej prowincji i dystryktu są różne i ograniczone do zarządzania edukacją w ramach zachęcania do poprawy kształcenia na poziomie szkół. Na przykład, zgodnie z dekretem premiera w sprawie obowiązkowego kształcenia, edukacja na poziomie szkoły podstawowej jest bezpłatna. Jednak rodzice uczniów i społeczności pokrywają koszty operacyjne w ramach opłaty rejestracyjnej na rzecz funkcjonowania szkoły, obsługi, materiałów szkolnych, napraw budynków i obiektów szkolnych oraz dotacji dla nauczycieli. W rezultacie rodzice uczniów są niezadowoleni z przywództwa w szkole (MOES, 2011; UNSCO, 2008).

Podsumowując, badacze i osoby odpowiedzialne za tworzenie polityki coraz częściej dostrzegają problem poprawy jakości edukacji dla nowych nauczycieli. Jednakże w Laosie nadal brakuje badań nad przywództwem edukacyjnym i poprawy kształcenia w tej dziedzinie. Badania dotyczące roli kolegium w przywództwie edukacyjnym nauczycieli pod względem wpływania na jakość edukacji oferowanej przez kolegium początkującym nauczycielom laotańskim mogą być postrzegane jako nowe badania. Widoczny w Laosie brak empirycznych badań poświęconych skutecznym praktykom przywództwa oraz poprawie kształcenia przyszłych nauczycieli ma wpływ na stan wiedzy w tej dziedzinie. Temat ten jest bardzo ważny, ponieważ wyznacza kierunek dla dalszych rozmów, refleksji, aby zrozumieć wkład ról przywódczych w tworzenie innowacji strategicznych i zarządzanie kolegiami nauczycielskimi - ich role pozostają niezbadane $w$ literaturze dotyczącej laotańskiej edukacji. Sugerowane badania wniosą nową wiedzę na temat roli przywództwa w odniesieniu do doskonalenia nauczania w kolegiach nauczycielskich w Laosie.

Przywództwo sektora edukacji - w postrzeganiu laotańskiego Ministerstwa Edukacji i Sportu oraz z perspektywy niektórych raportów na temat edukacji w Laosie - jest nieskuteczne w kierowaniu procesem uczenia się. Może to mieć związek z menedżerami pełniącymi funkcje administracyjne, którzy sami nie biorą udziału w kursach szkoleniowych w zakresie administracji. Brak jest monitoringu ze strony AQC oraz występuje niedobór funduszy na wspieranie procesu nauczania-uczenia się. Ponadto w ramach procesu decentralizacji można zaobserwować brak zaangażowania społeczności w proces kształcenia dzieci, nieodpowiednie przygotowanie zespołów przywódczych i personelu do wykonywania obowiązków (MOES, 2006; MOES, 2008d; MOES kontroler 2012a; UNSCO, 2008). 


\section{Możliwości związane z przywództwem edukacyjnym nauczycieli}

W wielu dokumentach (np. raportach: lokalnych i międzynarodowych) często wskazuje się, że przywództwo w zakresie edukacji jest jednym z kluczowych elementów powodzenia w kierowaniu organizacją w celu osiągnięcia sukcesu. Przywództwo edukacyjne ma zarówno bezpośredni, jak i pośredni wpływ na rozwój edukacyjny oraz efekty uczenia się i osiągnięcia studentów.

Raport Komitetu Związków Zawodowych ds. Edukacji (2012) wskazuje, że liderzy edukacyjni mają ogromny wpływ na jakość nauczania i na całokształt otoczenia nauczania, w tym na motywację personelu, morale i wyniki, praktyki nauczania oraz na postawy i aspiracje zarówno uczniów, jak i rodziców. Ponadto podkreślono tam, że istnieje potrzeba zapewnienia liderom edukacyjnym wystarczających możliwości, by mogli rozwijać i utrzymywać skuteczne umiejętności przywódcze. Wyniki badań dowodzą, że tacy przywódcy edukacyjni, jak dyrektorzy szkół, dyrektorzy i pozostali liderzy w kształceniu nauczycieli na poziomie szkoły wyższej, mają wpływ na jakość efektów edukacji studentów (Leithwood, Jantzi, 1999).

Według Davies i Davies (2004), przywódcy edukacyjni są zaangażowani w różne kluczowe działania na rzecz poprawy jakości nauczania w instytucjach oświatowych. Działania podejmowane przez przywódców edukacyjnych, w tym wyznaczanie kierunku, przekładanie strategii na konkretne działania, dostosowanie ludzi i organizacji do strategii, określają skuteczne punkty interwencji strategicznej oraz rozwijają strategiczne kompetencje (Davies, 2009).

Dlatego pożądane jest, aby osoby odpowiedzialne za tworzenie polityki na wysokim szczeblu, takim jak Ministerstwo Edukacji i Sportu, oraz inne osoby na kierowniczych stanowiskach odpowiedzialne za kształcenie w danej instytucji oświatowej wzięły pod uwagę to, że zagadnienia przywództwa edukacyjnego stanowią najważniejsze elementy organizacji. Jeśli style przywództwa edukacyjnego nauczycieli mają ulec poprawie i zmianie, uznaje się, że jakość kształcenia nauczycieli powinna stopniowo poprawiać się.

\section{Zalecenia}

W celu podniesienia jakości przywództwa edukacyjnego nauczycieli na poziomie instytucji szkolnictwa wyższego w Laosie, istnieją pewne możliwości, którymi powinni zająć się menedżerowie oświaty i osoby 
odpowiedzialne za tworzenie polityki na szczeblu ministerstwa. Poniżej sformułowano kilka zaleceń.

Po pierwsze, kwalifikacje i doświadczenie przywódcze są niezbędne dla skutecznego zarządzania instytucjami oświatowymi. Dlatego liderzy edukacyjni w instytucjach przywództwa nauczycieli muszą być przeszkoleni w rozwijaniu kompetencji przywódczych. Wiedza na temat różnych współczesnych teorii przywództwa oraz umiejętności i zdolności ważne dla przywództwa edukacyjnego są niezbędne w skutecznym zarządzaniu, kierowaniu i przewodzeniu organizacjami. Przywódcy edukacyjni muszą być odpowiednio wykształceni, jeśli chcemy, aby mierzyli się ze zmianami w dziedzinie kształcenia, a zwłaszcza kształcenia nauczycieli.

Po drugie, przywódcy edukacyjni, którzy uzyskują promocję na stanowiska w administracji oświatowej w instytucjach szkolnictwa wyższego, powinni mieć silną motywację, umiejętności przywódcze i kwalifikacje pedagogiczne. Przywódcy edukacyjni powinni być oceniani, aby mieć pewność, że zdobyli zarówno wiedzę z zakresu zarządzania, jak i umiejętności przywódcze. Ponadto powinni opanować różne rodzaje wiedzy potrzebnej w procesie nauczania-uczenia się. Powinni posiadać wiedzę przedmiotową, pedagogiczną, znajomość potrzeb uczniów i ich cech charakterystycznych, ogólną wiedzę w dziedzinie pedagogiki, wiedzę na temat treści edukacyjnych, programów nauczania, celów i wartości edukacyjnych.

Po trzecie, budżet finansowy na wspieranie i wdrażanie planów krótko-, średnio- i długoterminowych w uszeregowanych pod względem ważności działaniach pozostaje jednym z najważniejszych kluczy do sukcesu organizacyjnego. Dlatego niezbędne jest, by przywódcy na najwyższym szczeblu, takim jak Ministerstwo Edukacji, ostrożnie podejmowali decyzje dotyczące przeznaczania wystarczającej kwoty środków finansowych z budżetu dla przywódców w instytucjach kształcenia nauczycieli, którzy w najlepszy możliwy sposób wykorzystają przydzielone zasoby w celu wspierania i wnoszenia wkładu do planów ogólnych, projektów, programów i innych działań związanych z celami i wizją oświaty. Inne podczas planowania rozwoju instytucji nie mogą być realizowane.

Po czwarte, praca i role przywództwa edukacyjnego w instytucjach kształcenia nauczycieli powinny zostać poddane przeglądowi i poprawione w celu budowania zdolności w zakresie doradztwa i konsultacji dotyczących przywództwa edukacyjnego nauczycieli. 
Na koniec, wypłata regularnego, wystarczającego miesięcznego wynagrodzenia jest bardzo ważna dla pracowników dydaktycznych oraz ich poczucia stabilizacji życiowej i rozwoju kariery. Ten podstawowy warunek jest połączony z poprawą jakości nauczania i lepszymi osiągnięciami studentów w nauce. Zatem menedżerowie oświaty i osoby odpowiedzialne za tworzenie polityki na szczeblu ministerstwa powinny podejmować transparentne decyzje o ustalaniu wymiaru i podnoszeniu wynagrodzenia członków personelu oraz o poprawie ich warunków pracy.

\section{Podsumowanie}

Reasumując, przywództwo nauczycieli odgrywa ważną rolę we wspieraniu, zachęcaniu, inspirowaniu i promowaniu kreatywności pracowników dydaktycznych, tworzeniu i utrzymaniu lepszych warunków pracy w instytucjach oświatowych w celu poprawy jakości nauczania. Pójście naprzód i podniesienie jakości nauczania stanowi nie tylko wyzwanie, ale także szansę dla przywództwa nauczycieli, a przyszły sukces będzie zależał od wrażliwości osób odpowiedzialnych za tworzenie polityki na wysokim szczeblu, innych czynników oraz zdolności przywódców w zakresie kierowania organizacjami w obecnym kontekście, wysiłków podejmowanych przez pracowników dydaktycznych, nauczycieli-liderów, rodziców, studentów i całe społeczeństwo (Nguyen, Nguyen, 2006).

Przywództwo nauczycieli w ośmiu kolegiach kształcenia nauczycieli w Laosie stoi przed licznymi wyzwaniami związanymi ze zmianami w kontekście społeczno-ekonomicznym. W niniejszym artykule określono niektóre cechy oświaty, administracji oświatowej, zarządzania i kształcenia nauczycieli w Laosie, wyzwania (na poziomie lokalnym i krajowym) oraz możliwości. Zaproponowano zalecenia mające na celu poprawę przywództwa edukacyjnego nauczycieli w kolegiach kształcenia nauczycieli. 


\section{Bibliografia}

$\rightarrow$ Busher, H., Harris, A. and Wise, C. (2000), Subject Leadership and School Improvement, London: Paul Chapman.

$\rightarrow$ Davies, B.J., Davies, B. (2004), The nature of strategic leadership, School Leadership and Management, 4(1), s. 29-38.

$\rightarrow$ Davies, B. (2009), Developing a Strategic Leadership Perspective, Hull, UK: University of Hull.

$\rightarrow$ Del Favero, M. (2006), Disciplinary variation in preparation for the academic dean role, Higher Education Research \& Development, 25(3), s. 277-292.

$\rightarrow$ Gmelch, W.H. (2004), The department chair's balancing acts, New Directions for Higher Education, 126, s. 69-84.

$\rightarrow$ Keo Asa, B. (2017), Successful Leadership Strategies in Improving Teacher Education for Prospective Primary Teachers in Laos (Skuteczne strategie przywódcze i podnoszenie jakości kształcenia przyszłych nauczycieli szkół podstawowych w Laosie), unpublished doctoral dissertation written under the supervision of J. Madalińska-Michalak, Warszawa: Faculty of Education, University of Warsaw.

$\rightarrow$ Kittiphanh, D. (2011), The challenges of developing educational leadership in the Lao People's Democratic Republic, unpublished doctoral dissertation, Melbourne: RMIT University.

$\rightarrow \quad$ Kolb, A.Y., Kolb, D.A. (2005), Learning styles and learning spaces: Enhancing experiential learning in higher education, Academy of Management Learning \& Education, 4(2), s. 193-212.

$\rightarrow$ Leithwood, K., Jantzi, D. (1999), The relative effects of principal and teacher sources of leadership on student engagement with school, Educational Administration Quarterly, 35, s. 679-706.

$\rightarrow$ Madalińska-Michalak, J. (2015), Dyrektor szkoły liderem - inspiracje i perspektywy, Warszawa: Wolters Kluwer. 
$\rightarrow$ Ministry of Education and Sports (2003), The Education Law article 62, National Assembly No. 25/NA, 6 May 2003, Vientiane.

$\rightarrow$ Ministry of Education and Sports, Department of Teacher Education, Teacher Development Center and Education Management (2006), Pre-Service Primary Teacher Education Curriculum, Vientiane.

$\rightarrow$ Ministry of Education and Sports (2006), Teacher Education Strategy 2006-2015 and Action Plan 2006-2010. No 174/PM, Vientiane, Laos.

$\rightarrow$ Ministry of Education and Sports (2008a), The Prime Minister's Decree on MOE's Organization and Function No. 62/PM/07 (07 April 2008), Vientiane.

$\rightarrow$ Ministry of Education and Sports (2008b), The prime Minister's Decree on MOE's Organization and Function No. 2239/MOE.CB.08 (07 September 2008), Vientiane.

$\rightarrow$ Ministry of Education (2008c), Education for All Mid-Decade Assessment, Vientiane, MOES, Laos.

$\rightarrow$ Ministry of Education and Sports (2008d), National Education System Reform Strategy (NESRS) 2006-2015, Vientiane, Laos.

$\rightarrow$ Ministry of Education and Sports (2009a), The Ministerial Decree No. 1584/ MOE. DoP.09, 03 July 2009. Vientiane.

$\rightarrow$ Ministry of Education and Sports (2009b), The Ministerial Decree No 1572/ MOE. DoP.09 (03 July 2009), Vientiane.

$\rightarrow$ Ministry of Education and Sports (2010), Decree No. 814/MOE.PO/10, dated 09 April 2010, Vientiane.

$\rightarrow$ Ministry of Education and Sports (2011), Report of Implementing Plan of Education. Development 2010-2011 and Plan of Education Development 2011-2012. Vientiane Capital.

$\rightarrow$ Ministry of Education and Sports (2012a), Report of Implementing Plan of Education Development 2011-2012 and Plan of Education Development 2012-2013, Vientiane.

$\rightarrow$ Ministry of Education and Sports (2012b), Four Breakthroughs in the Sector of Education and Sport (translation), Vientiane.

$\rightarrow$ Ministry of Education and Sports (2014), DTE Annual Summary Report 2014-2015, Vientiane.

$\rightarrow$ Nguyen, Q.K., Nguyen, Q.Ch. (2006), Education in Vietnam Development History, Challenges and Solutions [w:] B. Fredriksen, J.P. Tan (Eds.), An African Exploration of the East Asian Education Experience, s. 109-154, Washington: The World Bank.

$\rightarrow$ TTEST (2004), Teacher Training and Recruitment into the Teaching Profession, Vientiane, Department of Teacher Education, Ministry of Education and Sports. 
$\rightarrow$ The Trade Union Committee for Education (2012), School Leadership in Europe: Issues, Challenges and Opportunities, Brussels: Trade Union Committee for Education.

$\rightarrow$ OECD (2013),'Synergies for Better Learning: An international perspective on evaluation \&assessment'. Dostępne online: http://www.oecd.org/edu/school/ Evaluation_and Assessment Synthesis_Report.pdf (dostęp: 26.10.2015).

$\rightarrow$ Ogawa, K. (2009), Higher Education in Lao PDR [w:] Y. Hirosato \& Y. Kitamura (Eds.), The political economy of educational reforms and capacity development in Southeast Asia, s. 283-301, Dordrecht: Springer.

$\rightarrow$ Partington, P., Stainton, C. (2003), Managing Staff Development, Buckingham: Open University Press.

$\rightarrow$ Qablan, A.M. (2005), Education for Sustainable Development at the University Level: Interactions of the need for community fear of indoctrination, and the demands of work. Doctoral dissertation, Tallahassee: University of Florida.

$\rightarrow$ Trash, A. (2012), Leadership in Higher Education, International Journal of Humanities and Social Science, 2(13), s. 1-12.

$\rightarrow$ UNESCO (2012), Lao PDR: UNESCO Country Programming Document 2012-2015, Bangkok: UNESCO Asia and Pacific Regional Bureau for Education.

$\rightarrow$ Wood, R.D. (2004), Leadership behaviors of academic college deans in Mississippi's eight state-supported universities, Doctoral dissertation, Hattiesburg: The University of Southern Mississippi. 


\section{Autorzy}

Christopher Bezzina

University of Malta

Uppsala University

\section{Bouakhong Keo Asa}

Bankeun Teacher Training College

Pete Boyd

University of Cumbria

\section{Liliana Budkowska}

Fundacja Rozwoju Systemu Edukacji

Narodowa Agencja Programu Erasmus+

\section{Lesley Curtis}

Everton Nursery School

and Family Centre

\section{Roman Dorczak}

Uniwersytet Jagielloński

\section{Maria Assunção Flores}

University of Minho

\section{Antoni J. Jeżowski}

Instytut Badań w Oświacie

\section{Malwina Magdalena Kałużyńska}

Uniwersytet Warszawski

\section{Jakub Kołodziejczyk}

Uniwersytet Jagielloński

\section{Olena Kovalchuk}

Lutsk National Technical University

\section{Stefan M. Kwiatkowski}

Akademia Pedagogiki Specjalnej

im. Marii Grzegorzewskiej w Warszawie

Joanna Madalińska-Michalak

Uniwersytet Warszawski

\section{Karolina Malinowska}

Instytut Badań Edukacyjnych

\section{Grzegorz Mazurkiewicz}

Uniwersytet Jagielloński

\section{Inetta Nowosad}

Uniwersytet Zielonogórski 


\section{Michał Pachocki}

Zespół Analityczno-Badawczy

Fundacja Rozwoju Systemu Edukacji

Narodowa Agencja Programu Erasmus+

\section{Livia Rößler}

Leopold-Franzens-

Universität Innsbruck

\section{Michael Schratz}

Leopold-Franzens-

Universität Innsbruck

\section{Svitlana Shchudlo}

Drohobych Ivan Franko State

Pedagogical University

\section{Mirosław J. Szymański}

Akademia Pedagogiki Specjalnej

im. Marii Grzegorzewskiej w Warszawie

\section{Oksana Zabolotna}

Pavlo Tychyna Uman State Pedagogical University 
Złożoność problemów w obszarze edukacji sprawia, że poszukujemy nauczycieli-liderów, nauczycieli, dla których motorem działania stają się odpowiedzialność, sprawczość i kreatywność. Nauczyciele jako formalni i nieformalni przywódcy to osoby mające swoje idee, marzenia i projekty dotyczące edukacji. Bez nauczycieli potrafiących podejmować wyzwania i ryzyko oraz rozpoznawać i przekraczać bariery rozwojowe uczestników procesu edukacyjnego - dziejącego się w szkole i poza nią - trudno o dobrą zmianę w szkole.

Autorzy książki pokazują, że przywództwo nauczycieli ma swoje przesłanki w prawie oświatowym. Jego obraz jest wielowymiarowy, zaś jego rozwój powinien być wspierany mądrymi działaniami dyrektorów szkół i ich postawami oraz odpowiednią polityką oświatową.

\section{Joanna Madalińska-Michalak}

Fundacja Rozwoju Systemu Edukacji (FRSE) funkcjonuje od 1993 roku. Jest jedyną w Polsce instytucją z tak dużym doświadczeniem w zarządzaniu kilkunastoma edukacyjnymi programami europejskimi. W latach 2007-2013 koordynowała w Polsce programy „Uczenie się przez całe życie" (Erasmus, Leonardo da Vinci, Comenius i Grundtvig) oraz "Młodzież w działaniu". Obecnie pełni funkcję Narodowej Agencji Programu Erasmus+ na lata 2014-2020. Równolegle Fundacja realizuje europejskie inicjatywy informacyjno-edukacyjne, tj. eTwinning, Eurodesk Polska, Eurydice, Europass, ECVET i EPALE. Wspiera również współpracę z krajami Wschodu, poprzez Polsko-Litewski Fundusz Wymiany Młodzieży, Polsko-Ukraińską Radę Wymiany Młodzieży oraz Centrum Współpracy SALTO z Krajami Europy Wschodniej i Kaukazu. Od 2014 roku FRSE uczestniczy we wdrażaniu Programu Operacyjnego Wiedza Edukacja Rozwój.

Fundacja jest organizatorem wielu wydarzeń edukacyjnych, w tym konkursów, których celem jest promowanie rezultatów projektów (EDUinspiracje i EDUinspirator, European Language Label, SElfie+). Koordynuje obchody Europejskiego Tygodnia Młodzieży oraz współorganizuje wydarzenia odbywające się w ramach Europejskiego Dnia Języków. Prowadzi działalność analityczno-badawczą oraz wydawniczą (wydaje m.in. kwartalniki o tematyce edukacyjnej: Języki Obce w Szkole oraz Europa dla Aktywnych).

Publikacja bezpłatna

www.frse.org.pl 